University of Michigan Law School

University of Michigan Law School Scholarship Repository

1904

\title{
The Conveyance of Estates in Fee by Deed : Being a Statement of the Principles of Law Involved in the Drafting and Interpretation of Deeds of Conveyance and in the Examination of Title to Real Property
}

\author{
James H. Brewster \\ University of Michigan Law School
}

Available at: https://repository.law.umich.edu/books/65

Follow this and additional works at: https://repository.law.umich.edu/books

Part of the Common Law Commons, Estates and Trusts Commons, Legal History Commons, Legal Profession Commons, and the Property Law and Real Estate Commons

\section{Recommended Citation}

Brewster, James H. The Conveyance of Estates in Fee by Deed : Being a Statement of the Principles of Law Involved in the Drafting and Interpretation of Deeds of Conveyance and in the Examination of Title to Real Property. Indianapolis: Bobbs-Merrill Company, 1904.

This Book is brought to you for free and open access by the Faculty Scholarship at University of Michigan Law School Scholarship Repository. It has been accepted for inclusion in Books by an authorized administrator of University of Michigan Law School Scholarship Repository. For more information, please contact mlaw.repository@umich.edu. 
The conveyance of estates in fee by deed : being a statemennt of the principles of law involved in the drafting and interpretation of deeds of conveyance and in the examination of title to real property / by James H. Brewster.

Brewster, James H. (James Henry), 1856-1920.

Indianapolis : Bobbs-Merrill, [1904]

https://hdl . handle. net/2027/hvd . 32044031800931
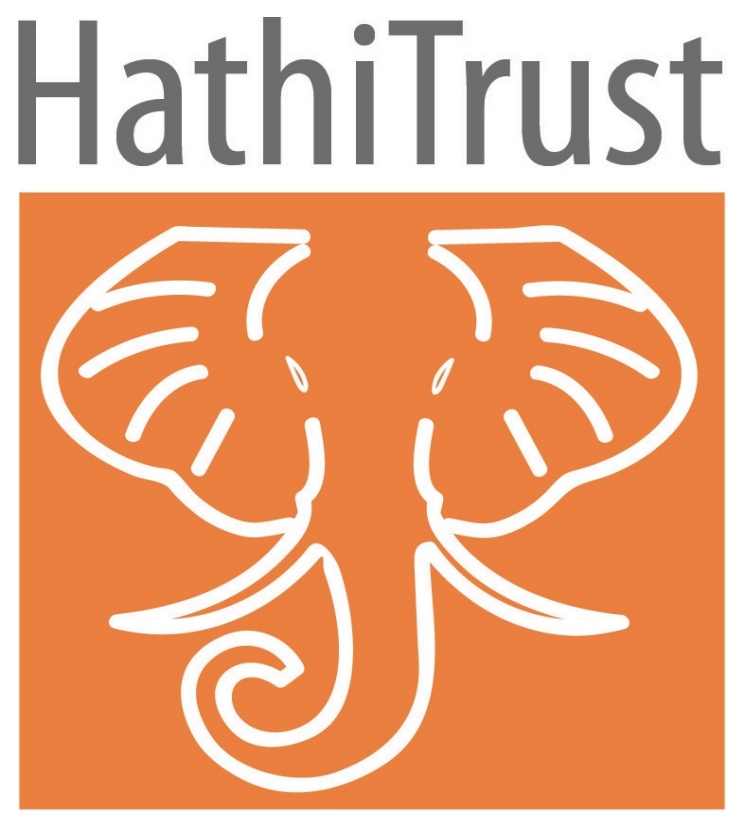

www.hathitrust.org

Public Domain, Google-digitized

http://www. hathitrust.org/access_use\#pd-google

We have determined this work to be in the public domain, meaning that it is not subject to copyright. Users are free to copy, use, and redistribute the work in part or in whole. It is possible that current copyright holders, heirs or the estate of the authors of individual portions of the work, such as illustrations or photographs, assert copyrights over these portions. Depending on the nature of subsequent use that is made, additional rights may need to be obtained independently of anything we can address. The digital images and OCR of this work were produced by Google, Inc. (indicated by a watermark on each page in the PageTurner). Google requests that the images and OCR not be re-hosted, redistributed or used commercially. The images are provided for educational, scholarly, non-commercial purposes. 

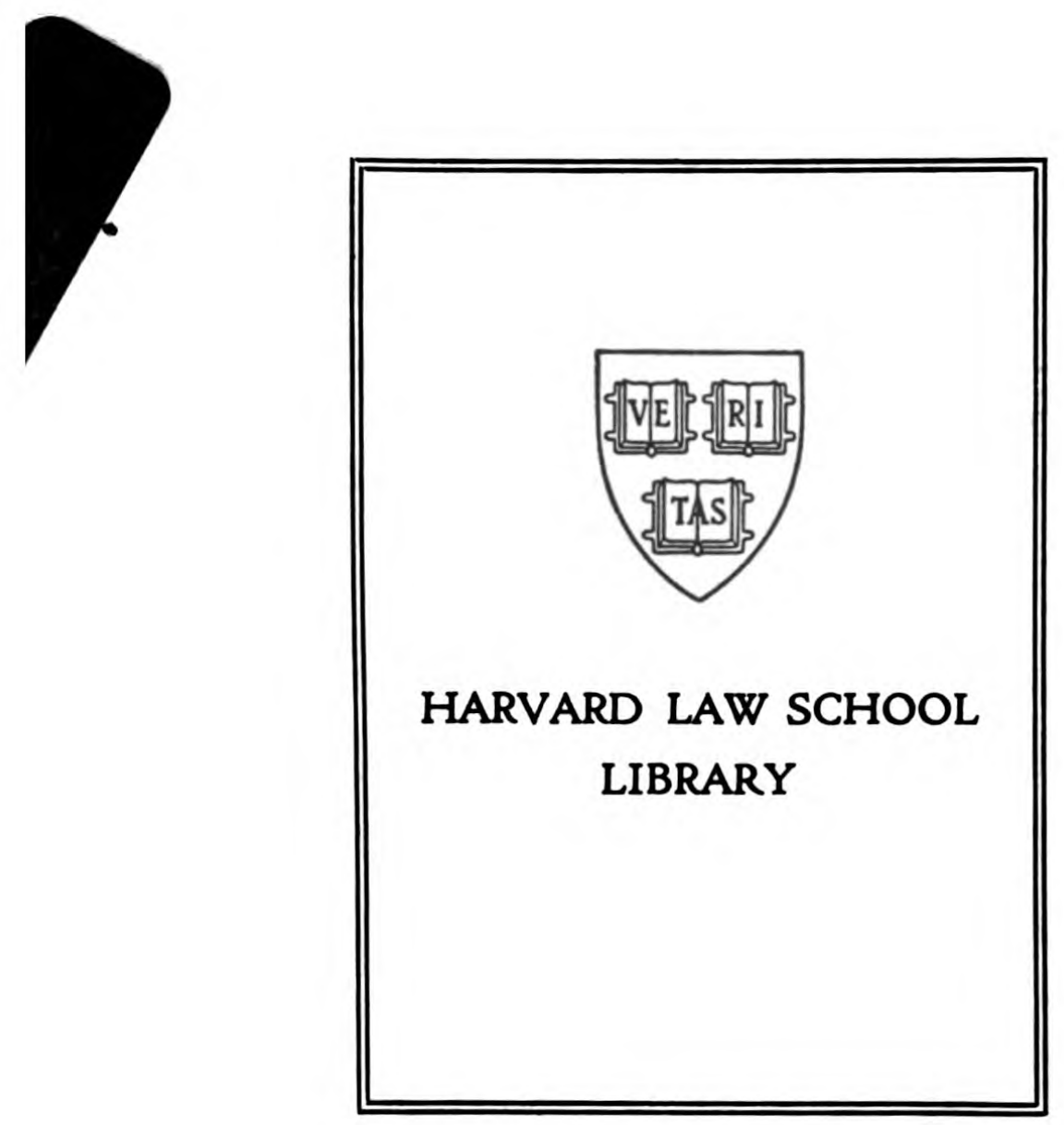


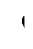




\author{
C $\quad c \neq$ \\ $\left(r^{6}\right) / j^{0}$ THE \\ $\cdots$ \\ CONVEYANCE OF ESTATES \\ IN FEE BY DEED \\ BEING A STATEMENT OF THE PRINCIPLES OF LAW \\ INVOLVED IN THE DRAFTING AND INTERPRETATION \\ OF DEEDS OF CONVEYANCE AND IN THE \\ EXAMINATION OF TITLE TO. \\ REAL PROPERTY
}

0

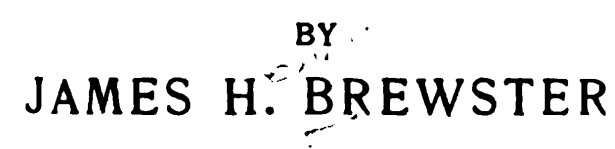

INDIANAPOLIS

THE BOBBS-MERRILL COMPANY

PUBLISHERS 
Tx
$B 8,10$

COPYRIGHT 1904

THE BOBBS-MERRILL COMPANY

Aec effer. 27, 1904 


\section{. PREFACE.}

THE purpose of the writer has been to state the principles of law applicable to the transfer of the title to real property by deed, in such manner as to assist one in drafting and interpreting the instrument of transfer.

No one whose attention has been directed to the questions that have arisen, and that are likely to arise, in the construction of deeds of conveyance is apt to fail in properly drawing a deed; he encounters serious practical difficulties, however, when, in the examination of title, it becomes necessary for him to construe instruments that have been prepared by others unaware of these questions. In the following pages a general view of the deed is first given; its several parts are then considered in the order in which they follow one another in the form that may be used in any state. After the delivery of the formally completed instrument is discussed, certain restrictions on the general freedom of alienation are considered. While the recording of conveyances has not been made especially a subject of discussion, it has been necessarily referred to at many points, and a chapter is given up to suggestions as to the examination of title and one to the, registration of title under the so called "Torrens System."

Statutes-practically so important-have been referred to on most points, and of ten states in which legislation is of similar import have been grouped; but the statutes arc 
so numerous and so varied that it has been found impracticable to cite all of them, although the several types have been compared and the effects of legislation on common law rules have been pointed out.

From the great number of decisions an attempt has been made to select those-chiefly from among the more recent-that best illustrate particular topics and indicate modern tendencies. Some preference has been given to those reported in the valuable series of annotated reports known as the American Decisions, American Reports, American State Reports and Lawyers' Reports Annotated; and the most useful notes found in these volumes have been cited. The writer here acknowledges his obligations to the annotators.

Those most familiar with this important part of the law of real property will most readily conceive the difficulties involved in treating it within the compass of a single volume.

J. H. B.

University of Michigan, Ann Arbor, March, 1904. 


\section{TABLE OF CONTENTS.}

\section{CHAPTER I.}

Srction

INTRODUCTORY.

1. Alienation in general-Inter vivos and by will.

2. Conveyancing-What the term implies.

3. Controlling effect of lex situs-Power of states as to real property.

4. Power of the United States-Effect of treaties on state laws.

5. Application of the doctrine that lex situs cantrols-Its reason.

6. Illustrations-Formal matters.

i. Illustrations-Capacity.

8. Illustrations-Construction and effect of instruments.

9. Statutes adopting foreign law-Not exceptions to rule.

10. Limitations to the application of the rale.

\section{CHAPTER II.}

THB CHIEF METHODS OF VOLUNTARY ALIENATION OF LAND

\section{Szetion} INTER VIVOS.

11. Formerly no writing necessary-The feoffment.

12. The bargain and sale-When deed necessary for.

13. The lease and release.

14. The feoffiment-When a deed became necessary for.

15. Deeds used though not necessary.

16. Livery of seisin in the United States-Conveyance generally by deed.

17. How title may still pass inter vivos without writing.

18. Fines and recoveries.

\section{(v)}




\section{CHAPTER III.}

SECTION

THE DEED.

19. Definition and characteristics of the deed.

20. Kinds of deeds-At common law-Under the statutes of uses.

21. Kinds-Indenture-Deed poll.

22. Indenture-Deed poll-Forms.

23. Indenture-Deed poll-Other differences in forms.

24. Indenture-Deed poll-Difference in effect.

25. Modern tendency to shorten deeds.

26. Reasons for considering settled forms.

27. The deed conveys a present interest-To be distinguished from other instruments.

28. Deeds distinguished from contracts to convey.

29. Deeds distinguished from instruments testamentary in character.

30. Statutory forms of deeds.

31. The parts of a deed.

\section{CHAPTER IV.}

SECTION

THE DATE.

32. The date not essential though desirable.

33. Presumption of delivery at date.

34. Date in deed and certificate of acknowledgment.

35. True date may be shown.

\section{CHAPTER V.}

THE PARTIES-THE METHOD OF DESIGNATING THEM.

Section

36. Manner of introducing and referring to parties.

37. Designation of parties-The grantor.

38. Designation of parties-The grantee.

39. Executing deed with grantee's name blank-Question as to authority to insert his name.

40. Parol evidence to identify grantee-When deed void for uncertainty as to grantee.

41. Use of names-Presumptions.

42. Names-Effect of discrepancies-Idem sonans.

43. Fictitious persons-Grantee must be in esse-Fictitious names.

44. Additions to name by way of recital-Effect of. 
45. Partnerships as parties.

46. Corporations as parties.

\section{CHAPTER VI.}

\section{Section}

\section{RECITALS.}

47. Recitals in general.

48. Recital often used to show purpose of conveyance.

49. Notice from recitals.

50. Recitals in conveyances by sheriffs, administrators, etc.

51. If not required, recitals may yet be useful.

\section{CHAPTER VII.}

Section

THE CONSIDERATION.

52. Apparent conflict as to necessity of a consideration.

53. No consideration necessary to a feoffment at common law-Effect of American statutes.

54. Seal importing consideration.

55. The equitable doctrine-Effect of the statute of uses.

56. What makes a deed of bargain and sale.

57. How the foregoing principles operate.

58. Parol evidence as to consideration.

59. Parol evidence of additional consideration.

60. Such evidence not restricted by most courts.

61. Parol eridence rule more strictly applied by some courts.

62. Parol evidence when statement as to consideration is contractual.

63. The true consideration may generally be shown by parol.

64. Shoring assumption of mortgage.

65. True consideration may not be shown as between the parties to defeat deed.

66. Statement of consideration not binding on others.

\section{CHAPTER VIII.}

SECTION

THE OPERATIVE WORDS.

68. Special operative words for special conveyances.

69. Superfluous use of operative words-Rule of construction.

70. Effect of assignments indorsed on deeds.

71. Operative words of some kind essential.

i2. Words generally considered sufficient. 


\section{CHAPTER IX.}

\section{SRCTION}

\section{THE DESCRIPTION OF THE PROPERTY.}

73. General considerations-Importance of the description.

74. Descriptions in recorded conveyances-How far notice to subsequent purchasers.

75. Certainty necessary-Parol evidence to apply description.

76. Parol evidence cannot supply description-Fatal uncertainty.

77. How uncertainty arises-Undefined purt of larger tract.

78. Uncertainty avoided when part of larger tract is designated, though not fully described.

79. Fatal uncertainty avoided where grantee of part of larger tract takes an undivided interest.

80. Uncertainty caused by lack of starting point of boundary.

81. A general description allowable and not necessarily uncertain.

82. Descriptions usually more specific-What particulars are to be regarded.

83. Conflicting parts of descriptions.

84. Rules for construing descriptions with conflicting parts.

85. The maxim, "Falsa demonstratio," etc.

86. Illustrations of the rules-Particular descriptions control general.

87. Illustrations-Monuments control courses and distances.

88. The part of a monument taken as a boundary.

89. Streets and highways as boundaries-When the grantee takes to the center.

90. Streets and highways as boundaries-Decisions not in accord as to what expressions exclude the way.

91. Streets and highways as boundaries-When grantee takes the entire street.

92. Description by courses and distances will control quantity named - "More or less"-When statement of quantity important.

93. Reference in descriptions to maps.

94. Grantee's rights in streets shown on map.

95. Statutory plats-Maps may aid description though not expressly referred to.

96. Incorrect maps controlled by monuments.

97. Reference may be made to other deeds, etc., for description.

98. Lands bounded by waters-General rule.

99. The basis of the rule-Application to cases where water is not named as boundary.

100. Application of general rule, how limited by grantor.

101. How far rule applies to public grants.

102. Public grants-The "meander line."

103. When the meander line will be taken as the boundary.

104. How far does title extend under water?-Tidal waters.

105. How far does title extend-Rivers-At common law. 
Section

TABLE OF CONTENTS. ix

106. Rivers in United States-Private title to bed in some states.

10i. 0 wner's rights incident to this title-Island-Ice-Shooting and fishing.

103. Rivers-No private title to bed in some states.

109. Navigable rivers-Practically three rules in United States.

110. Yon-tidal, non-navigable rivers.

111. Boundaries on lakes-Public and private ownership.

112. The "Great Lakes."

113. Smaller lakes and ponds.

114. Conflicting views as to smaller lakes in the United States.

.115. The sectional line rule.

116. Beds of inland natural lakes though of large size may be subject to private ownership.

117. States holding to the rule that private title extends to water's edge only.

118. Appurtenances.

CHAPTER X.

Section

EXCEPTIONS-RESERVATIONS.

119. Exceptions and reservations in general.

120. Difference in effect.

121. Expressions causing doubt.

122. Place for such clauses.

123. Effect of certain words.

124. Particular cases-Timber-Minerals.

125. Reservation of easements appurtenant to grantor's other land.

126. Exceptions and reservations repugnant to grant-Effect of.

127. Reservation to a stranger.

\section{CHAPTER XI.}

THE LIMITATION OF THE ESTATE-THE HABENDUM.

SECTIOY

128. The habendum, its function.

129. Effect of contradictions between premises and habendum.

130. Where habendum is not repugnant, it may explain and qualify the premises.

131. Effect of habendum in enlarging the premises.

132. The conveyance to be read and construed as a whole.

133. Naming the grantee in habendum-Effect of naming other or different persons.

134. Trusts may be declared in the habendum.

135. Use of the word "heirs" at common law in limiting an estate in fee. 
SeCtion

136. Effect of statutes on the rule requiring the word "heirs."

137. When the word "beirs" is not essential to create a fee, irrespective of statute.

138. Use of the word "assigns" in limiting estates.

139. The fee simple and the fee simple conditional.

140. The statute De donis conditionalibus-Estates tail.

141. Kinds of estates tail-What terms are necessary to create.

142. Estates tail in the United States.

143. Estates tail in the United States-The states classified.

144. Reversions-Remainders.

145. The rule in Shelley's Case.

146. Not a rule of construction, but one of law-When does not apply.

147. The rule in the United States.

\section{CHAPTER XII.}

Section

\section{CONCURRENT OWNERSHIP.}

148. Concurrent ownership in general.

149. Joint tenancy-Its characteristics.

150. A lienation by a joint tenant.

151. Joint tenancy not now favored-American statutes concerning it.

152. Statutes reversing the common law presumption-The estate still created by apt words.

153. Exceptions to the modern rule favoring estates in commonTrustees-Mortgagees.

154. Statutes abolishing survivorship-They do not destroy joint tenancy.

155. Joint tenancy expressly abolished.

156. Tenancy in common-Its characteristics-How created.

157. Alienation by tenant in common-Effect of conveyance of specific part.

158. Conveyance of the entire property by tenant in common-Ouster.

159. Coparcenary.

160. Partition-By deed.

161. Parol partition.

162. Tenancy by entireties.

163. Has been generally recognized as common law in the United States-Exceptions.

164. In what states now recognized-Effect of statutes as to joint tenancy and married women.

165. In what states not recognized because of statutes.

166. Conveyance of estates by entireties.

167. The community system. 


\section{CHAPTER XIII.}

Section

$$
\text { CONDITIONS. }
$$

168. Conditions and limitations in general.

169. Implied conditions.

170. Express conditions-Conditions precedent.

171. Express conditions-Conditions subsequent.

172. Conditions precedent and subsequent compared.

173. Determinable or special limitations.

174. Determinable fees.

175. Conditional limitations.

176. Causes of difficulties in construing.

177. Words used in creating conditions.

178. The place for the condition.

179. The re-entry clause.

180. Particular classes of cases-Conveyances for specified purposes.

181. Effect in such cases of consideration and nature of purpose.

182. Particular classes-Building restrictions-Restrictions as to use.

183. Particular classes-Conditions and stipulations for support.

184. Conditions not created in such cases by inference-Remedy in equity.

185. Void conditions-Requiring illegal acts-Restraining marriage.

186. Void conditions-Repugnant to estate granted or capricious.

187. General suggestions for drawing and construing conditions.

\section{CHAPTER XIV.}

COVENANTS.

Section

\section{Covenants for Title.}

183. Covenants-Effect, in general, of the presence or absence of covenanto for title.

189. Corenants for title in mortgages.

190. The usual covenants for title.

191. The form of covenants for title.

192. The designation of parties to be bound-The covenantor himself.

193. The covenantor's heirs, executors, etc.

194. Grantor's wife joining in her husband's deed-Husband in wife's deed.

195. Married woman's covenants in conveyance of her separate prop. erty.

198. Designation of parties-The covenantee, his heirs, etc.

197. The covenantee's "heirs and assigns." 
SECTION

198. The covenants for seisin, and good right to convey.

199. The covenant against incumbrances-Form.

200. What are incumbrances?

201. Mortgages, building restrictions, dower-Incumbrances.

202. Leasehold interests as incumbrances.

203. Distinction between incumbrances visibly affecting the physical condition and others.

204. If an incumbrance is to be excepted from the covenant, it should be so expressed.

205. The covenant for further assurance.

206. The covenants for quiet enjoyment and of warranty.

207. The covenant of warranty attaches only to the estate conveyed.

208. Effect of describing land as subject to an incumbrance.

209. Eviction necessary to a breach of covenant of warranty.

210. What is eviction-Constructive eviction.

211. Covenants implied-Common law-Statutory deeds.

212. Effect of such statutes.

213. Whether lex situs or lex loci contractus controls.

214. The running of covenants for title with the land.

215. Conflicting views as to the running of some covenants.

216. The "English rule" as to the covenant of seisin running.

217. The "American rule."

218. The rule as to the covenant against incumbrances.

219. Covenants for quiet enjoyment and warranty run with the land.

220. Subsequent grantees by quit claim deeds have the benefit of such covenants as run with the land.

221. "Personal" and "real" as used with reference to covenants for title.

\section{Covenants Other than Covenants for Title.}

222. General features of these covenants.

223. Form-No technical words essential.

224. Form-Effect of "heirs and assigns" or similar words in covenant.

225. The form of the deed in which covenants are-Effect of acceptance by grantee of deed poll containing covenants.

226. Distinction sometimes made between benefits and burdens.

227. Restrictive covenants and conditions, as to use of land, buildings, etc.

228. Building restrictions in pursuance of a "general plan."

229. The duration of such restrictions-Effect of laches, waiver, changes in neighborhood.

230. Provisions in effect restraining competition in trade.

231. Covenants in conveyances relating to party walls.

232. Agreements as to party walls without a conveyance. 


\title{
CHAPTER XV.
}

\author{
Section \\ SIGNING. \\ 233. Signing not essential at common law. \\ 234. Now generally necessary in the United States. \\ 235. Place of signature. \\ 236. Form of signature-Signing by mark. \\ 237. Form of signature-Part of name-Initials. \\ 233. Signing by another for grantor. \\ 239. Signing under power of attorney. \\ 240. Execution of conveyance by corporation. \\ 241. Conveyances by municipal, religious or literary corporations.
}

\section{CHAPTER XVI.}

Section

\section{SEALING.}

242. The seal-When necessary at common law.

243. Tendency to dispense with the seal-Efiect of statntes.

244. Importance of the seal at common law.

245. Some effects of the seal-Legal and equitable doctrines.

246. What is a sufficient seal.

247. Recital in instrument as to seal-Necessity for, and effect of, recital.

248. Adoption of one seal by several persons-Time and method of affixing the seal.

249. The corporate seal.

\section{CHAPTER XVII.}

Srction

\section{ATTESTATION.}

250. Witnesses to conveyances at common law.

251. Witnesses under statutes in the United States.

252. The method of attesting.

253. Disqualification of witness by interest. 


\title{
CHAPTER XVIII.
}

Section

\author{
ACKNOWLEDGIMNT.
}

254. Terms used.

255. What writings may be acknowledged.

256. The subject regulated by statute-Form of acknowledging deeds generally the test.

257. General purposes of acknowledgment.

258. First, to entitle the instrument to be recorded.

259. Purpose of acknowledgment-Statute relating to evidence.

260. Some points to notice as to such statutes.

261. When necessary to validity of conveyance.

262. Necessary to convey legal title in some states.

263. In many states acknowledgment necessary to validity of conveyance of homestead.

264. When necessary in conveyance by married woman.

265. The form of the certificate of acknowledgment.

266. Certificate should show facts necessary.

267. Substantial compliance with statutes enough-Clerical errors.

268. What is substantial compliance.

269. Substantial compliance-Fact of acknowledgment.

270. When the word "acknowledged" should appear.

271. Substantial compliance-Identity of party.

272. Identity of party-"Personally known."

273. Who may take the acknowledgment.

274. Authority to take wholly statutory.

275. Who may take-When acknowledgment is taken in the state where the land is.

276. Who may take-When acknowledgment is taken in another state -The commissioner of deeds.

277. When taken in another state-Questions as to what offlcers may take, etc.

278. Taken in another state-Showing as to official character, etc.

279. Taken in another state-Certificate of conformity to foreign law.

280. Acknowledgments taken out of the United States.

281. Competency of officer affected by interest-Party cannot take acknowledgment.

282. Practical effect of rule that party cannot take acknowledgment.

283. Rule disqualifying party generally applies to acknowledgments of all instruments.

284. Effect of relationship on officer's competency.

285. Undisclosed interest as affecting competency of officer to take.

286. Undisclosed interest as affecting competency.

287. Officer of corporation not generally disqualified unless also a shareholder. 
SECTION

TABLE OF CONTENTS.

$\mathrm{XV}$

285. Agent or attorney of party to a conveyance may generally take acknowledgment.

259. The parts of the certificate-Venue.

290. Date.

291. Signing by officer-His official, not his personal signature.

292. Sealing.

293. Impeachment of the certificate-When it is conclusive.

294. Form of certificate to conveyance of corporation or by attorney.

29.5. Proof instead of acknowledgment.

\section{CHAP'TER XIX.}

SECTION

\section{DELIVERY.}

296. Delivery essential to a deed and to the transfer of title.

297 . Exception to rule that delivery is essential.

298. Elements of delivery-Surrender of control by the grantor.

299. Elements-The intent of the grantor.

300 . Acceptance presumed until dissent is shown.

301. Acceptance by the grantee.

302. If acceptance is prevented there is generally no delivery.

303. Presumption of delivery from certain facts.

304. Presumption of delivery-Recording.

305. Postponing complete delivery till death of grantor.

306 . Effect of grantor's retention of possession and control of the deed.

$30 i$. Effect of grantor's depositing deed with a third person : reserving no control.

30. Effect of reserving control by grantor in such cases.

319. Delivery in escrow.

310. Effect of grantee's obtaining possession of escrow wrongfully.

311. Effect of surrender or destruction of a deed.

\section{CHAPTER XX.}

THE CONVEYANCE OF THE REAL ESTATE OF INFANTS.

SECTION

312. Reatrictions on alienation-Disabilities-"Void" and "voidable" conveyances.

313. Conveyances by minors-Voidable.

314. Former distinctions between different kinds of conveyances-Infants' powers of attorney still sometimes held void.

315. When conveyance by an infant may be disaffirmed.

316. How soon after majority must infant disaffirm-Doctrine that he has statutory period of limitation. 
SECTION

31i. How soon after majority must disaffirm-"Within a reasonable time."

318. Former infant may disaffirm though his grantee has conveyed to another.

319. Infant's heirs may disaffirm-Others may not generally.

320. Effect of infant's misrepresen tation as to age.

321 . The restoration of the consideration on disaffirmance.

322. What constitutes disaffirmance.

323. Effect of conveyance to an infant.

324. How infants' real property may be conveyed.

325. The general principle controlling in such cases.

326. The application by proper party-Notice.

327. Such conveyances allowed for certain purposes.

328. Hearing on the application-Guardian's bond-Approval by court.

329. Statutes curing effect of irregularities.

330. Power of chancery court to order conveyance of minor's lands.

\section{CHAPTER XXI.}

THE CONVEYANCE OF THE REAL ESTATE OF PERSONS OF UNSOUND MIND.

SEction

331. Insane persons' conveyances similar to infants'-Yet the two classes differ.

332. Conveyance of insane person, under guardianship, void.

333. While guardianship continues ward presumed incompetent-But not if merely adjudged insane or guardianship ended.

334. Effect of guardianship of spendthrifts and drunkards.

335. Conveyance of insane persons not under guardianship generally voidable.

336. Such conveyances sometimes considered roid-Powers of attorney.

337. Whether such a voidable deed conveys title without being affirmed.

338. The kinds and degrees of insanity.

339. The question as to insanity must relate to the time of the act.

340. Presumption of sanity - Not overcome by mere weakness of mind -Partial insanity.

341. Weakness of mind combined with inadequate consideration-Fiduciary relations.

342. The conveyance where regarded as voidable may be affirmed.

343. Deed of insane grantor may be disaffirmed by him when sane.

344. May be disaffirmed by his guardian.

345. Insane grantor's heirs may disaffirm-Creditors generally may not. 
SUTION

$3+\%$. As to the return of consideration on disaffirmance.

34 . Whether conveyance may be disaffirmed as against subsequent bona fide grantee.

348. Statutes providing for the disposal of insane persons' interests in lands.

\section{CHAPTER XXII.}

\section{CONVEYANCES IN WHICH MARRIED WOMEN ARE INTERESTED.}

SECTION

349. The married woman's different interests in real property.

3.50. The husband's rights in, and control over, his wife's property at common law.

351. The common law not wholly obsolete in this country.

3j2. The equitable separate estate-How created.

333. The intention to create the separate estate must generally be clearly expressed.

3.34. The "restraint on anticipation."

355 . The wife's power over her separate estate in the absence of such restraint.

$3 \%$. Manner of conveying separate estate.

$35 \%$. Effect of statates on the equitable separate estate.

3.5. Constitutional and statutory provisions creating a separate estate.

3.). Statutes creating separate estate do not always remove the married woman's disability to convey.

3it). Common law methods of alienation by married women-Deeds unusual-Fines.

361. The joinder of the husband at common law-The separate examination.

3,2. Early usages in the United States-The joint deed-Statutes requiring joinder.

$3 \nmid 3$. When the husband's joinder or assent is now necessary.

364 . Whether husband and wife should join as grantors or merely execute the deed.

355. The married woman's acknowledgment-The separate examination.

3iii. How far the separate examination must now be regarded.

$36 i$. How far compliance with statutory provisions as to particulars is necessary.

3hi. Conveyances between husband and wife.

3iti. Conveyances between husband and wife through a third person.

3:0. Fquitable view of conveyances between husband and wife.

3i1. Rule as to conveyances between husband and wife affected by statute.

3i2. Dower and its statutory substitute.

ii-Brews. CoN. 
SEction

373. Generally no act of the husband alone can defeat dower-Exceptions to this rule.

374. Inchoate right of dower not strictly property - Released not conveyed.

375. Wife cannot generally release dower to her husband.

376. Release of dower generally by deed of husband and wife.

377. Married women's powers of attorney to convey lands or release dower.

\section{CHAPTER XXIII.}

\section{Section}

\section{THE HOMESTEAD IN CONVEYANCING.}

378. The homestead in general.

379. Who may have a homestead-Not necessarily a married person only.

380. But restraints on its alienation apply usually to married persons only.

381. Restraints on alienation apply usually to residents only.

382. Occupancy generally essential-"Constructive occupancy."

383. Occupancy-Abandonment-"Temporary absence."

384. Occupancy as a home-Use for business purposes.

385. The selection of the homestead-By record-By occupancy.

386. The limits of the homestead.

387. May be a homestead in an estate less than fee simple-Joint estates.

388. Owner of a homestead may alienate it unless restrained-Partial restraints.

389. Some restriction on voluntary alienation usual.

390. Usually husband and wife must concur in the transfer.

39!. Effect of non-compliance with statute.

392. Effect of non-compliance with statute-The alienation void in many states.

393. Effect of wife's insanity.

394. Subsequent abandonment will not make the conveyance validNor death or divorce-Transfer by wife alone.

395. To what extent husband may lease-Sell timber-Grant rights of way.

396. The defective conveyance valid as to the excess over homestead.

397. Non-compliance with statutes does not make alienation void in some states.

398. The mode of manifesting consent to the alienation of the homestead.

399. The acknowledgment to the conveyance of the homestead.

400. Conveyance of the homestead between husband and wife. 


\section{CHAPTER XXIV.}

\section{CAPACITY OF CORPORATIONS TO PURCHASE AND CONVEY \\ REAL PROPERTY.}

SEction

f(1). Capacity of corporation to take title at common law-Statutes of mortmain.

402. Capacity to take title-May take in fee though its duration is limited.

403. Effect of corporation's dissolution on title.

404. May purchase and hold only lands appropriate to corporate purposes-Presumption that land is so beld.

40.5. When its power is exceeded the state only may complain-Conveyance to corporation in such case voidable, not void.

toi. Capacity of private corporation to alienate real property.

40i. Capacity of public and quasi-public corporations to alienate real property.

\section{CHAPTER XXV. \\ CAPACITY OF ALIENS TO PURCHASE AND CONVEY REAL PROPERTY.}

SETTION

40.5. At common law aliens could acquire title by purchase, not by descent.

409. Nature of title thus acquired-Office found.

410. Alien may convey before office found.

111. Common law as modified by statute.

412. Power of the states to remove disabilities.

\section{CHAPTER XXVI.}

CAPACITY OF CONVICTS TO TAKE AND CONVEY REAL PROPERTY.

SECTION

413. Attainder at common law-Statutory changes in England.

414. Effect of sentence for crime in this country-Statutes. 


\title{
CHAPTER XXVII.
}

\author{
THE DISABILITY OF A GRANTOR ARISING FROM ADVERSE \\ POSSESSION.
}

Section

415. Disability of disseisee at common law-Statute 32 Henry VIII.

416. Statutes in this country adopting the principles of this statute.

417. Disseisee's conveyance not void for all purposes.

418. The principle recognized in some states without legislation.

419. To what transfers the rule does not apply.

420. Character of possession rendering the transfer void.

421. The old rule generally abrogated in the United States.

\section{CHAPTER XXVIII.}

THE EXaMiNation OF THE titLe to REAL PROPERTY.

\section{Section}

422. General characteristics of the recording system.

423. Imperfections in title.

424. Defects shown by original instruments in the chain of title, and by records of them.

425. Defects shown by other records-The abstract of title.

426. Defects not shown by records-Forged instruments.

427. Defects not shown by records-Identity of person-Delivery-Infancy-Homestead.

428. Defects not shown by records-Questions on death of landowner. 429. Purchaser's risk in relying on the records alone.

430. Possession, not shown by records, always easily investigated.

431. Possession by grantor, after conveyance, as notice.

\section{CHAPTER XXIX.}

REGistration OF TITLE TO kEAL PROPERTY.

SECTION

432. Defects in present system suggest desirability of reform in registration laws.

433. The "Torrens System"-Briefly historical.

434. General principles of the title registration acts.

435. Proceedings to determine and register title are judicial-The ap)plication-The court. 
SECTION

436. Notice to adverse claimants-Process-Constitutional objections.

43i. The investigation of title-Functions of the examiner.

438. Appearance of interested parties-The conclusive effect of decree.

439. Subsequent dealings with the land appear on the registry.

440. No title can be acquired to registered land by adverse possession.

411. Transmission of title on death of owner of registered land.

42. The assurance or indemnity fund.

443. Voluntary, or compulsory, registration. 


\section{TABLE OF CASES.}

\section{[References are to Sections.]}

Abbott $\nabla$. Allen, 14 Johnson (New York) 248............. 198

v. Cremer (Wisconsin), 95 Northwestern $38 \ldots \ldots \ldots \ldots \ldots . . \ldots 117$

Abney v. DeLoach, 84 Alabama $393 \ldots . . \ldots \ldots \ldots \ldots \ldots \ldots \ldots \ldots . . \ldots 290$

Adams v. Akerlund, 168 Illinois $632 \ldots . \ldots \ldots \ldots \ldots \ldots \ldots \ldots . . \ldots$

v. Bishop, 19 nlinois $395 \ldots \ldots \ldots \ldots \ldots \ldots \ldots \ldots \ldots \ldots \ldots . \ldots 279$

v. Buford, 6 Dana (Kentucky) 406 ..................... 419

จ. Gilbert (Kansas), 72 Pacific 769................. 394, 397

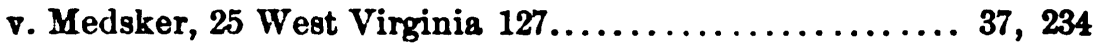

จ. Noble, 120 Michigan $545 \ldots \ldots \ldots \ldots \ldots \ldots \ldots \ldots \ldots \ldots . \ldots \ldots 232$

v. Ross, 30 New Jersey Law $505 . \ldots \ldots \ldots \ldots \ldots \ldots \ldots \ldots$ 141, 207

v. Teague, 123 Alabama 591.................. 37, 363, 364

Adams Paper Co. v. Cassard (Pennsylvania), 55 Atlantic 949..... 363

Adkins $\nabla$. Tomlinson, 121 Missouri 487................... 198

Agan v. Shannon, 103 Missouri $661 \ldots \ldots \ldots \ldots \ldots \ldots \ldots \ldots \ldots \ldots . \ldots \ldots 1$

Akerly $\nabla$. Vilag, 23 Wisconsin $207 \ldots \ldots \ldots \ldots \ldots \ldots \ldots \ldots \ldots . \ldots \ldots$

Albany Bridge Co. $\nabla$. People, 197 Illinois $199 \ldots \ldots \ldots \ldots \ldots \ldots . . \ldots 2$

Albany County Savings Bank v. McCarty, 149 New York 71 ...... 259

Albright $\nabla$. Albright, 70 Wisconsin $528 \ldots \ldots \ldots \ldots \ldots \ldots \ldots \ldots . \ldots \ldots$

v. Cortright, 64 New Jersey Law 330.................. 107

Alexander $v$. Vennan, 61 Iowa $160 \ldots \ldots \ldots \ldots \ldots \ldots \ldots \ldots \ldots . \ldots . \ldots 39$

Algonquin Coal Co. v. Northern \&c. Co., 162 Pennsylvania State

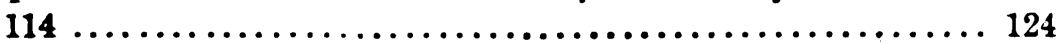

Allbright $\nabla$. Hannah, 103 Iowa $98 \ldots \ldots \ldots \ldots \ldots \ldots \ldots \ldots \ldots . \ldots \ldots 7$

Allebach v. Hunsicker, 132 Pennoylvania State $349 \ldots \ldots \ldots \ldots \ldots 66$

Allen v. Allen, 48 Minnesota $462 \ldots \ldots \ldots \ldots \ldots \ldots \ldots \ldots \ldots$ 38, 198

v. Baskerville, 123 North Carolina $126 \ldots \ldots \ldots \ldots \ldots \ldots \ldots . \ldots \ldots$

v. Berryhill, 27 Iowa $534 \ldots \ldots \ldots \ldots \ldots \ldots \ldots \ldots \ldots \ldots \ldots . \ldots \ldots$

v. Drake, 109 Missouri 626. ...................... 369

v. Withrow, 110 United States $119 . \ldots \ldots \ldots \ldots \ldots \ldots \ldots \ldots .38$

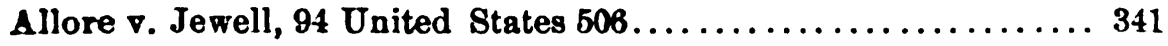

Alt v. Banholzer, 39 Minnesota $511 \ldots \ldots \ldots \ldots \ldots \ldots \ldots \ldots . .392,394$

v. Graff, 65 Minnesota $191 \ldots \ldots \ldots \ldots \ldots \ldots \ldots \ldots \ldots \ldots \ldots . \ldots \ldots$

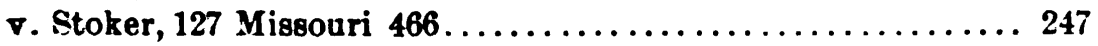

Alvarado $\nabla$. Nordholt, 95 California $116 . \ldots \ldots \ldots \ldots \ldots \ldots \ldots \ldots 297$

$\triangle$ mbe $\nabla$. Railroad, 44 Minnesota $266 \ldots \ldots \ldots \ldots \ldots \ldots \ldots \ldots .42$

( $\mathrm{x} \times \mathrm{iii})$ 


\section{[References are to Sections.]}

American Freehold Co. v. Dykes, 111 Alabama 178............ 316

American Freehold Land \& Mortgage Co. v. Thornton, 108 Alabama

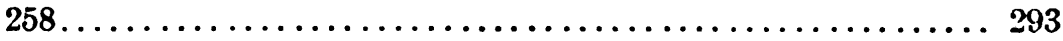

American Home Missionary Society $\nabla$. Wadhams, 10 Barbour (New

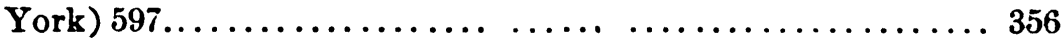

American Savings and Loan Association v. Burghardt, 19 Montana

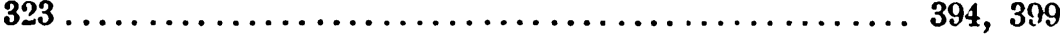

Amerman v. Deane, 132 New York $355 \ldots \ldots \ldots \ldots \ldots \ldots \ldots \ldots .229$

Ames v. Ames, 160 Illinois $599 \ldots \ldots \ldots \ldots \ldots \ldots \ldots \ldots \ldots \ldots . \ldots \ldots$

v. San Diego, 101 California $390 \ldots \ldots \ldots \ldots \ldots \ldots \ldots \ldots \ldots . \ldots 407$

Amick v. Woodworth, 58 Ohio State $86 \ldots \ldots \ldots \ldots \ldots \ldots . \ldots 253,281$

Ammant v. New Alexandria Turnpike Co., 13 Sergeant \& Rawle

(Penneylvania) 210............................. 407

Anderson v. Cosman, 103 Iowa 266....................... 387

v. Gaines, 156 Missouri 664. ........................ 184

v. Logan, 99 North Carolina $474 \ldots \ldots \ldots \ldots \ldots \ldots \ldots \ldots \ldots 262$

v. Smith, 159 Illinois $93 . \ldots \ldots \ldots \ldots \ldots \ldots \ldots \ldots \ldots \ldots . . \ldots 6,400$

v. Stadlemann, 17 Washington $433 \ldots \ldots \ldots \ldots \ldots \ldots \ldots \ldots . \ldots 393$

Andrews v. Appel, 22 Hun (New York) $429 \ldots \ldots \ldots \ldots \ldots \ldots \ldots 218$

v. Dyer, 81 Maine $104 \ldots \ldots \ldots \ldots \ldots \ldots \ldots \ldots \ldots \ldots \ldots .40$

v. Pearson, 68 Maine $19 \ldots \ldots \ldots \ldots \ldots \ldots \ldots \ldots \ldots \ldots \ldots, 86$

Andrus v. Smelting Co., 130 United States $643 \ldots \ldots \ldots \ldots \ldots \ldots .210$

Angell v. Rosenbury, 12 Michigan $241 \ldots \ldots \ldots \ldots \ldots \ldots \ldots \ldots \ldots \ldots \ldots$

Anglade v. St. Avit, 67 Missouri $434 \ldots \ldots \ldots \ldots \ldots \ldots \ldots \ldots \ldots . \ldots 9$

Answer of Court, 4 New Hampshire $565 \ldots \ldots \ldots \ldots \ldots \ldots \ldots . . \ldots 330$

Appeal of. See name of party.

Arambula v. Sullivan, 80 Texas $615 \ldots \ldots \ldots \ldots \ldots \ldots \ldots \ldots \ldots . . \ldots 5$

Arents v. Long Island R. Co., 156 New York $1 \ldots \ldots \ldots \ldots \ldots \ldots . \ldots 20$

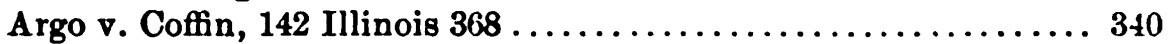

Armstrong v. Combs, 15 New York Appellate Division 246...... 283

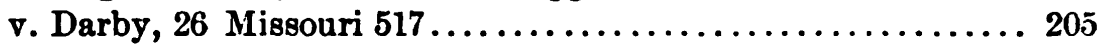

Arrington v. Arrington, 122 Alabama $510 \ldots \ldots \ldots \ldots \ldots \ldots 253,301$

Arthur v. Caverly, 98 Michigan $82 \ldots \ldots \ldots \ldots \ldots \ldots \ldots \ldots \ldots \ldots . \ldots \ldots$

Ashcraft v. DeArmond, 44 Iowa $229 \ldots \ldots \ldots \ldots \ldots \ldots \ldots \ldots . \ldots \ldots$

Ashelford v. Willis, 194 Illinois $492 \ldots \ldots \ldots \ldots \ldots \ldots \ldots \ldots \ldots .430$

Ashland v. Greiner, 58 Ohio State $67 \ldots \ldots \ldots \ldots \ldots \ldots \ldots \ldots$ 180, 181

Ashmead v. Reynolds, 134 Indiana $139 \ldots \ldots \ldots \ldots \ldots \ldots \ldots \ldots . \ldots \ldots 1$

Askey v. Williams, 74 Texas $294 \ldots \ldots \ldots \ldots \ldots \ldots \ldots \ldots \ldots \ldots . \ldots \ldots \ldots$

Atherstone v. Bostock, 2 Manning \& Granger $511 \ldots \ldots \ldots \ldots \ldots .21$

Atherton v. Roche, 192 Illinois $252 \ldots \ldots \ldots \ldots \ldots \ldots \ldots \ldots 141,143$

Atkins v. Atkins, 18 Nebraska $474 \ldots \ldots \ldots \ldots \ldots \ldots \ldots \ldots \ldots . \ldots \ldots$

Atkison v. Henry, 80 Missouri $151 \ldots \ldots \ldots \ldots \ldots \ldots \ldots \ldots \ldots . \ldots 6$

Atlanta Consolidated Street R. Co. v. Jackson, 108 Georgia

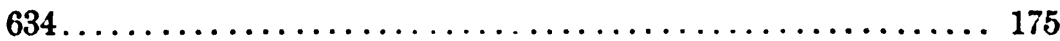

Attorney General v. Woods, 108 Massachusetts 436........... 110

Aultman v. Obermeyer, 6 Nebraska $260 \ldots \ldots \ldots \ldots \ldots \ldots \ldots . \ldots 371$

Aurora Agricultural \&c. Society v. Palliock, 80 Illinois 263 ..... 406 


\section{[References are to Sections.]}

Austerberry $\nabla$. Oldham, 29 Chancery Division $750 \ldots \ldots \ldots \ldots \ldots 226$

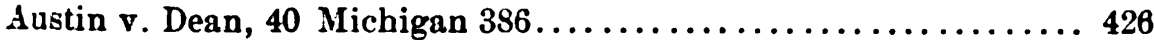

v. Dolbee, 101 Michigan 292..................... 81

v. Rutland R. Co., 45 Vermont $215 \ldots \ldots \ldots \ldots \ldots \ldots \ldots \ldots . . \ldots \ldots$

Aveline v. Whisson, 4 Manning \& Granger $801 \ldots \ldots \ldots \ldots \ldots \ldots 233$

A very $\nabla$. Everett, $110 \mathrm{New}$ York $317 \ldots \ldots \ldots \ldots \ldots \ldots \ldots \ldots . \ldots \ldots 14$

Axtell's Case, 95 Michigan 244...................... 325

A yer v. Brick Co., 157 Massachusetts $57 . \ldots \ldots \ldots \ldots \ldots \ldots \ldots \ldots . \ldots 208$

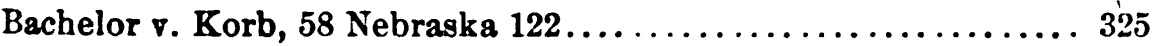

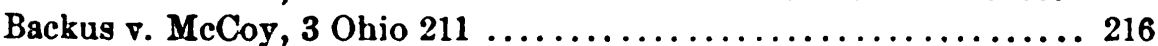

Bacon v. Sandberg, 179 Massachusetts $396 \ldots \ldots \ldots \ldots \ldots \ldots \ldots . . \ldots 229$

v. Thornton, 16 Utah $138 \ldots \ldots \ldots \ldots \ldots \ldots \ldots \ldots \ldots . \ldots . \ldots 193$

Bader $\nabla$. Dyer, 106 Iowa 715 ... ........................ 165

Bagby v. Emberson, 79 Missouri $139 \ldots \ldots \ldots \ldots \ldots \ldots \ldots \ldots \ldots . \ldots 65$

Bailey v. Platte \&c. Canal Co., 12 Colorado 230.............. 402

Baird v. Baird, 145 New York $659 \ldots \ldots \ldots \ldots \ldots \ldots \ldots \ldots \ldots 66$

Baker v. Atchison \&c. R. Co. 122 Missouri $396 \ldots \ldots \ldots \ldots \ldots \ldots . \ldots 373$

v. Bradt, 168 Massachusetts $58 \ldots \ldots \ldots \ldots \ldots \ldots \ldots \ldots \ldots . \ldots \ldots$

v. Haskell, 47 New Hampshire $479 \ldots \ldots \ldots \ldots \ldots \ldots \ldots \ldots . \ldots 308$

v. Kennett, 54 Missouri $82 \ldots \ldots \ldots \ldots \ldots \ldots \ldots \ldots \ldots \ldots \ldots \ldots \ldots$

v. Mather, 25 Michigan $51 \ldots \ldots \ldots \ldots \ldots \ldots \ldots \ldots \ldots \ldots .49$

v. Stone, 136 Massachusetts $405 \ldots \ldots \ldots \ldots \ldots \ldots \ldots \ldots \ldots . \ldots . \ldots . \ldots 20$

v. Westcott, 73 Texas $129 \ldots \ldots \ldots \ldots \ldots \ldots \ldots \ldots \ldots \ldots . \ldots \ldots$

จ. Whiting, 3 Sumner (United States) $475 \ldots \ldots \ldots \ldots \ldots \ldots . \ldots 15$

Baldwin v. Emery, 89 Maine $496 \ldots \ldots \ldots \ldots \ldots \ldots \ldots \ldots \ldots . \ldots \ldots$

v. Erie Shooting Club, 127 Michigan $659 . \ldots \ldots \ldots \ldots \ldots \ldots . \ldots 112$

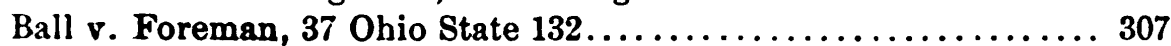

v. Houston, 11 Oklahoma $233 \ldots \ldots \ldots \ldots \ldots \ldots \ldots \ldots . \ldots . \ldots . \ldots 2$

Ballance $\nabla$. Peoria, 180 Illinois $29 \ldots \ldots \ldots \ldots \ldots \ldots \ldots \ldots \ldots . \ldots 9$

Baltimore v. Chester, 53 Vermont 315................... 414

Bangor v. Warren, 34 Maine $324 \ldots \ldots \ldots \ldots \ldots \ldots \ldots \ldots \ldots \ldots \ldots \ldots$

Bank v. Delano, 48 New York $326 \ldots \ldots \ldots \ldots \ldots \ldots \ldots \ldots \ldots \ldots, 49$

v. Fleming, 63 Kansas $139 \ldots \ldots \ldots \ldots \ldots \ldots \ldots \ldots \ldots \ldots . \ldots \ldots$

v. O'Brien, 94 Tennessee $38 \ldots \ldots \ldots \ldots \ldots \ldots \ldots \ldots \ldots \ldots . \ldots \ldots$

Bank of Benson v. Hove, 45 Minnesota $40 \ldots \ldots \ldots \ldots \ldots \ldots \ldots 286$

Bank of Boone v. Radtke, 87 Iowa $363 \ldots \ldots \ldots \ldots \ldots \ldots \ldots \ldots . \ldots \ldots$

Bank of Greenbrier $\nabla$. Effingham, 51 West Virginia $267 \ldots \ldots \ldots \ldots 154$

Bank of Louisville v. Gray, 84 Kentucky $565 \ldots \ldots \ldots \ldots \ldots \ldots . \ldots 377$

Bank of Woodland $v$. Oberhaus, 125 California $320 \ldots \ldots \ldots \ldots$ 287, 38.5

Banks $\nabla$. Ogden, 2 Wallace (United States) $57 \ldots \ldots \ldots \ldots \ldots \ldots . \ldots 1$

v. Poitiaux, 3 Rand (United States) $136 \ldots \ldots \ldots \ldots \ldots \ldots .405$

Banzer v. Banzer, 156 New York 429.................... 157

Bardgley v. Bank, 113 Iowa $216 \ldots \ldots \ldots \ldots \ldots \ldots \ldots \ldots \ldots . \ldots 287$

Barker v. Southern R. Co., 125 North Carolina $595 \ldots \ldots \ldots \ldots \ldots 80$

Barnard v. Gantz, 140 New York $249 \ldots \ldots \ldots \ldots \ldots \ldots \ldots . \ldots 246$

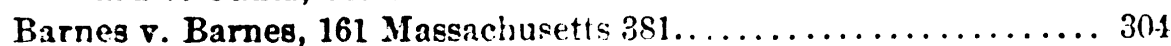




\section{[References are to Sections.]}

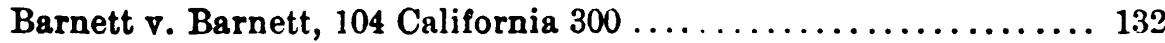

v. Bull, 81 Kentucky $127 \ldots \ldots \ldots \ldots \ldots \ldots \ldots \ldots \ldots \ldots . \ldots . \ldots . \ldots . \ldots 28$

Barney v. Pforr, 117 California 56..................... 249

v. Keokuk, 94 United States $324 \ldots \ldots \ldots \ldots \ldots \ldots \ldots \ldots$ 108, 109

Barnsdall v. Boley (United States), 119 Federal $191 \ldots \ldots \ldots \ldots \ldots . \ldots 37$

Barnum v. LeMaster (Tennessee), 75 South western 1045

Barrett . Cox, 112 Michigan 220................ 395, 398, 399

v. Davis, 104 Missouri $549 \ldots \ldots \ldots \ldots \ldots \ldots \ldots \ldots \ldots \ldots . \ldots \ldots$

Barron v. Mercure (Michigan) 93 North western 1071......... 303

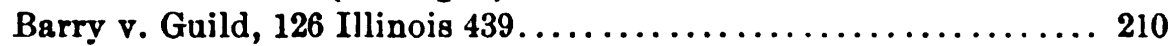

Bartels v. People, 152 Illinois $557 \ldots \ldots \ldots \ldots \ldots \ldots \ldots \ldots \ldots \ldots . \ldots \ldots 2$

Bartlett $\nabla$. Bartlett, 34 West Virginia 33................. 50

v. Cowles, 15 Gray (Massachusetts) $445 \ldots \ldots \ldots \ldots \ldots \ldots \ldots . \ldots . \ldots 321$

$\checkmark$ Drake, 100 Massachusetts $174 \ldots . \ldots \ldots \ldots \ldots \ldots \ldots \ldots . . . . .238$

v. Williams, 27 Indiana Appellate $637 \ldots \ldots \ldots \ldots \ldots \ldots \ldots . \ldots 363$

Barton v. Drake, 21 Minnesota 299...................... 385

Bason v. Mining Co., 90 North Carolina 417................ 240

Bassett v. Hawk, 114 Pennsylvania State $502 \ldots \ldots \ldots \ldots \ldots \ldots . \ldots 239$

Batchelor v. Brereton, 112 United States 396............ 37, 364

Batley v. Foerderer, 162 Pennsylvania State $460 \ldots \ldots \ldots \ldots \ldots \ldots 200$

Baum v. Lynn, 72 Mississippi $932 . \ldots \ldots \ldots \ldots \ldots \ldots \ldots \ldots \ldots .63$

Bay v. Posner, 78 Maryland $42 \ldots \ldots \ldots \ldots \ldots \ldots \ldots \ldots \ldots \ldots, 38$

Beach $\nabla$. Miller, 51 Illinois 206....................... 203

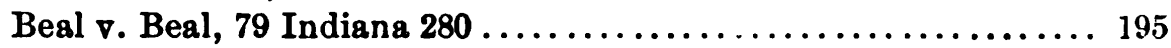

v. Blair, 33 Iowa $318 \ldots \ldots \ldots \ldots \ldots \ldots \ldots \ldots \ldots \ldots \ldots \ldots \ldots$

v. Harmon, 38 Missouri 435........................ 327

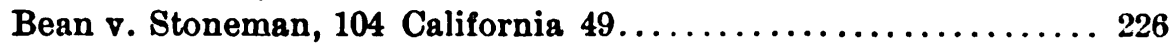

Beard v. Johnson, 87 Alabama $729 \ldots \ldots \ldots \ldots \ldots \ldots \ldots \ldots \ldots . \ldots . \ldots 38$

Beardsley v. Hotchkiss, 96 New York 201.................. 319

v. Knight, 10 Vermont $185 \ldots \ldots \ldots \ldots \ldots \ldots \ldots \ldots \ldots \ldots . \ldots \ldots$

Beasley v. Beasley, 180 Illinois $163 \ldots \ldots \ldots \ldots \ldots \ldots \ldots \ldots \ldots \ldots . \ldots . \ldots . \ldots . \ldots$

v. Phillips, 20 Indiana Appellate $185 \ldots \ldots \ldots \ldots \ldots \ldots \ldots . \ldots \ldots 212$

Beattie v. Crewdson, 124 California $57 \ldots \ldots \ldots \ldots \ldots \ldots \ldots \ldots . \ldots 40$

Beckel v. Pettigrew, 6 Ohio State $247 \ldots \ldots \ldots \ldots \ldots \ldots \ldots \ldots \ldots . \ldots \ldots$

Beckman $\nabla$. Kreamer, 43 Illinois 447...................... 107

Beckwith $\nabla$. Howard, 6 Rhode Island $8 \ldots \ldots \ldots \ldots \ldots \ldots \ldots .24$

Bedford $\nabla$. British Museum, 2 Mylne and Keen $552 . \ldots \ldots \ldots \ldots .229$

Bedford Lodge v. Lentz, 194 Penngylvania State $399 \ldots \ldots \ldots \ldots \ldots 132$

Beeson v. Green, 103 Iowa $406 \ldots \ldots \ldots \ldots \ldots \ldots \ldots \ldots \ldots \ldots \ldots . \ldots \ldots$

v. Patterson, 36 Pennsylvania State $24 . \ldots \ldots \ldots \ldots \ldots \ldots \ldots$ 24

Beezley v. Phillips (United States), 117 Federal $105 \ldots \ldots \ldots \ldots \ldots$. $32-$

Beinlein v. Johns, 102 Kentucky $570 \ldots \ldots \ldots \ldots \ldots \ldots \ldots \ldots . \ldots \ldots$

Bell v. Bell, 84 Alabama $64 \ldots \ldots \ldots \ldots \ldots \ldots \ldots \ldots \ldots \ldots \ldots \ldots$

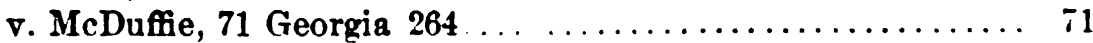

Bellefontaine Imp. Co. $\nabla$. Neidringhaus, 181 Illinois $426 \ldots \ldots \ldots 106,107$ 
[References are to Sections.]

Benedict $\nabla$. Jones, 129 North Carolina 470................ 293

v. Torrent, 83 Michigan $181 \ldots \ldots \ldots \ldots \ldots \ldots \ldots \ldots \ldots \ldots . \ldots \ldots$

Benevolent Society v. Murray, 145 Missouri $622 \ldots \ldots \ldots \ldots \ldots \ldots 46$

Bennet v. Davis, 2 Peere Williams $316 \ldots \ldots \ldots \ldots \ldots \ldots \ldots \ldots$. 352

Bennett v. Harms, 51 Wisconsin $251 \ldots \ldots \ldots \ldots \ldots \ldots \ldots \ldots \ldots . \ldots . \ldots . \ldots 37$

v. Pierce, 45 West Virginia $654 \ldots \ldots \ldots \ldots \ldots \ldots \ldots \ldots . \ldots 194,363$

จ. Pierce, 50 West Virginia $604 \ldots \ldots \ldots \ldots \ldots \ldots \ldots \ldots \ldots . \ldots . \ldots . \ldots 158$

v. Robinson, 27 Michigan 26.................... 431

v. Waller, 23 Illinois $97 \ldots \ldots \ldots \ldots \ldots \ldots \ldots \ldots \ldots \ldots . \ldots \ldots$

Bengieck v. Cook, 110 Missouri 173..................... 65

Bentley $\nabla$. DeForest, 2 Ohio $221 \ldots \ldots \ldots \ldots \ldots \ldots \ldots \ldots \ldots \ldots$. 0

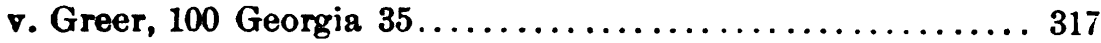

Benton v. Elizabeth, 61 New Jersey Law $411 \ldots \ldots \ldots \ldots \ldots \ldots 406$

Bernard Township $\nabla$. Stebbins, 109 United States $341 \ldots \ldots \ldots \ldots$ 245

Bernstein v. Humes, 60 Alabama 528.................. 415

Beronio v. Ventura \&c. Co., 129 California $232 \ldots \ldots \ldots \ldots \ldots \ldots . . . \ldots 84$

Berrigan v. Fleming, 70 Tennessee $271 \ldots \ldots \ldots \ldots \ldots \ldots \ldots \ldots . \ldots \ldots$

Berry $\nabla$. Meir, 70 Arkansas $129 \ldots \ldots \ldots \ldots \ldots \ldots \ldots \ldots \ldots \ldots . \ldots \ldots 4$

v. Seawall (United States), 65 Federal $742 \ldots \ldots \ldots \ldots \ldots \ldots 161$

จ. Tennessee \&c. R. Co., 134 Alabama $618 \ldots \ldots \ldots \ldots \ldots \ldots . . \ldots 18$

Berryman v. Schumaker, 67 Texas $312 \ldots \ldots \ldots \ldots \ldots \ldots \ldots \ldots . \ldots 183$

Bertschy v. Bank, 89 Wisconsin $473 \ldots \ldots \ldots \ldots \ldots \ldots \ldots \ldots . \ldots 377$

Bethell v. Bethell, 54 Indiana 428; 92 Indiana $318 \ldots \ldots \ldots \ldots 190,213$

Betz v. Bryan, 39 Ohio State $320 \ldots \ldots \ldots \ldots \ldots \ldots \ldots \ldots \ldots .216$

Bexar Building Association v. Heady, 21 Texas Civil Appeals

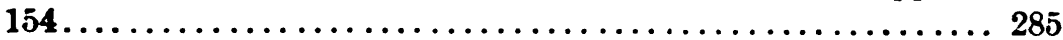

Bidwell v. Sullivan, 17 New York Appellate Division $629 \ldots \ldots \ldots 272$

Biles v. T. O. \& G. H. R. Co., 5 Washington $509 \ldots \ldots \ldots \ldots \ldots \ldots 123$

Bingham v. Weiderwax, 1 New York $509 \ldots \ldots \ldots \ldots \ldots \ldots \ldots, 403$

Bingler v. Bowman, 194 Penngylvania State $210 \ldots \ldots \ldots \ldots \ldots . \ldots 65$

Birchall $\nabla$. Ashton, 40 Chancery Division 437............. 300

Bissell v. Hively, 123 Michigan $106 \ldots \ldots \ldots \ldots \ldots \ldots \ldots \ldots \ldots . \ldots . \ldots$

Blagborne v. Hunger, 101 Michigan $375 \ldots \ldots \ldots \ldots \ldots \ldots \ldots \ldots 245$

Black v. Singley, 91 Michigan $50 \ldots \ldots \ldots \ldots \ldots \ldots \ldots \ldots \ldots . \ldots \ldots$

Blackburn v. Nelson, 100 California $336 \ldots \ldots \ldots \ldots \ldots \ldots \ldots \ldots . \ldots 7$

Blackman v. Henderson, 116 Iowa $578 \ldots \ldots \ldots \ldots \ldots \ldots \ldots \ldots . . \ldots 3$

Blair v. Brans, 8 Colorado $397 \ldots \ldots \ldots \ldots \ldots \ldots \ldots \ldots \ldots \ldots . . \ldots 1$

v. Osborne, 84 North Carolina 417.................. 133

Blaisdell v. Leach, 101 California $405 \ldots \ldots \ldots \ldots \ldots \ldots \ldots \ldots . . \ldots 238$

Blakeley $\nabla$. Adams (Kentucky), 68 Southwestern $393 \ldots \ldots \ldots \ldots 127$

Blanchard $\nabla$. Railroad, 31 Michigan $43 \ldots \ldots \ldots \ldots \ldots \ldots \ldots \ldots . \ldots \ldots$

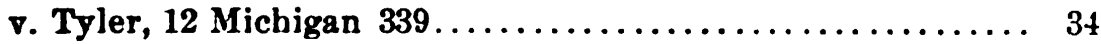

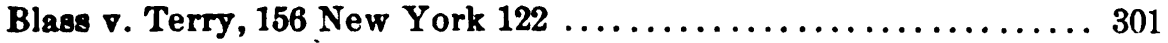

Blight $\nabla$. Schenck, 10 Pennsylvania State $285 \ldots \ldots \ldots \ldots \ldots \ldots \ldots . \ldots 10$

Blondeau $\nabla$. Sheridan, 81 Missouri $545 \ldots \ldots \ldots \ldots \ldots \ldots \ldots \ldots . \ldots \ldots$

Blood v. Goodrich, 9 Wendall (New York) 68............. 245

v. Land Co., 113 California $221 . \ldots \ldots \ldots \ldots \ldots \ldots \ldots \ldots \ldots .249$ 


\section{[References are to Sections.]}

Bloomer v. Henderson, 8 Michigan $395 \ldots \ldots \ldots \ldots \ldots \ldots \ldots \ldots$ 43I

Bloomingdale v. Chittenden, 74 Michigan $698 \ldots \ldots \ldots \ldots \ldots \ldots . \ldots 315$

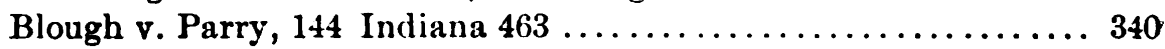

Blumer v. Albright, 64 Nebraska $249 \ldots \ldots \ldots \ldots \ldots \ldots \ldots \ldots . \ldots 383$

Blythe v. Hinckley, 127 California $431 \ldots \ldots \ldots \ldots \ldots \ldots \ldots, 412$

v. Hinckley, 180 United States $333 \ldots \ldots \ldots \ldots \ldots \ldots \ldots \ldots 412$

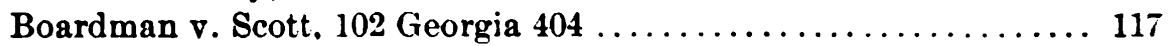

Boddie v. Bush, 136 Alabama $560 \ldots \ldots \ldots \ldots \ldots \ldots \ldots \ldots 336,337$

Bohannon v. Travis, 94 Kentucky $59 \ldots \ldots \ldots \ldots \ldots \ldots \ldots \ldots . \ldots \ldots$

Bolio v. Marvin, 130 Michigan $82 \ldots \ldots \ldots \ldots \ldots \ldots \ldots \ldots \ldots \ldots . \ldots \ldots$

Bolles v. Beach, 22 New Jersey Law $680 \ldots \ldots \ldots \ldots \ldots \ldots \ldots .65$

Bond v. Bond, 7 Allen (Massachusetts) $1 \ldots \ldots \ldots \ldots \ldots \ldots \ldots, 342$

Bone v. Tyrrell, 113 Missouri $175 \ldots \ldots \ldots \ldots \ldots \ldots \ldots \ldots \ldots . \ldots . \ldots . \ldots . \ldots$

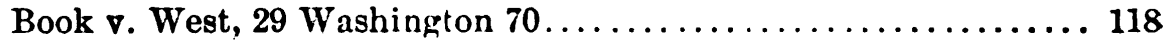

Booker v. Tarwater, 138 Indiana $385 \ldots \ldots \ldots \ldots \ldots \ldots \ldots \ldots .40$

Bool v. Mix, 17 Wendall (New York) $119 \ldots \ldots \ldots \ldots \ldots \ldots . \ldots . \ldots . \ldots . \ldots . \ldots . \ldots 22$

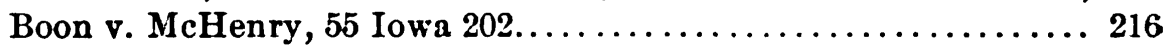

Boothroyd v. Engles, 23 Michigan 19..............234, 237, 271

Boreel v. Lawton, 90 New York $293 \ldots \ldots \ldots \ldots \ldots \ldots \ldots \ldots . \ldots \ldots$

Boreham v. Byrne, 83 California $23 \ldots \ldots \ldots \ldots \ldots \ldots \ldots \ldots . \ldots . \ldots 2$

Borer $\nabla$. Lange, 44 Minnesota $281 \ldots \ldots \ldots \ldots \ldots \ldots \ldots \ldots \ldots . \ldots 3$

Borland's Lessee v. Marshall, 2 Ohio State $308 \ldots \ldots \ldots \ldots \ldots \ldots .421$

Boston v. Richardson, 13 Allen (Massachusetts) $146 \ldots \ldots \ldots \ldots .88$

v. Richardson, 105 Massachusetts $351 \ldots \ldots \ldots \ldots \ldots \ldots \ldots . \ldots 1$

Bostick v. Williams, 36 Illinois $65 \ldots \ldots \ldots \ldots \ldots \ldots \ldots \ldots \ldots . \ldots \ldots$

Bourne v. Bourne, 92 Kentucky $211 \ldots \ldots \ldots \ldots \ldots \ldots \ldots \ldots \ldots .61$

Bowdoin College v. Merritt (United States), 75 Federal $480 \ldots \ldots \ldots 338$

Bowen v. Beck, 94 New York $86 \ldots \ldots \ldots \ldots \ldots \ldots \ldots \ldots \ldots . \ldots \ldots$

v. Chase, 94 United States $812 \ldots \ldots \ldots \ldots \ldots \ldots \ldots \ldots \ldots \ldots \ldots \ldots \ldots \ldots$

Bowler $\nabla$. Bowler, 176 Illinois $541 \ldots \ldots \ldots \ldots \ldots \ldots \ldots \ldots \ldots$

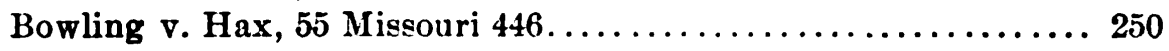

Bowne v. Walcott, 1 North Dakota $497 \ldots \ldots \ldots \ldots \ldots \ldots \ldots \ldots . \ldots 2$

Boyd v. De La Montague, 73 New York $498 \ldots \ldots \ldots \ldots \ldots \ldots . \ldots 369$

v. Haseltine, 110 Missouri $203 \ldots \ldots \ldots \ldots \ldots \ldots \ldots \ldots \ldots 212$

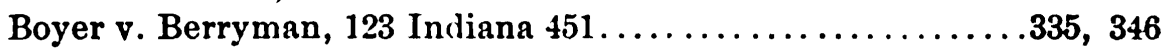

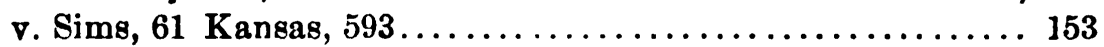

Bozeman v. Browning, 31 Arkansas $364 \ldots \ldots \ldots \ldots \ldots \ldots \ldots \ldots . \ldots 319$

Bradley v. Railroad, 91 Missouri $493 \ldots \ldots \ldots \ldots \ldots \ldots \ldots . . .37,364$

v. Walker, 138 New York $291 \ldots \ldots \ldots \ldots \ldots \ldots \ldots \ldots \ldots \ldots \ldots$

Bradshaw v. Van Winkle, 133 Indiana $134 \ldots \ldots \ldots \ldots \ldots \ldots \ldots 320$

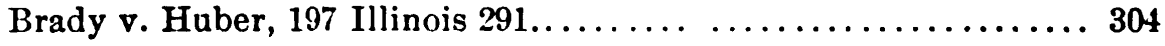

v. Spurck, 27 Illinois $478 \ldots \ldots \ldots \ldots \ldots \ldots \ldots \ldots \ldots \ldots .220$

Bragdon v. Blaisdell, 91 Maine $326 \ldots \ldots \ldots \ldots \ldots \ldots \ldots \ldots \ldots . \ldots \ldots$

Bramberry's Estate, 156 Pennsylvania State 628 ............ 164

Branch v. Jesup, 106 United States $468 \ldots \ldots \ldots \ldots \ldots \ldots \ldots \ldots . \ldots 407$

v. Polk, 61 Arkansas $388 \ldots \ldots \ldots \ldots \ldots \ldots \ldots \ldots \ldots \ldots \ldots$

Brasfield $\nabla$. Brasfield, 96 Tennessee $580 \ldots \ldots \ldots \ldots \ldots \ldots \ldots \ldots . \ldots \ldots 1$ 


\section{[References are to Sections.]}

Brasington v. Hanson, 149 Pennsylvania State $289 \ldots \ldots \ldots \ldots \ldots 138$

Brastow v. Rockport Ice Co., 77 Maine $100 \ldots \ldots \ldots \ldots \ldots \ldots \ldots 117$

Brattle Square Church v. Grant, 3 Grav (Massachusetts) $142 \ldots \ldots 175$

Bray v. Adams, 114 Missouri $486 \ldots \ldots \ldots \ldots \ldots \ldots \ldots \ldots \ldots . \ldots \ldots$

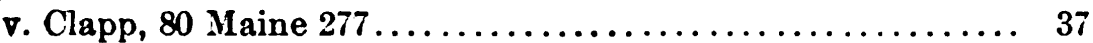

Breiten wischer v. Clough, 111 Michigan $6 \ldots \ldots \ldots \ldots \ldots \ldots \ldots 61$

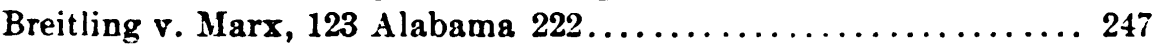

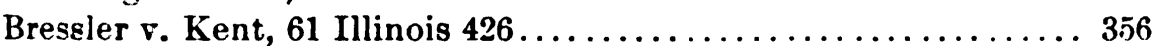

Brew v. Van Deman, 6 Heiskell (Tennessee) $433 \ldots \ldots \ldots \ldots \ldots \ldots 223$

Brewery Co. v. Primas, 163 Illinois 652........ 179, 182, 229, 230

Bricker v. Bricker, 11 Ohio State $240 \ldots \ldots \ldots \ldots \ldots \ldots \ldots \ldots 208$

Brigham v. Fayerweather, 144 Massachusette $48 \ldots \ldots \ldots \ldots 337,346$

v. Palmer, 3 Allen (Massachusetts) $450 \ldots \ldots \ldots \ldots \ldots \ldots \ldots 250$

Brine v. Insurance Co., 96 United States $627 \ldots \ldots \ldots \ldots \ldots \ldots \ldots 4$

Bristow v. Cormican, 3 Appeal Cases $641 \ldots \ldots \ldots \ldots \ldots \ldots \ldots . \ldots \ldots$

Broadwell v. Phillips, 30 Ohio State $255 \ldots \ldots \ldots \ldots \ldots \ldots \ldots \ldots . \ldots \ldots$

Brockway $\nabla$. Harrington, 82 Iowa $23 \ldots \ldots \ldots \ldots \ldots \ldots \ldots \ldots \ldots$

Brokken v. Baumann, 10 North Dakota 453................ 382

Bromberg v. Smee, 130 Alabama $601 \ldots \ldots \ldots \ldots \ldots \ldots \ldots \ldots \ldots, 78$

Brooklyn Park Commissioners v. Armstrong, 45 New York $234 . . .4407$

Brophy v. Richeson, 137 Indiana $114 \ldots \ldots \ldots \ldots \ldots \ldots \ldots \ldots \ldots$

Brothers v. Bank, 84 Wisconsin $381 \ldots \ldots \ldots \ldots \ldots \ldots \ldots \ldots . \ldots . \ldots . \ldots 4$

Brown $\nabla$. Bank, 148 Massachusetts $300 \ldots \ldots \ldots \ldots \ldots \ldots \ldots . \ldots 208$

จ. Barboo, 98 Wisconsin $273 \ldots \ldots \ldots \ldots \ldots \ldots \ldots \ldots \ldots . \ldots 8$

v. Brown, 39 Michigan $792 \ldots \ldots \ldots \ldots \ldots \ldots \ldots \ldots \ldots \ldots . \ldots \ldots$

v. Brown, 61 Texas 56............................ 298

v. Farmers' Supply Co., 23 Oregon $541 \ldots \ldots \ldots \ldots \ldots \ldots \ldots 240$

v. Hartman, 57 Nebraska $341 \ldots \ldots \ldots \ldots \ldots \ldots \ldots \ldots \ldots . \ldots \ldots \ldots$

v. Jordhal, 32 Minnesota $135 \ldots \ldots \ldots \ldots \ldots \ldots \ldots \ldots \ldots \ldots \ldots \ldots$

v. Mattocks, 103 Pennsylvania State $16 \ldots \ldots \ldots \ldots \ldots \ldots \ldots . \ldots \ldots$

v. Parker, 127 Michigan $390 \ldots \ldots \ldots \ldots \ldots \ldots \ldots \ldots \ldots \ldots . \ldots \ldots \ldots \ldots$

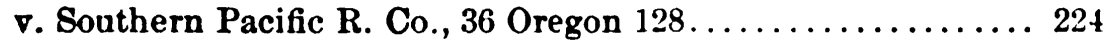

v. Sims, 22 Indiana Appellate $317 \ldots \ldots \ldots \ldots \ldots \ldots \ldots \ldots$ 425

v. Westerfield, 47 Nebraska $399 \ldots \ldots \ldots \ldots \ldots \ldots \ldots \ldots \ldots . \ldots . \ldots 7$

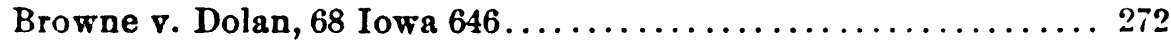

Broyles v. Cox, 153 Missouri $242 \ldots \ldots \ldots \ldots \ldots \ldots \ldots \ldots \ldots . \ldots . \ldots 380$

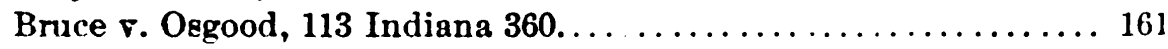

Bruckner's Lessee v. Lawrence, 1 Douglass (Michigan) $19 \ldots \ldots 415$

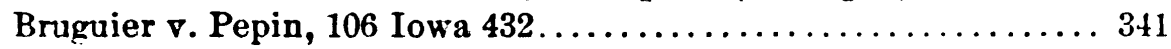

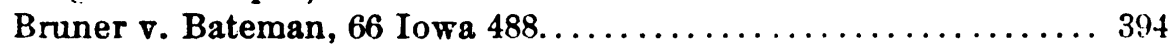

Brunswick Gas Light Co. v. United Gas Co., 85 Maine 532 ..... 407

Bryan v. Ramirez, 8 California $462 \ldots \ldots \ldots \ldots \ldots \ldots . . \ldots \ldots . . . .269$

Bryant v. Richardson, 126 Indiana $145 \ldots \ldots \ldots \ldots \ldots \ldots \ldots . \ldots 270$

Buchanan v. Hazzard, 95 Pennsylvania State $240 \ldots \ldots \ldots \ldots . \ldots 364$

Buchanan $\nabla$. Hubbard, 96 Indiana $1 \ldots \ldots \ldots \ldots \ldots \ldots \ldots \ldots \ldots \ldots \ldots$

Buck $\nabla$. Squiers, 22 Vermont $494 \ldots \ldots \ldots \ldots \ldots \ldots \ldots \ldots \ldots . \quad 89$

Buckey $\mathbf{v}$. Buckey, 38 West Virginia $168 \ldots \ldots \ldots \ldots \ldots \ldots \ldots \ldots . \ldots \ldots$ 


\section{[References are to Sections.]}

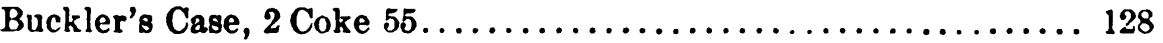

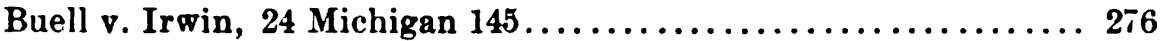

Building Association v. Scunlan, 144 Indiana $11 \ldots \ldots \ldots \ldots \ldots . \ldots 370$

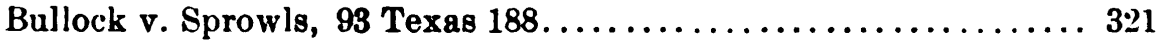

Bumstead v. Cook, 169 Massachusetts $410 \ldots \ldots \ldots \ldots \ldots \ldots \ldots . \ldots 118$

Bunnell v. Bunnell (Kentucky), 64 Southwestern 420.......... 298

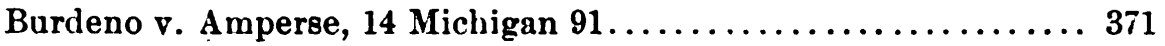

Burdett v. Spilsbury, 6 Manning \& Granger 456............ 250

Burdis v. Burdis, 96 Virginia $81 \ldots \ldots \ldots \ldots \ldots \ldots \ldots \ldots \ldots . \ldots \ldots 2$

Burk v. Hill, 48 Indiana $52 \ldots \ldots \ldots \ldots \ldots \ldots \ldots \ldots \ldots \ldots . \ldots 203$

v. Sproat, 96 Michigan 404.......................... 308

Burke v. McCowen, 115 California $481 \ldots \ldots \ldots \ldots \ldots \ldots \ldots \ldots . . \ldots 6$

Burkett $\nabla$. Burkett, 78 Caiifornia $310 \ldots \ldots \ldots \ldots \ldots \ldots \ldots \ldots . . \ldots 400$

Burling v. King, 96 Barbour (New York) 639............... 245

Burnap v. Sharpsteen, 149 Illinois 225................... 310

Burnett v. Burnett, 17 South Carolina 545 ................. 143

Burnham v. Kidwell, 113 Illinois $425 \ldots \ldots \ldots \ldots \ldots \ldots \ldots \ldots \ldots . \ldots 33$

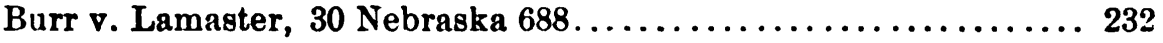

Burrows v. Pickens, 129 Alabama $648 \ldots \ldots \ldots \ldots \ldots \ldots \ldots \ldots 363,366$

Burton v. Perry, 146 Illinois $71 \ldots \ldots \ldots \ldots \ldots \ldots \ldots \ldots \ldots \ldots . \ldots 21$

Bush v. Genther, 174 Pennsylvania State $154 \ldots \ldots \ldots \ldots \ldots \ldots \ldots . \ldots 304$

Butler v. Barnes, 60 Connecticut $170 \ldots \ldots \ldots \ldots \ldots \ldots \ldots \ldots .217$

v. Grand Rapids \& Indiana R. Co., 85 Michigan 246...... 101, 107

v. Huestis, 68 Illinois $594 \ldots \ldots \ldots \ldots \ldots \ldots \ldots \ldots \ldots \ldots \ldots . \ldots \ldots$

v. Seward, 10 Allen (Massachusetts) $466 \ldots \ldots \ldots \ldots \ldots \ldots \ldots . \ldots \ldots$

Butler \& Baker's Case, 3 Coke 26...................... 300

Butrick v. Tilton, 141 Massachusetts $93 \ldots \ldots \ldots \ldots \ldots \ldots \ldots \ldots \ldots$

Butterfield v. Beal, 3 Indiana 203 ..................... 294

Butterworth \& Lowe v. Kritzer Milling Co., 115 Michigan 1..... 405

Byers v. Byers, 183 Pennsylvania State $509 \ldots \ldots \ldots \ldots \ldots \ldots \ldots . \ldots 161$

v. Wheatley, 62 Tennessee $160 \ldots \ldots \ldots \ldots \ldots \ldots \ldots \ldots \ldots .50$

Cable v. Cable, 146 Pennsylvania State $451 \ldots \ldots \ldots \ldots \ldots \ldots \ldots 261$

Cadematori v. Gauger, 160 Missouri $352 \ldots \ldots \ldots \ldots \ldots \ldots \ldots \ldots . \ldots \ldots$

Cagle v. Parker, 97 North Carolina $271 \ldots \ldots \ldots \ldots \ldots \ldots \ldots \ldots .242$

Caldwell v. Manufacturing Co., 121 North Carolina $339 \ldots \ldots \ldots \ldots 249$

California Canneries Co. v. Scatena, 117 California 447........ 235

Fruit Transportation Co. $\nabla$.Anderson (United States), 79 Federal 404. 390

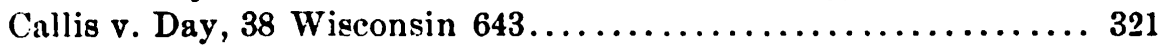

Cameron v. Calkins, 44 Michigan $533 \ldots \ldots \ldots \ldots \ldots \ldots \ldots \ldots \ldots . \ldots \ldots$

v. Gray, 202 Pennsylvania $566 \ldots \ldots \ldots \ldots \ldots \ldots \ldots \ldots \ldots . \ldots \ldots$

Camp v. Carpenter, 52 Michigan $375 \ldots \ldots \ldots \ldots \ldots \ldots \ldots \ldots . \ldots \ldots$

Campbell v. Equitable Loan \&c. Co. (South Dakota), 94 Northwest-

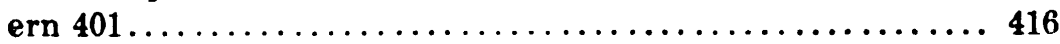

จ. Everts, 47 Texas $102 \ldots \ldots \ldots \ldots \ldots \ldots \ldots \ldots \ldots \ldots \ldots . \ldots 21$

Canal Co. v. Russell, 68 Illinois $426 \ldots \ldots \ldots \ldots \ldots \ldots \ldots \ldots 268,271$

Candee v. Hayward, 37 New York $653 \ldots \ldots \ldots \ldots \ldots \ldots \ldots \ldots .419$ 
[References are to Sections.]

Caperton v. Hall, 83 Alabama $171 \ldots \ldots \ldots \ldots \ldots \ldots \ldots \ldots \ldots \ldots . \ldots 262$

Caple v. Switzer, 122 Michigan $636 \ldots \ldots \ldots \ldots \ldots \ldots \ldots \ldots \ldots . \ldots . \ldots . \ldots 189$

Cardinal v. Hadley, 158 Massachusetts $352 \ldots \ldots \ldots \ldots \ldots \ldots \ldots . \ldots 4$

Carder v. Culbertson, 100 Missouri 269.................... 328

Carnagie v. Diven, 31 Oregon $366 \ldots \ldots \ldots \ldots \ldots \ldots \ldots \ldots \ldots \ldots . \ldots \ldots$

Carnall v. Wilson, 21 Arkansas $62 \ldots \ldots \ldots \ldots \ldots \ldots \ldots \ldots \ldots \ldots \ldots$

Carney v. Hopple, 17 Ohio State 39................... 279

Carpenter v. Bell, 96 Tennessee $294 \ldots \ldots \ldots \ldots \ldots \ldots \ldots \ldots \ldots, 7$

v. Carpenter, 126 Michigan $217 \ldots \ldots \ldots \ldots \ldots \ldots \ldots \ldots \ldots 251$

v. Dexter, 8 Wallace (United States) $513 \ldots \ldots \ldots \ldots \ldots .278,289$

v. Van Olinder, 127 Illinois $42 \ldots \ldots \ldots \ldots \ldots \ldots \ldots \ldots \ldots . \ldots \ldots$

Carr v. Maltby, 165 New York $557 \ldots \ldots \ldots \ldots \ldots \ldots \ldots \ldots \ldots \ldots$

v. Moore (Iowa), 93 North western $52 \ldots \ldots \ldots \ldots \ldots \ldots \ldots$. $\ldots 3,117$

จ. Winlock, 109 Kentucky $488 \ldots \ldots \ldots \ldots \ldots \ldots \ldots \ldots \ldots . \ldots 388$

Carroll County Academy v. Gallatin Academy Co., 104 Kentucky

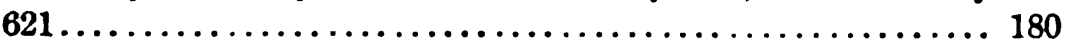

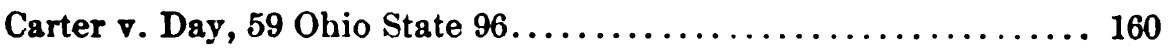

v. Denman, 23 New Jersey Law $260 \ldots \ldots \ldots \ldots \ldots \ldots \ldots . \ldots . \ldots 218$

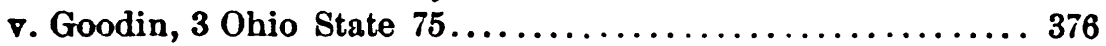

Carty v. Connolly, 91 California $15 \ldots \ldots \ldots \ldots \ldots \ldots \ldots \ldots . \ldots \ldots 1,341$

Cary v. Cary, 189 Pennsylvania State $65 \ldots \ldots \ldots \ldots \ldots \ldots \ldots \ldots .259$

Case v. Kelly, 133 United States $21 \ldots \ldots \ldots \ldots \ldots \ldots \ldots \ldots .404,405$

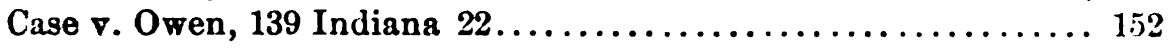

Case Threshing Machine Co. v. Joyce, 89 Tennessee $337 \ldots \ldots \ldots 387$

Cass County Bank v. Weber 83 Iowa $63 . \ldots \ldots \ldots \ldots \ldots \ldots \ldots . \ldots . \ldots . \ldots$

Cassedy v. Jackson, 45 Mississippi 397.................... 419

Cassidy's Succession, 40 Louisiana Annual 827............. 213

Castro v. Geil, 110 California 292...................335, 337

Cassilly $\nabla$. Cassilly, 57 Ohio State $582 \ldots \ldots \ldots \ldots \ldots \ldots \ldots \ldots, 63$

Catlin Co. v. Lloyd, 180 Illinois $398 \ldots \ldots \ldots \ldots \ldots \ldots \ldots \ldots 52,56$

Cazassa v. Cazassa, 92 Tennessee $573 \ldots \ldots \ldots \ldots \ldots \ldots \ldots \ldots . \ldots . \ldots . \ldots 1$

Center v. Banking Co., 185 Illinois $534 . \ldots \ldots \ldots \ldots \ldots \ldots \ldots . \ldots 194,363$

v. Davis, 113 California $307 \ldots \ldots \ldots \ldots \ldots \ldots \ldots \ldots \ldots . \ldots \ldots$

Central Land Co. $\nabla$. Laidley, 32 West Virginia $134 \ldots \ldots \ldots \ldots \ldots . \ldots 365$

Central Transportation Co. v. Pullman's Palace Car Co., 139 United

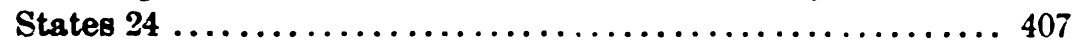

Chaffee $\nabla$. Browne, 109 California $211 \ldots \ldots \ldots \ldots \ldots \ldots \ldots \ldots .66$

Chamberlin $\nabla$. Gleason, 163 New York $214 \ldots \ldots \ldots \ldots \ldots \ldots \ldots . \ldots \ldots$

Chamblee $\nabla$. Broughton, 120 North Carolina $170 \ldots \ldots \ldots \ldots \ldots \ldots 1.17$

Chandler v. Simmons, 97 Massachusetts $508 \ldots \ldots \ldots \ldots \ldots \ldots \ldots . \ldots . \ldots . \ldots$

Chandos v. Mack, 77 Wisconsin 573.................. 101, 106

Chapin $\nabla$. Shafer, 49 New York $407 \ldots \ldots \ldots \ldots \ldots \ldots \ldots \ldots \ldots . \ldots \ldots$

Chapman v. Chapman, 91 Virginia $397 \ldots \ldots \ldots \ldots \ldots \ldots \ldots \ldots .430$

₹. Charter, 46 West Virginia $769 \ldots \ldots \ldots \ldots \ldots \ldots \ldots \ldots \ldots .69$

₹. Jones, 149 Indiana $434 \ldots \ldots \ldots \ldots \ldots \ldots \ldots \ldots \ldots \ldots \ldots . \ldots \ldots$

Chappel $\nabla$. Railroad, 62 Connecticut $195 \ldots \ldots \ldots \ldots \ldots \ldots \ldots \ldots . \ldots \ldots$

Charles $\nabla$. Hastedt, 51 New Jersey Equity $171 \ldots \ldots \ldots \ldots \ldots$ 320, 321 


\section{[References are to Sections.]}

Chrle v. Swayne, 88 Texas $218 \ldots \ldots \ldots \ldots \ldots \ldots \ldots \ldots \ldots \ldots \ldots \ldots$

Chesebro v. Palmer, 68 Connecticut $207 \ldots \ldots \ldots \ldots \ldots \ldots \ldots . \ldots \ldots$

Chevalier v. Carter, 124 Alabama $520 \ldots \ldots \ldots \ldots \ldots \ldots \ldots \ldots . \ldots 18$

Chicago v. Middlebrooke, 143 Illinois $265 \ldots \ldots \ldots \ldots \ldots \ldots \ldots . \ldots 407$

Chicago Co. v. Powell, 120 Michigan $51 \ldots \ldots \ldots \ldots \ldots \ldots \ldots \ldots . \ldots . \ldots 258$

Chicago \&c. R. Co. v. Ward, 128 Illinois $349 \ldots \ldots \ldots \ldots \ldots \ldots . \ldots 125$

v. Titterington, 84 Texas $218 \ldots \ldots \ldots \ldots \ldots \ldots \ldots \ldots \ldots \ldots . \ldots \ldots$

Chick v. Sisson, 95 Michigan $412 \ldots \ldots \ldots \ldots \ldots \ldots \ldots \ldots \ldots \ldots . . \ldots 9$

Child v. Baker, 24 Nebraska $188 \ldots \ldots \ldots \ldots \ldots \ldots \ldots \ldots \ldots . \ldots \ldots 3$

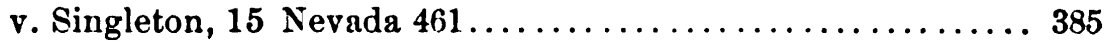

v. Starr, 5 Hill (New York) $369 \ldots \ldots \ldots \ldots \ldots \ldots \ldots \ldots . \ldots \ldots$

Childs v. Rue, 84 Minnesota $323 \ldots \ldots \ldots \ldots \ldots \ldots \ldots \ldots \ldots \ldots . \ldots \ldots$

Chiles v. Conley's Heirs, 2 Dana (Kentucky) $21 \ldots \ldots \ldots \ldots \ldots \ldots 25$

Chippewa Lumber Co. v. Tremper, 75 Michigan $36 \ldots \ldots \ldots \ldots \ldots 187$

Christopher v. Christopher, 64 Maryland $583 \ldots \ldots \ldots \ldots \ldots \ldots \ldots, 60$

Church v. Case, 110 Michigan $621 \ldots \ldots \ldots \ldots \ldots \ldots \ldots \ldots \ldots \ldots 66 . \ldots \ldots$

v. Meeker, 34 Connecticut $421 \ldots \ldots \ldots \ldots \ldots \ldots \ldots \ldots \ldots \ldots \ldots$

Cincinnati \&c. R. Co. v. Iliff, 13 Ohio State $235 \ldots \ldots \ldots \ldots \ldots \ldots 309$

Citizens' Loan Co. v. Witte, 116 Wisconsin $60 \ldots \ldots \ldots \ldots \ldots \ldots . . \ldots 165$

City of. See name of city.

Clapp v. Wilder, 176 Massachusetts $332 \ldots \ldots \ldots \ldots \ldots \ldots 176,179,182$

Clark v. Butts, 73 Minnesota $361 \ldots \ldots \ldots \ldots \ldots \ldots \ldots \ldots \ldots . \ldots \ldots$

v. Clark, 16 Oregon 224..................18, 37, 361, 364

v. Fisher, 54 Kansas $403 \ldots \ldots \ldots \ldots \ldots \ldots \ldots \ldots \ldots \ldots . \ldots 202$

v. Graham, 6 Wheaton (United States) $577 \ldots \ldots \ldots \ldots \ldots \ldots 6$

v. Lineberger, 44 Indiana $223 \ldots \ldots \ldots \ldots \ldots \ldots \ldots \ldots \ldots . \ldots 209$

v. Wilson, 127 Illinois $449 \ldots \ldots \ldots \ldots \ldots \ldots \ldots \ldots \ldots \ldots .291$

Clarke v. Clarke, 178 United States $186 \ldots \ldots \ldots \ldots \ldots \ldots \ldots \ldots .6$

v. Courtney, 5 Peters (United States) $319 \ldots \ldots \ldots \ldots \ldots \ldots .239$

v. Priest, 21 New York Appellate Division $174 \ldots \ldots \ldots \ldots .205$

Clay v. Hammond, 199 Illinois $370 \ldots \ldots \ldots \ldots \ldots \ldots \ldots \ldots \ldots \ldots \ldots \ldots$

Clement v. Bank, 61 Vermont $298 \ldots \ldots \ldots \ldots . \ldots \ldots \ldots \ldots \ldots . . \ldots 219$

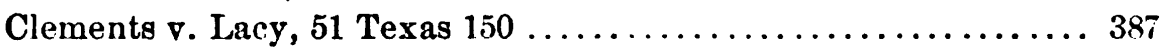

Cleveland v. Burnham, 64 Wisconsin $347 \ldots \ldots \ldots \ldots \ldots \ldots \ldots, 40$

v. Choate, 77 California 73

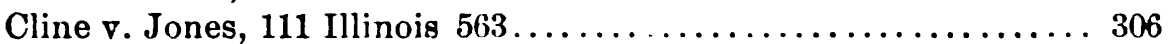

Clink v. Russell, 58 Michigan $242 \ldots \ldots \ldots \ldots \ldots \ldots \ldots \ldots \ldots . \ldots \ldots \ldots \ldots$

Clute v. Fisher, 65 Michigan $48 \ldots \ldots \ldots \ldots \ldots \ldots \ldots \ldots \ldots . \ldots \ldots$

Cobb v. Davenport, 32 New Jersey Law $369 \ldots \ldots \ldots \ldots \ldots \ldots \ldots . \ldots$

v. Taylor, 133 Indiana $605 \ldots \ldots \ldots \ldots \ldots \ldots \ldots \ldots \ldots \ldots \ldots$

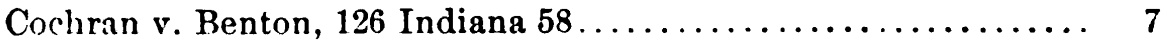

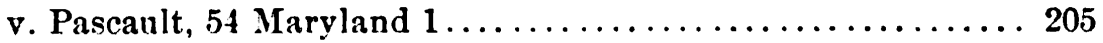

Cocke v. Bailey, 42 Mississippi $81 \ldots \ldots \ldots \ldots \ldots \ldots \ldots \ldots \ldots . \ldots \ldots$

Coe v. Columbus \&c. Railroad Co., 10 Ohio State $372 \ldots \ldots \ldots \ldots$. 407

Colby v. McOmber, 71 Iowa $469 \ldots \ldots \ldots \ldots \ldots \ldots \ldots \ldots \ldots . \ldots \ldots 1$

v. Osgood, 29 Barbour (New York) $249 \ldots \ldots \ldots \ldots \ldots \ldots \ldots .205$ 
Cole v. Cole, 126 Michigan $569 \ldots \ldots \ldots \ldots \ldots \ldots \ldots \ldots \ldots \ldots \ldots . \ldots . \ldots . \ldots 7$

v. Hadley, 162 Massachusetts $579 \ldots \ldots \ldots \ldots \ldots \ldots \ldots \ldots \ldots . \ldots \ldots$

v. The Lake Co., 54 New Hampshire $242 \ldots \ldots \ldots \ldots \ldots \ldots \ldots . \ldots \ldots$

v. Mette, 65 Arkansas $503 \ldots \ldots \ldots \ldots \ldots \ldots \ldots \ldots \ldots \ldots, 45$

Colee v. Colee, 122 Indiana $109 \ldots \ldots \ldots \ldots \ldots \ldots \ldots \ldots \ldots 298,301$

Coleman v. Improvement Co., 94 New York 229 .............. 81

r. Manhattan Beach Co., 94 New York $229 \ldots \ldots \ldots \ldots \ldots \ldots . \ldots 19$

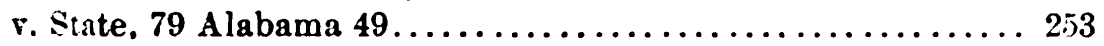

Colgan v. McKeon, 24 New Jersey Law $566 \ldots \ldots \ldots \ldots \ldots \ldots \ldots 410$

Collamore v. Collamore, 158 Massachusetts $74 \ldots \ldots \ldots \ldots \ldots \ldots 143$

Collins v. Asheville Land Co., 128 North Carolina 563.........93, 94

v. Cornwell, 131 Indiana $20 \ldots \ldots \ldots \ldots \ldots \ldots \ldots \ldots \ldots . \ldots \ldots 4$

Colorado Central R. Co. v. Allen, 13 Colorado 229 ............ 363

Commonwealth v. Clemmer, 190 Pennsylvania State $202 \ldots \ldots \ldots .414$

v. Yew York \&c. R. Co., 132 Pennsylvania State $591 \ldots \ldots \ldots .405$

Compton v. White, 86 Michigan 33.................... 301

Concord Manufacturing Co. v. Robertson, 66 New Hampshire 1... 117

Conduitt $\nabla$. Ross, 102 Indiana $166 \ldots \ldots \ldots \ldots \ldots \ldots \ldots \ldots \ldots . \ldots \ldots 232$

Congregational Society $\mathbf{v}$. Stark, 34 Vermont $243 \ldots \ldots \ldots \ldots \ldots 137,174$

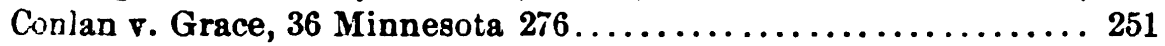

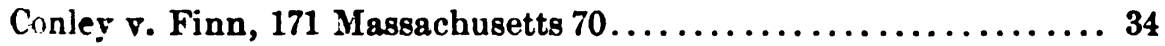

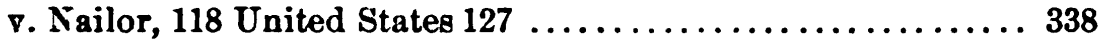

Connecticut Mutual Life Insurance Co. v. Smith, 117 Missouri 261. 404

Conrad v. Long, 33 Michigan $78 \ldots \ldots \ldots \ldots \ldots \ldots \ldots \ldots \ldots \ldots . \ldots \ldots$

Converse v. Converse, 21 Vermont $168 \ldots \ldots \ldots \ldots \ldots \ldots \ldots \ldots \ldots . \ldots 38$

Cook v. Higley, 10 Utah $228 \ldots \ldots \ldots \ldots \ldots \ldots \ldots \ldots \ldots \ldots \ldots . \ldots \ldots$

v. Walling, 117 Indiana $9 \ldots \ldots \ldots \ldots \ldots \ldots \ldots \ldots \ldots \ldots \ldots$

Cooley $\nabla$. Kinney, 109 Michigan $34 \ldots \ldots \ldots \ldots \ldots \ldots \ldots \ldots \ldots \ldots \ldots$

Cooper v. Hamilton, 97 Tennessee $285 \ldots \ldots \ldots \ldots \ldots \ldots \ldots \ldots \ldots . \ldots \ldots 6$

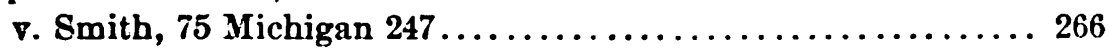

Copeland v. McAdory, 100 Alabama 553............. 203, 209

Coppage v. Alexander's Heirs, 2 B. Monroe (Kentucky) 313..... 185

Corbett $\nabla$. Norcross, 35 New Hampshire 99................ 253

Cordova $\nabla$. Hood, 17 Wallace (United States) $1 \ldots \ldots \ldots \ldots \ldots \ldots 49$

Crorey v. Smalley, 106 Michigan $257 \ldots \ldots \ldots \ldots \ldots \ldots \ldots \ldots \ldots . \ldots \ldots$

Cornell $\nabla$. Maltby, 165 New York $557 \ldots \ldots \ldots \ldots \ldots \ldots \ldots \ldots . \ldots 26$

Cosgrove v. Cummings, 195 Pennsylvania State $497 \ldots \ldots \ldots \ldots$ 54, 245

Cusner v. McCrum, 40 West Virginia $339 \ldots \ldots \ldots \ldots \ldots \ldots \ldots 247$

Costigan v. Pennsylvania R. Co., 54 New Jersey Law 233....... 226

Cruncil Bluffs Savings Bank v. Smith, 59 Nebraska 90........ 293

Coursolle $v$. Weyerhanser, 69 Minnesota $328 \ldots \ldots \ldots \ldots \ldots \ldots \ldots 314$

Cover v. Manaway, 115 Pennsylvania State $338 \ldots \ldots \ldots \ldots \ldots \ldots . \ldots \ldots$

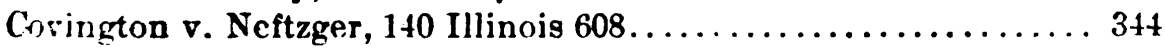

Cowan $\nabla$. Southern R. Co., 118 Alabama 544............ 392, 39.5

Correll v. Springs Co., 100 United States $55 \ldots \ldots \ldots \ldots \ldots$ 171, 186, 40;

Cowen $\nabla$. Truefit, 1899, 2 Chancery Division $309 \ldots \ldots \ldots \ldots \ldots .85$

iii-Brews. CoN. 


\section{[References are to sections.]}

Cox v. Holcomb, 87 Alabama 589...................... 367

v. Hart, 145 United States $376 \ldots \ldots \ldots \ldots \ldots \ldots \ldots \ldots \ldots .75$

v. James, 45 New York $557 \ldots \ldots \ldots \ldots \ldots \ldots \ldots \ldots \ldots \ldots .9 . \ldots$

Crane v. Reeder, 21 Michigan $24 \ldots \ldots \ldots \ldots \ldots \ldots \ldots \ldots \ldots$ 408, 410

Cravens v. Rossiter, 116 Missouri $338 \ldots \ldots \ldots \ldots \ldots \ldots \ldots \ldots$ 302, 304

Crawford v. Craw ford, 24 Nevada $410 \ldots \ldots \ldots \ldots \ldots \ldots \ldots \ldots \ldots . \ldots \ldots$

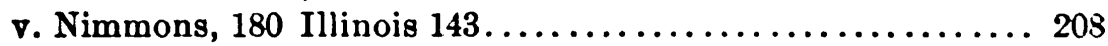

v. Scovell, 94 Pennsylvania State 48. ............. 337, 346

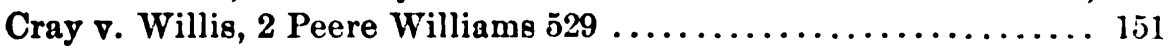

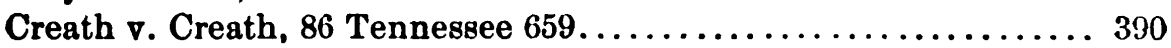

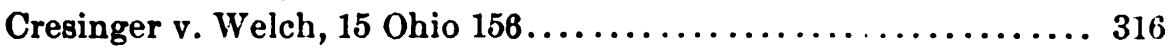

Cribben v. Deal, 21 Oregon $211 \ldots \ldots \ldots \ldots \ldots \ldots \ldots \ldots \ldots \ldots . \ldots \ldots$

Crocker v. Cotting, 166 Massachusetts $183 \ldots \ldots \ldots \ldots \ldots \ldots \ldots \ldots . . \ldots 9$

v. Smith, 94 Alabama $295 \ldots \ldots \ldots \ldots \ldots \ldots \ldots \ldots \ldots \ldots . \ldots 29$

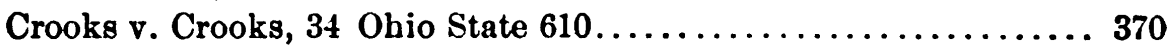

v. Whitford, 47 Michigan $283 \ldots \ldots \ldots \ldots \ldots \ldots \ldots \ldots \ldots, 73$

Cross v. Noble, 67 Pennsylvania State $74 \ldots \ldots \ldots \ldots \ldots \ldots \ldots \ldots . \ldots 202$

Crossen v. Oliver, 37 Oregon $514 \ldots \ldots \ldots \ldots \ldots \ldots \ldots \ldots \ldots \ldots \ldots, 33$

Crouse v. Murphy, 140 Pennsylvania State $335 \ldots \ldots \ldots \ldots \ldots \ldots \ldots 42$

Crowley v. Lumber Co., 66 Minnesota 400................ 201

v. Vaughan, 11 Bush (Kentucky) $517 \ldots \ldots \ldots \ldots \ldots \ldots \ldots . \ldots 17$

Croxall v. Shererd, 5 Wallace (United States) $268 \ldots \ldots \ldots \ldots \ldots \ldots 142$

Culbertson v. Witbeck Co., 127 United States $326 \ldots \ldots \ldots \ldots \ldots .252$

Cullen v. Sprigg, 83 California $56 \ldots \ldots \ldots \ldots \ldots \ldots \ldots \ldots \ldots \ldots$.9

Cunningham v. Neeld, 198 Pennsylvania State $41 \ldots \ldots \ldots \ldots \ldots \ldots+2$

Currey, In re, L. R, 32 Chancery Division $361 \ldots \ldots \ldots \ldots \ldots \ldots .354$

Currier v. Woodward, 62 New Hampshire $63 \ldots \ldots \ldots \ldots \ldots \ldots . \ldots 38$

Curry v Colburn, 99 Wisconsin $319 . \ldots \ldots \ldots \ldots \ldots \ldots \ldots \ldots \ldots . . \ldots 9$

v. Mortgage Co., 107 Alabama 429...................... 194

Curtis v. Bunnell \&c. Co., 6 Idaho $298 \ldots \ldots \ldots \ldots \ldots \ldots \ldots \ldots . \ldots . \ldots 7$

v. Simpson, 72 Vermont $232 \ldots \ldots \ldots \ldots \ldots \ldots \ldots \ldots \ldots \ldots \ldots \ldots \ldots \ldots$

Cutright $\nabla$. Stanford, 81 Illinois $240 \ldots \ldots \ldots \ldots \ldots \ldots \ldots \ldots \ldots . \ldots \ldots$

Cutts v. Young, 147 Missouri $587 \ldots \ldots \ldots \ldots \ldots \ldots \ldots \ldots \ldots \ldots . . \ldots \ldots$

Dagley v. Black, 197 Illinois 53 ...................... 301

Dahlam's Estate, 175 Pennsylvania State $455 \ldots \ldots \ldots \ldots \ldots \ldots .290$

Dakin v. Dakin, 97 Michigan $284 . \ldots \ldots \ldots \ldots \ldots \ldots \ldots \ldots \ldots \ldots . \ldots \ldots$

Daniel v. Whartenby, 17 Wallace (United States) $639 \ldots \ldots \ldots \ldots 146$

Danville v. Mott, 136 Illinois $289 \ldots \ldots \ldots \ldots \ldots \ldots \ldots \ldots \ldots 249,403$

Darling v. Butler (United States), 45 Federal 332............ 309

Darlington's Appeal, 86 Pennsylvania State $512 \ldots \ldots \ldots \ldots \ldots \ldots . \ldots 369$

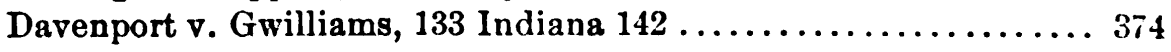

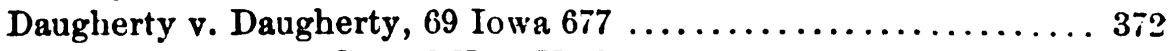

David v. Insurance Co., 83 New York $265 \ldots \ldots \ldots \ldots \ldots \ldots \ldots . \ldots 3$

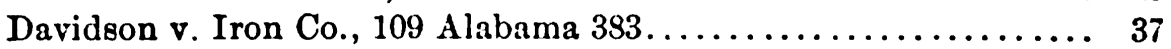

Davis v. Burton, 3 Scammon (Illinois) $41 \ldots \ldots \ldots \ldots \ldots \ldots \ldots . \ldots \ldots$

v. Converse (Texas), 46 South western $910 \ldots \ldots \ldots \ldots \ldots . \ldots 3 s 8$ 


\section{[References are to sections.]}

Davis v. Davis, 92 Iowa $147 \ldots \ldots \ldots \ldots \ldots \ldots \ldots \ldots \ldots \ldots \ldots . \ldots . \ldots . \ldots$

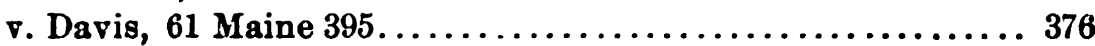

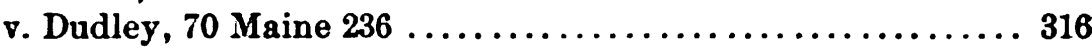

v. Hollingsworth, 113 Georgia $210 \ldots \ldots \ldots \ldots \ldots \ldots \ldots \ldots .43$

v. Jenkins, 93 Kentucky 353 .......................... 398

v. Kelly, 62 Nebraska $642 \ldots . \ldots \ldots \ldots \ldots \ldots \ldots \ldots \ldots \ldots . . \ldots 382$

v. Laning, 85 Texas $39 . \ldots \ldots \ldots \ldots \ldots \ldots \ldots \ldots \ldots \ldots \ldots \ldots . \ldots 14$

. McCullouch, 192 Illinois $277 \ldots \ldots \ldots \ldots \ldots \ldots \ldots \ldots \ldots . \ldots . \ldots$

v. McDonald, 42 Georgia $205 \ldots \ldots \ldots \ldots \ldots \ldots \ldots \ldots \ldots \ldots \ldots \ldots$

v. MeGrew, 82 California $135 \ldots \ldots \ldots \ldots \ldots \ldots \ldots \ldots \ldots \ldots, 71$

v. Semmes, 51 Arkansas $48 \ldots \ldots \ldots \ldots \ldots \ldots \ldots \ldots \ldots \ldots . \ldots \ldots$

v. Shields, 26 Wendall (New York) $341 \ldots \ldots \ldots \ldots \ldots \ldots \ldots . \ldots . \ldots . \ldots 235$

v. Steeps, 87 Wisconsin $472 \ldots \ldots \ldots \ldots \ldots \ldots \ldots \ldots \ldots \ldots, 42$

v. Sturgeon, 198 Illinois $520 \ldots \ldots \ldots \ldots \ldots \ldots \ldots \ldots \ldots \ldots . \ldots \ldots$

v. Ward, 109 California $186 \ldots \ldots \ldots \ldots \ldots \ldots \ldots \ldots \ldots \ldots .74$

Dawley $\nabla$. Brown, 79 New York $390 \ldots \ldots \ldots \ldots \ldots \ldots \ldots \ldots \ldots 421$

Dawson $\nabla$. Shirley, 6 Blackford (Indiana) $531 \ldots \ldots \ldots \ldots \ldots \ldots . \ldots 377$

Dean $v$. Long, 122 Illinois $447 \ldots \ldots \ldots \ldots \ldots \ldots \ldots \ldots \ldots \ldots . \ldots \ldots, 357$

v. Metropolitan R. Co., 119 New York $540 \ldots \ldots \ldots \ldots \ldots \ldots . \ldots 37$

v. Shelly, 57 Pennsylvania State $426 \ldots \ldots \ldots \ldots \ldots \ldots \ldots \ldots . . \ldots 194$

Deason v. Taylor, 53 Mississippi $697 \ldots \ldots \ldots \ldots \ldots \ldots \ldots \ldots \ldots . \ldots 9$

De Blanc $\nabla$. Lynch, 23 Texas $25 \ldots \ldots \ldots \ldots \ldots \ldots \ldots \ldots \ldots \ldots . \ldots \ldots$

Decatur $\nabla$. Niedermeyer, 168 Illinois $68 \ldots \ldots \ldots \ldots \ldots \ldots \ldots \ldots . . \ldots 6$

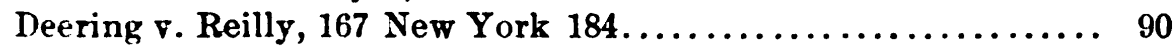

Deery v. Cray, 10 Wallace (United States) $263 \ldots \ldots \ldots \ldots \ldots \ldots . . \ldots 3$

De Gray v. Monmouth Beach Co., 50 New Jersey Equity 329...... 228

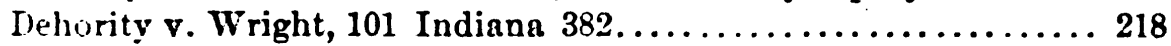

Delhi School District v. Everett, 52 Michigan 314..........137, 174

Delong v. Delong, 56 Wisconsin $514 \ldots \ldots \ldots \ldots \ldots \ldots \ldots \ldots \ldots . \ldots \ldots$

Iemars $v$. Koehler, 62 New Jersey Law $203 \ldots \ldots \ldots \ldots \ldots \ldots . . .200,202$

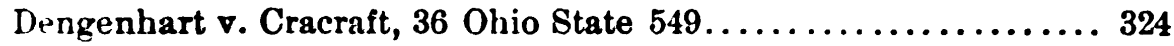

Dennett $\nabla$. Dennett, 44 New Hampshire $531 \ldots \ldots \ldots \ldots \ldots \ldots . . . .338,340$

Denton $\nabla$. Arnold, 151 Indiana $188 \ldots \ldots \ldots \ldots \ldots \ldots \ldots \ldots \ldots . \ldots \ldots$

Dentzel v. Waldie, 30 California $138 \ldots \ldots \ldots \ldots \ldots \ldots \ldots \ldots \ldots . \ldots \ldots$

De Segond v. Culver, 10 Ohio $188 \ldots \ldots \ldots \ldots \ldots \ldots \ldots \ldots \ldots \ldots . \ldots \ldots$

De Silver's Case, 5 Rawle (Pennsylvania) $111 \ldots \ldots \ldots \ldots \ldots \ldots . . \ldots 336$

Despain $\nabla$. Wagner, 163 mlinois 598...................371, 400

Dettmer $\nabla$. Behrens, 106 Iowa $585 \ldots \ldots \ldots \ldots \ldots \ldots \ldots \ldots . \ldots . \ldots 2,307$

De Vaughn $\nabla$. Hutchinson, 165 United States $566 \ldots \ldots \ldots \ldots \ldots . \ldots 146$

Dever $\nabla$. Hagerty, 169 New York $481 \ldots \ldots \ldots \ldots \ldots \ldots \ldots \ldots . \ldots 418$

Levereux v. McMahon, 108 North Carolina $134 \ldots \ldots \ldots \ldots \ldots . . . .236$

Devinney $\nabla$. Reynolds, $1 \mathrm{~W}$ alls and Sergeant (Penngylvania) 328. . 239

Devoe v. Sunderland, 17 Ohio State $52 \ldots \ldots \ldots \ldots \ldots \ldots \ldots \ldots . \ldots . \ldots . \ldots$

Derries v. Conklin, 22 Michigan $255 \ldots \ldots \ldots \ldots \ldots \ldots \ldots \ldots \ldots \ldots \ldots$

Dewey $\mathbf{v}$. Allgire, 37 Nebraska 6.....................333, 347

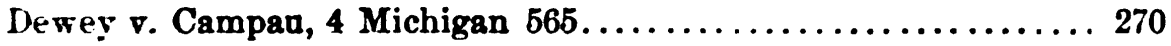

v. Goodman, 107 Tennessee $244 \ldots \ldots \ldots \ldots \ldots \ldots \ldots \ldots \ldots . .356$ 


\section{[References are to Sections.]}

Dewey v. Kimball (Minnesota), 95 North western 317 ; 96 North west-

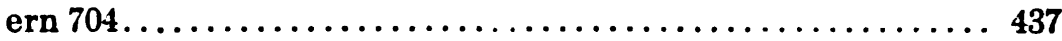

Dexter v. Hall, 15 Wallace (United States) $9 \ldots \ldots \ldots \ldots \ldots \ldots \ldots 336$

Dezendorf $\nabla$. Humphreys, 95 Virginia $473 \ldots \ldots \ldots \ldots \ldots \ldots \ldots . \ldots . \ldots . \ldots$

Dickle v. Abstract Co., 89 Tennessee $431 \ldots \ldots \ldots \ldots \ldots \ldots \ldots \ldots 425$

Dickson v. Desire's Administrator, 23 Missouri $151 \ldots \ldots \ldots \ldots \ldots 215$

v. United States, 125 Massachusetts $311 \ldots \ldots \ldots \ldots \ldots \ldots \ldots 7$

Diefendorf v. Diefendorf, 132 New York $100 \ldots \ldots \ldots \ldots \ldots \ldots . \ldots 307$

Dietrich v. Hutchinson, 73 Vermont $134 \ldots \ldots \ldots \ldots .37,351,363,364$

Disch v. Timm, 101 Wisconsin $179 \ldots \ldots \ldots \ldots \ldots \ldots \ldots \ldots . \ldots \ldots \ldots$

Dixon v. Bristol Savings Bank, 102 Georgia $461 \ldots \ldots \ldots \ldots \ldots \ldots . \ldots 310$

Doane v. Feather's Estate, 119 Michigan $691 \ldots \ldots \ldots \ldots \ldots \ldots \ldots .164$

Dodder v. Snyder, 110 Michigan $69 \ldots \ldots \ldots \ldots \ldots \ldots \ldots \ldots \ldots, 61$

Dodge v. Hollinshead, 6 Minnesota $25 \ldots \ldots \ldots \ldots \ldots \ldots \ldots \ldots .293$

Doe d. Griffith v. Pritchard, 5 Barnewall \& Alderson, $765 \ldots \ldots \ldots 413$

Doehrel v. Hillmer, 102 Iowa $169 \ldots \ldots \ldots \ldots \ldots \ldots \ldots \ldots \ldots 4,7,408$

Doescher v. Spratt, 61 Minnesota $326 \ldots \ldots \ldots \ldots \ldots \ldots \ldots \ldots \ldots \ldots$

Dohm v. Haskin, 88 Michigan $144 \ldots \ldots \ldots \ldots \ldots \ldots \ldots \ldots 10,278$

Dohms $\nabla$. Mann, 76 Iowa $723 \ldots \ldots \ldots \ldots \ldots \ldots \ldots \ldots \ldots \ldots . \ldots \ldots$

Dolph v. Hand, 156 Pennsylvania State $91 \ldots \ldots \ldots \ldots \ldots \ldots \ldots . \ldots 313$

Donahue v. Cricket Club, 177 Illinois $351 \ldots \ldots \ldots \ldots \ldots \ldots$ 396, 398

Donegan v. Donegan, 103 Alabama $488 \ldots \ldots \ldots \ldots \ldots \ldots \ldots \ldots . \ldots \ldots$

- Donnelly v. Eastes, 94 Wisconsin $390 . \ldots \ldots \ldots \ldots \ldots \ldots \ldots . \ldots 172$

Donnelly's Estate, 125 California $417 \ldots \ldots \ldots \ldots \ldots \ldots \ldots \ldots . \ldots 14$

Donovan v. St. Anthony Co., 8 North Dakota $585 \ldots \ldots \ldots \ldots \ldots . . \ldots 253$

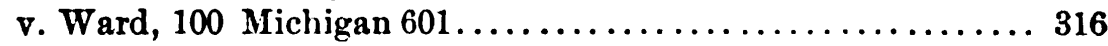

Doran v. Butler, 74 Michigan $643 \ldots \ldots \ldots \ldots \ldots \ldots \ldots \ldots \ldots \ldots .272$

Doren v. Gillum, 136 Indiana $134 \ldots \ldots \ldots \ldots \ldots \ldots \ldots \ldots \ldots . \ldots \ldots$

Douglass v. Lewis, 131 United States $75 \ldots \ldots \ldots \ldots \ldots \ldots \ldots 211,212$

v. Thomas, 103 Indiana $187 \ldots \ldots \ldots \ldots \ldots \ldots \ldots \ldots \ldots \ldots . \ldots \ldots$

Downham v. Holloway, 158 Indiana $626 \ldots \ldots \ldots \ldots \ldots \ldots .337,345$

Downing v. Birney, 112 Michigan $474 \ldots \ldots \ldots \ldots \ldots \ldots \ldots \ldots \ldots . \ldots \ldots$

v. Marshall, 23 New York $366 \ldots \ldots \ldots \ldots \ldots \ldots \ldots \ldots . \ldots 4$

Drew v. Carroll, 154 Massachusetts $181 \ldots \ldots \ldots \ldots \ldots \ldots \ldots \ldots .61$

Drury $\nabla$. Foster, 2 Wallace (United States) $24 \ldots \ldots \ldots \ldots \ldots \ldots \ldots 377$

v. Holden, 121 Illinois $130 \ldots \ldots \ldots \ldots \ldots \ldots \ldots \ldots \ldots . \ldots 208$

Duke v. Markham, 105 North Carolina $131 \ldots \ldots \ldots \ldots \ldots \ldots \ldots . \ldots 249$

Duncan v. Terre Haute, 85 Indiana $104 \ldots \ldots \ldots \ldots \ldots \ldots \ldots \ldots . \ldots . \ldots 3$

Duncombe v. Richards, 46 Michigan $166 \ldots \ldots \ldots \ldots \ldots \ldots \ldots . \ldots 341$

Dundas v. Bowler, 3 McLean (United States) $397 \ldots \ldots \ldots \ldots \ldots .10$

Dundy $\nabla$. Chambers, 23 Illinois $369 . \ldots \ldots \ldots \ldots \ldots \ldots \ldots \ldots . \ldots \ldots$

Dunlap v. Henry, 76 Missouri $106 \ldots \ldots \ldots \ldots \ldots \ldots \ldots \ldots . \ldots \ldots$

Dupont $v$. Wertheman, 10 California $354 \ldots \ldots \ldots \ldots \ldots \ldots \ldots \ldots$

Durant v. Ritchie, 4 Mason (United States) $45 \ldots \ldots \ldots \ldots \ldots \ldots . \ldots 62$

Durfee $\nabla$. Grinnell, 69 Illinois $371 \ldots \ldots \ldots \ldots \ldots \ldots \ldots \ldots \ldots \ldots 290$

D'Wolf $\nabla$. Hayden, 24 Illinois $525 \ldots \ldots \ldots \ldots \ldots \ldots \ldots \ldots \ldots \ldots$ 


\section{[References are to sections.]}

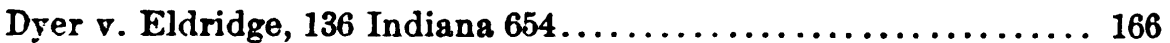

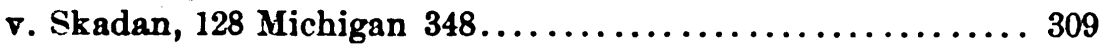

Eagan v. Scully, 29 New York Appellate Division $617 \ldots \ldots \ldots \ldots 319$

Eames v. Preston, 20 Illinois $389 \ldots \ldots \ldots \ldots \ldots \ldots \ldots \ldots \ldots . . \ldots 247$

Eare v. Snow, 2 Plowden 504........................ 360

Eaton v. Trowbridge, 38 Michigan $454 \ldots \ldots \ldots \ldots \ldots \ldots \ldots \ldots .34$

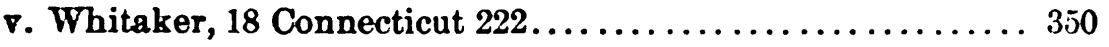

Eckler $\nabla$. Alden, 125 Michigan $215 \ldots \ldots \ldots \ldots \ldots \ldots \ldots \ldots \ldots .66$

Eckman v. Eckman, 68 Pennsylvania State $460 \ldots \ldots \ldots \ldots \ldots \ldots . \ldots$

Ecroyd $\nabla$. Coggeshall, 21 Rhode Island $1 \ldots \ldots \ldots \ldots \ldots \ldots \ldots \ldots 181$

Edens $\nabla$. Miller, 147 Indiana $208 \ldots \ldots \ldots \ldots \ldots \ldots \ldots \ldots \ldots . \ldots \ldots$

Edgerton v. Aycock, 123 North Carolina 134.............. 147

Edwards v. Clark, 83 Michigan $246 \ldots \ldots \ldots \ldots \ldots \ldots \ldots 200,202,204$

Edwards Hall Co. v. Dresser, 168 Massachusetts $136 \ldots \ldots \ldots \ldots . . . .127$

Egan v. Horrigan, 96 Maine $46 \ldots \ldots \ldots \ldots \ldots \ldots \ldots \ldots \ldots \ldots . \ldots . \ldots . \ldots 4$

Elcessor v. Elcessor, 146 Pennsylvania State $359 \ldots \ldots \ldots \ldots \ldots \ldots 340$

Elider v. Schumacher, 18 Colorado $433 \ldots \ldots \ldots \ldots \ldots \ldots \ldots \ldots . \ldots 36$

Eldredge $\nabla$. Palmer, 185 Illinois $618 \ldots \ldots \ldots \ldots \ldots \ldots \ldots \ldots \ldots . \ldots \ldots$

Electric City Land \&c. Co. v. West Ridge Coal Co., 187 Pennsylva-

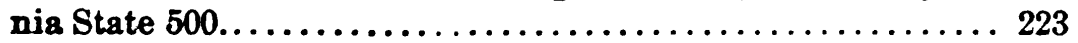

Eleventh Avenue, In re, 81 New York $436 \ldots \ldots \ldots \ldots \ldots \ldots \ldots . \ldots 4$

Eliason $\nabla$. Bronnenberg, 147 Indiana $248 \ldots \ldots \ldots \ldots \ldots \ldots \ldots . \ldots 28$

Elliott $\nabla$. Plattor, 43 Ohio State $198 \ldots \ldots \ldots \ldots \ldots \ldots \ldots \ldots \ldots . \ldots \ldots$

Ellis v. Alford, 64 Mississippi 8....................... 323

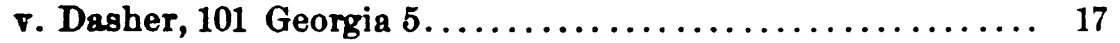

Ellison $\nabla$. Branstrator, 153 Indiana $146 \ldots \ldots \ldots \ldots \ldots \ldots \ldots \ldots .240$

Ellwood $\nabla$. Northrup, 106 New York $172 \ldots \ldots \ldots \ldots \ldots \ldots \ldots . \ldots . \ldots . \ldots$

Elmondorff v. Carmichael, 3 Littell (Kentucky) 472........... 409

Elsey v. McDaniel, 95 Pennsylvania State $472 \ldots \ldots \ldots \ldots \ldots \ldots 363$

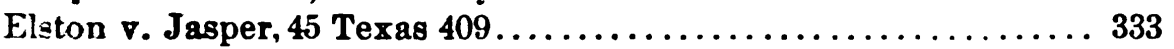

Elwelı $\nabla$. Shaw, 16 Massachusetts $42 \ldots \ldots \ldots \ldots \ldots \ldots \ldots \ldots . \ldots 230$

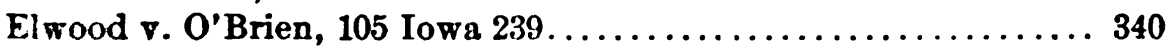

Ely's Administrator v. United States, 171 United States $220 \ldots \ldots .92$

Elyton Land Co. v. Railroad, 100 Alabama $396 \ldots \ldots \ldots \ldots \ldots . . \ldots 179$

Fineric $\nabla$. Alvarado, 90 California $444 \ldots \ldots \ldots \ldots \ldots \ldots \ldots . \ldots . \ldots 289$

Engel v. Ayer, 85 Maine 448....................... 123

Engle v. White, 104 Michigan 15..................... 396

Englebert $\nabla$. Troxell, 40 Nebraska $195 \ldots \ldots \ldots \ldots \ldots \ldots 313,317,321$

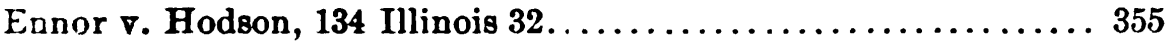

Ensign v. Colt (Connecticut), 52 Atlantic 829.............. 209

Enyeart v. Kepler, 118 Indiana 34.................... 166

Equitable Life Assurance Society v. Brennan, 148 New York 661.. 228

Eslava v. Lepretre, 21 Alabama $504 . \ldots \ldots \ldots \ldots \ldots \ldots \ldots \ldots \ldots . \ldots \ldots$

Essex v. Atkins, 14 Vesey $542 \ldots \ldots \ldots \ldots \ldots \ldots \ldots \ldots \ldots \ldots \ldots . \ldots \ldots$

Estate of. See name of party.

Eareks Co. $\nabla$. Edwards, 71 Alabama $248 \ldots \ldots \ldots \ldots \ldots \ldots \ldots \ldots . \ldots 21$ 


\section{[References are to Sections.]}

Evans v. Beaver, 50 Ohio State $190 \ldots \ldots \ldots \ldots \ldots \ldots \ldots \ldots \ldots .7$

v. Dickenson (United States), 114 Federal $284 \ldots \ldots \ldots \ldots \ldots . \ldots 365$

v. Etheridge, 99 North Carolina $43 \ldots \ldots \ldots \ldots \ldots \ldots \ldots \ldots 276$

v. Grand Rapids \&c. R. Co., 68 Michigan $602 \ldots \ldots \ldots \ldots$..... 385, 395

Evenson v. Webster, 3 South Dakota $382 \ldots \ldots \ldots \ldots \ldots \ldots \ldots 25,29$

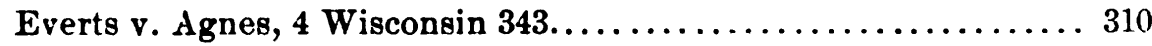

Ewertsen v. Gerstenberg, 186 Illinois $344 \ldots \ldots \ldots \ldots \ldots \ldots \ldots \ldots$ 2...

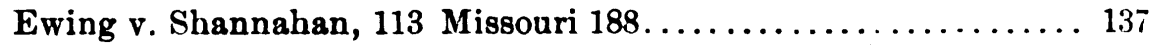

v. Smith, 3 Desaussure's Equity (South Carolina) 417........ 35.5

Ex parte. See name of party.

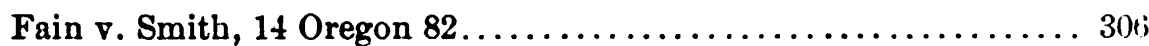

Fairfax v. Hunter, 7 Cranch (United States) $603 \ldots \ldots \ldots \ldots \ldots . \ldots 408$

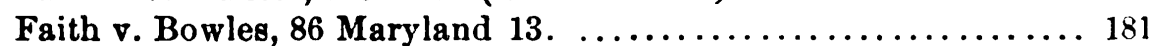

Fallon v. Chidester, 46 Iowa $588 \ldots \ldots \ldots \ldots \ldots \ldots \ldots \ldots \ldots \ldots . \ldots 28$

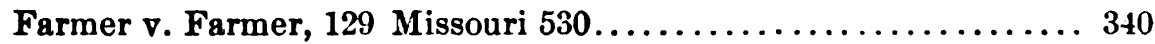

Farmers' Bank v. Pryse (Kentucky), 76 South western $358 \ldots \ldots \ldots 417$

v. Wallace, 45 Ohio State $152 \ldots \ldots \ldots \ldots \ldots \ldots \ldots \ldots \ldots \ldots . \ldots \ldots$

Farnham v. Thompson, 34 Minnesota $330 \ldots \ldots \ldots \ldots \ldots \ldots \ldots . \ldots 181$

Farnsworth v. Noffsinger, 46 West Virginia $410 \ldots \ldots \ldots \ldots \ldots \ldots 340$

Farnum v. Peterson, 111 Massachusetts $148 \ldots \ldots \ldots \ldots \ldots \ldots \ldots 417$

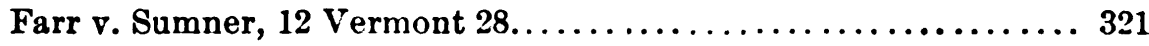

Farrar v. Farrar, 4 New Hampshire $191 \ldots \ldots \ldots \ldots \ldots \ldots \ldots \ldots . . \ldots 311$

Farrell County v. Dart, 26 Connecticut $376 \ldots \ldots \ldots \ldots \ldots \ldots \ldots . \ldots \ldots$

Farrington v. Putnam, 90 Maine $405 \ldots \ldots \ldots \ldots \ldots \ldots \ldots \ldots \ldots$ 405

Farwell v. Des Moines Manufacturing Co., 97 Iowa 286......... 33

Faulkner $\nabla$. Adams, 126 Indiana $459 \ldots \ldots \ldots \ldots \ldots \ldots \ldots \ldots . \ldots \ldots$

v. Davis, 18 Grattan (Virginia) $651 \ldots \ldots \ldots \ldots \ldots \ldots \ldots \ldots \ldots \ldots \ldots$

Fayette Land Co. v. Louisville \&c. R. Co., 93 Virginia 274. .. 401, 405

Fears v. Brooks, 12 Georgia $195 \ldots \ldots \ldots \ldots \ldots \ldots \ldots \ldots \ldots .352,354$

Feas's Estate, 30 Washington $51 \ldots \ldots \ldots \ldots \ldots \ldots \ldots \ldots \ldots \ldots . \ldots \ldots$

Feeney v. Howard, 79 California $525 \ldots \ldots \ldots \ldots \ldots \ldots \ldots \ldots, 66$

Felix v. Patrick, 145 United States $317 \ldots \ldots \ldots \ldots \ldots \ldots \ldots \ldots . \ldots . \ldots 9$

Feurt v. Caster, 174 Missouri $289 \ldots \ldots \ldots \ldots \ldots \ldots \ldots \ldots \ldots \ldots . \ldots . \ldots . \ldots 2$

Ferguson v. Houston R. Co., 73 Texas $344 \ldots \ldots \ldots \ldots \ldots \ldots . . \ldots 314$

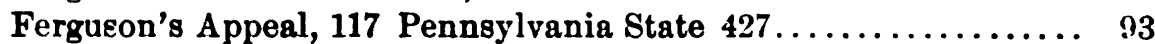

Final v. Backus, 18 Michigan 218....................... 291

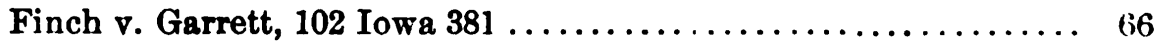

Fincher v. Hanegan, 59 Arkansas $151 \ldots \ldots \ldots \ldots \ldots \ldots \ldots \ldots, 42$

Findley v. Hill, 133 Alabama $229 \ldots \ldots \ldots \ldots \ldots \ldots \ldots \ldots \ldots .40$

Finlay $\nabla$. King's Lessee, 3 Peters (United States) $346 \ldots \ldots \ldots \ldots \ldots 172$

Finley $\nabla$. Prescott, 104 Wisconsin $614 \ldots \ldots \ldots \ldots \ldots \ldots \ldots \ldots .236$

v. Simpson, 22 New Jersey Law $311 \ldots \ldots \ldots \ldots \ldots \ldots \ldots \ldots .24$

Firmstone v. Spaeter, 150 Pennsylvania State $616 \ldots \ldots \ldots \ldots \ldots .89$

First English Evangelical Church $\nabla$. Arkle, 49 West Virginia 92.. 405 


\section{[References are to sections.]}

First National Bank $\nabla$. Hollingsworth, 78 Iowa $575 \ldots \ldots \ldots \ldots \ldots . . . .382$

v. Paul, 75 Virginia $594 \ldots \ldots \ldots \ldots \ldots \ldots \ldots \ldots \ldots \ldots \ldots . \ldots 65$

First Parish in Sutton v. Cole, 3 Pickering (Massachusetts) 232 ... 401

First Universalist Society v. Boland, 155 Massachusetts $171 \ldots \ldots \ldots 174$

Fisher v. Clark, 8 Kansas Appellate $483 \ldots \ldots \ldots \ldots \ldots \ldots \ldots \ldots . \ldots 4$

v. Meister, 24 Michigan $447 \ldots \ldots \ldots \ldots \ldots \ldots \ldots \ldots \ldots \ldots \ldots . \ldots . \ldots . \ldots 9$

v. Parry, 68 Indiana $465 \ldots \ldots \ldots \ldots \ldots \ldots \ldots \ldots \ldots \ldots \ldots \ldots \ldots$

Fisk v. Brayman, 21 Rhode Island $195 \ldots \ldots \ldots \ldots \ldots \ldots \ldots \ldots \ldots$

v. Hopping, 169 Illinois $105 \ldots \ldots \ldots \ldots \ldots \ldots \ldots \ldots 276,291,292$

v. Osgood, 58 Nebraska 486....................... 261

Fitch $\nabla$. Johnson, 194 Illinois $111 \ldots \ldots \ldots \ldots \ldots \ldots \ldots \ldots \ldots . \ldots \ldots$

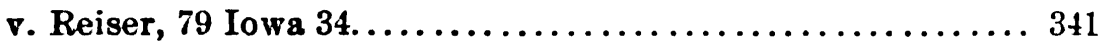

Fitzgerald v. Fitzgerald, 100 Illinois $385 \ldots \ldots \ldots \ldots \ldots \ldots \ldots \ldots 293$

v. Fitzgerald, 168 Massachusetts $488 \ldots \ldots \ldots \ldots \ldots \ldots \ldots \ldots . \ldots \ldots 9$

v. Goff, 99 Indiana $28 \ldots \ldots \ldots \ldots \ldots \ldots \ldots \ldots \ldots \ldots \ldots . \ldots . \ldots 299$

Fitzhugh v. Croghan, 2 J. J. Marshall (Kentucky) 429 ......... 198

Flege v. Garvey, 47 California $371 \ldots \ldots \ldots \ldots \ldots \ldots \ldots \ldots \ldots . \ldots 393$

Fleming v. Katahdin Pulp Co., 93 Maine $110 \ldots \ldots \ldots \ldots \ldots \ldots . \ldots 157$

Fleschner $\nabla$. Sumpter, 12 Oregon $161 \ldots \ldots \ldots \ldots \ldots \ldots \ldots \ldots . \ldots \ldots$

Fletcher $\nabla$. Shepherd, 174 Illinois $262 \ldots \ldots \ldots \ldots \ldots \ldots \ldots . \ldots \ldots 11,374$

Flowers $\nabla$. Flowers, 89 Georgia $632 \ldots \ldots \ldots \ldots \ldots \ldots \ldots \ldots . \ldots \ldots$

Flynn v. Bourneuf, 143 Massachusetts $277 \ldots \ldots \ldots \ldots \ldots \ldots \ldots . \ldots 204$

v. Flynn, 68 Michigan $20 \ldots \ldots \ldots \ldots \ldots \ldots \ldots \ldots \ldots \ldots \ldots, 65$

v. Flynn, 171 Massachusetts $312 \ldots \ldots \ldots \ldots \ldots \ldots \ldots \ldots \ldots . \ldots \ldots \ldots \ldots$

v. Jackson, 93 Virginia $341 \ldots \ldots \ldots \ldots \ldots \ldots \ldots \ldots \ldots \ldots, 67$

Folsom v. Asper, 25 Utah $299 \ldots \ldots \ldots \ldots \ldots \ldots \ldots \ldots \ldots \ldots \ldots . \ldots \ldots 2$

Fond du Lac v. Otto's Estate, 113 Wisconsin 39............. 240

Fontaine $\nabla$. Savings Institution, 57 Missouri $552 \ldots \ldots \ldots \ldots \ldots \ldots . \ldots 34$

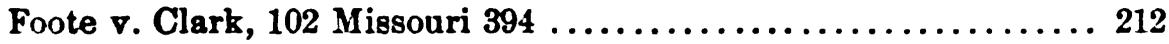

Fort Wayne v. Lake Shore \&c. R. Co., 132 Indiana 558........ 407

Forrester v. Boston \& Montana Copper Co., 21 Montana 544 ..... 406

Fort Jefferson Improvement Co. v. Dupoyster, 108 Kentucky 792 .. 417

Foeter v. Foster, 62 New Hampshire 46................... 201

v. Hall, 12 Pickering (Massachusetts) 89.............. 67

v. Joice (United States), 3 Washington Circuit Court 498.... 135

v. Mansfield, 3 Metcalf (Massachusetts) $412 \ldots \ldots \ldots \ldots \ldots . \ldots 309$

v. Runk, 109 Pennsylvania $291 \ldots \ldots \ldots \ldots \ldots \ldots \ldots \ldots \ldots . \ldots \ldots$

Foundry Co. v. Hovey, 21 Pickering (Massachusetts) $417 \ldots \ldots \ldots 247$

Fowler v. Lewis, 36 West Virginia $112 \ldots \ldots \ldots \ldots \ldots \ldots \ldots \ldots . \ldots 27$

v. Shearer, 7 Massachusetts $14 \ldots \ldots \ldots \ldots \ldots \ldots \ldots \ldots \ldots . \ldots \ldots 2$

จ. Poling, 2 Barbour (New York) $300 \ldots \ldots \ldots \ldots \ldots \ldots \ldots 206$

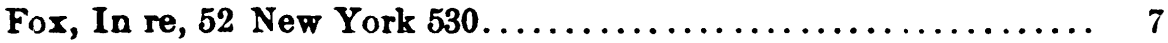

v. Reil, 3 Johnson (New York) $477 \ldots \ldots \ldots \ldots \ldots \ldots \ldots \ldots . \ldots \ldots$

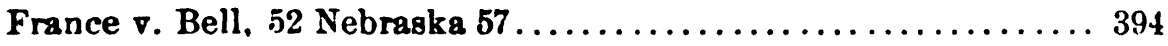

Francis $\nabla$. Wilkinson, 147 Illinois $370 \ldots \ldots \ldots \ldots \ldots \ldots \ldots \ldots . \ldots \ldots$

Franklin Institute $\nabla$. Savings Bank, 14 Rhode Island $632 \ldots \ldots \ldots 153$

Frazer $\nabla$. Supervisors, 74 Illinnic $9 ؟ 2 \ldots \ldots \ldots \ldots \ldots$ 
Frazier v. Jeakins, 64 Kansas $615 \ldots \ldots \ldots \ldots \ldots \ldots \ldots \ldots \ldots . \ldots . \ldots . \ldots 28$

Frederick v. Emig, 186 Illinois $319 \ldots \ldots \ldots \ldots \ldots \ldots \ldots \ldots . \ldots 373,374$

v. Wilcox, 119 Alabama $355 \ldots \ldots \ldots \ldots \ldots \ldots \ldots \ldots \ldots . \ldots \ldots 7$

Freeman v. Foster, 55 Maine $508 \ldots \ldots \ldots \ldots \ldots \ldots \ldots \ldots \ldots .208$

Freiermuth v. Steigleman, 130 California $392 \ldots \ldots \ldots \ldots \ldots \ldots .400$

French $\nabla$. Lord, 69 Maine $537 \ldots \ldots \ldots \ldots \ldots \ldots \ldots \ldots \ldots \ldots .374$

French Lumber Co. v. Theriault, 107 Wisconsin $627 \ldots \ldots \ldots . .335,337$

Frenche v. Chancellor, 51 New Jersey Equity $624 \ldots \ldots \ldots \ldots \ldots, 92$

Frickee v. Donner, 35 Michigan $151 \ldots \ldots \ldots \ldots \ldots \ldots \ldots \ldots \ldots . \ldots \ldots 3$

Frey v. Clifford, 44 California $335 \ldots \ldots \ldots \ldots \ldots \ldots \ldots \ldots \ldots \ldots, 81$

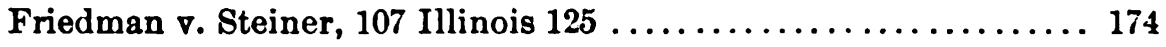

Frink v. Hughes (Michigan), 94 Northwestern $601 \ldots \ldots \ldots \ldots \ldots 228$

Fritts v. Palmer, 132 United States $282 \ldots \ldots \ldots \ldots \ldots \ldots \ldots \ldots . \ldots 5$

Fritz v. Pusey, 31 Minnesota $368 \ldots \ldots \ldots \ldots \ldots \ldots \ldots \ldots \ldots . \ldots 20 . \ldots \ldots$

Frost v. Courtis, 172 Massachusetts $401 \ldots \ldots \ldots \ldots \ldots \ldots \ldots \ldots . \ldots \ldots$

v. Wolf, 77 Texas $455 \ldots \ldots \ldots \ldots \ldots \ldots \ldots \ldots \ldots \ldots \ldots . \ldots \ldots$

Fudickar $\nabla$. East Riverside, 109 California 29.............. 249

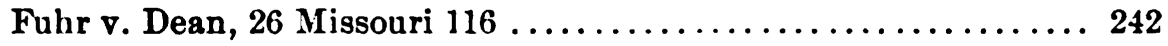

Fuikerson v. Holmes, 117 United States $389 \ldots \ldots \ldots \ldots \ldots \ldots \ldots, 44$

Fuller $\nabla$. Shedd, 161 Illinois $462 . \ldots \ldots \ldots \ldots \ldots \ldots \ldots \ldots \ldots ., 114$

Fulmer v. Williams, 122 Pennsylvania State $191 \ldots \ldots \ldots \ldots \ldots 109,110$

Fulton $\nabla$. Priddy, 123 Michigan $298 \ldots \ldots \ldots \ldots \ldots \ldots \ldots \ldots 251,307$

Funk v. Rentchler, 134 Indiana $68 \ldots \ldots \ldots \ldots \ldots \ldots \ldots \ldots \ldots \ldots \ldots \ldots \ldots$

Furrow $\nabla$. Athey, 21 Nebraska $671 \ldots \ldots \ldots \ldots \ldots \ldots \ldots \ldots .400$

G. V. B. Mining Co. v. Bank (United States), 95 Federal $23 \ldots \ldots 249$ Gadsby v. Monroe, 115 Michigan $282 \ldots \ldots \ldots \ldots \ldots \ldots \ldots . \ldots 392,397$

Gage v. Consumers' Electric Light Co., 194 Illinois 30.......... 437

จ. Railroad, 11 Iowa $310 \ldots \ldots \ldots \ldots \ldots \ldots \ldots \ldots \ldots . \ldots \ldots$

จ. Wheeler, 129 Illinois $197 \ldots \ldots \ldots \ldots \ldots \ldots \ldots \ldots \ldots .263,387$

Galbraith v. Paine (North Dakota), 96 North western $258 \ldots \ldots \ldots 417$

Gallagher v. Delargy, 57 Missouri $29 \ldots \ldots \ldots \ldots \ldots \ldots \ldots \ldots . \ldots 363$

Galloway v. Henderson, 131 Alabama $280 \ldots \ldots \ldots \ldots \ldots \ldots \ldots . \ldots \ldots$

Gamble v. McClure, 69 Pennsylvania State $282 \ldots \ldots \ldots \ldots \ldots \ldots 68$

Games v. Stiles, 14 Peters (United States) $322 \ldots \ldots \ldots \ldots \ldots \ldots \ldots 42$

Gann v. Free Fishers, 11 House of Lords Cases 192 ........... 104

Gannett v. Leonard, 47 Missouri $205 \ldots \ldots \ldots \ldots \ldots \ldots \ldots \ldots \ldots . \ldots . \ldots . \ldots$

Gardner v. Batts, 114 North Carolina $496 \ldots \ldots \ldots \ldots \ldots \ldots \ldots \ldots . \ldots 380$

v. Gardner, 5 Cushing (Massachusetts) $483 \ldots \ldots \ldots \ldots \ldots \ldots 238$

จ. Gardner, 123 Michigan $673 \ldots \ldots \ldots \ldots \ldots \ldots \ldots \ldots \ldots . \ldots \ldots 38$

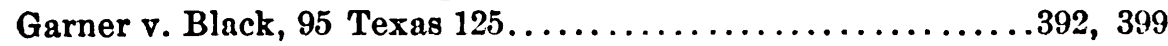

Garrett $\nabla$. Belmont Co., 94 Tennessee $459 \ldots \ldots \ldots \ldots \ldots \ldots \ldots . \ldots 249$

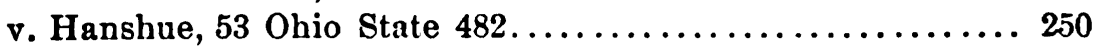

$\nabla$. Lister, 1 Levinz 25 (England)................... 250

Garstang v. Davenport, 90 Iowa $359 \ldots \ldots \ldots \ldots \ldots \ldots \ldots \ldots . \ldots 4$

Garth v. Arnold (United States), 115 Federal $468 \ldots \ldots \ldots \ldots \ldots \ldots 330$ 
[References are to Sections.]

Gaston v. Dashiell, 55 Texas $517 \ldots \ldots \ldots \ldots \ldots \ldots \ldots \ldots \ldots \ldots . \ldots 49$

v. Portland, 16 Oregon $255 \ldots \ldots \ldots \ldots \ldots \ldots \ldots \ldots \ldots \ldots . \ldots . \ldots . \ldots 9$

v. Weir, 84 Alabama $193 \ldots \ldots \ldots \ldots \ldots \ldots \ldots \ldots \ldots \ldots . \ldots \ldots$

Gate City Abstract Co. $\nabla$. Post, 55 Nebraska 742............ 425

Gates v. Salmon, 35 California $576 \ldots \ldots \ldots \ldots \ldots \ldots \ldots \ldots \ldots . \ldots \ldots$

v. Winslow, 1 Massachusetts $65 \ldots \ldots \ldots \ldots \ldots \ldots \ldots \ldots \ldots \ldots$

Gault $\nabla$. Van Zile, 37 Michigan $22 \ldots \ldots \ldots \ldots \ldots \ldots \ldots \ldots \ldots \ldots$

Geil $\nabla$. Geil, 9 Virginia Law Register $530 \ldots \ldots \ldots \ldots \ldots \ldots \ldots . \ldots 36$

Geiszler $\nabla$. De Graaf, 166 New York $339 \ldots \ldots \ldots \ldots \ldots \ldots \ldots .218$

Geofroy $\nabla$. Riggs, 133 United States $258 \ldots \ldots \ldots \ldots \ldots \ldots \ldots \ldots, 4$

George v. Bates, 90 Virginia $839 \ldots \ldots \ldots \ldots \ldots \ldots \ldots \ldots \ldots \ldots .81$

Georgia \&c. Railroad Co. v. Scott, 38 South Carolina 34......... 357

German-American Bank v. Carondelet, 150 Missouri $570 \ldots \ldots \ldots 283$

German Saving Loan Society v. De Lashmutt (United States), 67

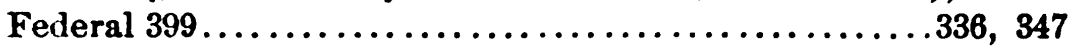

Gibbs v. Swift, 12 Cushing (Massachusetts) $393 \ldots \ldots \ldots \ldots \ldots \ldots$

Gibson v. Holden, 115 Illinois $199 \ldots \ldots \ldots \ldots \ldots \ldots \ldots \ldots \ldots .232$

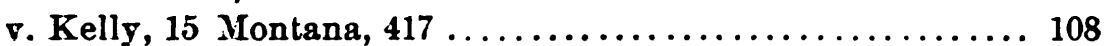

v. Richart, 83 Indiana $313 \ldots \ldots \ldots \ldots \ldots \ldots \ldots \ldots \ldots . \ldots . \ldots 188$

Gilbert $\nabla$. Berlin, 70 New Hampshire $396 \ldots \ldots \ldots \ldots \ldots \ldots \ldots .405$

v. Emerson, 55 Minnesota $254 \ldots \ldots \ldots \ldots \ldots \ldots \ldots \ldots \ldots . \ldots \ldots$

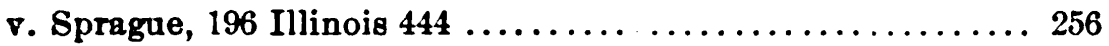

Giles v. Miller, 36 Nebraska $346 \ldots \ldots \ldots \ldots \ldots \ldots \ldots \ldots \ldots \ldots . \ldots \ldots 7$

Gill v. Gill, 69 Arkansas $596 \ldots \ldots \ldots \ldots \ldots \ldots \ldots \ldots \ldots \ldots . \ldots \ldots 2$

Gillenwaters v. Campbell, 142 Indiana $529 \ldots \ldots \ldots \ldots \ldots \ldots \ldots . \ldots \ldots$

Gilmer v. Mobile \&c. R. Co., 79 Alabama $569 \ldots \ldots \ldots \ldots \ldots \ldots 226$

Gilmore v. Sapp, 100 Illinois $297 \ldots \ldots \ldots \ldots \ldots \ldots \ldots \ldots \ldots \ldots . \ldots \ldots 7$

Gladney v. Sydnor, 172 Missouri $318 \ldots \ldots \ldots \ldots \ldots \ldots \ldots \ldots \ldots . \ldots 388$

Glascott $\nabla$. Bragg, 111 Wisconsin $605 \ldots \ldots \ldots \ldots \ldots \ldots \ldots \ldots \ldots 428$

Glaze $\nabla$. Insurance Co., 87 Michigan $349 \ldots \ldots \ldots \ldots \ldots \ldots \ldots . \ldots 298$

Gleason v. Spray, 81 California $217 \ldots \ldots \ldots \ldots \ldots \ldots \ldots \ldots \ldots \ldots$

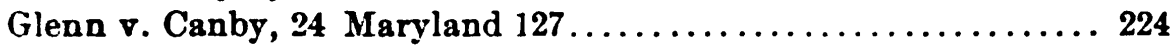

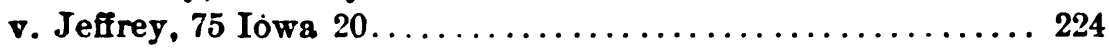

Globe Insurance Co. $v$. Reid, 19 Indiana Appellate $203 \ldots \ldots \ldots 240$

Glocke $\nabla$. Glocke, 113 Wisconsin $303 \ldots \ldots \ldots \ldots \ldots \ldots \ldots . \ldots 183,184$

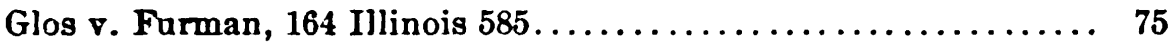

v. Kingman \& Co. (Illinois), 69 North western $632 \ldots \ldots \ldots \ldots 438$

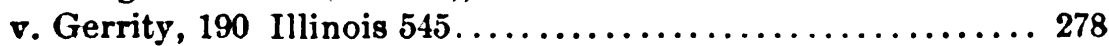

Glynn v. Glynn, 62 Nebraska $872 \ldots \ldots \ldots \ldots \ldots \ldots \ldots \ldots \ldots .408$

Goad v. Lawrence (Kentucky), 68 Southwestern $411 \ldots \ldots \ldots \ldots \ldots 29$

Goddard's Case, 2 Coke $4 b, 5 \ldots \ldots \ldots \ldots \ldots \ldots \ldots \ldots \ldots . \ldots \ldots, 247$

Godfrey $\mathbf{v}$. Thornton, 46 Wisconsin $677 \ldots \ldots \ldots \ldots \ldots . \ldots 390,398,399$

Goff $\vee$ Cougle, 118 Michigan $307 \ldots \ldots \ldots \ldots \ldots \ldots \ldots \ldots \ldots \ldots, 98$

Goldsmith $\nabla$. Goldemith, 46 West Virginia $426 \ldots \ldots \ldots \ldots \ldots \ldots 183$

Goodman v. Randall, 44 Connecticut $321 \ldots \ldots \ldots \ldots \ldots \ldots \ldots \ldots 234$

Goodnow v. Lumber Co., 31 Minnesota $468 \ldots \ldots \ldots \ldots \ldots \ldots \ldots . \ldots 317$

Goodrich $\nabla$. Russell, 42 New York $177 \ldots \ldots \ldots \ldots \ldots \ldots \ldots . \ldots 410$ 


\section{[References are to Sections.]}

Goodwin v. Goodwin, 113 Iowa $319 \ldots \ldots \ldots \ldots \ldots \ldots \ldots \ldots \ldots . \ldots . \ldots 2$

v. Keney, 49 Connecticut $563 \ldots \ldots \ldots \ldots \ldots \ldots \ldots \ldots \ldots \ldots \ldots$

v. Thompson, 83 Tennessee $209 \ldots \ldots \ldots \ldots \ldots \ldots \ldots \ldots$. $\ldots 8,109$

Gordon v. Heywood, 2 New Hampshire $402 \ldots \ldots \ldots \ldots \ldots \ldots \ldots . \ldots 2$

v. San Diego, 101 California 522.................... 157

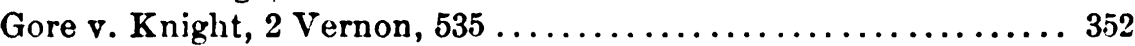

Goree v. Wadsworth, 91 Alabama $416 \ldots \ldots \ldots \ldots \ldots \ldots \ldots . \ldots 278$

Gorman v. Mullins, 172 Illinois $349 \ldots \ldots \ldots \ldots \ldots \ldots \ldots \ldots \ldots . \ldots \ldots$

Gormley v. Clark, 134 United States $338 \ldots \ldots \ldots \ldots \ldots \ldots \ldots \ldots$. 4

Gould v. Railroad, 142 Massachusetts $85 \ldots \ldots \ldots \ldots \ldots \ldots \ldots \ldots .69$

Goulet $\nabla$. Debreuille, 84 Minnesota 72.................. 293

Gouverneur v. National Ice Co., 134 New York $355 \ldots \ldots \ldots \ldots \ldots 116$

Gourerneur's Heirs v. Robertson, 11 Wheaton (United States) 332.409

Grady v. McCorkle, 57 Missouri $172 \ldots \ldots \ldots \ldots \ldots \ldots \ldots \ldots \ldots . \ldots \ldots$

Graham v. Stern, 168 New York $517 \ldots \ldots \ldots \ldots \ldots \ldots \ldots \ldots \ldots . .69$

Grand Rapids v. Hastings, 36 Michigan 122 ................. 292

v. Powers, 89 Michigan $94 \ldots \ldots \ldots \ldots \ldots \ldots \ldots \ldots \ldots \ldots . \ldots \ldots$

Grand Rapids Ice Co. v. Ice Co., 102 Michigan 227 ............ 116

Grand Rapids and Indiana R. Co. $\nabla$. Butler, 159 United States

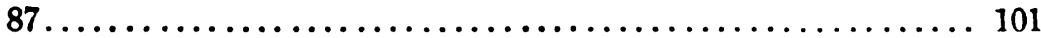

Granger v. A very, 64 Maine $292 \ldots \ldots \ldots \ldots \ldots \ldots \ldots \ldots \ldots \ldots \ldots \ldots \ldots$

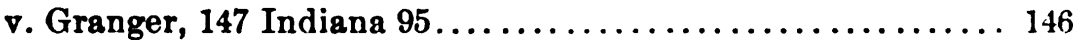

Grant v. Carpenter, 8 Rhode Island $36 \ldots \ldots \ldots \ldots \ldots \ldots \ldots \ldots 138$

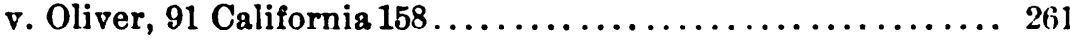

Graves v. Deterling, 120 New York $447 \ldots \ldots \ldots \ldots \ldots \ldots . \ldots \ldots, 226$

Gray v. Blanchard, 8 Pickering (Massachusetts) $284 \ldots \ldots \ldots \ldots 186$

v. Chicago, Milwaukee and St. Paul R. Co., 189 Illinois $400 \ldots 181$

v. Jones (United States), 14 Federal $83 \ldots \ldots \ldots \ldots \ldots \ldots \ldots . \ldots 426$

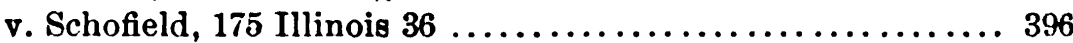

v. Waldron, 101 Michigan $612 \ldots \ldots \ldots \ldots \ldots \ldots \ldots \ldots \ldots . \ldots . \ldots . \ldots 249$

Green $\nabla$. Bennett, 120 North Carolina 394...............363, 364

v. Cumberland \&c. Co. (Tennessee), 72 Southwestern, 459..417, 421

v. Green, 69 New York $553 \ldots \ldots \ldots \ldots \ldots \ldots \ldots \ldots \ldots \ldots . \ldots \ldots . \ldots \ldots$

v. Irving, 54 Mississippi $454 \ldots \ldots \ldots \ldots \ldots \ldots \ldots \ldots \ldots \ldots \ldots$

v. Jordan, 83 Alabama $220 \ldots \ldots \ldots \ldots \ldots \ldots \ldots \ldots \ldots \ldots, 78$

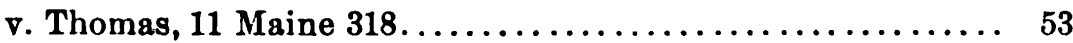

v. Wilding, 59 Iowa $679 \ldots \ldots \ldots \ldots \ldots \ldots \ldots \ldots \ldots \ldots \ldots \ldots$

Greenby $\nabla$. Wilcocks, 2 Johnson (New York) $1 \ldots \ldots \ldots \ldots \ldots \ldots 217$

Greene $\nabla$. O'Connor, 18 Rhode Island $56 \ldots \ldots \ldots \ldots \ldots \ldots \ldots 179,180$

Greenslade v. Dare, 20 Beaver $284 \ldots \ldots \ldots \ldots \ldots \ldots \ldots \ldots \ldots . \ldots \ldots \ldots$

Greenwood v. Jenswald, 69 Iowa $53 \ldots \ldots \ldots \ldots \ldots \ldots \ldots \ldots \ldots . \ldots \ldots$

Greer v. Major, 114 Missouri $145 \ldots \ldots \ldots \ldots \ldots \ldots \ldots \ldots \ldots \ldots . \ldots \ldots$

v. Wintersmith, 85 Kentucky $516 \ldots \ldots \ldots \ldots \ldots \ldots \ldots \ldots .419$

Grier's Appeal, 101 Pennsylvania State $412 \ldots \ldots \ldots \ldots \ldots \ldots \ldots . \ldots \ldots$

Griffin v. Catlin, 25 Washington $474 \ldots \ldots \ldots \ldots \ldots \ldots \ldots \ldots \ldots . \ldots \ldots 1$ 
[References are to Sections.]

Griffith v. Godey, 113 United States $89 . \ldots \ldots \ldots \ldots \ldots \ldots \ldots . \ldots 341$

v. Holman, 23 Washington $347 \ldots \ldots \ldots \ldots \ldots \ldots \ldots . \ldots 108,110$

v. Pritchard, 5 Barnewall and Adolphus $765 \ldots \ldots \ldots \ldots \ldots 413$

Griswold v. Hicks, 132 Illinois $494 \ldots \ldots \ldots \ldots \ldots \ldots \ldots \ldots \ldots 147$

Groff $\nabla$. Bank, 50 Minnesota $234 \ldots \ldots \ldots \ldots \ldots \ldots \ldots \ldots \ldots \ldots 431$

Groneweg $\nabla$. Beck, 93 Iowa $717 \ldots \ldots \ldots \ldots \ldots \ldots \ldots \ldots \ldots \ldots . \ldots \ldots$

Gmre v. Todd, 41 Maryland $633 \ldots \ldots \ldots \ldots \ldots \ldots \ldots \ldots \ldots \ldots \ldots$

Groves v. Groves, 65 Ohio $442 \ldots \ldots \ldots \ldots \ldots \ldots \ldots \ldots \ldots \ldots . \ldots 6$

Grubbs $\nabla$. Leyendecker, 153 Indiana $348 \ldots \ldots \ldots \ldots \ldots \ldots \ldots . \ldots \ldots$

Guerin v. Smith, 62 Michigan $369 \ldots \ldots \ldots \ldots \ldots \ldots \ldots \ldots \ldots .218$

Guertin $\nabla$ Mombleau, 144 Illinois $32 \ldots \ldots \ldots \ldots \ldots \ldots \ldots \ldots \ldots+2$

Guggenheimer v. Lockridge, 39 West Virginia $457 \ldots \ldots \ldots \ldots \ldots 300$

Guilioyle, In re, 96 California $598 \ldots \ldots \ldots \ldots \ldots \ldots \ldots \ldots \ldots . \ldots \ldots$

Gulf \& Ship Island R. Co. v. Singleterry, 78 Mississippi $772 \ldots \ldots 395$

Gulf R. Co. v. Jones, 82 Texas $156 \ldots \ldots \ldots \ldots \ldots \ldots \ldots \ldots \ldots$. 61

Gullett v. Arnett (Kentucky), 44 South western $957 \ldots \ldots \ldots \ldots \ldots . . . . .388$

Gully v. Grubbs, 1 J. J. Marshall (Kentucky) $387 \ldots \ldots \ldots \ldots \ldots . \ldots 9$

Gunnison $\nabla$. Twitchel, 38 New Hampshire 62 . .............. 397

Guyer v. Smith, 22 Maryland $239 \ldots \ldots \ldots \ldots \ldots \ldots \ldots \ldots \ldots . \ldots \ldots$

Gwynne v. Cincinnati, 3 Ohio $24 \ldots \ldots \ldots \ldots \ldots \ldots \ldots \ldots \ldots \ldots$

Haberman v. Baker, 128 New York $253 \ldots \ldots \ldots \ldots \ldots \ldots \ldots \ldots . . \ldots 1$

Hacker's Appeal, 121 Pennsylvania State $192 \ldots \ldots \ldots \ldots \ldots \ldots \ldots 246$

Hackett $\mathrm{v}$. Moxley, 68 Vermont $210 \ldots \ldots \ldots \ldots \ldots \ldots \ldots \ldots . \ldots \ldots, 353$

Hackney $\nabla$. Butts, 41 Arkansas $393 \ldots \ldots \ldots \ldots \ldots \ldots \ldots \ldots \ldots . \ldots \ldots$

Haddock $\nabla$. Railroad, 146 Massachusetts $155 \ldots \ldots \ldots \ldots \ldots \ldots \ldots 428$

Hafner $\nabla$. St. Louis, 161 Missouri 34.................. 405

Hagerstown Manufacturing \&c. Co. v. Keedy, 91 Maryland 430... 405

Haggerty $\nabla$. Wagner, 148 Indiana $625 \ldots \ldots \ldots \ldots \ldots \ldots \ldots \ldots . \ldots \ldots \ldots$

Haight $\nabla$. Vallet, 89 California $245 \ldots \ldots \ldots \ldots \ldots \ldots \ldots \ldots \ldots$. 426

Haldane v. Sweet, 55 Michigan 196..................... 203

Hale v. Cottle, 21 Oregon $580 \ldots \ldots \ldots \ldots \ldots \ldots \ldots \ldots \ldots \ldots . \ldots 7$

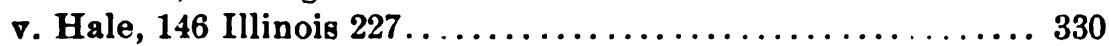

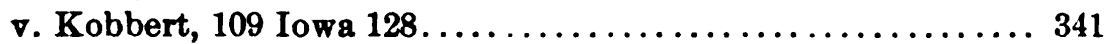

Hall v. Alford, 114 Michigan 165................... 106, 107

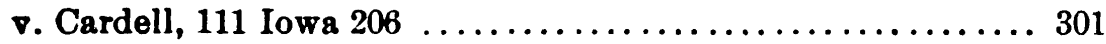

จ. Dean, 13 Johnson (New York) $105 \ldots \ldots \ldots \ldots \ldots \ldots \ldots \ldots . \ldots \ldots$

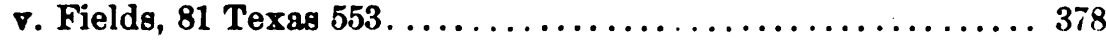

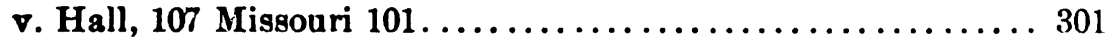

v. Powell, 8 Oklahoma 276....................... 400

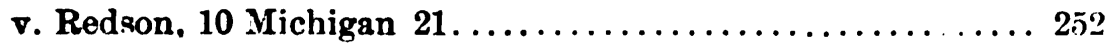

v. Solomon, 61 Connecticut $476 \ldots \ldots \ldots \ldots \ldots \ldots \ldots \ldots \ldots, 61$

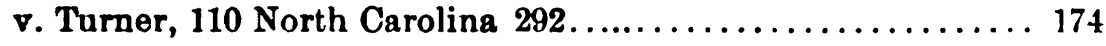

v. Walker, 118 North Carolina $377 \ldots \ldots \ldots \ldots \ldots \ldots \ldots \ldots \ldots . \ldots \ldots 3$

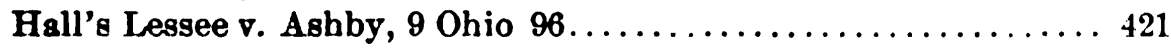

Halstead $\nabla$. Board Commissioners, 56 Indiana $363 \ldots \ldots \ldots \ldots \ldots 410$

Hamaker v. Hamaker, 88 Alabama $431 \ldots \ldots \ldots \ldots \ldots \ldots \ldots . \ldots \ldots 2$ 
[Rcferences are to sections.]

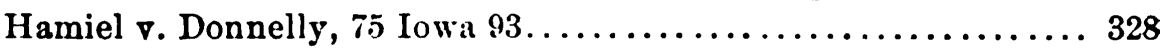

Hamilton v. Detroit, 85 Minnesota $83 \ldots \ldots \ldots \ldots \ldots \ldots \ldots \ldots . \ldots . \ldots$

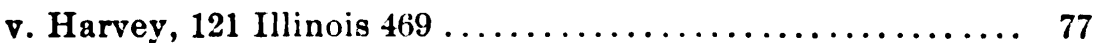

จ. Hubbard, 134 California $603 \ldots \ldots \ldots \ldots \ldots \ldots \ldots \ldots$. 353

v. Nutt, 34 Connecticut $501 \ldots \ldots \ldots \ldots \ldots \ldots \ldots \ldots \ldots . \ldots 49$

Hamlen v. Werner, 144 Massachusetts $396 \ldots \ldots \ldots \ldots \ldots \ldots \ldots 228$

Hammers v. Dole, 61 Illinois $307 \ldots \ldots \ldots \ldots \ldots \ldots \ldots \ldots . \ldots 281,283$

Hammond v. Shepard, 186 Illinois $235 \ldots \ldots \ldots \ldots \ldots \ldots \ldots \ldots 112,114$

Hampton v. Cook, 64 Arkansas $353 . \ldots \ldots \ldots \ldots \ldots \ldots \ldots \ldots \ldots . \ldots . \ldots 36$

Hand v. Weidner, 151 Pennsylvania State $362 \ldots \ldots \ldots \ldots \ldots \ldots . \ldots 376$

Hanlon v. Hobson, 24 Colorado $284 \ldots \ldots \ldots \ldots \ldots \ldots \ldots \ldots \ldots . .68$

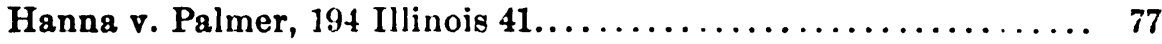

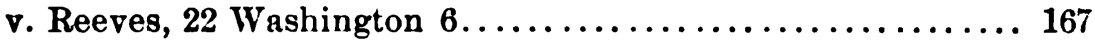

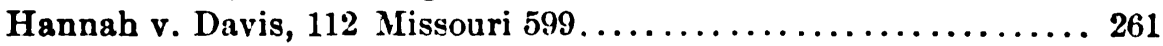

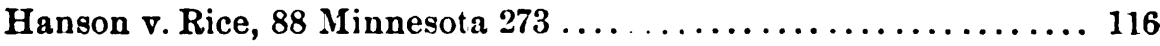

Hardin v. Jordan, 140 United States $371 \ldots \ldots \ldots \ldots 4,102,113,114,115$

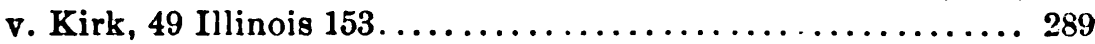

จ. Osborne, 60 Illinois $93 \ldots \ldots \ldots \ldots \ldots \ldots \ldots \ldots \ldots . \ldots \ldots . \ldots . \ldots 289$

v. Shedd, 177 Illinois $123 \ldots \ldots \ldots \ldots \ldots \ldots \ldots \ldots \ldots \ldots . \ldots \ldots 114$

v. Shedd, 190 United States $508 \ldots \ldots \ldots \ldots \ldots \ldots \ldots \ldots 101,114$

Harding v. American Glucose Co., 182 Illinois $551 \ldots \ldots \ldots \ldots \ldots .406$

Hare v. Murphy, 60 Nebraska $135 \ldots \ldots \ldots \ldots \ldots \ldots \ldots \ldots \ldots \ldots . \ldots \ldots 1$

Hargis v. Ditmore, 86 Kentucky $653 \ldots \ldots \ldots \ldots \ldots \ldots \ldots \ldots \ldots . \ldots \ldots$

Harkins v. Forsyth, 11 Leigh (Virginia) $294 \ldots \ldots \ldots \ldots \ldots \ldots \ldots . \ldots \ldots 5$

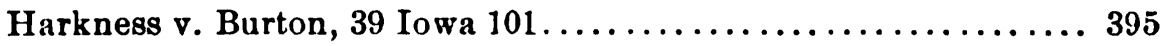

Harley v. State, 40 Alabama $689 \ldots \ldots \ldots \ldots \ldots \ldots \ldots \ldots \ldots \ldots . \ldots \ldots$

Harlowe $\nabla$. Hudgins, 84 Texas $107 \ldots \ldots \ldots \ldots \ldots \ldots \ldots \ldots \ldots, 70$

Harmon v. Stearns, 95 Virginia $58 \ldots \ldots \ldots \ldots \ldots \ldots \ldots \ldots \ldots \ldots .44$

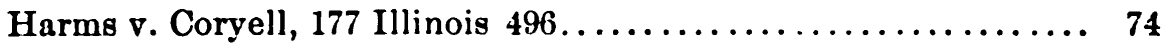

Harral v. Leverty, 50 Connecticut $46 \ldots \ldots \ldots \ldots \ldots \ldots \ldots \ldots .419$

Harrass v. Edwards, 94 Wisconsin $459 \ldots \ldots \ldots \ldots \ldots \ldots \ldots \ldots 251,253$

Harraway $\nabla$. Harraway, 136 Alabama $499 \ldots \ldots \ldots \ldots \ldots \ldots \ldots . \ldots \ldots$

Harriman v. Queen Insurance Co., 49 Wisconsin $71 \ldots \ldots \ldots \ldots . . .384$

Harrington v. Bean, 89 Maine $470 \ldots \ldots \ldots \ldots \ldots \ldots \ldots \ldots . \ldots 209$

Harriot v. Harriot, 25 New York Appellate Division $245 \ldots \ldots \ldots .143$

Harris v. McCann, 75 Mississippi $805 \ldots \ldots \ldots \ldots \ldots \ldots \ldots \ldots . \ldots \ldots$

Harrison v. Des Moines R. Co., 91 Iowa $114 \ldots \ldots \ldots \ldots \ldots \ldots . . \ldots 208$

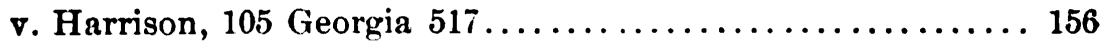

v. Stipes, 34 Nebraska $431 \ldots \ldots \ldots \ldots \ldots \ldots \ldots \ldots \ldots \ldots . \ldots \ldots 2$

$\nabla$. Vreeland, 38 New Jersey Law $366 \ldots \ldots \ldots \ldots \ldots \ldots \ldots \ldots 24$

Harsh $\nabla$. Griffin, 72 Iowa $608 \ldots \ldots \ldots \ldots \ldots \ldots \ldots \ldots \ldots \ldots . \ldots \ldots$

Harshbarger v. Carroll, 163 Illinois $636 \ldots \ldots \ldots \ldots \ldots \ldots \ldots \ldots .29$

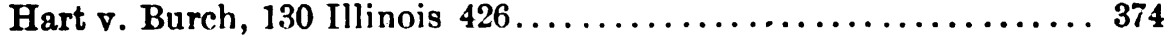

v. Church, 126 California $471 \ldots \ldots \ldots \ldots \ldots \ldots \ldots \ldots \ldots \ldots . \ldots \ldots$

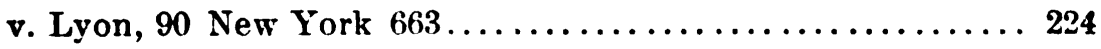

v. Randolph, 142 Illinois $521 \ldots \ldots \ldots \ldots \ldots \ldots \ldots \ldots \ldots 272$

Hartung $\nabla$. Witte, 59 Wisconsin $285 \ldots \ldots \ldots \ldots \ldots \ldots \ldots \ldots \ldots$ 


\section{[References are to sections.]}

Hatch's Estate, 62 Vermont $300 \ldots \ldots \ldots \ldots \ldots \ldots \ldots \ldots \ldots \ldots . \ldots . \ldots . \ldots$

Hatfield v. Sneden, 54 New York $280 \ldots \ldots \ldots \ldots \ldots \ldots \ldots \ldots . \ldots . \ldots 36$

Hathaway v. Cass, 84 Minnesota $192 \ldots \ldots \ldots \ldots \ldots \ldots \ldots \ldots . \ldots 303$

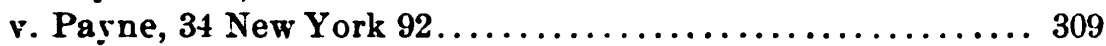

Hatton v. Holmes, 97 California $208 \ldots \ldots \ldots \ldots \ldots \ldots \ldots \ldots . \ldots 272$

Hauenstein v. Lynham, 100 United States $483 \ldots \ldots \ldots \ldots \ldots \ldots 4$

Haremeyer v. Dahn, 48 Nebraska $536 \ldots \ldots \ldots \ldots \ldots \ldots \ldots \ldots . \ldots 288$

Havens v. Seashore Co., 47 New Jersey Equity $365 \ldots \ldots \ldots \ldots . \ldots 7,69$

Hawes $v$. Hawes, 177 Illinois $409 \ldots \ldots \ldots \ldots \ldots \ldots \ldots \ldots \ldots . \ldots \ldots$

v. Hawes, 1 Wilson $165 ; 3$ Atkyns $524 \ldots \ldots \ldots \ldots \ldots \ldots \ldots 151$

v. Railroad Co., 64 Iowa $315 \ldots \ldots \ldots \ldots \ldots \ldots \ldots \ldots \ldots . \ldots . \ldots 21$

Hawke $\nabla$. Chicago \&c. R. Co., 165 Illinois $561 \ldots \ldots \ldots \ldots \ldots \ldots .428$

v. Euyart, 30 Nebraska $149 \ldots \ldots \ldots \ldots \ldots \ldots \ldots \ldots \ldots \ldots . \ldots \ldots$

Hawkes v. Pike, 105 Massachusetts $560 \ldots \ldots \ldots \ldots \ldots \ldots \ldots \ldots . \ldots . \ldots 2$

Hawley $v$. Northampton, 8 Massachusetts $3 \ldots \ldots \ldots \ldots \ldots \ldots \ldots 142$

Haworth $\nabla$. Taylor, 108 Illinois $275 \ldots \ldots \ldots \ldots \ldots \ldots \ldots \ldots \ldots 430$

Hayden $v$. Peirce, 165 Massachusetts $359 \ldots \ldots \ldots \ldots \ldots \ldots \ldots . \ldots 261$

Hayes v. Association, 124 Alabama $663 \ldots \ldots \ldots \ldots \ldots \ldots \ldots \ldots . \ldots \ldots$

Haynes $\mathbf{v}$. Bennett, 53 Michigan 15.................... 322

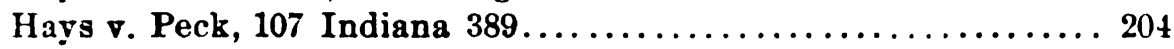

จ. St. Paul's Church, 196 Illinois $633 \ldots \ldots \ldots \ldots \ldots \ldots \ldots 228$

Head v. Chesbrough, 13 Ohio Circuit Court $354 \ldots \ldots \ldots \ldots \ldots . .69$

v. Chesbrough, 60 Ohio State $594 \ldots \ldots \ldots \ldots \ldots \ldots \ldots \ldots . \ldots 9$

Healey $\nabla$. Babbitt, 14 Rhode Island $533 \ldots \ldots \ldots \ldots \ldots \ldots \ldots, 91$

Heath $\nabla$. Hewitt, 127 New York $166 \ldots \ldots \ldots \ldots \ldots \ldots \ldots . \ldots 40$

Hedbloom $\nabla$. Pierson (Nebraska), 90 North western 218........ 282

Heintz $\nabla$. Thayer, 92 Texas $658 \ldots \ldots \ldots \ldots \ldots \ldots \ldots \ldots \ldots 260,269$

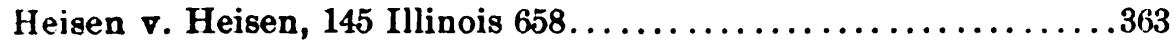

Heinsen $\nabla$. Lamb, 117 Illinois $549 \ldots \ldots \ldots \ldots \ldots \ldots \ldots \ldots \ldots . \ldots 25$

Heller $\nabla$. Cowen, 154 New York $299 \ldots \ldots \ldots \ldots \ldots \ldots \ldots \ldots \ldots$ 85

Helrie v. Hoover (Oklahoma), 69 Pacific $958 \ldots \ldots \ldots \ldots \ldots \ldots \ldots$

Hemphill v. Holford, 88 Michigan $293 \ldots \ldots \ldots \ldots \ldots \ldots \ldots \ldots . \ldots \ldots$

Henderson $\nabla$. Hatterman, 146 Illinois $555 \ldots \ldots \ldots \ldots \ldots \ldots \ldots \ldots .69$

Henry $\mathbf{v}$. Root, 33 New York 526. ...................312, 323

Henschel, In re (United States), 109 Federal $861 \ldots \ldots \ldots \ldots \ldots . .259$

Herd v. Catron, 97 Tennessee $662 \ldots \ldots \ldots \ldots \ldots \ldots \ldots \ldots \ldots \ldots \ldots$

Hershman $\mathbf{v}$. Hershman, 63 Indiana $451 \ldots \ldots \ldots \ldots \ldots \ldots \ldots . \ldots \ldots$

Heỹn v. Ohman, 42 Nebraska $693 \ldots \ldots \ldots \ldots \ldots \ldots \ldots \ldots \ldots . \ldots 210$

Heyrood $\nabla$. Lumber Co., 70 New Hampshire $24 \ldots \ldots \ldots \ldots \ldots \ldots .64$

Hibblewhite $\nabla$. M'Morine, 6 Meeson \& Welsby $200 \ldots \ldots \ldots \ldots \ldots 245$

Hickey v. Lake Shore \& Michigan Southern R. Co., 51 Ohio State

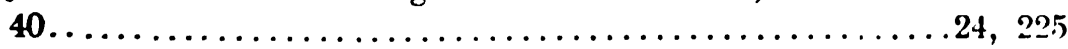

Hicks $\nabla$. Blakeman, 74 Mississippi $459 \ldots \ldots \ldots \ldots \ldots \ldots \ldots \ldots 29$

Higgins $\nabla$. Higgins, 121 California $487 \ldots \ldots \ldots \ldots \ldots \ldots \ldots \ldots, 81$

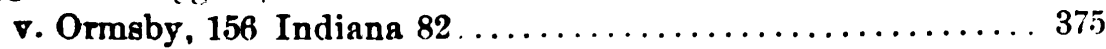

Higinbotham $\nabla$. Stoddard, 72 New York $94 \ldots \ldots \ldots \ldots \ldots \ldots \ldots 87$ 


\section{[References are to sections.]}

Hileman v. Bouslaugh, 13 Pennsylvania State $344 \ldots \ldots \ldots \ldots \ldots \ldots 147$

Hiles v. Fisher, 144 New York $306 \ldots \ldots \ldots \ldots \ldots \ldots \ldots \ldots . \ldots . \ldots 164,166$

Hill v. Banks, 61 Connecticut $25 \ldots \ldots \ldots \ldots \ldots \ldots \ldots \ldots \ldots \ldots . \ldots \ldots$

v. Chambers, 30 Michigan $422 \ldots \ldots \ldots \ldots \ldots \ldots \ldots \ldots \ldots . \ldots 363$

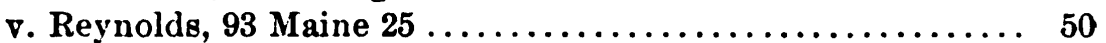

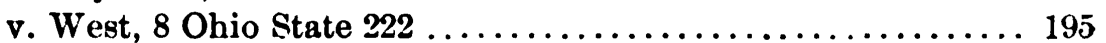

Hills v. Metzenroth, 173 Massachusetts $423 \ldots \ldots \ldots \ldots \ldots \ldots \ldots . \ldots 228$

Hilmert v. Christian, 29 Wisconsin $104 \ldots \ldots \ldots \ldots \ldots \ldots \ldots \ldots . \ldots 2$

Hilpire v. Claude, 109 Iowa $159 \ldots \ldots \ldots \ldots \ldots \ldots \ldots \ldots \ldots .428$

Hinchliffe v. Shea, 103 New York $153 \ldots \ldots \ldots \ldots \ldots \ldots \ldots \ldots . \ldots \ldots$

Hitner's Appeal, 54 Pennsylvania State $110 \ldots \ldots \ldots \ldots \ldots \ldots \ldots . \ldots . \ldots$

Hitz v. Jenks, 123 United States, $297 \ldots \ldots \ldots \ldots \ldots \ldots \ldots 18,293,365$

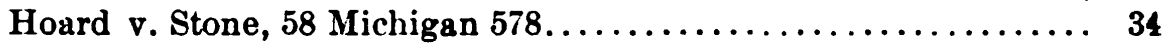

Hoback v. Miller, 44 West Viaginia $635 \ldots \ldots \ldots \ldots \ldots \ldots \ldots \ldots . \ldots . \ldots \ldots$

Hoban v. Cable, 102 Michigan $206 \ldots \ldots \ldots \ldots \ldots \ldots \ldots \ldots \ldots \ldots . \quad 87$

Hobson v. Hale, 95 New York $588 \ldots \ldots \ldots \ldots \ldots \ldots \ldots \ldots \ldots .6$

Hodge v. Sloan, 107 New York $244 \ldots \ldots \ldots \ldots \ldots \ldots \ldots \ldots \ldots .230$

Hoffman v. Port Huron, 102 Michigan $417 \ldots \ldots \ldots \ldots \ldots \ldots \ldots .92$

Hofsass v. Mann, 74 Maryland $400 \ldots \ldots \ldots \ldots \ldots \ldots \ldots \ldots \ldots . \ldots \ldots, 136$

Hogan v. Barry, 143 Massachusetts $538 . \ldots \ldots \ldots \ldots \ldots \ldots \ldots . . \ldots 23$

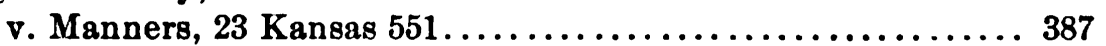

Hogg v. Beerman, 41 Ohio State $81 \ldots \ldots \ldots \ldots \ldots \ldots \ldots \ldots \ldots . \ldots . \ldots 112$

Hollenbeck v. Hollenbeck, 185 Illinois $101 \ldots \ldots \ldots \ldots \ldots \ldots \ldots .299$

Holliday v. Hively, 198 Pennsylvania State $335 \ldots \ldots \ldots . .353,355,357$

Holloway v. Southmayd, 139 New York $390 \ldots \ldots \ldots \ldots \ldots \ldots . .90$

Holmes v. McDonald, 119 Michigan 563 .................. 304

Holmes \&c. Manufacturing Co. v. Holmes \&c. Metal Co., 127 New

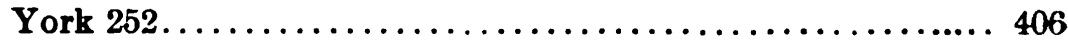

Holston v. Needles, 115 Illinois $461 \ldots \ldots \ldots \ldots \ldots \ldots \ldots \ldots \ldots . . \ldots 5$

Hopkins v. Smith, 162 Massachasetts $444 \ldots \ldots \ldots \ldots \ldots \ldots \ldots \ldots .228$

Hopper v. Calhoun, 52 Kansas $703 \ldots \ldots \ldots \ldots \ldots \ldots \ldots \ldots \ldots .65$

Horbach v. Tyrrell, 48 Nebraska $514 \ldots \ldots \ldots \ldots \ldots \ldots \ldots \ldots \ldots . . \ldots 287$

Hornbrook v. Hetzel, 27 Indiana Appellate $79 \ldots \ldots \ldots \ldots \ldots \ldots .35$

Horne v. Smith, 159 United State $40 \ldots \ldots \ldots \ldots \ldots \ldots \ldots \ldots . \ldots \ldots$

Horner v. Chicago, Milwaukee \& St. Paul R. Co., 38 Wisconsin

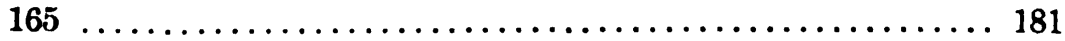

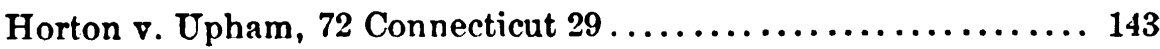

Hostetter $\nabla$. Railroad, 108 California $38 \ldots \ldots \ldots \ldots \ldots \ldots \ldots \ldots . . \ldots 2$

Hottell $\nabla$. Farmers' Association, 25 Colorado $67 \ldots \ldots \ldots \ldots \ldots \ldots 226$

House v. Jackson, 50 New York $161 \ldots \ldots \ldots \ldots \ldots \ldots \ldots \ldots . \ldots . \ldots 373$

Houston v. Blackman, 66 A labama $559 \ldots \ldots \ldots \ldots \ldots \ldots \ldots .60$

Hout $\nabla$. Hout, 20 Ohio State $119 \ldots \ldots \ldots \ldots \ldots \ldots \ldots \ldots 262,291$

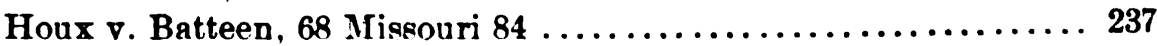

Hovey v. Hobson, 53 Maine $451 \ldots \ldots \ldots \ldots \ldots \ldots \ldots \ldots \ldots \ldots . \ldots \ldots 74$

v. Newton, 11 Pickering (Massachusetts) $421 \ldots \ldots \ldots \ldots \ldots \ldots 193$

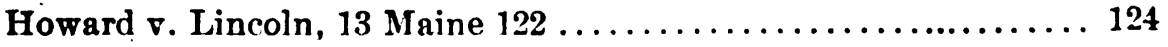

v. Russell, 104 Georgia $230 \ldots \ldots \ldots \ldots \ldots \ldots \ldots \ldots \ldots \ldots \ldots \ldots \ldots$ 
Howard $\nabla$. Turner, 125 North Carolina $107 \ldots \ldots \ldots \ldots \ldots \ldots \ldots .52$

Howell v. Folsom, 38 Oregon $184 \ldots \ldots \ldots \ldots \ldots \ldots \ldots \ldots \ldots \ldots$

v. Jones, 91 Tennessee $402 \ldots \ldots \ldots \ldots \ldots \ldots \ldots \ldots \ldots \ldots \ldots . \ldots \ldots 2$

Howes $\nabla$. Burt, 130 Massachusetts $368 \ldots \ldots \ldots \ldots \ldots \ldots \ldots \ldots \ldots \ldots \ldots \ldots$

Hoy v. Varner, 100 Virginia $600 \ldots \ldots \ldots \ldots \ldots \ldots \ldots \ldots \ldots . \ldots . \ldots . \ldots . \ldots$

Hoyt $\mathbf{v}$. Hoyt, 69 Iowa $174 \ldots \ldots \ldots \ldots \ldots \ldots \ldots \ldots \ldots \ldots \ldots \ldots \ldots \ldots$

v. Sprague, 103 United States $613 \ldots \ldots \ldots \ldots \ldots \ldots \ldots . \ldots 324,330$

v. Thompson, 19 New York $207 \ldots \ldots \ldots \ldots \ldots \ldots \ldots \ldots$

Hrouska v. Janke, 66 Wisconsin $252 \ldots \ldots \ldots \ldots \ldots \ldots \ldots \ldots, 37$

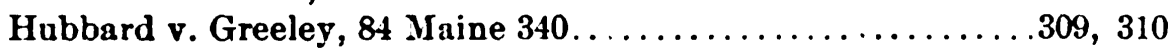

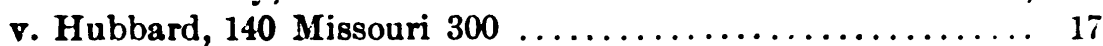

จ. Norton, 10 Connecticut $423 \ldots \ldots \ldots \ldots \ldots \ldots \ldots \ldots . \ldots 203$

จ. Sage Land \&c. Co., 81 Mississippi 616............392, 398

Hudgins v. Chupp, 103 Georgia $484 \ldots \ldots \ldots \ldots \ldots \ldots \ldots \ldots \ldots \ldots \ldots$

Huff v. Hastings Express Co., 195 Illinois $257 \ldots \ldots \ldots \ldots \ldots \ldots .89$

v. McCauley, 53 Pennsylvania State $206 \ldots \ldots \ldots \ldots \ldots \ldots 242$

Hughes v. Jones, 116 New York $67 \ldots \ldots \ldots \ldots \ldots \ldots \ldots \ldots . \ldots . \ldots 32$

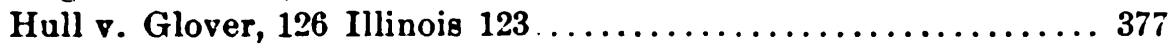

จ. Hull, 35 West Virgina $155 \ldots \ldots \ldots \ldots \ldots \ldots \ldots \ldots \ldots \ldots . \ldots . \ldots 207$

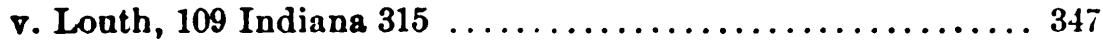

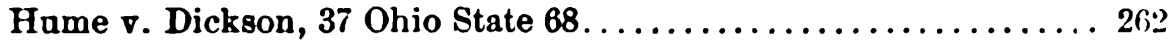

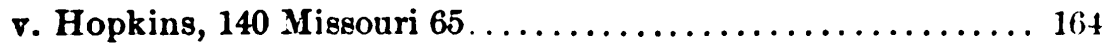

Hammelman $\nabla$. Mount, 87 Indiana $178 \ldots \ldots \ldots \ldots \ldots \ldots \ldots$ i1

Humphreys $\nabla$. McKissock, 140 United States $304 \ldots \ldots \ldots \ldots . .99,118$

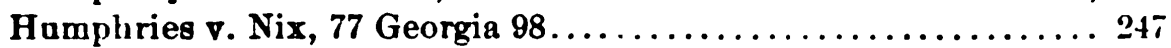

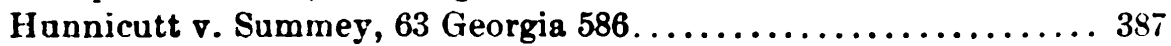

Iunt $v$. Yiddlesworth, 44 Michigan $448 \ldots \ldots \ldots \ldots \ldots \ldots \ldots \ldots . .220$

v. Tolles (Vermont), 52 Atlantic $1042 \ldots \ldots \ldots \ldots \ldots \ldots \ldots .40$

Hunter $\nabla$. Eastham (Texas), 67 Southwestern 1080............ 239

Hanton v. Wood (Virginia), 43 Southeastern $186 \ldots \ldots \ldots \ldots \ldots 281$

Haron Land Co. $\nabla$. Davison (Michigan), 90 North western 1034.... 124

v. Robarge, 128 Michigan $686 \ldots \ldots \ldots \ldots \ldots \ldots \ldots \ldots \ldots . \ldots 1$

Harst v. Dulaney, 87 Virginia $444 \ldots \ldots \ldots \ldots \ldots \ldots \ldots \ldots \ldots . \ldots \ldots$

v. Wilson, 89 Tennessee $270 \ldots \ldots \ldots \ldots \ldots \ldots \ldots \ldots \ldots \ldots \ldots \ldots$

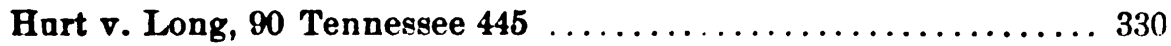

Hutchins $\nabla$. Barre Water Co., 74 Vermont $36 \ldots \ldots \ldots \ldots \ldots \ldots 240$

Huyck v. Andrews, 113 New York 81...............200, 203

Hyne v. Osborn, 62 Michigan 235..................245, 311

Hyser $\nabla$. Mansfield, 72 Vermont $71 \ldots \ldots \ldots \ldots \ldots \ldots \ldots \ldots . \ldots \ldots$

nlinois Central R. Co. v. Chicago, 173 Illinois 471; 176 United States

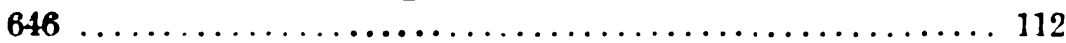

v. Illinois, 146 United States $387 \ldots \ldots \ldots \ldots \ldots \ldots \ldots 105,112$

Mlinois Land Co. v. Speyer, 138 Illinois $137 \ldots \ldots \ldots \ldots \ldots \ldots 421$

Illinois Steel Co. $\nabla$. Bilot, 109 Wisconsin $418 \ldots \ldots \ldots \ldots \ldots 1,112$

Imhoff $\nabla$. Witmer's Administrator, 31 Penngylvania State $243 \ldots 332$

In re. See name of party. 


\section{[References are to Sections.]}

Indianapolis \&c. R. Co. v. Hood, 66 Indiana $580 \ldots \ldots \ldots \ldots \ldots 181$

Inman v. Swearingen, 198 Illinois $437 \ldots \ldots \ldots \ldots \ldots \ldots \ldots \ldots 303$

Insurance Co. v. Nelson, 103 United States $544 \ldots \ldots \ldots \ldots \ldots \ldots 259$

v. White, 106 Illinois $67 \ldots \ldots \ldots \ldots \ldots \ldots \ldots \ldots \ldots . \ldots . \ldots 249$

Ireland v. Geraghty (United States), 15 Federal 35........... 306

Iron Belt Building Association v. Groves, 96 Virginia 138 ....... 283

Irons v. Webb, 41 New Jersey Law $203 \ldots \ldots \ldots \ldots \ldots \ldots \ldots . \ldots \ldots$

Irvine v. Irvine, 9 Wallace (United States) $617 \ldots \ldots \ldots \ldots \ldots . . .316,322$

v. McCreary, 108 Kentucky $495 \ldots \ldots \ldots \ldots \ldots \ldots \ldots \ldots . \ldots \ldots$

Irving $\nabla$. Campbell, 121 New York $353 \ldots \ldots \ldots \ldots \ldots \ldots \ldots . . .295$

Irwin v. Dixion, 9 Howard (United States) $10 \ldots \ldots \ldots \ldots \ldots \ldots .94$

v. Longworth, 20 Ohio State $581 \ldots \ldots \ldots \ldots \ldots \ldots \ldots \ldots \ldots \ldots$

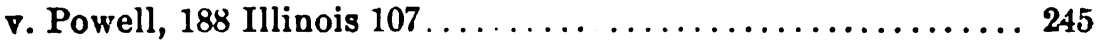

Isham $\nabla$. Bennington Iron Co., 19 Vermont $230 \ldots \ldots \ldots \ldots \ldots \ldots 240$

Ison $\nabla$. Cornett (Kentucky), 75 South western $204 \ldots \ldots \ldots \ldots \ldots \ldots 321$

Ivarson v. Mulvey, 179 Massachusetts $141 \ldots \ldots \ldots \ldots \ldots \ldots \ldots .228$

Ivey,v. Granberry, 66 North Carolina $223 \ldots \ldots \ldots \ldots \ldots \ldots \ldots . \ldots 3$

Jackson v. Adams, 7 Wendall (New York) $367 \ldots \ldots \ldots \ldots \ldots \ldots 409$

v. Alexander, 3 Johnson (New York) $484 \ldots \ldots \ldots \ldots \ldots \ldots .55$

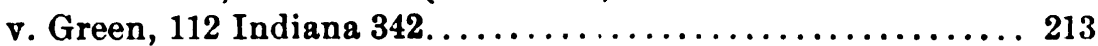

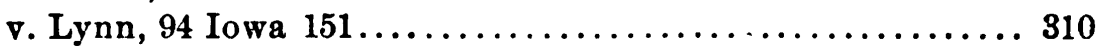

v. McChesney, 7 Cowen (New York) $360 \ldots \ldots \ldots \ldots \ldots \ldots 67$

v. Myers, 3 Johnson (New York) $388 \ldots \ldots \ldots \ldots \ldots \ldots \ldots . \ldots \ldots$

v. Phillips, 9 Cowen (New York) $94 \ldots \ldots \ldots \ldots \ldots \ldots \ldots \ldots 252$

v. Phipps, 12 Jonnson (New York) $418 \ldots \ldots \ldots \ldots \ldots \ldots \ldots . \ldots 302$

v. Railroad, 54 Missouri Appellate $636 \ldots \ldots \ldots \ldots \ldots \ldots, 63$

v. Schoonmaker, 2 Johnson (New York) $230 \ldots \ldots \ldots \ldots \ldots \ldots, 32$

v. Stevenson, 156 Massachusetts $496 \ldots \ldots \ldots \ldots \ldots \ldots \ldots \ldots .229$

v. Wood, 12 Johnson (New York) $73 \ldots \ldots \ldots \ldots \ldots \ldots \ldots \ldots .244$

Jaeger v. Hardy, 48 Ohio State $335 \ldots \ldots \ldots \ldots \ldots \ldots \ldots \ldots \ldots \ldots, 430$

James v. Patten. 6 New York 9 ........................ 23.)

Jurvis v. Seele Milling Co., 173 Illinois $192 \ldots \ldots \ldots \ldots \ldots \ldots \ldots . \ldots \ldots$

Jenkins v. Dewey, 49 Kansas $49 \ldots \ldots \ldots \ldots \ldots \ldots \ldots \ldots \ldots . \ldots 363$

Jenks v. Pawlowski, 98 Michigan $110 \ldots \ldots \ldots \ldots \ldots \ldots \ldots 187,229$

v. Quinn, 137 New York 223...................... 220

Jenness v. Smith, 58 Michigan $280 \ldots \ldots \ldots \ldots \ldots \ldots \ldots \ldots \ldots . \ldots . \ldots 28$

Jennings, Ex parte, 6 Cowen (New York) $518 \ldots \ldots \ldots \ldots \ldots \ldots . . \ldots 101$

v. Bloomfield, 199 Pennsylvania State $638 \ldots \ldots \ldots \ldots \ldots \ldots .49$

Jensen v. Crosby, 80 Minnesota $158 \ldots \ldots \ldots \ldots \ldots \ldots \ldots \ldots .60$

Jerdee v. Furbush, 115 Wisconsin $277 \ldots \ldots \ldots \ldots \ldots \ldots \ldots \ldots \ldots . \ldots . \ldots . \ldots$

Jerome v. Ortman, 66 Michigan $668 \ldots \ldots \ldots \ldots \ldots \ldots \ldots \ldots \ldots . \ldots \ldots$

Jewell v. Walker, 109 Georgia $241 \ldots \ldots \ldots \ldots \ldots \ldots \ldots \ldots \ldots .56$

v. Warner, 35 New Hampshire $176 \ldots \ldots \ldots \ldots \ldots \ldots \ldots \ldots . \ldots \ldots$

Jinright $v$. Nelson, 105 A labama $399 \ldots \ldots \ldots \ldots \ldots \ldots \ldots \ldots . . \ldots 49$

Johns v. Tiers, 114 Pennsylvania State $611 \ldots \ldots \ldots \ldots \ldots \ldots \ldots 324$ 


\section{[References are to Bections.]}

Johnson v. Elmen, 94 Texas 168....................... 204

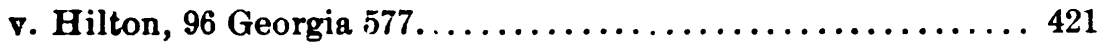

v. Hollensworth, 48 Michigan $140 \ldots \ldots \ldots \ldots \ldots \ldots \ldots \ldots \ldots 19$

v. Johnson, 170 Missouri $34 \ldots \ldots \ldots \ldots \ldots \ldots \ldots \ldots \ldots . \ldots 220$

v. Johnson (Rhode Island), 54 Atlantic 378............ 308

v. Jouchert, 124 Indiana $105 \ldots \ldots \ldots \ldots \ldots \ldots \ldots \ldots \ldots \ldots \ldots \ldots \ldots \ldots$

v. Moore, 28 Michigan 3........................... 34

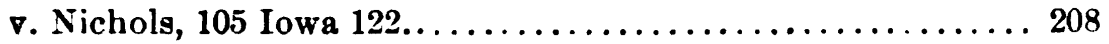

v. Warren, 74 Michigan $491 \ldots \ldots \ldots \ldots \ldots \ldots \ldots \ldots \ldots$ 170, 172

v. Williams, 37 Kansas $179 \ldots \ldots \ldots \ldots \ldots \ldots \ldots \ldots \ldots . \ldots \ldots$

Johnston v. Markle Paper Co., 153 Pennsylvania State 189....... 204

v. Virginia Coal Co., 96 Virginia $158 \ldots \ldots \ldots \ldots \ldots \ldots \ldots \ldots 158$

Jones, Ex Parte, 18 Chancery Division 108 (England)......... 320

v. Chesapeake and Ohio R. Co., 14 West Virginia 514....... 170

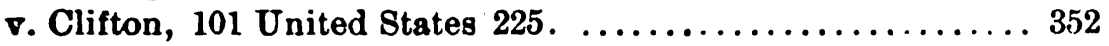

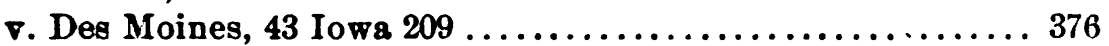

จ. Gurlie, 61 Mississippi $423 \ldots \ldots \ldots \ldots \ldots \ldots \ldots \ldots \ldots \ldots . \ldots . \ldots 234$

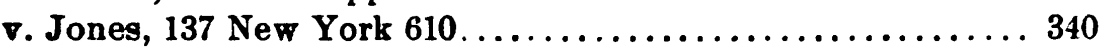

จ. Jones, 96 Virginia $749 \ldots \ldots \ldots \ldots \ldots \ldots \ldots \ldots \ldots . \ldots . \ldots . \ldots 2,357$

v. Minogue, 29 Arkansas $637 \ldots \ldots \ldots \ldots \ldots \ldots \ldots \ldots \ldots \ldots . . \ldots 408$

จ. Morris, 61 Alabama $518 \ldots \ldots \ldots \ldots \ldots \ldots \ldots \ldots \ldots \ldots . \ldots \ldots$

v. Port Haron Co., 171 Illinois 502................... 186

v. Porter, 59 Mississippi 628...................... 284

v. Smith, 73 New York $205 \ldots \ldots \ldots \ldots \ldots \ldots \ldots \ldots \ldots . \ldots 6$

₹. Soulard, 24 Howard (United States) 41.............. 101

v. Swayzee, 42 New Jersey Law $279 \ldots \ldots \ldots \ldots . \ldots \ldots . \ldots . \ldots 300$

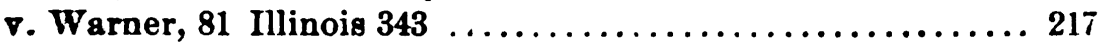

Joseph v. Bigelow, 4 Cushing (Massachusetts) $82 \ldots \ldots \ldots \ldots \ldots$ 35

Jossman $\nabla$. Rice, 121 Michigan 270. ................... 382

Jourdan $\nabla$. Patterson, 102 Michigan $602 \ldots \ldots \ldots \ldots \ldots \ldots \ldots \ldots . \ldots 304$

Joyner r. Sugg, 131 North Carolina $324 \ldots \ldots \ldots \ldots \ldots \ldots \ldots \ldots . \ldots 39$

Judd $\mathbf{v}$. Randall, 36 Minnesota $12 \ldots \ldots \ldots \ldots \ldots \ldots \ldots \ldots \ldots . \ldots \ldots$

Justice $\nabla$. Lawson, 46 West Virginia $163 \ldots \ldots \ldots \ldots \ldots \ldots \ldots \ldots 161$

Justice Mining Co. v. Lee, 21 Colorado $260 \ldots \ldots \ldots \ldots \ldots \ldots \ldots . . .409$

Kaeding $\mathbf{v}$. Joachimsthal, 98 Michigan 78................ 383

Kansas $\nabla$. Railroad Co.. 77 Missouri $180 \ldots \ldots \ldots \ldots \ldots \ldots \ldots . . \ldots 249$

Kansas City Street R. Co. v. Railway Co., 129 Missouri 62........ 291

Karcher $\nabla$. Gans, 13 South Dakota $383 \ldots \ldots \ldots \ldots \ldots \ldots \ldots . \ldots . \ldots 9$

Karchner ₹. Hoy, 151 Pennsylvania State $383 \ldots \ldots \ldots \ldots \ldots \ldots \ldots 131$

Karmuller $\nabla$. Kmtz, 18 Iowa 352 . ...................... 119

Kash v. Coleman, 145 Missouri 645................... 161

Kaufman v. Burgert, 19.5 Pennsylvania State $274 \ldots \ldots \ldots \ldots \ldots . \ldots 186$

Kean $\nabla$. Calamet Canal \&c. Co., 190 United States $452 \ldots \ldots \ldots \ldots .11 .5$

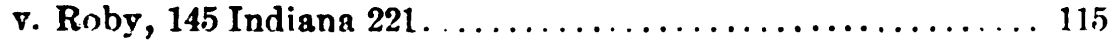

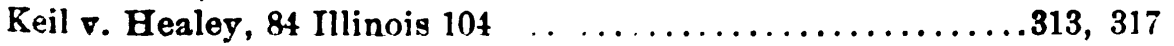

Kelley $\nabla$. Shimer, 152 Indiana $290 \ldots \ldots \ldots \ldots \ldots \ldots \ldots \ldots \ldots, 29$

iv-Brews. Con. 
TABLE OF CASES.

\section{[References are to sections.]}

Kellogg $\nabla$. Cook, 18 Washington $516 \ldots \ldots \ldots \ldots \ldots \ldots \ldots \ldots \ldots \ldots$

v. Malin, 50 Missouri $496 \ldots \ldots \ldots \ldots \ldots \ldots \ldots \ldots \ldots \ldots \ldots . \ldots \ldots$

v. Peddicord, 181 Illinois $22 \ldots \ldots \ldots \ldots \ldots \ldots \ldots \ldots \ldots \ldots \ldots \ldots$

Kellum v. Insurance Co., 101 Indiana $455 \ldots \ldots \ldots \ldots \ldots \ldots \ldots . \ldots 202$

Kelly v. Bourne, 15 Oregon $476 \ldots \ldots \ldots \ldots \ldots \ldots \ldots \ldots \ldots \ldots .45$

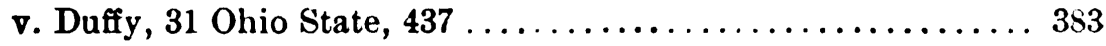

v. Nypano R. Co., 200 Pennsylvania State $229 \ldots \ldots \ldots \ldots \ldots .225$

v. Rosenstock, 45 Maryland $389 \ldots \ldots \ldots \ldots \ldots \ldots \ldots \ldots .296$

Kendall v. Lawrence, 22 Pickering (Massachusetts) 540........ 319

v. Powers, 96 Missouri 142..................... 387

Kennedy v. Gaines, 51 Mississippi $625 \ldots \ldots \ldots \ldots \ldots \ldots \ldots \ldots . \ldots 321$

v. Haskell (Kansas), 73 Pacific $913 . . . \ldots \ldots \ldots \ldots \ldots \ldots . \ldots . \ldots . \ldots 3$

v. Owen, 136 Massachusetts $199 \ldots \ldots \ldots \ldots \ldots \ldots \ldots \ldots \ldots . . \ldots 225$

Kenney v. Parks, 125 California 146; 137 California 527.......308, 299

Kentucky Lumber Co. v. Green, 87 Kentucky $257 \ldots \ldots \ldots \ldots .106$

Kenyon v. Charlevoix Improvement Co. (Michigan), 97 Northwest-

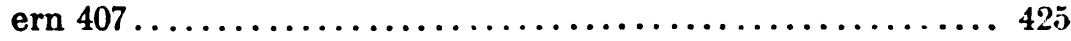

v. Saunders, 18 Rhode Island $590 \ldots \ldots \ldots \ldots \ldots \ldots \ldots \ldots 414$

Keppel v. Bailey, 2 Mylne and Keen 517 (England) ......... 226

Kerner v. McDonald, 60 Nebraska $663 \ldots \ldots \ldots \ldots \ldots \ldots \ldots \ldots . \ldots 163$

Kettle River Co. v. Eastern \&c. Co., 41 Minnesota 461 .......224, 230

Kettleschlager v. Ferrick, 12 South Dakota $455 \ldots \ldots \ldots \ldots \ldots \ldots 400$

Key v. Snow, 90 Tennessee $663 \ldots \ldots \ldots \ldots \ldots \ldots \ldots \ldots \ldots . \ldots \ldots$

Kickland v. Menasha Woodenware Co., 68 Wisconsin $34 \ldots \ldots \ldots 60$

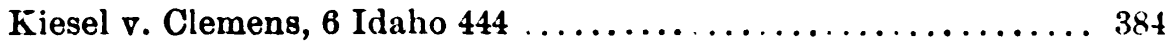

Kilgore v. Jordan, 17 Texas $341 \ldots \ldots \ldots \ldots \ldots \ldots \ldots \ldots \ldots . \ldots . \ldots 21$

Kilpatrick v. Baltimore, 81 Maryland 179 ................. 180

Kimball $\vee$. Fenner, 12 New Hampshire 248................

Kimm v. Griffin, 67 Minnesota 25 ....................... 232

King $\nabla$. Brown, 54 Indiana $368 \ldots \ldots \ldots \ldots \ldots \ldots \ldots \ldots \ldots . \ldots 2$

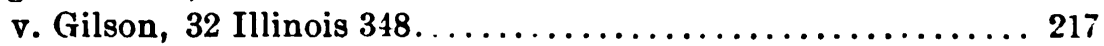

v. Kilbride, 58 Connecticut $109 \ldots \ldots \ldots \ldots \ldots \ldots \ldots \ldots . \ldots 208$

v. Mead, 60 Kansas $539 \ldots \ldots \ldots \ldots \ldots \ldots \ldots \ldots \ldots \ldots \ldots, 67$

v. Merritt, 67 Michigan $194 \ldots \ldots \ldots \ldots \ldots \ldots \ldots \ldots \ldots \ldots . \ldots \ldots 7$

v. Norfolk \& Western R. Co., 99 Virginia $625 \ldots \ldots \ldots \ldots \ldots \ldots 179$

v. Rhew, 108 North Carolina $696 \ldots \ldots \ldots \ldots \ldots \ldots \ldots \ldots . \ldots \ldots$

v. Welborn, 83 Michigan $195 \ldots \ldots \ldots \ldots \ldots \ldots \ldots \ldots \ldots \ldots . \ldots \ldots$

v. Wight, 155 Massachusetts $444 \ldots \ldots \ldots \ldots \ldots \ldots \ldots \ldots .232$

Kingdon v. Nottle, 1 Maule and Selwyn 355; 4 Maule and Selwyn

(England) $53 \ldots \ldots \ldots \ldots \ldots \ldots \ldots \ldots \ldots \ldots \ldots 216,217,221$

Kingman $\nabla$. Loyer, 40 Ohio State $109 . \ldots \ldots \ldots \ldots \ldots \ldots \ldots \ldots .262$

Kingsley v. Holbrook, 45 New Hampshire $313 \ldots \ldots \ldots \ldots \ldots .251$

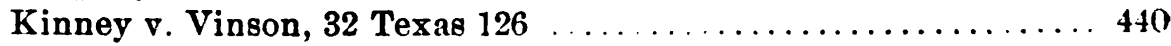

Kirby $\nabla$. Boyette, 118 North Carolina $244 \ldots \ldots \ldots \ldots \ldots \ldots 35,356$

Kirkendall $\nabla$. Mitchell, 3 McLean (United States) 144.......... 206

Kister v. Reeser, 98 Pennsylvania State $1 \ldots \ldots \ldots \ldots \ldots \ldots \ldots 119$

Kitchell v. Mudgett, 37 Michigan $81 \ldots \ldots \ldots \ldots \ldots \ldots \ldots \ldots . . \ldots 194$

Kitterlin v. Insurance Co.. 134 Iliinois $64 \ldots \ldots \ldots \ldots \ldots \ldots \ldots . \ldots 263$ 
[References are to Sections.]

Kleimann v. Geiselmann, 114 Missouri $437 \ldots \ldots \ldots \ldots \ldots \ldots \ldots . \ldots 378$

Klenke v. Koeltze, 75 Missouri $239 \ldots \ldots \ldots \ldots \ldots \ldots \ldots \ldots \ldots . \ldots 35$

Knapp $\mathbf{v}$. Woolverton, 47 Michigan $292 \ldots \ldots \ldots \ldots \ldots \ldots \ldots \ldots . \ldots \ldots$

Knight $\nabla$. Leary, 54 Wisconsin $459 \ldots \ldots \ldots \ldots \ldots \ldots \ldots \ldots . \ldots \ldots$

v. Mahoney, 152 Massachugetts 523 .................... 185

Knight $\nabla$. Thayer, 125 Massachusetts $25 \ldots \ldots \ldots \ldots \ldots \ldots \ldots \ldots . \ldots 195$

Knowlton $\nabla$. Railroad, 72 Connecticut $188 \ldots \ldots \ldots \ldots \ldots \ldots \ldots . \ldots 125$

Knox's Estate, 131 Pennsylvania State $220 \ldots \ldots \ldots \ldots \ldots \ldots \ldots . \ldots 237$

Knudsen $\nabla$. Omanson, $10 \mathrm{Utah} 124 \ldots \ldots \ldots \ldots \ldots \ldots \ldots \ldots \ldots . \ldots \ldots$

Kuutson v. Bostrak, 99 Wisconsin $469 \ldots \ldots \ldots \ldots \ldots \ldots \ldots \ldots . \ldots \ldots$

Koch v. Hustis, 113 Wisconsin $604 \ldots \ldots \ldots \ldots \ldots \ldots \ldots \ldots \ldots . \ldots \ldots$

hoppelmann $\mathbf{v}$. Koppelmann, 94 Texas $40 \ldots \ldots \ldots \ldots \ldots \ldots \ldots . \ldots 304$

Kothe v. Krag-Reynolds Co., 20 Indiana Appellate 293 ........ 285

Kramer v. Carter, 186 Massachusetts 504................. 210

Krieger v. Crocker, 118 Missouri $531 \ldots \ldots \ldots \ldots \ldots \ldots \ldots \ldots . \ldots \ldots, 366$

Kreuger $\nabla$. Schultz, 6 North Dakota $310 \ldots \ldots \ldots \ldots \ldots \ldots \ldots \ldots .420$

จ. Walker, 80 Iowa $733 \ldots \ldots \ldots \ldots \ldots \ldots \ldots \ldots \ldots \ldots \ldots . \ldots \ldots$

Kruger $\nabla$. Walker, 94 Iowa $506 \ldots \ldots \ldots \ldots \ldots \ldots \ldots \ldots \ldots 261,279$

Kutz v. McCune, 22 Wisconsin 628.................. 203

La Chapelle v. Burpee, 69 Hun (New York) 436............ 414

Lacy $\nabla$. Pixler, 120 Missouri $383 \ldots \ldots \ldots \ldots \ldots \ldots \ldots \ldots \ldots . \ldots \ldots . \ldots \ldots, 318$

Ladd $\nabla$. Noyes, 137 Massachusetts $151 \ldots \ldots \ldots \ldots \ldots \ldots \ldots . \ldots . \ldots . \ldots 218$

Lafferty $\nabla$. Lafferty, 42 West Virginia $783 \ldots \ldots \ldots \ldots \ldots \ldots \ldots . \quad 39$

La Frane $\nabla$. Richmond, 5 Sawyer (United States) $601 \ldots \ldots \ldots \ldots . . \ldots 0$

Lagger $\nabla$. Loan Association, 146 Illinois 283................. 212

Lake Erie R. Co. v. Priest, 131 Indiana 413................ 225

v. Whitham, 155 Illinois $514 \ldots \ldots \ldots \ldots \ldots \ldots \ldots \ldots \ldots, 86$

Lake Shore R. Co. v. Platt, 53 Ohio State $254 \ldots \ldots \ldots . .98,99,106,116$

Lamb $\nabla$. Pierce, 113 Massachusetts $72 \ldots \ldots \ldots \ldots \ldots \ldots \ldots \ldots .430$

Lambert $\nabla$. Smith, 9 Oregon $185 \ldots \ldots \ldots \ldots \ldots \ldots \ldots \ldots \ldots \ldots 69$

Lamont v. LeFevre, 96 Michigan $175 \ldots \ldots \ldots \ldots \ldots \ldots \ldots \ldots \ldots . \ldots 384$

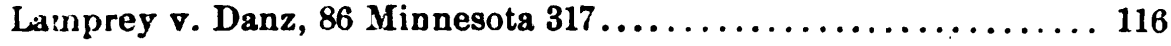

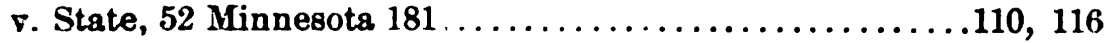

Lancaster v. Roberts, 144 Illinois $213 \ldots \ldots \ldots \ldots \ldots \ldots \ldots \ldots \ldots . \ldots \ldots$

Lancy v. Snow, 180 Massachusette $411 \ldots \ldots \ldots \ldots \ldots \ldots \ldots \ldots . \ldots 48$

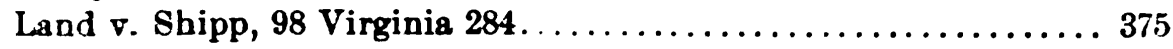

Land Company v. Saunders, 103 United States 316........... 87

Landell v. Hamilton, 175 Penngylvania State $327 \ldots \ldots \ldots \ldots \ldots \ldots 229$

Lane $v$. Utz, 130 Indiana $235 \ldots \ldots \ldots \ldots \ldots \ldots \ldots \ldots \ldots \ldots \ldots$

Lang v. Dietz, 191 Illinois $161 \ldots \ldots \ldots \ldots \ldots \ldots \ldots \ldots \ldots \ldots \ldots . \ldots 5$

Langdon v. Clayson, 75 Michigan $204 \ldots \ldots \ldots \ldots \ldots \ldots \ldots \ldots \ldots . \ldots 323$

Lange v. Geiser, 138 California $682 \ldots \ldots \ldots \ldots \ldots \ldots \ldots \ldots \ldots . \ldots . \ldots . \ldots 39$

Langley $\nabla$. Chapin, 134 Massachusetts $82 \ldots \ldots \ldots \ldots \ldots \ldots 171,179,182$

I.angmede $v$. Weaver, 65 Ohio State $17 \ldots \ldots \ldots \ldots \ldots \ldots \ldots \ldots . \ldots \ldots$

I.anman v. Crooker, 97 Indiana $163 \ldots \ldots \ldots \ldots \ldots \ldots \ldots \ldots . . \ldots 5$

Lansing Iron \& Engine Works v. Walker, 91 Michigan 409...... 118 


\section{[References are to sections.]}

Lariverre v. Rains, 112 Michigan $276 \ldots \ldots \ldots \ldots \ldots \ldots \ldots \ldots .258$

Lathrop v. Commercial Bank, 8 Dana (Kentucky) 114......... 401

v. Elsner, 93 Michigan $599 \ldots \ldots \ldots \ldots \ldots \ldots \ldots \ldots \ldots \ldots$

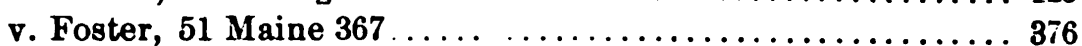

Latimer v. Latimer, 53 South Carolina $483 \ldots \ldots \ldots \ldots \ldots \ldots \ldots .60$

Lautenschlager's Estate, 80 Michigan $285 \ldots \ldots \ldots \ldots \ldots \ldots \ldots . \ldots 29$

Lawe v. Hyde, 39 Wisconsin 345 . ................. 133

Lawrence v. Heister, 3 Harris and Johnson (Maryland) $371 \ldots \ldots .362$

v. Hennessy, 165 Missouri $659 \ldots \ldots \ldots \ldots \ldots \ldots \ldots \ldots . \ldots \ldots$

v. McArter, 10 Ohio State $37 \ldots \ldots \ldots \ldots \ldots \ldots \ldots \ldots \ldots . \ldots . \ldots . \ldots . \ldots 14$

Lawyer $\nabla$. Slingerland, 11 Minnesota $447 \ldots \ldots \ldots \ldots \ldots \ldots . \ldots 398,399$

Leach $v$. Rains, 149 Indiana $152 \ldots \ldots \ldots \ldots \ldots \ldots \ldots \ldots \ldots \ldots . \ldots . \ldots . \ldots$

Leacox $\nabla$. Griffith, 76 Iowa $89 \ldots \ldots \ldots \ldots \ldots \ldots \ldots \ldots \ldots \ldots \ldots \ldots \ldots$

Learned $\nabla$. Cutler, 18 Pickering (Massachusetts) $9 \ldots \ldots \ldots \ldots \ldots 376$

Leathers v. Gray, 101 North Carolina 162................ 147

Leavitt v. Lamprey, 13 Pickering (Massachusetts) $382 \ldots \ldots \ldots \ldots 386$

v. Leavitt, 179 Illinois $87 \ldots \ldots \ldots \ldots \ldots \ldots \ldots \ldots \ldots .299$

Leazure v. Hillegas, 7 Sergeant \& Rawle (Pennsylvania) $313 \ldots \ldots 401$

Leddy $v$. Enos, 6 Washington $247 \ldots \ldots \ldots \ldots \ldots \ldots \ldots \ldots . \ldots \ldots$

Lee v. Kellogg, 108 Michigan $535 \ldots \ldots \ldots \ldots \ldots \ldots \ldots \ldots \ldots \ldots 426$

v. Murphy, 119 California $364 \ldots \ldots \ldots \ldots \ldots \ldots \ldots \ldots . \ldots . \ldots . \ldots 281$

Leftwich v. Richmond, 100 Virginia $164 \ldots \ldots \ldots \ldots \ldots \ldots \ldots . \ldots 281$

Leggate v. Clark, 111 Massachusetts $308 \ldots \ldots \ldots \ldots \ldots \ldots \ldots . \ldots 33$

Lego v. Medley, 79 Wisconsin $211 \ldots \ldots \ldots \ldots \ldots \ldots \ldots \ldots \ldots \ldots$

Lehigh Coal Co. v. Early, 162 Pennsylvania State $338 \ldots \ldots \ldots 179,187$

Lehndorf v. Cope, 122 Illinois $319 \ldots \ldots \ldots \ldots \ldots \ldots \ldots \ldots 143,207,212$

Lemay v. Furtado, 182 Massachusetts $280 \ldots \ldots \ldots \ldots \ldots \ldots \ldots . . \ldots 9$

Lembeck v. Nye. 47 Ohio State $336 \ldots \ldots \ldots \ldots \ldots \ldots \ldots \ldots \ldots . \ldots \ldots$

LeMesnager v. Hamilton, 101 California $532 \ldots \ldots \ldots \ldots \ldots \ldots . . . .292$

Lemon v. Graham, 131 Pennsylvania State, 447........... 70

Leonard $\nabla$. Leonard, 14 Pickering (Massachusetts) $280 \ldots \ldots \ldots . \ldots 33$

Leroy v. Jamieson, 3 Sawyer (United States) 369 . . . . . . . . . . 297

Leuders $v$. Thomas, 35 Florida $518 \ldots \ldots \ldots \ldots \ldots \ldots \ldots \ldots \ldots . \ldots 25$

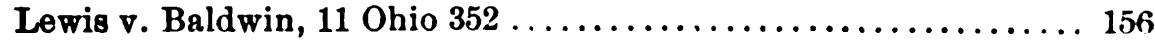

v. Watson, 98 Alabama $479 \ldots \ldots \ldots \ldots \ldots \ldots \ldots \ldots \ldots . \ldots \ldots$

Lewig's Appeal, 85 Michigan $340 \ldots \ldots \ldots \ldots \ldots \ldots \ldots \ldots \ldots . \ldots . \ldots 2$

Ligare $\nabla$. Semple, 32 Michigan $438 \ldots \ldots \ldots \ldots \ldots \ldots \ldots \ldots \ldots \ldots$

Lincoln v. Burrage, 177 Massachusetts $378 \ldots \ldots \ldots \ldots \ldots \ldots \ldots . \ldots 231$

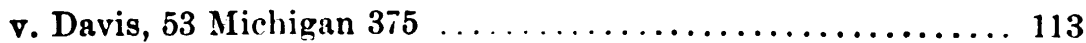

v. Lincoln, 107 Massachusetts $590 \ldots \ldots \ldots \ldots \ldots \ldots \ldots \ldots . \ldots . \ldots 137$

Lindley v. Lindley, 92 Texas $446 \ldots \ldots \ldots \ldots \ldots \ldots \ldots \ldots \ldots . \ldots \ldots$

Link v. Connell, 48 Nebraska $574 \ldots \ldots \ldots \ldots \ldots \ldots \ldots \ldots \ldots 252$

Linton v. National Life Insurance Co. (United States), 104 Federal

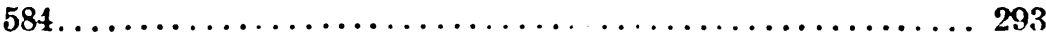

Lippincott v. Mitchell, 94 United States $767 \ldots \ldots \ldots \ldots \ldots \ldots . . \ldots 33$

Liter $\nabla$. Fishback (Kentucky), 75 Southwestern $232 \ldots \ldots \ldots . .327,330$ 


\section{[References are to sections.]}

Little Sawmill Co. v. Federal R. Co., 194 Pennsylvania State 144.. 249 Littlefield $\mathbf{v}$. Mott, 14 Rhode Island $288 \ldots \ldots \ldots \ldots \ldots \ldots \ldots 127$ Live Stock Co. v. Springer, 35 Oregon 312; 185 United States 47 .. 103 Lloyd v. Quimby, 5 Ohio State $262 \ldots \ldots \ldots \ldots \ldots \ldots \ldots \ldots \ldots . \ldots 189$

v. Taylor, 1 Dallas (United States) $17 \ldots \ldots \ldots \ldots \ldots \ldots \ldots . \ldots 362$

Locke $\nabla$. Hale, 165 Massachusetts $20 \ldots \ldots \ldots \ldots \ldots \ldots \ldots \ldots . \ldots 201$

v. Homer, 131 Massachusetts $93 . \ldots \ldots \ldots \ldots \ldots \ldots \ldots \ldots . \ldots \ldots$

v. Redmond, 6 Kansas Appellate 86..... .............. 398

Lockhart $v$. Vandyke, 97 Virginia $356 \ldots \ldots \ldots \ldots \ldots \ldots \ldots \ldots$

Lombard v. Chicago Sinai Congregation, 64 Illinois $477 \ldots \ldots \ldots 241$

Long v. Cockern, 128 Illinois $29 \ldots \ldots \ldots \ldots \ldots \ldots \ldots \ldots . \ldots \ldots 6,274$

v. Georgia Pacific R. Co., 91 Alabama $519 \ldots \ldots \ldots \ldots \ldots \ldots 405$

v. Moler, 5 Ohio State $271 \ldots \ldots \ldots \ldots \ldots \ldots \ldots \ldots \ldots \ldots . \ldots \ldots$

Longworth $\nabla$. Bank, 6 Ohio $536 \ldots \ldots \ldots \ldots \ldots \ldots \ldots \ldots \ldots \ldots, 50$

Loomis v. Pingree, 43 Maine $299 \ldots \ldots \ldots \ldots \ldots \ldots \ldots \ldots \ldots, 34$

Loree $\nabla$. Abner, 6 United States Appeals $649 \ldots \ldots \ldots \ldots \ldots \ldots \ldots 273$

Lorimer $\nabla$. Jadge, 116 Michigan $682 . \ldots \ldots \ldots \ldots \ldots \ldots \ldots \ldots 428$

Los Angeles Land Co. v. Southern Pacific R. Co., 136 California

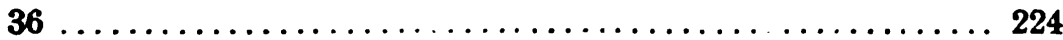

Losey $\nabla$. Stanley, 147 New York $560 \ldots \ldots \ldots \ldots \ldots \ldots \ldots \ldots . \ldots \ldots$

Lonisville \&c. R. Co. v. Neafus, 93 Kentacky $53 \ldots \ldots \ldots \ldots \ldots, 61$

Love $\nabla$. Blauw, 61 Kansas $496 \ldots \ldots \ldots \ldots \ldots \ldots \ldots \ldots \ldots \ldots . \ldots 29$

จ. Breedlove, 75 Texas $649 \ldots \ldots \ldots \ldots \ldots \ldots \ldots \ldots \ldots . \ldots 431$

Lovejoy $\nabla$. Lovett, 124 Massachusetts $270 \ldots \ldots \ldots \ldots \ldots \ldots \ldots . \ldots 7$

Low $\nabla$. Anderson, 41 Iowa $476 \ldots \ldots \ldots \ldots \ldots \ldots \ldots \ldots \ldots . \ldots \ldots$

Lowe v. Lowe, 83 Minnesota 206......................... 363

จ. Morris, 13 Georgia $147 \ldots \ldots \ldots \ldots \ldots \ldots \ldots \ldots \ldots \ldots . \ldots 244$

Lowman $\nabla$. Crawford, 99 Virginia $688 \ldots \ldots \ldots \ldots \ldots \ldots \ldots \ldots . \ldots \ldots$

Lowenthal v. Coonan, 135 California $381 \ldots \ldots \ldots \ldots \ldots \ldots \ldots \ldots . \ldots 38$

Lowndes $\nabla$. Huntington, 153 United States $1 \ldots \ldots \ldots \ldots \ldots \ldots \ldots 112$

Lozo $\nabla$. Sutherland, 38 Michigan 168.................... 387

Ladeke $\nabla$. Sutherland, 87 Illinois $481 \ldots \ldots \ldots \ldots \ldots \ldots \ldots \ldots \ldots 64$

Luhrs $\nabla$. Hancock, 181 United States $567 \ldots \ldots \ldots \ldots \ldots \ldots \ldots . \ldots . \ldots 36$

Lamb $\nabla$. Jenkins, 100 Massachusetts $527 \ldots \ldots \ldots \ldots \ldots \ldots \ldots \ldots$

Lumpkins $\nabla$. Johnson, 61 Arkansas $80 \ldots \ldots \ldots \ldots \ldots \ldots \ldots . \ldots . \ldots . \ldots 28$

Lansford $\nabla$. LaMotte Co., 54 Missouri 426................ 248

Luttrell $\nabla$. Boggs, 168 Illinois $361 \ldots \ldots \ldots \ldots \ldots \ldots \ldots \ldots \ldots \ldots 37$

Lyddal v. Weston, 2 Atkyns (England) $20 \ldots \ldots \ldots \ldots \ldots \ldots 423$

Lyle v. Richards, 9 Sergeant and Rawle (Pennsylvania) 322 .... 142

Lyman v. Conkey, 1 Metcalf (Massachusetts) 317............. 327

Lynch $\nabla$. Doran, 95 Michigan $395 \ldots \ldots \ldots \ldots \ldots \ldots \ldots \ldots \ldots . \ldots 400$

v. Moser, 72 Connecticut $714 \ldots \ldots \ldots \ldots \ldots \ldots \ldots \ldots \ldots \ldots \ldots \ldots$

Maatta $\nabla$. Kippola, 102 Michigan $116 \ldots \ldots \ldots \ldots \ldots \ldots \ldots \ldots \ldots . \ldots \ldots 7$

McAlligter v. Parcell, 124 North Carolina 262............... 284

McAnaw $\nabla$. Tiffin, 143 Missouri 667...............179, 335, 337 


\section{[References are to Sections.]}

McBreen $\nabla$. McBreen, 154 Missouri 323................. 375

McBride v. Whitaker (Nebraska), 90 North western 966....... 102

McCandless v. Engle, 51 Pennsylvania State $309 \ldots \ldots \ldots \ldots \ldots \ldots 293$

McCann v. McCann, 197 Pennsylvania State $452 \ldots \ldots \ldots \ldots \ldots \ldots$

McCardia v. Billings, 10 North Dakota 373................. 269

McCartney v. McCartney, 93 Texas $359 \ldots \ldots \ldots \ldots \ldots \ldots \ldots \ldots . \ldots 299$

McCarty v. Rochel, 85 Iowa $427 \ldots \ldots \ldots \ldots \ldots \ldots \ldots \ldots \ldots$ 4t

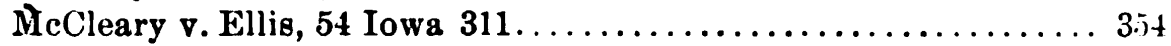

McCleery $\nabla$. Wakefield, 76 Iowa $529 \ldots \ldots \ldots \ldots \ldots \ldots \ldots \ldots$

McClelland v. McClelland, 176 Illinois $83 . \ldots \ldots \ldots \ldots \ldots \ldots \ldots . \ldots \ldots$

McClunn v. McClunn, 176 Illinois $376 \ldots \ldots \ldots \ldots \ldots \ldots \ldots 336,339$

McClure v. Gamble, 27 Pennsylvania State $288 \ldots \ldots \ldots \ldots \ldots \ldots 193$

v. Herring, 70 Missouri $18 \ldots \ldots \ldots \ldots . \ldots \ldots . \ldots . \ldots . . \ldots 239$

McCord v. Massie, 155 Illinois 123.................... 201

McCorry v. King's Heirs, 3 Humphreys (Tennessee) 267 ....... 169

McCoy $\nabla$. Fahney, 182 Illinois $60 \ldots \ldots \ldots \ldots \ldots \ldots \ldots \ldots \ldots .48$

McCrae v. McCrae, 103 Tennessee $719 \ldots \ldots \ldots \ldots \ldots \ldots \ldots \ldots . \ldots 378$

v. Purmort, 16 Wendall (New York) $460 \ldots \ldots \ldots \ldots \ldots \ldots 61$

McCreary v. McCorkle (Tennessee), 54 Southwestern 53......239, 377

McCullock v. Holmes, 111 Missouri $445 \ldots \ldots \ldots \ldots \ldots \ldots \ldots . \ldots \ldots$

McDonald v. McElroy, 60 California $484 \ldots \ldots \ldots \ldots \ldots \ldots \ldots . \ldots 193$

McDougal $\nabla$. Musgrave, 46 West Virginia $509 \ldots \ldots \ldots \ldots \ldots \ldots 126$

McDowell v. Creditors, 103 California $264 \ldots \ldots \ldots \ldots \ldots \ldots \ldots . \ldots 384$

McElroy v. Hiner, 133 Illinois $156 \ldots \ldots \ldots \ldots \ldots \ldots \ldots \ldots \ldots . \ldots . \ldots 2$

McElwain, Ex parte, 29 Illinois $442 \ldots \ldots \ldots \ldots \ldots \ldots \ldots \ldots \ldots \ldots \ldots$

McGahan v. Bank, 156 United States $218 \ldots \ldots \ldots \ldots \ldots \ldots \ldots \ldots, 45$

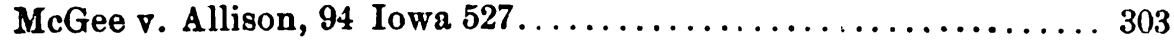

McGinn v. Tobey, 62 Michigan $252 \ldots \ldots \ldots \ldots \ldots \ldots \ldots \ldots \ldots .426$

McGoon v. Scales, 9 Wallace (United States) $23 \ldots \ldots \ldots \ldots \ldots \ldots \quad 8$

McGraw's Estate, In re, 111 New York 66.............401, 405

McGrael v. Taylor, 167 United States $688 \ldots \ldots \ldots \ldots \ldots \ldots \ldots \ldots . \ldots . \ldots 321$

McGregor v. Comstock, 17 New York $162 \ldots \ldots \ldots \ldots \ldots \ldots \ldots 16$

McGrew v. Harmon, 164 Pennsylvania State $115 \ldots \ldots \ldots \ldots \ldots . . \ldots 210$

McGuire v. Caskey, 62 Ohio State $419 \ldots \ldots \ldots \ldots \ldots \ldots \ldots \ldots .229$

McIlhinny v. McIlhinny, 137 Indiana $411 \ldots \ldots \ldots \ldots \ldots 143,147$

Mackay v. Easton, 19 Wallace (United States) $619 \ldots \ldots \ldots \ldots \ldots 236$

McKenzie v. Donnell, 151 Missouri $431 \ldots \ldots \ldots \ldots \ldots \ldots \ldots \ldots . \ldots \ldots+\ldots \ldots$

v. Sifford, 52 South Carolina $104 \ldots \ldots \ldots \ldots \ldots \ldots \ldots \ldots \ldots 6$

v. Shows, 70 Mississippi $388 \ldots \ldots \ldots \ldots \ldots \ldots \ldots \ldots \ldots . \ldots \ldots$

McKinley Creek Mining Co. v. Alaska Mining Co., 183 United

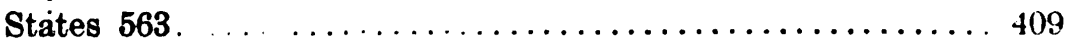

McLaughlin v. Ham, 84 Georgia $786 \ldots \ldots \ldots \ldots \ldots \ldots \ldots \ldots \ldots \ldots \ldots \ldots$

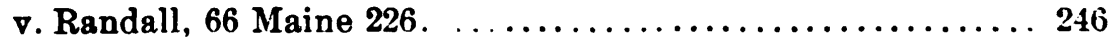

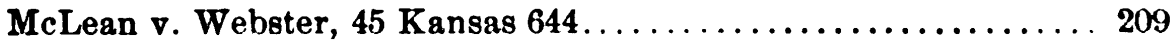

McLeod v. Tarrant, 39 South Carolina $271 \ldots \ldots \ldots \ldots \ldots \ldots \ldots$. 133,164

McMahan v. Bowe, 114 Massachusetts $140 \ldots \ldots \ldots \ldots \ldots \ldots \ldots .416$

McMannis v. Rice, 48 Iowa $361 \ldots \ldots \ldots \ldots \ldots \ldots \ldots \ldots . \ldots \ldots, 328$ 


\section{[References are to sections.]}

McManus v. Carmichael, 3 Iowa $1 \ldots \ldots \ldots \ldots \ldots \ldots \ldots \ldots \ldots 108,109$

v. Commow, 10 North Dakota $340 \ldots \ldots \ldots \ldots \ldots \ldots \ldots . \ldots . \ldots . \ldots 250$

Ic.Michael v. McMichael, 51 South Carolina 555........... 135

Ir.Minn v. O'Connor, 27 California $238 \ldots \ldots \ldots \ldots \ldots \ldots \ldots \ldots$

MeNeeley v. South Pennsylvania Oil Co., 52 West Virginia 616 ... 165

M.Pike v. Heaton, 131 California $109 \ldots \ldots \ldots \ldots \ldots \ldots \ldots \ldots . \ldots \ldots$

M.Qunade v. Whaley, 31 California $526 \ldots \ldots \ldots \ldots \ldots \ldots \ldots \ldots . \ldots \ldots$

Ml丷oberts v. McArthur, 62 Minnesota $310 \ldots \ldots \ldots \ldots \ldots \ldots$. 77

Yahoning Co. v. Young, 16 United States Appeals $253 \ldots \ldots \ldots 179,180$

Irain v. Main (A rizona), 60 Pacific $888 \ldots \ldots \ldots \ldots \ldots \ldots \ldots . \ldots \ldots 7$

Mallett v. Simpson, 94 North Carolina $37 \ldots \ldots \ldots \ldots \ldots \ldots 401,405$

Yanchester $\nabla$. Hough, 5 Mason (United States) $67 \ldots \ldots \ldots \ldots \ldots 362$

Mandlebsum v. McDonnell, 29 Michigan $78 \ldots \ldots \ldots \ldots \ldots \ldots 186$

Mann v. Keene Co. (United States), 86 Federal $51 \ldots \ldots \ldots \ldots \ldots 338$

Manning v. Perkins, 86 Maine $419 \ldots \ldots \ldots \ldots \ldots \ldots \ldots \ldots .246$

Mansfield v. Gordon, 144 Massachusetts $168 \ldots \ldots \ldots \ldots \ldots \ldots \ldots . \ldots 319$

Mansur v. Blake, 62 Maine $38 \ldots \ldots \ldots \ldots \ldots \ldots \ldots \ldots \ldots \ldots . \ldots \ldots$

Manuel v. Wulff, 152 United States $505 . \ldots \ldots \ldots \ldots \ldots \ldots \ldots 408$

Manufacturing Co. v. Railroad, 121 North Carolina $514 \ldots \ldots \ldots \ldots 63$

Maratta v. Anderson, 172 Illinois $377 \ldots \ldots \ldots \ldots \ldots \ldots \ldots \ldots \ldots .299$

Marden v. Dorthy, 160 New York 39.................293, 426

Yarkoe $\nabla$. Wakeman, 107 Illinois $251 \ldots \ldots \ldots \ldots \ldots \ldots \ldots \ldots \ldots . \ldots \ldots 7$

Marler v. Handy, 88 Texas $421 \ldots \ldots \ldots \ldots \ldots \ldots \ldots \ldots \ldots \ldots . \ldots . \ldots 2,394$

Marston v. Brashaw, 18 Michigan $81 \ldots \ldots \ldots \ldots \ldots \ldots \ldots \ldots \ldots . \ldots \ldots 1$

จ. Brittenham, 76 Illinois $611 \ldots \ldots \ldots \ldots \ldots \ldots \ldots \ldots \ldots . \ldots \ldots 9$

v. Hobbs, 2 Massachusetts 433.................... 198

Martin v. Almond, 25 Missouri $313 \ldots \ldots \ldots \ldots \ldots \ldots \ldots \ldots \ldots . \ldots \ldots$

จ. Baker, 5 Blackford (Indiana) $232 \ldots \ldots \ldots \ldots \ldots \ldots \ldots 216,221$

v. Cook, 102 Michigan $267 \ldots \ldots \ldots \ldots \ldots \ldots \ldots \ldots . \ldots . . \ldots 127$

จ. Dwelly, 6 Wendall (New York) 9...............18, 361

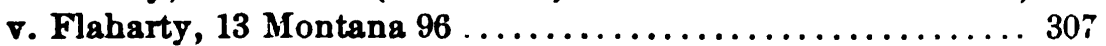

v. Gilson, 37 Wisconsin $360 \ldots \ldots \ldots \ldots \ldots \ldots \ldots \ldots \ldots . \ldots \ldots$

v. Harrington, 73 Vermont 193................392, 394, 397

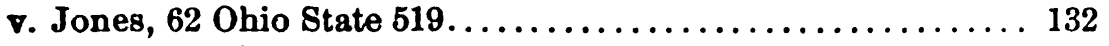

v. Lloyd, 94 California $195 \ldots \ldots \ldots \ldots \ldots \ldots \ldots \ldots \ldots \ldots, 86$

จ. Martin, 170 Illinois $639 \ldots \ldots \ldots \ldots \ldots \ldots \ldots \ldots \ldots \ldots \ldots, 17$

v. Martin, 1 Maine $394 \ldots \ldots \ldots \ldots \ldots \ldots \ldots \ldots \ldots \ldots \ldots . \ldots \ldots 6$

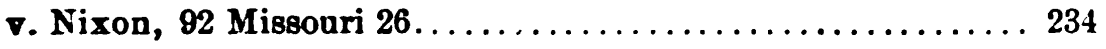

v. Smith, 5 Binney (Pennsylvania) $16 \ldots \ldots \ldots \ldots \ldots \ldots \ldots 151$

Marvel v. Phillips, 162 Massachusetts $401 \ldots \ldots \ldots \ldots \ldots \ldots \ldots . \ldots . \ldots . \ldots$

Marvin $\nabla$. Anderson, 111 Wisconsin $387 \ldots \ldots \ldots \ldots \ldots \ldots \ldots . \ldots \ldots$

Marx $\nabla$. Threet, 131 Alabama $340 \ldots \ldots \ldots \ldots \ldots \ldots \ldots \ldots . \ldots 384,399$

Mason v. Brock, 12 Illinois $273 \ldots \ldots \ldots \ldots \ldots \ldots \ldots \ldots \ldots \ldots . \ldots . \ldots 2$

v. Mason, 140 Massachusetts 63 ................... 374

Iassie $\nabla$. Hiatt, 82 Kentucky $314 \ldots \ldots \ldots \ldots \ldots \ldots \ldots \ldots . \ldots \ldots$

Yissterson $\nabla$. Munro, 10.5 California $431 \ldots \ldots \ldots \ldots \ldots \ldots . \ldots 3,95$

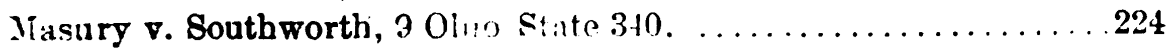


Matney v. Linn, 59 Kansas $613 \ldots \ldots \ldots \ldots \ldots \ldots \ldots \ldots \ldots . \ldots \ldots$

Matteson v. Vaughn, 38 Michigan $373 \ldots \ldots \ldots \ldots \ldots \ldots \ldots \ldots \ldots$

Mattson v. Mattson, 29 Washington $417 \ldots \ldots \ldots \ldots \ldots \ldots \ldots \ldots \ldots$

Maverick $\nabla$. Burney, 88 Texas $560 \ldots \ldots \ldots \ldots \ldots \ldots \ldots \ldots 7$

Maxwell v. East River Bank, 3 Bosworth (New York) 124 ...... 227

v. Roach, 106 Louisiana $123 \ldots \ldots \ldots \ldots \ldots \ldots \ldots . \ldots \ldots$

May v. Sturdivant, 75 lowa $116 \ldots \ldots \ldots \ldots \ldots \ldots \ldots \ldots \ldots \ldots \ldots$

Maynard v. Davis, 127 Michigan $571 \ldots \ldots \ldots \ldots \ldots \ldots \ldots \ldots \ldots$

Mayor v. Mabie, 13 New York $151 \ldots \ldots \ldots \ldots \ldots \ldots \ldots \ldots \ldots \ldots$

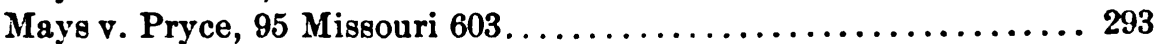

Mead v. Fitzpatrick, 74 Connecticut $521 \ldots \ldots \ldots \ldots \ldots \ldots \ldots \ldots \ldots$

v. Parker, 115 Massachusetts $413 \ldots \ldots \ldots \ldots \ldots \ldots \ldots \ldots \ldots$

Meazles v. Martin, 93 Kentucky $50 \ldots \ldots \ldots \ldots \ldots \ldots \ldots \ldots \ldots \ldots . \ldots \ldots$

Mecklem v. Blake, 22 Wisconsin $495 \ldots \ldots \ldots \ldots \ldots \ldots \ldots \ldots \ldots \ldots \ldots$

Medara v. Dubois, 187 Pennsylvania State $431 \ldots \ldots \ldots \ldots \ldots \ldots \ldots$

Mee v. Benedict, 98 Michigan $260 \ldots \ldots \ldots \ldots \ldots \ldots \ldots \ldots \ldots \ldots$

Meech v. Wilder (Michigan), 89 Northwestern $556 \ldots \ldots \ldots \ldots \ldots . \ldots 307$

Meeks v. Stillwell, 64 Ohio State $541 \ldots \ldots \ldots \ldots \ldots \ldots \ldots . \ldots . \ldots 299$

Meier v. Portland Cable Co., 16 Oregon $500 \ldots \ldots \ldots \ldots \ldots \ldots \ldots \ldots . . \ldots 4$

Meigs v. Dexter, 172 Massachusetts 217..............301, 340

Melley v. Casey, 99 Massachusetts $241 \ldots \ldots \ldots \ldots \ldots \ldots \ldots \ldots \ldots \ldots . \ldots 364$

Memmert v. McKeen, 112 Pennsylvania State $315 \ldots \ldots \ldots \ldots \ldots \ldots . . .203$

Memphis \&c. R. Co. v. Grayson, 88 Alabama $572 \ldots \ldots \ldots \ldots \ldots \ldots \ldots 7$

Mendenhall v. Elwert, 36 Oregon $375 \ldots \ldots \ldots \ldots \ldots \ldots \ldots \ldots \ldots$

v. Parish, 53 North Carolina $105 \ldots \ldots \ldots \ldots \ldots \ldots \ldots \ldots \ldots \ldots 9$

Mercantile Trust Co. v. South Park Co., 94 Kentucky 271....... 198

Merrick v. Merrick, 37 Ohio State $126 \ldots \ldots \ldots \ldots \ldots \ldots \ldots \ldots$

Merritt $\nabla$. Yates, 71 Illinois $636 \ldots \ldots \ldots \ldots \ldots \ldots \ldots \ldots \ldots \ldots \ldots$

Merwin v. Morris, 71 Connecticut $555 \ldots \ldots \ldots \ldots \ldots \ldots \ldots \ldots \ldots \ldots 420$

Meservey v. Snell, 94 Iowa $223 \ldots \ldots \ldots \ldots \ldots \ldots \ldots \ldots \ldots \ldots \ldots \ldots$

Messer v. Oestreich, 52 Wisconsin $693 \ldots \ldots \ldots \ldots \ldots \ldots \ldots \ldots \ldots$

Methodist Church v. Hoboken, 33 New Jersey Law 13......... 407

v. Remington, 1 Watts (Pennsylvania) 218.............4 401

Mettler v. Miller, 129 Illinois $630 \ldots \ldots \ldots \ldots \ldots \ldots \ldots \ldots \ldots \ldots, 367$

Meyer v. Kinzer, 12 California 247 ................... 167

Michener v. Cavender, 38 Pennsylvania State $334 \ldots \ldots \ldots \ldots \ldots \ldots 293$

Michigan Trust Co. v. Chapin, 106 Michigan $384 \ldots \ldots \ldots \ldots \ldots \ldots \ldots 387$

Mickey v. Barton, 194 Illinois $446 \ldots \ldots \ldots \ldots \ldots \ldots \ldots \ldots$

Middlebrook v. Barefoot, 121 Alabama $642 \ldots \ldots \ldots \ldots \ldots \ldots \ldots \ldots 238$

Middlecoff $v$. Hemstreet, 135 California $173 \ldots \ldots \ldots \ldots \ldots \ldots . \ldots 289$

Middlesex R. Co. v. Boston \&c. R. Co., 115 Massachusetts 347 . ... 407

Middleton v. Findla, 25 California $76 \ldots \ldots \ldots \ldots \ldots \ldots \ldots \ldots$

v. Pritchard, 4 Illinois 510....... . . . . . . . . . . . . . 101

Midgett v. Brooks, 12 Iredell Law (North Carolina) $145 \ldots . . . . .206$;

Midgley $\mathbf{v}$. Walker, 101 Michigan $583 \ldots \ldots \ldots \ldots \ldots \ldots \ldots$

Miles v. Fisher, 10 Ohio $1 \ldots \ldots \ldots \ldots \ldots \ldots$. . . . . . . . . .

Mill River Manufacturing Co. v. Smith, 34 Connecticut $462 \ldots \ldots$. . 11 
[References are to sections.]

Miller, Ex parte, 49 Arkansas $18 \ldots \ldots \ldots \ldots \ldots \ldots \ldots \ldots \ldots . \ldots 236$

v. Miller, 140 Indiana $174 \ldots \ldots \ldots \ldots \ldots \ldots \ldots \ldots \ldots$. . . 195

v. Miller, 89 North Carolina $402 \ldots \ldots \ldots \ldots \ldots \ldots \ldots \ldots \ldots 0$

v. Parsons, 9 Johnson (New York) $336 \ldots \ldots \ldots \ldots \ldots \ldots . \ldots 205$

v. Ruble, 107 Pennsylvania State $395 \ldots \ldots \ldots \ldots \ldots \ldots \ldots . \ldots 234$

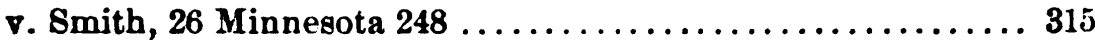

Millett $\mathbf{v}$. Mullen, 95 Maine $400 \ldots \ldots \ldots \ldots \ldots \ldots \ldots \ldots \ldots \ldots \ldots \ldots$

Mills v. Seattle \& Montana R., 10 Washington 520........... 177

Milner $\nabla$. Nelson, 86 Iowa $452 \ldots \ldots \ldots \ldots \ldots \ldots \ldots \ldots \ldots \ldots . \ldots \ldots 7$

Miner $\mathbf{v}$. Wilson, 107 Michigan $57 \ldots \ldots \ldots \ldots \ldots \ldots \ldots \ldots \ldots \ldots 430$

Mineral Co. $\mathbf{v}$. James, 97 Virginia $403 \ldots \ldots \ldots \ldots \ldots \ldots \ldots .28$

Minneapolis Stockyards Co. v. Halonen, 56 Minnesota 469...... 67

Minnesota Stoneware Co. v. McCrossen, 110 Wisconsin $316 \ldots \ldots 383$

Miskey's A ppeal, 107 Pennsylvania State $611 \ldots \ldots \ldots \ldots \ldots \ldots . \ldots 33$

Mitchell $v$. Kepler, 75 Iowa $207 \ldots \ldots \ldots \ldots \ldots \ldots \ldots \ldots \ldots \ldots . \ldots \ldots$

v. Leavitt, 30 Connecticut $587 \ldots \ldots \ldots \ldots \ldots \ldots \ldots \ldots \ldots . \ldots \ldots$

v. Smale, 140 United States $406 \ldots \ldots \ldots \ldots \ldots \ldots \ldots \ldots 102,114$

Mitchell's Lessee v. Ryan, 3 Ohio State $377 \ldots \ldots \ldots \ldots \ldots \ldots \ldots . \ldots 300$

Yittel v. Karl, 133 Illinois $65 \ldots \ldots \ldots \ldots \ldots \ldots \ldots \ldots \ldots \ldots . \ldots 6$

Joffitt $\nabla$. Lytle, 165 Pennsylvania State 173 ................ 121

v. Maness, 102 North Carolina $457 \ldots \ldots \ldots \ldots \ldots \ldots \ldots \ldots 62$

Monroe v. Arthur, 126 Alabama $362 \ldots \ldots \ldots \ldots \ldots \ldots \ldots \ldots . \ldots 285$

v. Bowles, 187 Illinois $346 \ldots \ldots \ldots \ldots \ldots \ldots \ldots \ldots \ldots \ldots . \ldots \ldots$

Montello, The, 20 Wallace (United States) $430 \ldots \ldots \ldots \ldots \ldots \ldots 110$

Montgomery $\nabla$. Sturdivant, 41 California $290 \ldots \ldots \ldots \ldots \ldots \ldots . \ldots$

Moore v. Baker, 92 Kentucky $518 \ldots \ldots \ldots \ldots \ldots \ldots \ldots \ldots \ldots . \ldots 19$

จ. Cornell, 68 Pennsylvania State $320 \ldots \ldots \ldots \ldots \ldots \ldots \ldots \ldots .359$

v. Farmer, 156 Missouri $33 \ldots \ldots \ldots \ldots \ldots \ldots \ldots \ldots \ldots \ldots . \ldots \ldots$

v. Graves, 97 Iowa $4 \ldots \ldots \ldots \ldots \ldots \ldots \ldots \ldots \ldots \ldots \ldots \ldots . \ldots \ldots$

v. Harmon, 142 Indiana $555 \ldots \ldots \ldots \ldots \ldots \ldots \ldots \ldots \ldots, 92$

v. Page, 111 United States $117 \ldots \ldots \ldots \ldots \ldots \ldots \ldots \ldots \ldots . \ldots \ldots$

Joran $\mathbf{v}$. Clark, 30 West Virginia $358 \ldots \ldots \ldots \ldots \ldots \ldots \ldots \ldots . . \ldots 38$

v. Lezotte, 54 Michigan $83 \ldots \ldots \ldots \ldots \ldots \ldots \ldots \ldots \ldots \ldots, \quad 84$

v. Moran, 106 Michigan $8 \ldots \ldots \ldots \ldots \ldots \ldots \ldots \ldots 35,337,346$

Moreau $\nabla$. Detchemendy, 18 Missouri 522................ 167

Morehead $\nabla$. Hall, 126 North Carolina $213 \ldots \ldots \ldots \ldots \ldots \ldots \ldots .79$

Moreland v. Strong, 115 Michigan 211 ................. 157

Morgan $\mathbf{v}$. Snodgrass, 49 West Virginia 387... .........363, 364

Jorley Bros. $\nabla$. Loan Co., 120 Michigan 171.............. 394

Mormon Church $\nabla$. United States, 136 United States $1 \ldots \ldots \ldots \ldots . . .403$

Morris $\nabla$. Caudle, 178 Illinois 9........................ 43

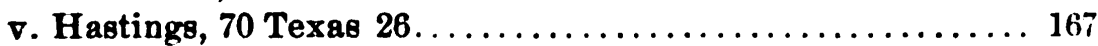

จ. Jansen, 99 Michigan $436 \ldots \ldots \ldots \ldots \ldots \ldots \ldots \ldots \ldots . \ldots \ldots$

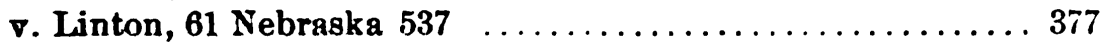

v. McCarty, 158 Massachusetts $11 \ldots \ldots \ldots \ldots \ldots \ldots \ldots . \ldots \ldots$

Morrow v. Cole, 58 New Jereey Equity 203.............. 286 


\section{[References are to Sections.]}

Mott v. Danville Seminary, 129 Illinois $403 \ldots \ldots \ldots \ldots \ldots \ldots \ldots .403$

v. Oppenheimer, 135 New York $312 \ldots \ldots \ldots \ldots \ldots \ldots \ldots . \ldots . \ldots 232$

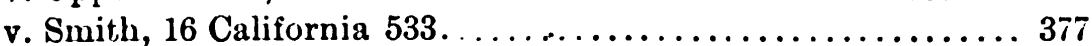

Mueller v. Conrad, 178 Illinois $276 \ldots \ldots \ldots \ldots \ldots \ldots \ldots \ldots \ldots . \ldots \ldots$

Muldoon v. Deline, 135 New York $150 \ldots \ldots \ldots \ldots \ldots \ldots \ldots \ldots . . .65$

Mullen v. Penobscot Co., 90 Maine $55 \ldots \ldots \ldots \ldots \ldots \ldots \ldots \ldots \ldots . \ldots 112$

Muller $v$. Landa, 31 Texas $265 \ldots \ldots \ldots \ldots \ldots \ldots \ldots \ldots \ldots . \ldots \ldots$

Mullins v. Butte Hardware Co., 25 Montana 525 .......... 430

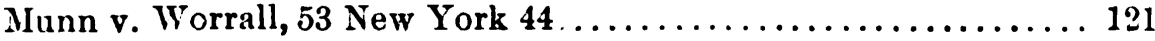

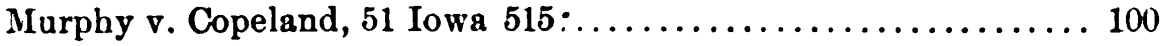

v. Gabbert, 166 Missouri $596 \ldots \ldots \ldots \ldots \ldots \ldots \ldots \ldots \ldots .29$

v. Lockwood, 21 Illinois $611 \ldots \ldots \ldots \ldots \ldots \ldots \ldots \ldots \ldots \ldots \ldots$

v. Ryan, 2 Irish Common Law 143 (Ireland)...........105, 107

Murray v. Hoyle, 92 Alabama $559 \ldots \ldots \ldots \ldots \ldots \ldots \ldots \ldots \ldots .420$

v. Klinzing, 64 Connecticut $78 \ldots \ldots \ldots \ldots \ldots \ldots \ldots \ldots .56,95$

v. Quigley (Iowa), 92 North western $869 \ldots \ldots \ldots \ldots \ldots \ldots \ldots \ldots$

v. Tulare Co., 120 Californa $311 \ldots \ldots \ldots \ldots \ldots \ldots \ldots \ldots \ldots . \ldots . \ldots 28$

Muskingum Co. v. Ward, 13 Ohio $120 \ldots \ldots \ldots \ldots \ldots \ldots \ldots \ldots . \ldots 3$

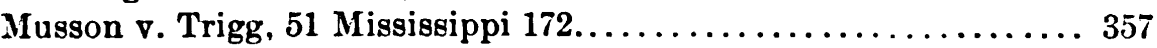

Mutual Life Insurance Co. $\nabla$. Corey, 135 New York 326.......... 293

$\nabla$. Shipman, 119 New York $324 \ldots \ldots \ldots \ldots \ldots \ldots \ldots . \ldots . \ldots . \ldots . \ldots 4$

Muzzarelli v. Hulshizer, 163 Pennsylvania State $643 \ldots \ldots \ldots \ldots \ldots$ 228

IIyers v. Ford, 22 Wisconsin $139 \ldots \ldots \ldots \ldots \ldots \ldots \ldots \ldots \ldots \ldots . \ldots \ldots$

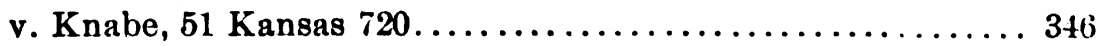

v. McGavock, 39 Nebraska $843 \ldots \ldots \ldots \ldots \ldots \ldots \ldots \ldots$ 324, 326

Mygatt v. Coe, 152 New York $457 \ldots \ldots \ldots \ldots \ldots \ldots \ldots \ldots . \ldots 363,194$

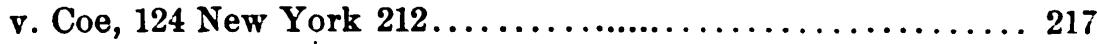

v. Coe, 147 New York $456 \ldots \ldots \ldots \ldots \ldots \ldots \ldots \ldots \ldots 214,224$

National Bank v. Matthews, 98 United States 621........... 405

v. Segar, 39 New Jersey Law $173 \ldots \ldots \ldots \ldots \ldots \ldots \ldots \ldots . \ldots 26$

v. Wheelock, 52 Ohio State $534 . \ldots \ldots \ldots \ldots \ldots \ldots \ldots \ldots . \ldots \ldots 12$

National Building and Loan Association v. Cunningham, 130 Ala-

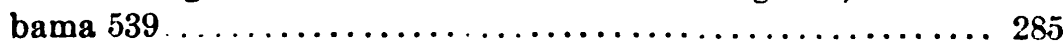

Naylor v. Minock, 96 Michigan $182 \ldots \ldots \ldots \ldots \ldots \ldots \ldots \ldots \ldots \ldots$

Neal v. Nelson, 117 North Carolina $393 \ldots \ldots \ldots \ldots \ldots \ldots \ldots \ldots .43$

v. Neales, 9 Wallace (United States) $1 \ldots \ldots \ldots \ldots \ldots \ldots \ldots, 17$

Neely $\nabla$. Hoskins, 84 Maine $386 \ldots \ldots \ldots \ldots \ldots \ldots \ldots \ldots \ldots . \ldots . \ldots 181$

Nevels $\nabla$. Kentucky Lumber Co., 108 Kentucky 550............ 157

New England Co. v. Spitler, 54 Kansas 560............ 332, 342

Newberry v. Newberry, 114 Iowa $704 \ldots \ldots \ldots \ldots \ldots \ldots . \ldots . \ldots . \ldots 37,375$

Newman $v$. Tymeson, 13 Wisconsin $172 \ldots \ldots \ldots \ldots \ldots \ldots \ldots \ldots . \ldots 7$

New Orleans Pacific R. Co. v. Parker, 143 United States 42 ...... 118

Newpoint Lodge v. Newpoint, 138 Indiana $141 \ldots \ldots \ldots \ldots \ldots \ldots$. 1 \&1

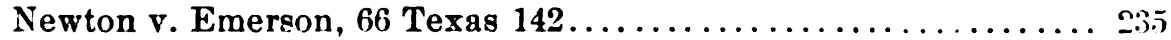

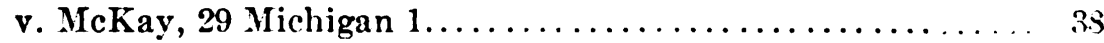

Nicholl's A ppeal, 190 Pennsylvania State $308 \ldots \ldots \ldots \ldots \ldots \ldots \ldots .602$ 
[References are to Sections.]

Nichols v. Boston, 98 Massachusetts 39.................... 104

v. Furniture Co., 100 Michigan $230 \ldots \ldots \ldots \ldots \ldots \ldots \ldots$ 93, 100

Nicoll v. New York and Erie R. Co., 12 New York 121 ......172, 402

Nicrosi $\mathbf{v}$. Phillipi, 91 Alabama $299 \ldots \ldots \ldots \ldots \ldots \ldots \ldots \ldots$ 41.

Nightingale v. Hidden, 7 Rhode Island $115 \ldots \ldots \ldots \ldots \ldots \ldots . \ldots \ldots$

Niles v. Cedar Point Club, 175 United States $300 \ldots \ldots \ldots \ldots \ldots .10 . . \ldots$

Noble v. Googins, 99 Massachusetts $231 \ldots \ldots \ldots \ldots \ldots \ldots \ldots \ldots . . \ldots 2$

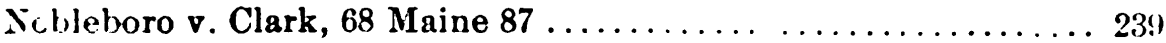

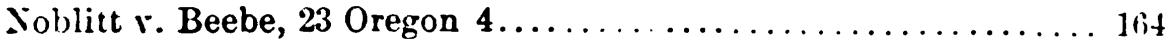

Nurcross $\nabla$. Griffiths, 65 Wisconsin $599 \ldots \ldots \ldots \ldots \ldots \ldots \ldots 98$, 99

v. James, 140 Massachusetts $188 \ldots \ldots \ldots \ldots \ldots \ldots \ldots 214,2: 0$

Norfolk v. Cooke, 27 Grattan (Virginia) $430 \ldots \ldots \ldots \ldots \ldots \ldots . \ldots 108$

Yorris v. Dains, 52 Ohio State $215 \ldots \ldots \ldots \ldots \ldots \ldots \ldots \ldots 46,240$

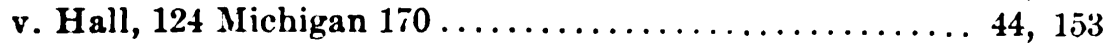

Northern Lake Ice Co. v. Orr, 102 Kentucky $586 \ldots \ldots \ldots \ldots \ldots . . \ldots 43$

Northumberland v. Cobleigh, 59 New Hampshire 250......... 24k

Norwalk Heating \&c. Co. v. Vernam, ij Connecticut $662 . \ldots \ldots \ldots$. $4: 0$

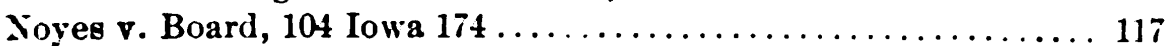

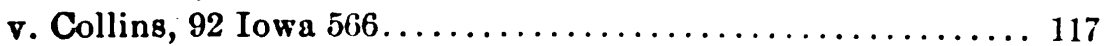

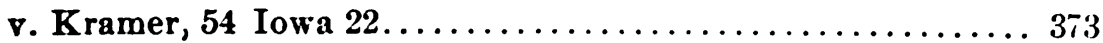

Nyce v. Obertz, 17 Ohio $71 \ldots \ldots \ldots \ldots \ldots \ldots \ldots \ldots \ldots \ldots \ldots . \ldots \ldots$

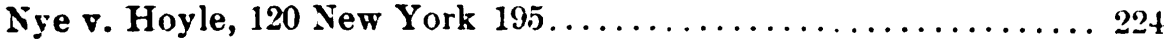

v. Lowry, 82 Indiana $316 \ldots \ldots \ldots \ldots \ldots \ldots \ldots \ldots \ldots . \ldots \ldots$

v. Taunton R. Co., 113 Massachusetts $277 \ldots \ldots \ldots \ldots \ldots \ldots 373$

Oakes v. DeLancey, 133 New York $227 \ldots \ldots \ldots \ldots \ldots \ldots \ldots .92,102$

Oakland v. Hewitt, 105 Iowa $663 \ldots \ldots \ldots \ldots \ldots \ldots \ldots \ldots \ldots . \ldots \ldots$ 259

v. Oakland Co., 118 California $160 \ldots \ldots \ldots \ldots \ldots \ldots \ldots \ldots \ldots \ldots \ldots$

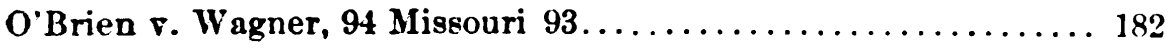

O'Conner $\nabla$. O'Conner, 100 Iowa 476................ 302, 304

Odom v. Riddick, 104 North Carolina 515.................. 347

O'Donnell v. Kelliher, 62 Illinois Appellate $641 \ldots \ldots \ldots \ldots \ldots 238$

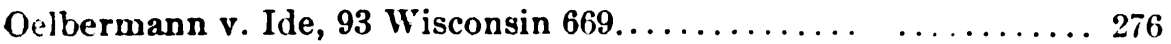

Ogburn's Estate, 105 California $95 \ldots \ldots \ldots \ldots \ldots \ldots \ldots \ldots \ldots . \ldots . \ldots 384$

Ogden v. Ogden, 60 Arkansas $70 \ldots \ldots \ldots \ldots \ldots \ldots \ldots \ldots \ldots . \ldots \ldots$

Ogden Building Association $\nabla$. Mensch, 196 Illinois $5 \overline{5} 4 \ldots \ldots \ldots .285$

Olcott $\nabla$. Gabert, 86 Texas $121 \ldots \ldots \ldots \ldots \ldots \ldots \ldots \ldots \ldots \ldots \ldots$

Olin v. Denver and Rio Grande R. Co., 25 Colorado $177 \ldots \ldots \ldots .89$

Oliver $\nabla$. Dickinson, 100 Massachusetts $114 \ldots \ldots \ldots \ldots \ldots \ldots \ldots$

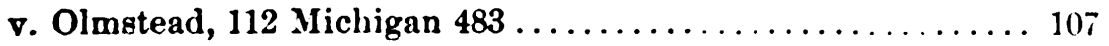

v. Piatt, 3 Howard (United States) $333 \ldots \ldots \ldots \ldots \ldots \ldots \ldots$

Olson v. Huntamer, 6 South Dakota $364 \ldots \ldots \ldots \ldots \ldots \ldots \ldots \ldots \ldots \ldots$

v. Seattle (Washington), 71 Pacific $201 \ldots \ldots \ldots \ldots \ldots \ldots \ldots$ 96

v. Thorndike, 76 Minnesota $399 \ldots \ldots \ldots \ldots \ldots \ldots \ldots \ldots . \ldots 2$

Omaha Real Estate Co. v. Kragscow, 47 Nebraska $592 \ldots \ldots \ldots \ldots 276$

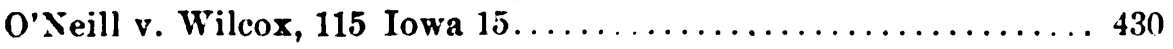

Ordway v. Downey, 18 Washington $412 \ldots \ldots \ldots \ldots \ldots \ldots \ldots \ldots$. 65 


\section{[References are to Sections.]}

Ormsby $\mathbf{v}$. Budd, 72 Iowa $80 \ldots \ldots \ldots \ldots \ldots \ldots \ldots \ldots \ldots \ldots . \ldots \ldots$

Oregon Mortgage Co. v. Carstens, 16 Washington $165 \ldots \ldots \ldots \ldots 410$

Oregon R. Co. v. Oregonian R. Co., 130 United States $1 \ldots \ldots \ldots .407$

Osborne v. Cooper, 113 Alabama $405 \ldots \ldots \ldots \ldots \ldots \ldots \ldots \ldots \ldots . \ldots . \ldots . \ldots$

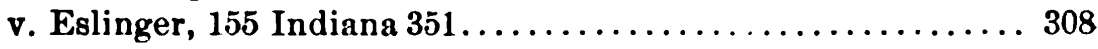

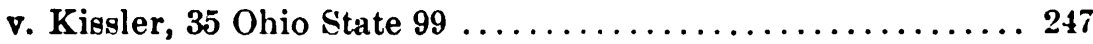

Ottumwa Woolen Mill Co. v. Hawley, 44 Iowa $57 \ldots \ldots \ldots \ldots \ldots . \ldots 118$

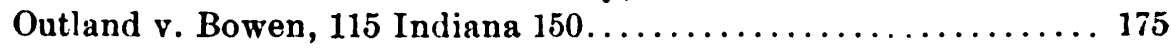

Overacre v. Blake, 82 California $77 \ldots \ldots \ldots \ldots \ldots \ldots \ldots \ldots 272$

Overfleld v. Christie, 7 Sergeant and Rawle (Pennsylvania) 173.. 421

Overland Machinery Co. v. Alpenfels (Colorado), 69 Pacific 574.... 89

Ozark Land Co. $\nabla$. Franks, 156 Missouri $673 \ldots \ldots \ldots \ldots \ldots \ldots$ i4

Pacific R. Co. v. Seely, 45 Missouri $212 \ldots \ldots \ldots \ldots \ldots \ldots \ldots \ldots . \ldots 405$

Packer v. Bird, 71 California $134 ; 137$ United States $661 \ldots \ldots .101,108$

Paddock v. Pulsifer, 43 Kansas $718 \ldots \ldots \ldots \ldots \ldots \ldots \ldots \ldots \ldots . \ldots 1$

Page v. Heineberg, 40 Vermont $81 \ldots \ldots \ldots \ldots \ldots \ldots \ldots \ldots \ldots . \ldots 4$

Paine v. Woods, 108 Massachusetts $160 \ldots \ldots \ldots \ldots \ldots \ldots \ldots \ldots . . \ldots 8$

Paine's Executor v. Consumers' Storage Co. (United 8tates), 71

Federal $627 . \ldots \ldots \ldots \ldots \ldots \ldots \ldots \ldots \ldots \ldots \ldots \ldots \ldots, 89$

Painter v. Water Co., 91 California $74 \ldots \ldots \ldots \ldots \ldots \ldots \ldots \ldots . \ldots \ldots$

Palmer v. Farrell, 129 Pennsylvania State, $162 \ldots \ldots \ldots \ldots \ldots . .100,108$

v. Palmer, 150 New York $139 \ldots \ldots \ldots \ldots \ldots \ldots \ldots \ldots \ldots \ldots \ldots$

v. Ryan, 63 Vermont $227 \ldots \ldots \ldots \ldots \ldots \ldots \ldots \ldots \ldots \ldots \ldots \ldots$

Paolillo v. Taber, 56 New York Appellate Division $241 \ldots \ldots \ldots \ldots 272$

Papst v. Hamilton, 133 California $631 \ldots \ldots \ldots \ldots \ldots \ldots \ldots \ldots 179,181$

Parent v. Callerand, 64 Illinois $97 \ldots \ldots \ldots \ldots \ldots \ldots \ldots \ldots \ldots . \ldots \ldots$

Parish v. Whitney, 3 Gray (Massachusetts) $516 \ldots \ldots \ldots \ldots \ldots \ldots 225$

Park v. Wilkinson, 21 Utah 279.................... 87

Parker v. Marco (United States), 76 Federal $510 \ldots \ldots \ldots \ldots \ldots . . \ldots 36$

Parks v. Hazlerigg, 7 Blackford (Indiana) $536 \ldots \ldots \ldots \ldots \ldots \ldots 233$

Parmelee v. Simpson, 5 Wallace (United States), $81 \ldots \ldots \ldots \ldots \ldots . \ldots 2$

Parrish v. Hawes, 95 Texas $185 \ldots \ldots \ldots \ldots \ldots \ldots \ldots \ldots \ldots . \ldots . \ldots . \ldots . \ldots . \ldots$

Parrott v. Avery, 159 Massachusetts $594 \ldots \ldots \ldots \ldots \ldots \ldots \ldots \ldots . \ldots . \ldots 6$

Parsons v. Boyd, 20 Alabama $112 \ldots \ldots \ldots \ldots \ldots \ldots \ldots \ldots \ldots . \ldots \ldots$

Patterson v. Galliher, 122 North Carolina $511 \ldots \ldots \ldots \ldots \ldots \ldots . \ldots 247$

v. Nixon, 79 Indiana $251 \ldots \ldots \ldots \ldots \ldots \ldots \ldots \ldots \ldots \ldots \ldots \ldots \ldots$

v. Patterson, 81 Iowa $626 \ldots \ldots \ldots \ldots \ldots \ldots \ldots \ldots \ldots \ldots \ldots$

Patton v. Nixon, 33 Oregon $159 \ldots \ldots \ldots \ldots \ldots \ldots \ldots \ldots \ldots \ldots . \ldots \ldots$

Pawling v. United States, 4 Cranch $219 \ldots \ldots \ldots \ldots \ldots \ldots \ldots \ldots . \ldots 309$

Payette v. Ferrier, 20 Washington $479 \ldots \ldots \ldots \ldots \ldots \ldots \ldots . \ldots \ldots$

Pearce v. Schotcher, 9 Queen's Bench Division 162.........105, 107

Pearl v. Lockwood, 123 Michigan $142 \ldots \ldots \ldots \ldots \ldots \ldots \ldots \ldots . \ldots \ldots$

Pearsoll v. Chapin, 44 Pennsylvania State $9 \ldots \ldots \ldots \ldots \ldots \ldots \ldots . \ldots 312$

Pearson v. Adams, 129 A labama $157 \ldots \ldots \ldots \ldots \ldots \ldots \ldots \ldots .418$

v. Allen, 151 Massachusetts $79 \ldots \ldots \ldots \ldots \ldots \ldots \ldots \ldots .69$

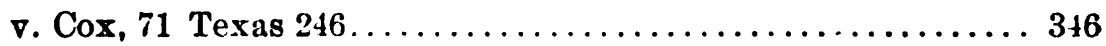




\section{[References are to sections.]}

Pearson v. Davis, 41 Nebraska 608...................... 251

Pease v. Bridge, 49 Connecticut $58 \ldots \ldots \ldots \ldots \ldots \ldots \ldots \ldots \ldots . \ldots \ldots$

v. Inhabitants of Whitman, 182 Massachusetts $363 \ldots \ldots \ldots \ldots 165$

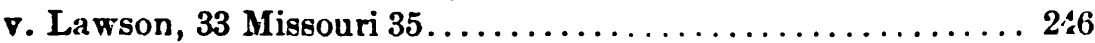

Peck v. Denniston, 121 Massachusetts $17 \ldots \ldots \ldots \ldots \ldots \ldots \ldots . \ldots 90$

v. Houghtaling, 35 Michigan $127 \ldots \ldots \ldots \ldots \ldots \ldots \ldots \ldots . \ldots 206$

v. Sims, 120 Indiana $345 \ldots \ldots \ldots \ldots \ldots \ldots \ldots \ldots \ldots \ldots \ldots$

Pemberton Building Association v. Adams, 53 New Jersey Equity

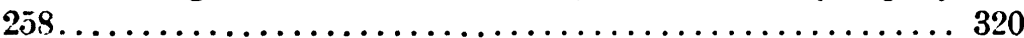

Penfold v. Warner, 96 Michigan $179 \ldots \ldots \ldots \ldots \ldots \ldots \ldots . . \ldots 374,377$

Penn v. Garvin, 56 Arkansas $511 \ldots \ldots \ldots \ldots \ldots \ldots \ldots \ldots \ldots . \ldots \ldots$

Penny v. British \&c. Mortgage Co., 132 Alabama 357 .......... 399

People v. Ballard, 134 New York $269 \ldots \ldots \ldots \ldots \ldots \ldots \ldots \ldots 406$

v. Chase, 165 Illinois $527 \ldots \ldots \ldots \ldots \ldots \ldots \ldots \ldots \ldots .433,437$

v. Miller, 79 Michigan $93 \ldots \ldots \ldots \ldots \ldots \ldots \ldots \ldots \ldots \ldots \ldots$

v. O'Brien, 111 New York $1 \ldots \ldots \ldots \ldots \ldots \ldots \ldots \ldots \ldots . \ldots \ldots$

v. Pullman's Palace Car Co., 175 Illinois $125 \ldots \ldots \ldots \ldots \ldots \ldots 404$

v. Silberwood, 110 Michigan $103 \ldots \ldots \ldots \ldots \ldots \ldots \ldots \ldots \ldots . \ldots \ldots$

จ. Simon, 176 Illinois $165 \ldots \ldots \ldots \ldots \ldots \ldots \ldots \ldots \ldots \ldots 436,442$

v. Stockton Savings and Loan Society, 133 California $611 \ldots \ldots 405$

Perkins v. McAuliffe, 105 Wisconsin $582 \ldots \ldots \ldots \ldots \ldots \ldots \ldots 65$

Perrin v. Carey, 24 Howard (United States) $465 \ldots \ldots \ldots \ldots \ldots . \ldots 4$

Peter v. Byrne (Missouri), 75 Southwestern 433.............. 364

Peters $\nabla$. Bowman, 98 United States $56 \ldots \ldots \ldots \ldots \ldots \ldots \ldots . \ldots 188$

v. Cartier, 80 Michigan $124 \ldots \ldots \ldots \ldots \ldots \ldots \ldots \ldots \ldots . \ldots 188$

Pettigrew v. Dobbelaar, 63 California $396 \ldots \ldots \ldots \ldots \ldots \ldots \ldots . \ldots 1$

Peuker v. Canter, 62 Kansas $363 \ldots \ldots \ldots \ldots \ldots \ldots \ldots \ldots \ldots \ldots . \ldots . \ldots 102$

Pewankee v. Savoy, 103 Wisconsin $271 \ldots \ldots \ldots \ldots \ldots \ldots \ldots \ldots . \ldots 117$

Phillips v. Ferguson, 85 Virginia 509................... 185

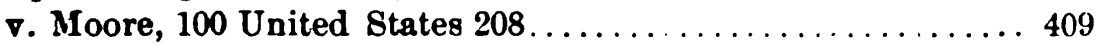

จ. Providence Steam Engine Co., 21 Rhode Island $302 \ldots \ldots .406$

v. Phillips, 30 Colorado $516 \ldots \ldots \ldots \ldots \ldots \ldots \ldots \ldots \ldots . \ldots \ldots$

v. Swank, 120 Pennsylvania State $76 \ldots \ldots \ldots \ldots \ldots \ldots 28,137$

Philpot v. Bingham, 55 Alabama $435 \ldots \ldots \ldots \ldots \ldots \ldots \ldots \ldots . \ldots \ldots$

Pickens v. Rymer, 90 North Carolina $283 \ldots \ldots \ldots \ldots \ldots \ldots \ldots .248$

Pierce $\nabla$. Indseth, 106 United States $546 \ldots \ldots \ldots \ldots \ldots \ldots \ldots 246$

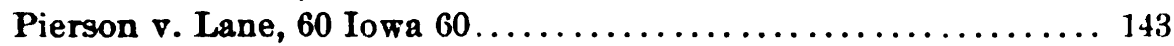

Pike v. Clark, 40 New Hampshire $9 \ldots \ldots \ldots \ldots \ldots \ldots \ldots \ldots . \ldots . \ldots . \ldots 3$

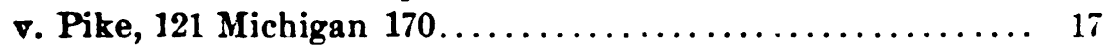

Pilcher v. Atchison \&c. R. Co., 38 Kansas $516 \ldots \ldots \ldots \ldots \ldots \ldots$. 395

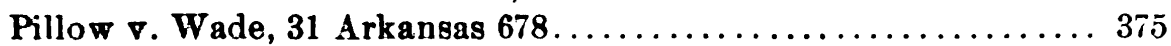

Pimental v. San Francisco, 21 California $351 \ldots \ldots \ldots \ldots \ldots \ldots 241$

Pinkham v. Pinkham, 55 Nebraska 729.................. 29

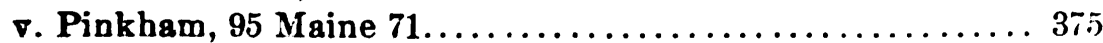

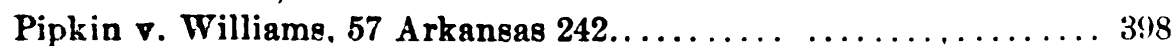

Pitts v. Seavey, 88 Iowa $336 \ldots \ldots \ldots \ldots \ldots \ldots \ldots \ldots . \ldots \ldots \ldots 2$

Pitteburgh Iron Co. $\nabla$. Lake Superior Iron Co., 118 Michigan 109. . 116 


\section{[References are to Sections.]}

Plaster v. Rigney (United States), 97 Federal $12 \ldots \ldots \ldots \ldots \ldots . \ldots 336$

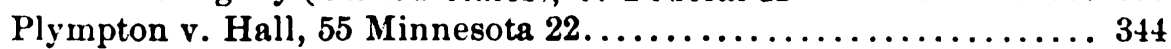

Plummer v. Gould, 92 Michigan $1 \ldots \ldots \ldots \ldots \ldots \ldots \ldots \ldots \ldots . \ldots 6$

Poe v. Dixon, 60 Ohio State $124 \ldots \ldots \ldots \ldots \ldots \ldots \ldots \ldots \ldots . \ldots \ldots$

Point Street Iron Works v. Simmons, 11 Rhode Island $496 \ldots \ldots \ldots 188$

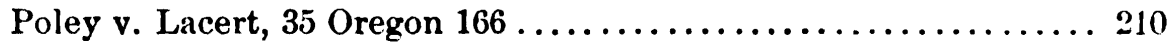

Polk v. Faris, 9 Yerger (Tennessee) $209 \ldots \ldots \ldots \ldots \ldots \ldots \ldots \ldots 147$

Poliock v. Speidel, 27 Ohio State $86 . \ldots \ldots \ldots \ldots \ldots \ldots \ldots \ldots \ldots . \ldots \ldots$

Polson v. Stewart, 167 Massachusetts $211 \ldots \ldots \ldots \ldots \ldots \ldots \ldots \ldots, 10$

Porcher v. Daniel, 12 Richardson Equity $349 \ldots \ldots \ldots \ldots \ldots .355,356$

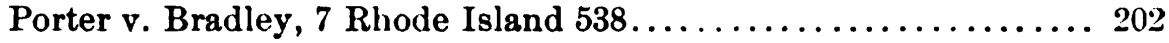

v. Cook, $114 \mathrm{Wisconsin} 60 \ldots \ldots \ldots \ldots \ldots \ldots \ldots \ldots \ldots \ldots \ldots \ldots \ldots$

v. Read, 19 Maine $363 . \ldots \ldots \ldots \ldots \ldots \ldots \ldots \ldots \ldots \ldots \ldots$ i0

v. Woodhouse, 59 Connecticut $568 \ldots \ldots \ldots \ldots \ldots \ldots \ldots \ldots . \ldots . \ldots . \ldots 3$

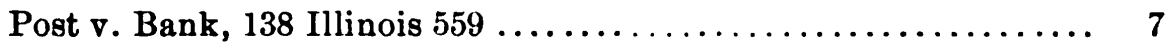

v. Campau, 42 Michigan $90 \ldots \ldots \ldots \ldots \ldots \ldots \ldots$ 199, 215, 218

v. Railroad Co., 50 Hun (New York) $301 . \ldots \ldots \ldots \ldots \ldots \ldots .22$. .)

v. Weil, 115 New York $361 \ldots \ldots \ldots \ldots \ldots \ldots \ldots \ldots \ldots . \ldots 179,228$

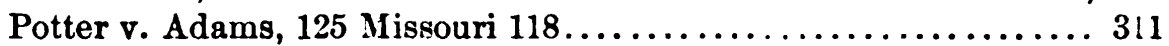

v. Couch, 141 United States $296 \ldots \ldots \ldots \ldots \ldots \ldots \ldots \ldots \ldots \ldots \ldots$

v. Potter (Oregon), 72 Pacific 702................ 371, 375

Pounds v. Clarke, 70 Mississippi $263 \ldots \ldots \ldots \ldots \ldots \ldots \ldots \ldots \ldots . \ldots \ldots 0$

Powell v. Lantzy, 173 Pennsylvania State $543 \ldots \ldots \ldots \ldots \ldots \ldots . \ldots 148$

v. Monson, 3 Mason (United States) $355 \ldots \ldots \ldots \ldots \ldots \ldots . \ldots 201$

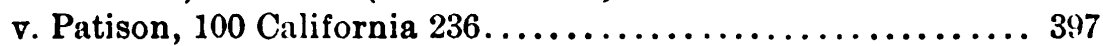

Powers v. Bank of Oroville, 136 California $486 \ldots \ldots \ldots \ldots \ldots \ldots .67$

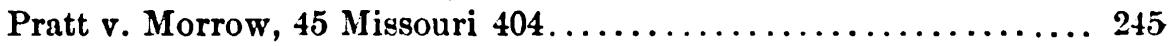

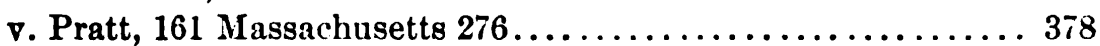

Pray v. Stebbins, 141 Massachusetts $219 \ldots \ldots \ldots \ldots \ldots \ldots \ldots \ldots . \ldots \ldots$

Prentice v. Railroad Co., 154 United States $163 \ldots \ldots \ldots \ldots \ldots \ldots .66$

v. Stearns, 113 United States $435 \ldots \ldots \ldots \ldots \ldots \ldots \ldots \ldots .65$

Prescott v. Edwards, 117 California $298 \ldots \ldots \ldots \ldots \ldots \ldots \ldots \ldots .94$

v. Trueman, 4 Massachusetts $627 \ldots \ldots \ldots \ldots \ldots \ldots \ldots \ldots .200$

Preston v. Bosworth, 153 Indiana $458 \ldots \ldots \ldots \ldots \ldots \ldots \ldots \ldots \ldots \ldots \ldots$

Prewit v. Wilson, 103 United States $22 \ldots \ldots \ldots \ldots \ldots \ldots \ldots \ldots \ldots . \ldots 5$

Price v. Hall, 140 Indiana $314 \ldots \ldots \ldots \ldots \ldots \ldots \ldots \ldots \ldots \ldots . \ldots \ldots$

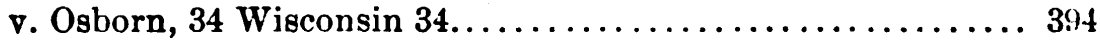

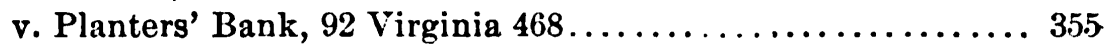

Pritchett v. Davis, 101 Gieorgia 236..................392, 395

Priewe v. Wisconsin Co., 93 Wisconsin $534 \ldots \ldots \ldots \ldots \ldots \ldots \ldots . . \ldots 117$

Prouty v. Tilden, 164 Illinois $163 \ldots \ldots \ldots \ldots \ldots \ldots \ldots \ldots \ldots \ldots . . \ldots 5$

Provident Co. v. Fiss, 147 Pennsylvania State $232 \ldots \ldots \ldots \ldots \ldots \ldots 219$

Prutsman v. Baker, 30 Wisconsin $644 \ldots \ldots \ldots \ldots \ldots \ldots \ldots \ldots . \ldots . \ldots . \ldots$

Pry v. Pry, 109 Illinois $466 \ldots \ldots \ldots \ldots \ldots \ldots \ldots \ldots \ldots \ldots . \ldots . \ldots . \ldots \ldots$

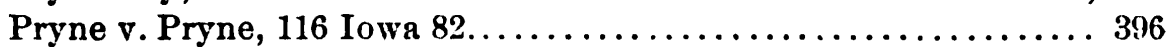

Purczell v. Smidt, 21 Iowa $540 \ldots \ldots \ldots \ldots \ldots \ldots \ldots \ldots \ldots \ldots . \ldots 10$ 


\section{[References are to Sections.]}

Purdy v. Coar, 109 New York 448...................... 33

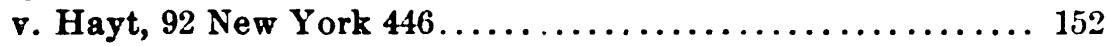

Purinton v. Railroad Co., 46 Illinois $297 \ldots \ldots \ldots \ldots \ldots \ldots \ldots . \ldots 6$

Pynchon v. Stearns, 11 Metcalf (Massachusetts) $312 \ldots \ldots \ldots \ldots \ldots 129$

Quatman v. McCray, 128 California $285 \ldots \ldots \ldots \ldots \ldots \ldots \ldots \ldots . \ldots 182$

Quehl v. Peterson, 47 Minnesota $13 . . . \ldots \ldots \ldots \ldots \ldots \ldots \ldots . \ldots . \ldots 2$

Quick v. Milligan, 108 Indiana $419 \ldots \ldots \ldots \ldots \ldots \ldots \ldots \ldots \ldots . \ldots \ldots$

Quicksall v. Philadelphia, 177 Pennsylvania State $301 \ldots \ldots \ldots \ldots .94$

Quimby $\nabla$. Dill, 40 Maine $528 \ldots \ldots \ldots \ldots \ldots \ldots \ldots \ldots \ldots \ldots . \ldots \ldots$

Radford v. Carwile, 13 West Virginia $572 \ldots \ldots \ldots \ldots \ldots \ldots \ldots . \ldots \ldots$

Railroad $\nabla$ Bank, 178 Illinois $506 \ldots \ldots \ldots \ldots \ldots \ldots \ldots \ldots \ldots . \ldots 6$

v. Platt, 53 Ohio State $254 \ldots \ldots \ldots \ldots \ldots \ldots \ldots \ldots 98,99,106,116$

v. Schurmeir, 7 Wallace (United States) $272 \ldots \ldots \ldots \ldots \ldots 102$

Rand Lumber Co. v. Atkins, 116 Iowa $242 \ldots \ldots \ldots \ldots \ldots \ldots \ldots 383$

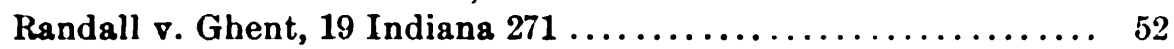

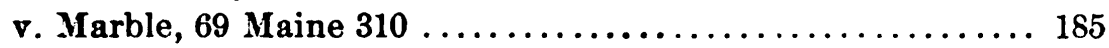

Ranken v. Donovan, 46 New York Appellate Division 225...... 307

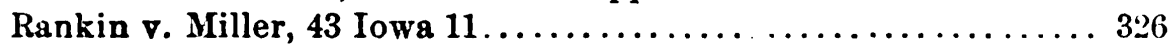

Rankin's Heirs v. Rankin's Executors, 6 T. B. Monroe (Ken-

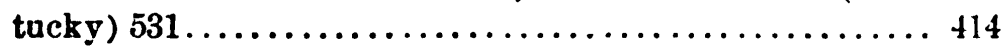

Rannells v. Gerner, 80 Missouri $474 \ldots \ldots \ldots \ldots \ldots \ldots \ldots \ldots 332,333$

Ransom v. Ransom, 30 Michigan 328 ............358, 359, 368, 371

Rawles $\nabla$. Reichenbach (Nebraska), 90 Northwestern $943 \ldots \ldots \ldots 387$

Rawson v. School District, 7 Allen (Massachusetts) 129 ......180, 181

Ray v. Long (North Carolina), 44 Southeastern $652 \ldots \ldots \ldots \ldots \ldots 164$

Raymond v. Raymond, 10 Cushing (Massachusetts) $140 \ldots \ldots \ldots \ldots 198$

Read v. Toledo Loan Co., 68 Ohio State $280 \ldots \ldots \ldots \ldots \ldots \ldots . \ldots 286$

Ready $\nabla$. Pinkham, 181 Massachusetts $351 \ldots \ldots \ldots \ldots \ldots \ldots \ldots . \ldots 21$

Rebhan $\nabla$. Mueller, 114 Illinois $343 \ldots \ldots \ldots \ldots \ldots \ldots \ldots \ldots \ldots$. $42 \mathrm{~S}$

Reck v. Clapp, 98 Pennsylvania State $581 \ldots \ldots \ldots \ldots \ldots \ldots \ldots 426$

Redemptorist Fathers v. Lawler, 205 Pennsylvania State 24..... 154

Rector v. Hartford Deposit Co., 190 Illinois $380 \ldots \ldots \ldots \ldots \ldots \ldots 405$

v. Rotton, 3 Nebraska $171 \ldots \ldots \ldots \ldots \ldots \ldots \ldots \ldots \ldots \ldots . \ldots . \ldots . \ldots . \ldots . \ldots$

Redmond v. Chandley, 119 North Carolina 575............. 67

Reed v. Carlson (Minnesota), 95 Northwestern $303 \ldots \ldots \ldots \ldots \ldots 438$

v. Douthit, 62 Illinois 348.......................... 298

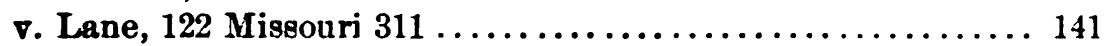

v. Smith, 125 California $491 \ldots \ldots \ldots \ldots \ldots \ldots \ldots \ldots \ldots \ldots . \ldots \ldots$

Reg v. Morton, 28 Law Times Reports (New Series) 452........ 19

Regents of University $\nabla$. Detroit Young Men's Society, 12 Michigan

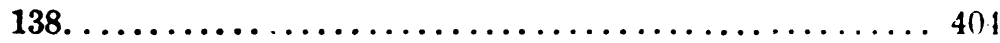

Reid's Administrator $\nabla$. Benge (Kentucky), 66 South western 997 . 428

Reiff $\nabla$. Horst, 55 Maryland $42 \ldots \ldots \ldots \ldots \ldots \ldots \ldots \ldots \ldots \ldots \ldots \ldots \ldots$

Reilly $\nabla$. Otto, 108 Michigan $330 \ldots \ldots \ldots \ldots \ldots \ldots \ldots \ldots \ldots \ldots 229$

Remington Co. v. O'Dougherty, 81 New York $474 \ldots \ldots \ldots \ldots \ldots 284$ 


\section{[References are to Sections.]}

Rendleman's Case, 156 Illinois $568 \ldots \ldots \ldots \ldots \ldots \ldots \ldots \ldots \ldots .54$

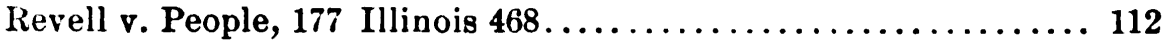

Reyes $\nabla$. Middleton, 36 Florida $99 \ldots \ldots \ldots \ldots \ldots \ldots \ldots \ldots \ldots . \ldots 18$

Reynolds $\mathbf{v}$. Shaver, 59 Arkansas $299 \ldots \ldots \ldots \ldots \ldots \ldots \ldots \ldots \ldots . \ldots \ldots$

Reysen v. Roate, 92 Wisconsin $543 \ldots \ldots \ldots \ldots \ldots \ldots \ldots \ldots \ldots . \ldots 107$

Rhea v. Bagley, 63 Arkansas $374 \ldots \ldots \ldots \ldots \ldots \ldots \ldots \ldots \ldots . \ldots . \ldots . \ldots . \ldots$

v. Rhenner, 1 Peters (United States) $105 \ldots \ldots \ldots \ldots \ldots \ldots . \ldots 363$

Rhoades $\nabla$. Davis, 51 Michigan 306 ...................... 375

v. Fuller, 139 Missouri $179 \ldots \ldots \ldots \ldots \ldots \ldots \ldots \ldots \ldots \ldots \ldots . \ldots \ldots$

Richard $v$. Bent, 59 Illinois $38 \ldots \ldots \ldots \ldots \ldots \ldots \ldots \ldots \ldots \ldots \ldots . \ldots \ldots$

v. East Tennessee \&c. R. Co., 106 Georgia $614 \ldots \ldots \ldots \ldots \ldots . . .330$

Richards v. McClelland, 29 Pennsylvania State $385 \ldots \ldots \ldots \ldots \ldots 363$

Richardson v. Bates, 8 Ohio State $257 \ldots \ldots \ldots \ldots \ldots \ldots \ldots \ldots . \ldots 251$

v. Clements, 89 Pennsylvania State $503 \ldots \ldots \ldots \ldots \ldots \ldots \ldots 121$

v. De Giverville, 107 Missouri $422 \ldots \ldots \ldots \ldots \ldots \ldots \ldots \ldots . \ldots \ldots 35$

v. International Pottery Co., 63 New Jersey Law 248........ 118

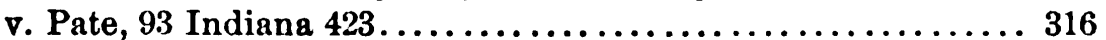

v. Richardson, 80 Maine $585 \ldots \ldots \ldots \ldots \ldots \ldots \ldots \ldots \ldots \ldots . \ldots \ldots$

v. Stodder, 100 Massachusetts $528 \ldots \ldots \ldots \ldots \ldots \ldots \ldots \ldots \ldots . \ldots \ldots \ldots$

v. Tobey, 121 Massachusetts $457 \ldots \ldots \ldots \ldots \ldots \ldots \ldots \ldots \ldots . \ldots \ldots \ldots$

v. Woodstock Iron Co., 90 Alabama $266 \ldots \ldots \ldots \ldots \ldots \ldots \ldots . \ldots 39$

Richey v. Sinclair, 167 Illinois $184 \ldots \ldots \ldots \ldots \ldots \ldots \ldots \ldots \ldots, 78$

Rico v. Brandenstein, 98 California $465 \ldots \ldots \ldots \ldots \ldots \ldots \ldots \ldots . \ldots \ldots$

Ridden v. Baker, 86 Indiana $191 \ldots \ldots \ldots \ldots \ldots \ldots \ldots \ldots \ldots \ldots \ldots \ldots$

Rilgeway v. Herbert, 150 Missouri $606 \ldots \ldots \ldots \ldots \ldots \ldots \ldots \ldots . \ldots . \ldots . \ldots . \ldots 1$

Riggin v. Love, 72 Illinois $553 \ldots \ldots \ldots \ldots \ldots \ldots \ldots \ldots \ldots \ldots \ldots$

Riggles v. Erney, 154 United States $244 \ldots \ldots \ldots \ldots \ldots \ldots \ldots \ldots 17$

Riley v. Burroughs, 41 Nebraska $296 \ldots \ldots \ldots \ldots \ldots \ldots \ldots \ldots . \ldots 213$

v. Carter, 76 Maryland $581 \ldots \ldots \ldots \ldots \ldots \ldots \ldots \ldots . \ldots 35,336,345$

v. Wilson, 86 Texas $240 \ldots \ldots \ldots \ldots \ldots \ldots \ldots \ldots \ldots \ldots . \ldots \ldots \ldots$

Rinard v. West, 92 Indiana $359 \ldots \ldots \ldots \ldots \ldots \ldots \ldots \ldots \ldots . \ldots \ldots$

Rines v. Mansfield, 96 Missouri $394 \ldots \ldots \ldots \ldots \ldots \ldots \ldots \ldots \ldots \ldots \ldots$

Ring $v$. Lawless, 190 Illinois $520 \ldots \ldots \ldots \ldots \ldots \ldots \ldots \ldots \ldots \ldots . \ldots . \ldots . \ldots$

Ritchie v. Railroad, 55 Kansas $36 \ldots \ldots \ldots \ldots \ldots \ldots \ldots \ldots \ldots . \ldots \ldots$

Robeno v. Marlatt, 136 Pennsylvania State $35 \ldots \ldots \ldots \ldots \ldots \ldots \ldots 428$

Roberts v. Decker (Wisconsin), 97 North western $519 \ldots \ldots \ldots \ldots .430$

v. Morgan, 30 Vermont $319 \ldots \ldots \ldots \ldots \ldots \ldots \ldots \ldots \ldots \ldots \ldots$

Robertson v. Pickrell, 109 United States $608 \ldots \ldots \ldots \ldots \ldots \ldots \ldots 66$

Robbins, In re, 34 Minnesota $99 \ldots \ldots \ldots \ldots \ldots \ldots \ldots \ldots \ldots \ldots .61$

v. Rascoe, 120 North Carolina $79 \ldots \ldots \ldots \ldots \ldots \ldots \ldots . . .301,304$

v. Webb, 68 Alabama $393 \ldots \ldots \ldots \ldots \ldots \ldots \ldots \ldots \ldots \ldots . \ldots 230$

Robinson v. Bierce, 102 Tennessee $428 \ldots \ldots \ldots \ldots \ldots \ldots \ldots \ldots . \ldots 210$

v. Coulter, 90 Tennessee $705 \ldots \ldots \ldots \ldots \ldots \ldots \ldots \ldots \ldots \ldots \ldots$

จ. Thrailkill, 110 Indiana $117 \ldots \ldots \ldots \ldots \ldots \ldots \ldots \ldots . \ldots 40$

Robinson's Appeal, 88 Maine $17 \ldots \ldots \ldots \ldots \ldots \ldots \ldots \ldots \ldots . . \ldots 5$

Rockford R. Co. v. Beckemeier, 72 Illinois $267 \ldots \ldots \ldots \ldots \ldots \ldots$ 4

Rocks $\nabla$. Cornell, 21 Rhode Island $532 \ldots \ldots \ldots \ldots \ldots \ldots \ldots . \ldots . \ldots$ 


\section{[References are to sections.]}

Rockwell v. Swift, 59 Connecticut 289 ...................... 154

Rogere $\nabla$. Day, 115 Michigan $664 \ldots \ldots \ldots \ldots \ldots \ldots \ldots \ldots \ldots \ldots . \ldots . \ldots . \ldots 2$

v. McFarland, 89 Iowa $286 \ldots \ldots \ldots \ldots \ldots \ldots \ldots \ldots \ldots \ldots \ldots \ldots$

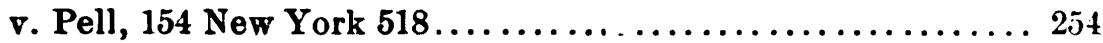

Rohrbaugh $\nabla$. Hamblin, 57 Kansas $393 \ldots \ldots \ldots \ldots \ldots \ldots \ldots \ldots . \ldots \ldots$

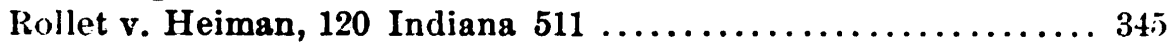

Ronan v. Bluhm, 173 Illinois $277 \ldots \ldots \ldots \ldots \ldots \ldots \ldots \ldots \ldots .431$

Rondot v. Rogers Township (United States), 99 Federal $202 \ldots \ldots .243$

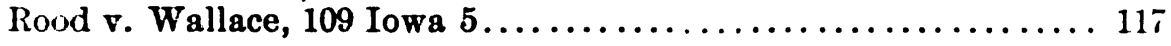

Root v. Brotherson, 4 McLean (United States) $230 \ldots \ldots \ldots \ldots \ldots .9$

Rose v. Taunton, 119 Massachusetts $99 \ldots \ldots \ldots \ldots \ldots \ldots \ldots \ldots .67$

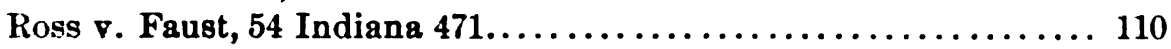

Rossmiller v. State, 114 Wisconsin $169 \ldots \ldots \ldots \ldots \ldots \ldots \ldots 112,117$

Rothschild $\nabla$. Dougher, 85 Texas $332 \ldots \ldots \ldots \ldots \ldots \ldots \ldots \ldots . \ldots 282$

Roulston $\nabla$. Hall, 66 Arkansas $305 \ldots \ldots \ldots \ldots \ldots \ldots \ldots \ldots \ldots . \ldots \ldots 4$

Roussain $\nabla$. Norton, 53 Minnesota $560 \ldots \ldots \ldots \ldots \ldots \ldots \ldots \ldots . \ldots 289$

Row v. Row, 53 Ohio State $249 \ldots \ldots \ldots \ldots \ldots \ldots \ldots \ldots \ldots \ldots . \ldots . \ldots . \ldots 44$

Rowe v. Hamilton, 3 Maine $63 \ldots \ldots \ldots \ldots \ldots \ldots \ldots \ldots \ldots \ldots \ldots \ldots$

Rowland v. Miller, 139 New York $93 \ldots \ldots \ldots \ldots \ldots \ldots \ldots \ldots \ldots . \ldots 229$

₹. Rowland, 93 North Carolina $214 \ldots \ldots \ldots \ldots \ldots \ldots \ldots \ldots . \ldots \ldots$

v. Warren, 10 Oregon $129 \ldots \ldots \ldots \ldots \ldots \ldots \ldots \ldots \ldots \ldots \ldots . \ldots \ldots$

Rowley $v$. Berrian, 12 Illinois $198 \ldots \ldots \ldots \ldots \ldots \ldots \ldots \ldots \ldots \ldots . \ldots \ldots 1$

Rozier v. Graham, 146 Missouri $352 \ldots \ldots \ldots \ldots \ldots \ldots \ldots \ldots \ldots . \ldots \ldots$

Ruch $\nabla$. Rock Island, 97 United States $693 \ldots \ldots \ldots \ldots \ldots \ldots \ldots 171$

Ruckman v. Ruckman, 32 New Jersey Equity $259 \ldots \ldots \ldots \ldots \ldots .298$

Ruiz v. Dow, 113 California $490 \ldots \ldots \ldots \ldots \ldots \ldots \ldots \ldots \ldots \ldots . \ldots \ldots$

Runnells v. Webber, 59 Maine $488 \ldots \ldots \ldots \ldots \ldots \ldots \ldots \ldots \ldots \ldots . \ldots \ldots$

Rupert $\nabla$. Penner, 35 Nebraska 587.................97, 130

Rushton v. Davis, 127 Alabama 279 ...................... 364

Russell v. Doyle, 84 Kentucky $386 \ldots \ldots \ldots \ldots \ldots \ldots \ldots \ldots \ldots . \ldots 16$

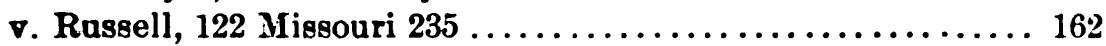

Rutherford $v$. Tracy, 48 Missouri $325 \ldots \ldots \ldots \ldots \ldots \ldots \ldots \ldots \ldots .86$

Ryan v. Growney, 125 Missouri $474 \ldots \ldots \ldots \ldots \ldots \ldots \ldots \ldots . \ldots . \ldots 320$

Ryder v. Flanders, 30 Michigan $336 \ldots \ldots \ldots \ldots \ldots \ldots \ldots \ldots . \ldots . \ldots . \ldots 28$

Ryland v. Banks, 151 Missouri $1 \ldots \ldots \ldots \ldots \ldots \ldots \ldots \ldots . \ldots 352,356$

Sacramento $\nabla$. Clunie, 120 California $29 \ldots \ldots \ldots \ldots \ldots \ldots \ldots \ldots, 94$

Sage $\nabla$. Mayor of New York, 154 New York $61 \ldots \ldots \ldots \ldots \ldots \ldots . . .104$

St. Louis \&c. R. Co. v. Ramsey, 53 A rkansas 314...........108, 109

St. Paul \&c. R. Co. v. St. Paul \&c. Pacific R. Co., 26 Minnesota 31. 108

Sala, Succession of, 50 Louisiana Annual 1009 .............. 4

Salem National Bank v. White, 159 Illinois $136 \ldots \ldots \ldots \ldots \ldots 239,428$

Salishury $\nabla$. Clarke, 61 Vermont $453 \ldots \ldots \ldots \ldots \ldots \ldots \ldots \ldots \ldots 66$

Sallee $\nabla$. Chandler, 26 Miseouri $124 \ldots \ldots \ldots \ldots \ldots \ldots \ldots \ldots . \ldots \ldots$

Salmon Manufacturing Co. v. Goddard, 14 Howard (United Stateg)

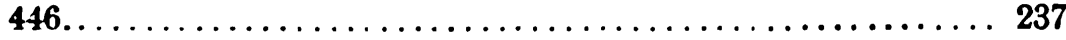

$\nabla$-Brews. Con. 
Ixvi

TABLE OF CASES.

[References are to Sections.]

Samme's Case, 13 Coke $54 \ldots \ldots \ldots \ldots \ldots \ldots \ldots \ldots \ldots \ldots \ldots . . \ldots \ldots$

Sammon v. Wood, 107 Michigan 506..................... 396

Sanborn v. Flagler, 9 Allen (Massachusettg) $474 \ldots \ldots \ldots \ldots \ldots \ldots 237$

Sanders v. Godding, 45 Iow a $463 \ldots \ldots \ldots \ldots \ldots \ldots \ldots \ldots \ldots . . \ldots 2$

Sands v. Lynham, 27 Grattan (Virginia) $291 \ldots \ldots \ldots \ldots \ldots \ldots .410$

Sandwich Manufacturing Co. v. Zellmer, 48 Minnesota 408...... 208

Sanford v. Kane, 133 Illinois $199 \ldots \ldots \ldots \ldots \ldots \ldots \ldots \ldots \ldots . \ldots 194$

San Francisco v. Grote, 120 California 59 ................... 395

v. Itsell, 80 California $57 \ldots \ldots \ldots \ldots \ldots \ldots \ldots \ldots \ldots \ldots+4(17$

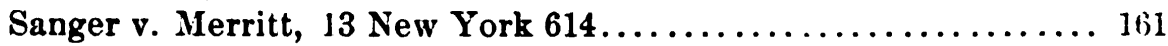

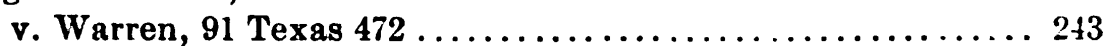

Sarazin v. Railroad, 153 Missouri $479 . \ldots \ldots \ldots \ldots \ldots \ldots \ldots \ldots . . \ldots 269$

Sartor v. Bolinger, 59 Texas $411 \ldots \ldots \ldots \ldots \ldots \ldots \ldots \ldots \ldots . \ldots 280$

Sassenberg v. Huseman, 182 Illinois $341 \ldots \ldots \ldots \ldots \ldots \ldots \ldots . \ldots 259$

Saunders v. Blythe, 112 Missouri $1 \ldots \ldots \ldots \ldots \ldots \ldots \ldots \ldots \ldots . \ldots \ldots$

v. Hackney, 78 Tennessee $194 \ldots \ldots \ldots \ldots \ldots \ldots \ldots \ldots \ldots . \ldots \ldots$

v. Saunders, 115 Iowa $275 \ldots \ldots \ldots \ldots \ldots \ldots \ldots \ldots \ldots \ldots .29$

Savage v. Savage, 80 Maine $472 \ldots \ldots \ldots \ldots \ldots \ldots \ldots \ldots \ldots \ldots . \ldots \ldots \ldots$

Savings Bank v. Kennedy, 58 Iowa 454.................. 381

Savings Society v. Deering, 66 California $281 \ldots \ldots \ldots \ldots \ldots \ldots \ldots . \ldots 1$

Sayers v. Collyer, 28 Chancery Division $103 \ldots \ldots \ldots \ldots \ldots \ldots \ldots 229$

Sayles v. Christie, 187 Illinois $420 \ldots \ldots \ldots \ldots \ldots \ldots \ldots \ldots . . . \ldots 17,319$

Scanlan v. Grimmer, 71 Minnesota $351 \ldots \ldots \ldots \ldots \ldots \ldots \ldots \ldots .43$

v. Wright, 13 Pickering (Maseachusetts) 523........ 323, 410

Schafer v. Hauser, 111 Michigan $622 \ldots \ldots \ldots \ldots \ldots \ldots \ldots \ldots \ldots, 17$

Schaps v. Lehner, 54 Minnesots $208 \ldots \ldots \ldots \ldots \ldots \ldots \ldots \ldots \ldots . \ldots \ldots$

Scharpf $\nabla$. Schmidt, 172 Illinois $255 \ldots \ldots \ldots \ldots \ldots \ldots \ldots \ldots \ldots$ 4

Schermerhorn v. Mahaffie, 34 Kansas $108 . \ldots \ldots \ldots \ldots \ldots \ldots . . \ldots 394$

Schley v. Pullman Car Co., 120 United States 575......... 272, 364

Schlosser v. Hemphill, 118 Iowa 452..................... 103

Schmisseur v. Pennsylvania, 47 Illinois Appellate 278......... 203

Schofield v. Homestead Co., 32 Iowa $317 \ldots \ldots \ldots \ldots \ldots \ldots \ldots . \ldots 216$

$\nabla$. Jennings, 68 Indiana $233 \ldots \ldots \ldots \ldots \ldots \ldots \ldots \ldots \ldots \ldots, 42$

Scrimper v. Railroad, 115 Iowa $35 \ldots \ldots \ldots \ldots \ldots \ldots \ldots \ldots \ldots .62$

Schumacher v. Truman, 134 California $930 \ldots \ldots \ldots \ldots \ldots \ldots \ldots .430$

Schurtz v. Colvin, 55 Ohio State $274 \ldots \ldots \ldots \ldots \ldots \ldots \ldots \ldots \ldots . \ldots \ldots$

Schweiss v. Woodruff, 73 Michigan $473 \ldots \ldots \ldots \ldots \ldots \ldots \ldots \ldots .74$

Schwindt v. Schwindt, 61 Kansas $377 \ldots \ldots \ldots \ldots \ldots \ldots \ldots \ldots \ldots, 17$

Scofield v. Hopkins, 61 Wisconsin $370 \ldots \ldots \ldots \ldots \ldots \ldots \ldots \ldots . \ldots \ldots 2$

Scott v. Bassett, 174 Illinois $390 \ldots \ldots \ldots \ldots \ldots \ldots \ldots \ldots \ldots \ldots . .259$

v. Kirkendall, 88 Illinois $465 \ldots \ldots \ldots \ldots \ldots \ldots \ldots \ldots \ldots \ldots . \ldots \ldots$

v. Trustees, 50 Michigan $528 \ldots \ldots \ldots \ldots \ldots \ldots \ldots \ldots \ldots \ldots . \ldots \ldots \ldots$

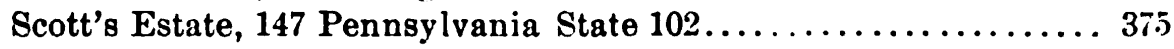

Scovill v. McMahon, 62 Connecticut $378 \ldots \ldots \ldots \ldots \ldots \ldots \ldots 179,187$

Scranton v. Wheeler, 113 Michigan $565 \ldots \ldots \ldots \ldots \ldots \ldots \ldots \ldots . \ldots \ldots$

v. Wheeler, 179 United States $141 \ldots \ldots \ldots \ldots \ldots \ldots \ldots \ldots \ldots . \ldots \ldots$

Scriver v. Smith, 100 New York $471 \ldots \ldots \ldots \ldots \ldots \ldots \ldots \ldots \ldots . . \ldots 209$ 
Scrugham v. Wood, 15 Wendell (New York) 545............. 298 Searcy v. Hunter, 81 Texas $644 \ldots \ldots \ldots \ldots \ldots \ldots \ldots \ldots \ldots . . . \ldots 318,319$ Sears $\nabla$. Ackerman, 138 California $583 \ldots \ldots \ldots \ldots \ldots \ldots \ldots \ldots . \ldots \ldots$

v. Broady (Nebraska), 92 Northwestern $214 \ldots \ldots \ldots \ldots \ldots \ldots 218$

Sebald v. Mulholland, 155 New York 455................ 232

Security Bank v. Holmes, 65 Minnesota 531..............189, 218

v. Holmes, 68 Minnesota $538 \ldots \ldots \ldots \ldots \ldots \ldots \ldots \ldots \ldots . \ldots . \ldots . \ldots$

Security Co. v. Payne, 107 Alabama 578................... 289

Security Land \&c. Co. $\nabla$. Burns, 87 Minnesota $97 \ldots \ldots \ldots \ldots \ldots . . \ldots 3$

Security Loan Co. v. Kauffman, 108 California 214........... 390

Security Savings Bank v. Smith, 38 Oregon 72............. 377

Sedgwick $\nabla$. Hollenback, 7 Johnson (New York) 376 ........... 210

See v. Deer, 57 Michigan $369 \ldots \ldots \ldots \ldots \ldots \ldots \ldots \ldots \ldots \ldots . \ldots 43$

Seeley v. Price, 14 Michigan $541 . \ldots \ldots \ldots \ldots \ldots \ldots \ldots \ldots \ldots . . \ldots 34$

Seiffert \&c. Lumber Co. v. Hartwell, 94 Iowa $576 \ldots \ldots \ldots \ldots \ldots . . \ldots 398$

Sell v. Miller, 11 Ohio State $331 \ldots \ldots \ldots \ldots \ldots \ldots \ldots \ldots \ldots \ldots, 7$

Sellers v. Sellers, 98 North Carolina $13 . \ldots \ldots \ldots \ldots \ldots \ldots \ldots \ldots . \ldots . \ldots 236$

Sengfelder v. Hill, 21 Washington $371 \ldots \ldots \ldots \ldots \ldots \ldots \ldots \ldots \ldots .74$

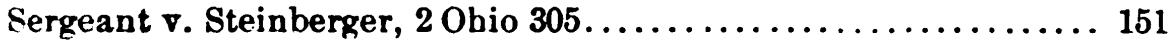

Serleg $v$. Serles, 35 Oregon $289 \ldots \ldots \ldots \ldots \ldots \ldots \ldots \ldots \ldots \ldots \ldots . \ldots \ldots$

Sewell v. Sewell, 92 Kentucky $500 \ldots \ldots \ldots \ldots \ldots \ldots \ldots \ldots \ldots . \ldots \ldots, 320,321$

Sever $\nabla$. Lyons, 170 Illinois $395 \ldots \ldots \ldots \ldots \ldots \ldots \ldots \ldots \ldots \ldots . \ldots \ldots$

Sermour v. Bowles, 172 Illinois $521 \ldots \ldots \ldots \ldots \ldots \ldots \ldots \ldots \ldots \ldots, 40$

Shaft v. Carev, 107 Wisconsin $273 \ldots \ldots \ldots \ldots \ldots \ldots \ldots \ldots \ldots . \ldots \ldots$

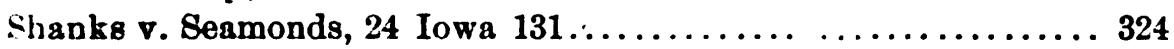

Shannon v. Timm, 22 Colorado $167 \ldots \ldots \ldots \ldots \ldots \ldots \ldots \ldots \ldots . \ldots . \ldots 23$

Shapley v. Diehl, 203 Pennsylvania State $566 \ldots \ldots \ldots \ldots \ldots \ldots . \ldots \ldots$

Sharp $\nabla$. Bailey, 14 Iowa $387 \ldots \ldots \ldots \ldots \ldots \ldots \ldots \ldots \ldots \ldots . \ldots \ldots 8$

Shattuck v. Lamb, 65 New York $499 \ldots \ldots \ldots \ldots \ldots \ldots \ldots \ldots . \ldots . \ldots 210$

Shaughnessy v. Lewis, 130 Massachusetts $355 \ldots \ldots \ldots \ldots \ldots \ldots .35$

Shaw v. Kirby, 93 Wisconsin $379 \ldots \ldots \ldots \ldots \ldots \ldots \ldots \ldots \ldots . \ldots . \ldots . \ldots 2$

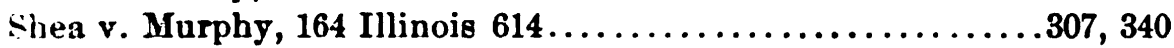

Sheehan v. Davis, 17 Ohio State $571 \ldots \ldots \ldots \ldots \ldots \ldots \ldots \ldots \ldots 249$

Sheeley $\nabla$. Neidhammer, 182 Pennsylvania State $163 \ldots \ldots \ldots \ldots \ldots 147$

Shelby $\nabla$. Chicago \&c. R. Co., 143 Illinois $385 \ldots \ldots \ldots \ldots \ldots \ldots \ldots 405$

Shelden $\nabla$. Freeman, 116 Michigan 646................... 259

Sheldon v. Carter, 90 Alabama $380 \ldots \ldots \ldots \ldots \ldots \ldots \ldots \ldots \ldots . . \ldots \ldots$

Shell v. Matteson, 81 Minnesota 38...................... 116

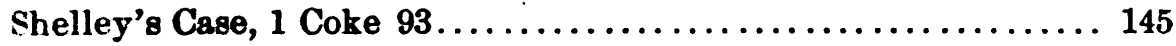

Shelton v. Aultman \&c. Co., 82 Alabama 315............... 398

Sherwood v. Commissioner of Land Office, 113 Michigan 227 ..... 112

v. Landon, 57 Michigan 219...................... 217

Sherrid $\nabla$. Southwick, 43 Michigan $515 \ldots \ldots \ldots \ldots \ldots \ldots \ldots \ldots \ldots 390$

Shields $\nabla$. Bush, 189 Illinois $534 \ldots \ldots \ldots \ldots \ldots \ldots \ldots \ldots \ldots \ldots .400$

Shipp $\nabla$. McKee, 80 Mississippi $741 \ldots \ldots \ldots \ldots \ldots \ldots \ldots \ldots \ldots . \ldots \ldots$

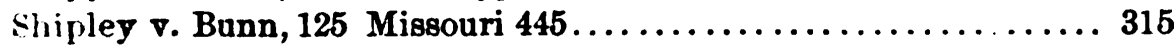

Shively $\nabla$. Bowlby, 152 United States $1 \ldots \ldots \ldots \ldots \ldots 101,102,104,112$ 


\section{[References are to Sections.]}

Shoemaker $\nabla$. Collins, 49 Michigan $595 \ldots \ldots \ldots \ldots \ldots \ldots \ldots \ldots \ldots . \ldots 94$

Short v. Conlee, 28 Illinois $219 \ldots \ldots \ldots \ldots \ldots \ldots \ldots \ldots \ldots \ldots . \ldots \ldots$

Shrock v. Crowl, 83 Indiana $243 \ldots \ldots \ldots \ldots \ldots \ldots \ldots \ldots \ldots \ldots . \ldots \ldots$

Shropshire v. Behrens, 77 Texas $275 \ldots \ldots \ldots \ldots \ldots \ldots \ldots \ldots \ldots 249$

Shroyer $v$. Pittenger (Indiana), 67 Northeastern $475 \ldots \ldots \ldots . .321,322$

Sicard v. Davis, 6 Peters (United States) 124............... 234

Silcock v. Baker, 25 Texas Civil Appeals 508............... 284

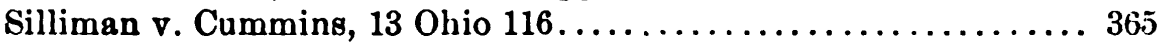

Sillyman v. King, 36 Iowa $207 \ldots \ldots \ldots \ldots \ldots \ldots \ldots \ldots \ldots \ldots . \ldots \ldots$

Silverman v. Kristufek, 162 Illinois $222 \ldots \ldots \ldots \ldots \ldots \ldots \ldots \ldots \ldots . \ldots \ldots$

Simmons v. Kichardson, 107 Alabama $697 \ldots \ldots \ldots \ldots \ldots \ldots \ldots . \ldots 35$

Simons v. Bollinger, 154 Indiana $83 \ldots \ldots \ldots \ldots \ldots \ldots \ldots \ldots . \ldots \ldots 164$

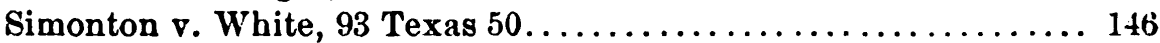

Simpson v. Commonwealth, 89 Kentucky $412 \ldots \ldots \ldots \ldots \ldots \ldots 238$

Simpson v. Mikkelsen, 196 Illinois $575 \ldots \ldots \ldots \ldots \ldots \ldots \ldots \ldots 227$

Simpson v. Railroad, 176 Massachusetts $359 \ldots \ldots \ldots \ldots \ldots \ldots 119,125$

Sims v. Everhardt, 102 United States $300 \ldots \ldots \ldots \ldots \ldots . \ldots 315,316,320$

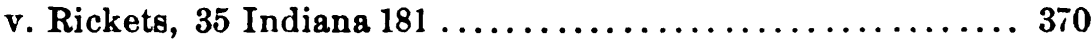

Simson v. Bank, 43 Hun (New York) $156 \ldots \ldots \ldots \ldots \ldots \ldots \ldots . \ldots . \ldots . \ldots$

Singer Manufacturing Co. v. Lamb, 81 Missouri 221........313, 322

Sioux City \& St. Paul R. Co. v. Singer, 49 Minnesota $301 \ldots \ldots \ldots .186$

Sizor $\nabla$. Logansport, 151 Indiana $626 \ldots \ldots \ldots \ldots \ldots \ldots \ldots \ldots \ldots$

Slater v. Granger, 165 Illinois $329 \ldots \ldots \ldots \ldots \ldots \ldots \ldots \ldots \ldots \ldots . \ldots \ldots 2$

v. Gunn, 170 Massachusetts $509 \ldots \ldots \ldots \ldots \ldots \ldots \ldots \ldots \ldots . \ldots \ldots$

v. Nason, 15 Pickering (Massachusetts) $345 \ldots \ldots \ldots \ldots \ldots \ldots . \ldots \ldots \ldots \ldots$

Sleeper v. Laconia, 60 New Hampshire $201 \ldots \ldots \ldots \ldots \ldots \ldots \ldots . \ldots 100$

Slegel v. Lauer, 148 Pennsylvania State $236 \ldots \ldots \ldots \ldots \ldots \ldots 174$

Slingerland v. International Contracting Co., 169 New York $60 \ldots 106$

Sloan v. Biemiller, 34 Ohio State 492................... 112

Slone v. Grider (Kentucky), 44 Southwestern $384 \ldots \ldots \ldots \ldots \ldots . \ldots 161$

Smith v. Barrie, 56 Michigan $314 \ldots \ldots \ldots \ldots \ldots \ldots \ldots \ldots \ldots \ldots \ldots \ldots$

v. Becker, 62 Kansas $541 \ldots \ldots \ldots \ldots \ldots \ldots \ldots \ldots \ldots \ldots .414$

v. Clark, 100 Iowa $605 \ldots \ldots \ldots \ldots \ldots \ldots \ldots \ldots \ldots \ldots \ldots . \ldots \ldots . \ldots \ldots$

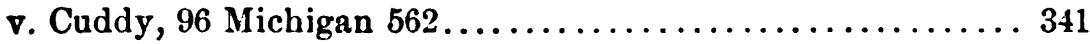

v. Furbish, 68 New Hampshire $123 \ldots \ldots \ldots \ldots \ldots \ldots \ldots \ldots .125$

v. Howell, 11 New Jersey Equity $349 \ldots \ldots \ldots \ldots \ldots \ldots \ldots .235$

v. Ingram, 132 North Carolina $959 \ldots \ldots \ldots \ldots \ldots \ldots \ldots \ldots . \ldots 365$

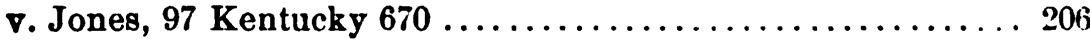

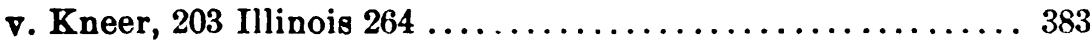

จ. Lloyd, 29 Michigan $382 \ldots \ldots \ldots \ldots \ldots \ldots \ldots \ldots \ldots \ldots \ldots \ldots \ldots$

$\nabla$. Lowry, 113 Indiana $37 \ldots \ldots \ldots \ldots \ldots \ldots \ldots \ldots \ldots \ldots \ldots \ldots$

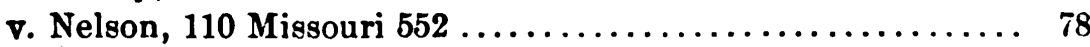

v. Olmstead, 88 California $582 \ldots \ldots \ldots \ldots \ldots \ldots \ldots \ldots \ldots \ldots . \ldots 28$

v. Porter, 10 Gray (Massachusetts) $66 \ldots \ldots \ldots \ldots \ldots \ldots \ldots, 32$

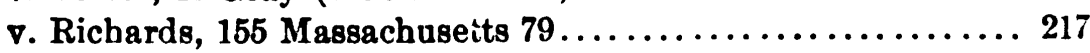

v. Scarbrough, 61 Arkansas $104 \ldots \ldots \ldots \ldots \ldots \ldots \ldots \ldots \ldots . \ldots \ldots$

v. Sherman, 113 Iowa $601 \ldots \ldots \ldots \ldots \ldots \ldots \ldots \ldots \ldots \ldots . \ldots . \ldots 256$ 


\section{[References are to sections.]}

Smith v. Smith, 22 Colorado $480 \ldots \ldots \ldots \ldots \ldots \ldots \ldots \ldots \ldots \ldots . \ldots \ldots$

v. Smith, 71 Michigan $633 \ldots \ldots \ldots \ldots \ldots \ldots \ldots \ldots \ldots \ldots \ldots$

v. Smith (Wisconsin), 93 Northwestern $452 \ldots \ldots \ldots \ldots \ldots . . \ldots 304$

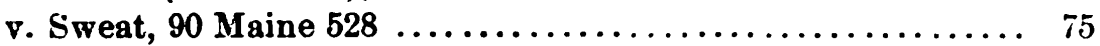

v. Wheeler, 1 Ventris $128 \ldots \ldots \ldots \ldots \ldots \ldots \ldots \ldots \ldots \ldots \ldots . \ldots \ldots$

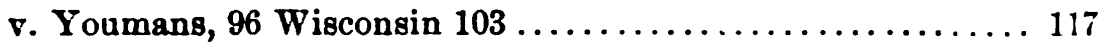

Smith's Lessee v. Hunt, 13 Ohio $260 \ldots \ldots \ldots \ldots \ldots \ldots \ldots \ldots \ldots 26 . \ldots . \ldots 2$

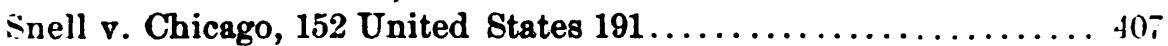

Snoddy v. Bolen, 122 Missouri 479 ...................... 124

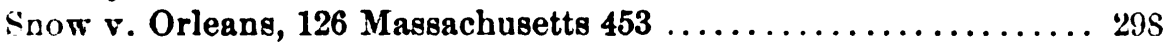

Society v. Haines, 47 Ohio State $423 \ldots \ldots \ldots \ldots \ldots \ldots \ldots \ldots \ldots, 65$

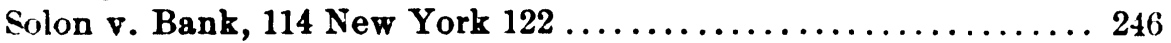

Sonkup v. Union Investment Co., 84 Iowa $448 \ldots \ldots \ldots \ldots \ldots \ldots .78$

South \& North Alabama R. Co. v. Highland Avenue \& Belt R. Co.,

119 Alabama $105 \ldots \ldots \ldots \ldots \ldots \ldots \ldots \ldots \ldots \ldots \ldots \ldots . \ldots \ldots 4$

Southport v. Stanley, 125 North Carolina $464 \ldots \ldots \ldots \ldots \ldots \ldots \ldots 407$

Spader v. Powers, 56 Hun (New York) $153 \ldots \ldots \ldots \ldots \ldots \ldots \ldots 14$

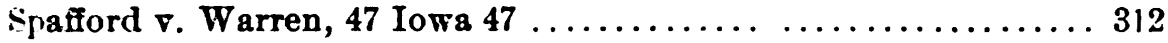

Spangler $v$. Dukes, 39 Obio State $642 \ldots \ldots \ldots \ldots \ldots \ldots \ldots \ldots \ldots . \ldots \ldots$

Spencer v. Austin, 38 Vermont $258 \ldots \ldots \ldots \ldots \ldots \ldots \ldots \ldots \ldots . \ldots \ldots$

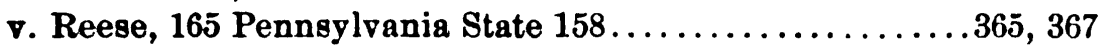

v. Spruell, 196 Illinois $119 \ldots \ldots \ldots \ldots \ldots \ldots \ldots \ldots \ldots \ldots . \ldots \ldots 2$

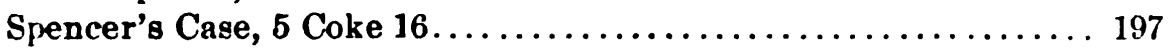

Spicer v. Bonker, 45 Michigan 630 ....................... 243

Spivey v. Rose, 120 North Carolina $163 \ldots \ldots \ldots \ldots \ldots \ldots \ldots \ldots . \ldots 293$

Spokane v. Amsterdam School Trustees, 22 Washington 172 .... 406

Spreckels $\nabla$. Spreckels, 116 California 339 . ............... 167

Springfield Engine Co. v. Donovan, 147 Missouri $622 \ldots \ldots \ldots \ldots \ldots 259$

springs v. Hanks, 5 Iredell (North Carolina) 30............. 58

Squires v. Amberst, 145 Massachusetts $192 \ldots \ldots \ldots \ldots \ldots \ldots \ldots \ldots 63$

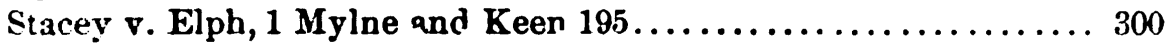

Stackpole v. Robbins, 47 Barbour (New York), 212........... 59

Stamm v. Bostwick, 122 New York $48 \ldots \ldots \ldots \ldots \ldots \ldots \ldots \ldots . \ldots 408$

Stanton $\nabla$. Button, 2 Connecticut $527 \ldots \ldots \ldots \ldots \ldots \ldots \ldots \ldots \ldots \ldots$

v. Hitchcock, 64 Michigan $316 \ldots \ldots \ldots \ldots \ldots \ldots \ldots \ldots \ldots . \ldots \ldots$

Star Brewery Co. v. Primas, 163 Illinois 652 ........179, 182, 229, 230

Starnes $\nabla$. Allen, 151 Indiana $108 \ldots \ldots \ldots \ldots \ldots \ldots \ldots \ldots . \ldots \ldots 0 . \ldots \ldots$

Starr $\nabla$. Child, 20 Wendell (New York) $149 \ldots \ldots \ldots \ldots \ldots \ldots \ldots 100$

State v. Commissioners, 39 Ohio State $58 \ldots \ldots \ldots \ldots \ldots \ldots \ldots . \ldots 324$

v. Eason, 114 North Carolina $787 \ldots \ldots \ldots \ldots \ldots \ldots \ldots . \ldots 108$

v. Fishing and Shooting Club, 127 Michigan $580 \ldots \ldots \ldots \ldots 112$

v. Guilbert, 56 Ohio State $575 \ldots \ldots \ldots \ldots \ldots \ldots 433,436,437,442$

v. Hudson Land Co., 19 Washington $85 . \ldots \ldots \ldots \ldots \ldots \ldots 411$

v. Lee, 21 Ohio State $662 \ldots \ldots \ldots \ldots \ldots \ldots \ldots \ldots \ldots \ldots . \ldots \ldots$

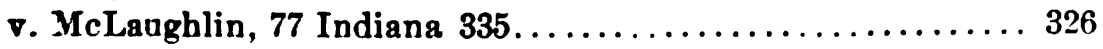

v. Ryland, 163 Missouri $280 \ldots \ldots \ldots \ldots \ldots \ldots \ldots \ldots \ldots \ldots . \ldots \ldots 272$

v. Shannon, 36 Ohio State $423 \ldots \ldots \ldots \ldots \ldots \ldots \ldots \ldots \ldots \ldots . \ldots \ldots$ 


\section{[References are to sections.]}

State $\nabla$. Smith, 70 California $153 \ldots \ldots \ldots \ldots \ldots \ldots \ldots \ldots \ldots . \ldots 12$

v. Stevenson, 6 Idaho $367 \ldots \ldots \ldots \ldots \ldots \ldots \ldots \ldots \ldots \ldots . \ldots 10$

v. Thompson, 81 Missouri Appellate $549 \ldots \ldots \ldots \ldots \ldots \ldots 272$

v. Westfall, 85 Minnesota $437 \ldots \ldots \ldots \ldots \ldots \ldots \ldots 436,438,443$

State Bank v. The State, 1 Blackford (Indiana) $267 \ldots \ldots \ldots \ldots .403$

State Savings Bank v. Stewart, 93 Virginia $447 \ldots \ldots \ldots \ldots \ldots .85,93$

Stebbins v. Duncan, 108 United States $32 \ldots \ldots \ldots \ldots \ldots \ldots \ldots \ldots, 41$

Steeple v. Downing, 60 Indiana $478 \ldots \ldots \ldots \ldots \ldots \ldots \ldots \ldots \ldots . \ldots 18$

Stelz v. Shreck, 128 New York $263 \ldots \ldots \ldots \ldots \ldots \ldots \ldots \ldots \ldots \ldots . \ldots \ldots 2$

Stephenson v. Osborne, 41 Mississippi $119 \ldots \ldots \ldots \ldots \ldots \ldots \ldots . \ldots \ldots$

Sterling v. Jackson, 69 Michigan $488 \ldots \ldots \ldots \ldots \ldots \ldots \ldots \ldots \ldots . \ldots \ldots$

Stetson $\nabla$. Adams, 91 Maine $178 \ldots \ldots \ldots \ldots \ldots \ldots \ldots \ldots \ldots . . \ldots 6$

Stevens v. Hulin, 53 Michigan $93 \ldots \ldots \ldots \ldots \ldots \ldots \ldots \ldots \ldots . \ldots 431$

Stevenson v. Brasher, 90 Kentucky $23 \ldots \ldots \ldots \ldots \ldots \ldots \ldots \ldots \ldots 281$

v. Cofferin, 20 New Hampshire $150 \ldots \ldots \ldots \ldots \ldots \ldots \ldots . . \ldots 159$

Stewart v. Bailey, 28 Michigan $251 . \ldots \ldots \ldots \ldots \ldots \ldots \ldots \ldots \ldots . \ldots 28$

v. Thomas, 64 Kansas $511 \ldots \ldots \ldots \ldots \ldots \ldots \ldots \ldots \ldots \ldots . \ldots \ldots$

v. Welch, 41 Ohio State $483 \ldots \ldots \ldots \ldots \ldots \ldots \ldots \ldots \ldots \ldots . \ldots 21$

Stickel v. Crane, 189 Illinois $211 \ldots \ldots \ldots \ldots \ldots \ldots \ldots \ldots \ldots . \ldots . \ldots 2,400$

Stidham v. Matthews, 29 Arkansas $650 \ldots \ldots \ldots \ldots \ldots \ldots \ldots \ldots . \ldots \ldots$

Stockbridge Iron Co. v. Hudson Iron Co., 107 Massachusetts 290 .. 124

Stockton v. Weber, 98 California $433 \ldots \ldots \ldots \ldots \ldots \ldots \ldots \ldots 170$

Stockton Savings Bank v. Staples, 98 California $189 \ldots \ldots \ldots \ldots \ldots 404$

Stoever v. Whitman, 6 Binney (Pennsylvania) 416.......... 421

Stokes v. Maxson, 113 Iowa $122 \ldots \ldots \ldots \ldots \ldots \ldots \ldots \ldots \ldots \ldots . \ldots . \ldots 95$

Stone v. French, 37 Kansas $145 \ldots \ldots \ldots \ldots \ldots \ldots \ldots \ldots \ldots \ldots . \ldots \ldots$

v. Marvel, 45 New Hampshire $481 \ldots \ldots \ldots \ldots \ldots \ldots \ldots \ldots .235$

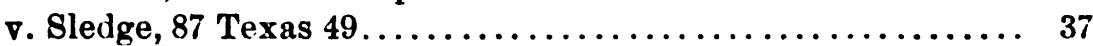

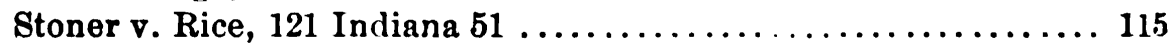

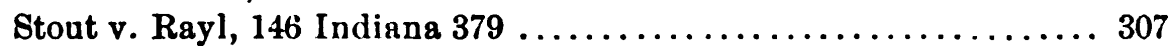

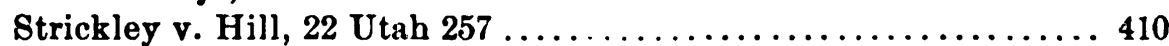

Strough $\nabla$. Wilder, 119 New York $530 \ldots \ldots \ldots \ldots \ldots \ldots \ldots \ldots . \ldots . \ldots 251$

Studwell $\nabla$. Shapter, 54 New York $249 \ldots \ldots \ldots \ldots \ldots \ldots \ldots \ldots . \ldots . \ldots . \ldots 20$

Stull v. Harrie, 51 Arkansas $294 \ldots \ldots \ldots \ldots \ldots \ldots \ldots \ldots \ldots . . . . . .616,321$

Succession of. See name of party.

Sullivan v. Cummins, 13 Ohio $116 \ldots \ldots \ldots \ldots \ldots \ldots \ldots \ldots \ldots . \ldots . \ldots . \ldots$

v. Eddy, 154 Illinois $199 \ldots \ldots \ldots \ldots \ldots \ldots \ldots \ldots \ldots \ldots \ldots . \ldots . \ldots 4$

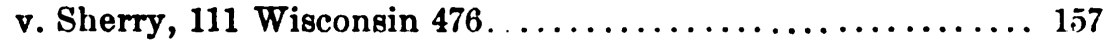

v. Wichita, 64 Kansas $539 \ldots \ldots \ldots \ldots \ldots \ldots \ldots \ldots \ldots \ldots \ldots . \ldots . \ldots . \ldots . \ldots$

Sulzberger v. Sulzberger, 50 California $385 \ldots \ldots \ldots \ldots \ldots \ldots \ldots 378$

Summers $\nabla$. Beeler, 90 Maryland $474 \ldots \ldots \ldots \ldots \ldots \ldots \ldots \ldots .228$

Sumner v. Conant, 10 Vermont $9 \ldots \ldots \ldots \ldots \ldots \ldots \ldots \ldots \ldots \ldots . \ldots \ldots$

v. Williams, 6 Massachusetts $162 \ldots \ldots \ldots \ldots \ldots \ldots \ldots \ldots \ldots 208$

Sutton v. Head, 86 Kentucky $156 \ldots \ldots \ldots \ldots \ldots \ldots \ldots \ldots . \ldots \ldots$

Sutton's Hospital, Case of, 10 Coke 30a.................. 406

Suydam v. Jones, 10 Wendall (New York) $180 \ldots \ldots \ldots \ldots \ldots \ldots . . \ldots 219$

Svetinich v. Sheean, 124 Cali fornia $216 \ldots \ldots \ldots \ldots \ldots \ldots \ldots \ldots . \ldots \ldots 7$ 


\section{[References are to Sections.]}

Swank v. Swank, 37 Oregon $439 . \ldots \ldots \ldots \ldots \ldots \ldots \ldots \ldots \ldots . \ldots . \ldots 3$ Ewedieh American Bank v. Germania Bank, 76 Minnesota 409... 35 Sweet v. Brown, 12 Metcalf (Massachusetts) $175 \ldots \ldots \ldots \ldots \ldots \ldots 207$ Sweetland v. Buell, 164 New York $541 \ldots \ldots \ldots \ldots \ldots \ldots \ldots . \ldots \ldots, 304$

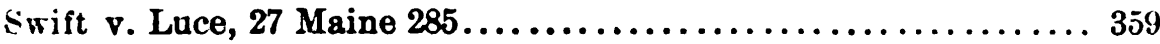

Taft v. Taft, 59 Michigan 185............................. 309 Tallmadge v. East River Bank, 26 New York 105............. 227

v. Wallis, 25 Wendall (New York) $107 \ldots \ldots \ldots \ldots \ldots \ldots \ldots . \ldots 206$

Tardy v. Creasy, 81 Virginia $553 \ldots \ldots \ldots \ldots \ldots \ldots \ldots \ldots \ldots \ldots \ldots \ldots$

T:rrlton v. Griggs, 131 North Carolina 216................. 308

Tartt v. Clayton, 109 Illinois $579 \ldots \ldots \ldots \ldots \ldots \ldots \ldots \ldots \ldots \ldots \ldots \ldots$

Tate $\mathbf{v}$. Lawrence, 11 Heiskell (Tennessee) $503 \ldots \ldots \ldots \ldots \ldots \ldots 252$

Tatham $v$. Vernon, 29 Beavan $604 \ldots \ldots \ldots \ldots \ldots \ldots \ldots \ldots \ldots \ldots . \ldots \ldots$

Taunton v. Pepler, 6 Maddock $166 \ldots \ldots \ldots \ldots \ldots \ldots \ldots \ldots \ldots . \ldots \ldots$

Tarenner $\nabla$. Barrett, 21 West Virginia $656 \ldots \ldots \ldots \ldots \ldots \ldots \ldots 282$

Taylor $\nabla$. Armstrong, 24 Arkansas $102 \ldots \ldots \ldots \ldots \ldots \ldots \ldots \ldots . . \ldots 1$

v. Glaser, 2 Sergeant and Rawle (Pennsylvania) $502 \ldots \ldots \ldots \ldots 247$

v. Jones, 1 Salkeld $389 \ldots \ldots \ldots \ldots \ldots \ldots \ldots \ldots \ldots \ldots \ldots . \ldots \ldots \ldots$

v. Meads, 4 De Gex, Jones and Smith $597 \ldots \ldots \ldots \ldots \ldots 355,356$

v. Peabody Co., 65 Maryland $388 \ldots \ldots \ldots \ldots \ldots \ldots \ldots \ldots . \ldots \ldots$

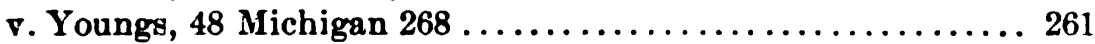

Tefit v. Munson, 57 New York $97 \ldots \ldots \ldots \ldots \ldots \ldots \ldots \ldots \ldots$

Ten Eyck v. Witbeck, 135 New York $40 \ldots \ldots \ldots \ldots \ldots \ldots \ldots, 67$

Thalls v. Smith, 139 Indiana $496 \ldots \ldots \ldots \ldots \ldots \ldots \ldots \ldots \ldots \ldots . \ldots . \ldots . \ldots . \ldots 189$

Thaw v. Ritchie, 136 United States $519 . \ldots \ldots \ldots \ldots \ldots \ldots \ldots . \ldots 26$

Thayer v. Nehalem Mill Co., 31 Oregon 437................. 249

$\nabla$. Thayer, 14 Vermont $107 \ldots \ldots \ldots \ldots \ldots \ldots \ldots \ldots \ldots \ldots . \ldots \ldots$

$\nabla$. Torrey, 37 New Jersey Law $339 \ldots \ldots \ldots \ldots \ldots \ldots \ldots \ldots$

Thomas $\nabla$. Bland, 91 Kentucky $1 \ldots \ldots \ldots \ldots \ldots \ldots \ldots \ldots \ldots . \ldots \ldots$

v. Caldwell, 50 Illinois $138 \ldots \ldots \ldots \ldots \ldots \ldots \ldots \ldots \ldots \ldots . \ldots \ldots \ldots \ldots$

จ. Hunt, 134 Missouri $392 \ldots \ldots \ldots \ldots \ldots \ldots \ldots \ldots \ldots \ldots . .69$

v. Marshfield 10 Pickering (Massachusetts) $364 \ldots \ldots \ldots \ldots, 40$

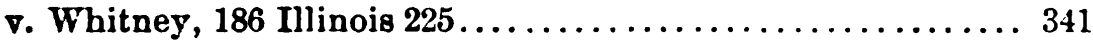

Thompson $\nabla$. Becker, 194 Illinois $119 \ldots \ldots \ldots \ldots \ldots \ldots \ldots \ldots \ldots . \ldots 188$

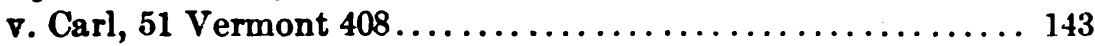

v. Catlett, 24 West Vinginia $524 \ldots \ldots \ldots \ldots \ldots \ldots \ldots \ldots \ldots, 92$

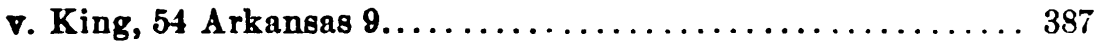

จ. Leach, 2 Ventris 198, 3 Modern Reports $301 \ldots \ldots \ldots \ldots 300,314$

v. Lovrein, 82 Pennsylvahia State $432 \ldots \ldots \ldots \ldots \ldots \ldots \ldots$. 37

จ. McConnell (United States), 107 . Federal $33 \ldots \ldots \ldots \ldots \ldots 400$

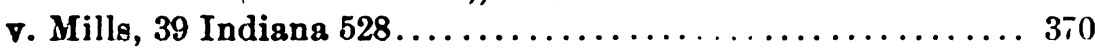

จ. Mortgage Co., 110 Alabama $400 \ldots \ldots \ldots \ldots \ldots \ldots \ldots \ldots . \ldots . \ldots 3$

v. Scheid, 39 Minnesota $102 \ldots \ldots \ldots \ldots \ldots \ldots \ldots \ldots \ldots \ldots 2$

v. Waters, 25 Michigan $214 \ldots \ldots \ldots \ldots \ldots \ldots \ldots \ldots \ldots 40,412$

Thomson v. Kyle, 39 Florida $582 \ldots \ldots \ldots \ldots \ldots \ldots \ldots \ldots \ldots$

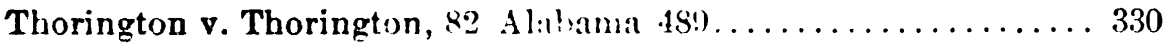




\section{[References are to sections.]}

Thorkildsen $\nabla$. Carpenter, 120 Michigan $419 \ldots \ldots \ldots \ldots \ldots \ldots . \ldots 188$

Thormaehlen v. Kaeppel, 86 Wisconsin $378 \ldots \ldots \ldots \ldots \ldots \ldots 317,320$

Thorpe . Hanscom, 64 Minnesota $201 \ldots \ldots \ldots \ldots \ldots \ldots \ldots \ldots . \ldots . \ldots 33$

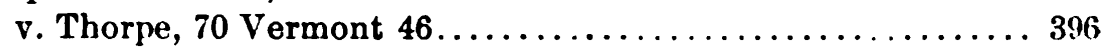

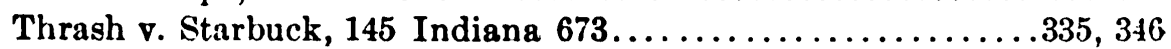

Thrush v. Graybill, 110 Iowa $585 \ldots \ldots \ldots \ldots \ldots \ldots \ldots \ldots \ldots . \ldots 6$

Thummel v. Holden, 149 Missouri $677 \ldots \ldots \ldots \ldots \ldots \ldots \ldots \ldots . . \ldots 9$

Tierney v. Brown, 65 Mississippi $563 \ldots \ldots \ldots \ldots \ldots \ldots \ldots \ldots . \ldots \ldots$

Tiffany $\nabla$. Worthington, 96 Iowa $560 \ldots \ldots \ldots \ldots \ldots \ldots \ldots \ldots \ldots \ldots \ldots$

Tiffin $\nabla$. Shawhan, 43 Ohio State $178 \ldots \ldots \ldots \ldots \ldots \ldots \ldots \ldots \ldots \ldots \ldots \ldots$

Tilley v. King, 109 North Carolina $461 \ldots \ldots \ldots \ldots \ldots \ldots \ldots \ldots . \ldots . \ldots . \ldots 172$

Tillotson $\nabla$. Prichard, 60 Vermont $94 \ldots \ldots \ldots \ldots \ldots \ldots \ldots \ldots . \ldots . \ldots . \ldots . \ldots$

v. Webber, 96 Michigan $144 \ldots \ldots \ldots \ldots \ldots \ldots \ldots \ldots \ldots, 41$

Tindell v. Tindell (Tennessee), 37 Southwestern $1105 \ldots \ldots \ldots \ldots \ldots 157$

Titman v. Riker, 43 New Jersey Equity $122 \ldots \ldots \ldots \ldots \ldots \ldots \ldots . \ldots 28$

Todd $\nabla$. Eighmie, 4 New York Appellate Division $9 \ldots \ldots \ldots \ldots 245$

Toledo Shooting Club v. Erie Shooting Club (United States), 90

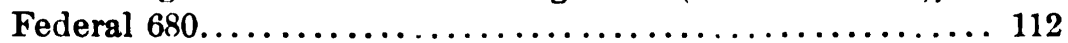

Topeka Water Supply Co. v. Root, 56 Kansas $187 \ldots \ldots \ldots \ldots \ldots 33$

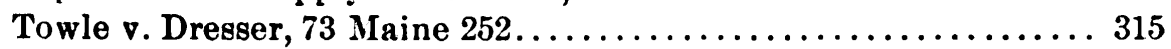

Town of. See name of town.

Town v. Gensch, 101 Wisconsin $445 \ldots \ldots \ldots \ldots \ldots \ldots \ldots \ldots . \ldots$

Townsend v. Blanchard, 117 Iowa $36 \ldots \ldots \ldots \ldots \ldots \ldots \ldots \ldots \ldots$

v. Hubbard, 4 Hill (New York) $351 \ldots \ldots \ldots \ldots \ldots \ldots \ldots . \ldots . \ldots 239$

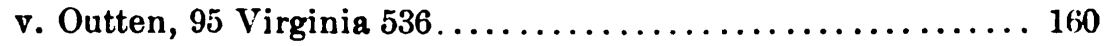

Townsend's Appeal, 68 Connecticut $358 \ldots \ldots \ldots \ldots \ldots \ldots \ldots .228$

Townson $\nabla$. Tickell, 3 Barnewald and Alderson $31 \ldots \ldots \ldots \ldots \ldots 300$

Traynor v. Palmer, 86 Illinois $477 \ldots \ldots \ldots \ldots \ldots \ldots \ldots \ldots . \ldots 2$

Treadwell v. Salisbury Manufacturing Co., 7 Gray (Massachusetts)

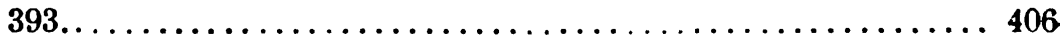

Trich's Executor v. Trich, 165 Pennsylvania State $586 \ldots \ldots \ldots \ldots 340$

Trout v. Lucas, 54 New Jersey Equity $361 \ldots \ldots \ldots \ldots \ldots \ldots \ldots 229$

Trowbridge v. Addoms, 23 Colorado 518.............. 9, 273

v. Cross, 117 Illinois $109 \ldots \ldots \ldots \ldots \ldots \ldots \ldots \ldots \ldots \ldots \ldots . \ldots \ldots$

Troxell v. Stevens, 57 Nebraska $329 \ldots \ldots \ldots \ldots \ldots \ldots \ldots \ldots . \ldots 220$

Trueblood v. Trueblood, 8 Indiana $195 \ldots \ldots \ldots \ldots \ldots \ldots \ldots \ldots . \ldots . \ldots 14$

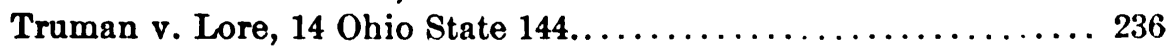

Trumbull $\nabla$. Trumbull, 149 Massachusetts $200 \ldots \ldots \ldots \ldots \ldots \ldots 146$

Trustees of Union College v. New York, 173 New York $38 \ldots \ldots \ldots 180$

Trustees v. Haven, 11 Illinois $554 \ldots \ldots \ldots \ldots \ldots \ldots \ldots \ldots . . \ldots 9$

Trustees of Methodist Episcopal Church v. Hoboken, 33 New Jer-

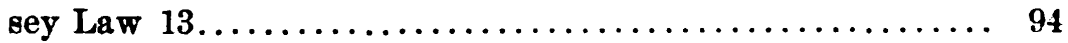

Tucker v. Moreland, 10 Peters (United States) $58 \ldots \ldots \ldots \ldots . . .314,322$ v. Tucker, 78 Kentucky $503 \ldots \ldots \ldots \ldots \ldots \ldots \ldots \ldots \ldots, 40$

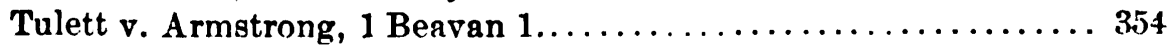

Tunison $v$. Chamblin, 88 Illinois $379 \ldots \ldots \ldots \ldots \ldots \ldots \ldots \ldots \ldots . \ldots \ldots$

Turman v. Bell, 54 Arkansas $273 \ldots \ldots \ldots \ldots \ldots \ldots \ldots \ldots \ldots .431$ 


\section{[References are to sections.]}

Turner $\nabla$. Bernheimer, 95 Alabama $241 \ldots \ldots \ldots \ldots \ldots \ldots \ldots \ldots .400$

v. Rusk, 53 Maryland $65 \ldots \ldots \ldots \ldots \ldots \ldots \ldots \ldots \ldots \ldots \ldots \ldots \ldots \ldots$

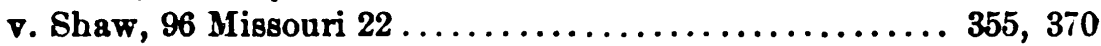

v. Turner, 107 Alabama $465 \ldots \ldots \ldots \ldots \ldots \ldots \ldots \ldots \ldots \ldots \ldots . \ldots . \ldots . \ldots 2$

v. Warren, 160 Pennsylvania State $336 \ldots \ldots \ldots \ldots \ldots \ldots \ldots . \ldots . \ldots 11$

Tyler $v$. Anderson, 106 Indiana $185 \ldots \ldots \ldots \ldots \ldots \ldots \ldots \ldots \ldots . . . \ldots 2$

v. Jewett, 82 Alabama $93 \ldots \ldots \ldots \ldots \ldots \ldots \ldots \ldots \ldots \ldots . \ldots \ldots 7$

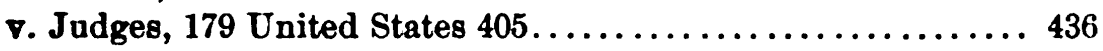

v. Judges of Court of Registration, 175 Massachusetts 7

v. Moore, 42 Pennsylvania State $374 \ldots \ldots \ldots \ldots \ldots \ldots \ldots . \ldots 130$

Uecker $\nabla$. Koehn, 21 Nebraska $559 \ldots \ldots \ldots \ldots \ldots \ldots \ldots \ldots \ldots . . \ldots 23$

United States v. Crosby, 7 Cranch (United States) $115 \ldots \ldots \ldots \ldots .6$

v. Fox, 94 United States $315 \ldots \ldots \ldots \ldots \ldots \ldots \ldots \ldots \ldots \ldots, 7$

จ. Mission Rock Co., 189 United States $391 \ldots \ldots \ldots \ldots \ldots \ldots 112$

v. Pacheco, 2 Wallace (United States) $587 \ldots \ldots \ldots \ldots \ldots \ldots 104$

v. Schurz, 102 United States $378 \ldots \ldots \ldots \ldots \ldots \ldots \ldots \ldots \ldots . \ldots 297$

Tnited States Investment Co. v. Ulrickson, 84 Minnesota 14..... 321

Cnited States v. Sliney (United States), 21 Federal $894 \ldots \ldots \ldots \ldots 430$

Epington v. Corrigan, $151 \mathrm{New}$ York $143 \ldots \ldots \ldots \ldots \ldots \ldots \ldots 171$

Lipton v. Archer, 41 California $85 \ldots \ldots \ldots \ldots \ldots \ldots \ldots \ldots \ldots \ldots$

จ. Coxen, 60 Kansas $1 \ldots \ldots \ldots \ldots \ldots \ldots \ldots \ldots \ldots \ldots . \ldots . \ldots . \ldots 2$

Valter $\nabla$. Blavka, 195 Illinois $610 \ldots \ldots \ldots \ldots \ldots \ldots \ldots \ldots \ldots \ldots . \ldots 298$

Van Baalen v. Cotney, 113 Michigan $202 \ldots \ldots \ldots \ldots \ldots \ldots \ldots \ldots . . \ldots 30$

Vance v. Funk, 3 Illinois $263 \ldots \ldots \ldots \ldots \ldots \ldots \ldots \ldots \ldots \ldots . \ldots . \ldots . \ldots 247$

v. Hill, 26 South Carolina $227 . \ldots \ldots \ldots \ldots \ldots \ldots \ldots \ldots \ldots . \ldots . \ldots 38$

v. Vance, 103 United States $514 \ldots \ldots \ldots \ldots \ldots \ldots \ldots \ldots \ldots . \ldots 38$

Van Dyke v. Grigsby, 11 South Dakota 30................ 306

Van Etten v. Newton, 134 New York $143 \ldots \ldots \ldots \ldots \ldots \ldots \ldots . \ldots 3$

Van Keuren $\nabla$. Railroad, 38 New Jersey Law $165 \ldots \ldots \ldots \ldots \ldots .431$

Van Ormer v. Harley, 102 Iowa $150 \ldots \ldots \ldots \ldots \ldots \ldots \ldots \ldots \ldots . \ldots \ldots$

Van Wagner $v$. Van Nostrand, 19 Iowa $422 \ldots \ldots \ldots \ldots \ldots 204,206,212$

Velten $\nabla$. Carmack, 23 Oregon $282 \ldots \ldots \ldots \ldots \ldots \ldots \ldots \ldots \ldots \ldots . \ldots \ldots$

Venable v. Wabash R. Co., 112 Missouri $103 \ldots \ldots \ldots \ldots \ldots \ldots \ldots . \ldots 372$

Vestal v. Garrett, 197 Illinois $398 \ldots \ldots \ldots \ldots \ldots \ldots \ldots \ldots \ldots \ldots . \quad 85$

Village of. See name of village.

Virginia-Tennessee Coal Co. v. McClelland, 98 Virginia 424

$389,392,395$

Virginia Coal Co. $\nabla$. Kelly, 93 Virginia $332 \ldots \ldots \ldots \ldots \ldots \ldots \ldots . \ldots 148$

Visalia Gas \&c. Co. $\nabla$. Sims, 104 California 326.............. 407

Vogel $\nabla$. Lehritter, 139 New York $223 \ldots \ldots \ldots \ldots \ldots \ldots \ldots .6$

Wachendorf $\nabla$. Lancaster, 66 Iowa $458 \ldots \ldots \ldots \ldots \ldots \ldots \ldots . . \ldots 204$

Wadsworth $\nabla$. Murray, 161 New York $274 \ldots \ldots \ldots \ldots \ldots \ldots . . \ldots 1$

Wager $\nabla$. Wagoner, 53 Nebrakka $511 \ldots \ldots \ldots \ldots \ldots \ldots \ldots . \ldots . \ldots . \ldots 44,346$ 


\section{[References are to Sections.]}

Wait v. Baldwin, 60 Michigan $622 \ldots \ldots \ldots \ldots \ldots \ldots \ldots \ldots \ldots . \ldots \ldots$

v. Maxwell, 5 Pickering (Massachusetts) 217............. 332

Wakefield $\nabla$. Van Tassell, 202 Illinois $41 \ldots \ldots \ldots \ldots \ldots \ldots \ldots . \ldots . \ldots 2$

Wales v. Coffin, 13 Allen (Massachusetts) $213 \ldots \ldots \ldots \ldots \ldots \ldots 166$

Wall v. Mines, 130 California $27 \ldots \ldots \ldots \ldots \ldots \ldots \ldots \ldots \ldots .46$

v. Wall, 126 North Carolina $405 \ldots \ldots \ldots \ldots \ldots \ldots \ldots \ldots \ldots . \ldots \ldots$

Wallace v. Berdell, 97 New York $13 \ldots \ldots \ldots \ldots \ldots \ldots \ldots \ldots \ldots . \ldots 298$

v. Insurance Co., 54 Kansas $442 \ldots \ldots \ldots \ldots \ldots \ldots \ldots \ldots \ldots . \ldots \ldots \ldots$

v. McCullough, 1 Richardson Equity (South Carolina) 426 .... 238

Walling v. Christian \&c. Co., 41 Florida $479 \ldots \ldots \ldots \ldots \ldots \ldots \ldots 363$

Walsh v. Barton, 24 Ohio State $28 \ldots \ldots \ldots \ldots \ldots \ldots \ldots \ldots \ldots . \ldots 407$

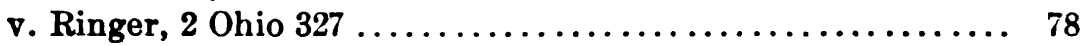

Walton $\nabla$. Follansbee, 131 Illinois $147 \ldots \ldots \ldots \ldots \ldots \ldots \ldots \ldots . \ldots . \ldots 188$

v. Gaines, 94 Tennessee $420 \ldots \ldots \ldots \ldots \ldots \ldots \ldots \ldots . . . . .313,319$

Walz v. Walz, 101 Michigan $167 \ldots \ldots \ldots \ldots \ldots \ldots \ldots \ldots \ldots \ldots . \ldots \ldots$

Wambole v. Foote, 2 Dakota $1 \ldots \ldots \ldots \ldots \ldots \ldots \ldots \ldots \ldots \ldots \ldots \ldots$

Warbritton v. Demorett, 129 Indiana $346 \ldots \ldots \ldots \ldots \ldots \ldots \ldots \ldots . \ldots 9$

Ward v. Anderson, 111 North Carolina $115 \ldots \ldots \ldots \ldots \ldots \ldots \ldots . . . . . . .22$

v. Dougherty, 75 California $240 \ldots \ldots \ldots \ldots \ldots \ldots \ldots \ldots \ldots . \ldots \ldots$

v. Edge, 100 Kentucky $757 \ldots \ldots \ldots \ldots \ldots \ldots \ldots \ldots \ldots \ldots \ldots . \ldots 19$

Ward v. Ward, 40 West Virginia $611 \ldots \ldots \ldots \ldots \ldots \ldots \ldots \ldots . \ldots \ldots$

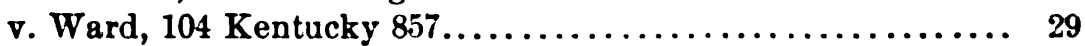

Warfield v. Lindell, 38 Missouri $581 \ldots \ldots \ldots \ldots \ldots \ldots \ldots \ldots \ldots . \ldots \ldots$

v. Wurfield, 76 Iowa $633 \ldots \ldots \ldots \ldots \ldots \ldots \ldots \ldots \ldots \ldots \ldots$

Warner $v$. Peck, 11 Rhode Island $431 . \ldots \ldots \ldots \ldots \ldots \ldots \ldots \ldots . . \ldots 364$

Warthen $\nabla$. Siefert, 139 Indiana $233 \ldots \ldots \ldots \ldots \ldots \ldots \ldots \ldots \ldots . \ldots \ldots$

Washburn v. Burns, 34 New Jersey Law $18 \ldots \ldots \ldots \ldots \ldots \ldots \ldots \ldots$

Washington Ice Co. $\nabla$. Shortall, 101 Illinois 46.............. 107

Washougal \&c. Transportation Co. $\nabla$. Dalles \&c. Navigation Co., 27

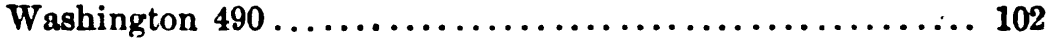

Watkins v. Youll (Nebraska), 96 Northwestern 1042........... 399

Watson v. Billings, 38 Arkansas 278.................... 320

v. Muirhead, 57 Pennsylvania State $167 \ldots \ldots \ldots \ldots \ldots \ldots \ldots, 2$

v. Peters, 26 Michigan 508........................... 99

Watts $\nabla$. Parker, 27 Illinois $228 \ldots \ldots \ldots \ldots \ldots \ldots \ldots \ldots \ldots \ldots . \ldots . \ldots 198$

Watuppa Reservoir Co. v. Fall River, 147 Massachusetts 548 ..... 111

Waverly \&c. Improvement Co. $v$. White, 97 Virginia $176 \ldots \ldots \ldots .98$

Wea Gas, Coal \&c. Co. v. Franklin Land Co., 54 Kansas 533 ...... 395

Webb v. Demopolis, 95 Alabama $116 \ldots \ldots \ldots \ldots \ldots \ldots \ldots \ldots \ldots . \ldots . \ldots$

v. Holt, 113 Michigan $338 \ldots \ldots \ldots \ldots \ldots \ldots \ldots \ldots \ldots \ldots \ldots . \ldots . \ldots . \ldots . \ldots$

v. Mullins, 78 Alabama $111 \ldots \ldots \ldots \ldots \ldots \ldots \ldots \ldots \ldots \ldots .71$

Webber v. Pere Marquette Boom Co., 62 Michigan 626......... 116

Weber v. Christen, 121 Illinois $91 \ldots \ldots \ldots \ldots \ldots \ldots \ldots \ldots \ldots \ldots . \ldots \ldots \ldots$

v. Tanner (Kentucky), 64 Southwestern $741 \ldots \ldots \ldots \ldots 363,364$

Webster v. Harris (Tennessee), 69 Southwestern $782 \ldots \ldots \ldots \ldots 116$

v. Warner, 119 Michigan $461 \ldots \ldots \ldots \ldots \ldots \ldots \ldots \ldots \ldots . \ldots . \ldots 2$

Weeks v. Bridgman, 159 United States $541 \ldots \ldots \ldots \ldots \ldots \ldots . \ldots 312$ 
[References are to Sections.]

Weihl . Robertson, 97 Tennessee $458 \ldots \ldots \ldots \ldots \ldots \ldots \ldots \ldots, 43$

Weiss v. Binnian, 178 Illinois $241 \ldots \ldots \ldots \ldots \ldots \ldots \ldots \ldots \ldots \ldots . \ldots \ldots$

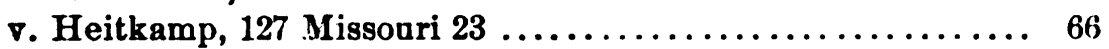

Weitzner $\nabla$. Thingstad, 55 Minnesota 244................ 396

Welbon $\nabla$. Welbon, 109 Michigan $356 \ldots \ldots \ldots \ldots \ldots \ldots \ldots \ldots . \ldots 208$

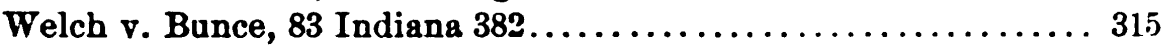

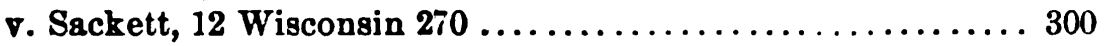

v. Welch, 183 Illinois $237 \ldots \ldots \ldots \ldots \ldots \ldots \ldots \ldots \ldots \ldots$

Weld v. Johnson Manufacturing Co., 84 Wisconsin $537 \ldots \ldots \ldots . .328$

Welles v. Bailey, 55 Connecticut $292 \ldots \ldots \ldots \ldots \ldots \ldots \ldots \ldots \ldots 110$

Wellman v. Churchill, 92 Maine $193 \ldots \ldots \ldots \ldots \ldots \ldots \ldots \ldots \ldots . \ldots \ldots$

Welle v. Caywood, 3 Colorado $487 \ldots \ldots \ldots \ldots \ldots \ldots \ldots \ldots \ldots \ldots . \ldots \ldots \ldots$

v. Estes, 154 Missouri $291 \ldots \ldots \ldots \ldots \ldots \ldots \ldots \ldots \ldots \ldots \ldots . \ldots \ldots$

$\nabla$. Tolman, 156 New York $636 \ldots \ldots \ldots \ldots \ldots \ldots \ldots \ldots \ldots . \ldots \ldots$

Wescott $\nabla$. Binford, 104 Iowa $645 \ldots \ldots \ldots \ldots \ldots \ldots \ldots \ldots \ldots . \ldots \ldots$

West $\nabla$. Bretelle, 115 Missouri $653 \ldots \ldots \ldots \ldots \ldots \ldots \ldots \ldots \ldots . \ldots \ldots$

จ. Fitz, 109 Illinois $425 \ldots \ldots \ldots \ldots \ldots \ldots \ldots \ldots \ldots \ldots \ldots \ldots, 137$

จ. Wright, 115 Georgia $277 . \ldots \ldots \ldots \ldots \ldots \ldots \ldots \ldots \ldots .29$

West Side Auction Co. v. Connecticut Mutual Life Insurance Co.,

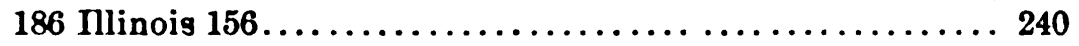

West Virginia Transportation Co. v. Pipe Line Co., 22 West Vir-

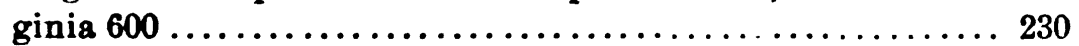

Wetmore v. Bruce, 118 New York $319 \ldots \ldots \ldots \ldots \ldots \ldots \ldots . \ldots 201,223$

Wetzell v. Richcreek, 53 Ohio State 62.................. 198

Wheeler v. Laird, 147 Massachusetts $421 \ldots \ldots \ldots \ldots \ldots \ldots \ldots \ldots .17$

v. Wayne Co., 132 Illinois $599 \ldots \ldots \ldots \ldots \ldots \ldots \ldots 206,211,212$

Wheelock v. Cavitt, 91 Texas $679 \ldots \ldots \ldots \ldots \ldots \ldots \ldots \ldots \ldots . \ldots . \ldots . \ldots 293$

Whitaker $\nabla$. Brown, 46 Pennsylvania State $197 \ldots \ldots \ldots \ldots \ldots \ldots . \ldots 123$

7. Miller, 83 Illinois $381 \ldots \ldots \ldots \ldots \ldots \ldots \ldots \ldots \ldots \ldots \ldots, 38$

White v. Brocaw, 14 Ohio State 339 ..................... 207

v. Foster, 102 Massachusetts $375 \ldots \ldots \ldots \ldots \ldots \ldots \ldots \ldots \ldots .49$

v. Howard, 38 Connecticut $342 \ldots \ldots \ldots \ldots \ldots \ldots \ldots \ldots \ldots, 7$

v. Howard, 46 New York $144 \ldots \ldots \ldots \ldots \ldots \ldots \ldots \ldots \ldots, 7$

จ. Luning, 93 United States $514 \ldots \ldots \ldots \ldots \ldots \ldots \ldots \ldots \ldots .87$

v. New York \&c. R. Co., 156 Massachusetts $181 \ldots \ldots \ldots \ldots \ldots 121$

v. Wager, $25 \mathrm{New}$ York $328 \ldots \ldots \ldots \ldots \ldots \ldots \ldots \ldots \ldots . \ldots \ldots$

White Sewing Machine Co. v. Wooster, 66 Arkansas $382 \ldots \ldots \ldots .400$

White's Charities, In re, 1 Chancery Division 659........... 99

Whitehead v. Ragan, 106 Missouri $231 \ldots \ldots \ldots \ldots \ldots \ldots \ldots \ldots . \ldots 6$

Whiteman v. Field, 53 Vermont $554 \ldots \ldots \ldots \ldots \ldots \ldots \ldots \ldots \ldots . \ldots \ldots 7$

Whitlock, In re, 19 Howard's Practice (New York) $380 \ldots \ldots \ldots . . .326$

v. Gosson, 35 Nebraska 829.....................392, 393

Whitney $\nabla$. Closson, 138 Massachusetts $49 \ldots \ldots \ldots \ldots \ldots \ldots \ldots . \ldots \ldots$

v. Detroit Lumber Co., 78 Wisconsin $240 \ldots \ldots \ldots \ldots \ldots \ldots .103$

จ. Fitchburg R. Co., 178 Massachusetts 559.............. 119

v. Union R. Co., 11 Gray (Massachusetts) 359.........49, 228

Whitsett $\nabla$. Wamack, 159 Missouri 14................... 160 


\section{[References are to Sections.]}

Whittemore v. Farrington, 76 New York $452 \ldots \ldots \ldots \ldots \ldots \ldots 188$

Whittlesey v. Fuller, 11 Connecticut $337 \ldots \ldots \ldots \ldots \ldots \ldots \ldots 1,163$

Wicks v. Dean, 103 Kentucky $69 \ldots \ldots \ldots \ldots \ldots \ldots \ldots \ldots \ldots . \ldots . \ldots 369$

Wieland v. Kobick, 110 Illinois $16 \ldots \ldots \ldots \ldots \ldots \ldots \ldots \ldots . . \ldots 4,320$

Wilber v. Wilber, 52 Wisconsin $298 \ldots \ldots \ldots \ldots \ldots \ldots \ldots \ldots . \ldots 375$

Wiley $v$. Lovely, 46 Michigan $83 \ldots \ldots \ldots \ldots \ldots \ldots \ldots \ldots . \ldots . \ldots . \ldots 3$

Wilhelm v. Wilken, 149 New York $447 \ldots \ldots \ldots \ldots \ldots \ldots \ldots . \ldots \ldots$

Wilkesbarre v. Society, 134 Pennsylvania State $616 \ldots \ldots \ldots \ldots \ldots 137$

Wilkins v. Bevier, 43 Minnesota $213 \ldots \ldots \ldots \ldots \ldots \ldots \ldots \ldots \ldots .430$

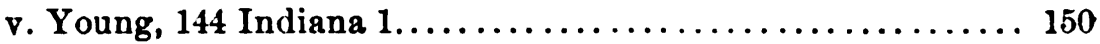

Wilkinson v. Elliott, 43 Kansas $590 \ldots \ldots \ldots \ldots \ldots \ldots \ldots \ldots \ldots . \ldots \ldots$

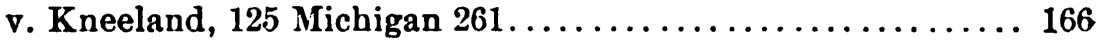

v. Scott, 17 Massachusetts $249 \ldots \ldots \ldots \ldots \ldots \ldots \ldots \ldots \ldots \ldots .59$

Will of. See name of party.

Willard v. Cramer, 36 Iowa 22 ....................... 291

Williams v. Burrell, 1 Common Bench 402................ 211

v. Daubner, 103 Wisconsin $521 \ldots \ldots \ldots \ldots \ldots \ldots \ldots \ldots \ldots . \ldots . \ldots . \ldots$

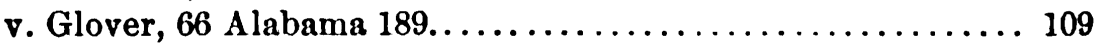

จ. Paine, 169 United States $55 \ldots \ldots \ldots \ldots \ldots \ldots \ldots \ldots 28,239,377$

v. Sapieha, 94 Texas $430 \ldots \ldots \ldots \ldots \ldots \ldots \ldots \ldots \ldots \ldots \ldots \ldots$

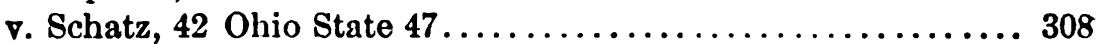

v. Shackleford, 97 Missouri $322 \ldots \ldots \ldots \ldots \ldots \ldots \ldots \ldots \ldots . \ldots 14$

v. Spitzer, 203 Illinois $505 \ldots \ldots \ldots \ldots \ldots \ldots \ldots \ldots \ldots \ldots \ldots . \ldots \ldots$

v. Wetherbee, 1 Aiken (Vermont) $233 \ldots \ldots \ldots \ldots \ldots \ldots \ldots, 206$

Williamsburg Boom Co. v. Smith, 84 Kentucky 372.........98, 101

Williamson v. Branning, 86 Hun (New York) $203 \ldots \ldots \ldots \ldots \ldots 276$

v. Carskadden, 36 Ohio State $664 \ldots \ldots \ldots \ldots \ldots \ldots \ldots \ldots .293$

Willow River Club v. Wade, 100 Wisconsin $86 \ldots \ldots .106,107,108,110$

Willingham v. King, 23 Florida $478 \ldots \ldots \ldots \ldots \ldots \ldots \ldots \ldots .414$

Willwerth v. Leonard, 156 Massachusetts $277 \ldots \ldots \ldots \ldots \ldots \ldots . \ldots 33$

Wilmans v. Robinson, 67 Arkansas $517 \ldots \ldots \ldots \ldots \ldots \ldots \ldots 143,146$

Wilmurt v. McGrane, 16 New York Appellate Division 412...... 224

Wilson v. Alston, 122 Alabama $630 \ldots \ldots \ldots \ldots \ldots \ldots \ldots \ldots \ldots 147$

v. Campbell, 119 Indiana $286 \ldots \ldots \ldots \ldots \ldots \ldots \ldots \ldots \ldots, 17$

v. Griess, 64 Nebraska $792 \ldots \ldots \ldots \ldots \ldots \ldots \ldots \ldots \ldots \ldots .285$

v. Hildreth, 118 Massachusetts $578 \ldots \ldots \ldots \ldots \ldots \ldots \ldots .92$

v. Leary, 120 North Carolina $90 \ldots \ldots \ldots \ldots \ldots \ldots \ldots \ldots \ldots . \ldots 402$

v. Peelle, 78 Indiana $384 \ldots \ldots \ldots \ldots \ldots \ldots \ldots \ldots \ldots \ldots \ldots$

v. Randall, 67 New York $338 \ldots \ldots \ldots \ldots \ldots \ldots \ldots \ldots \ldots, 92$

$\nabla$. Terry, 130 Michigan $73 . \ldots \ldots \ldots \ldots \ldots \ldots \ldots \ldots \ldots \ldots . \ldots \ldots \ldots$

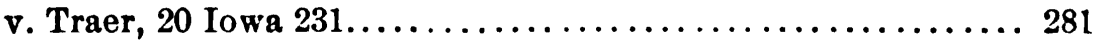

v. White, 84 California $239 \ldots \ldots \ldots \ldots \ldots \ldots \ldots \ldots \ldots \ldots .43$

v. Widenham, 51 Maine $567 \ldots \ldots \ldots \ldots \ldots \ldots \ldots \ldots \ldots \ldots \ldots$

v. Wilson, 158 Illinois $567 \ldots \ldots \ldots \ldots \ldots \ldots \ldots \ldots \ldots \ldots \ldots . \ldots \ldots$

v. Wilson, 43 Minnesota $398 \ldots \ldots \ldots \ldots \ldots \ldots \ldots \ldots \ldots \ldots \ldots \ldots$

v. Wilson, 6 Idaho $597 \ldots \ldots \ldots \ldots \ldots \ldots \ldots \ldots \ldots 167,365,367$

Windsor $\nabla$. Collinson, 32 Oregon $297 \ldots \ldots \ldots \ldots \ldots \ldots \ldots .68$ 
Winscomb \& Dunches Case, Godbolt $270 \ldots \ldots \ldots \ldots \ldots \ldots \ldots \ldots . \ldots \ldots 7$

Windstandley v. Stipp, 132 Indiana $548 \ldots \ldots \ldots \ldots \ldots \ldots \ldots . \ldots 18$

Winsted Bank v. Spencer, 26 Connecticut $195 \ldots \ldots \ldots \ldots \ldots \ldots . \ldots 251$

Winston v. Hodges, 102 Alabama $304 \ldots \ldots \ldots \ldots \ldots \ldots \ldots \ldots . . \ldots 235$

Winter $\nabla$. Stock, 29 California $407 \ldots \ldots \ldots \ldots \ldots \ldots \ldots \ldots \ldots \ldots . \ldots \ldots$

Winterbottom $\nabla$. Patterson, 152 Illinois $334 \ldots \ldots \ldots \ldots \ldots \ldots \ldots . \ldots 1$

Wolf $\mathbf{v}$. Brass, $\mathbf{7 2}$ Texas $133 \ldots \ldots \ldots \ldots \ldots \ldots \ldots \ldots \ldots \ldots . \ldots \ldots$

v. Holton, 104 Michigan $107 \ldots \ldots \ldots \ldots \ldots \ldots \ldots \ldots \ldots 44,324$

Wolfe v. Sullivan, 133 Indiana $331 \ldots \ldots \ldots \ldots \ldots \ldots \ldots \ldots \ldots . \ldots \ldots$

Wood v. Bach, 54 Barbour (New York) $134 \ldots \ldots \ldots \ldots \ldots \ldots . . \ldots 27 ?$

v. Fleet, 36 New York $499 \ldots \ldots \ldots \ldots \ldots \ldots \ldots \ldots \ldots \ldots \ldots$

v. Fowler, 26 Kansas $682 \ldots \ldots \ldots \ldots \ldots \ldots \ldots \ldots \ldots \ldots \ldots . \ldots \ldots$

v. Goodridge, 6 Cushing (Massachusetts) $117 \ldots \ldots \ldots \ldots \ldots . \ldots 239$

v. Leadbitter, 13 Meeson and Welsby $838 \ldots \ldots \ldots \ldots \ldots \ldots 242$

v. Wood, 83 New York 575....................257, 352

Woodbury v. Fisher, 20 Indiana $387 \ldots \ldots \ldots \ldots \ldots \ldots \ldots \ldots . \ldots . \ldots 2$

Woodhull v. Longstreet, 18 New Jersey Law $405 \ldots \ldots \ldots \ldots \ldots \ldots 161$

Woodruff $\nabla$. Woodruff, 44 New Jersey Law $349 \ldots \ldots \ldots \ldots \ldots \ldots 24$

Woods $\nabla$. James, 87 Kentucky $511 \ldots \ldots \ldots \ldots \ldots \ldots \ldots \ldots \ldots .266$

Woolley v. Gaines, 114 Georgia $122 . \ldots \ldots \ldots \ldots \ldots \ldots \ldots \ldots \ldots . \ldots . \ldots 33$

Workman's Mutual Aid Association v. Monroe (Texas), 53 Southwestern $1029 \ldots \ldots \ldots \ldots \ldots \ldots \ldots \ldots \ldots \ldots \ldots \ldots . \ldots . \ldots . \ldots 285$

Worley $\nabla$. Hineman, 6 Indiana Appellate $240 \ldots \ldots \ldots \ldots \ldots \ldots 218$

Worrell $\nabla$. Drake (Tennessee), 75 Southwestern 1015 ......... 371

Worthington $\nabla$. Middleton, 6 Dana (Kentucky) $300 \ldots \ldots \ldots \ldots .376$

v. Staunton, 16 West Virginia $209 \ldots \ldots \ldots \ldots \ldots \ldots \ldots \ldots \ldots \ldots$

Wright v. DeGroff, 14 Michigan $164 \ldots \ldots \ldots \ldots \ldots \ldots \ldots \ldots \ldots \ldots \ldots$

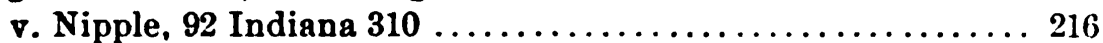

v. Whittock, 18 Colorado $54 \ldots \ldots \ldots \ldots \ldots \ldots \ldots \ldots \ldots . \ldots . \ldots . \ldots 38$

Wronkow v. Oakley, 133 New York 505 .................. 377

Wunderle $\nabla$. Wunderle, 144 Illinois $40 \ldots \ldots \ldots \ldots \ldots \ldots \ldots . \ldots, 408$

Wynn $\mathbf{v}$. Wynn, 112 Georgia $214 \ldots \ldots \ldots \ldots \ldots \ldots \ldots \ldots \ldots .29$

Wysong v. Nealis, 13 Indiana Appellate 165............... 216

Yates v. Van De Bogert, 56 New York 526............... 407

Young v. Cosgrove, 83 Iowa $682 \ldots \ldots \ldots \ldots \ldots \ldots \ldots \ldots \ldots . . \ldots 3$

v. Edwards, 33 South Carolina $404 \ldots \ldots \ldots \ldots \ldots \ldots \ldots \ldots \ldots \ldots \ldots$

v. Lohr, 118 Iowa $624 \ldots \ldots \ldots \ldots \ldots \ldots \ldots \ldots \ldots \ldots \ldots .425$

v. McKee, 13 Michigan $552 \ldots \ldots \ldots \ldots \ldots \ldots \ldots \ldots \ldots \ldots . \ldots \ldots 21$

v. Overbaugh, $145 \mathrm{New}$ York $158 \ldots \ldots \ldots \ldots \ldots \ldots \ldots \ldots \ldots \ldots \ldots$

v. Shulenberg, 165 New York $385 \ldots \ldots \ldots \ldots \ldots \ldots \ldots \ldots .44$

Zann v. Haller, 71 Indiana $136 \ldots \ldots \ldots \ldots \ldots \ldots \ldots \ldots \ldots \ldots \ldots$

Zent v. Picken, 54 Iowa $535 \ldots \ldots \ldots \ldots \ldots \ldots \ldots \ldots \ldots \ldots . \ldots \ldots . \ldots \ldots \ldots$

Zimpelman $\nabla$. Robb, 53 Texas 274..................... 167

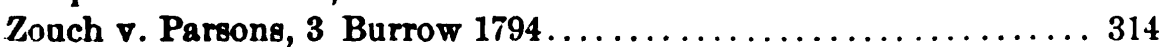




\section{THE CONVEYANCE OF ESTATES IN FEE BY DEED}




\section{CHAPTER I.}

\section{INTRODUCTORY.}

61. Alienation in general-Inter vivos and by will.

2. Conveyancing $-W$ hat the term implies.

3. Controlling effect of lex situs - Power of states as to real property.

4. Power of the United StatesEffect of treaties on state laws.
85. Application of the doctrine that lex situs controls-Its reason.

6. Illustrations - Formal matters.

7. Illustrations-Capacity.

8. Illustrations - Construction and effect of instruments.

9. Statutes adopting foreign law -Not exceptions to rule.

10. Limitations to the application of the rule.

\$1. Alienation in general-Inter vivos and by will.One entitled to rights in land may, by his voluntary act, alienate them, or transfer them to another, in one of two modes : his alienation may be inter vivos or it may be by will.

Of these modes the former is more often used in the practical affairs of life than the latter, and it is that mode to which the following pages are devoted.

Alienation inter vivos is now generally accomplished by a deed of conveyance, and it is proposed to consider the essential features of the deed.

A will of lands is regarded as a conveyance operating upon the death of the testator, but a will and a deed are made under different circumstances, and, moreover, the rules as to the interpretation of the two classes of instruments differ in many respects. It is intended, therefore, to refer but incidentally to the law of wills. 
Owners of interests in lands have not always had the power of transferring their interests, either inter vivos or by will, ${ }^{1}$ but at the present time, speaking generally, the owner of the fee has the absolute right of alienation.

In order, however, that the alienation may be effectual the persons from whom and to whom the particular interest is intended to be transferred must be capable in law of transferring it on the one hand and, on the other, of taking and keeping it; the object or purpose of the transfer must be valid in law; and the manner of alienation prescribed by law must be observed.

Restraints upon the right of alienation-arising either from the personal incapacity of the parties to the transfer or from the nature of the particular interest intended to be transferred, or from the purpose or object of the transfer-are exceptions to the general doctrine that permits alienation, and will therefore be considered after the deed has been discussed.

§2. Conveyancing-What the term implies.-The term conveyancing, used in a broad sense, includes, it is true, much more than an examination of the subject of deeds. Deeds of conveyance and devises are not the only written instruments affecting interest in lands, as an estate for years, for example, is generally created by a "lease," and a "mortgage" in some states conveys the legal title to the mortgagee.

Moreover, rights in land may be acquired without any written instrument to show what they are; for not only does an estate in fee simple, if undisposed of by its owner, descend at his death to his heirs, but valuable interests may be gained by prescription, and an estate in fee simple may be acquired by adverse possession.

One properly performing the functions of a convey-

${ }^{1}$ See Digby Hist. L. Real Prop., 5th ed., pp. 100, 133, 157, 376; Pollock and Maitland Hist. Eng. Law, 2d ed., I, pp. 329 et seq., II, p. 315. 
ancer should, therefore, have "an acquaintance with the general principles of the law of real property and a large amount of practical knowledge, which can only be derived from experience", ${ }^{2}$ for in his work is included not merely the drafting of many different documents intended to affect interests in real property, but an inquiry into the legal effect of acts and events which in the past have concerned the property.

However, almost innumerable decisions relating to title indicate ignorance and carelessness on the part of those actually acting as conveyancers, and irrespective of decisions, it is well known that the task of examining titles and the drafting and interpretation of instruments affecting them are too often left to those wholly unfitted by study and training for such work.

While the full duty of the conveyancer is not attempted to be set forth in this volume, it will probably be found to be true that a study of the principles involved in the preparation and interpretation of deeds will include a consideration of most of his important functions.

§ 3. Controlling effẻct of lex situs-Power of states as to real property.-One principle of practical importance may not inappropriately be referred to at this point. It is a well settled general rule of law that all questions relating to the transfer of title to real property are governed by the law of the place where the property is situatedlex loci rei sitæ or lex situs.

It is especially important for the American lawyer to keep this principle in mind because he must in practice frequently consider questions as to the title to real property in states other than his own, and each state is as to every other state sovereign in its power to regulate the acquisition and transfer of real property within its limits. While the law of one state upon these subjects may resemble in some particulars the laws of other states much

2 Justice Sharswood in Watson v. Muirhead, $57 \mathrm{~Pa} .167$. 
diversity in other respects exists, the general result being that the real property laws of no two states are identical.

§ 4. Power of the United States-Effect of treaties on state laws.-Moreover, as to most matters relating to such property the federal government has no power of regulation.

The courts of the United States will generally respect and follow the law of the state where the property is as that law exists in the statutes and decisions of the state. ${ }^{3}$

The federal and state courts sometimes disagree as to what the law of the state is," but such instances do not affect the general principle that the federal courts will apply the state law, when it is clear what that law is.

There should, however, be noted in this connection the provision of the constitution of the United States that " all treaties made, or which shall be made, under the authority of the United States, shall be the supreme law of the land." 5

The protection which should be afforded to the citizens of foreign countries who may acquire property in this country is a proper subject for regulation by treaty, ${ }^{6}$ and the statutes of any state as to the property rights of aliens, therefore, must be construed with reference to a treaty, should there be one touching the matter, between the United States and the government of the alien. The law of the place where the land is, still governs in such a case, because the treaty is the law and may abrogate or amend, as the case may be, the

' Gormley v. Clark, 134 U. 8. 338, 348; Brine v. Insurance Co., 96 U. S. 627.

- As illustrating such disagreement compare the case of Hardin v. Jordan, 140 U. S. 371, 380, 384, with that of Fuller v. Shedd, 1896, 161 Ill. 462,$490 ; 44$ N. E. 286 ; 52 Am. St. R. 380 , which are discussed in $\$ 114$, post.

Art. VI, § 2.

- Geofroy v. Riggs, 133 U. S. 258, 266. 
statute of the state; allowing it, however, to remain in force as to other cases not affected by treaty.

\$. Application of the doctrine that lex situs controls -Its reason.-This principle, that the law of the place of the real property controls, applies, generally speaking, to the different kinds of instruments conveying or affecting title, that is, deeds, mortgages, wills, etc.; it applies to matters of form; to matters relating to the capacity of the person from whom the title proceeds and to the capacity of the person taking title, as well as, generally, to questions relating to the construction or interpretation of the instrument.

The reason for the doctrine is to be found in the fact that from the very nature of the subject-matter, which is immovable and fixed permanently at a particular place, no other rules of law than those of that place can ultimately control the disposition of the property. For no court of one country or state could enforce its judgments, rendered in accordance with its own laws, relating to the title to real property in another independent country or state. $^{8}$

\$6. Illustrations-Formal matters.-(a) Formal matters.-If by the law of the place where the land lies "no estate of freehold can be conveyed, unless by a deed or conveyance under the hand and seal" of the party

7 Hauenstein v. Lynham, 100 U. S. 483. The doctrine of the supremacy of treaties over state laws is stated broadly as it appears to be lail down by the supreme court of the United States. The government through the treaty-making power seems able to do indirectly what it could not do directly by an act of congress. The consideration of treaties as affecting title to land arises most frequently in cases of descent, and state courts admit the supremacy of the treaty over state laws: Scharpf v. Schmidt, 1898, 172 Ill. 255; 50 N. E. 182; Adams v. tkerlund, 1897, 168 Ill. 632 ; 48 N. E. 454; Doehrel v. Hillmer, 1897, 102 Iowa, 169; 71 N. W. 204; Succession of Sala, 1898, 50 La. Ann. 1009 ; 24 So. 674.

See Minor, Conflict of Lawe, pp. 28, 29. 
conveying, and an instrument is executed in another jurisdiction, the residence of both grantor and grantee, without a seal, sufficient, where executed, to pass real estate there, it is not a good conveyance of the land in question; ${ }^{9}$ or if the law of the place where the land is requires a deed for the conveyance of land to be executed in the presence of two witnesses, a deed executed in the presence of one only is void. ${ }^{10}$ So, a will executed in one state and valid there, may be invalid as a will devising real estate in another, and its probate in the former state does not establish its validity in the latter state unless the laws of the latter permit it; and the same is, of course, true of a will executed in a foreign country. ${ }^{11}$

$\S$ 7. Illustrations-Capacity.-(b) Capacity of those from whom and to whom title passes.-A will executed by a married woman in Kentucky, where a married woman was (at that time) incompetent to make a valid will devis. ing real property, is, nevertheless, held valid in Tennessee as to such property there, the formalities required by the Tennessee statutes having been observed..$^{12}$ And though in most states a mortgage is not, strictly speaking, a conveyance, the capacity of a mortgagor of real property to make the mortgage in question will be determined, generally, by the law of the place where the mortgaged premises are situated, rather than by the law of the domicil of the mortgagor, should that differ from the former. Hence, though by the law of her domicil a married woman is incompetent to make a valid mortgage of land situated there, her mortgage of land in another

- United States v. Crosby, 7 Cranch 115.

${ }^{10}$ Clark v. Graham, 6 Wheat. 577.

" Robertson v. Pickrell, 109 U. S. 608; Vogel v. Lohritter, 1893, 139 N. Y. $223 ; 34$ N. E. 914.

12 Carpenter v. Bell, 96 Tenn. 294 ; 34 S. W. 209. 
state where married women are competent, will be held valid, though executed at her domicil. ${ }^{13}$

And, in general, the capacity of one to take title as grantee, devisee or heir, is determined by the same principle. For example, one Fox died possessed of real and personal property situated in New York, having by his will devised and bequeathed all his property to the government of the United States. His heirs contested the will and the state courts held ${ }^{14}$ that the United States could take the personal property, but could not take the real property, because the New York statute of wills provided that a devise of lands may be made "to any person capable by law of holding real estate; but no devise to a corporation shall be valid unless such corporation be expressly authorized by its charter or by statute to take by devise".

The supreme court of the United States, in affirming the decrees of the New York courts, stated the principle that each state has power to regulate the tenure of real property within its limits, the modes of its acquisition and transfer, the rules of descent and the extent to which testamentary disposition of it may be made, and held that "person" in the New York statute signified a natural person, or an artificial person deriving its existence from legislation ; that the United States is not such a "person",

23 Thomson v. Kyle, 1897, 39 Fla. 582 ; 23 So. 12 ; 63 Am. St. R. 193 ; Cochran v. Benton, 1890, 126 Ind. 58; 25 N. E. 870; Sell v. Miller, 11 Ohio St. 331 ; Post v. First Nat. Bank, 138 Ill. 559; 28 N. E. 978. In none of these cases does it appear that the mortgage was given to secure an obligation void where entered into and where it was to be performed. They seem, therefore, distinguishable from such a case as Evans v. Beaver, 1893, 50 Ohio St. $190 ; 33$ N. E. 643; 40 Am. St. R. $66 f$, in which the question was as to the validity of a mortgage of Ohio land, executed in Indiana by a married woman living there, to secure an obligation as surety to be performed in Indiana where such a contract is void: and it was held that the mortgage, being merely the eccurity for the performance of a void obligation, could not be enforced.

14 In the matter of will of Fox, 52 N. Y. 530. 
and that "corporation" applied only to such corporations as are created by the laws of the state. ${ }^{15}$

The government of the United States has capacity, however, to take real estate as devisee, when it lies in a state where no such restrictions as these exist; ${ }^{16}$ and a New York corporation, having power to hold land and whose charter contains no prohibition against taking by will, may take Connecticut lands as devisee, ${ }^{17}$ though it cannot take New York lands under the same will. ${ }^{18}$

So the law of the state where the land lies will determine who are the heirs of a deceased owner of the land, capable of inheriting it.

The laws of one state may provide, for example, that aliens, whether resident or non-resident, may take title by descent, ${ }^{19}$ while those of another may prevent non-resident aliens from inheriting (such laws being subject to existing treaties ). ${ }^{20}$

\$8. Illustrations-Construction and effect of instruments.-(c) Validity and effect determined by lex situs. -Whether, for example, the effect of a conveyance to a trustee is to vest the legal title in him or in the beneficiary, will depend on the construction of its provisions under the lex situs. ${ }^{21}$ So the question whether under a will there has been an "equitable conversion" into personalty of the testator's real estate situated in a state other than that of his domicil will be settled by the law of the state where the land is. This law may be very different from that of the testator's domicil, and the result of the

${ }^{15}$ United States v. Fox, 94 U. S. 315.

${ }^{16}$ Dickson v. United States, 125 Mass. 311.

${ }^{27}$ White v. Howard, 38 Conn. 342.

${ }^{18}$ White v. Howard, 46 N. Y. 144, 167.

${ }^{19}$ Blythe v. Hinckley, 1900, 127 Cal. 431 ; 59 Pac. 787 ; Lumb v. Jenkins, 100 Mass. 527.

${ }^{20}$ Wunderle v. Wunderle, 144 Ill. $40 ; 33$ N. E. $195 ; 19$ L. R. A. 84 ; Doehrel v. Hillmer, 102 Iowa 169; 71 N. W. 204.

21 McGoon v. Scales, 9 Wall. 23. 
application of the principle in such cases may be that the testator's real estate in one state will pass to persons other than those to whom his real estate in another will pass although all his property in different states is referred to in the same terms in his will. ${ }^{22}$ And the decision of a court of the testator's domicil that his will worked an equitable conversion into personalty of all realty wherever situated, is not conclusive on the courts of another state where part of the realty is. ${ }^{23}$

\$ 9. Statutes adopting foreign law-Not exceptions to rule.-There are statutes in many of the states that provide that instruments transferring or affecting real property within their limits, but executed beyond these limits, shall be valid for many purposes if they conform to, and are valid under, the law of the place where executed. Cases arising under such statutes are sometimes inaccurately considered as exceptions to the general rule that the law of the place where the land lies controls in such matters.

They are not, however, really exceptions to this rule, for the law of the place where the property is, by adopting the foreign law for the particular cases specified, makes that foreign law for the time being and under the particular circumstances its own law, and thus the principle still applies. The foreign law derives its efficacy in such cases not from the law-making power of the place of its creation, but from that of the place which adopts it for these special purposes. ${ }^{24}$

And if there be no such adopting law in the place where the real property is, the foreign law cannot have the effect there that it would have in the place of its origin. ${ }^{25}$

22 Hobson v. Hale, 95 N. Y. 588.

Clarke v. Clarke, 1899, 178 U. S. 186. The principle as applied to the construction of devises is well discussed in $41 \mathrm{Am}$. L. R. (N. S.), pp. $623,718$.

${ }^{34}$ Root v. Brotherson, 4 McLean 230 ; West v. Fitz, 109 Ill. 425, 443.

${ }_{25}^{25}$ Trowbridge v. Addoms, 1897, 23 Colo. 518, 522; 48 Pac. 535. 
$\$ 10$. Limitations to the application of the rule.But while the principle is of very extensive application, it does not necessarily follow that the law of the place of the realty will determine the validity for all purposes of every instrument which, though relating to real property, may create simply a personal liability, ${ }^{26}$ nor of every instrument through which title to real property may be ultimately obtained. Hence, the Massachusetts courts will enforce a covenant made in North Carolina by a husband with his wife to release and extinguish his rights in her land in Massachusetts, the contract being valid under the law of North Carolina where the parties lived, and being a personal covenant, though concerning Massachusetts land, and though it seems that the same contract if made in Massachusetts would have been invalid. ${ }^{27}$ So, while a mortgage of real estate is generally governed by the law of the state where the realty is, an assignment of the mortgage is often-regarded as a new contract passing a chattel interest, and its validity will not necessarily depend upon the law of the place where the property is, ${ }^{28}$ though that law may control as to the remedy and procedure when the assignee seeks to foreclose the assigned mortgage. ${ }^{29}$

26 See post, $\$ 213$.

27 Polson v. Stewart, 1897, 167 Mass. 211 ; 45 N. E. 737 ; 36 L. R. A. $771 ; 57$ Am. St. R. 452.

${ }^{28}$ Dundas v. Bowler, 3 McLean 397, 401; Hoyt v. Thompson, $19 \mathrm{~N}$. Y. 207, 224.

29 Dohm v. Haskin, 88 Mich. 144; 50 N. W. 108. 


\section{CHAPTER II.}

THE CHIEF METHODS OF VOLUNTARY ALIENATION OF LAND INTER VIVOS.

6 11. Formerly no writing necessary-The feoffment.

12. The bargain and sale-When deed necessary for.

13. The lease and release.

14. The feoffment-When a deed became necessary for.
$\$ 15$. Deeds used though not necessary.

16. Livery of seisin in the United States - Conveyance generally by deed.

17. How title may still pass inter vivos without writing.

18. Fines and recoveries.

\section{\$11. Formerly no writing necessary-The feoffment.-} Owing to repeated allusions in modern statutes and opinions to earlier law a brief view of former methods of transferring interests in real property will be found to be not only interesting, but of practical importance.

From the Norman Conquest, 1066, onward for a period of over four hundred and sixty years no writing of any kind was necessary for the legal transfer of a freehold estate in possession in corporeal hereditaments.

Such transfer was accomplished generally by "the most valuable of assurances"-the feoffment. This consists simply and solely in livery of seisin, that is the delivery by the feoffor to the feoffee of possession of the land : "Some phrases in common use, which seem to imply a distinction between the feoffment and the livery are so far incorrect." 1

' Challis, Real Prop., ch. 28. As to the conveyance of those interests in land that could not be transferred at common law by feoffment, i. e., incorporeal intereste, see post $\$ 242$. 
$\S 12$. The bargain and sale-When deed necessary for. -In 1535, just after the Statute of Uses ${ }^{2}$ was enacted, the Statute of Enrolments required that "bargains and sales" intended to pass any estate of inheritance or freehold in any hereditaments should be "by writing, indented, sealed and enrolled" among certain records. ${ }^{3}$

Before this enactment "bargains and sales" were not required to be by deed, i. e., a writing under seal, and the statute was intended to prevent secret conveyances.

$\S 13$. The lease and release.-The statute of enrolments did not apply to interests less than a freehold, and therefore a bargain and sale for a year, or a term of years, took effect in spite of the statute and without enrolment; the statute of uses did, however, apply to it, and immediately after the execution of the bargain and sale the lessee became in possession by virtue of this statute, and being thus in possession, he could take a release of the reversion. ${ }^{5}$

This conveyance by lease and release was for more than two centuries, 1620-1841, the common mode of conveying freehold lands in England, and is referred to occasionally in American decisions and statutes. ${ }^{6}$ It was not necessary that the bargain and sale for a year should be by deed, though after the Statute of Frauds ${ }^{7}$ it was necessary that it should be in writing.

$\S 14$. The feoffment-When a deed became necessary for.-But the common law conveyance by feoffment was still legal (and, indeed, was necessary in some cases, and

227 Hen. VIII, ch. 10.

s See the Act, Digby, Hist. L. Real Prop., 5th ed., p. 368.

42 Bl. Comm. 338.

52 Bl. Comm. 339. See post, $\S 20,25$.

${ }^{6}$ E. g. Ky. Stat., 1899, § 492: "Every deed of release shall be as effectual for the purposes therein expressed, without the execution of a lease, as if the same had been executed."

'(1677) 29 Car. II, ch. 3. 
still is in England) ${ }^{8}$ and for this method of conveyance still no written instrument of any kind was required until nearly one hundred and fifty years after "bargains and sales" were required by the Statute of Enrolments to be by deed. That is, until the Statute of Frauds, 1677, no writing was essential to a feoffment, and a deed was not required for a feoffment until $1845 .^{9}$

So far as form of expression was concerned a feoffment was (before these statutes) an oral grant, and the words, "I enfeoff thee and thy heirs forever of black acre" were as effectual as the longest form of deed; but any form of statement, long or short, was wholly ineffectual without livery of seisin.

\$15. Deeds used though not necessary.-Nevertheless, during the time when deeds were not necessary they appear to have been often used for the purpose of preserving some record of the transaction.

The charter, or deed of feoffment, when used for this purpose was properly enough expressed as testifying to a past act: "I have given and granted." 10

Many deeds now in ordinary use contain language which is a relic of this custom, but they also contain words in the present tense-the combination expressing something that in most cases is not true. For example: "I, A B, etc., have given, granted, bargained, sold, remised, released, conveyed, aliened and confirmed, and by these presents do give, grant, bargain, sell, remise, etc."

Aside from the needless multiplication of operative words (which arose from overanxious care that the deed

- Digby, Hist. L. Real Prop., 5th ed., p. 412.

98 and 9 Vict., ch. 106; Williams' Real Prop., 17th ed., p. 185 ; Sheppard's Touchstone, Preston's ed., 203. Except in the case of a feoffment to a corporation aggregate and not being a gift in frank-almoigne; Challis Real Prop., p. 326.

${ }^{10}$ See Digby, Hist. L. R. Prop., 5th ed., 60, 61, 145; 2 Bl. Comm., Appendix, form 1. 
might operate as one kind of conveyance, if not as another), the employment of both tenses is a worse than useless perpetuation of an old custom.

\$16. Livery of seisin in the United States-Conveyance generally by deed.-It is sometimes stated that livery of seisin has not been used in the United States," but as late as 1827 a conveyance by feoffment with livery of seisin was made in New York, ${ }^{12}$ and it was not until 1830 that it was abolished in that state.

However, it appears that it is now either expressly abolished or impliedly declared to be unnecessary in every state.

The statute of Michigan on the subject is substantially like those of many of the states:

"Conveyances of lands * * may be made by deed * * without any other act or ceremony whatever." 13

In Illinois it is provided: "Livery of seisin shall in no case be necessary," etc., ${ }^{14}$ while in New York the statute declares that, "Conveyance by feoffment with livery of seisin has been abolished." 15

In some states it is excluded by the terms of the statute ; for example, "Conveyances of land * * shall be by deed in writing," 16 or, "An estate in real property * * can be transferred only by operation of law or by an instrument in writing," 17 while some statutes simply specify how deeds shall be executed without reference or allusion to livery of seisin..$^{18}$

11 E. g., 4 Kent Comm. 489.

12 McGregor v. Comstock, 17 N. Y. 162, 171.

${ }^{18}$ C. L. Mich. 1897 , $\S 8956$. So, also, e. g., Kan. G. S. 1901, 1205 ;

Minn. G. S. $1894, \S 4160$; Mo. R. S. 1899, §900; Wis. St. 1898, 2203.

${ }^{14}$ R. S. ch. $30, \S 1$.

${ }^{16}$ L. 1896, ch. 547, § 206; 3 Birdseye, p. 3050, § 206.

${ }^{16}$ Ind. Burns' R. S. 1901, 83335.

${ }^{17}$ Cal. Civ. Co., $\$ 1091$.

18 E. g., Ohio R. S., $\$ 4106$. 
\$17. How title may still pass inter vivos without writing. From a consideration of such statutes as those just referred to and the Statute of Frauds it might naturally be inferred, at first thought, that there could be now no voluntary transfer of lands inter vivos, so as to convey absolute title in fee simple, without at least some writing; but such is not the case, for there may be a complete and voluntary transfer in fee simple without any writing whatever; as where one enters upon real estate by virtue of a parol gift, his legal title will become absolute if he continues in possession, claiming as owner, for the period prescribed by the statute of limitations. ${ }^{19}$ It will be noticed that in such cases as those just cited the transfer of title to the donee is not dependent on any consideration paid by him, nor on any improvements made by him on the property. By simply taking possession under the gift his title may ultimately become perfect, although the voluntary transfer by the donor does not comply with the formalities required by the statutes, but may be repudiated by him at any time before his legal rights are barred by the statute of limitations.

Such cases differ, therefore, from those in which parol gifts have been made of real estate, and the respective donees have taken possession and made valuable improvements on the property, relying on the gift.

In these latter cases, while the legal title may not have yet passed to the donee, nevertheless a court of equity will, as it has often been beld, protect his equitable title. ${ }^{20}$

And where, instead of a gift merely, there has been an oral contract for the sale of real estate which has been partly performed by one party, a court of equity will gen-

'9 Schafer v. Hauser, 1897, 111 Mich. $622 ; 70$ N. W. 136 ; 3 D. L. N. 801; 35 L. R. A. 835; Wilson v. Campbell, 119 Ind. 286; 21 N. E. 893; Wheeler จ. Laird, 147 Mass. 421 ; 18 N. E. 212.

×0 Neale v. Neales, 9 Wall. 1, 9; Schwindt v. Schwindt, 1900, 61 Kan. 377; 59 Pac. 647; Hubbard v. Hubbard, 1897, 140 Mo. 300; 41 S. W. 749; Young v. Overbaugh, 1895,145 N. Y. 158 ; 39 N. E. 712 . See Fllis v. Dasher, 1897, 101 Ga. 5, 7; 29 S. E. 268. 
erally decree a specific performance of the contract in favor of that party in spite of the statute of frauds. In such cases the courts proceed on the general principle that one who has made an oral promise, by reason of which he has obtained some benefit from another, will not be permitted to justify his refusal to perform that promise on the ground that certain statutory requirements have not been complied with. ${ }^{21}$

The cases cited in this section have one feature in common, that is: the title to the real property involved in each case has passed without the execution of any written instrument by the former owner of the property.

\$18. Fines and recoveries.-The feoffment was anciently the only direct way of conveying a freehold interest in lands in possession from one person to another.

But as early as the reign of Henry II, 1154-1189, forms of litigation were used for the purpose of effecting a conveyance of land.

The law of fines was formerly most intricate, but as this method of dealing with land is wholly abolished a knowledge of its details seems unnecessary, though every lawyer should understand the general nature of a fine.

Briefly, it was an amicable compromise-a final concord - of an action, by leave of court, whereby the lands in question in the action, were acknowledged to be the right of one of the parties. Sometimes the concord put an end to genuine litigation, but generally the action was begun merely in order that the pretended compromise might be made. The plaintiff, the intending purchaser, was at first called the demandant, and the defendant (the vendor) the deforceant, but afterward they became known, the latter as conusor, and the former as conusee -these terms referring to the recognition of the right of the one party by the other.

21 Riggles v. Erney, 1894, 154 U. S. 244; Pike v. Pike, 1899, 121 Mich. 170 ; 80 N. W. 5 ; 6 D. L. N. 405; 80 Am. St. R. 488; Martin v. Martin, 1897, 170 Ill. 639; 48 N. E. 924 . See Pomeroy Eq. Jur., § 1409. 
The fine was so called because it put an end, not only to the matter in dispute, but also to all claims to the land by other persons than the parties who did not within a given time assert their claims, unless they could excuse themselves by showing infancy or some other disability.

Thus the advantages of a fine were: (1) that there was indisputable evidence of the transaction (the concord being enrolled among the court records); (2) the title conferred by the fine was a bar to the claims of all persons (not under disability), whether or not they were parties to the action, who did not within due time put in their claims. ${ }^{22}$

In considering a recent statute adopting the so-called "Torrens System," Holmes, C. J., in meeting an objection to the constitutionality of the statute, refers to the effect of a fine in barring claims to land:23 and in modern decisions, where conveyances by married women are considered, references are necessarily made to the law of. fines. 24 Such instances afford illustrations of the truth that "the study of what is obsolete in practice is not necessarily a waste of time." 25

A "common recovery" was a collusive action of recovery, not compromised, but prosecuted to judgment by the demandant or recoveror against the tenant or recoveree. It was the mode of barring estates tail, and the result of the proceeding was that the lands passed from the tenant in tail to the claimant in fee simple, free from the claims of reversioner, remainderman or issue in tail, ${ }^{26}$ and it was used in this country at one time for the same purpose. ${ }^{27}$

2 Bl. Comm. 348; Pollock \& Maitland, Hist. Eng. Law, II, 94-105; Shep. Touch., ch. 2.

${ }^{23}$ Tyler $\nabla$. Court of Registration, 1900, 175 Mass. 71, 74; 55 N. E. 812 ; 51 L. R. A. 433.

थ Hitz จ. Jenks, 1887, 123 U. S. 297,301; Martin v. Dwelly, 6 Wend. 9 ; 21 Am. Dec. 245; Clark v. Clark, 16 Ore. 224, 226; 18 Pac. 1.

${ }^{25}$ Williams Real Prop., 17th ed., 174.

$\approx 2$ Bl. Comm. 357.

${ }^{27}$ See post, $\$ 142$. 2-Brews. Con. 


\section{CHAPTER III.}

THE DEED.

§19. Definition and characteristics of the deed.

20. Kinds of deeds-At common law-Under the statutes of uses.

21. Kinds - Indenture - Deed poll.

22. Indenture - Deed poll Forms.

23. Indenture - Deed poll Other differences in forms.

24. Indenture - Deed pollDifference in effect.

25. Modern tendency to shorten deeds.
$\S 26$. Reasons for considering settled forms.

27. The deed conveys a present interest - To be distinguished from other instruments.

28. Deeds distinguished from contracts to convey.

29. Deeds distinguished from instruments testamentary in character.

30. Statutory forms of deeds.

31. The parts of a deed.

\$19. Definition and characteristics of the deed.-It will be noticed that while such statutes as those referred to $^{1}$ provide for the conveyance of interests in real property by deed, they neither define "deed" nor state all its essentials.

There are, it is true, in about one half the states short statutory forms of conveyances that may be used, and the statute prescribes their effect, but they are not adapted by form to be used in all cases, and no statute provides that such forms must be used..$^{1 a}$

Statutes provide also certain things that are essential in the execution of conveyances to make them valid or to entitle them to record, but such statutes, while of great practical importance, relate to a part only of the conveyance.

${ }^{1}$ Ante, $\$ 16$.

1a See post, $\$ 30$. 
What a deed is, therefore, is generally to be determined by the rules of the common law.

While it is desirable when possible to define legal terms, it is by no means easy to define a deed-to state concisely its essential characteristics so that the statement shall be both properly inclusive and exclusive.

Washburn says: "A deed is defined to be a writing containing a contract sealed and delivered by the party thereto." "2

This and most modern definitions appear to be based on Coke's definition: "A deed signifieth in the common law an instrument consisting of three things, viz.: writing, sealing and delivery comprehending a bargain between party and party." 2a

Coke also enumerates the ten requisites of a deed as follows: (1) a writing; (2) in parchment or paper; (3) a person able to contract; (4) by a sufficient name; (5) a person able to be contracted with; $(6)$ by a sufficient name ; (7) a thing to be contracted for ; (8) apt words required by law ; (9) sealing; (10) delivery.

One of the noticeable points in the foregoing and similar definitions is the prominence given to "contract" and "bargain."

But as pointed out in an interesting English decision, ${ }^{3}$ where the question was as to whether there had been a " felonious forging of a deed," the alleged deed being "letters of orders" by a bishop, under his seal, the term is clearly not confined to contracts. There may be a valid conveyance by deed of lands to an infant who cannot contract.

Such definitions and descriptions as the following, which are often seen, are, strictly speaking, incomplete and inaccurate :

"A writing under seal by which lands, tenements, or

2 Real Prop., III, 6th ed., § 2086.

2. Co. Lit., 171 b.

${ }^{3}$ Reg. v. Morton, 28 L. T. R. (N. S.) 452 ; $12 \operatorname{Cox}$ C. C. 456. 
hereditaments are conveyed for an estate not less than a freehold"-(lands are not conveyed by the writing-the writing is not a deed till delivered); "deed includes all varieties of sealed instruments" - (a magistrate's warrant or a will may be sealed instruments, but they are not deeds).

It seems difficult to improve on the following definition:

"A deed is a writing sealed and delivered; or, to speak more particularly, it is a writing done on paper or parchment, testifying to the performance, by some person named therein, of some act in the law (such as the conveyance of property or the making of a contract), authenticated by the seal of the person to be bound thereby, and delivered to the person intended to benefit thereunder."'4

The prominent features of the deed are :-

(a) Writing testifying to the performance of some act in the law: i.e., the instrument must be wholly written before delivery - must not be incomplete, with blanks left to be afterward filled in ${ }^{5}$ the writing - set forth with certainty-testifies to some act intended to affect the party's position in the law.

(b) Seal : Of vital importance at common law-and it will appear later that the doctrines associated with the seal are not easily disposed of by modern statutes "abolishing" seals.

(c) Delivery: Always important and without which the most complete and formal writing is not a deed-factum, a thing done; notitle passes without it, and whether there has been delivery is a constantly recurring question. ${ }^{6}$

In its broad signification, "deed" applies, of course, to many instruments in the law besides "conveyances."

Ency. Laws Eng. IV, p. 171.

'Shep. Touch., p. 54.

${ }^{6}$ See post, ch. XIX. 
We shall deal, however, with deeds of conveyance, and in using the term deed, it will be generally used in its popular sense as the formal instrument prepared, but not necessarily delivered.

$\$ 20$. Kinds of deeds-At common law-Under the Statute of Uses.-According to English law as it existed when this country was settled there were several different kinds of deeds, each having its appropriate use and effect. The general rules relating to them were introduced here with other parts of the law, and while many of the old rules are obsolete, it is still necessary at times to recur to them to appreciate the effect of modern conveyances or to understand modern statutes and decisions.

At present it may suffice to simply classify and enumerate them.

The so-called common law deeds were :

The original or primary deeds (i. e., deeds creating estates); feoffment, creating a fee simple; gift, creating a fee tail; grant, creating an estate in incorporeal real property; lease, creating an estate less than that of grantor; exchange, creating mutual estates in consideration of each other; partition, creating estates in severalty out of estates in joint tenancy or in common; and the derivative or secondary deeds (i. e., deeds modifying estates already created): release, conveying to present particular tenant the estate in remainder or reversion; surrender, conveying to remainderman or reversioner the present particular estate; confirmation, rendering a voidable estate sure and unavoidable; assignment, transferring the whole of an existing estate; defeasance, declaring conditions upon which an accompanying deed is to be defeated. ${ }^{7}$

Besides these common law deeds there were certain deeds which derived their force and effect as legal convey-

'The foregoing discussed 2 Bl. Comm., pp. 310-327. 
ances from the Statute of Uses. These were: bargain and sale, covenant to stand seised to uses, and lease and release; the last, being really composed of two instruments, is sometimes not classed as a deed by itself; but, as the lease was made in order that a release might immediately afterward be made, and as the purpose of the whole transaction was to convey, it is called by most authorities "conveyance by lease and release." 8 .

$\S 21$. Kinds-Indenture-Deed poll.-A further classification arises from a difference in the number of the parties executing the deed.

An indenture is or purports to be a deed between two or more parties; a deed poll is or purports to be the deed of one party.

Indentures were formerly in at least two parts written on the same parchment and afterward separated by cutting in an indented line; of ten before the parchment was cut a word was written along the line of division: the parts were called counterpanes or counterparts, and when put together made the deed; they were at one time interchangeably executed, the one part by one party and the other by the other party and exchanged; then the practice grew up of having each part executed by all the parties, making them "duplicate originals"; where each part was not executed by all parties, that part executed by the party from whom the estate moved was sometimes called the original and that executed by the party accepting the estate was called the counterpart. ${ }^{9}$ American indentures were formerly actually indented as sold by the stationer, but the practice became obsolete. In 1845 it was enacted in England that a deed purporting to be an indenture need not be actually indented. ${ }^{10}$

${ }^{8} 2 \mathrm{Bl}$. Comm. 338-and Appendix for form of lease and release. See ante, $\S 13$.

${ }^{9}$ Atherstone v. Bostock, 2 Man. \& Gr. 511, 518, note; 40 Eng. C. L. Rep. 722, note.

${ }^{10} 8$ \& 9 Vict., ch. 106. 
Deeds poll were so called because they were formerly polled or cut even and not indented.

\$22. Indenture-Deed poll-Forms.-Because these deeds were executed, the one kind by the several parties to it, and the other kind by but one, there was naturally a difference in form, and this difference is still maintained, though the method of execution of the two kinds may not always differ.

The indenture commences as follows :

This Indenture, made the - day of - in the year one thousand, etc., - between A B, of (town, county and state), party of the first part, and X Y, of party of the second part, witnesseth, that, etc.

The "testimonium clause" and the end of the instrument will vary with the circumstances, thus :

In witness whereof, to one part of these presents, remaining with the said party of the first part, the said party of the second part has, on the day first above written, affixed his hand and seal ; and to the other part thereof, remaining with the said party of the second part, the said party of the first part has on the said day affixed his hand and seal.

Or,

In witness whereof, the parties hereto have hereunto interchangeably set their hands and seals, the day and year first above written.

Or,

In witness whereof, the said party of the first part has hereunto set his hand and seal the day and year first above written.

As the form of indenture is very commonly used for a variety of written instruments besides deeds $\longrightarrow$. g., mortgages of real and personal property, leases, agreements, etc. - and as it is the appropriate form where there are several parties who reciprocally bind themselves (and there are often more than two), it may be noted that it is convenient in practice to state immediately after the first 
introduction of the name of the party, the character or capacity in which he acts, or some other brief description of him, and thereafter refer to him by that description throughout the instrument, rather than to refer to him as "party of first part," etc., or to repeat his name each time (in instruments to which corporations or partnerships are parties the names are long). For example :

This Indenture made, etc., between $\mathrm{A}, \mathrm{B}$ and $\mathrm{C}$, copartners doing business under the firm name of - , etc., hereinafter called "the mortgagors" (or vendors, lessors, etc., as the case may be), parties of the first part; the M N Mfg. Co., hereinafter called "the Company," party of the second part, and X Y, hereinafter called "the trustee," party of the third part, etc. ${ }^{11}$

The formal commencement of the deed poll is:

Know all men by these presents, that I, A B, of, etc.;

Or (more rarely),

To all to whom these presents shall come: I, A B, of, etc., send greeting: Know ye that I, etc.

The English practice is to vary the formal commencement of a deed poll according as the deed does or does not contain "recitals" at its beginning, using the second form above given when the deed contains recitals; and this is also the approved practice in this country; e. g., a deed by an executor, selling by order of court, should recite his authority and also that he gave notice, etc., as follows:

To all to whom these presents shall come: I, A B, of -, executor of the last will and testament of X Y, late of $\longrightarrow$, send greeting:

Whereas, by an order (reciting briefly the date of the court's order and the fact that A B was licensed to sell the land) and,

Whereas, I, the said A B, have given due notice by (reciting how the notice was given and the giving of a bond and the taking of an oath, etc.).

"See Jones Forms, 5th erl., pp. 346, 560; Birdseye's Abbott, p. 676. 
Now, therefore, know ye that I, said A B, by virtue of the power and authority in me vested (then stating that he conveys, etc.).

The testimonium clause of the deed poll is:

In witness whereof $I$, the said $\longrightarrow$, have hereunto set my hand and seal this - day of -

Or, frequently: Signed (and sealed, if so), this - day of - A. D., 19- (the date being in either case first mentioned at the conclusion of the instrument).

\$23. Indenture-Deed poll-0ther differences in form. -In indentures the parties are generally referred to in the third person-in deeds poll the party is referred to in the first person; this is, of course, not an essential difference in form; but the reference in the same instrument in one place to a party in the first person and in another place to him in the third person should be avoided as an awkward and somewhat misleading combination ; e. g., see the form of deed given in Appendix to Missouri Statutes : 12

"Know all men by these presents, that I, John Smith, of, etc., . . . do grant, etc., unto John Jones the following (describing the land) . . . I, the said John Smith, hereby covenanting to and with the said John Jones, his heirs and assigns, for himself, his heirs, etc., to warrant and defend the title, etc." (John Smith means to say: "I, the said John Smith, hereby covenanting . . . . for myself, my heirs," etc.)

So the combination, sometimes seen in printed forms, in one instrument of parts of an indenture with parts of a deed poll is, to say the least, clumsy.

Instruments in the form of the indenture are more common in the United States than are those in the form of the deed poll.

In some of the older states the deed poll is more usual "Vol. I, App., No. 99. 
than the indenture, but both forms seem to be used in almost every state.

Where the instrument is not merely a grant or conveyance, but contains stipulations binding both parties, the indenture is the more appropriate form-as in the case of leases, trust mortgages where the trustee agrees to certain things, etc. ${ }^{13}$ while where the instrument is simply a grant or conveyance-as in the case of the usual "power of attorney"- the deed poll is better.

\$24. Indenture-Deed poll-Difference in effect.-It is often broadly stated that there is now no difference whatever in effect between an indenture and a deed poll, but it is believed that this statement is not strictly accurate.

(a) Effect on construction: It is a general rule of construction in the case of private grants that if the meaning of the words be doubtful they shall be construed most strongly against the grantor. This rule is sometimes held to apply with most force to deeds poll, where the words of the deed are considered as solely the words of the grantor, ${ }^{14}$ while in an indenture actually executed by both parties the words may be taken either as the words of both, or, if there are stipulations proceeding from either party, doubtful terms are to be construed most strongly against the party who may be properly held to make use of the terms. ${ }^{15}$

(b) Remedy against grantee: Though a deed in form an indenture is seldom executed by the grantee, he is nevertheless, when he accepts it, bound by its terms; and, though it has been executed by the grantor alone, it has been held in some cases that it is the grantee's deed also, as if executed by him, and more strongly binding on him than a deed poll would have been; for example, in a case ${ }^{16}$

\footnotetext{
13 And see post, § 225.

14 Beeson v. Patterson, $36 \mathrm{~Pa}$. St. 24.

${ }^{25}$ Beckwith v. Howard, 6 R. I. 8.

${ }^{16}$ Finley v. Simpson, 22 N. J. L. 311 . See briefs in this case.
} 
where the question was whether the grantee could be held in an action of covenant brought by the grantor upon the agreement contained in a deed, called an indenture, that he should pay a mortgage on the premises conveyed, though he had not executed the deed; and it was held that such a deed accepted by the grantee is the deed of both parties, and the grantee is bound by the covenants contained in it on his part, and may be held in an action of covenant. ${ }^{17}$

And the difference between the two forms of deeds is noticed in a case ${ }^{18}$ where the defendant was sought to be held in an action of covenant on a similar clause in a deed in which he was grantee; his defense was that the action should have been assumpsit, which was barred by the statute of limitations, while covenant was not barred; the court refers to the fact that the deed purports to be an indenture-a mutual deed of both, and for the purpose of the remedy should be so regarded.

In Poe v. Dixon, ${ }^{19}$ where an action was brought by the grantor against the grantee on a similar clause in a deed poll, the bar of the statute of limitations was successfully interposed, as it was considered that the defendant had made no agreement or promise in writing nor by specialty. ${ }^{20}$

17 In Harrison v. Vreeland, 38 N. J. L. 366, the doctrine of Finley v. Simpson was restricted to the case of an indenture, and held not to apply to a deed poll. And see Woodruff v. Woodruff, 44 N. J. Eq. 349 ; 16 Atl. 4.

us Bowen v. Beck, 94 N. Y. 86.

1899,60 Ohio St. 124 ; 54 N. E. 86 ; 71 Am. St. R. 713.

${ }^{20}$ See further as to the remedy in such cases: Locke $\nabla$. Homer, 131 Mass. 93, 102 ; Rockford R. Co. v. Beckemeier, 72 Ill. 267; Baldwin v. Emery, 1897, 89 Maine 496; 36 Atl. 991; and note to Hickey v. L. S. \&c. R. Co., 1894, 51 Ohio St. 40; 36 N. E. 672 ; 23 L. R. A. 396. The form in which the assumption by a grantee of payment of a mortgage on the conveyed lands is expressed will be discussed later. Post, $\$ 65$. Many courts have held that by accepting any deed the grantee is bound by stipulations in the deed intended to bind him, and in many reported cases nothing is said as to the form of the deed-whether it is an indenture or deed poll. 
$\S 25$. Modern tendency to shorten deeds.-It is clear that in early times deeds of conveyance, when used either because they were required or because they were convenient, were simple and brief. And the modern tendency is to return to such simplicity and brevity. However, from the first part of the seventeenth century till well into the nineteenth the common mode of conveying land in England was by the "lease and release," which involved the making of two long deeds. ${ }^{21}$ Moreover, these increased very much in length, partly because of the greater complication of interests to be dealt with and new precautions invented to meet new difficulties, and partly because, until recently in England, the pernicious practice prevailed of rewarding professional skill in proportion to the number of words written. From 1833 until almost the present time many acts of parliament have tended to simplify the forms of deeds in England, and now in ordinary cases the use there of a comparatively few words prescribed by statute will incorporate in a deed the old clauses which were before inserted at full length.

In this country statutes have been. enacted in many states ${ }^{21 a}$ expressly providing short forms of conveyances. While these forms appear to be growing in favor and are much used in some states, they are ignored in others, even where there are statutes authorizing them.

Irrespective of statute, very informal and brief documents have often been sustained by the courts as deeds.

What is often called "Kent's Deed" is as follows :

"I, A B, in consideration of one dollar to me paid by C D, do bargain and sell (or in New York, grant) to C $D$ and his heirs (in New York, Virginia, etc., the words and his heirs may be omitted) the lot of land (describe it). Witness my hand and seal," etc. ${ }^{22}$

And an instrument quite as short as, and even more

22 Ante, $\S 13,20$.

21: Post, § 30 .

${ }^{22}$ See 4 Kent Comm. 460. 
informal than, this has been considered as having all the requisites of a conveyance in fee simple, namely :

"For value received, I bargain and sell unto $A$ C, my whole right of improvement made by $\mathrm{J} \mathrm{B}$, and all the land as far as T M's claim interferes with my claim. Given under my hand and seal, this 7th day, etc."

Test (two witnesses).

Signed and sealed..$^{23}$

Many modern decisions may be found sustaining as deeds almost equally simple instruments. See, for example, Evenson v. Webster, ${ }^{24}$ where an informal instrument, called by the draftsman "a will," was held to be a deed-upon principles to be stated presently. ${ }^{24 a}$

And the well-settled general rule is that courts will give effect if possible to an instrument as a deed of conveyance when it is clearly the intention to convey, regardless of the form of the instrument.

Nevertheless, it is not always possible to give such effect to an instrument even much more formal in general appearance than those set out in the cases just cited.

The reasons why many instruments, evidently intended as deeds of conveyance, have been ineffectual will become clear as the parts of the deed are considered in detail.

$\$ 26$. Reasons for considering settled forms.-Coke, after stating that deeds may be good though informal, proceeds: "And yet no well-advised man will trust to such deeds which the law by construction maketh good, ut res magis valeat; but when forme and substance concurre, then is the deede faire and absolutely good." 25

The fact that peculiarly informal writings have been held to be deeds only after prolonged and expensive litigation, and the fact that the statutes just mentioned-providing short forms-not only permit the use of the old forms, but in declaring the effect of the forms provided

2 Chiles v. Conley's Heirs, 2 Dana (Ky.) 21.

24 1892, 3 8. Dak. 382 ; 44 Am. St. R. 802.

Me Post, \$29.

${ }^{25}$ Co. Litt. 7a. 
by them, refer to the principles which gave rise to the former, induce many lawyers to agree with Coke that it is not well to depart from well settled forms.

Morever, the circumstances attending the conveyance of interests in real estate often require that the deed shall be something more than a mere conveyance of a definite piece of land from the present owner in fee to another person in fee. The estate or interest conveyed may be intended to be qualified or restricted in various ways; the land may be subject to various kinds of incumbrances, regarding which stipulations of one kind or another may be desired; there may be exceptions to be made from the land granted; rights may be intended to be reserved in it; conditions may be attached to its use; covenants, general or special, as to its condition or character may be desired, etc. So that a simple or short form 'will often be found not so well adapted for use as one more prolix.

$\S 27$. The deed conveys a present interest-To be distinguished from other instruments.-Whatever be its form the characteristic effect of a proper deed of conveyance (i. e., a written instrument executed with the formalities required by lex situs and delivered) is that it conveys a present legal interest.

When customary forms are disregarded in drawing a deed, or peculiar provisions are inserted in it, it is apt to be confounded with other instruments from which it is essentially distinct.

There are two general classes of instruments especially to be noted, with one or the other of which the deed may be so confounded in particular cases, namely:

(a) Contracts to convey.

(b) Instruments testamentary in character.

$\$ 28$. Deeds distinguished from contracts to convey.It is not easy to determine in all cases whether an instru- 
ment purporting to transfer an interest in realty is a deed of conveyance or simply an agreement for a deed.

In such cases its operation and effect as to whether it is the one or the other depends, not necessarily on particular words and phrases, but on the intention of the parties to be gathered from the whole instrument, read, if need be, in the light of the circumstances of the transaction.

Though the instrument may contain words of conveyance, yet if it be clear that the parties contemplate the execution of a further conveyance, such an instrument is not a deed of conveyance. ${ }^{26}$

In Williams v. Paine ${ }^{27}$ there is a clause in an instrument, in general form a conveyance, made by an attorney under a letter of attorney, as follows:

"And I (attorney) hereby further agree in behalf of (principals) that they will as soon as convenient make and execute a proper deed of conveyance of said premises to said (grantee) in fee simple," as to the effect of which clause there was a difference of opinion among the justices, some regarding the instrument as only an agreement to convey, and not a deed of conveyance, the majority, however, being of opinion that it was a conveyance of the legal title, though defectively executed as the attorney's deed rather than that of his principals.

\$29. Deeds distinguished from instruments testamentary in character.-Sometimes instruments in the general form of deeds will be construed to be wills, and those in appearance wills will be construed to be deeds.

Writings in the form of absolute deeds'often contain a provision that they are not to take effect until at or after the death of the "grantor"; for example, such provisions are :-

* Phillipg v. Swank, 120 Pa. St. 76; 13 Atl. 712; 6 Am. St. R. 691; Mineral Co. v. James, 1899, 97 Va. 403 ; 34 S. E. 37.

${ }^{n 1} 1898,169$ U. S. $55,76$. 
"This indenture made, etc., between, etc. (only to take effect at the death of the grantor), witnesseth, etc.;"22

Or, "This deed is to take effect and be in full force on and after the death of this grantor;" 29

Or, "To have and to hold the above described premises to the said B W, of the second part, his heirs and assigns, to be his at my death and the death of my wife." 30

The question in such cases is whether the writing is a deed of conveyance, or is, in effect, a will. And the distinction is important. If a deed, the interest of the grantee cannot be defeated by the grantor after the execution and delivery of the instrument-if a will, it is revocable by the maker at any time before his death.

Moreover, in many states (e. g., California, Colorado, Illinois, Indiana, Iowa, Kansas and Missouri), no witnesses are necessary to a deed, but, generally speaking, two witnesses at least are necessary to a will. Hence, if an instrument in general form a deed, and without witnesses be held to be really testamentary in character, the result is, in such states, that the instrument is wholly inoperative-it cannot operate as a deed because testamentary in character, nor as a will because it lacks the witnesses necessary to a will.

In states where this result would follow, if unwitnessed instruments containing such clauses as those just quoted were held to be testamentary in character, and hence not deeds, the courts are apt to sustain the instrument as a deed, if possible, rather than have it entirely fail..$^{31}$

${ }^{26}$ Harshbarger v. Carroll, 1896, 163 Ill. 636; 45 N. E. 565; Bowler v. Bowler, 1898, 176 Ill. 541; 52 N. E. 437; Murphy v. Gabbert, 1902, 166 Mo. 596 ; 66 S. W. 536 ; 89 Am. St. R. 733.

${ }^{29}$ Kelley v. Shimer, 1899, 152 Ind. 290; 53 N. E. 238; Pinkham v. Pinkham, 1898, 55 Neb. $729 ; 76$ N. W. 411.

${ }^{30}$ Wynn v. Wynn, 1900, 112 Ga. 214 ; 37 S. E. 378.

${ }^{31}$ Love v. Blauw, 1900, 61 Kan. 496 ; 59 Pac. 1059; 78 Am. St. R. 334 ; 48 L. R. A. 257 ; Saunders v. Saunders, 1901, 115 Iowa 275 ; 88 N. W. 329. See West v. Wright, 1902, 115 Ga. 277 ; 41 S. E. 602. 
The decisions involving these points are numerous, and in some respects conflicting. ${ }^{32}$

The general rule appears to be that if a present vested right to property then owned by the maker of the writing passes to the person named as grantee, the instrument is a deed, if properly executed and delivered, and the mere fact that the enjoyment in possession is postponed does not make it a will. On the other hand, if the instrument passes no present interest or right, but requires the death of the maker before either interest or enjoyment arises, it is a will, if executed as such.

Therefore, if the writing passes a present interest it may be held to be a deed (if properly executed, etc.), even though called by the maker a will, ${ }^{33}$ while if it passes no present interest (because, e. g., the maker has none to pass), it cannot operate as a deed, though having the general form of one, but may operate as a will (if properly executed as a will). ${ }^{34}$

And a document in general form a warranty deed may be admitted to probate as a will and take effect as a will, if properly executed, especially when not delivered as a deed, ${ }^{35}$ while, on the other hand, an instrument in which are used some of the terms appropriate to a will-as "give, devise and bequeath," instead of the usual operative words of a deed-cannot be probated as a will, if, in reality, a present estate is granted..$^{36}$

In many cases of this general character the question of delivery is the vital question, and the principles on which they are decided will be discussed when the subject of delivery is reached..$^{368}$

See note, 89 Am. St. R. 495.

${ }^{33}$ Evenson v. Webster, 1892, 3 S. Dak. 382; 53 N. W. 747; 44 Am. St. R. 803.

* Crocker v. Smith, 1891, 94 Ala. 295 ; 10 So. 258; 16 L. R. A. 576.

${ }^{25}$ Lautenschlager'e Estate, 1890, 80 Mich. 285 ; 45 N. W. 147.

* Ward v. Ward, 1898, 104 Ky. 857; 48 S. W. 411; Goad v. Lawrence . (Ky. 1902), 68 8. W. 411.

35: See post, $\$ 307,308$.

3-Brews. Con. 
$\S 30$. Statutory forms of deed. ${ }^{36 b}$-As in practice the Indiana short statutory form of deed is much used, and as the statute is similar to those of many other states (some having been but recently enacted), the section relating to the statutory form of the "warranty deed" is here given : ${ }^{37}$

"Any conveyance of lands worded in substance as follows,- - A B conveys and warrants to C D (here describe the premises), for the sum of (here insert the consideration )'-the said conveyance being dated, and duly signed, sealed and acknowledged by the grantor-shall be deemed and held to be a conveyance in fee simple to the grantee, his heirs and assigns, with covenant from the grantor for himself and his heirs and personal representatives that he is lawfully seized of the premises, has good right to convey the same, and guarantees the quiet possession thereof; that the same are free from all incumbrances, and that he will warrant and defend the title to the same against all lawful claims."

Statutes almost identical with the foregoing will be found in Michigan and Kansas, ${ }^{38}$ while a somewhat different form of statute, producing much the same effect, exists in Illinois and other states, ${ }^{39}$ and still another form, producing in some respects a different effect, is used in California and states adopting its statutes. ${ }^{40}$ Reference is now made to the foregoing statutes for the purpose of calling attention to their existence and, in a general way, to resemblances and differences in form. Similar statutes exist in several states besides those named, all having in view the shortening of conveyances.

See ante, $\S 25$.

87 Burns' R. S. 1901, § 3346 .

${ }^{28}$ Michigan C. L. 1897, §9014; Kansas Gen. St. 1901, § 1203.

89 IHlinois R. S., ch. 30 , \$9; Minnesota Laws 1901, ch. 197; Utah R. S. $1898, \S 1981$; Washington Ball. Ann. Co. 1897, § 4519; Wisconsin Stat. - $1898, \S 2208$. See Iowa code, $\S 2958$.

${ }^{10}$ California Civ. Co., $\$ \$ 1092,1113$; Montana Civ. Co., $\$ \$ 1501,1519$; South Dakota Ann. Stat. 1901, $\$ \$ 4435,4437$. 
One important consequence of such statutes is to import into the deed, by the use of certain words named in the statute, the covenants specified in it with the same effects on the rights and liabilities of the parties as if the covenants had been fully expressed. The words necessary to accomplish this result vary in the different states, and the covenants thus implied by the use of certain words are not always general in their nature, but are often restricted or special. ${ }^{41}$

It will be noticed that where there are such statutes providing for a short "warranty" deed, there are generally those providing short forms for other conveyances also (e. g., mortgages).

In practice, these instruments, when used, are seldom as short as the statutory forms, but have the formal beginning and conclusion of an indenture or deed poll, and sometimes contain many of the parts of the older forms.

Statutes somewhat different from those just mentioned, though having the same general objects in view, are to be found occasionally ${ }^{2}$ in which "pattern covenants" are set forth in brief terms as being fully equivalent to the older long forms, which are also set out in the statute; and full forms of conveyances containing such short clauses are provided : in New York a charge of $\$ 5$ additional to the usual recording fee may be made if the long forms are used.

\$31. The parts of a deed.-In none of the states having statutes such as those just mentioned is it necessary to use the statutory form, and longer conveyances are still in general use.

Generally speaking, throughout the United States there may be used a deed containing the following principal and subordinate parts-not that all these parts need be in

"See post, $\$ 211$.

a E. g., N. Y. The Real Property Law, §223; Birdseye’s ed., N. Y. R. S. 1901, p. 3055 . 
every deed (for plainly there may be deeds containing neither "exception," "reservation," "condition," nor "covenant"), but when some or all are needed they should appear in their proper relative places in the deed:

The premises, or introductory part, including date (though in deed poll this is properly at end); parties (their names, residences, and, sometimes, occupation or other special designation); explanatory recitals ; statement of payment and receipt of consideration; operative words; description of property conveyed (followed in some forms by the "general words" and "all estate" clause)-exception.

THE HABENDUM-limiting or declaring the estate or interest granted. (Following the habendum was formerly the tenendum, a clause used to express the tenure by which the estate granted was to be held by the grantee; prior to statute Quia emptores-1290-it was important to state whether the grantee was to hold of the grantor or of his lord, and the kind of tenure was also marked out; now it is a mere form and is joined with the habendum in the clause "To have and to hold").

The REDDENDUM-specifying what new thing is reserved to the grantor in the thing granted.

(This clause is more usual in leases where there is a reservation of rent-" Yielding and paying, etc."-than in deeds of absolute conveyance, but there may be important "reservations" in the latter.)

Conditions-qualifications or restrictions affecting the use and enjoyment of the estate granted, by virtue of which it is made to vest, to be enlarged, or defeated, on the happening or not happening of a particular event, or the doing or not doing of a particular act.

Covenants-agreements or promises collateral to the main purpose of the deed-giving assurances as to things already done or providing that some thing shall be (or shall not be) done hereafter: the most common are the 
covenants for title, of which "the usual covenants" are : for seisin, of good right to convey, against incumbrances, for quiet enjoyment, for further assurance, of warranty.

The conclusion-the testimonium clause, reciting the fact of execution; the date, either expressly or by reference to the beginning; signing, sealing, attestation. (Following is generally the certificate of acknowledgment -not strictly a part of the deed, nor, generally speaking, necessary to its validity as a conveyance.)

The parts will now be taken up in detail in substantially the order given above. 


\section{CHAPTER IV.}

\section{THE DATE.}

\$32. The date not essential, though degirable.

33. Presumption of delivery at date.
\$34. Date in deed and certificate of acknowledgment.

35. True date may be shown.

\$32. The date not essential, though desirable.-As deeds are now drawn in most of the states the first recital in the premises is the date.

While it has been for centuries the usual practice to put a date to a deed, the date was not at common law necessary to the conveyance. So that if the date were omitted entirely, or were an impossible time, as the 31st of February, it has been considered that the conveyance is nevortheless valid. ${ }^{1}$

Most of our modern statutes permitting short forms of deeds $\mathrm{s}^{1 \mathrm{a}}$ provide among other things that they shall be "dated." How far the date in such cases would be considered essential cannot be stated in the absence of decisions on the point, but, while it is believed that the omission of the date would not affect the validity of such conveyances, it is clearly best to date them.

And even though other deeds than these are valid without dating, still they ought regularly to be dated on the day of their execution. The rights of parties are often made to depend upon an accurate statement of time, and the date may become important in determining questions of priority or in ascertaining whether all the statutory

1 Goddard's Case, 2 Rep. 4 b.

2. Ante, \$ 30. 
requirements in force at the time of the execution of the instrument have been complied with. ${ }^{2}$

The date may be stated in any part of the deed, but in "indentures" the appropriate place is at the beginning; in "deeds poll," near the end in the testimonium clause.

It is better in stating the date to write it out in words rather than to express it in figures. Mistakes are more likely to occur where figures alone are used than where words are used, either alone or in addition to figures, and a date in figures would seem to be less regarded than one in a different form. ${ }^{8}$

§33. Presumption of delivery at date.-The all-important time in regard to deeds is the time of delivery, and the date of a deed is often of value in fixing this time.

The delivery of a conveyance having been shown, ${ }^{4}$ it very often becomes of great importance, in view of conflicting claims to the property described in the conveyance, to determine when delivery took place.

In the absence of direct evidence on this point resort is had to a presumption of law, and it is a general rule that if a date is stated in the deed, that will be taken prima facie as the date of the execution and delivery. ${ }^{5}$

\$34. Date in deed and certificate of acknowledgment. -When the date of the deed and that of the certificate of

2 Smith v. Porter, 10 Gray 66.

Jackson v. Schoonmaker, 2 Johns. 230, 233.

- As to what constitutes delivery, see ch. XIX.

B Purdy v. Coar, 109 N. Y. 448; 4 Am. St. R. 491 ; 17 N. E. 352; Faulkner v. Adams, 1890, 126 Ind. 459; 26 N. E. 170; Crossen v. Oliver, 1900, 37 Ore. 514; 61 Pac. 885; Farwell v. Des Moines Mfg. Co., 1896, 97 Iowa 286, 299; 66 N. W. 176; 35 L. R. A. 63, 69. (One question in this case was whether a certain person was the owner of land when ascessmente were made; the general rule as to date is applied, and it is held that, though the deed was not recorded till some time after it bore date, it must be presumed prima facie to havo been delivered at its date.) 
acknowledgment ${ }^{6}$ are the same the presumption of delivery at that date is strengthened, as the certifying offcer is required by statute in many states to name the true date, and generally would have no object in expressing it falsely. ${ }^{7}$

But it very often happens that the date of the deed and the date of the certificate of acknowledgment differ.

In such cases the general rule appears to be that the former (i. e., date expressed in deed) will, in the absence of evidence to the contrary, be taken as the true date. ${ }^{8}$

The reason generally given for this rule is that the deed may be delivered before its acknowledgment or without acknowledgment-the acknowledgment, generally speaking, being unnecessary to its validity. ${ }^{9}$

But this doctrine is not accepted by all courts, and it has been held in some jurisdictions that, as the deed is not usually delivered till it has been acknowledged, there will be no presumption that there was delivery till the acknowledgment has taken place. ${ }^{10}$

${ }^{6}$ See post, ch. XVIII.

' Cover v. Manaway, 115 Pa. St. 338; 8 Atl. 393; 2 Am. St. R. 552. (In this case it was attempted to be shown that the deed was not executed till some years after the time stated as its date.)

${ }^{8}$ Conley v. Finn, 1898, 171 Mass. 70; 50 N. E. 460; 68 Am. St. R. 399. (Here there was a difference of twenty years between the date of the deed and that of acknowledgment-the acknowledgment being after the death of the grantee.) And see L. E. \&c. Ry. Co. v. Whitham, 1895, 155 Ill. 514 ; 40 N. E. 1014 ; 46 Am. St. 355 ; 28 L. R. A. 612 ; Smith v. Scarbrough, 1895, 61 Ark. 104 ; 32 S. W. 382.

${ }^{9}$ See post, $\$ 261$.

${ }^{10}$ Loomis v. Pingree, 43 Maine 299, 308; Fontaine v. Savings Inst., 57 Mo. 552. This is the rule in Michigan: Blanchard v. Tyler, 12 Mich. 339; 86 Am. Dec. 57; Johnson v. Moore, 28 Mich. 3; Hoard v. Stone, 58 Mich. 578,$583 ; 26 \mathrm{~N}$. W. 141 . But in any case the presumption may be overcome by other direct evidence or by circumstances; e. g., in Eaton $\nabla$. Trowbridge, 38 Mich. 454, 458, where the acknowledgment was three years after the date of the deed, and the grantee had died after the date of the deed and before the date of acknowledgment; it was held that the fact that the grantor acknowledged the deed after the death of the grantee was a circumstance which overcame the 
\$35. True date may be shown.-The date not being essential, it is a well-settled rule that the true date may be shown by parol, without regard to the date recited, and the actual date of delivery may be shown though it be different from the date of the conveyance.

Applying this principle, it was held in Swedish American Bank v. Germania Bank, "1 where the controversy was as to the amount of indebtedness secured by a deed given as security, that the deed might be shown to have been delivered and to have taken effect at a later time than the date named in it, at which later time a much larger sum was due than at the date recited in the deed.

This deed was expressed to have been given and received "as security for money owing," but it is worth noting that a slight variation in the form of expression might have materially affected the result. If, for example, the form had been: "Owing at the date above named," or a similar expression had been used, the date as named would, it seems, have been taken as the time for fixing the amount of indebtedness. ${ }^{12}$

The statutes of many states require that certain instruments, more especially mortgages, shall be recorded within a limited time "after the date thereof" or "after execution." In such cases the true date may be shown, and the time intended by such statutes would seem to be

presumption which would ordinarily prevail in Michigan-because if the conyevance had not been delivered before the acknowledgment, that is, before the grantee's death, the ceremony of acknowledgment would have been without effect. As there is a conflict of opinion on this point, it is interesting to note the recent recommendation of the California Commiseion for the revision of the codes and the amendment made to California Civil Code, $\$ 1055$, changing the time when a grant is presumed to have been delivered from that of its date to that of the date of its certificate of acknowledgment, "this latter presumption being, in the opinion of the commissioners, more usually in accord with the facts."

"1 1899,76 Minn. $409 ; 79$ N. W. 399.

2Joseph v. Bigelow, 4 Cush. 82. 
the date of delivery rather than the date recited in the instrument, should they differ. ${ }^{13}$

13 Shaughnessy v. Lewis, 130 Mass. 355; Hornbrook v. Hetzel, 1901, 27 Ind. App. 79 ; 60 N. E. 965. 


\section{CHAPTER V.}

THE PARTIES-THE METHOD OF DESIGNATING THEM.

$\S 36$. Manner of introducing and referring to parties,

37. Designation of parties-The grantor.

38. Designation of parties-The grantee.

39. Executing deed with grantee's name blank-Question as to authority to insert his name.

40. Parol evidence to identify grantee-When deed roid for uncertainty as to grantee
§41. Use of names-Presumptions.

42. Nameg-Effect of discrepancies-Idem sonans.

43. Fictitious persons-Grantee must be in esse-Fictitious names.

44. Additions to name by way of recital-Effect of.

45. Partnerships as parties.

46. Corporations as parties.

\$ 36. Manner of introducing and referring to parties. -To a deed there must be parties-competent, on the one hand, to give title, and on the other, to take. Assuming, for the present, that the parties are under neither natural nor legal disability, ${ }^{1}$ there will be considered here the manner or method of designating them.

In indentures the parties are described or referred to as of different parts, there being as many parties of different parts as are necessary in the particular instrument.

There may be several persons whose relations to the subject-matter of the instrument are substantially the same, and whose intentions regarding it are also the same. They may all properly be joined as parties of the same part—of the "first," "second," "third," etc., parts, respectively.

${ }^{1}$ See post, $\$ 312$. 
The order in which the several parties follow each other is usually the natural order, the party who conveys something being mentioned before the party to whom the conveyance is made. Where there are but two parties, or sets of parties, one conveying an interest and the other taking it, the arrangement is a simple matter. Where there are more than two parties, or sets of parties, the order of arrangement becomes somewhat a matter of taste, regulated by practice and experience-the giver, however, generally preceding the taker; and, for example, trustees who are made parties for the interest of those to whom the conveyance is made generally being mentioned last.

Examples-

One desires to purchase a part of mortgaged lands freed from the mortgage. He, the mortgagor, and the mortgagee, having agreed upon terms, etc., could become parties thus:

This indenture, made the - day of - etc., between (mortgagor) of - party of the first part; (mortgagee) of - , party of the second part, and (purchaser) of - , party of the third part.

Whereas (recital as to the mortgage, the agreement of the mortgagor to sell, the purchaser to buy and the mortgagee to concur and release the part on receiving a proportion of the proceeds).

Now this Indenture witnesseth that in consideration, etc.

Or, in the above, the mortgagee might have been named as first party and the mortgagor as second party.

A "marriage settlement," made in view of an intended marriage, may be :

This indenture, made this - day of -, etc., between (intended husband), of - party of the first part; (intended wife), of $\longrightarrow$, party of the second part; and and - , of - , trustees, parties of the third part.

Whereas (reciting the intended marriage and the agreement that certain property "hereinafter described" should 
be settled "upon the trusts and to the uses hereinafter declared and limited").

Now this indenture witnesseth that, etc.

Strictly speaking, in deeds poll the parties are not referred to as parties of different parts, being simply grantor and grantee; though usage in some states authorizes the practice of referring to the parties to a deed in form a deed poll as parties of the first, second parts, etc.

Where there are but two parties they are frequently referred to as parties of the "one part" and parties of the "other part," respectively, instead of as of the first and second parts.

\$37. Designation of parties-The grantor.-Whatever be the form of the deed, the parties ought to be named or otherwise designated in the body of the instrument.

To save all question, the party intending to convey should be designated as the granting or conveying party in the deed, for the signing and sealing a deed by one who is not in some way so designated as intending to convey is not, generally speaking, enough to convey his interest. ${ }^{2}$

Because of the carelessness or ignorance of those drawing deeds this question has often been before the courts in one form or another, and it is believed that the general and proper rule is that stated above.

There are, however, decisions to the effect that one signing a deed is bound as grantor, though he is not named as such in the body of the deed. ${ }^{3}$

2 Batchelor v. Brereton, 112 U. S. 396, 404; Stone v. Sledge, 1894, 87 Tex. 49; 47 Am. 8t. 65; 26 S. W. 1068; King v. Rhew, 1891, 108 N. C. 696 ; 23 Am. 8t. 76 ; 13 S. E. 174 ; Adams v. Medsker, 25 W. Va. 127; Davidson v. Iron Co., 1895, 109 Ala. 383; 19 So. 390; Bradley v. Mo. Pac. R. Co., 91 Mo. 493; 4 S. W. 427; Barngdall v. Boley, 1902, 119 Fed. R. 191.

${ }^{3}$ Hargis v. Ditmore, 86 Ky. 653 ; 7 S. W. 141; Hrouska v. Janke, 66 
The reasoning in such cases is that the execution of a deed manifests the intention of the one executing to be bound by it, and that the instrument should be so construed as to give effect to the intention. But in answer to this it is said, on the other hand, that the intention of the parties to an instrument must be gathered from the instrument, and when there is nothing in a deed to show an understanding on the part of one of the signers and sealers to convey, the mere execution of the deed does not sufficiently manifest such a purpose; and that when a deed expresses in terms that it is the conveyance of $A$ and $B$ we should do violence to its obvious intent were we to hold that $\mathrm{C}$ also conveyed because he signed and sealed it.

In properly construing deeds as to which this question may arise, much, of course, must depend upon the context as well as upon the purpose of executing the deed by one not named as grantor.

For example, where no names are mentioned at all in the deed, but such expressions are used as "We convey," -and the deed is executed by several, it should be held to be the deed of all executing it."

Or, where a husband executes with his wife a conveyance of her property, for the purpose of manifesting his consent to her conveyance (as is required by some statutes), it may with some reason be held sufficient, though he is not described as grantor in the conveyance, ${ }^{5}$ and this would especially be so in states where the husband has no freehold interest in his wife's real estate, as he had at common law, for in such cases he has nothing to grant. $^{6}$

Wis. $252 ; 28$ N. W. 166-this case citing as authority Wash. R. Prop. III, 566 .

4 Sheldon v. Carter, 1890, 90 Ala. 380; 8 So. 63.

${ }^{5}$ Pease v. Bridge, 49 Conn. 58, 61; Thompson v. Lovrein, $82 \mathrm{~Pa} . \mathrm{St}$. 432; Dentzel v. Waldie, 30 Cal. 138; Clark v. Clark, 16 Ore. 224; 18 Pac. 1.

- Bray v. Clapp, 1888, 80 IIaine $277 ; 13$ Atl.900; 6 A m. St. R. 197. 
While such cases as these are sometimes cited as sustaining the doctrine that one may be bound as grantor by executing a deed without being otherwise designated as grantor, it seems that they cannot properly be considered as authorities for that doctrine, but, at most, merely for the doctrine, that, under some statutes, the husband's assent to his wife's conveyance of her land may be shown by his merely executing her deed. And it has been held, on the other hand, that the assent and concurrence of the husband, required in some states, to give validity to a conveyance of the wife's lands, can be manifested only by his joining in such a way as would be necessary to the conveyance of his interest if the land belonged to him, ${ }^{7}$ especially where he has a freehold interest in her real property by virtue of the marital relation. ${ }^{8}$

\$38. Designation of parties-The grantee.-As in a deed there must be a grantee, as well as a grantor, he must also be designated.

$\mathrm{He}$ is, of course, usually designated in the premises by his name, but this is not indispensable, for if from the whole instrument it appears who he is, it is enough. ${ }^{9}$ The grantee need not be actually mentioned by name at all, if he is otherwise definitely designated. He may be identified by other means than by name, and any description which indicates the person and distinguishes him from others is enough, so far as the validity of the deed is concerned; for example, a valid conveyance may be made to the eldest son of a person named or to his wife, without, in either case, naming the grantee.

If, however, there is nothing on the face of the deed indicating the grantee, it is defective and passes no legal

'Adams v. Teague, 1898, 123 Ala. 591; 26 So. 221; 82 Am. Bt. R. 144.

- Dietrich v. Hutchinson, 1901, 73 Vt. 134; 50 Atl. 810; 87 Am. St. R. fig8.

9 Newton v. McKay, 29 Mich. 1; Bay v. Posner, 1893, 78 Md. 42; 26 Atl. 1084. 
title; as, for example, if the name of the grantee is by mistake placed among those of the grantors, and there is nothing else in the deed to indicate the grantee, no legal title is conveyed.10 So if the name of the grantee is left blank, there being no other designation of him in the "deed," the instrument is wholly inoperative as a conveyance so long as it remains in this condition, though complete in other respects. ${ }^{11}$

§39. Executing deed with grantee's name blankQuestion as to authority to insert his name.-It is not unusual in practice, however, for one to execute a "deed" complete in all particulars except the name or other designation of the grantee. If the blank thus left is afterward filled by one having authority to fill it, the instrument (which up to this time is really no deed because there is but one party to it) becomes valid.

Whether in such cases the authority to insert the grantee's name must itself be conferred by deed, or may be given by parol, is a disputed question. Formerly the general rule was that such authority-which is authority, really, to make a deed-could be given only by an instrument of as high a character as the one to be made, and this doctrine would, it seems, still be adhered to by some courts. ${ }^{12}$ But in many recent decisions the extremely technical character of this rule is pointed out, and it is held that parol authority to insert the grantee's name is sufficient; and in some cases it is not considered necessary to the validity of the deed that the blank shall be filled before delivery. ${ }^{18}$

${ }^{10}$ Allen v. Allen, 48 Minn. $462 ; 51$ N. W. 473.

"Allen v. Withrow, 110 U. S. 119, 128; Clark v. Butte, 1898, 73 Minn. 361 ; 76 N. W. 199; Whitaker v. Miller, 83 Ill. 381.

${ }^{18}$ Mickey v. Barton, 1902, 194 Ill. 446, 455; 62 N. E. 802; Upton $\nabla$. A rcher, 41 Cal. 85; 10 Am. R. 266.

13 McCleery v. Wakefield, 76 Iowa $529 ; 41$ N. W. 210; 2 L. R. A.529; Bank y. Eleming 1901, 63 Kan. 139; 65 Pac 213; Thummel v. Holden, 1899, 149 Mo. 677 ; 51 S. W. 404; Cribben v. Deal, 1891, 21 Ore. 211 ; 27 
\$40. Use of parol evidence to identify the granteeWhen deed void for uncertainty as to grantee.-Even where the grantee is named, some evidence outside the deed must often be resorted to in order that the real grantee may be identified. The name is simply a means of identifying him.

While it is desirable to use his correct name, his identity may nevertheless be shown should his name be erroneously written. ${ }^{14}$

It will be observed that in such cases an actual grantee is designated, but imperfectly or incompletely ; and parol evidence is admissible, not to add any new terms to the deed, but for the purpose of completing what is imperfectly expressed, and applying the terms to the person thus erroneously designated. While it is inconvenient to have such a state of facts occur, because the necessary evidence is not always easily obtainable, nevertheless, the validity of the deed is not affected by the error in name, because there is no error as to the person: the name may be one or another-is changeable, and, so far as the validity of the deed is concerned is unimportant, but the person is unchangeable and is essential to the operation of the deed.

Hence there is a great difference between the erroneous designation of a grantee and the designation of a grantee by a description which is inherently uncertain; to correct the latter by parol evidence as to the person intended, when the description given furnishes no means of identification, is to add new terms to the deed, which may not be done: therefore, in such cases the deed is void for uncertainty as to the grantee.

For example: A grant to "one of the sons of A," he

Pac. 1046; 28 Am. 8t. R. 746; Lafferty v. Lafferty, 1896, 42 W. Va. 783, 787 ; 26 S. E. 262.

14 Andrews v. Dyer, 81 Maine 104; 16 Atl. 405 ; Cleveland v. Burnham, 64 Wis. $347 ; 25$ N. W. 407.

4-Brews. Con. 
having several sons; or to "the poor relations" of the grantor, when the deeds furnish no other means of identifying the persons intended, would be fatally defective or "incurably uncertain."

A grant to the inhabitants of a "neighborhood," without defining the neighborhood, would seem to be void for uncertainty, ${ }^{15}$ and a conveyance to the "heirs" of a living person, with nothing appearing on the face of the deed to indicate the grantor's use of the word "heirs" in other than its technical legal sense, is void for uncertainty. ${ }^{16}$ But the general purpose of the law to sustain, if possible, conveyances rather than declare them void, is shown by instances where the word "heirs" (in cases similar to that last cited) is construed as "children," which is a proper construction when it is manifest from the deed, as a whole, that the grantor did not use the word in its technical sense. Such will be the result, for example, if the fact that the ancestor is living at the time is recognized by the grantor in the deed. ${ }^{17}$

\$ 41. Use of names-Presumption.-It is clear, then, that the better way to designate the parties is by name, and this is, of course, the usual way.

Care should always be used in ascertaining the names of parties before drawing instruments, as the liability to err in this respect is great; the names of the grantors occur in several parts of a deed besides appearing as signed to it, and again in the certificate of acknowledgment, and the amount of litigation in regard to titles that has been caused by errors as to names in conveyances and

${ }^{13}$ Thomas v. Marshfield, 10 Pick. 364 ; Hunt v. Talles (Vt. 1902), 52 Atl. 1042.

${ }^{16}$ Booker v. Tarwater, 1894, 138 Ind. 385 ; 37 N. E. 979; and it might be held void for the reason that there are no such persons in existence, see post, $\S 43$.

${ }^{17}$ Heath v. Hewitt, 1891, 127 N. Y. 166; 27 N. E. 959; 24 Am. St. R. 438; Seymour v. Bowles, 1898, 172 Ill. 521 ; 50 N. E. 122 ; Tucker $\nabla$.

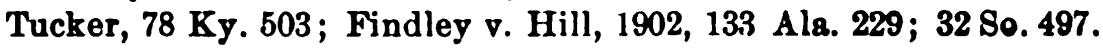


records is very great. Many ignorant persons spell their names in different ways at different times, and many cannot spell them at all.

Where in a chain of title we see land conveyed to a person by a certain name and afterward the same land is conveyed by a person of the same name, the legal presumption arises that the persons are the same-the identity of names prima facie establishes the fact of identity of persons, and this presumption is generally sufficient for practical purposes ; though, of course, evidence may be received to rebut it. ${ }^{18}$

\$42. Names-Effect of discrepancies-Idem sonansNiddle name.-While it is desirable that the names of parties, if possible, should always be stated correctly, nevertheless errors or discrepancies in names will not invalidate the title, but will often make additional evidence necessary to identify the party, and this evidence is sometimes difficult to obtain.

In many cases the difference in name will be of such a character as to be considered immaterial.

Of frequent application in this connection is the familiar doctrine of idem sonans-where to the eye the names are different, by reason of difference in spelling, but to the ear are the same. ${ }^{19}$

So other differences than those of spelling have been sometimes held to be immaterial; as, for example, a variation of the middle name or initial, or an omission of it entirely, has been held to be of no consequence. ${ }^{20}$

Such cases are based largely upon the common law doctrine that the middle name or initial is no part of a per-

${ }^{26}$ Stebbins v. Duncan, 108 U. S. 32; Tillotson v. Webber, 1893, 96 Mich. $144 ; 55$ N. W. 837.

19 E. g., where the grantee in a deed is Mitchell Allen and the next deed in the chain of title is from Mitchell Allain, it will be presumed that they are the names of the same person. Guertin v. Mombleau, 1893,144 Ill. $32 ; 33$ N. E. 49.

${ }^{20}$ Games v. Stiles, 14 Pet. 322 ; Schofield v. Jennings, 68 Ind. 233. 
son's name: this doctrine arose in times when the baptismal name was the important means of distinguishing one person from another, and, as each person had properly but one baptismal name, the early authorities regarded but this alone-this "Christian name" was specially looked to, even to the neglect of the family name, or "surname" (which was "super nomen," a name over or added to "the name," and in its origin of secondary importance.)

The common-law rule recognizing but one Christian name is still quite generally in force. But as it is evident that the middle name or initial is now one of the usual means of distinguishing persons having names otherwise the same, many courts have shown dissatisfaction with the old doctrine, and, especially in matters involving the title to real estate; it is nowadays not prudent to consider the middle initial or name as of no importance. ${ }^{21}$

§43. Fictitious persons-Grantee must be in esseFictitious names.-A conveyance to a fictitious person is void. If the owner of property, in order to escape some burden or liability as its owner, or for other reasons, conveys it, not to some real person who takes it under an assumed name, but to an imaginary or fictitious person,

${ }^{21}$ Cunningham v. Neeld, 1901, $198 \mathrm{~Pa}$. St. 41; 47 Atl. 954; Ambs $\nabla$. Railroad, 1890, 44 Minn. 266, 270; 46 N. W. 321.

The middle name has been regarded as of importance in cases involving the question of record notice to third parties where the difference in names has consisted solely in the difference of the middle name or initial. For example, in Crouse v. Murphy, 1891, $140 \mathrm{~Pa}$. St. 335; 21 Atl. $358 ; 23$ Am. St. R. $232 ; 12$ L. R. A. 58, the real name of the owner of land was Daniel J. Murphy, and the title to the land was held in that name ; a judgment against him by the name of "Daniel Murphy," on a note signed in the same way and so indexed, was held not to be a lien on the land as against a bona fide purchaser for value who had searched for judgments against Daniel J. Murphy. See S. P., Davis v. Steeps, 1894, 87 Wis. 472; 58 N. W. 769 ; 23 L. R. A. 818; Fincher v. Hanegan, 1894, 59 Ark. 151 ; 26 S. W. 821 ; 24 L. R. A. 543 . 
the conveyance is entirely void, and title to the property remains in the would-be grantor, for the simple reason that there is no grantee in his attempted conveyance. ${ }^{22}$

For a person not in being cannot be the grantee of an immediate estate, as, for example, an unborn child, though en ventre sa mere ${ }^{23}$ or a person deceased at the time of the deed's execution. ${ }^{24}$

Any real person, however, may be a grantee or mortgagee under a fictitious or assumed name, ${ }^{25}$ and the real owner of property may make a valid conveyance of it under any name he may care to assume. ${ }^{26}$

\section{\$44. Additions to name by way of recital-Effect.-} It is usual to add to the names of parties a statement as to their places of residence; often the occupation or calling of the parties is also designated, and these particulars are of assistance in identifying the parties.

22 Muskingum Turnpike Co. v. Ward, 13 Ohio 120; 42 Am. Dec. 191; David v. Ins. Co., 83 N. Y. 265 ; 38 Am. R. 418.

"Morris v. Caudle, 1899, 178 Ill. 9; 52 N. E. 1036; 44 L. R. A. 489 ; $69 \mathrm{Am}$. St. R. 282; though he may be the grantee of an estate in remainder. See v. Derr, 57 Mich. 369; 24 N. W. 108. See Davis v. Hollingsworth, 1897, 113 Ga. 210; 38 S. E. 827 ; 84 Am. St. R. 233, and note.

24 Neal v. Nelson, 1895,117 N. C. $393 ; 23$ S. E. 428 ; 53 Am. St. R. 590 , though by statute in Kentucky the deceased's children take in such case. Northern Lake Ice Co. v. Orr, 1898, 102 Ky. 586; 44 S. W. 216.

${ }^{25}$ Scanlan v. Grimmer, 1898, 71 Minn. 351; 74 N. W. 146; 70 Am. St. R. 326; Wilson v. White, 1890, 84 Cal. 239; 24 Pac. 114.

× David v. Ins. Co., 83 N. Y. 265; 38 Am. R. 418; Weihl v. Robertson, 1896, 97 Tenn. 458; 37 S. W. 274; 39 L. R. A. 423; Blackman v. Henderson, 1901, 116 Iowa 578; 87 N.W. $655 ; 56$ L. R. A. 902. In David v. Ins. Co., 83 N. Y. 265, defendant insurance company resisted payment to plaintiff of a loss by fire on the ground that she had no title to the property which she had insured with defendant. H. J. David, the frrmer owner, had conveyed the property to a fictitious person, "Marx Iavid," and then in the name of "Marx David" had conveyed to plaintiff, who insured the property, which afterward burned. The court said that the conveyance to "Marx" was inoperative; the title remained in H. J. David, who then could convey, as he did, to plaintiff, using the name "Marx." Hence, the plaintiff had title as against H. J. David, and-no other claimant to the property appearing-could maintain her action against defendant. 
It is also customary to add further descriptions, as that the party is " unmarried," or "heir of " a certain person. So far as these recitals aid in determining the identity of the parties they are useful, but their effect is often misunderstood by those dealing in real property, and it is quite generally assumed (among laymen, at least) that such statements are evidence of the facts stated and may be relied on as such.

But it is clear that the statement by a grantor that he is "a single man," cannot preclude his wife, if he is really married, from claiming her dower or its statutory substitute.

So a description in a deed of the grantors as " heirs of" a former owner is not ordinarily proof of that fact. ${ }^{27}$

When, however, recitals of such facts are found in "ancient" deeds-this term is applicable generally to a deed thirty years old-they may generally be taken as prima facie evidence of the facts recited. ${ }^{23}$

$\$ 45$. Partnership as parties. - A conveyance of real property by or to a partnership should not generally be made in the firm name.

Where it is intended to take a conveyance of partnership real property the prudent method is to have all the partners join in the conveyance, for, if they do not all join, those making and executing the conveyance must have

27 Wolf v. Holton, 1895, 104 Mich. 107 ; 62 N. W. 174; McCarty v. Rochel, 1892, 85 Iowa 427; 52 N. W. 361.

* Norris v. Hall, 1900, 124 Mich. 170,$175 ; 82$ N. W. 832 ; 7 D. L. N. 155; Fulkerson v. Holmes, 117 U. S. 389, 397 ; Harmon v. Stearns, 1897, 9.5 Va. 58,63 ; 27 S. E. 601 ; Young v. Shulenberg, 1901, 165 N. Y. $385 ; 59$ N. E. 135 ; 80 Am. St. R. 730 ; and see Laws Wis. 1901, ch. 28, making such recitals prima facie evidence after twenty years' record. And in many cases recitals may estop the party making them, or one in privity with him from disputing the facts recited. But even as to the party making them, they cannot be allowed in all cases to work an estoppel; for example, a statement in a deed by a minor that she is " unmarried and of age" will not prevent her disaffirmance of the deed after she reaches her majority. Wieland v. Kobick, 110 Ill. 16; see post, § 320. 
authority from the partnership to do so ; and while this authority may be inferred from circumstances-such as the presence of the other partners ${ }^{29}$-it is not best to leave such a matter open for proof.

A partnership not being a legal person, either natural or artificial, cannot, as such, be the grantee of the legal title to lands..$^{30}$

A conveyance of lands to partners for the purpose of their business should contain their individual names in full, with a recital that they are partners doing business under their firm name, and that they wish the property conveyed to them as partners and as part of their partnership estate.

Should the conveyance be made to the partnership in the firm name, its effect upon the legal title to the land described will depend somewhat on the form of the firm name. This form varies : it may be "John Doe \& Co.," or "Doe \& Roe," or-not containing the names of persons at all- "The United States Improvement Co.," or a similar name more appropriate for a corporation.

There is not perfect agreement among the authorities as to the effect of conveyances in all such cases, but the general rules appear to be, that:

Where the names of some of the partners appear in the name, followed by "\& Co." the effect is to vest the legal title in those named, but not in those indicated by "\& Co." " 1

Where the firm name is made up of the surnames of the several partners, the effect is to vest the title in all whose surnames appear..$^{82}$

Where the firm name does not contain the names of persons, the conveyance to the partnership in such name is not void for uncertainty as to the grantee (as has been

McGahan v. Bank, 1895, 156 U. S. 218.

๑ Silverman v. Kristufek, 162 Ill. 222; 44 N. E. 430.

Winter v. Stock, 29 Cal. 407 ; 89 Am. Dec. 57.

2 Cole v. Mette, 1898, 65 Ark. 503; 47 S. W. 407 ; 67 Am. St. R. 945. 
sometimes contended), but an equitable title passes to those who actually comprise the partnership. ${ }^{33}$

$\S 46$. Corporations as parties.-So far as form is concerned, the chief features that distinguish the conveyance of an ordinary business corporation from the conveyance of an individual are the execution and acknowledgment. Consideration will be given later to these features. ${ }^{34}$

The corporation, whether grantor or grantee, must be designated, and if it is grantor the conveyance must purport to be the conveyance of the corporation, and not merely that of certain officers of the corporation. ${ }^{35}$

And, for the same reasons that an unreal, fictitious and non-existing individual cannot be a grantee, an alleged corporation which, because of some defect in organizing it, is not in existence, cannot be a grantee..$^{36}$

But if such an attempt at conveyance has been made, though the legal title does not pass by it for want of a grantee, the supposed corporation has an equitable title, and on incorporating properly, may compel the grantor, who retains the consideration paid for the conveyance, to make a new conveyance to it. ${ }^{37}$

a Kelly v. Bourne, 15 Ore. 476; 16 Pac. 40.

3 See post, $\S \$ 240,249,294$.

${ }^{25}$ Norris v. Dains, 1894, 52 Ohio St. 215 ; 39 S. E. 660.

* Wall v. Mines, 1900, 130 Cal. 27, 43; 62 Pac. 386.

$"$ Benevolent Society $\nabla$. Murray, 1898, 145 Mo. 622; 47 8. W. 501. 


\section{CHAPTER VI.}

\section{RECITALS.}

\$47. Recitals in general.

48. Recital often used to show purpose of conveyance.

49. Notice from recitals.
550. Recitals in conveyances by sheriffs, administrators, etc.

51. If not required, recitals may yet be useful.

\$47. Recitals-In general.-There are many kinds of recitals in deeds; they may be very brief (as in the instances cited above, $\$ 44)$; they may be in the nature of a preamble, beginning with "Whereas" and ending just before the words "Now this indenture witnesseth," they may contain a more or less extended history of the title to the property conveyed-as, after the description of the property-"being the same premises conveyed to - by , by a deed duly recorded in, etc." Though this last kind of recital seems not used as often as it formerly was, it is nevertheless still used by many conveyancers. If such a recital were made accurately and carefully in successive conveyances of the same property-each recital carrying back the title one step-in the end the recitals combined would form a connected history of the title.

Recitals, while generally introductory, and found in the " premises," are not always so ; the term is applied to statements regarding the estate or title found in other parts of the deed. $\S 22$.

${ }^{2}$ See, for example, ante, $\$ 36$. As to recitals in deed poll, see ante, 
$\S 48$. Recital often used to show purpose of conveyance.-A recital may set forth the purpose of the grantor in making the conveyance; in such a case it may throw light upon ambiguous terms occurring in other parts of the conveyance, and may be used in construing it where the meaning is not clear.

For example, where a landuwner conveys land to a trustee by a deed reciting that he is "desirous of making arrangements to liquidate said debts, and to secure a permanent support and maintenance for the use of his wife and children," and by a later clause in the deed directs the trustee, on the death of the wife, to convey the lands to "all the children" of the wife-the court, in construing the instrument, regards the expressed intention of the grantor as contained in the recital and holds that "children" means only the grantor's children, and does not include the wife's children by a second marriage-in spite of the later clause mentioning all the wife's children. ${ }^{2}$

$\$ 49$. Notice from recitals. - It should be remembered in investigating titles that one important effect of a recital in a conveyance is that of giving notice to all who derive title through the conveyance.

If a purchaser of land accepts a conveyance which refers to the fact that some previous owner has granted an interest in the land, he has notice of that fact when he reads his own conveyance, and it makes no difference that the grant by the former owner is unrecorded. If, for instance, the vendee's deed contains a recital that this conveyance "is subject to the oil lease" given by a former owner to a third person, the vendee must take notice of the third person's outstanding interest in the land under the "lease"; and if in legal effect the lease referred to is a sale of a part of the land, the vendee must, by virtue of

${ }^{2}$ McCoy v. Fahrney, 1899,182 Ill. $60 ; 55$ N. E. 61 (in this report the deed is set out at length, and the general form of recitals in such a case is shown). 
such a recital, be regarded as having notice of a prior unrecorded absolute grant of the oil in the land bought by him. ${ }^{3}$

The person accepting a conveyance containing such recitals and references cannot plead ignorance of them; he is presumed to have read his deed, and is chargeable with notice of the facts recited in it which affect his title. If, for example, he actually knows of one mortgage on the land (and is willing to buy the land, or take a mortgage on it, subject to the mortgage he knows of), and accepts a conveyance which refers to two mortgages, he must take his title subject to the two mortgages, though one of them is unrecorded, and though he did not read the reference to the two in his conveyance."

Such are cases where the recital of some fact affecting the title is in the conveyance under which the purchaser immediately holds. But the principle applies to recitals in all conveyances under which he must derive title; hence he is chargeable with notice of matters affecting the title recited in a conveyance to his grantor, though not recited in the conveyance to himself. ${ }^{5}$

The land he buys may thus be subject to some restriction as to its use contained in a deed from some former owner, ${ }^{6}$ or it may be subject to a trust, ${ }^{7}$ or, by the recital in the consideration clause of a conveyance by a former owner, through which conveyance the present grantee must derive his title, that the consideration is "to be paid," the land in the present grantee's hands may be subject to a vendor's lien for the purchase-money. ${ }^{8}$ In general, therefore, a purchaser of real property is charged

- Jennings $\nabla$. Bloomfleld, 1901, 199 Pa. 638; 49 Atl. 135.

- Hamilton v. Nutt, 34 Conn. 501.

${ }^{3}$ Cordova v. Hood, 17 Wall. 1; Town v. Gensch, 1899, 101 Wis. 445;

76 N. W. $1096 ; 77$ N. W. 893; Baker v. Mather, 25 Mich. 51.

- Whitney v. Union Ry. Co., 11 Gray 359; 71 Am. Dec. 715.

'Dean v. Long, 122 Ill. 447, 460; 14 N. E. 34.

- Cordova v. Hood, 17 Wall. 1; Deason v. Tuylor, 1896, 53 Miss. 697. 
with notice of recitals in each conveyance in the chain of title to the property; and, if any of such conveyances contain references to others not in the direct chain of title, he is chargeable by such reference with notice of these conveyances and their contents. ${ }^{9}$

$\$ 50$. Recitals in conveyances by sheriffs, administrators, etc.-Deeds of executors, administrators, guardians, sheriffs and others who are acting in representative or official capacities, usually contain one or more formal recitals setting forth the authority under which the grantor acts, and briefly giving a history of the proceedings leading to the conveyance.

Such official deeds (especially those of sheriffs) are often required by statute to contain recitals of certain facts, and it being thus the duty of the grantor to make such recitals, they are, when made, prima facie evidence of the truth of the facts stated. ${ }^{10}$

While it is regarded as the better practice to have all such deeds contain recitals, yet administrators' or sheriffs' deeds are not generally held invalid if the usual recitals are lacking or incomplete, for the existence of the facts giving authority to convey may be shown otherwise than by the recitals. ${ }^{11}$

There are, however, decisions holding that a sheriff's deed on execution must recite everything necessary to make a valid title-and a deed which does not recite the existence of a judgment, execution and levy is fatally defective. ${ }^{12}$

9 White v. Foster, 102 Mass. 375, 380; Bank v. Delano, 48 N. Y. 326 ; Gaston v. Dashiell, 55 Texas 517; Smith v. Lowry, 113 Ind. 37 ; 15 N. E. 17.

${ }^{10}$ Bray $\nabla$. Adams, 1893, 114 Mo. 486, 491; 21 S. W. 853; Longworth $\nabla$. Bank, 6 Ohio 536 ; Miller v. Miller, 89 N. C. 402.

"1'Hill v. Reynolde, 1899, 93 Maine 25; 44 Atl. 135; Bartlett v. Bartlett, 1890, 34 W. Va. 33; 11 S. E. 732.

12 Byers $\nabla$. Wheatley, 3 Baxt. (62 Tenn.) 160. 
$\$ 51$. If not required recitals may yet be useful.-Irrespective of statutes, recitals explaining the capacity in which the grantor acts and his authority for acting are quite customary in certain kinds of deeds.

Where an instrument has created a trust and has given the trustee power to convey the property, if he afterward carries out or executes the power thus given him, the conveyance by which he does so ought regularly to indicate not only the capacity in which he executes it, but also should show by recital the facts which warrant its execution.

For example, a deed by an executor under a will giving him power to convey may be expressed, as to the recitals, as follows:

This indenture made this (date) between A B, of etc., executor of the last will and testament of $C D$, late of - deceased, of the first part, and X Y, of $\longrightarrow$, of the second part, witnesseth: Whereas, the said $C D$, by his said last will bearing date the - of - 19-, devised the lands hereinafter mentioned to his executor aforesaid, in trust, to hold the same during the minority of his son, $\mathrm{N}$ $\mathrm{D}$, and on his attaining his majority, or on his death, if it should sooner occur, to sell and convert the same into money for the purposes in said will specified, with power in such case to sell in such manner as he should deem proper; and, Whereas, the said N D died on - before attaining his majority, now this indenture witnesseth: That the said party of the first part, by virtue of the power and authority to him given in and by said last will and testament, and in consideration of the sum of, etc. (words of grant, description).

And the form may be varied to adapt it to other circumstances-as where the trust is created and the power given by another instrument than a will.

Such recitals may be of importance to the grantee from the trustee, for should his title be attacked on the ground that the conveyance to him was not authorized by the existing circumstances, a recital of those circumstances showing that it was proper for the trustee to make the 
conveyance, will be, in many states, prima facie evidence that the proper circumstances did exist. ${ }^{13}$

${ }^{13}$ Savings Society v. Deering, 66 Cal. 281; 5 Pac. 353; Beal v. Blair, 33 Iowa 318; Tartt v. Clayton, 109 Ill. 579. 


\section{CHAPTER VII.}

THE CONSIDERATION.

\$52. Apparent conflict as to necessity of a consideration.

53. No consideration neceseary to a feoffment at common law-Effect of American statutee.

54. Seal importing consideration.

55. The equitable doctrineEffect of the statute of nses.

56. What makes a deed of bargain and sale.

57. How the foregoing principles operate.

58. Parol evidence as to congideration.

59. Parol evidence of additional consideration.
§60. Such evidence not restricted by most courte.

61. Parol evidence rule more strictly applied by some courts.

62. Parol evidence when statement as to consideration is contractual.

63. The true consideration may generally be shown by parol.

64. Showing assumption of mortgage.

65. True consideration may not be shown as between the parties to defeat deed.

66. Statement of consideration not binding on others.

\$52. Apparent conflict as to necessity of a consideration.-In the premises of a deed there is usually a recital of the receipt of consideration by the grantor. The form of this will vary with the circumstances of the case. The simple receipt of money may be stated, or the recital may be in the form of a contract; as, "In consideration of the sum of one dollar, and the agreement of the party of the second part" to do certain things.

Questions that arise at the outset are, whether any consideration is necessary, and, if so, whether it should be stated in the deed.

Upon these questions we find statements in the author(63) 
ities which are apparently conflicting. For example, it is sometimes stated that "A deed made upon no consideration, whether one be expressed or not, is valid," 1 while, on the other hand, Blackstone, in speaking of the requisites of a deed, says: "The deed must be founded upon good and sufficient consideration." 2 And in a recent case $^{3}$ a deed was offered in evidence, as a foundation for plaintiff's claim of title, in which the consideration clause had been changed by erasures three different times, the result being that it read: "In consideration of - dollars." The court declared it inadmissible in evidence, because it was left without the consideration required by law to support it.

The causes of this seeming conflict will be clearer if we remember that there have been different kinds of conveyances, each capable of transferring title to real property, but each depending for its efficacy upon different principles. And while the authorities, in making statements like the foregoing, often speak in general terms of a "deed," they are not always, in reality, speaking of the same thing.

$\$ 53$. No consideration necessary to a feofiment at common law-Effect of American statutes.-By the ancient common law a gift of land to one and his heirs, accompanied by livery of seisin, was effectual in law to convey the entire estate without any consideration. This was the feoffment referred to above. ${ }^{3 a}$ The conveyance operated by transmutation of possession. There need have been no charter or deed, and though, as before stated, a deed became usual when not necessary, in this deed there need have been no consideration stated, at common law, nor need there have been any proved.

${ }^{1}$ Randall v. Ghent, 19 Ind. 271; Howard v. Turner, 1899, 125 N. C. 107, 109 ; 34 S. E. 229.

Bl. Com. II, p. 296.

3 Catlin Co. v. Lloyd, 1899, 180 Ill. 398; 54 N. E. 214.

s See ante, § 11. 
Statutes of our states have been mentioned "which provide that all deeds or other conveyances of land, duly executed by the grantor, shall be valid to convey the land "without any other act or ceremony whatever;" and where such are not found, statutes of a slightly different character exist, not alluding to livery of seisin, but impliedly doing away with it by declaring how conveyances of real estate shall be made.

It was early considered in this country that statutes of this kind made a deed properly executed equivalent to a feoffment.

Green $\mathbf{v}$. Thomas ${ }^{5}$ contains a clear statement of this view. That was an action by the grantor's heirs to recover land, and it was urged that the deed made by the grantor was void, because without consideration. The court says: "At common law there could be no feoffment without livery of seisin, and in some jurisdictions deeds not accompanied with this ceremony can never be regarded as feoffments; but it is otherwise in Maine and Massachusetts, where it is provided that all conveyances signed and sealed, shall be valid to pass title to the lands described in them without any other act or ceremony whatsoever; therefore a deed is regarded as having the effect of a feoffment if necessary to uphold it. At common law a feoffment was valid without any consideration, or, if any was implied, it was the feudal duty or service to the grantor. This deed then operates under our statute as a feoffment."

As illustrating the view of this matter where the statute is somewhat different, see Baker v. Westcott, ${ }^{6}$ where the court states that it is not necessary that a consideration should appear on the face of the conveyance itself or by pleading and proof, because the statute requiring that

- See supra, $\$ 16$.

11 Maine 318.

- 73 Texas 129, 133; 11 S. W. 157.

5-BREws. CoN. 
a conveyance shall be in writing, signed and sealed by the grantor, was intended to dispense with the formality of livery of seisin and to make such a deed practically equivalent to the old feoffment. ${ }^{7}$

Hence American deeds under such statutes, being regarded as equivalent in effect to the old common law feoffment, may properly be said to require no consideration.

$\S 54$. Seal importing consideration.-Another somewhat peculiar doctrine has contributed to the same result, i. e., the dispensing with a consideration. This doctrine is usually briefly expressed as "A seal imports a consideration."

It is interesting to note the way in which this doctrine arose. Writing was not in early times employed for many purposes. It was a solemn matter to express an agreement in writing, and as people could not sign their names, they affixed their seals. A charter or writing whereby a man formally expressed an intention of gift, or bound himself to do something, was held to afford conclusive proof of the matter expressed in the sealed instrument (unless fraud, force or forgery were shown).

In very early times it appears that even an unsealed charter might have this effect. It came, however, to be settled that the charter must have affixed to it the seal of the person whose act or promise it recorded in order to be admitted as conclusive evidence against him.

When writing came into common use and men signed their names, the old rule survived, so that deeds were regarded as superior to other writings. By other writings a man was, in general, no more conclusively bound than by spoken words; agreements made by deed, however, were enforceable in law by reason of their formal and solemn character, and without any exception in the case of gratu-

${ }^{7}$ And see Ivey v. Granberry, 66 N. C. 223. 
itous promises. As to agreements made without deed, though in writing, it became established that they could not be enforced by the one to whom the written promise was made, unless he had given some valuable consideration for the promise.

After this doctrine had become established, the efficacy of a deed, in conclusively binding a man who executed it, was explained by saying that a deed in law imports a consideration. This explanation, though it is generally regarded as erroneous, became a rule of law, so that we now constantly see it stated that "a seal imports a consideration." 8

$\$ 55$. The equitable doctrine. - On the other hand, the doctrine that a consideration is necessary arose from the importance which equity attached to the consideration. Equity disregarded the rule as to the feoffment, and disregarded the rule as to the seal importing a consideration.

When a conveyance was made without consideration, and without declaring the uses for which the conveyance was made, the doctrine of the court of chancery was that the intention of the donor must have been that the donee should hold the land mentioned in the deed, not for his own benefit, but for the benefit of the donor. It was considered, that is, that there was no motive or reason for the grantor's conveyance, and, there being no motive or reason, it must have been the intention that the donee or grantee was to hold to the use of the grantor; that is, the use was said to come back, or "result," to the grantor.

- Brockway v. Harrington, 1891, 82 Iowa 23 ; 47 N. W. 1013; Rendleman's Case, 1895, 156 Ill. 568 ; 41 N. E. 223; Saunders v. Blythe, 1892, 112 Mo. 1; 20 S. W. 319; Cosgrove v. Cummings, 1900, 195 Pa. St. 497; 46 Atl. 69. See Williams Real Prop., pp. 180, 181; Holmes Com. Law, pp. 272-3; Holland Jurisprudence, p. 246, note: "It has been given as the reason of the sufficient character of a deed that it imports consideration. The statement is artificial on the face of it, and it becomes donbly so when we remember that deeds were binding before the doctrine of consideration had been worked out." 
Only two kinds of consideration were regarded as affording a sufficient motive: either blood (i. e., natural affection felt toward a relative), or money. Where the consideration was natural affection for a relative, the grant took the form of a "covenant to stand seized to uses." The consideration of natural affection was sufficient to "raise a use" in favor of the covenantee. Where the consideration was money - the grant being a "bargain and sale"- the amount was immaterial, for any amount was sufficient evidence of the intention of the donor to part with the beneficial, as well as the legal, interest in the lands. ${ }^{9}$

These different kinds of consideration came to be spoken of as "good" and "valuable"-but a valuable consideration need not necessarily be pecuniary or capable of being measured in money: for example, marriage is a valuable consideration. ${ }^{10}$

\$56. Effect of the Statute of Uses.-The bargain and sale.-When the Statute of Uses ${ }^{11}$ transferred the legal estate to the use "the bargain and sale" and "covenant to stand seized," which had formerly been simply equitable conveyances, became legal. After that statute it became further necessary to a feoffment that there should be either a consideration for the gift, or that it should be expressed to be made, not merely as formerly to the feoffee, but "unto and to the use of" the feoffee. This was regarded as necessary to prevent the resulting or coming back to the feoffor of the estate; for, if there had been neither consideration nor an expression of the use of the feoffee, the donor would himself, according to the doctrine of equity, have had the use, and then the statute

' Digby Hist. L. R. P., p. 329; Jackson v. Alexander, 3 Johns. 484; 3 Am. Dec. 517.

10 Prewit v. Wilson, 103 U. S. 22.

" 27 Hen. VIII, ch. 10, 1535. 
of uses in effect directed that he who had the use should have the legal seisin and estate.

Most of our American deeds have been based upon the " bargain and sale," and where a deed is considered as a deed of bargain and sale and not as a feoffment at common law, it is generally held that a consideration must either be expressed in the deed or otherwise proved.

Hence, the court in Catlin Co. v. Lloyd, ${ }^{12}$ which case concerned a bargain and sale deed, is correct in holding that there must have been a consideration for the deed in question shown in some way; but whether the erasures did really leave the deed without consideration may be doubted, for "__ dollars" would seem to mean some dollars; and recent similar cases hold such to be a sufficient statement of consideration. ${ }^{13}$

§57. What makes a deed of bargain and sale. - It is not necessary that the words bargain and sale be used to constitute a deed of bargain and sale.

In Havens v. Seashore Co., ${ }^{14}$ the contest centered in a deed made in 1788 (one hundred years before the case was decided). The consideration stated in the deed was sirteen pounds; the words of conveyance used were "remise, release and quit claim," and it was contended that they were not words of conveyance, but only of release, and that as the grantee was without any right in the land it could not operate as a deed of release to him. The court, however, says that any instrument which shows that title was meant to be given in return for value received is effectual.- "Words to raise a use and a consideration to support it, being all that is requisite to call the statute of uses into operation, and constitute a bargain and sale * * ${ }^{*}$ The deed

12180 Ill. 398 (cited above $\$ 52$ ).

"Jewell $\nabla$. Walker, 1899, 109 Ga. 241, 245; 34 S. E. 337 ; Murray $\nabla$. Klinzing, 1894, 64 Conn. 78; 29 Atl. 244.

14 1890, 47 N. J. Eq. $365 ; 20$ Atl. 497. 
shows on its face that it was founded on a valuable consideration paid by the grantee * * effect must be given to the deed as a bargain and sale."

\$58. How the foregoing principles operate.-The decision just cited enforces the principle acted on by courts that deeds will be sustained, if possible, and made to operate either as one kind or another when no settled rule prevents.

And a consideration of the preceding paragraphs will enable one to appreciate the reason and effect of a statement like that of Judge Sharswood, ${ }^{15}$ that a deed shall be so construed as to give it effect, and that if it cannot be treated as a bargain and sale because there was no pecuniary consideration, yet if the consideration of blood did exist it shall be supported as a covenant to stand seized, and further that a recorded deed will be construed as having the effect of a feoffment or as a deed under the statute of uses, as will best accomplish the intention of the parties.

And a consideration of the same principles will also enable one to understand how it is, on the other hand, that an apparently solem $n$ instrument, in general form a deed, cannot always be sustained as one. For example, see Springs v. Hanks, 5 Ire. (N. C.) 30 , where such an instrument could not be sustained as a conveyance, because there was neither a valuable nor a good consideration to make it operate under the statute of uses, nor was there livery of seisin (or its equivalent) ${ }^{16}$ to make it operate as a feoffment at common law.

\$59. Parol evidence as to consideration-To contradict receipt.-There is a familiar rule of law regarding written instruments, which in its most general form is

${ }^{16}$ In Eckman v. Eckman, 68 Pa. St. 460, 470.

${ }^{16}$ See above $\$ 53$. 
stated as : Parol evidence is inadmissible to contradict or vary the terms of a written contract.

Doctrines have developed in regard to the admission of parol evidence concerning the consideration of a deed, that, as applied, often materially change the apparent effect of other clauses in the deed; these doctrines also have, in many cases, an important bearing on the question as to the proper method of stating the consideration -and if we consider the matter of form merely, they should be referred to at this point.

The acknowledgment of the receipt of the consideration was by the earlier decisions held conclusive upon the grantor; hence after he had admitted the payment of the consideration he was not allowed to show in an action against the grantee for the purchase-money that it had not in fact been paid. He was held estopped by his - statement under seal that he had been paid, from showing the contrary. This was the doctrine in some American courts as late as $1860 .{ }^{17}$

But, as a fact, the acknowledgment of payment was generally a mere formal matter, having no special meaning, except to prevent a resulting trust, and, on the ground that it was merrely a receipt, it has come to be held that the fact of payment may be contradicted in this case as in the case of any other receipt. ${ }^{18}$

So upon this principle it is generally held that the grantor may now, in an action against the grantee, show that he has not received a consideration, though he acknowledges that he has.

It is quite usual for the consideration clause in a deed

17 See Mendenhall v. Parish, 53 N. C. 105; 78 Am. Dec. 269.

${ }^{18}$ This view seems to bave been adopted in this country earlier than in England. See Wilkinson v. Scott, 17 Mass. 249, 1821, where it was beld that the fact of payment may be disputed by the grantor in an action against the grantee, the court saying: "A receipt is always open to explanation, and this acknowledgment, though under seal, is nothing more than a receipt, for the seal gives it no additional solemnity." And see, to the same effect, Gully v. Grubbs, 1 J. J. Marshall 387. 
to recite more than a simple receipt of the money: as"In consideration of - dollars, to him in hand paid, the receipt whereof is hereby acknowledged; and the said party of the second part forever released and discharged therefrom;" that is, containing a release and discharge as well as a mere receipt. The fact that this release is contained in the recital does not, it seems, interfere with the now recognized rule that the statement of receipt of consideration may be disputed. ${ }^{19}$

$\$ 60$. Parol evidence of additional consideration.-Besides admitting parol evidence to contradict the statement of payment of a consideration, the courts now generally admit parol evidence of an additional consideration; as, where the sum named in the deed is $\$ 100$, and this has been actually paid, it may be shown that it was also agreed that more money should be paid in the future on the sale of the land by the grantee..$^{20}$

Some courts hold that any other or additional consideration than that expressed cannot be shown in this way, unless it is of the same kind as that expressed.

Hence, according to this view, a deed from husband to wife, expressed to be in consideration of love and affection, cannot be shown to be for a valuable consideration, i. e., $\$ 4,000$; for to show this would be to change the character of the deed. ${ }^{21}$ In Groves v. Groves, ${ }^{22}$ a deed was made from father to son, reciting a substantial money consideration; after the son's death his brother and sister attempted to show that the land was a gift to

\footnotetext{
${ }^{19}$ Stackpole v. Robbins, 47 Barb. 212, 219: "In speaking of a release as an extinguisher of itself, I do not understand the courts (e. g., 16 Wend. 460,$474 ; 1 \mathrm{~J} . \mathrm{J}$. Marshall, 387) to mean the releasing clause in a conveyance which usually accompanies an acknowledgment of receipt of money, but an absolute, separate and distinct release."

${ }^{20}$ Kickland v. Menasha Co., 68 Wis. 34 ; 31 N. W. 471; Jensen v. Crosby, 1900, 80 Minn. 158; 83 N. W. 43.

${ }^{21}$ Houston v. Blackman, 66 Ala. 559.

22 1902, 65 Ohio St. 442 ; 62 N. E. 1044.
} 
him, and that no consideration was paid ; for if the land came to him by gift his widow would have but a life estate, and his brother and sister would have the remainder in fee, whereas if it came to him by purchase his widow would take it in fee; but it was held that it was not competent to show that the title was acquired by gift rather than by purchase, and thereby change the line of descent. ${ }^{23}$

\$61. Such evidence not restricted by most courts.But the general rule now is that not only may a greater or less consideration than that recited in the conveyance be proved, but that one of a different kind or quality may be proved as well. For example, where the consideration expressed in a deed was $\$ 5$, and an attempt was made by an heir of the grantor to set aside the deed for fraud, shown by gross inadequacy of consideration, the grantee was allowed to show a consideration of a different species, i. e., "love and affection," as well as an additional valuable consideration. ${ }^{24}$

And see the discussion in McCrae v. Purmort, ${ }^{20}$ which is considered a leading case, in which, though the expressed consideration was money, it was permitted to be shown that iron of a specified quality and at a stipulated price was the real consideration.

Extending this principle, it has been held that though the expressed consideration in a deed to a railroad is "the benefit to be derived from the building of the road and one dollar paid," the grantor may show by parol evidence that the real consideration was the agreement of the company to erect a depot on the land conveyed, ${ }^{26}$ and in Dod-

and that the character of the consideration cannot be shown by parol to have been different from that recited in the deed, see Latimer v. Latimer, 1897, 53 S. C. 483 ; 31 S. E. 304 ; Christopher v. Christopher, 64 Md. 583 ; 3 Atl. 296.

* Carty v. Connolly, 1891, 91 Cal. 15, 19; 27 Pac. 599.

${ }^{23} 16$ Wend. 460; 30 Am. Dec. 103.

* Lonisville \&c. R. Co. v. Neafus, 1892, 93 Ky. 53; 18 S. W. 1030; Gulf Ry. Co. $\nabla$. Jones, 1891, 82 Texas 156 ; 17 S. W. 534. 
der v. Snyder, ${ }^{27}$ under the rule that the true consideration may be shown, the plaintiff, grantor, was permitted to show that in addition to the expressed consideration of $\$ 2,000$ his grantee had agreed to build a fence between the land conveyed and other land of the plaintiff; and the fence not having been built, plaintiff now sues for damages arising from the escape of his cattle.

And the grantor may show that he was to have the privilege of raising a crop for himself on the land conveyed. ${ }^{28}$

As illustrating how far the courts have gone in practically incorporating new terms in a deed, under the rule allowing the true consideration to be shown by parol, see Hall v. Solomon, ${ }^{29}$ which was an action by the grantors to restrain the grantee from using the premises for the sale of intoxicating liquors, and evidence was offered of a parol agreement that part of the corrsideration for the grant was the understanding that the property should not be used for such purposes. It was objected by the grantee that such evidence made what purported to be an absolute deed one upon condition, and created by parol a "negative easement," and that the parol agreement was inconsistent with the deed. But the court held that the parol agreement, being a part of the consideration for the sale, could be shown, and the admission of this parol evidence was no infringement of the rule that parol evidence is not admitted to contradict, vary or explain a written instrument.

And, again, the effect of this doctrine, that the true consideration may be shown, has been to allow a parol reservation to the grantor of certain rents and profits of

${ }^{27} 1896,110$ Mich. $69 ; 67$ N. W. 1101.

${ }^{28}$ Breiten wischer v. Clough, 1896, 111 Mich. 6; 69 N. W. 88 ; 66 Am. St. R. 372.

20 1892, 61 Conn. 476; 23 Atl. 8i6; 29 Am. St. R. 218. 
land granted which would, under the deed, pass to the grantee of the land. ${ }^{30}$

\$62. "Parol evidence rule" more strictly applied by some courts.-Some of the decisions just cited plainly make very uncertain the application of the rule rejecting parol evidence, and, indeed, seem to practically do away with it in particular cases.

They will not always be followed. For example, where it was attempted to be shown that a railroad company in taking a grant of a right of way for the expressed consideration of $\$ 230$, had made a parol contract with the grantor regarding a crossing over the right of way, the court held that this agreement must be treated either as a reservation or a part of the consideration, and that it is clear that a reservation cannot rest in parol, and that when the consideration is "fully stated" it is not competent to add to or vary it by parol evidence "for the purpose of varying the effect of a deed." 31

\$63. Parol evidence when statement as to consideration is contractual.-While it is not always possible to say how far the "parol evidence" rule will be recognized where the statement of the receipt of consideration is in the ordinary form, there are, nevertheless, limits placed on the admission of parol evidence to show even what may have been the true consideration, when the recital as to the consideration is contractual in its form and character.

The principle upon which oral evidence is admitted to

¿ Bourne v. Bourne, 1891, 92 Ky. 211; 17 S. W. 443.

a Schrimper v. Chicago \&c. Ry. Co., 1901, 115 Iowa 35; 82 N. W. 916; 87 N. W. 731. In Moffitt v. Maness, 1889,102 N. C. 457,$459 ; 9$ S. E. 399, the court says: "There is, we fear, too great a tendency to relax the well settled rules of evidence against the admissibility of parol testimony to contradict, vary or add to the terms of a written contract . . . the courts . . . are gradually construing away a principle which has always been considered one of the greatest barriers against fraud and perjury." 
contradict an ordinary receipt (that is, one not contained in a deed) is, that the receipt is generally not a contract, but is simply some evidence of a fact, hence the receipt, being simply some evidence of a fact, may be disputed. But when the receipt goes further, and embodies in itself the terms of a contract, parol evidence is inadmissible to vary or contradict its terms, in the absence of fraud..$^{32}$

The acknowledgment in a deed of conveyance of the receipt of the purchase-money is ordinarily not contractual in its nature. It is therefore like the ordinary receipt, and hence there is good reason for holding, as has been held, that the fact of payment may be disputed and contradicted.

Ordinary simple receipts-not, that is, in a deedwhen they are contractual, may not be varied by parol. So on the same principle when a statement as to consideration in a deed is contractual it may not be contradicted or varied any more than an ordinary receipt may be.

It is not unusual for a deed to recite the payment of money, and also some further agreement.

For example, the consideration clause in a deed to a railway company recited a payment of money, and that the railway company was to provide and maintain for the use of the grantors certain grade crossings, cattle-guards, etc. The company had complied with the terms thus expressed, and in this action, brought by the grantor for damages to his land caused by overflow, the plaintiff attempted to show that the cause of the overflow was the failure of the company to dig and maintain a ditch, and alleged that the company had agreed to do so as a part of the consideration for this deed. But it was held that the evidence was not admissible, the court saying: "If the parties express their contracts as to the consideration in terms which show that it is a contract, then it can no more be altered or varied than any other contract.

s2 Squires v. Amherst, 145 Mass. $192 ; 13$ N. E. 609 ; Cassilly v. Cassilly, 1898, 57 Ohio St. 582 ; 49 N. E. 795. 
When the common form of expression reciting a sum of money is departed from and an unusual provision inserted, thereby evidencing a contractual intention, it is as binding as any other contract." ${ }_{33}$

The statement of the consideration may be both a receipt for money paid and a contract, as in the cases just cited. In such cases, so far as it is a mere receipt it ought, on principle, to be susceptible of contradiction, while so far as it is a contract it should not be. ${ }^{34}$

In drawing deeds in which the statement of consideration is anything more than a mere recital of the payment and receipt of money, it is well to bear this principle in mind, and if any further agreement is inserted in the consideration clause, it should be inserted accurately and completely, so as to leave nothing open for parol proof.

$\$ 64$. The true consideration may generally be shown by parol. - With the limitations suggested in the last section (i. e., where the consideration clause expresses a contract, or is evidently fully stated), the principle is well established, in general, that the true consideration may be shown.

One application of this principle is to cases where land is sold by the quantity, at so much per acre or square foot, and there is either an excess or a deficiency.

For example, where land conveyed is described as "containing 140 acres more or less," the price being twenty-seven dollars per acre, and the consideration stated in the deed is what the number of acres mentioned would

\footnotetext{
w Jackson v. Railroad, 1893, 54 Mo. App. 636, 644 ; See also, Baum v. Lynn, 1895, 72 Miss. 932 ; 30 L. R. A. 441; 18 So. 428; Purinton v. Railroad, 46 Ill. 297.

s This question, however, does not appear to have arisen in the case of a conveyance, but the clauses are analogous to bills of lading, which are held to be both receipts and contracts, and explainable in so far as they are receipts. Railroad v. Bank, 1899, 178 Ill. 506; 53 N. E. 326; Van Etten v. Newton, 1892, 134 N. Y. 143; 31 N. E. 334 ; Manuf. Co. v. Railroad, 1897, 121 N. C. 514 ; 28 S. E. 474.
} 
amount to at that price: the quantity proving in excess, the grantor may show an oral agreement that a survey was to be made, and that the grantee was to pay for the excess, at the price named per acre. ${ }^{35}$ So, on the other hand, if the grantor has been overpaid the grantee may recover the excess, if it was orally agreed that the price of the land was to depend on the number of square feet in it, and a mistake was made in computing the area : the grantee does not waive his right to recover the excess by accepting a deed conveying all the land shown him, because the agreement is not for an entire sum, in such a case, but the price is to be fixed by the quantity. ${ }^{36}$

$\$ 65$. Showing assumption of mortgage. - It is also upon this principle-that the true consideration of the deed may be shown by parol-that many courts have proceeded in allowing an agreement to be shown outside the deed that the grantee had contracted to assume and pay, as part of the consideration, a mortgage on the land conveyed.

The best way of establishing this agreement is by inserting in the deed a recital that the grantee assumes and agrees to pay the incumbrance. This recital may be immediately after the description, or where the usual covenants are inserted in the deed, it may be stated as an exception to the covenant against incumbrances, briefly thus: "Said premises are free and clear from all incumbrances, except a certain mortgage (describing it) which the said party of the second part hereby assumes and agrees to pay."

But if a clause of this kind is not inserted in the deed it is quite generally held that the grantor, or the holder of the mortgage, may show by parol evidence that the grantee agreed to assume and pay the mortgage as a part

${ }^{36}$ Ludeke v. Sutherland, 87 Ill. 481 ; 29 Am. R. 66.

${ }^{36}$ Cardinal v. Hadley, 1893, 158 Mass. 352 ; 33 N. E. 575 ; 35 Am. St. R. 492. 
of the consideration..$^{3 \pi}$ Many such cases are where the grantor has given a warranty deed, and it is held in them that he is not estopped by his covenants to show what the true consideration was. This question is discussed in a case ${ }^{38}$ where the plaintiff had, by a deed containing a covenant against incumbrances, conveyed land to the defendant, there being in fact a mortgage on the land. The grantor, having paid off the mortgage, sued the grantee for the amount paid, on the ground that the grantee had agreed to pay it. The defendant (grantee) urged that the plaintiff (grantor) was estopped by his covenant against incumbrances from proving the existence of the mortgage, or that the grantee undertook to pay it. But the court held that the law of estoppel did not apply, as the question was one merely collateral to the deed, the action not being founded directly on the deed or the covenants, and that the evidence offered was merely to show the nature and extent of the payment of the consideration, and therefore came within the doctrine of the American authorities.

It will be observed from an examination of the authorities just cited that they are chiefly cases where the grantor, or some person who has succeeded to his rights, seeks to recover the real consideration, and where the agreement to pay the mortgage was regarded as collateral to the main purpose of the deed and as not in conflict with the express provisions of the conveyance, the deed being regarded as not the whole contract of the parties. ${ }^{39}$

$\$ 66$. True consideration may not be shown as between the parties to defeat deed.-While the true consider-

${ }^{\top}$ Lang v. Dietz, 1901, 191 Ill. 161; 60 N. E. 841; Society v. Haines, 1890, 47 Ohio 8t. 423; 25 N. E. 119; Bensieck v. Cook, 1892, 110 Mo. 173 ; 19 S. W. 642 ; Hopper v. Calhoun, 1894, 52 Kan. 703 ; 35 Pac. 816 ; Ordway v. Downey, 1898, 18 Wash. 412; 63 Am. St. 892 ; 51 Pac. 1047; 52 Pac. 228; Flynn v. Flynn, 68 Mich. 20; 35 N. W. 817; Perkins v. McAuliffe, 1900, 105 Wis. $582 ; 81$ N. W. 645.

${ }^{28}$ Bolles v. Beach, 22 N. J. L. 680; 53 Am. Dec. 263.

Where the action is directly on the covenants, see post, $\$ 204$. 
ation may thus be shown for almost every purpose, nevertheless, as between the parties and those in privity with them, it is not permissible, in the absence of fraud or mistake, to explain or contradict the consideration expressed for the purpose of defeating the conveyance or changing its legal effect as a conveyance. ${ }^{40}$

Nor may the grantor defeat his deed by showing that the consideration is illegal. ${ }^{41}$

\$67. Statement of consideration not binding on others.-But the recital of the consideration is not generally evidence as against third persons, ${ }^{42}$ and creditors of the - grantor who seek to set aside the conveyance are never conclusively bound by such a recital.

It has been said that the recital of payment of consideration is prima facie evidence in such cases of its payment, ${ }^{43}$ but the better rule appears to be that it is not evidence as against those claiming adversely to the convey-

${ }^{40}$ Salisbury v. Clarke, 61 Vt. 453; 17 Atl. 135; Feeney v. Howard, 79 Cal. 525, 530; 21 Pac. 984; 12 Am. St. R. 162; Weiss v. Heitkamp, 1894, 127 Mo. 23 ; 29 S. W. 709; Finch v. Garrett, 1893, 102 Iowa 381 ; 71 N.W. 429.

"Allebach $\nabla$. Hunsicker, 1890, 132 Pa. St. 349; 19 Atl. 139. But in Eckler v. Alden, 1900, 125 Mich. $215 ; 84$ N. W. 141, the contrary is held, and a grantor is permitted to deny the consideration "for the purpose of rendering the deed void." The decision may have been based on fraud; as reported, it seems contrary to the weight of authority. This rule does not apply to mortgages. They may be defeated between the parties or their representatives by showing that they are without consideration. The mortgagor, on attempted foreclosure by the mortgagee, is not estopped by the mortgage, but may show that there was no consideration, and in this way defeat it. The executory character of the instrument is regarded as making this difference. Baird $\nabla$. Baird, 1895,145 N. Y. 659 ; 40 N. E. 222 ; Chaffee v. Brown, 1895, 109 Cal. 211; 41 Pac. 1028; Church v. Case, 1896, 110 Mich. 621; 68 N. W. 424.

- Rose v. Taunton, 119 Mass. 99; King v. Mead, 1899, 60 Kan. 539; 57 Pac. 113; Ten Eyck v. Witbeck, 1892, 135 N. Y. 40; 31 Am. St. R. 809 ; 31 N. E. 994.

Foster v. Hall, 12 Pick. 89; 22 Am. Dec. 400; Jackson v. McChesney, 7 Cow. 360; 17 Am. Dec. 521. 
ance, especially where the relationship of grantor and grantee is such as to raise a presumption of fraud."

uillyman v. King, 36 Iowa 207, 213; Kimball v. Fenner, 12 N. H. 248; Redmond v. Chandley, 1896, 119 N. C. 575; 26 8. E. 255; Flynn v. Jackson, 1896, 93 Va. 341; 25 S. E. 1 ; Mendenhall v. Elwert, 1900, 36 Ore. 375 ; 59 Pac. 805; 52 Pac. 22 ; Minneapolis Stockyards \&c. Co. $\nabla$. Halonen, 1894, 56 Minn. 469 ; 57 N. W. 1136.

6-Brews. Con. 


\section{CHAPTER VIII.}

THE OPERATIVE WORDS.

\$68. Special operative words for special conveyances.

69. Superfluous use of operative words-Rule of construction.
§70. Effect of assignments indorsed on deeds.

71. Operative words of some kind essential.

72. Wordsgenerally considered sufficient.

\$68. Special operative words for special conveyances.-In that part of the premises known as the granting clause occur the "operative words." In former times the particular words used were of special importance, each one of the several kinds of conveyances having its appropriate operative word or words which made it effective as the special kind of conveyance it purported to be.

The name of the particular conveyance (see above, $\S 20$ ) is generally suggestive of the appropriate operative words formerly always used in it. While these technical words have lost much of their former force and special significance, they seem still appropriate if it be intended that a particular conveyance shall have the characteristic properties it possessed at the common law as distinguishing it from others.

For example, the "exchange" at common law was the appropriate conveyance in special circumstances, and the technical exchange was attended with results peculiar in many respects to itself-there was a warranty with a condition of re-entry, so that if the title to either piece of land exchanged proved bad, and the party or his assigns were evicted, he or his assigns could recover the 
other piece of land which had been given in exchange. But to produce this result it was necessary that the word "exchange" should be used, and a modern conveyance cannot operate as a technical exchange at common law without the use of the same word. ${ }^{1}$

§69. Superfluous use of operative words-Rule of construction.-It was formerly the practice always to use a great many words without regard to their true meaning, and it is still the common practice to insert in deeds nearly all the operative terms ever needed in transferring real estate.

When deeds were construed technically this was done in order that the deed might operate in one way if it could not operate in another, but in modern conveyances most of these words are surplusage.

The general rule of construction is that if from an examination of the whole instrument an intent to convey may be gathered, the absence of the usual or proper operative words will not render the instrument void as a conveyance.

Careful attention, of course, must be given to words from which covenants may be implied, under such statutes as are referred to above (at $\S 30$ ), and the particular effect in this respect produced by particular words must not be lost sight of. But as conveyances of the property merely, the courts will construe deeds as operative in one form or another if possible.

Illustrations: The words "bargain and sell" are not needed to make a deed a bargain and sale, operating as such, but the words " remise, release and quit claim" will accomplish the same result, the deed expressing that it is made for a valuable consideration. ${ }^{2}$

So where the statute provides a form of deed intended

2 Windsor v. Collinson, 32 Ore. 297 ; 52 Pac. 26; Gamble v. McClure, 69Pa. St. 282.

${ }^{2}$ Havens v. Seashore Co., 1890, 47 N. J. Eq. 365, 372; 20 Atl. 497. 
to transfer the grantor's whole interest, in which form the single operative word is "grant," the word "convey" used in a deed has been held equivalent to this word "grant." 8

And if a deed containing the words: "bargain, sell and convey" cannot operate as a deed of bargain and sale, for want of consideration," it sometimes may as a grant at common law, the word "convey" being as effective as "grant" for this purpose."

Even where there were no distinctively operative words, but the deed stated that the grantee was "to have" a designated proportion of the estate, absolutely and in full property, and it was contended that the deed was void as containing no operative words, the court sustained it, saying: "The words were plainly intended to operate in præsenti, and though the most apt words are not used, the intention appearing from the deed as a whole should not be defeated." $" 6$

$\S 70$. Effect of assignments indorsed on deeds.-The question has arisen whether indorsements on deeds "assigning" the grantee's interest in the deed are valid transfers of the legal title to the land.

Where the grantee named in the deed indorsed on it an assignment under his hand and seal of all his right, title and interest "in and to the within deed" to his son, for value, such assignment, when delivered, was held to con-

'Chapman v. Charter, 1899, 46 W. Va. 769, 779; 34 8. E. $768 . \quad$ The statutory word here was not intended to import covenants into the deed, but simply to transfer the grantor's entire interest. So such a decision is not inconsistent with the general rule that, when certain statutory words have a special and peculiar effect they alone should be used to produce that effect; as in the case of the statutory words in the short statutory forms which have the dual capacity of transferring title and importing covenants. See post, \$212.

- See ante, $\$ 56$.

- Lambert v. Smith, 9 Ore. 185.

- Anglade v. St. Avit, 67 Mo. 434. 
vey the title, the surrounding circumstances indicating an intention to transfer the real property described in the deed..$^{7}$

And the words "I assign the within to A B for value received" indorsed on a deed, signed by the grantee named in the deed, and regularly acknowledged, have been held sufficient to convey title to the land described in the conveyance on which they were indorsed. ${ }^{8}$

It has, however, been held in similar cases that such an indorsement conveys no legal title to the land, one reason being, in most cases, that there are not words effectual to transfer the legal title; in such cases the assignment is regarded as at best entitling the assignee to relief in equity as upon an executory contract. ${ }^{9}$

\$71. Operative words of some kind essential.-Many of the foregoing cases illustrate the general rule, that courts will sustain deeds in this particular, as in others, if possible, and make them effectual according to the intent of the parties.

Nevertheless, it often happens that title is not transferred by an instrument probably intended to transfer it, because there are no words in it sufficient to give it effect as a conveyance.

Even if the instrument purports in form to be a deed of indenture, duly signed, sealed and acknowledged, but the only operative words in it are "warrant and defend unto $\mathrm{C} \mathrm{D}$, her heirs and assigns, forever, the receipt whereof is hereby acknowledged," it would not operate as a conveyance of the real estate described in it. ${ }^{10}$

${ }^{7}$ Lemon v. Graham, 1890, 131 Pa. St. 447; 19 Atl. 48.

B Harlowe v. Hudgins, 1892, 84 Texas 107; 19 S. W. 364.

- Bentley v. De Forest, 2 Ohio 221; Dupont v. Wertheman, 10 Cal. 354 ; Porter v. Read, 19 Maine 363.

${ }^{10}$ Hummelman v. Mount, 87 Ind. 178. In this case Judge Elliott says: "It is no doubt true that an instrument purporting to be a deed will be effectual if it contains in any part of it apt words of conveyance. In all well drawn deeds these words appear in their appropriate place. But here there are none in any part of this instrument." 
And "waive and renounce" are not words of conveyance sufficient to convey title."

In some states statutes provide that any instrument in writing signed by the grantor is effectual to transfer the legal title if such was the intention of the grantor to be collected from the whole instrument.

Such a statute, however, is not intended to dispense with operative words: it simply imposes upon the courts the duty of construing liberally the words of transfer; hence, even under such statutes, some words of conveyance are necessary. ${ }^{12}$

§72. Words generally considered as sufficient.-In spite of the long established practice of inserting in conveyances all the words which have been appropriate to the different forms of deeds, it appears that even as early as Lord Coke's time the word "grant" was sufficient to amount to a grant, a feoffment, a gift, a lease, a release, confirmation or surrender. ${ }^{13}$ And the words "give, grant, bargain and sell" seem to be, according to the authorities, sufficient for all purposes as operative words transferring the title.

While it is evident that many carelessly drawn conveyances will be sustained by the courts, the only prudent and proper practice is to use those terms which, after long usage, have been determined by the courts with substantial unanimity to be effectual as words of transfer.

And while the difference between different conveyances

"Davis v. McGrew, 82 Cal. 135; 23 Pac. 41.

12 Bell v. McDuffie, 71 Ga. 264; Webb v. Mullins, 78 Ala. 111. In the last case the instrument was substantially as follows: "Know all men by these presents: That I, A B, for and in consideration of love and affection which $I$ have toward my son, $J$ B, the following described real estate . . . . To have and to hold to the said $J B$, his heirs and assigns, forever. In testimony whereof, etc." It was held that this instrument contained no words which could be construed to trinsfer the legal title, even with the assistance of such a statute.

${ }^{13}$ Co. Litt. 301 b. 
in this respect is not as marked as formerly, there are still other cases than those already mentioned where particular operative words are more appropriate for the conveyance than are others. This propriety may arise from statute or usage. For example: "Mortgage" is now by statute in many states made the appropriate word to use in a mortgage. In the creation of a term of years the appropriate words are "grant, demise and to farm let," the characteristic word being "demise" (but here, as in conveyances of larger interests, no particular form of words is absolutely necessary, and the words "lease" and "let" are often used alone), and the words "remise, release and forever quit claim" are used in the common form of a quit claim deed. 


\section{CHAPTER IX. \\ THE DESCRIPTION OF THE PROPERTY.}

673. General considerations Importance of the description.

74. Descriptions in recorded conveyances - How far notice to subsequent parchasers.

75. Certainty necessary-Parol evidence to apply description.

76. Parol evidence cannot supply description - Fatal uncertainty.

77. How uncertainty arises Undefined part of larger tract.

78. Uncertainty avoided when part of larger tract is designated, though not fully described.

79. Fatal uncertainty avoided where grantee of part of larger tract takes an undivided interest.

80. Uncertainty caused by lack of starting point of boundary.

81. A general description allowable and not necessarily uncertain.

82. Descriptions usually more specific - What particulars are to be regarded.

83. Conflicting parts of descriptions.
\$84. Rules for construing descriptions with conflicting parts.

85. The maxim, "Falsa dem.onstratio," etc.

86. Illustrations of the rulesParticular descriptions control general.

87. Illustrations - Monuments control courses and distances.

88. The part of a monument taken as a boundary.

89. Streets and highways as b o u nd a rieo-When the grantee takes to the center.

90. Streets and highways as b o u n d a ries-Decisions not in accord as to what expressions exclude the way.

91. Streets and highways as boundaries-W hen grantee takes the entire street.

92. Description by courses and distances will control quantity named - "More or less" - When statement of quantity important.

93. Reference in descriptions to maps.

94. Grantee's rights in streets shown on map. 
\$95. Statutory plats-Maps may aid description though not expressly referred to.

96. Incorrect maps controlled by monuments.

97. Reference may be made to other deeds, etc., for description.

98. Lands bounded by waters -General rule.

99. The basis of the rule-Application to cases where water is not named as boundary.

100. Application of general rule, how limited by grantor.

101. How far the rule applies to pablic grants.

102. Public grants - The "meander line."

103. When the mesnder line will be taken as the boundary.

104. How far' does title extend nnder water? - Tidal waters.

106. How far does title extend - $R$ i ver $\theta-A t$ common law.
106. Rivers in United States Private title to bed in some states.

107. Owner's rights incident to this title - Islands - Ice -Shooting and fishing.

108. Rivers-No private title to bed in some states.

109. Navigable rivers - Practically three rules in United States.

110. N o n-tidal, non-navigable rivers.

111. Boundaries on lakes-Public and private ownership.

112. The "Great Lakes."

113. Smaller lakes and ponds.

114. Conflicting views as to smaller lakes in the United States.

115. The sectional line rule.

116. Beds of inland natural lakes though of large size may be subject to private ownership.

117. States holding to the rule that private title extends to water's edge only.

118. Appurtenances.

73. General considerations-Importance of the description.-In an orderly arrangement of the parts of a conveyance the description of the thing conveyed appears in the premises, immediately after the words of conveyance, or operative words. Where printed forms are used this part of the conveyance is not supplied by the printer, and when it is supplied to the draftsman by his client it is often inaccurate. There is, therefore, hardly a part of the instrument to which more careful attention should be given, whether in its preparation or in the examination of a series of conveyances forming the chain of title to land. While descriptions will be construed liberally, so as, if possible, to carry out the intention of the parties, 
nothing passes by a deed but what is described in it, whatever the intention of the parties may have been, and evidence is inadmissible to make the deed operate on land not embraced in the descriptive words.

Many singularly indefinite, defective and inaccurate descriptions in deeds, mortgages, or wills may be cured, as will appear from the decisions to be cited, either by the application of rules of construction adopted for the purpose of reaching the probable intent of the parties, or by parol evidence (used within limits not always easily defined) of circumstances under which the conveyance was madewhich is often admitted for the same purpose of getting at the intent of the parties. But there must, of course, be some description, for a wholly omitted description cannot be supplied by evidence outside the deed or will. ${ }^{1}$

Controversies in which the chief question is as to the construction of the description arise in a great many different ways; for example, in equitable proceedings to quiet title or to settle boundaries; in bills for specific performance of contracts for the sale of lands; in actions on covenants brought because the land attempted to be conveyed has not been conveyed; in actions sounding in tort brought for trespass; in actions for purchase-money, or, on the other hand, in proceedings to restrain the collection of purchase-money; and, probably most frequently, in ejectment. These controversies arise, of course, not.merely between the parties to the conveyance themselves, but between them, or their successors, and other parties, and it will be seen that what may be a sufficient description as between the grantor and grantee, or mortgagor and mortgagee, may not be good as against third parties.

\$74. Descriptions in recorded conveyances-How far notice to subsequent purchasers. - Under our general

' Crooks v. Whitford, 47 Mich. 283, 291; 11 N. W. 159. 
system of recording conveyances, it is understood that the record is notice to subsequent purchasers. But the record is notice so far as the land is correctly described, and no farther, unless it is apparent that there is a misdescription, or unless there is enough in the record to put the later purchaser, exercising reasonable diligence, on inquiry as to property intended to be conveyed that would lead to a correct knowledge of the matter. ${ }^{2}$

Therefore, a grantee with his conveyance on record, containing an inaccurate or insufficient description, is not entitled to relief as to such mistakes against one, who for a valuable consideration, has purchased the property from the grantor without actual notice, unless this later purchaser is chargeable with constructive notice, which the record of the former conveyance, with its defective description, does not necessarily impart. ${ }^{3}$ But descriptions of the same land may, of course, be made at different times in different language, owing to changed conditions which render a former description inappropriate in a later conveyance. In such cases the rule just stated does not apply. A purchaser, therefore, from one who appears by the records to have made a conveyance of some land by a former deed, containing a description differing from that now found in his own deed, will not always be allowed to take advantage of the rule, against the former grantee, simply because he finds a description in the former deed not exactly corresponding with that used in his own. One intending to buy land, finding such a deed on record, should inquire outside the record whether or not there was at the time the recorded deed was made property to which the description therein might have been applied, and ascertain, at his peril, whether

\footnotetext{
2 Schweiss v. Woodruff, 73 Mich. 473; 41 N. W. 511.

3 Harms v. Coryell, 1899, 177 Ill. 496, 504; 53 N. E. 87; Ozark Land \&c. Co. v. Franks, 1900, 156 Mo. 673, 686; 57 S. W. 540; Davis v. Ward, 1895, 109 Cal. 186 ; 41 Pac. 1010; 50 Am. St. R. 29.
} 
that deed conflicts with the title to the property he now intends to purchase."

\$ 75. Certainty necessary-Parol evidence to apply description.-The description of land cannot, of course, identify the land, but it can and should furnish the means of identification.

Among the essentials of ten stated to be of first importance are certainty and particularity on the face of the instrument. But no matter how certain and specific the description is on paper, nothing will be conveyed unless the description can be applied to the earth and the land described located. A peculiar description in an Illinois case will illustrate this proposition. In Glos v. Furman $^{5}$ there was a bill filed to remove a cloud on title, it being alleged that the defendant had given a mortgage on the plaintiff's lands. The defendant claimed under a tax deed with the following description, and alleged that he had given a mortgage only on the interest conveyed to him by that deed: "The east vigintillionth of a vigintillionth of the east one-sixty-fourth inch of lot one, in the southwest quarter, etc., and the east vigintillionth of a vigintillionth of the east one-quarter inch of lot two, etc." The court says of this description: "A tract of land described as the above may perhaps be pictured in the imagination, but could not be bounded. It could not be located, nor could a person take possession of such a tract of land. . . . And where land in a deed is so described that it cannot be identified, or if the description calls for premises not having an existence, or that cannot be found, the conveyance must be regarded as void."

Indeed, as to certainty it may be noted that there may be a clear description without any uncertainty or ambiguity on its face, and another later description equally clear on

4 Sengfelder v. Hill, 1899, 21 Wash. 371; 58 Pac. 250.

51897,164 Ill. 585 ; 45 N. E. 1019. 
its face, and in the identical language of the former, and yet the latter will apply to and include more land than the former. ${ }^{6}$

It is therefore evident that extrinsic evidence must be resorted to where descriptions of land are concerned, because the description must be applied to its subjectmatter, and by the rule requiring certainty in descriptions it is not meant that no extrinsic evidence is allowable. In Cox v. Hart, ${ }^{7}$ where it was doubtful as to which of two pieces of land, both in the same neighborhood, and both owned by the execution debtor, a description in a marshal's deed applied, the court, quoting $\mathrm{Ch}$. J. Marshall, says : "It is undoubtedly essential to the validity of a grant that there should be a thing granted, which must be so described as to be capable of being distinguished from other things of the same kind. But it is not necessary that the grant itself should contain such a description as, without the aid of extrinsic testimony, to ascertain precisely what is conveyed." And in Mead v. Parker, ${ }^{8}$ the principle is stated as follows: "The most specific and precise description of the property intended requires some parol proof to complete its identification. A more general description requires more."

\$ 76. Parol evidence cannot supply description-Fatal uncertainty. - While it thus appears not only allowable but necessary to use extrinsic evidence to apply the description, the difference must be noted between such evidence and evidence to describe the property intended to be conveyed. What is meant by the rule that descriptions must be certain, is, that the words used to describe a tract of land must do so in such a manner as to show, with the help of this necessary extrinsic evidence to apply

\footnotetext{
- How this may be, will be clear from the diagram and description in the case of Smith v. Sweat, 1897, 90 Maine 528; 38 Atl. 654.

${ }^{7} 1892,145$ U. S. $376,388,389$.

- 115 Mass. 413.
} 
it, what tract is intended. For if the words used to describe a tract of land fail to do so in such a manner as to show (with proper extrinsic evidence to apply it) what tract was intended, the deed will be void for uncertainty of description, and in such a case parol evidence to explain the intention of the party is inadmissible. The difference between the required certainty, and the incurable uncertainty which renders a conveyance void, will be clearer from an examination of decided cases where the question has occurred.

\section{\$ 77.-How uncertainty arises - Undefined part of} larger tract.-Uncertainty of description making void a conveyance arises in a great variety of ways. A not unusual way of creating this uncertainty is to name and partially describe a part of a larger tract of land, without affording the means of determining what part of the larger tract is intended. As, for example, a deed for "a part of the west half" of a certain quarter section "containing one acre, more or less," without designating what part of the tract it is to be taken from, is void for uncertainty. ${ }^{9}$ So a conveyance of " nine and three-quarters acres lying in the north half of northwest quarter of section one," is void for uncertainty. ${ }^{10}$ In such cases even an experienced surveyor would be unable to locate the land. So in Hamilton v. Harvey, ${ }^{11}$ which was a bill to compel specific performance of a contract: "I hereby agree to lease my building, etc., and will allow you as commission for said location one-third interest in five acres located near said works," the conclusion is that this description is too uncertain to sustain a decree for specific performance as to the contract for commission.

'Hanna v. Palmer, 1901, 194 Ill. 41; 56 L. R. A. 93; 61 N. E. 1051.

${ }^{10}$ Gaston v. Weir, 84 Ala. 193 ; 4 So. 258 . And to the same effect, see McRoberts v. McArthur, 1895, 62 Minn. 310; 64 N. W. 903; Millett v. Mullen, 1901, 95 Me. 400, $412 ; 49$ Atl. 871.

"121 Ill. $469 ; 13$ N. F. 210. 
\$78. Uncertainty avoided when part of larger tract is designated, though not fully described.-The difference, however, between such descriptions as these and those that indicate, though not in the best form, what part of the larger tract is intended, should be noted. For example, such a description as: "The south part of section 5 , etc., being 225 acres," is not void for uncertainty, as a parallelogram containing that number of acres may be laid off. ${ }^{12}$ And if the description is of a certain quantity of land, in or out of a designated corner of a certain parcel, it will, generally, be taken as a square in that corner containing the quantity named..$^{13}$ So the description of land as a certain one-quarter section, "except two acres in the southeast corner," is sufficiently certain and definite, the exception being construed to mean two acres in such corner lying in a square. ${ }^{14}$

The result, however, in such cases as these last mentioned will not always be to convey or to except a square.

For example: In Lego $\nabla$. Medley ${ }^{15}$ the exception of "one acre from the southwest corner, . . . together with the buildings thereon," was held to render admissible parol evidence to show the boundaries, and if it appeared from such evidence that the grantor was at the time in possession of a dwelling and other buildings and a tract sixteen rods long from east to west and ten rods wide from north to south, on which such buildings were situated, and that an acre could not be laid off at that corner which would include the buildings without being of the dimensions named, that then the exception must not be considered as calling for a tract in a square form,

12 Tierney v. Brown, 65 Miss. 563; 5 So. 104; 7 Am. St. R. 679; Soukup v. Union Investment Co., 1892, 84 Iowa 448; 51 N. W. 167 ; Cobb v. Taylor, 1892, 133 Ind. 605 ; 32 N. E. 822 ; 33 N. E. 615.

"Richey v. Sinclair, 1897, 167 Ill. 184; 47 N. E. 364; Smith v. Nelson, 1892, 110 Mo. 552; 19 S. W. 734; Walsh v. Ringer, 2 Ohio 327 ; 15 Am. Dec. 555.

1 Green v. Jordan, 83 Ala. 220; 3 So. 513; 3 Am. St. R. 711.

is 1891, 79 Wis. 211 ; 48 N. W. $375 ; 24$ Am. St. R. 706. 
but as embracing such parallelogram; parol evidence being resorted to in such a case, not to contradict or vary the words of the grant, but to show from the situation and condition of the subject-matter what meaning the parties attached to the words used. ${ }^{16}$

§79. Fatal uncertainty avoided when grantee of part of larger tract takes an undivided interest.-It will be noticed that in most cases where descriptions are beld void for uncertainty because an attempt has been made to convey an undesignated part of a larger tract (such as are cited in section 77 above) the evident intention has been to convey a specific part of the larger tract in severalty. The description in such cases is void, because, while the deed purports to express this intention and attempts to describe the smaller tract, it does so in such an uncertain manner that no one can say what land is described.

Where, however, the deed does not purport or attempt to specifically describe a part of a larger tract, but, without locating the part, describes it as a certain quantity out of the larger tract, it has often been construed as granting an undivided interest in the larger tract, in the proportion which the number of acres in the part named bears to the whole area of the larger tract: the grantor and grantee thus becoming tenants in common of the whole tract. ${ }^{17}$

Such decisions illustrate the general rule, applied under varied circumstances, and not merely in cases where the description is concerned, that conveyances will not be held

16 It will be evident from these latter cases that the principles concerning the construction of descriptions apply to exceptions as well as to the principal land conveyed. Where a good description is followed by an exception which is void for uncertainty the grant may be valid, the exception alone being void. Thayer v. Torrey, 37 N. J. L. 339 ; Bromberg v. Smee, 1900, 130 Ala. 601; 30 So. 483.

${ }^{17}$ Cullen v. Sprigg, 1890, 83 Cal. 56 ; 23 Pac. 222 ; Morehead v. Hall, 1900,126 N. C. 213 ; 35 S. E. 428; Gibbs v. Swift, 12 Cush. 393. 
to be void if they can reasonably be sustained: ut res magis valeat quam pereat (that the thing may rather have effect than be destroyed).

\$ 80. Uncertainty caused by lack of starting point of boundary.-Uncertainty, making the description void, also frequently occurs where the starting point of a boundary line cannot be identified.

A case frequently cited as a leading one on this point is LaFranc v. Richmond, ${ }^{18}$ where the description was (substantially) "from the C-Creek, cutting through the middle of a small hill, to a point adjoining A B, up to the range of blue hills." The starting point was thus on a creek, but the creek was eight thousand feet long, and Justice Field says: "Any position on it may be indefinitely taken as the starting point, and a line run so as to meet the conditions of the description. The tract deeded cannot, therefore, be located with certainty, unless the starting point is established. The land intended by the grantor remains incapable of identification, and the deed is inoperative." So where the description is of land " adjoining lands of the grantor, beginning at a stake on the east side of the railroad track and on said track, and runs east, etc., to a stake ;" here it is evident that there is no starting point, and the description, standing alone, is void for uncertainty. ${ }^{19}$

\$81. A general description allowable and not necessarily uncertain. - The rules applicable to such cases as those cited in $\$ \S 77$ and 80 , however, do not prevent the use of a general description not ambiguous on its face,

"2 5 Sawyer 601.

20 Barker v. Southern Ry. Co., 1899, 125 N. C. 596; 34 S. E. 701, though in this case the plaintiff, who was the original grantor, was held estopped, as he had surveyed the land and put the grantor of the present defendant in possession. See also, Pry v. Pry, 109 Ill. 466, 478, and Edens v. Miller, 1899, 147 Ind. 208; 46 N. E. 526.

7-Brews. CoN. 
and in practice it is sometimes necessary to resort to such a description. Descriptions, therefore, in general terms, are not void for uncertainty, because it may be shown by extrinsic evidence what particular property is embraced in the general description.

Examples of such descriptions are, "All my land" in a certain town, county or state $;^{20}$ or, "All my lands, wherever situated ;" ${ }^{21}$ or, "All my right, title and interest in and to my father's estate at law." 22

Or a general name may sufficiently describe the property to be conveyed, as where the property is described as "Pelican Beach, near Barren Island, in the town of, etc.," there being certain definite land known as Pelican Beach. ${ }^{23}$

It will be noticed that in all these instances of very general description there is no uncertainty appearing on the face of the description. Each can be applied to its subject-matter just as well as if more specific, and extrinsic evidence is admissible to show to what land the description was to be applied.

But a general description may on its face be void, as any other may, as being too vague and indefinite.

For example, a description consisting only of the words "a piece or parcel of land near Bacon Quarter Branch" is too uncertain. ${ }^{24}$

\$ 82. Descriptions usually more specific-What particulars are to be regarded.-While, therefore, general descriptions have often been sustained as sufficient, and must be used at times as being the best obtainable, ordi-

${ }^{20}$ Frey v. Clifford, 44 Cal. 335; Blair v. Bruns, 8 Colo. 397 ; 8 Pac. 569 ; Drew v. Carroll, 1891, 154 Mass. 181; 28 N. E. 148.

23 Pettigrew v. Dobbelaar, 63 Cal. 396; Higgins v. Higgins, 1898, 121 Cal. 487 ; 53 Pac. 1081.

${ }^{22}$ Austin v. Dolbee, 1894, 101 Mich. 292; Huron Land Co. v. Robarge, 1901, 128 Mich. 686; 8 D. L. N. 835; 87 N. W. 1032. See Wadsworth $\nabla$. Murray, 1900, 161 N. Y. 274, 289 ; 55 N. E. 910.

${ }^{23}$ Coleman v. Improvement Co., 94 N. Y. 229.

" George v. Bates, 1894, 90 Va. 839 ; 20 S. E. 828. 
narily a description should be more specific, and should contain particular and accurate statements. The particulars which should be mentioned in order that the description may be identified with certainty will, of course, vary with the nature of the land and its location; as, for example, whether it is a city lot or a farm.

Among the more important particulars which ought to be considered before drawing a conveyance (though, of course, not all need be mentioned in any one description) are :

The state, county and town where the land is situated;

Public or private surveys;

Monuments, either natural or artificial, from which courses and distances may be laid off;

Streets and highways, a point on which may form the starting point and end of the description;

The boundaries of the land and their measurements, known as metes and bounds, and

The quantity or area of the land.

In describing a town lot, reference may often well be made to the street number and the particular side of the street, as well as a reference to the plat, to former occupancy of the land conveyed and to adjoining ownership.

Most careful lawyers, in drawing a description, prepare a diagram of the land described, drawn to a scale in order to see that the words used fit the thing described, and in construing descriptions already drawn the same method may profitably be employed.

\$83. Conflicting parts of descriptions.-A grantor thus describing land by general and particular words, and as bounded by lines running to and from objects, or at certain angles with one another for certain distances, and as containing a certain number of acres or feet, is very likely, in his anxiety for fullness of description (in adding one description to another, or mentioning incidents connected with the history of the title), to err in having 
too much of a description. Often in such cases one part of the description conflicts with another. A line, for instance, may be described as starting from one monument and extending a certain distance to another, whereas in fact the distance between the points is either greater or less than that recited; or, a description may be made by lines of a tract said to contain a certain quantity of land, whereas, when the lines are run and the measurements taken, as prescribed in the deed, the real amount included is shown to be either greater or less than the quantity stated.

In drawing descriptions all additions to a sufficient description should be avoided, unless the draftsman is satisfied that they are accurate and consistent with the rest of the description.

$\$ 84$. Rules for construing descriptions with conflicting parts.-In construing descriptions, however, where such conflicts occur courts of law often apply certain rules of construction, the purpose of which is to carry out the meaning and intent of the grant, so far as they can be ascertained from reading the description and inspecting the land. ${ }^{240}$

These rules are based on the principle of regarding, in case of conflict, that as of first importance about which there is the least likelihood of a mistake having been made, or on the principle that what is more certain shall prevail or control what is ordinarily less so. The chief general rules of this kind are:

1. Particular and definite descriptions will control general descriptions with which they conflict.

2. Descriptions of boundaries by landmarks or monu-

200 These so-called rules are not fixed rules of law, but are guides to aid in the construction of the description: on the question of intent the fact must be found according to the weight of evidence. Heywood v. Lumber Co., 1899, 70 N. H. 24, 31 ; 47 Atl. 294. 
ments are to be preferred to, or will control, those by courses and distances with which they conflict.

3. Among monuments, permanent natural monuments are preferred to artificial monuments.

4. Descriptions by courses and distances generally control statements as to quantity. ${ }^{25}$

The first thing to do in cases where there is a seeming conflict is to reconcile the conflict, if possible, and give effect to every part of the description, rather than to assume at the outset that the conflict is irreconcilable. This is illustrated by Judge Cooley's interpretation of a description by reading the word "to" as "toward," in accordance with a meaning sometimes given to it, and with the result that effect was given to the whole description..$^{26}$

When, however, the different parts of a description cannot be reconciled, as is frequently the case, the foregoing general rules, or some of them, may be used to advantage.

It is important, however, to remember in regard to the application of these rules to the different kinds of cases which arise, that they are not inflexible. In the case just cited, ${ }^{27}$ Judge Cooley discusses the rules, and shows that in some cases the statement of quantity, which is considered generally the least certain part of the description, may control; and he says: "The only purpose of rules of construction is to enable us to reach the probable intent of the parties, in order that we may give it effect, and unless they are somewhat flexible they would in many cases defeat the actual intent, even when upon the face of the instrument it is obvious what the intent was. The errors in deeds are infinite in variety and form, and any one case of mistake may present considerations a little different from any other. ' 28

25 See note, $30 \mathrm{Am}$. Dec. 734.

${ }^{26}$ Moran v. Lezotte, 54 Mich. 83; 19 N. W. 757.

n 54 Mich. 83, 88.

${ }^{28}$ See illustrations of their flexibility, post, $\S \S 86,87$. 
\$ 85. The maxim "Falsa demonstratio, etc." - In using these rules as means of interpreting descriptions, we are obliged to disregard erroneous or false portions of the description in order to carry out the intent of the parties. In discussing such descriptions the following legal maxim is repeatedly referred to: Falsa demonstratio non nocet, cum de corpore constat; that is, "a false description does not vitiate, when a description of the essential matter remains."

This maxim is frequently used in an abbreviated form : Falsa demonstratio non nocet; but this abbreviation does not fully express the law, unless the rest of the maxim is understood or implied. ${ }^{29}$

The maxim simply means, that where a sufficient and accurate description is preceded or followed by an erroneous statement or reference, the erroneous part may be disregarded, and the conveyance given effect according to the remaining description; or, in other words, "if there be a description of the property sufficient to render certain what is intended, the addition of a wrong name or an erroneous statement as to quantity, occupancy, locality, or an erroneous enumeration of particulars, will have no effect." "30

In Wiley v. Lovely, ${ }^{31}$ an action brought for breach of covenant of seisin, the description was: "Lot 77" of a certain village "as laid out, platted and recorded." There were two village plats recorded, one containing lots numbered from 1 to 29 , and another containing two lots numbered 78 , side by side, but not lot 77 . So it appeared that in neither case did any record of a plat of the village disclose lot 77, as described ; and the claim of the plaintiff was, that the covenant had been broken, because the property defendant assumed to convey never had any existence. There was, however, another plat, which had not

${ }^{29}$ Heller v. Cohen, 1897, 154 N. Y. 299, $312 ; 48$ N. E. 527.

${ }^{30}$ Elphinstone, Interp. Deeds, p. 158.

${ }^{31} 46$ Mich. $83 ; 8$ N. W. 416. 
been recorded, which did contain a lot 77 , and it was held that the error in the description did not invalidate the conveyance, but that the part of the deed which mentioned the registry or recording of the plat, if found incorrect, might be rejected..$^{32}$

In the application of this maxim it is a matter of no consequence in what part of the description the incorrect statement occurs; that is, whether it precedes or follows the description which is correct. The courts will reject the false wherever found, and give effect to the intention of the party if the remainder of the description is sufficient. $^{33}$

The principle underlying the maxim, however, cannot be invoked to reform a deed in an action at law when there is no ambiguity created in applying the description in the deed to the subject-matter. For example, in Muldoon v. Deline, ${ }^{34}$ which was ejectment to recover a small triangular piece of land, the parties owned adjoining lands, and both claimed under the same grantor. The plaintiff took his deed shortly before the defendant took his, and in the description in the plaintiff's deed the gore in dispute was included. The defendant offered parol evidence to show that it was not intended to include it in the plaintiff's description, and that the first course in the plaintiff's deed should not run at right angles, but diagonally, and sought the application of the maxim as to the rejection of false particulars. But the court held that here there was no ambiguity-there was no false description which, within the rule, could be disregarded. If the defendant had a remedy it was by an action to reform the deed. ${ }^{35}$

* See Merrick v. Merrick, 37 Ohio St. 126; Lanman. v. Crooker, 97 Ind. 163; 49 Am. R. 437; Holston v. Needles, 115 Ill. 461 ; 5 N. E. 530 ; Vestal v. Garrett, 1902, 197 Ill. 398; 64 N. E. 345.

* State Savings Bank v. Stewart, 1896, 93 Va. 447; 25 S. E. 643; Cowen v. Truefit, 1899, 2 Ch. 309; 81 L. T. R. 104.

u 1892,135 N. Y. $150 ; 31$ N. E. 1091.

* See Prentice v. Stearns, 113 U. S. 435, 446, 448. 
\$86. Illustrations of the rules-Particular descriptions control general.-To appreciate the force of the foregoing general rules, with their exceptions, it will be necessary to consider their application to the facts in a few decided cases.

When, as is often the case, a conveyance contains two descriptions of the same land, one particular and definite and the other general in its terms, the general rule is that the particular description controls in a case of conflict, for the reason that such a particular description is more likely than the general one to have received the attention of the parties. For example, where land is described in general terms, as "the land called the Cross lot, now in possession of B," and is then particularly described by boundaries, the latter description will prevail in case of discrepancy, and the boundaries will not be extended to include land beyond them but in "possession of B." 36

But what Judge Cooley called ${ }^{37}$ the flexibility of rules of construction is seen in cases where there is an error in a particular or specific description, and in such cases the general description will control. Therefore, a description of a town lot by its number and the number of the block, followed by a description by particular metes and bounds including only a part of it, will carry the whole lot under the general description. ${ }^{38}$ So where a description by a general, well known name, such as "the Dunlap place," is followed by an uncertain or erroneous particular description, the general will not be controlled by the particular description ; ${ }^{39}$ and a conveyance describing the land as the grantor's "homestead farm," and then giving a particular description of the parcels composing it, omitting

${ }^{36}$ Jones v. Smith, 73 N. Y. 205. (See also, Prentice จ. Railway Co., 1894, 154 U. S. 163; Plummer v. Gould, 1892, 92 Mich. 1; 52 N. W. 146.) unte, $\$ 84$.

${ }^{*}$ Rutherford v. Tracy, 48 Mo. 325.

${ }^{99}$ Martin v. Lloyd, 1892, 94 Cal. 195 ; 29 Pac. 491. 
several acres, is sufficient to pass the whole farm..$^{10}$ In such cases as these latter, it is clear that the general description, or the description of the tract of land as a whole, really indicates the property the parties had in view, and their intention ought not to be defeated by a mistake in setting out the specific boundaries. In fact, whether the general or the particular description be preferred in a particular case, the reason is the same, namely, the description which conforms to the plain intention of the parties prevails.

\$87. Illustrations - Monuments control courses and distances.-Of very frequent application is the rule that in case of conflict monuments named control courses and distances given in a deed; and to carry out this rule courses must be deflected and distances named must be contracted or extended, if necessary. The reason for this rule is that errors are more apt to occur with respect to angles and measurements than with respect to objects which are fixed and visible. Early and late decisions may be found in every state applying this general rule.

Within the meaning of the rule, the law recognizes a great variety of monuments; not merely those things that would popularly be called monuments-as stakes, etc., or even trees, or hills-but streets and highways, springs, ponds, rivers, and small streams, railways, houses, party walls, or other tracts of land are such within the rule.

For example, a well-known tract of land included in a grant by a state, and generally known by a special name (e. g., "Hart's Location"), if called for as a boundary by that name in a subsequent grant, will be regarded as a monument named in this subsequent grant, and the rule as to its controlling distances will be applied so as to prevent the state from later granting land between the

10 Andrews v. Pearson, 68 Maine 19 ; Lake Erie \&c. R. Co. v. Whitham, 1895, 155 Ill. 514; 40 N. E. 1014 ; 28 L. R. A. 612. 
two prior grants, ${ }^{41}$ and an adjoining lot designated by its owner's name is a monument.. ${ }^{42}$ So a creek is a natural monument, and (even though not mentioned as such at the end of a particular course) if it is clear that the parties intended to carry a boundary line to the creek, that line may be extended by reading into the description the words necessary to bring the end of the line to the creek, though the distance recited in the deed is too short. ${ }^{33}$ So a party wall mentioned as fixing a boundary line is a monument: if the measurement of the line is too short it will be extended to it. ${ }^{44}$ Hoban v. Cable ${ }^{45}$ affords a good illustration of the application of this rule (although the rule is not mentioned in the opinion). A map is given in the report of the case, from which it will be seen that the starting point is clear, and certain monuments-one a street - are named, but it appears that if the courses as given are followed no land whatever will be included in the description, hence they are disregarded, and the lines run so as to reach the street-that is, the monument.

But this rule as to the controlling effect of monuments over courses and distances is as flexible as the others, and if it clearly appears from the description, in the light of surrounding circumstances, that the courses and distances as given correctly describe the land intended to be conveyed, they will prevail. "To hold otherwise would be to give the rule itself more importance than the reason of the rule", 46 and, of course, where the monument referred to is lost or destroyed and cannot be located by

4 Land Co. v. Saunders, 103 U. S. 316.

${ }^{2}$ Powers v. Bank of Oroville, 1902, 136 Cal. 486; 69 Pac. 151.

4s Park v. Wilkinson, 1900, 21 Utah 279; 60 Pac. 945.

" Medara v. Dubois, 1898, 187 Pa. St. 431 ; 41 Atl. 322.

45 1894, 102 Mich. 206.

${ }^{16}$ Hale v. Cottle, 1892, 21 Ore. 580; 28 Pac. 901 ; White v. Luning, 93 U. S. 514, 525; Higinbotham v. Stoddard, 72 N. Y. 94. 
oral testimony, effect will be given in fixing the boundaries to course and distance..$^{47}$

\$88. The part of the monument taken as the boundary.-Ordinarily when a monument having appreciable width is referred to, the courts will construe the center of the monument as intended, in the absence of qualifying expressions or circumstances making such a construction impossible or unreasonable.

This would especially be the case where the grantor owns the monument designated as a boundary in his conveyance, and in such cases the middle line or central point of the monument, rather than its exterior, will be taken as the point to which lines should be run.

The rule will not apply where such monuments as buildings or other tracts of land are referred to: in such cases the side of the land or building will be the limit of the grant. ${ }^{48}$

\$89. Streets and highways as boundaries - When grantee takes to the center.-It is upon this principlethat the legal terminus of a boundary by a monument is at the central point of the monument-that the general rule governing boundaries on streets or highways is based in some of the most carefully considered decisions. ${ }^{49}$

This general rule is that conveyances of land bounded by an existing street or highway carry the title to at least the center of the way, subject to the public use, unless there is something in the description showing an intent to the contrary, or unless the circumstances are such that the rule cannot be applied..$^{50}$

${ }^{47}$ Blackburn v. Nelson, 1893, 100 Cal. 336; 34 Pac. 775.

- See Boston $\nabla$. Richardson, 13 Allen 146, 154.

- Paine's Ex. v. Consumers' Storage Co., 1895, 71 Fed. R. 627 ; 37 U. S. App. 539.

so Lemay v. Furtado, 1902, 182 Mass. 280 ; 65 N. E. 395 ; Gould v. Easttern R. R., 1896, 142 Mass. $85 ; 7$ N. E. 543; Henderson v. Hatterman, 
It will be noticed that in several of these cases it is considered unimportant whether the description of the lot as bordering on a street is by the number of the lot on a plat, or by boundary lines running from the street. Where the grantor owns the street it is generally held that a conveyance of a lot bordering on a street will carry title to his grantee to the middle of the street, unless his description expressly excludes that construction. If, however, by the terms of a recorded plat the ownership of the street is not in the grantor, but has been conveyed by him to the public, this, of course, will be a circumstance which would prevent his conveyance of the adjoining lot from being so construed.

The rule by which the mention of a way as a boundary is presumed to mean the center of the way, if it belongs to the grantor, is not an absolute rule of law irrespective of manifest intention, but is merely a principle of interpretation, adopted for the purpose of finding out the true meaning of the words used..$^{51}$ It is founded on the presumption that in ordinary cases the grantor has no intention of reserving a fee in the street adjoining the land conveyed, when the street and its use have ceased to be of benefit to him..$^{52}$ Therefore, this presumption of inten-

1893, 146 Ill. 555 ; 34 N. E. 1041 ; Thomas v. Hunt, 1896, 134 Mo. 392 ; 35 S. W. 581 ; 32 L. R. A. 857 ; Brown v. Baraboo, 1898, 98 Wis. 273 ; 74 N. W. 223; Warbritton v. Demorett, 1891, 129 Ind. 346; 27 N. E. 730; 28 N. E. 613; Olin v. D. \& R. G. R. Co., 1898, 25 Colo. 177; 53 Pac. 454. In Firmstone v. Spaeter, 1892, $150 \mathrm{~Pa}$. St. 616; $25 \mathrm{Atl}$. 41, there was a contract for the purchase of a tract of land bounded on two sides by streets, "containing forty acres, more or less, to be surveyed, and to be paid for by the acre." and the question arose whether the purchaser was to pay for nearly two acres contained in half of these streets. In this action for the purchase price the court held that he must do so, because the acreage must be ascertained in accordance with the boundaries called for, and the price must be paid for the acreage within those boundaries. The difference in price was $\$ 2,400$.

${ }^{51}$ Crocker v. Cotting, 1896, 166 Mass. 183 ; 44 N. E. 214; 33 L. R. A. 245.

${ }^{52}$ Buck v. Squiers, 22 Vt. 494. 
tion should yield to evidence-shown by the deed or by circumstances-of a different intention. ${ }^{68}$

\$90. Streets and highways as boundaries-Decisions not in accord as to what expressions exclude the way.As to what expressions in a description will be sufficient to prevent the operation of the "center rule", there is a lack of harmony in the decisions: some courts having been more ready than others to find an intention to exclude the street from the grant. By some decisions naming the side of the way, or a monument on its side, as the place of beginning, is not enough to exclude the way from the grant, while by others such indirect expressions of intention will make the margin, rather than the center, the boundary; and while generally such expressions as "by the line of ", or "by the side of" a way, will exclude any part of the way, they will not always be held to do so..$^{54}$ Even in the same state the decisions are not always harmonious.

In Holloway $\nabla$. Southmayd, ${ }^{55}$ the court says there is great difficulty in reconciling the decisions in New York upon the question as to when a description in a deed which bounds the premises on a highway or street shall be deemed to take in the fee to the center line of the roadbed in front of the premises. There is no doubt about the rule being settled that there is a legal presumption against the grantor's intending to reserve to himself the title to the soil in the highway, and such presumption is generally only overcome by language in the conveyance clearly indicating such an intention on his part, but the application of the rule is made uncertain through the

${ }^{33}$ Huff v. Hastings Ex. Co., 1902, 195 Ill. 257 ; 63 N. E. 105; Graham v. Stern, 1901, 168 N. Y. 517; 61 N. E. 891 ; Overland Machinery Co. v. Alpenfels (Colo. 1902), 69 Pac. 574.

4 See cases cited in the preceding section and compare Peck $\nabla$. Denniston, 121 Mass. 17, with Deering v. Reilly, 1901, 167 N. Y. 184, 193; 60 N. E. 447.

\$ 1893,139 N. Y. $390 ; 34$ N. E. 1047, 1052. 
varying opinions of courts as to the inferences which we shall draw concerning the intention from the words in which the grant is couched.

$\S 91$. Streets and highways as boundaries-When grantee takes the entire street.-This rule has been extended so as to include the whole street which is on the margin of the platted land-as where one lays out a street entirely on his own land, and at one side of it, so that the boundary of his land and the boundary of the street coincide. If then, he conveys land as bounded on that street, the grantee takes not merely to the middle of the street, but the whole of it. ${ }^{56}$ When, however, the grantor has an interest in the half of the street at the extreme margin of his platted land, or has rights beyond the margin-as, for example, riparian rights-his conveyance of lots abutting on the street should not be construed as conveying the entire street.

For example, in Banks $\mathbf{v}$. Ogden, ${ }^{57}$ the question was as to the ownership of accretions which had formed at the shore line of Lake Michigan near Chicago, this line being the outer edge of a street, and the lots adjoining it having been conveyed by the original proprietor: it was decided that, in conveying lots on the street, he conveyed only to the center of the street, and after his conveyance still owned the part adjoining the lake, and so owned the land formed by accretions on that part.

$\$ 92$. Description by courses and distances will control quantity named-"More or less"-When statement of quantity important.-Courses and distances mentioned

${ }^{56}$ Healey v. Babbitt, 14 R. I. 533, where the question was as to the ownership of land in a street upon the discontinuance of the street which was on the margin of a former grantor's plat: it was held that the grantee of the former owner of the whole body of land was entitled to the fee of the entire highway. See also, In re Robbins, 34 Minn. 99; 24 N. W. 356; Taylor v. Armstrong, 24 Ark. 102; Haberman v. Baker, 1891,128 N. Y. 253 ; 28 N. E. 370 ; 13 L. R. A. 611.

st 2 Wall. 57 ; see the map. 
generally control the statement of quantity, the latter being considered, generally speaking, as less likely to be definite. A statement of quantity has little effect where the rest of the description is definite and accurate.

It is common, in speaking of quantity, to use the expressions "about," or "more or less," or similar qualifying words, and it is understood that in such cases the parties assume the risk of a deficiency or an excess within reasonable limits. Where there has been no fraud in the sale, and simply an estimate of quantity has been made, the purchaser takes the risk of its correctness. And if the statement of a number of acres is a mere matter of description, and not of the essence of the contract, the buyer clearly assumes the risk of the quantity, provided there is no intermixture of fraud. ${ }^{58}$

These words, "more or less," have been allowed to cover considerable deficiencies in many cases. For example, where an action was brought on a note for the purchase price of land conveyed, the description of the land was by metes and bounds, "containing 451 acres, more or less ;" the consideration was stated to be $\$ 20,000$. There was a deficiency of 54 acres. It was held that it was not a sale by acre, but in bulk, for a gross sum..$^{59}$

In Noble v. Googins, ${ }^{60}$ there was a contract for the sale of a certain lot, measuring "about 220 feet on $\mathrm{C}$ street, more or less". There were but 170 feet. Nevertheless, it was held that unless the deficiency was so great as to show fraud, the defendant must pay the whole gross price, the court stating the general principle that the description of land by its boundaries or the insertion of the words "more or less" will control a statement as to quantity, so that neither party will be entitled to relief.

Even if a sale be by the acre, and the discrepancy is slight, and the words "more or less" are used, equity

${ }^{38}$ Tyler $\nabla$. Anderson, 106 Ind. $185 ; 6$ N. E. 600.

${ }^{59} \mathrm{King} \nabla$. Brown, 54 Ind. 368.

so 99 Mass. 231. 
will not interfere on behalf of either the vendor or vendee; as, in a sale of 195 acres there was a deficiency of $1 \frac{37}{100}$ acres. This was held to be controlled by the phrase "more or less", and not such a deficiency as to entitle the vendee to relief. ${ }^{61}$

The sale in cases where the quantity is named as "more or less," without any other understanding, is generally held to indicate a sale in gross and not by the acre, but where there is a misrepresentation as to the quantity, or an express sale by the acre, and there proves to be a substantial deficiency, the vendee may recover back an overpayment, or equity will enjoin the collection of the purchase price, ${ }^{62}$ and in such a case the words "more or less" will not prevent the vendee from showing that a certain number of acres was named as the inducement for his purchase. ${ }^{63}$ Of course, also, by an express covenant, or by other terms in the conveyance, the quantity may become the chief element in the description; as, for example, where the deed, after describing the land by courses and distances, provided that "said tract shall contain just one acre, and the distances shall be so construed ".64

And, although the statement of quantity is the last part of the description relied upon, it is often allowed controlling force where there is uncertainty from the rest of the description as to the land conveyed, even where the words "more or less" are used.60

\$93. Reference in description to maps.-It is very common practice to refer in a conveyance to a map or

" Frenche v. Chancellor, 1893, 51 N. J. Eq. 624 ; 27 Atl. 140.

Wilson v. Randall, 67 N. Y. 338; Thompson v. Catlett, 24 W. Va. 524.

Moore v. Harmon, 1895, 142 Ind. 555 ; 41 N. E. 599.

* Sanders v. Godding, 45 Iowa 463.

os Ely's Administrator v. United States, 1898, 171 U. S. 220, 234 ; Hoffman v. Port Huron, 1894, 102 Mich. 417, 435; Oakes v. DeLancey, 1892, 133 N. Y. 227 ; 30 N. E. 974 ; Hostetter v. Railway, 1895, 108 Cal. 38 ; 41 Pac. 330; Wilson v. Hildreth, 118 Mass. 578. 
plat. Such a reference has the effect of incorporating the map or plat in the conveyance. ${ }^{67}$ The reference to a map or plat is usually to one that is properly recorded, but if the plat referred to does not conform to statutory requirements and is hence invalid as a plat and is improperly recorded, the deed referring to it is not affected : it is a good conveyance as between the parties and is binding on them and all who have notice of the plat by the reference to it in the conveyance, ${ }^{68}$ and the reference may be made with the same effect to a map or plat not recorded or filed in any public office. ${ }^{69}$

\$94. Grantee's rights in streets shown on map.Where the owner of land has platted it into lots with adjoining streets and alleys, and sells lots referring in his conveyances to such streets as bounding the lots, or referring to the plat or map on which they are shown, the grantees of the lots acquire a right of way in the streets so referred to, even though they may not be actually opened - for the grantor is estopped (as against his grantees) to deny the existence of the streets, ${ }^{70}$ provided the land so described as streets belongs to the grantor. ${ }^{71}$ By some decisions the grantee in such cases is entitled to the use of all the streets shown on the plat; none of them can, as against any grantee who has bought by the plat, be

o Masterson v. Munroe, 1895, 105 Cal. 431; 45 Am. St. R. 57 ; 38 Pac. 1106 ; Nichols v. N. E. Furniture Co., 1894, 100 Mich. 230; Ferguson's Appeal, 117 Pa. 427; 11 Atl. 885; State Savings Bank v. Stewart, 1896, 93 Va. 447 ; 25 S. E. 543.

Nichols v. Furniture Co., 1894, 100 Mich. 230; Young v. Cosgrove, 1891, 83 Iowa 682; 49 N. W. 1040; Borer v. Lange, 1890, 44 Minn. 281; 46 N. W. 358.

Wiley v. Lovely, 46 Mich. 83; 8 N. W. 716; Collins v. Asheville Land Co., 1901, 128 N. C. 563 ; 39 S. E. 21; 83 Am. St. R. 720; Deery v. Cray, 10 Wall. 263.

${ }^{7}$ Garstang จ. Davenport, 1894, 90 Iowa 359 ; 57 N. W. 876; Cox v. James, 45 N. Y. 557; Wolf v. Brass, 72 Texas 133 ; 12 S. W. 159.

"Cole v. Hadley, 1895, 162 Mass. 579 ; 39 N. E. 279.

8-Brews. Con. 
closed, for the general scheme shown by the plat is regarded as a unity. ${ }^{i 2}$ But, by other decisions, the grantee, while entitled to a way over the streets shown on the plat which are necessary or convenient to the use of his lot, is not entitled to have every street indicated on the plat left open. ${ }^{73}$

§95. Statutory plats-Maps may aid description though not expressly referred to.-.!n most states there are statutes authorizing a landowner to survey his land and lay it off into blocks and lots, with parks, intersecting streets, etc., and to file among the public records a map or plat of the land so laid off, when the map is certified and authenticated in accordance with the statute. Under such statutes there will generally be a dedication of the streets, parks, etc., shown on the plat. Original subdivisions are often subjected to re-subdivision. Lots in such subdivisions are generally sold by a brief reference to their number on the recorded plat, often no other description being given than the lot and block number of the subdivision. These plats are important to be considered in conveyancing and examining titles. It is often necessary to consult the original plats, and it is well to become familiar with the system of indexing and record-

$n$ Wolfe v. Sullivan, 1892, 133 Ind. 331 ; 32 N. E. 1017; Collins v. Asheville Land Co., 1901, 128 N. C. 563; 83 Am. St. R. 720 ; 39 S. E. 21.

${ }^{73}$ Pearson v. Allen, 1890, 151 Mass. 79; 23 N. E. 731; 21 Am. St. R. 426. By what appears to be the general rule a conveyance by the owner of the platted land, with reference to the plat showing the streets, amounts to a dedication of the streets to the public. Quicksall v. Philadelphia, 1896, 177 Pa. 301 ; 35 Atl. 609 ; Meier v. Portland Cable Co., 16 Ore. 500; 19 Pac. 610; Trustees M. E. Church v. Hoboken, 33 N. J. L. 13; 97 Am. D. 696 ; Irwin v. Dixion, 9 How. 10, 31. But by some decisions the filing of the plat and making conveyances with reference to streets not actually opened is not considered as a dedication to the public at large, though individual purchasers have rights of way in them. In re Eleventh Ave., 81 N. Y. 436; Sacramento v. Clunie, 1898, 120 Cal. 29; 52 Pac. 44 ; Prescott v. Edwards, 1897, 117 Cal. 298; 49 Pac. 178; 59 Am. St. R. 186. 
ing them, as well as with the chief statutory requirements for platting and subdividing land.

Plats and maps may be used to explain the description, though not expressly referred to in the conveyance, where it is evident the parties had the map or plat in mind. This must generally be the case where land is described, as it often is, as "lot No. — , of - 's addition to. the city of -". This method, without further explicit reference to a plat is careless. And the plat should be consulted by the purchaser. The advantage of consulting the original plat may be illustrated by a case where one granted two lots, each described in the deed as sixty feet wide, in a certain block owned and laid out by him, a plat of which had been filed, by which plat the block mentioned contained a larger number of lots, each only twenty-six feet wide. It was held that the words describing the width as sixty feet must be rejected, and that, in the absence of competent proof to the contrary, the parties must be presumed to have contracted with reference to the real condition of the property. ${ }^{74}$ As these publicly filed maps may aid the description, though not expressly referred to, so also private maps, though not referred to, may be treated as part of the description when evidently intended to be so treated..$^{75}$ And a map is sometimes indorsed on the deed, and may be looked to in explanation of the description, though not expressly referred to in it. ${ }^{76}$

\$96. Incorrect maps controlled by monuments.-But maps and plats are only one method of helping to make a description; and where, as is often the case, the map does not correctly represent the actual portion of land as staked out or otherwise marked on the earth, and there is a con-

"Arambula v. Sullivan, 1891, 80 Texas $615 ; 10 \mathrm{~S}$. W. 436 . And see, Masterson v. Munroe, 1895, 105 Cal. 431 ; 38 Pac. 1106; 45 Am. St. R. 57. ${ }^{25}$ Prouty v. Tilden, 1896, 164 Ill. 163; 45 N. E. 445.

Marray v. Klinzing, 1894, 64 Conn. $78 ; 29$ Atl. 244. 
flict between the map and the monuments on the land, the monuments will control the description. These monuments on the land are facts. Plats and maps and notes regarding them are but descriptions which serve to assist in ascertaining the facts. Parol evidence will therefore be received to show that the map as drawn does not correspond with the survey as made and marked on the ground. ${ }^{77}$

$\$ 97$. Reference may be made to other deeds, etc., for description.-A conveyance may refer to another deed or contract for a more complete description of the land conveyed, and the description referred to is thus a part of the later conveyance, and may be used to make certain what is uncertain in the latter. ${ }^{78}$ But the reference in a deed to an earlier one for the purpose of showing the present grantor's chain of title (in the ordinary form, as: " being the same premises conveyed to me by, etc.") is not necessarily conclusive that the grantor intended to convey all the land conveyed to him by the deed referred to. ${ }^{79}$

$\$ 98$. Lands bounded by waters-General rule.-As land increases in value with increasing population, the question as to how far the grantee's title extends when land is bounded by waters increases in importance. It presents itself in various and interesting forms.

Cities have grown up on the margins of rivers and lakes; artificial and natural causes have changed physical conditions; drainage, for agricultural and other purposes, has caused lakes and ponds to become dry

$\pi$ Burke v. McCowen, 1896, 115 Cal. 481, 486; 47 Pac. 367 ; Decatur v. Niedermeyer, 1897, 168 Ill. 68; 48 N. E. 72; Thrush v. Graybill, 1900, 110 Iowa $585 ; 81$ N. W. 798; Stetson v. Adams, 1898, 91 Maine 178; 39 Atl. 575; Whitehead จ. Ragan, 1891, 106 Mo. 231; 17 S. W. 307; Olson v. Seattle (Wash. 1903), 71 Pac. 201.

${ }^{78}$ West v. Bretelle, 1893, 115 Mo. 653; 22 S. W. 705 ; Rupert v. Penner, 1892, 35 Neb. 587; 53 N. W. 598; 17 L. R. A. 824; Newman v. Tymeson, 13 Wis. $172 ; 80$ Am. D. 735 .

Tovejoy v. Lovett, 124 Mass. 270. 
land, and streams to change their courses; islands have sprung up or been swept away; the erection of wharves, docks and bridges; the building of railroads ; the cutting of ice; the location near water-courses and lakes of summer resorts and shooting and fishing clubs-all these varied conditions bring forward questions regarding both riparian rights and the titles of marginal landowners to submerged soil.

While natural differences in the kinds of bodies of water taken as boundaries produce, not unnaturally, different results, the question as to how far sub-aqueous land is conveyed is further complicated by a lack of harmony among the authorities as to the law on some points, the result being that the grantee's title will be deemed to extend further in some jurisdictions than it will in others, even when the water boundary is of the same character in each. And in some jurisdictions such questions appear to be still unsettled.

While much depends on the circumstances of each case and on local laws, some general rules seem established which assist one in drawing descriptions of this character or in construing those drawn by others.

A broad general rule, of perhaps first importance, may be stated as follows:

Where water of any kind is made a boundary in the description of lands granted, the presumption is that the grantor conveys title to the grantee as far as his own title extends (even though in some cases this may extend to land under water) unless the terms of the conveyance clearly indicate that the grantor excepts the land at the water's edge and beyond. ${ }^{80}$

to Ballance v. Peoria, 1899, 180 Ill. 29, 36 ; 54 N. E. 428; Goff v. Cougle, 1898, 118 Mich. 307 ; 76 N.W. 489 ; 5 D. L. N. 517 ; 42 L. R. A. 161 ; Railroad Co. v. Platt, 1895, 53 Ohio St. 254, 266 ; 41 N. E. 243 ; Hanlon v. Hobson, 1897, 24 Colo. 284 ; 51 Pac. 433 ; 42 L. R. A. 502 ; Williamsburg Boom Co. v. Smith, 84 Ky. 372; 1 S. W. 765; Norcross v. Grifliths, 65 Wis. $599,610,615 ; 27$ N. W. 606 ; 56 Am. R. 642; Waverly Inp. Co. v. 
It should not, however, be understood from this general rule, that when one owns lands on both sides of a stream, and also owns the bed of the stream, and conveys land on one side only, he conveys the whole bed; in such cases the central point of the monument (i. e., the stream) is to be taken as a general rule. ${ }^{81}$

\$99. The basis of the rule-Application to cases where water is not named as a boundary.-This general rule, or presumption, is founded partly on public policy, for when one conveys land bounded by water, to the land under which he may have certain rights, he does not as a fact intend ordinarily to reserve to himself any rights in or under the water which bounds the dry land, and it would be contrary to public policy to allow him or his representatives afterward-and perhaps under very different conditions-to claim rights which he has not expressly reserved or excepted. As by every conveyance many things pass without special mention-for example, minerals, fences, trees, rights in the air above the land conveyed and in the waters beneath it-so the soil owned by the grantor under the water boundary passes as a part of the adjacent dry land conveyed. ${ }^{82}$

For the application of this rule it is immaterial whether

White, 1899, 97 Va. 176; 33 S. E. 534; 45 L. R. A. 227. In Paine v. Woods, 108 Mass. 160, 169, it is said: "The general ruce of construction of all grants of land bounded by water of any kind is now well established; that unless qualified by restrictive words they pass the soil toward the center of the water as far as the grantor owns. For example, where, as in this commonwealth, the shore of the sea between high and low water mark is private property, it is included in a grant of land bounded 'by the sea' or 'harbor' or 'bay' or other word descriptive of tide water."

${ }^{81}$ See ante, $\S 88$, and Muller v. Landa, 1868, 31 Texas 265; $98 \mathrm{Am}$. Dec. 529.

82 There is no conflict here with the general rule that "land cannot be appurtenant to land"-Humphreys v. McKissock, 140 U. S. 304, 314because, where subaqueous land passes in such cases, it does so, not as an "appurtenance" of the dry land, but as described in the deed as part of it by virtue of this presumption. 
the water be named as a boundary of the land granted, or whether there be a description by courses and distances bringing the boundary to the body of water. ${ }^{83}$ So the rule applies where land bordering on water is platted, and the water lots are conveyed by their lot numbers without special mention of the water. ${ }^{84}$

\$100. Application of general rule, how limited by grantor.-Grantors may, of course, limit their conveyances and reserve to themselves proprietary rights in front of the land conveyed, but such limitation and reservation will not generally be presumed.

The limitation by way of exception or reservation may be expressed in the conveyance-and some courts will be more ready to find such restriction from the words used than will others. Or, on the principle that maps and plats referred to become incorporated in the description, the same end may also be accomplished by a reference to a plat: and, if on the face of the plat, so referred to, there is indicated an intent on the part of the grantor to make the case exceptional, and to reserve to himself rights in front of the water lots marked on the plat, the general rule will not apply. ${ }^{85}$ As to what terms will be enough to show a grantor's intention to restrict his grant, in the absence of an unqualified exception in the conveyance, or one by such reference to a plat as has just been mentioned, somewhat the same difficulties are experienced as arise in the case of a boundary on a street or highway..$^{86}$

If a stream is given as a boundary in general terms, or

Railway Co. v. Platt, 1895, 53 Ohio St. 254, 266 ; 41 N. E. 243 ; Norcross $\nabla$. Griffiths, 65 Wis. 599, 610, 615; 27 N. W. 606; 56 Am. R. 642.

st Head v. Chesbrough, 1897, 13 Ohio Cir. Ct. 354; 60 Ohio St. 594 ; 54 N. E. 1102; Watson v. Peters, 26 Mich. 508. See In re White's Charities, 1898, 1 Ch. 659, 664 ; Trustees v. Haven, 11 Ill. 554.

* Nichols v. Furniture Co., 1894, 100 Mich. 230; Gilbert v. Emerson, 1893, 55 Minn. 254, 261; 56 N. W. 818; Palmer v. Farrell, 129 Pa. St. $162 ; 18$ Atl. $761 ; 15$ Am. St. R. 708.

$\checkmark$ See above, $\$ 90$. 
the line is described as "running along" the stream, the general presumption will ordinarily govern, and the grantee will take as far toward the center of the stream as the grantor owns. But if the land is described as bounding on the "shore" or "bank," it has often been held that the grantor intends to reserve whatever title he may have to the bed of the water, for the special reference to the bank has been considered as excluding the bed.

But, as illustrating how descriptions of this general character may be differently interpreted by different courts, one or two cases may be noted. In Starr v. Child ${ }^{87}$ part of the description was: "thence parallel with B street to the Genesee river; thence northeasterly along the shore of said river to B street." The construction of this by Justice Cowen was that the bed of the stream to the center passed to the grantee; but this decision was reversed on appeal to the court of errors by a vote of eleven to ten. ${ }^{88}$ Whereas a similar description in Sleeper v. Laconia ${ }^{89}$ was construed as not restricting the grant to the bank or shore, and it was held that the grantor could not be considered as having retained the strip of land under the stream..$^{90}$

$\S 101$. How far the rule applies to public grants.-It is often necessary to consider how far the general rule of construction applies to public grants from a state or the United States; for conflicting claims frequently arise as to the ownership of islands, beds of streams, etc., from the fact that public grants are made, attempting to convey what appears (if the rule applies to such grants) to have been previously conveyed by the government.

As to boundaries on non-tidal waters, at least, the general rule has been held to apply to public grants-the

871838,20 Wend. 149.

${ }^{88}$ Child v. Starr, 1842, 4 Hill 369.

${ }^{89} 60$ N. H. 201.

${ }^{90}$ And compare, Murphy v. Copeland, 51 Iowa $515 ; 1$ N. W. 691. 
presumption, that is, being against the grantor in such cases as it would be in the case of private grants.

The rule has been considered, therefore, as applying to grants from a state, ${ }^{91}$ and to grants from the United States, even to patents for lands on navigable rivers above tide waters in states where private persons may have title to the beds of such rivers. And it is said in some cases that the government forms no exception to the maxim that grants must be construed most strongly against the grantors..$^{92}$

In spite of such expressions, however, the rule of construction as to public grants is properly different from that which governs private grants, for public grants are generally to be strictly construed against the grantee. Therefore, where the grant from the United States is of lands bordering on tidal waters the same presumption against the government does not prevail, ${ }^{98}$ nor does it where the lands are bounded by a navigable river in those states which do not recognize private ownership of the beds of navigable rivers." For "when land under navigable water passes to the riparian proprietor, along with the grant of the shore by the United States, it does not pass by force of the grant alone, because the United States does not own it, but it passes by force of the declaration of the state which does own it that it is attached to the shore." 96 Nor does this presumption prevail in the case of grants by the government of lands bounded by the waters of one of the "Great Lakes," the

${ }^{91}$ Boston v. Richard8on, 105 Mass. 351, 355; Granger v. Avery, 64 Maine 292; Ex parte Jennings, 6 Cow. 518.

${ }^{2}$ Butler v. G. R. \& I. R. Co., 1891, 85 Mich. 246, 255 ; 48 N. W. 569 ; $24 \mathrm{Am}$. St. R. 84, affirmed by the supreme court of the United States, 159 U. S. 87; Jones v. Soulard, 24 How. 41 ; Middleton v. Pritchard, 3 Scam. (4 Ill.) 510; 38 Am. Dec. 112; Chandos จ. Mack, 77 Wis. 573 ; 20 Am. St. R. 139 ; 10 L. R. A. 207; Williamsburg Boom Co. v. Smith, 84 Ky. 372.

Shively v. Bowlby, 152 U. S. 1, 10, 13.

* Packer v. Bird, 1890, 71 Cal. 134; 137 U. S. 661.

$\$$ Hardin v. Shedd, 1903, 190 U. S. 508; 23 Sup. Ct. R. 685. 
beds of which are held in trust for the public, and are analogous to tidal waters. ${ }^{96}$.The United States supreme court, in passing on the effect of such grants, will generally apply the law of the state where the granted land is; and, as all the states do not hold to the same doctrines as to the extent of private ownership of land under water, the effect of decisions of the supreme court on this matter will vary with the location of the land. ${ }^{97}$

$\$ 102$. Public grants-The "meander line."-In many of the states the comparatively recent source of title to most land is the United States.

The general government, after a survey of its public lands, has conveyed them to settlers, often in localities which have since become thickly populated

In opinions discussing questions concerning titles to lands bordering on waters, the "meander line" is often referred to in connection with these public grants.

The meander line is the line run in surveying lands bordering on waters, and follows, in a general way, the windings or curves of the land at the edge of the stream or lake surveyed, but is not generally coincident with the actual margin of the water..$^{98}$

96 Illinois Steel Co. v. Bilot, 1901, 109 Wis. 418; 85 N. W. 402; 83 Am. St. R. 905 ; see post, $\S 112$.

${ }^{97}$ Compare, for example, Packer v. Bird, 1890, 71 Cal. 134; 137 U. S. 661, with Grand Rapids \&c. R. Co. v. Butler, 1894, 159 U. S. 87.

${ }^{98}$ The "meander line" is not expressly created by law, but early United States statutes, governing the surveys of public lands, provided for the subdivision of the lands into townships six miles square, sections one mile square, and quarter sections, these subdivisions to be bounded by north and south, and east and west lines, "unless where the line of an Indian reservation, or of tracts of land heretofore surveyed or patented, or the course of navigable rivers, may render this impracticable": a plat of the land surveyed was to be made by the district surveyor-general on the return of the contents of each subdivision. The meanderings of a water-course, being the boundary of a "fractional" subdivision, would thus be shown by the "meander line." See Shively v. Bowlby, 1894,152 U. S. 1, 33; U. S. R. S., \$\$ 2395, 2396, 2399, 2407.

Particular instructions were issued from the general land office from 
Often there is much dry land between the line as surveyed and the water's edge, and the question arises as to whether this intermediate land has been conveyed by the government when it has sold lands according to the survey, or whether it shall be regarded as undisposed of, and so subject to a future grant by the government.

The meander line is run for the purpose of ascertaining the quantity of land subject to sale-the number of acres the purchaser shall pay for-and is not run as a boundary line.

Consequently, the general rule is that the first grantee from the government of such lands takes to the water at least, and not merely to the meander line, even though the line as surveyed does not nearly coincide with the water line. Hence the government cannot convey the land between the meander line and the water-course or lake, where it has previously conveyed the lands according to its survey, without restriction or reservation.

This rule is well established by decisions of the United States supreme court, ${ }^{99}$ and has often been applied by the state courts. ${ }^{100}$ The application of the rule produces, in particular cases, somewhat peculiar results ; as, for example, where a small fractional lot of four and a half acres was held to include an unsurveyed point, running beyond the meander line into a lake, and containing twenty-five

time to time: for example, in 1855 , deputy surveyors were instructed as to the method of meandering navigable streams; and they were also instructed to meander "all lakes and deep ponds of the area of twentyfive acres and upward; also navigable bayous; shallow ponds, readily to be drained, or likely to dry up are not to be meandered." Lester's Land Laws, p. 714 (ed. of 1860).

Railroad v. Schurmeir, 1868, 7 Wall. 272 ; Hardin v. Jordan, 1891, 140 U. S. $371,380$.

100 Albany Bridge Co. v. People, 1902, 197 Ill. 199 ; 64 N. E. 350 ; Sizor v. Logansport, 1898, 151 Ind. 626; 44 L. R. A. 814; 50 N. E. 377; Peuker v. Canter, 1901, 62 Kan. 363; 63 Pac. 617; Olson v. Thorndike, 1899, 76 Minn. 399; 79 N. W. 399; Knudsen v. Omanson, 1894, 10 Utah 124; 37 Pac. 250; Washougal \&c. Trans. Co. v. Dalles \&c. Nav. Co., 1902, 27 Wash. 490. 
acres. ${ }^{1}$ But, on the whole, its application has resulted in giving, what was evidently contemplated, a water frontage at least. ${ }^{2}$

$\$ 103$. When the meander line will be taken as the boundary.-It is important to notice that while this general rule, as to meander lines, is thus well recognized, it will not be applied where it clearly appears to have been the intention when the survey, maps and patents are compared, not to convey the government title beyond the meander line. ${ }^{8}$ Moreover, the courts in other recent decisions, while admitting the general rule, hold that where there has been either fraud or mistake in making the survey, and the so-called meander line does not in fact outline or approach a body of water, it must be taken as the boundary line.

Such mistakes have occurred where the government surveyors have carelessly assumed that a body of water was, at the time of the survey, of much greater extent than it actually was, ${ }^{4}$ or where they have assumed that what proves later to have been but a temporary lake was a

1 Mitchell v. Smale, 1891, 140 U. S. 406.

In Harrison v. Stipes, 1892, 34 Neb. 431 ; 51 N. W. 976; it is held that "an entry of government land bounded by a meander line does not include land lying at the time between such meander line and the bank of the river," which appears to be an exceptional doctrine as thus stated, contrary to the weight of authority. This and earlier decisions in Nebraska are explained in the recent case of McBride v. Whittaker, 1902,90 N. W. 966.

${ }^{3}$ Niles v. Cedar Pt. Club, 1898, 85 Fed. R. 45 ; 54 U. S. App. 668 ; affirmed in the United States supreme court, 175 U.S. 300 . In this case the survey stopped at the border of a marsh, called by the surveyor "impassable marsh and water": over 4,000 acres lay between the "meandered line" of early patents and the open waters of Lake Erie, and the club got later patents of this marsh from the United States, its title being sustained in these decisions. See also, Horne v. Smith, 1895, 159 U. S. 40 .

4 Whitney v. Detroit Lumber Co., 1890, 78 Wis. 240 ; 47 N. W. 42:; Live Stock Co. v. Springer, 1899, 35 Ore. 312; 58 Pac. 102; same case on appeal U. S. supreme court, 185 U. S.47; 22 Sup. Ct. 563; Security Land \&c. Co. v. Burns, 1902, 87 Minn. 97; 91 N. W. 304. 
body of water proper to be "meandered." 5 In such cases the meander line, not having been fairly and honestly drawn, after an actual survey, rather than a fictitious one, the plat does not represent the contour of the body of water, nor even approximately the true quantity of upland between the meander line and the water. These latter cases appear to be instances of gross carelessness on the part of the government surveyors. The decisions in general, however, give no definite answer to the question : how near the actual water line must the meander line approach in order that the general rule, stated in the last section, shall apply, rather than its exception, as illustrated by these decisions?

$\S 104$. How far does title extend under water \&-Tidal waters.-Taking the general rule stated above ${ }^{6}$ as a guide - that is, that the grantor is presumed, in the absence of words of restriction, to convey his title, to lands bounded by water, as far as his title extends (not generally beyond, however, the "middle thread" of a stream) - the practical question will then be in each case, how far beyond the actual dry land does the grantor's title extend, under the laws of the place where the land lies?

The answer to this question will depend somewhat upon the character of the water named as a boundary; as, for example, whether it is tide water, or a river, or a lake, etc.

It has been taken for granted by many authorities that, In waters affected by the tides, the title to all lands below high water mark is, by the common law, in the king.

This proposition has, however, not always been accepted as a correct statement of the common law, and it is doubtful whether it is really as well established as it has been assumed to be. ${ }^{7}$

Schlosser v. Hemphill, 1902, 118 Iowa 452; 90 N. W. 842; Carr v. Moore, 1903 (Iowa); 93 N. W. 52.

\$ 98.

' See a valuable discussion of the question in 45 L. R. A. 227, 237. 
It having been thus assumed that the shore of the sea belongs to the king, up from the sea as far as the high water mark, it is presumed that the title of others to lands adjoining tide water extends to this line only ; and while private persons may, by grant or, according to some decisions, by prescription, ${ }^{8}$ acquire title below high water mark, the ordinary presumption is against such ownership.

So it is generally stated, that, by the common law, private ownership of land bordering on tide waters extends, prima facie, to high water mark only. ${ }^{9}$ Whatever title, however, the king once had of a private, personal nature has long since given place in England to a representative title by which he holds for the people. ${ }^{10}$ In this country many of the principles relating to tidal waters have been applied to our larger inland lakes, and are, therefore, of importance to others than dwellers on the seacoast.

The following brief summary of part of an important opinion $^{11}$ is given :

On the settlement of the American colonies the rights of the king passed to the grantees named in the royal charters, in trust for the communities to be established, and on the American Revolution these rights, charged with a like trust, were vested in the original states, subject to the rights surrendered by the Constitution to the United States. On the acquisition of new territory by the United States, either by cession from a state or by treaty,

${ }^{B}$ Church v. Meeker, 1867, 34 Conn. 421, 429; Nichols v. Boston, 1867, 98 Mass. 39; 93 Am. D. 132; Oakes v. DeLancey, 1892, 133 N. Y. 227, 231 (obiter); 28 Am. St. R. 628 ; 30 N. E. 974.

${ }^{9}$ Sage v. Mayor, 1897, 154 N. Y. 61, 69; 61 Am. St. R. 592 ; 38 L. R. A. 606 ; 47 N. E. 1096; United States v. Pacheco, 1864, 2 Wall. 587, Field, J.: "When the sea or a bay is named as a boundary the line of ordinary high water mark is intended where the common law prevails."

${ }^{10}$ Gann v. Free Fishere, 1865, 11 H. L. Cas. 192.

"Shively v. Bowlby, 1894, 152 U. S. 1; pp. 18 to 26. 
or by discovery and settlement, the same title and dominion passed to the United States for the benefit of the whole people, and in trust for the several states to be ultimately formed out of the new territory.

New states admitted into the union, since the adoption of the Constitution, have the same rights as the original states in the tide waters and in the lands under them within their respective jurisdictions.

The title and rights of riparian proprietors in the soil below high water mark, therefore, are governed by the laws of the several states, subject to the rights granted to the United States by the Constitution. The matter of title to lands under tidal waters, being subject to control by the several states, we find the common law rule much modified by usage and statute among the older states along the Atlantic seaboard, many of the statutes being early colonial ordinances.

Some of these states have reserved to the state the lands under tide water, others have, by general laws, or by grants or usage, given to private persons either title below high-water mark or rights in the shore practically equivalent to it. The decisions of these states must be read in the light of such statutes and usages: "Great caution, therefore, is necessary in applying precedents in one state to cases arising in another." 12

105. How far does title extend ?-Rivers-At common law.-As it came to be generally regarded as settled that the title to the soil under the sea was in the king, so his title was considered as extending inland as far as the sea went, and the sea extended inland up bays and rivers as far as the tide ebbed and flowed.

Hence the same rule was applied, in determining whether the king or the private subject had title to lands under inland streams, as to the seashore.

12152 U. S., p. 26. 
The ebb and flow of the tide, as marking the extent of the sea, seems to have been the test, and wherever the tide is there no private person (ordinarily, and in the absence of special grant or prescription) owns below high water mark at common law. On the other hand, above the point of tidal flux and reflux, the bed and soil of a river are vested in the riparian proprietors, those on either bank possessing it usque ad medium filum aquæ, and this none the less because it is actually navigable. For the word "navigable," used in a legal sense as applied to a river in which the soil prima facie belongs to the crown, and, for example, the fishing to the public generally, imports that the river is one in which the tide ebbs and flows. ${ }^{13}$

As it was generally, though not universally, a fact that, in England, only those rivers that were affected by the tides were navigable, and as the rivers so affected were ordinarily public rivers, and, in the technical sense, thus navigable, many courts and text-writers have drawn the conclusion that the test at common law of public ownership of the bed of a river was actual navigability and not the ebbing and flowing of the tide. ${ }^{14}$ But this appears to be an error arising naturally from the very general coincidence of English navigable waters and tidal waters.

$\$ 106$. Rivers in the United States-Private title to bed in some states.-The courts of many of our states have followed the English rule as to non-tidal streams, regardless of whether the stream is navigable or not, and in those jurisdictions the title of purchasers of lands bordering on navigable rivers extends to the middle of the main channel of the river.

18 Murphy v. Ryan, 1868, 2 Ir. C. L. Rep. 143; Pearce v. Schotcher, 1882, L. R. 9 Q. B. D. 162 ; Leake, "Law of Uses and Profits of Land," pp. 153, 156, 158, 159, 162, 180, 182; 42 L. R. A. 162, 305.

16 See Illinois Central R. v. Illinois, 1892, 146 U. S. 387, 435, 436. And post, \$108. 
This is the rule in Illinois, Kentucky, Michigan, Ohio and Wisconsin. ${ }^{15}$

Where this doctrine is held, private ownership is subject to the public right of navigation; and the adjoining landowner's title to the bed of a navigable river is sometimes spoken of as a qualified, rather than an absolute, title. ${ }^{16}$

In Scranton v. Wheeler ${ }^{17}$ it was held that the title to submerged lands along navigable rivers, and the right of access thereto, are subject to the paramount right of the United States to use the land in such manner as it shall - determine to be necessary in aid of navigation, as by building piers, etc.; and in affirming this decision, the supreme court of the United States ${ }^{18}$ holds that the government need make no compensation for the injury to the riparian owner's right of access to navigable waters, as this is not taking property for public use: three justices dissent, Shiras, J., stating for them that the question of title to submerged land is not involved, and basing the dissent on the ground that access to navigable water is private property, and cannot be taken for public purposes without compensation. In states, therefore, where this "middle thread" rule prevails as to navigable rivers, while the adjoining landowner has title to the submerged lands, he has simply the "bare, technical title."19

1s Bellefontaine Imp. Co. v. Neidringhaus, 1899, 181 Ill. 426; 55 N. E. 184 ; 72 Am. St. R. 269; Kentucky Lumber Co. v. Green, 1888, 87 Ky. 257; 8 S. W. 439; Hall v. Alford, 1897, 114 Mich. 165; 72 N. W. 137; 38 L. R. A. 205 ; Lake Shore R. v. Platt, 1895, 53 Ohio St. 254; 41 N. E. 243 ; 29 L. R. A. 52; Chandos v. Mack, 1890, 77 Wis. 573 ; 46 N. W. 803; 20 Am. St. R. 139 ; 10 L. R. A. 207.

${ }^{16}$ Willow River Club v. Wade, 1898, 100 Wis. $86 ; 76$ N. W. 273; 42

L. R. A. 305 .

17 1897, 113 Mich. 565; 71 N. W. 1091 ; 67 Am. St. R. 484.

,2s Scranton $\nabla$. Wheeler. 1900, 179 U. S. 141.

19 Scranton $\nabla$. Wheeler, 1897, 57 Fed. R. 803, 811. See Slingerland $\nabla$. Int. Con. Co., 1901, 169 N. Y. 60; 61 N. E. 995; 56 L. R. A. 494.

9-Brews. Con. 
$\$ 107$. Owner's rights incident to this title-IslandsIce-Shooting and fishing.-Even this limited title is not without value, however, as the person having it is the owner of islands which have formed on his side of the channel ${ }^{20}$ he has the exclusive right to the ice over his portion of the river bed;21 as well as the exclusive right to shoot game on the waters over it, ${ }^{22}$ though, perhaps, only on those waters on his side, that are not generally navigable. ${ }^{23}$

At common law the riparian owner on non-tidal, though navigable, rivers had the exclusive right to fish in the waters over his part of the stream's bed, ${ }^{24}$ for the public right of navigation does not carry with it the right of fishing. ${ }^{25}$ In the United States fishing is to a great extent regulated by statute, and it has been held that the legislature may give the public in general the right to fish in such waters. ${ }^{26}$ In the absence, however, of such a statute it seems that as a rule the riparian owner on a navigable non-tidal stream may control the fishing there in those states where his title to the bed of such stream is recognized. ${ }^{27}$

\$108. Rivers-No private title to bed.-The courts of other states, however, have considered that the ebbing

${ }^{20}$ Bellefontaine Imp. Co. $\nabla$. Neidringhaus, 1899, 181 Ill. 426; $55 \mathrm{~N}$. E. 184 ; 72 Am. St. R. 269; Butler v. G. R. \& I. R. Co., 1891, 85 Mich. 246; 48 N. W. 569; 24 Am. St. R. 84 (aff'd, 159 U. S. 87).

${ }^{21}$ Washington Ice Co. . Shortall, 1881, 101 Ill. 46; 40 Am. R. 196 ; Oliver v. Olmstead, 1897, 112 Mich. 483; 70 N. W. 1036; Reysen v. Roate, 1896,92 Wis. 543 ; 66 N. W. 599.

28 State v. Shannon, 1881, 36 Ohio St. 423; 38 Am. R. 599.

23 Hall v. Alford, 1897, 114 Mich. 165; 72 N. W. 137; 38 L. R. A. 205.

24 Murphy v. Ryan, 1868, 2 Ir. C. L. 143; Smith v. Andrews [1891], 2 Ch. 678.

${ }^{25}$ Pearce v. Scotcher, 1882, L. R. 9 Q. B. D. 162.

${ }^{26}$ Willow River Club v. Wade, 1898, 100 Wis. 86; 76 N. W. 273; 42 L. R. A. 305.

${ }^{27}$ See Sterling v. Jackson, 1888, 69 Mich. 488; 37 N.W. $845 ; 13$ Am. St. R. 405; Albright v. Cortright, 1900, 64 N. J. L. 330; 45 Atl. 634; 81 Am. St. R. 504; 48 L. R. A. 616; Beckman v. Kreamer, 1867, 43 Ill. 447 ; 92 Am. D. 146. 
and flowing of the tide was, at common law, simply evidence of navigability, and that it was really navigability that determined the character of the river as being a "royal river."

Or, if not taking this view precisely, they hold that the proper test to apply under the physical conditions existing in this country, in deciding whether the title to the beds of our rivers shall be public or private, is navigability.

In these states the bed of a river navigable in fact is not subject to private ownership, hence a boundary on such a river carries the grantee's title to the water's edge: in some states to its edge at "high water," and in others to its edge at "low water."

It has been observed that this test of navigability is wanting in that accuracy and certainty at which the law aims, for it can be made certain only by the addition of some arbitrary rule, such as depth of water, quantity of tonnage, etc.; while the tidal test, as a rule by which persons may be guided in ascertaining what rights belong to them as a portion of the public, and what are within the domain of private ownership, has the merit of uniformity and certainty, and is easy of application. ${ }^{29} \mathrm{Nev}-$ ertheless, this latter rule prevails in perhaps the greater number of states, among others in Alabama, Arkansas, California, Iowa, Kansas, Minnesota, Missouri, Montana, North Carolina, Pennsylvania and Virginia. ${ }^{30}$

${ }^{28}$ See next section.

${ }^{29}$ Cobb v. Davenport, 1867,32 N. J. L. 369 . This lack of certainty is well illustrated by a comparison of two recent decisions involving the question of "navigability" of two rivers that appear from the cases to be of about the same size: Willow River Club v. Wade, 100 Wis. 86; if X. W. 273; 42 L. R. A. 305; Griffith v. Holman, 1900, 63 Pac. 239; 2 Wash. 347; $83 \mathrm{Am}$. St. R. 821. In the Wisconsin case the river was held to be navigable in fact, while in the Washington case it was held non-navigable.

:C Webb v. Demopolis, 1891, 95 Ala. 116; 21 L. R. A. 62; 13 So. 289 ; St. Louis \&c. Ry. Co. v. Ramsey, 1890, 53 Ark. 314 ; 8 L. R. A. $559 ; 22$ Am. St. R. 195; Packer v. Bird, 1890, 137 U. S. 661 ; 71 Cal. 134; Mc- 
$\$ 109$. Navigable rivers-Practically three rules in United States.-Navigable rivers above the ebb and flow of the tide are subject to fluctuations not the effect of tides, and these fluctuations have been considered by some courts, the result being that three different rules are in force in the United States as to the extent of private ownership of lands adjacent to such rivers:

1. Private ownership extends to the middle thread of the stream. ${ }^{31}$

2. Private ownership extends to high water mark, title to all below that being in the state. ${ }^{82}$

3. Private ownership extends to low water mark. ${ }^{33}$

It would seem that if all navigable rivers are to be regarded as tidal waters were regarded at common law, then, in so far as they have a high water mark, as distinguished from a low water mark, it should be taken as the limit of private ownership, as it was at common law on tidal rivers. ${ }^{34}$

$\S 110$. Non-tidal, non-navigable rivers.-On streams and rivers not affected by the tide and not actually navigable, the rule in the United States seems to be universal that the riparian owner of one side has title to the middle

Manus v. Carmichael, 1856, 3 Iowa 1 (a "leading case") ; Barney v. Keokuk, 1876, 94 U. S. 324; Wood v. Fowler, 1882, 26 Kan. 682; 40 A m. R. 330 ; St. Paul \&c. R. Co. v. St. Paul \& Pac. R. Co., 1879, 26 Minn. $31 ; 49$ N. W. 303 ; Moore v. Farmer, 1900, 156 Mo. 33 ; 79 Am. St. R. 504 ; 56 S. W. 493; Gibson v. Kelly, 1895, 15 Mon. 417; 39 Pac. 517; State v. Eason, 1894, 114 N. C. 787 ; 41 Am. St. R. 811 ; 19 S. E. 88; 23 L. R. A. 520; Palmer v. Farrell, 1889, 129 Pa. St. 162; 15 Am. St. R. 708; 18 Atl. 761; Goodwin v. Thompson, 1885, 15 Lea 209, 83 Tenn. 209; 54 Am. R. 410; Norfolk v. Cooke, 1876, 27 Gratt. 430.

"Supra, § 106.

"McManus v. Carmichael, 1856, 3 Iowa 1; St. L. \&c. Ky. Co. v. Ramsey, 1890, 53 Ark. 314; 8 L. R. A. 559 ; 22 Am. St. R. 195 ; 13 S. W. 931. ${ }^{39}$ Williams v. Glover, 1880, 66 Ala. 189; Fulmer v. Williams, $122 \mathrm{~Pa}$. St. 191; 9 Am. St. R. 88; 1 L. R. A. 603; 15 Atl. 726; Goodwin v. Thompson, 1885, 15 Lea 209, 83 Tenn. 209; 54 Am. R. 410.

u Barney v. Keokuk, 1876, 9\& U. S. 324, 338, 339. 
thread of the stream, and his conveyance ordinarily passes title to this extent. ${ }^{35}$

Exact definitions, however, of "navigability" and "non-navigability," universally applicable, seem impossible to frame.

Rivers are "navigable in fact when they are used or are susceptible of being used, in their ordinary conditions as highways of commerce, over which trade and travel are or may be conducted in the customary modes of trade and travel on water. * * The capability of use by the public for purposes of transportation and commerce affords the true criterion of the navigability of a river rather than the extent and manner of that use." ${ }_{36}$ Adaptability to navigation for pleasure renders a stream navigable according to some courts, ${ }^{37}$ though the expressions used in most cases where the question is discussed would seem to limit navigability to such streams as are, or may be, used for commercial purposes. ${ }^{88}$

\section{\$111. Boundaries on lakes-Public and private owner-} ship.-In view of recent decisions concerning boundaries on lakes and ponds the subject is worthy of especial attention. Statements as to the matter in some textbooks are misleading, for example, it is sometimes stated as the law that: "If the pond or lake is a natural object, the boundary line is along the edge at low water mark.

25 See Ross v. Faust, 1876, 54 Ind. 471, 474; 23 Am. R. 655; Welles v. Bailey, 1887, 55 Conn. 292; 3 Am. St. R. 48; 10 Atl. 565; Fulmer v. Willians, 1888, 122 Pa. St. 191 ; 9 Am. St. R. 88; 1 L. R. A. 603; 15 Atl. 726.

${ }^{36}$ 'The Montello, 1874, 20 Wall. 430, 439.

37 See Atty. Gen. v. Woods, 1871, 108 Mass. 436; 11 Am. R. 380. S.e Lamprey v. State, 1893, 52 Minn. 181 ; 38 Am. St. R. 541 ; 53 N. W. 1139 ; 18 L. R. A. 670; Grand Rapids v. Powers, 1891, 89 Mich. 94 ; 28 Am. St. R. 276; 14 L. R. A. 498.

* See for recent discussions of the subject, Griffith $\nabla$. Holman, 1900, 23 Wash. 347; 63 Pac. 239; 83 Am. St. R. 821; Willow River Club v. W:ule, 1898,100 Wis. $86 ; 76$ N. W. $273 ; 42$ L. R. A. 305. 
If the pond is artificial the boundary is through its center." 39

It will be seen ${ }^{40}$ that the distinction between natural lakes and artificial ponds is not recognized in several states and that the foregoing is not an entirely correct statement of the law universally applicable. There is, in fact, no fixed and uniform rule as to public and private ownership of the beds of smaller inland lakes, nor as to the extent of private ownership where this is allowed.

Some courts and text-writers have followed Massachusetts decisions, which have generally limited private ownership on lakes to the water's edge, without noticing that they are based on early ordinances, making lakes and ponds, of more than ten acres in area, public, ${ }^{41}$ while others have followed what they consider the common law rule that private persons may have title to the beds of such lakes.

\$112. The "Great Lakes."-Concerning what are known as the Great Lakes, it appears to be now uniformly held that the title to the beds of these lakes is prima facie in the public-that is, in the adjoining state for the use of the public; and the same rule has been applied to other lakes of great size, like Lake Champlain. ${ }^{42}$

s9 Tiedeman, Real Property, § 836, citing Massachusetts and Maine decisions, and following Washburn, Real Property, 5th ed., IIJ, p. 6iit. Substantially the same rule is given in Angell on Water-courses, $\S+1$.

co $§ 115,116$.

4 "The law relating to great ponds is peculiar to this commonwealth and to Maine, which was formerly a part of this commonwealth." Slater v. Gunn, 1898, 170 Mass. 509, 512 ; 49 N. E. 1017 ; 41 L. R. A. 268. "Under the ordinance [of 1641-7] the state owns the great ponds as public property, held in trust for public uses. It has not only the ownership of the soil, but also the right to control and regulate the public uses to which the ponds shall be applied." Watuppa Reservoir Co. v. Fall River, 1888, 147 Mass. 548, 557 ; 18 N. E. 465 ; 1 L. R. A. 466 ;

4 Austin v. Rutland R. Co., 1873, 45 Vt. 215. By some courts this rule is applied to all meandered lakes, whether navigable or non-navigable. Hammond v. Shepard, 1900, 186 Ill. 235, 241; 57 N. E. 86i; 75 Am. St. R. 274 ; see post. $\$ \S 114,117$; and if meandered, a lake is to be 
On these lakes, therefore, the private shore owner's title does not, prima facie, embrace the bed of the lake, consequently he cannot generally convey title beyond the line at which the water stands when free from disturbing causes. ${ }^{43}$ And, as the state holds the beds of these lakes in trust for the whole public, it has been considered that it is not within its power to grant them in fee to any private person." Nor, it has been held, may title to them be acquired as against the state by adverse possession continued merely for the period which would ordinarily give title. ${ }^{45}$ Nor may the shore owner, without authority from the state, build wharves or piers which intrude upon the submerged lands of the state. ${ }^{46}$

However, the supreme court of the United States considers this matter of title to submerged public lands a question of local law; and should a state court hold that the state legislature had power to grant, and had granted to private persons either the title to such lands, or special privileges in them, it appears that the supreme court would not hold the grant invalid unless the state's action interfered with commerce. ${ }^{47}$

There have been instances of private ownership, arising

regarded as navigable in some states, and therefore to be beld in trust for the whole people, hence exclusive privileges as to cutting ice thereon cannot be granted by the state. Rossmiller v. State, 1902, 114 Wis. $169 ; 89$ N. W. $839 ; 58$ L. R. A. 93.

w Sloan v. Biemiller, 1878, 34 Ohio St. 492; People v. Silberwood, 1896, 110 Mich. 103; 67 N. W. 1087; 32 L. R. A. 694; Sherwood v. Com'r Land Office, 1897, 113 Mich. 227; 71 N. W. 532.

" Ill. Cent. R. Co. v. Chicago, 1898, 173 Ill. 471; 50 N. E. 1104 ; affirmed by United States supreme court, 1899, 176 U. S. 646; Ill. Cent. R. v. Illinois, 1892, 146 U. S. 387, 452.

${ }^{45}$ Ill. Steel Co. $\nabla$. Bilot, 1901, 109 Wie. $418 ; 85$ N. W. 402 ; 83 Am. St. R. 905. And see the minority opinion of Hooker, J., in State v. Fishing and Shooting Club, 1901, 127 Mich. 580; 87 N. W. 117.

* Revell v. People, 1899, 177 Ill. 468; 52 N. E. 1052 ; 69 Am. St. R. 257;

43 L. R. A. 790. See Ill. Cent. R. v. Illinois, 1892, 146 U. S. 387.

${ }^{7}$ See Illinois Cent. R. v. Chicago, 1899, 176 U. S. 646, 659, 660; Lowndes $\nabla$. Huntington, 1893, 153 U. S. 1; Shively v. Bowlby, 1894, 152 U. 8. 1, 13; dissent in Illinois Cent. R. v. Illinois, 1892, 146 U. S. 387. 
from public grants, of lands under the navigable waters of bays on the Great Lakes, ${ }^{48}$ and it has also been held that those parts of these lakes may be privately owned which, though covered with a few feet of water, are practically marshes. ${ }^{49}$

$\S 113$. Smaller lakes and ponds.-When smaller lakes are considered difficulties are encountered, partly because of the impracticability of applying any one rule to lakes of varying shapes and sizes, and partly because of the different views which the courts entertain as to what, if any, were the rules of the common law on the subject. The common law apparently provided no rule as to the matter, except that the public title-that is, the title of the king in trust for the public-did not extend beyond tide-water, and so did not extend to inland lakes. It did not, however, clearly regulate the matter of the division of the bed of a lake among the owners of the land adjoining the lake. The English decisions are few. One of the few is Bristow v. Cormican, ${ }^{50}$ and on this case is chiefly based an important decision of the supreme court of the United States, to be noticed presently. ${ }^{51}$

In Bristow v. Cormican the right of an exclusive fishery in one of the largest lakes of Great Britain, from fourteen to sixteen miles long and from six to eight miles broad and containing about 100,000 acres, was involved. The plaintiff claimed his exclusive fishery and title to the lake under a grant from Charles II, without showing how

${ }^{48}$ Hogg v. Beerman, 1884, 41 Ohio St. 81 ; 52 Am. R. 71.

49 Toledo Shooting Co. v. Erie Shooting Club, 1898, 90 Fed. R. 680; Brown v. Parker, 1901, 127 Mich. 390; 86 N. W. 989; Baldwin v. Erie Shooting Club, 1901, 127 Mich. 659; 87 N. W. 59. And see as to grants to private persons in tidal waters: Mullen v. Penobscot Co., 1897, 90 Maine 55; 38 Atl. 557; Oakland v. Oakland Co., 1897, 118 Cal. 160; 50 Pac. 268; United States v. Mission Rock Co., 1903, 189 U. 8. 391; 23 Sup. Ct. R. 606, and 42 L. R. A. 163, note.

so 1878, L. R. 3 App. Cas. 641.

61 Hardin v. Jordan, 1891, 140 U. S. 371. 
the king got his title. It was held that the crown has of common right no prima facie title to the soil of a lake. And the court says: "Whether the rule that each adjoining proprietor, where there are several, is entitled to the middle thread of the water should apply to a lake is a different question. It does not seem convenient that each proprietor of a few acres fronting on the lake should have a piece of the soil of the lake many miles in length tacked on to his frontage. But no question arises in this case as to the rights of the riparian proprietors among themselves, for no title is made by either party through any one as riparian owner." It is thus seen that the court did not decide that adjoining proprietors should be regarded as owning to the center of the lake; though it has been said of this case that the holding that the crown has not prima facie title to the soil under the waters of an inland lake, leads to the conclusion that such soil belongs to the riparian proprietor. ${ }^{52}$ Exactly what their rights would be when the land on the shore belongs to several different owners appears not to have been decided in England.

$\$ 114$. Conflicting views as to smaller lakes in the United States.-The peculiar condition of American law on this question is forcibly illustrated by decisions relating to a lake, called Wolf lake, about twelve miles from Chicago, partly in Illinois and partly in Indiana. The lake is two or three miles in extent and "unnavigable," and the question is whether the title of the owner of a fractional section of land bordering on the lake extends to the center or stops at the water's edge.

In Hardin v. Jordan ${ }^{63}$ and Fuller v. Shedd this question is considered, some of the same parties being involved in each case, and the same map being used in each

Lincoln v. Davis, 1884, 53 Mich. 375; 51 Am. R. 116; 19 N. W. 103. * 1891, 140 U. S. 371.

b4 1896, 161 Ill. 462 ; 44 N. E. 286 ; 52 Am. St. R. 380 ; 33 L. R. A. 146. 
case to illustrate the decision. The United States supreme court is unanimous in holding that the question must be decided according to local law, but is divided as to what the law of Illinois is; and as the members of the court are not agreed as to what the law of Illinois is, so they are not agreed as to what the common law is. The majority hold the common law is the law of Illinois, and that by that law, under a grant of lands bounded on a nontidal and non-navigable lake, the grantee takes to the center, citing as "directly in point" the case of Bristow v. Cormican, referred to in the last section. So the supreme court of the United States decided that the riparian owner on Wolf lake owned to the center. The minority, doubting the correctness of the view of the common law taken by the majority, maintained that at any rate Illinois law made a distinction between running waters and lakes, and that in grants on lakes the grantee took to the water's edge only. The minority's view is the law of Illinois. ${ }^{55}$

The supreme court of the state says: "The determination of boundary lines to the center of a river is not attended with any serious difficulty. * * This, as well as the injustice of holding that the purchaser of a small rim of the lake, consisting of but a few acres, would at once become the owner of thousands of acres of a nonnavigable lake, has caused many courts to hold that the riparian proprietor takes only to the water's edge." 56 Whether or not the lake has been surveyed by the general government and marked by meander lines is considered as important by the supreme court of Illinois, for if the lake was not sufficiently large or important to have been

${ }^{55}$ Fuller v. Shedd, 1896, 161 Ill. $462 ; 44$ N. E. $286 ; 52$ Am. St. R. 380 ; 33 L. R. A. 146; Hardin v. Shedd, 1898, 177 Ill. 123; 52 N. E. 380 ; Hammond v. Shepard, 1900, 186 Ill. 235; 57 N. E. 867; 78 Am. St. R. 274.

${ }^{56}$ Fuller $\nabla$. Shedd, 161 Ill. p. 483 -in this case purchasers of 153 acres would acquire title to 1,100 acres if the central rule prevailed. And see Mitchell v. Smale, 140 U. S. 406. 
meandered in the original survey the riparian proprietor takes its bed. ${ }^{57}$

Following the Illinois decisions, the supreme court of the United States has recently held that a patentee of the United States, of land bounded on a non-navigable lake in Illinois, takes no title to the adjacent submerged lands. ${ }^{58}$

115. The sectional line rule.-This same Wolf lake is in Indiana, and the method of settling the question there would divide its bed in still another way-that is, the patentee of a fractional lot bordering on the lake takes so much of the lake bed as is necessary to fill out the section or quarter section of which he owns the fraction; that is, while he is not restricted to the water's edge, neither does he own to the lake's center, unless the lines of his fractional lot extend so far. ${ }^{59}$ The supreme court of the United States says ${ }^{60}$ that such cases are departures from the common law, though this method of disposing of the subject might be convenient if sanctioned by law. ${ }^{61}$

\$ 116. Beds of inland natural lakes (though of large area) may be subject to private ownership in several other states.-This sectional line rule just mentioned is sometimes said to prevail in Michigan, because of the case of Clute v. Fisher, ${ }^{62}$ but it is not the Michigan rule, for it is there held in one case that the relative rights of shore owners on such lakes are to be determined without refer-

${ }^{67}$ Fuller $\nabla$. Shedd, 1896, 161 Ill. 462, 489; 44 N. E. 286; 52 Am. St. R. 380 ; 33 L. R. A. 146; Hammond v. Shepard, 1900, 186 Ill. 235, 241; 57 N. F. $867 ; 78$ Am. St. R. 274.

so Hardin v. Shedd, 1903, 190 U. S. 508; 23 Sup. Ct. Rep. 685, attiming s. c. 177 Ill. 123 ; 52 N. E. 380.

so Stoner $\nabla$. Rice, 1889, 121 Ind. 51; 22 N. E. 968; 6 L. R. A. 387; Brophy v. Richeson, 1894, 137 Ind. 114 ; 36 N. E. 424.

(o Hardin v. Jordan, 1891, 140 U. S. 371, 399.

6 See further as to Indiana lakes, Kean v. Calumet Canal \&e. Co., 1903, 190 U. S. 452 ; 23 Sup. Ct. Rep. 651 affirming 150 Ind. 699 ; Kean v. Roby, 1896, 145 Ind. 221; 42 N. E. 1011.

21887,65 Mich. 48 ; 31 N. W. 614. 
ence to the extension of sectional lines, but by the principles governing the rights of riparian proprietors, depending upon their frontage, and the form of the lake; $;^{63}$ and in another it is conceded that a meandered lake, a mile in length by about one-third of a mile in width, may be privately owned, but it is said by the court that " no fixed rule ever has been or ever can be laid down for the division of the territory covered by these inland lakes, with their irregular shores." ${ }^{64}$ And in earlier decisions it had been held that the beds of small inland lakes, navigable or unnavigable, belong to the shore owners, subject to the public right of navigation where the lake is actually navigable, and that the shore owners' title extends to the middle line of the lake, unless the irregular shape of the lake makes such a division impracticable..$^{65}$

In Ohio a lake covering about 400 acres and "non-navigable" was considered subject to private ownership, and it was held that where a lake of this character is mentioned as a boundary (and not its margin) the presumption is that the grantor reserves no title to land under water and the grantee's title extends to the center. ${ }^{66}$

In New York it is also held that the title to the land under the waters of small inland lakes is presumed to be in the proprietors of the adjoining uplands, and that describing one boundary in a conveyance as along a certain pond will carry title to the center ${ }^{67}$

In Olson $\nabla$. Huntamer ${ }^{68}$ the lake was meandered, but

Ga Grand Rapids Ice \&c. Co. v. Ice Co., 1894, 102 Mich. 227; 60 N. W. 681 ; 25 L. R. A. $815 ; 47$ Am. St. R. 516.

64 Pittsburgh \&c. Iron Co. v. Lake Superior Iron Co., 1898, 118 Mich. $109 ; 76$ N. W. 395.

${ }_{65}$ Webber v. Pere Marquette Boom Co., 1886, 62 Mich. 626; 30 N. W. 469 , and cases cited.

${ }^{66}$ Lembeck v. Nye, 1890, 47 Ohio St. 336; 21 Am. St. R. 828; 24 N. E. $636 ; 8$ L. R. A. 578 . See Railway Co. v. Platt, 1895, 53 Ohio St. 254, $268 ; 41$ N. E. $243 ; 29$ L. R. A. 52.

${ }^{57}$ Gouverneur v. National Ice Co., 1892, 134 N. Y. 355 ; 31 N. E. 865 ; 18 L. R. A. $697 ; 30$ Am. St. R. 669.

${ }^{68} 1894,6$ S. D. $364 ; 61$ N. W. 479. 
"non-navigable," and it was held that the grantee took to the center of it; the result being, in this instance, that by the drying up of the lake the adjoining owner acquired thirty-eight acres, his original dry land on its margin being but twenty-three acres.

In Minnesota, owing to the fact that many of the lakes have been gradually drying up, the questions as to the ownership of lake beds and the method of dividing them, have been discussed in several cases. The smaller unnavigable lakes-for example, one of about five hundred acres in area, not meandered by the government and not navigable for other purposes than hunting-may be owned absolutely by a private person, and he may exclude the public therefrom. ${ }^{69}$

Riparian owners have title to the lake bed in severalty and not in common, and their title extends to the center of the lake, the boundaries being fixed by extending converging lines from the meander line to the center. ${ }^{70}$

In Lamprey $\nabla$. State, ${ }^{71}$ the plaintiffs claimed a large part of 300 acres, worth $\$ 250,000$, the bed of a former lake, which had been surveyed and meandered by the government and the shore conveyed to plaintiffs. The state claimed the lake by virtue of its sovereignty.

The court held that "where a meandered lake is nonnavigable in fact, the patentee of land bordering on it takes to the middle of the lake; but where the lake is navigable in fact, its waters and bed belong to the state; - " that "so long as these lakes are capable of use for boating, even for pleasure, they are navigable; * " " but "where the waters of any of them have so dried up as to be no longer capable of any beneficial use by the public, they are no longer public waters, and their former beds would become the private property of the riparian own-

- Lamprey v. Danz, 1902, 86 Minn. 317; 90 N. W. 578.

${ }^{70}$ Shell v. Matteson, 1900, 81 Minn. $38 ; 83$ N. W. 491; Hanson v. Rice, 1903, 88 Minn. 273; 92 N. W. 982; Scheifert v. Briegel (Minn.), 1903,96 N. W. 44.

${ }^{71} 1893,52$ Minn. 181 ; 53 N. W. 1139 ; 18 L. R. A. 670 ; 38 Am. St. 541. 
ers." Hence the plaintiffs took the bed of the former lake.

In Tennessee it has recently been held that the bed of a lake fifteen to twenty miles long and two to seven miles wide, non-navigable in the "strict legal sense," but navigable in the common acceptation of the term, may be the subject of private ownership, though the grants may limit title to low water mark, as it was held they had done in this case. ${ }^{72}$

\$117. States holding to the rule that private title extends to water's edge only. - In the New England states there has been a tendency to follow the policy of the Massachusetts colonial ordinance, and to consider natural lakes of over ten acres in area as public, and the water's edge as the boundary, ${ }^{73}$ though when land is bounded by an artificial pond the center of the pond would ordinarily be the boundary line. ${ }^{\text {t4 }}$

The doctrine of these New England decisions has been followed by the courts of some of the western states. ${ }^{75}$

In Iowa the title to all lake beds, especially those of navigable lakes, is in the state, ${ }^{76}$ nor have shore owners prima facie title to the beds of unnavigable, meandered, lakes unless by the conveyances to them a purpose to include the bed of the lake is indicated; therefore, a shore owner on a lake five miles long, 100 rods wide and from three to seven feet deep, is not entitled to its bed when the lake becomes dry land by drainage, which

7 Webster v. Harris (Tenn. 1902), 69 S. W. 782.

${ }^{7}$ Concord Mfg. Co. v. Robertson, 1889, 66 N. H. 1; 25 Atl. 718; 18 L. R. A. 679; Brastow v. Rockport Ice Co., 1885, 77 Maine 100, and see $\S 111$.

" Mansur v. Blake, 1873, 62 Maine 38; Mill River Mfg. Co. v. Smith, 1867, 34 Conn. 462.

${ }^{75}$ As to Illinois, see $\$ 114$.

${ }^{7}$ Rood v. Wallace, 1899, 109 Iowa 5 ; 79 N. W. 449. 
perceptively, and not gradually and insensibly, causes its waters to disappear. ${ }^{77}$

The supreme court adheres to the rule, which it says is "generally recognized," that the title of riparian owners on a natural lake or pond does not extend beyond the natural shore. ${ }^{78}$ Nevertheless the riparian owner may have his land extended into the lake by gradual and imperceptible additions to it, or by similar recession of the waters from it. ${ }^{79}$ The fact, however, that a body of water has been surveyed and meandered as a lake by the government surveyors does not determine its character as a lake so as to make the principles of accretion or reliction applicable. ${ }^{80}$

In Wisconsin, while unmeandered ponds may be privately owned, ${ }^{81}$ meandered or navigable lakes are held by the state, as trustee, for the use of the public generally, but not as proprietor, with power to dispose of their beds or waters for the purpose of adding to the public revenues. ${ }^{82}$ Therefore the riparian proprietor on navigable lakes and ponds takes only to the water's edge, but as such proprietor he has the exclusive right of access to the lake; hence the state cannot drain a lake and cut off riparian rights, and grant to private parties the strip which is left between the new line and the old, for, as the waters are thus made to recede, the shore owner's rights extend to the water, and the uncovered land is his. ${ }^{83}$

On the other hand, if the waters are artificially raised, the public rights extend inland ; and if the artificial condition is continued for a sufficient time and under such

7 Noyes $\nabla$. Collins, 1894, 92 Iowa 566 ; 61 N. W. 250; 26 L. R. A. 609 ; 54 Am. St. R. 571.

70 Noyes v. Board, 1897, 104 Iowa 174; 73 N. W. 480.

- Carr v. Moore (Iowa, 1903), 93 N. W. 52.

Ib. ; Rood v. Wallace, 1849, 109 Iowa $5 ; 79$ N. W. 449.

" Abbott v. Cremer (Wis., 1903), 95 N. W. 387.

* Rossmiller v. State, 1902, 114 Wis. $169 ; 89$ N. W. 839 ; 58 L. R. A. 93.

- Priewe v. Wisconsin State Land and Imp. Co., 1896, 93 Wis. 534, $546 ; 67$ N. W. $918 ; 33$ L. R. A. 645. 
circumstances as to change the title to the land submerged, this artificial condition is considered as the natural condition with all the incidents of the latter: the state, and private owners of lands affected by the artificial condition, may enforce the maintenance of that condition. ${ }^{84}$

\$118. Appurtenances.-Deeds in general use, where the longer forms of conveyances still prevail, contain usually "general words" following the description, the chief of which is "appurtenances." In some forms of deeds this term appears first in the habendum. Whatever is an appurtenance, however, will pass with the land conveyed without the use of such words, for the incident follows the principal, ${ }^{85}$ and a thing is appurtenant to something else only when it stands in the relation of an incident to a principal. ${ }^{* 6}$

Easements ${ }^{87}$ of various sorts are the most important appurtenances, and, properly, the term applies only to things of an incorporeal character. The term is flexible and is to be construed with reference to the character of the principal thing granted So, for example, the conveyance by a gas company of all its property, "with the

Smith v. Youmans, 1897, 96 Wis. $103 ; 70$ N. W. 1115; 37 L. R. A. 285 ; 65 Am. St. R. 30; Pewaukee v. Savoy, 1899, 103 Wis. 271; 79 N. W. $436 ; 74$ Am. Bt. R. 859 ; 50 L. R. A. 836. In Boardman v. Scott, 1897, 102 Ga. 404 ; 51 L. R. A. 178 ; 30 S. E. 982 , there is an extended discussion of the question of boundaries on lakes and ponds: the conclusion being reached that when one owning the land adjacent to, and covered by a pond, bounds land "by the pond," he does not convey beyond the edge of the pond. This conclusion is contrary to the general rule stated above $(\$ 98)$ and is criticised by the annotator in 51 L. R. A. 178: "There is no doubt but the title to the bed of the pond is in the private owner, and not in the state, so that the principal reason for limiting grants on natural lakes to the water's edge, as was done in the cases cited by the court (in this Georgia case) does not exist."

ss Shep. Touch., 89.

* Humphreys v. McKissock, 1891, 140 U. S. 304, 313 ; Book v. West, 1902, 29 Wash. 70 ; 69 Pac. 630.

${ }^{87}$ See as to the effect of reservation of easements, post, $\$ 119,125$. 
rights, privileges and appurtenances thereunto belonging," carries a franchise which the company has to use the streets for its pipes and mains; $; 8$ and if mill property is conveyed, a right of flowing land of the grantor, necessary to the proper enjoyment of the property granted, passes to the grantee as an appurtenance, ${ }^{89}$ and, generally, one conveying part of his land impliedly conveys with it an apparent and visible right of way, or other easement, over that part retained by him, which is reasonably necessary for the use of the part conveyed; ${ }^{90}$ but in order to so pass by implication the easement must belong to the estate conveyed. ${ }^{91}$

Though apparently other things than those of an incorporeal nature sometimes pass as appurtenances, ${ }^{92}$ they actually pass as part of the thing described and granted; for, as a rule, "land cannot be appurtenant to land," and pass under the term "appurtenance," 93 nor can personal property which is not in a legal sense part of the real property conveyed. ${ }^{94}$

${ }^{8}$ Lawrence v. Hennesey, 1901, 165 Mo. 659; 65 S. W. 719.

- Jarvis v. Seele Milling Co., 1898, 173 Ill.192 ; 50 N. E. 1044; 64 Am. St. R. 107.

90 Irvine v. McCreary, 1900, 108 Ky. 495 ; 56 S. W. 966 ; 49 L. R. A. 417 : Richardson v. International Pottery Co., 1899, 63 N. J. L. 248; 43 Atl. 692.

"2 Bumstead v. Cook, 1897, 169 Mass. 410; 48 N. E. 767; 61 Am. St. R. 293.

2 See, supra, $\S 99$, note 82.

New Orleans Pac. Ry. Co. $\nabla$. Parker, 1891, 143 U. S. 42, 55; Oliver v. Dickinson, 100 Mass. 114.

* Lansing Iron \& Engine Works v. Walker, 1892, 91 Mich. 409; $51 \mathrm{~N}$. W. 1061; Ottumwa Woolen Mill Co. v. Hawley, 44 Iowa 57; 24 Am. R.719.

10-Brews. Con. 


\section{CHAPTER X.}

\section{EXCEPTIONS-RESERVATIONS.}

\$119. Exceptions and reserva- \$125. Reservation of easements tions in general.

120. Difference in effect. appurtenant to grantor's other land.

121. Expressions causing doubt.

122. Place for such clauses.

123. Effect of certain words.

124. Particular caseo-TimberMinerals.

126. Exceptions and reservations repugnant to grantEffect of.

127. Reservation to a stranger.

\$119. Exceptions and reservations in general.-Often it is the understanding of the parties to a conveyance that the grantor shall not convey the land described without retaining some part of it or having some rights in it.

These ends are accomplished by inserting in the deed the proper clauses of exception or reservation.

If he is to retain some existing part of the thing granted, which would otherwise pass to the grantee by the grant, he makes an exception of that part, and title to it simply remains in him. The result is, obviously, that his interest or estate in the thing excepted is the same as it was before, and if he had an estate in fee in it he still has the same estate, and no words of inheritance or perpetuity are needed to produce this effect.

An exception relates to something in existence at the time of the conveyance as a part of the thing granted. ${ }^{1}$

By a reservation there is created some new interest for the grantor in the thing granted, and a reservation, therefore, relates to something not in existence at the time the grant is made.

${ }^{1}$ Co. Litt. 47a ; Shep. Touchstone, pp. 78-80. 
Technically and strictly the term reservation is applicable only to rents and services and whatever things are stipulated to be rendered for the tenure of the land.

But the application of the term has been extended, and easements are now said to be reserved. An easement reserved, being a new right created for the grantor in property which he conveys, is often regarded as created by a regrant, or a counter-grant, made by the grantee to the grantor. ${ }^{3}$

This counter-grant, however, is a fiction (generally, at least, as the grantee does not execute the deed); it exists only in the imagination, or, at least, the only part of it in existence is the reservation clause in the actual deed. Hence, if the new right thus created is to last beyond the life of the grantee in the imaginary deed (who is the grantor in the actual deed), it must be so stated in that part of the imaginary deed which is in existence, and this is the reservation clause in the actual deed; in this clause, therefore, it should appear whether the regrant is to the grantor alone and for life, or to the grantor and his heirs, that is, in fee. This would be necessary, at least, where the reservation is regarded as a regrant and where at the same time the common law rule has not been modified by a statute making words of inheritance unnecessary to the creation of a fee." Where the technical word "heirs" is no longer necessary to create a fee in an ordinary grant, it may not be necessary for this purpose in a reservation, ${ }^{6}$ but its use, if a reservation in fee be intended, can do no harm and would clearly indicate the intention.

'Hence it is said, "a reservation operates by way of implied grant." Whitney $\nabla$. Fitchbarg R., 1900, 178 Mass. 559, 563; 60 N. E. 384.

- Kister v. Reeser, 98 Pa. St. 1 ; Simpson v. B. \& M. R., 1900, 176 Mass. 359 ; 57 N. E. 674.

- See post, §136.

- See Karmaller v. Krotz, 18 Iowa 352. 
\$120. Difference in effect.-A simple illustration will perhaps bring out the difference in effect between an exception and a reservation.

$I$, the owner in fee of "Lot A," convey Lot A to $M$ and his heirs, "excepting theref rom a strip twenty feet wide, running easterly and westerly, off the north side thereof." The result is that $I$ own in fee the strip kept out, and. everything below it and above it. No one can use it, or build upon it, or over it, or dig under it, without my consent. I may convey it, or part of it. I may sell separately the trees on it, or the minerals beneath it. And if I die, not having conveyed it, or a part of it, all these incidents descend to my heirs.

If, on the other hand, I convey said lot A, "reserving therefrom for a roadway, easterly and westerly, twenty feet off the northerly side thereof," I have reserved, according to the usual American view, an easement-a right of way. The fee in the twenty feet has passed together with the rest of lot A, subject, however, to my easement. Another person may build over the space, provided my right of way is not interfered with; I do not own the trees on the strip of land, nor the minerals beneath it; and, unless I have reserved the exclusive use, my grantee (of lot A) may use the way also; furthermore, unless the duration of this easement is defined or limited to extend to my heirs, its use as an easement ceases with my life.

\$ 121. Expressions causing doubt.-A slight variation in the phraseology makes it less clear whether the intention is to create a reservation or an exception. As, I grant lot A, "reserving a road twenty feet wide for my own use." Is this a reservation of a right of way-an easement-merely, and for life, or is it an exception of a strip twenty feet wide which I may use as a right of way and for other purposes, also? It is at least doubtful, from reading the clause, which I have intended.

If, in this last case, a reservation of the easement, sim- 
ply, is made, the fee passes subject to the easement, and the grantee has all the rights in the strip of an owner in fee subject to the easement reserved. . And the reservation of "a road" would ordinarily be construed by many courts as retaining an easement, merely, in the grantor. ${ }^{8}$ But if the road already existed when the deed was executed such a clause might be held an exception, at least to the extent of not requiring words of inheritance to make its use perpetual, even in those states where such words would be generally required for a reservation in fee. ${ }^{9}$ And it might be held an exception to the further extent of reserving not only a perpetual use (without words of inheritance) but of retaining in the grantor the fee of the land over which the road extended. ${ }^{10}$ In multitudes of cases litigation has been necessary to settle the doubts as to meaning, but it seems clear, from an examination of the authorities, that, in nearly every case, confusion might have been avoided by the exercise of care when the conveyance was drawn, and the intention of the parties so plainly expressed as to leave no doubt about it.

Just what expressions should be used it would be impossible to state for all cases, as exceptions and reservations are almost numberless in variety, but it can not be difficult to clearly express in words whether the intention is to retain an incorporeal right for life, or whether it is to retain a definite part of the thing granted.

It is generally of greater importance to the grantor and his successors than to the grantee that the intention be clearly expressed, for if it is left in doubt the grantee will generally get the benefit of the doubt, but if it is clearly expressed there is no need of applying this rule.11

'Moffitt v. Lytle, 1895, 165 Pa. 173; 30 Atl. 922.

- Wellman v. Churchill, 1898, 92 Maine 193; 42 Atl. 352; Bolio v. Marvin, 1902, 130 Mich. 82; 89 N. W. 563; 8 D. L. N. 160.

- White v. New York \&c. R., 1392, 156 Mass. 181; 30 N. E. 612.

${ }^{10}$ Munn v. Worrall, 53 N. Y. 44 ; 13 Am. R. 470.

"Richardson v. Clements, $89 \mathrm{~Pa}$. St. 503. 
$\$ 122$. Place for such clauses.-Attention to certain matters in drawing these clauses will often prevent obscurity, and consideration of the same principles will sometimes assist in the proper interpretation of them as drawn by others.

The appropriate place for an exception is just after the description of the property conveyed; the place for a reservation of rent is in the reddendum, as is now commonly seen in the "lease;" if the reservation is of an easement it is usually placed now after the description, it being quite generally regarded, as before stated, as a regrant rather than as a technical reservation.

As an illustration of the propriety of placing a clause in its proper place may be taken the case of Knapp $v$. Woolverton; ${ }^{12}$ in this case the deed was in the usual form, with covenants; following the covenants, in the blank space left in the printed form, were inserted the words, "except all the wheat on the ground or land as above described." The result was that instead of conveying the property "except the wheat," it was a conveyance of all the property, with covenants, except that the wheat was taken out from the operation of the covenants; and the dispute in this case having arisen as to whether the grantor could recover from the grantee damages for injury to the wheat by the grantee's cattle, it was held that he could not, because the grantee, and not the grantor, owned the wheat, which was simply excepted from the warranty.

If the exception had been in its proper place there could have been no such question.

\$123. Effect of certain words.-The appropriate word or words for the creation of an exception are: "saving and excepting" or "excepting," alone; for a reservation, "reserving."

1247 Mich. 292; 11 N. W. 164. 
But these words are, as deeds are drawn, often used interchangeably, so very little assistance in construing doubtful clauses is to be derived from them, for the use of the one or the other does not control in fixing the character of the clause as an exception or a reservation.

Illustrations: An exception may be created by words more appropriate to a reservation, as: "Saving and reserving for his own use the coal contained in said parcel of land, together with free ingress and egress by wagon road to haul the coal therefrom as wanted "-this clause was held to except the coal-something already existing as a part of the thing granted-and not to reserve merely the right to use coal for the grantor's life, as was contended..$^{18}$

Sometimes the words are used together; as where the clause was: "excepting and reserving, however, the full right of keeping and maintaining booms on the flats between high and low water mark of said river along the premises hereby conveyed, either to use myself or to let or sell to other persons" -and it was construed not to be merely the reservation of an easement but practically an exception. ${ }^{14}$

So where the same two words were used-"reserving and excepting" a strip of land, it was held that a reservation, rather than an exception, was created..$^{15}$

From such cases, and there are many, the conclusion is sometimes hastily drawn that there is no advantage to be gained from considering the distinction between an exception and a reservation-if, indeed, the distinction exists.

But the truth is, that while there is often difficulty in determining whether a particular clause is one or the other, and while, also, in particular cases, there is much room for difference of opinion, yet when once the character of the provision has been settled, the legal incidents

13 Whitaker v. Brown, 46 Pa. St. 197.

14 Engel v. Ayer, 1893, 85 Maine 448; 27 Atl. 352.

${ }^{16}$ Biles v. Railroad, 1893, 5 Wash. 509; 32 Pac. 211. 
belonging to it as of that particular character attach to it, and so in most cases the distinction cannot be disregarded.

\$124. Particular cases-Timber-Minerals.-It is not unusual for the grantor to retain in one form or another an interest in a portion of the growing timber on land conveyed by him.

He may except it, in which case the actual ownership of the timber is in him, together with an implied power to enter on the land to cut the timber and remove it, as also the right to have it left unhurt by the removal of the soil; subsequent purchasers must take notice of his rights, and if no time is named within which he is to remove the timber, it seems that he is not required to remove it within a limited time. ${ }^{16}$ And even if a time has been limited within which the grantor must remove timber cut by him under an exception which leaves the title in him, his title to the excepted timber will not be forfeited to the grantee by his failure to remove what he has cut within the time limited. ${ }^{17}$

On the other hand, he may reserve simply the right to cut the timber and to do it within a limited time, in which case the title to the timber does not remain in him, and should he neglect to cut it within the time limited it would become the property of the grantee. ${ }^{18}$

Exceptions of minerals of one kind or another are not uncommon, but here, also, the distinction must be borne in mind between keeping back a specified thing, and reserving a right to enter the lands and remove it.

For example, where a deed reserved to the grantor

${ }^{16}$ Wait v. Baldwin, 60 Mich. 622; 27 N. W. 697; 1 Am. St. R. 551 ; Howard v. Lincoln, 13 Maine 122; Sears $\nabla$. Ackerman, 1903, 138 Cal. $583 ; 72$ Pac. 171. Though see, Huron Land Co. v. Davison (Mich. 1902), 90 N. W. 1034 ; 9 D. L. N. 239 ; holding that the grantor must remove the timber within a reasonable time after notice from the grantee.

${ }^{17}$ Irons v. Webb, 41 N. J. L. 203; 32 Am. R. 193.

${ }^{18}$ Martin $\nabla$. Gilson, 37 Wis. 360 . 
"the right of mining on the above granted premises" a certain amount of ore annually, "at a duty of thirtyseven and one-half cents per ton, including all the facilities needful for doing the same," it was held that the property in the mines themselves and in the ore they contained passed to the grantee, and that there was reserved to the grantor a license to enter on the granted premises and exercise certain rights for the purpose of extracting from the mines a limited quantity of the ore, and revesting in the grantor the property in that which was thus separated from the mass; and that if the reservation had been of an exclusive right it might be held to retain in the grantor the property in the mines, being practically an exception ; but, as it was not exclusive, there was nothing to prevent the grantee from working the mines at the same time. ${ }^{19}$

And a deed containing a clause by which a grantor "reserves for himself, his heirs and assigns, a free toleration of getting coal for their own use without hindrance or denial," conveys the land with its minerals to the grantee subject only to the privilege kept by the grantor, which is not an exclusive right to the coal. ${ }^{20}$ Whereas, on the other hand, by a clause in the deed reading, "except the right to all valuable minerals in said land, which we hereby reserve, together with the right to mine the same," the grantor retains the exclusive right to and ownership in the minerals. ${ }^{21}$

\$125. Reservation of easements appurtenant to grantor's other land.- It often happens that the grantor reserves a right of way or other easement for the benefit of other land of his in the vicinity, and the question has arisen in such cases as to the duration of the easement.

19 Stockbridge Iron Co. v. Hudson Iron Co., 107 Mass. 290, 321, 322.

* Algonquin Coal Co. v. Northern \&c. Co., 1894, 162 Pa. 114; 29 Atl. 402.

${ }^{21}$ Snoddy v. Bolen, 1894, 122 Mo. 479; 24 S. W. 142; 25 S. W. 932. 
While the general rule is recognized that a reservation, in order to continue in fee, should be limited to the grantor and his heirs, as if it were actually a regrant, such cases as those now referred to are considered as justifying a disregard of this technical rule, and the easement in such cases is held to be one in fee (though words of inheritance are wanting), and capable of passing to subsequent grantees as appurtenant to the land retained by the grantor. ${ }^{22}$ And in such cases, besides looking at the reservation in this way, the courts sometimes regard it as an exception, considering the grantor's estate at the time the conveyance is made as a collection of rights in esse, from which collection the one reserved is excepted, with the same incidents attached to it as if it were a technical exception, among which incidents is the non-requirement of words of inheritance to create a fee, provided the owner's estate was formerly a fee. ${ }^{23}$

While such doctrines have undoubtedly resulted in substantial justice in particular cases, they are not adopted by all courts, ${ }^{24}$ and there are consequently, in the law as to reservations of easements in this country, uncertainty and confusion which are annoying. ${ }^{25}$

$\$ 126$. Exception and reservations repugnant to grant -Effect of.-Exceptions and reservations will be held void if repugnant to the estate granted; because the grant in such case would be inoperative were the repugnant exception or reservation to stand.

Having, therefore, granted a specific and definite num-

${ }^{22}$ Lathrop v. Elsner, 1892, 93 Mich. 599 ; 53 N. W. 791; Walz v. Walz, 1894, 101 Mich. 167; 59 N. W. 431; Chicago \&c. R. $\nabla$. Ward, 128 Ill. 349 ; 18 N. E. 828 ; 21 N. E. 562 ; Wells v. Tolman, 156 N. Y. 636 ; 51 N. E. 271.

${ }^{23}$ Chappel v. Railroad, 1892, 62 Conn. $195 ; 24$ Atl. 997 ; 17 L. R. A. 420 ; Smith v. Furbish, 1894, 68 N. H. 123, 145; 44 Atl. 398 ; 47 L. R. A. 226. See Knowlton $\nabla$. Railroad, 1899, 72 Conn. $188 ; 44$ itl. 8.

${ }^{24}$ See, for example, Simpson v. Railroad, 1900, 176 Mass. 359; $57 \mathrm{~N}$. E. 674 .

${ }^{25}$ There is a useful note on this subject in 20 L. R. A. 631 . 
ber of acres, the grantor cannot except part of the number granted; or having granted an estate in fee he cannot by exception or reservation retain absolute control in fee of the estate granted.

But exceptions may be very broad without being held repugnant; as an exception of all minerals, valuable earths, substances, coals, ores, all manner of compositions, etc., was held to leave something for the grantee in the water, timber and ordinary soil. ${ }^{26}$

And, the grant being in general terms, an exception of a part is valid ; as, if the grant be of the " $\mathrm{S}$. W. quarter, etc.," an exception may be made of five acres in the southwest corner, etc.; or, even if the boundaries be definitely given, but the grant does not name a specific number of acres as conveyed, the woodland or marsh may be excepted. ${ }^{27}$

So there is no repugnancy, if, having granted a fee, the grantor reserves a life estate, or an estate for years; and express reservations of such interests are not unusual. ${ }^{28}$

\$127. Reservation to a stranger. - It is a general principle that a reservation to a stranger not a party to the conveyance is void, and the stranger can take nothing by virtue of the reservation. ${ }^{29}$ In order, however, to carry out the intention of the parties, such a reservation has sometimes been construed as an exception, practically giving the stranger the benefit of the reservation, and as giving notice of his rights. ${ }^{30}$ And in Wall $\mathrm{v}$. Wall, ${ }^{31}$ where a reservation clause was: "reserving to herself

* Foster v. Runk, $109 \mathrm{~Pa} .291$.

27 Painter v. Water Co., 1891, 91 Cal. 74 ; 27 Pac. 539.

McDougal v. Musgrave, 1899, 46 W. Va. 509; 33 S. E. 281; Fisk v. Brayman, 1899, 21 R. I. $195 ; 42$ Atl. 878.

20 Edwards Hall Co. v. Dresser, 1896, 168 Mass. 136; 46 N. E. 420; Littlefield v. Mott, 14 R. I. 288.

\$ Martin v. Cook, 1894, 102 Mich. 267; 60 N. W. 679; Beinlein v. Johns, 1898, $102 \mathrm{Ky} .570$; 44 S. W. 128.

1900, 126 N. C. 405 ; 35 S. E. 811. 
(grantor), the possession, use, enjoyment and control of the tract of land for her natural life, and reserving, also, the care and support of her daughter for and during the life of the said daughter," it was held that the reservation for the support of the daughter was a lien on the land, enforceable by the daughter against the land in the hands of a subsequent grantee, who took it with notice of this clause. ${ }^{32}$

2s See also, Blakeley จ. Adams (Ky., 1902), 68 S. W. 393. 


\section{CHAPTER XI.}

\section{THE LIMITATION OF THE ESTATE-THE HABENDUM.}

\$128. The habendum, its function.

129. Effect of contradictions between premises and habendum.

130. Where habendum is not repugnant, it may explain and qualify the premises.

131. Effect of habendum in enlarging the premises.

132. The conveyance to be read and construed as a whole.

133. Naming the grantee in habendum-Effect of naming other or different persons.

134. Trusts may be declared in the habendum.

135. Use of the word "heirs" at common law in limiting an estate in fee.

136. Effect of statutes on the rule requiring the word "heirs."
\$137. When the word heirs is not essential to create a fee, irrespective of statute.

138. Use of the word assigns in limiting estates.

139. The fee simple and the fee simple conditional.

140. The statute De donis conditionalibus - Est a t es tail.

141. Kinds of estates tail-What terms are necessary to create.

142. Estates tail in the United States.

143. Estates tail in the United States-The states classified.

144. Reversions-Remainders.

145. The rule in Shelley's Case.

146. Not a rule of construction, but one of law-When does not apply.

147. The rule in the United States.

128. The habendum, its function.- "The office of the habendum is to limit the estate." 1

The word "limit" is here used not in its sense of "to restrict," but as meaning to mark out, or to define.

The premises having properly designated the parties and the thing granted, the habendum then declares or

' Buckler's Case, 2 Rep. (Coke) 55. 
defines the estate of the grantee in the thing grantedwhether it is for life, in fee, etc.

It will have been noticed that in most of the statutory short forms of deeds there is no habendum; and, irrespective of such statutes, it is not an essential part of a deed, if the estate is otherwise limited or defined. Yet, as most of the deeds in actual use have the habendum, the general principles applicable to it require notice.

$\S 129$. Effect of contradictions between premises and habendum.-Where each part of the deed is so drawn as to perform its office, there can almost no question arise as to the operation of the deed as a whole.

But it is not unusual to find discrepancies between different parts of the deed, especially between the premises and the habendum.

Among the most common discrepancies may be mentioned the following:

(a) An estate of one kind having been limited in the premises, a different estate is limited in the habendum.

(b) Different persons are named as grantees in the premises and in the habendum.

It is not necessary that the premises should contain any mention of the estate to be granted; and there is, indeed, authority for the view that it is not only unnecessary but improper for the estate to be there mentioned. ${ }^{2}$ Nevertheless it is very common for the estate granted to be named after the designation of the grantee in the premises. And an instance of the first kind of discrepancy would be where the lands conveyed are stated in the premises to be granted "to A and his heirs," while the habendum is "to have and to hold to said A for the term of his natural life." In such a case, applying technical rules of construction, the habendum is void, as it is irreconcilable with the premises by which an estate

${ }^{2}$ Shep. Touch. 75. 
has been already vested..$^{3}$ It is, therefore, a general rule that where the estate is expressly set forth in the premises it cannot be defeated by repugnant words in the habendum. The habendum is void, and the estate as given in the premises stands. But to have this effect the repugnancy must be clear, for if it is not so, effect may be given to the habendum, as will appear from cases cited in the three following sections.

$\$ 130$. Where habendum is not repugnant, it may explain and qualify the premises.-Where the habendum is not repugnant to the premises in respect to the estate granted it may serve to lessen, enlarge, explain or qualify the estate which would otherwise be granted by the premises standing alone. For example, a fee simple and a fee tail are both estates of inheritance, and if a grant be made "to $A$ and his heirs, to have and to hold to the. said A and the heirs of his body," the grantee would take a fee tail."

These estates being both estates of inheritance-though not identical-there is no such incompatibility between the premises and the habendum as to make them irreconcilably repugnant-as there is in the case of a fee granted in the premises, with a life estate in the habendum; hence the habendum may modify and to some extent lessen the estate as named in the premises.

So if the estate given in the premises is a fee by implication, and is not expressly stated to be such, the habendum may abridge the estate that would arise by the implication alone.

For example, were the conveyance substantially: "A conveys and warrants to $B$ (certain described real estate), to have and to hold the same for life "-here, there being no express grant in fee in the premises, though, standing

'See Smith v. Smith, 71 Mich. 633, 640; 40 N. W. 21; Pynchon v.. Stearns, 11 Met. (Mass.) 312, 316.

'Tyler v. Moore, 42 Pa. St. 374, 386. 
alone, "convey and warrant" would amount to it in many states, ${ }^{5}$ the habendum may properly be given effect - "controlling," as is sometimes said, the premises. ${ }^{6}$ And, where by virtue of statutes, which exist in most of the states, dispensing with the word "heirs" to create an estate in fee, a fee would be created by the premises alone which merely described the property and the grantee, the same result, as noted in these last cases, would follow from the use of an habendum expressly modifying the estate arising by legal implication from the premises.? Such cases are sometimes spoken of as instances of repugnancy between the premises and the habendum, and the habendum is said to " control" the premises; but it is evident, when the deed is read as a whole, that there is no contradiction or repugnancy, for the habendum simply expresses what is unexpressed in the premises, and does away with the necessity for resorting to legal implication to learn the intention of the parties. There is, in fact, no estate in the premises to be "controlled" by the habendum, but the habendum for the first time mentions and defines the estate intended to be granted.

\$131. Effect of habendum in enlarging the premises.It is very generally stated that the habendum may "enlarge" or extend the estate granted, and Coke is cited as authority for the proposition that if land be granted to one for life, "to have and to hold to him and his heirs," the grantee will take an estate in fee. ${ }^{8}$ Where the granting clause is in general terms, and from the whole deed read in the light of surrounding circumstances, it appears that it did not express the grantor's intention, the practi-

- By virtue of statutes, see ante, $\S 30$.

- Doren v. Gillum, 1893, 136 Ind. 134; 35 N. E. 1101; Welch v. Welch, 1899, 183 Ill. 237 ; 55 N. E. 694.

${ }^{7}$ Riggin v. Love, 72 Ill. 553; Rupert v. Penner, 1892, 35 Neb. 587 ; 53 N. W. 598; Montgomery จ. Sturdivant, 41 Cal. 290.

Co. Litt., 299a. 
cal effect of the habendum may be to enlarge the premises : as, if the granting clause is to a woman "and her children and assigns," "To have and to hold to her and her heirs and assigns," it would convey to her a fee, the habendum explaining and enlarging the estate granted in the premises. ${ }^{9}$ But while this may be true when the statement in the premises is in general terms, the habendum can not be allowed to enlarge the estate named in the premises when the premises specifically and expressly define and limit it. For example, one conveyed land to his daughter and her husband, "their heirs and assigns," and after the description of the land, there followed in the premises: "It is expressly understood by all parties hereto that, if the said husband and wife should have a child or children of their two bodies begotten and born, then the land herein conveyed shall vest in the said husband and wife and their heirs forever. But should this event not happen, then the said husband and wife, or the survivor of either of them, shall have and enjoy a life estate in the said land "-and it was provided that if no issue were born the land should be sold and the proceeds divided among certain persons. The habendum clause followed: "To have and to hold the said lands . . . unto the said parties of the second part, their heirs and assigns, to and for the only proper use of the said parties of the second part, their heirs and assigns, forever." The wife having died before her husband, never having had a child, it was held that the husband took but a life estate in the land-because the interest grantod was "so fully, circumstantially, and precisely defined and limited" in the premises. ${ }^{10}$

$\$ 132$. The conveyance to be read and construed as a whole.-In construing conveyances where there is a seem-

' Rines v. Mansfleld, 96 Mo. 394 ; 9 S. W. 798.

20 Karchner v. Hoy, 1892, $151 \mathrm{~Pa} .383$; 25 Atl. 20. 11-Brews. Cox. 
ing repugnancy, the entire conveyance should be read, in order to get at the intention from the language of the whole instrument.

"In the exposition of deeds, the construction must be upon the view and comparison of the whole instrument, and with an endeavor to give every part of it meaning and effect." 11

Practically, the court will reconcile, if possible, the contradictory clauses, without special regard to what particular parts of the instrument they occur in; and effect is given in many cases to the habendum, if it appears clearly to have been the grantor's intention that the terms used therein should control; for example, in Martin v. Jones ${ }^{12}$ there was a grant "to $A \mathrm{~J}$ and his children after him, * to have and to hold said premises to said A J and his heirs forever." After A J's death, when his administrator desired to sell the land for the purpose of paying A J's debts, his children claimed he had but a life estate with remainder to them, and that therefore the administrator could not sell; but the court held that the premises and the habendum are not irreconcilably repugnant, and that $\mathrm{A} J$ took an estate in fee.

So a grant expressed in the premises to be to one, "her heirs and assigns," with an habendum, "to have and to hold for and during the natural life, only, of [the grantee], with the remainder in fee simple" to others, was held to grant a life estate only, to the grantee, and not a fee, because such was clearly the grantor's intention when the whole conveyance was read. ${ }^{13}$ Of course, no lawyer would draw conveyances containing such contradictory statements as the deeds passed on in several of the fore-

${ }^{11}$ Ch. J. Kent in Jackson v. Myers, 3 Johns. 388, 395.

121900,62 Ohio St. $519 ; 57$ N. E. 238.

${ }^{13}$ Wilson $\nabla$. Terry, 1902, 130 Mich. 73; 89 N. W. 566; 8 Det. Leg. News 1151. And see, Bedford Lodge v. Lentz, 1900, 194 Pa. St. 399; 45 Atl. 378; Barnett v. Barnett, 1894, 104 Cal. 300; 37 Pac. 1049. 
going cases contain, when it is so simple a matter, with a little care, to avoid doing so.

\$133. Naming the grantee in habendum-Effect of naming other or different persons.-Where the habendum is used the grantee should be named or clearly designated there, as well as in the premises. If the persons named in the two parts are different, confusion and uncertainty result.

If no grantee be named in the premises, but one is named in the habendum, he will take the estate, ${ }^{14}$ for there is no repugnancy in such a case: the habendum simply supplies what should have been in the premises.

If, however, different persons are named in the premises and in the habendum as grantees, there is such a repugnancy as to make the habendum ineffective, and the person named in the premises is the grantee.

If one is named as grantee in the premises and also in the habendum with other persons, these others cannot, according to the general rule, take an immediate estate, ${ }^{15}$ though one not named in the premises may take an estate in remainder, by being named for the first time in the habendum. ${ }^{16}$

§ 134. Trusts may be declared in the habendum.-In conveyances creating a trust, and in assignments for the benefit of creditors, etc., the habendum may appropriately

${ }^{34}$ Irwin $\nabla$. Longworth, 20 Ohio 581, 603; Lawe v. Hyde, 39 Wis. 345. 25 Samme's Case, 13 Coke 54.

${ }^{26}$ Downing v. Birney, 1897, 112 Mich. 474; 70 N. W. 1006 ; 4 Det. I.t. News 21; McCullock v. Holmes, 1892, 111 Mo.445; 19 S. W. 1096 ; Blair v. Osborne, 84 N. C. 417 . But in McLeod v. Tarrant, 1892, 39 S. C. 271; 17 S. E. $773 ; 20$ L. R. A. 846, husband and wife-the latter being first mentioned in the habendum-were held to have taken the estate, though the grant in the premises was to the husband alone: and the wife having survived her husband took the whole, "tenancy by entireties" being recognized in South Carolina. 
declare the trusts on which the property is to be held. ${ }^{17}$ For example :

"This indenture, made the - day, etc., between of, etc., and -, of, etc., as trustee, Witnesseth, That the said party of the first part (granting clause, description, etc., as in an ordinary deed), To have and to hold the above granted premises, etc., unto the said party of the second part, as trustee, his successors and assigns forever, upon the trusts, and to and for the uses, interests and purposes, hereinafter limited, described and declared - that is to say, upon trust to receive the issues, rents and profits of the said premises, and apply the same to the use of X Y during the term of his natural life, and after the death of the said X Y, to convey the same by deed to C $D$ in fee.

"In witness whereof, etc."

$\$ 135$. Use of the word "heirs" at common law in limiting an estate in fee.-At common law it was necessary in a limitation to a natural person in fee simple to use the word "heirs" in connection with the name or other designation of the grantee. The general rule was that no other words in a deed, though clearly indicating an intent to create a fee, could do so if the technical word "heirs" were omitted. So that in England, before 1882, a limitation to a natural person "in fee simple," to him "and his seed," to him "and his issue generally," to him "and his successors" -gave him in each case an estate for his own life only. ${ }^{18}$

In this country, while it has sometimes been considered, irrespective of a statute on the subject, that the strict rule of the common law should not be applied because it was based on principles of feudal policy not adapted to our institutions, and often defeated the plain

${ }^{17}$ Nightingale v. Hidden, 7 R. I. 115, 118, 133.

$182 \mathrm{Bl}$. Com. 107: Shep. Touchstone 106. By the Conveyancing Act, $1881,44-45$ Vict., ch. 41, s. 51, an estate in foe simple may now be created by the words "in fee simple." 
intent of the parties, ${ }^{19}$ it has nevertheless been generally enforced unless modified by statute.

Consequently, conveyances, for example, to one "and his generation, to endure as long as the waters of the Delaware should run;" 20 to one "his executors, administrators and assigns;" 21 to several "and their representatives;" 22 to them and "assigns forever;" ${ }^{23}$ have been held to convey life estates only to the respective grantees. ${ }^{24}$

$\$ 136$. Effect of statutes on the rule requiring the word "heirs" in limiting an estate in fee.-Statutes expressly providing short forms for deeds ${ }^{25}$ usually make one of the effects of the operative words prescribed by the statute to be the passing of an estate in fee, and where such a conveyance is permissible and is used, of course the common law rule as to the use of the word "heirs" is inapplicable.

Moreover, in most of the states statutes either expressly enact that the word "heirs" need not be used in a deed to create an estate in fee, or in effect dispense with it by providing that every conveyance shall pass all the estate of the grantor unless a contrary intent is expressed in the conveyance or appears by necessary implication from its terms. ${ }^{26}$

${ }^{29}$ See the discussion in Cole $\nabla$. The Lake Co., 1874, 54 N. H. 242, 279.

${ }^{20}$ Foster v. Joice, 3 Wash. C. C. 498.

${ }^{21}$ Hofsass v. Mann, 1891, 74 Md. 400; 22 Atl. 65.

22 Brown v. Mattocks, 1883, 103 Pa. St. 16.

25 Mc Michael v. McMichael, 1897, 51 S. C. 555; 29 S. E. 403.

"See, as to the necessity of "heirs" to make a reservation in fee, ante, $\$ \S 119,125$.

${ }^{25}$ See ante, $\S 30$.

${ }^{26}$ The states which seem to have provided neither short forms of deeds having the effect noticed above, nor general statutes, directly or indirectly dispensing in deeds with the word "heirs" for the creation of a fee, are: Connecticut, Delaware, Florida, Maine, Massachusetts, New Jersey, Ohio, Pennsylvania, South Carolina, and Vermont; in Rhode Island there may be used either "heirs" or the words "in fee simple," without "heirs": Gen. L. 1896, p. 661. 
But as these statutes, altering the common law rule, are in many instances recent, and as they do not affect conveyances taking effect before their enactment, the rule cannot be ignored in investigating titles, even in states where such statutes exist. ${ }^{27}$

\$137. When the word heirs is not essential to create a fee, irrespective of statute.-The word "heirs" is not necessary in the following cases:

(a) Where an estate is given in trust and it is necessary for the purposes of the trust that the trustee shall have the legal estate in fee, a fee simple will be held to pass, though words of inheritance are lacking. ${ }^{28}$

(b) In conveyances to corporations aggregate the word "heirs" is inappropriate and unnecessary, nor need the word "successors," though usual and proper, be used, as the corporation being deemed to have perpetual existence, a grant to it for life is a grant in fee. ${ }^{29}$

(c) The common law rule does not apply to executory contracts for the sale of land enforceable in equity as a conveyance, where it is clear that an estate in fee was intended. ${ }^{30}$

(d) Words in a will showing an intention to devise an estate in fee simple are enough for this purpose, though words of inheritance are lacking. ${ }^{81}$

138. Use of the word "assigns" in limiting estates.The word "assigns," so commonly associated with "heirs" in the premises and habendum, is unnecessary. It was

${ }^{87}$ Allen v. Baskerville, 1898, 123 N. C. 126 ; 31 S. E. 383 ; Hofsass v. Mann, 1891, 74 Md. 400; 22 Atl. 65.

${ }^{*}$ Angell v. Rosenbury, 12 Mich. 241; West v. Fitz, 109 Ill. 425; Ewing $\nabla$. Shannahan, 1892, 113 Mo. 188; 20 S. W. 1065.

${ }^{20}$ Wilkes-Barre v. Wyoming Hist. Soc., 1890, 134 Pa. St. 616; 19 Atl. 809; Congregational Soc. v. Stark, 34 Vt. 243; Delhi School District v. Everett, 52 Mich. 314; 17 N. W. 926. "Successors" is necessary in a grant to a corporation sole: $2 \mathrm{Bl}$. Comm. 109.

${ }^{20}$ Phillips v. Swank, 120 Pa. St. $76 ; 13$ Atl. 712.

812 Bl. Comm. 108; Lincoln v. Lincoln, 107 Mass. 590. 
once considered necessary in order to give the quality of alienability to lands, ${ }^{82}$ but any such necessity for its use -if it ever really existed-has long since ceased to exist. ${ }^{83}$

$\$ 139$. The fee simple and the fee simple conditional -If, therefore, at common law "heirs" were not named, the taker had no interest beyond his own life, ${ }^{34}$ and he could give no interest to another greater than this. His power of alienation depended on the terms of the grant to him.

If, however, "heirs" were named, the interest conferred on the grantee (or donee) was the greatest interest that a subject was deemed capable of having in landsthe "estate in fee simple." And it came to be the law finally that he could alienate this estate whenever he chose, and, speaking generally, either entirely or partially, and on such terms as he chose, and for any length of time..$^{35}$

If, however, instead of naming the donee's "heirs" (i. e. in general) terms were used in the grant restricting the generality of this expression to heirs of a certain kind -as, for example, "to A and the heirs of his body" or "the heirs male of his body"-the donee could not alienate until some one of the specially designated class was in existence capable of succeeding him. The donee's interest in such a case was not a complete or absolute fee simple until the condition was fulfilled, and an heir of the named class came into existence. His estate was there-

2 Poll. \& Mait. Hist. Eng. L. II, 14; Williams R. P., 17th ed. 77.

* Grant v. Carpenter, 8 R. I. 36; Brasington v. Haneon, 1892, $149 \mathrm{~Pa}$. 289 ; 24 Atl. 344 . As to the necessity, or desirability, of the use of "assigns" in other parts of a deed, as, for example, in connection with covenants, see post, $\S \S 197,224$.

u See, supra, § 135.

* This power of alienation came gradually, it was not created by any one statute; it, was, however, confirmed by statute in 1290, the statute of "Quia Emptores," 18 Edward I, c. 1. See Digby Hist. Law Real Prop. (5th. ed.), pp. 157-161, 234-239. 
fore called a "fee simple conditional." When the condition was fulfilled the particular course of descent appointed by the form of the grant was not affected so long as the donee (or tenant) held the land.

But it was claimed that in such cases the donee might, immediately on the coming into existence of an heir of the kind named in the grant, that is on the fulfillment of the condition, treat his estate as an absolute fee simple, and alienate it as he might have done had it been made a fee simple absolute by the terms of the grant; and this claim was made even though in the grant there was an express condition that if the donee should die without heirs of the kind named the land should revert to the donor or his heirs.

These broad rights claimed on behalf of donees of such "fees simple conditional" being admitted, the result was that the donee, after having issue of the class named in the grant, actually alienated his estate to another person in fee simple in whose hands it would be an ordinary estate in fee simple descending, if not alienated by him, according to the general rules of law ; or it might be reconveyed to the original donee, who would hold it himself in fee simple.

Thus the estate was no longer confined to the particular course of succession originally designated, nor could the landowner who had created the "fee simple conditional" claim the estate by escheat on the failure of the specially named heirs of the original donee.

$\$ 140$. The statute De donis conditionalibus-Estates tail.-This liberal construction placed upon grants limited in their terms was unpopular with the great landowners whose chances of reversions were thus lessened. Therefore, in 1285 they procured the passing of the celebrated statute, De donis conditionalibus, the object of which was to protect inheritances and to lessen the danger of the lord's right of escheat being defeated or indefinitely post- 
poned by the alienation of the tenant, and which, in effect, provided that the donee of such an estate could not alienate it as against either his issue or the donor; but that, on his decease his issue, and upon failure of these the donor or the donor's heir, should take the land per formam $d o n i$, in spite of any attempted alienation by the donee. Thereafter the tenant who would have had, before the statute De donis, a fee simple conditional, had only a limited and inalienable estate; which as being cut down from the freedom of alienation incident to a fee simple, was regarded as a new kind of estate-a "fee tail" (feodum talliatum, taillé).

So that if, after the statute De donis, land was granted, for example, "to A, and the heirs of his body," while A had the rights of a tenant in fee simple as to the use of the land, he could not grant it away for any time beyond his own life; and his lineal heirs succeding under the grant were in the same position. He and they were "tenants in tail" - tenants in fee with limited powers.

For some time the restriction placed by the statute $\mathrm{De}$ donis upon the alienation of estates tail seems to have been effectual, but before two centuries had elapsed it was wholly evaded. Judges and lawyers administering the law reflected the popular dislike for inalienable estates, and the form of proceeding known as the Common Recovery became established as a regular means of "barring" or destroying an entail, and converting the estate tail into an estate in fee simple, and the "fine" was afterward used for the same purpose.

By various later acts of parliament restrictions on alienation have been removed, and the English tenant in tail has, generally speaking, complete powers of dealing with the land.

\$141. Kinds of estates tail-What terms are necessary to create.-The kinds of estates tail are chiefly four, namely: 
(a) The estate in tail general, which arises where the limitation is to one and the heirs of his body; the estate being descendible to all issue of the donee, but not to collateral heirs.

(b) The estate in tail male (or female) general: the limitation being in the same form as the last, with the added qualification of sex-for example, "to $A$ and the heirs male of his body": the estate being descendible to all the issue of the donee, being of the specified sex, according to the canons of descent.

(c) The estate in tail special, which arises where the limitation is to one and the heirs of his body by a certain wife, or to one and the heirs of her body by a certain husband; it may arise by a gift to two persons married and the heirs of their bodies, or by a gift to two persons of different sexes and capable of lawful marriage, and the heirs of their bodies. Only the issue of the two persons named can inherit.

(d) The estate in tail male (or female) special, being like the last named except that the inheritance is restricted to the issue of a specified sex ; for example, a limitation to "A and the heirs male, of his body, by his wife M."

And in all these cases, as the word "heirs" was necessary at common law to create a fee simple in a deed, so it is necessary to create a fee tail $;^{36}$ but the particular formula "of his body," though the most appropriate expression, is not indispensable where there are other words of procreation which restrict the meaning of "heirs" to the lineal descendants of the grantee. ${ }^{37}$

\$142. Estates tail in the United States.-In this country estates tail were early recognized in most of the original states as part of the common law taken from England,

${ }^{36}$ Adams v. Ross, 30 N. J. L. 505.

7 Reed v. Lane, 1894, 122 Mo. 311; 26 S. W. 957; Atherton v. Roche, 1901, 192 Ill. 252; 61 N. E. 357; Challis Real Prop., p. 236. 
and in some, at least, the common recovery was the means of barring them..$^{38}$ But by statutes (some of them early) in many states estates tail have been abolished, or have been changed into estates of another character.

The modification of the law, as it stood at the time of the settlement of this country, has not, however, been uniform, so that now expressions in a deed or will creating what would have been (after the statute De donis) an estate tail, create in one state, by virtue of its statute, an estate in fee simple, while in another they create a life estate only for the donee in tail-the first tenant in tailwith estates in fee simple for his issue in some states, or, in others, for those who take the estate after him by the course of the common law.

Moreover, in several states, while no statutes exist directly bearing on the matter, it has been held that the statute De donis (the effect of which was to change the "fee simple conditional" into the "fee tail") is not in force as part of the common law of those states.

\$143. Estates tail in the United States-The states classified.-Grouping the states, therefore, we find: (1) States having statutes which provide in effect that every estate which would be (but for such statute) considered a fee tail is an estate in fee simple.

Among such states are, Alabama, California, Florida, Georgia, Indiana, Kentucky, Michigan, Minnesota, Mississippi, Montana, New York, North Carolina, North Dakota, Pennsylvania, South Dakota, Tennessee, Virginia, West Virginia, Wisconsin. ${ }^{89}$

* Hawley v. Northampton, 8 Mass. 3; 5 Am. Dec. 66; Croxall v. Shererd, 5 Wall. 268, 283; Lyle v. Richards, 9 Serg. \& R. 322.

Ala. Civ. Co., 1896, § 1021; Cal. Civ. Co., 1901, § 763; Fla. R. S., 1892, § 1818; Ga. Co., 1895, §3085; Ind. Burns' R. S. 1901, § 3378; Ky. St., 1899, § 2343; Mich. C. L., 1897, § 8785; Minn. G. S., 1894, § 4364; Mis9. Ann. Co., 1892, § 2436; Mon. Civ. Co., 1895, § 1212; N. Y. R. S. (1903, Birdseye), p. 3017, § 22 ; N. C. Co., § 1325; N. D. Civ. Co., 1899, § 3327 ; Pa., Bright. Purd. Dig., 1894, p. 810, § 8, act of April 27, 1855; 
The statutory provisions are not identical in the foregoing states, but the general effect of them is to give the grantee in tail full power to alienate the estate, as if it were an estate in fee in him.

In California, Indiana, Michigan, New York, North and South Dakota there may be a remainder taking effect upon the death of the first grantee without issue, the statutes providing that an estate in fee tail is an estate in fee simple, and "if no valid remainder be limited thereon it is a fee simple absolute; and while these statutes in terms declare that "estates tail are abolished," the estate tail is only abolished by being changed into an estate in fee simple, which, if no valid remainder is limited thereon, ${ }^{40}$ is a fee simple absolute; so that a grant to one "and to the heirs of her body," without more, vests in the grantee an absolute fee. ${ }^{11}$

(2) A smaller number of states in which by statute what would have been an estate tail before the statute is declared to be an estate in fee simple, not, however, as in the states just mentioned, a fee in the first taker.

(a) In several states of this class a life estate only is expressly given to the first taker, but a fee simple absolute is given to the person to whom the estate would first pass after his death, according to common law, by virtue of the conveyance.

S. D. Ann. St., 1901, §3648; Tenn. Co. (Shannon), 1896, $\$ 3673$; Va. Co., 1887, § 2421 ; W. Va. Co., 1899, ch. 71, §9; Wis. St., 1898, § 2027. The statutes of several of these states, e. g., California, Indiana, North and South Dakota, provide that every estate "which would be at common law adjudged a fee tail, is a fee simple": such statutes refer to the effect of the statute De donis, for at common law, strictly speaking, there was no estate tail.

${ }^{40}$ Harriot v. Harriot, 1898, 25 App. Div. (N. Y.) 245, 248. See McIlhinny v. McIlhinny, 1894, 137 Ind. 411; 37 N. E. 147 ; 45 Am. St. R. 186 ; 24 L. R. A. 489.

1 Lane 8. Utz, 1891, 130 Ind. 235; 29 N. E. 772. 
Such states are Arkansas, Colorado, Illinois, Missouri and Vermont. ${ }^{42}$

(b) In other states of this class a fee simple estate is given to the "issue" of the first taker, though the nature of the first taker's estate is not expressly defined as a life estate: Connecticut and Ohio have statutes of this character. ${ }^{43}$ In all these states the estate of the donee in tailthe first taker-is such that he cannot convey a valid title in fee to the land acquired by him under a deed or will attempting to make him and his specified heirs tenants in tail."4

(3) In several states statutes in effect provide simply that a tenant in tail may convey the land, of which he is seised in that capacity, by an ordinary deed, as if he were seised in fee simple; the statutes not in terms converting the estate tail into an estate in fee simple, but authorizing the grantee to do so by a deed instead of by fine or common recovery. Maine, Maryland and Massachusetts have statutes of this kind, ${ }^{45}$ and in them, therefore, any deed which will convey the land will bar the entail. ${ }^{46}$

(4) A number of states appear to have no statutes on the subject of estates tail, namely: Iowa, Kansas, Nebraska, New Hampshire, Oregon, South Carolina, Texas, Utah and Washington; but in some of these the statute

- Ark. Sand \& H. Dig., $\$ 700$; Colo. Mills Stat., $\$ 432$; Ill. R. S., ch. 30, § 6; Mo. R. S. 1899, §4592; Vt. Stat. 1894, § 2201.

- Conn. Gen. St. (Rev. 1902), §4027; Ohio R. S., § 4200.

* Wilmans v. Robinson, 1900, 67 Ark. 517 ; 55 S. W. 950; Lehndorf จ. Cope, 1887, 122 Ill. 317; 13 N. E. 505; Atherton จ. Roche, 1901, 192 III. 252 ; 61 N. E. 357 ; 55 L. R. A. 591 ; Rozier v. Graham, 1898, 146 Mo. 352 ; 48 S. W. 470; Horton v. Upham, 1899, 72 Conn. 29; 43 Atl. 492 ; Chesebro v. Palmer, 1896, 68 Conn. 207; 36 Atl. 42; Pollock v. Speidel, 27 Ohio St. 86; Thompson v. Carl, 51 Vt. 408.

- Maine R. 8. 1883, ch. 73, $\$ 4$; Md. Pub. G. L. 1888, art. 21, § 24 ; Mass. R. L. 1902, ch. $127, \S 24$.

- Richardson v. Richardson, 1888, 80 Maine 585; 16 Atl. 250; Collamore v. Callamore, 1893, 158 Mass. 74; 32 N. E. 1034. 
De donis has been held to be not in force, irrespective of express statute. ${ }^{17}$

\$144. Reversions-Remainders.-The writer's intention is to confine himself, as far as possible, to the consideration of the transfer of estates in fee in possession, with the incidents of such transfer. It is not, therefore, within the scope of this work to discuss estates in general, nor to treat of those "incorporeal hereditaments" known at common law as reversions and remainders-future interests, which, though not now conferring possession, will do so in the future, and which are thus estates in futuro. ${ }^{48}$ Owing, however, to the effect still of ten given to an ancient rule of law affecting the limitation of estates, known as the rule in Shelley's Case, the general characteristics of these estates should be noted.

A "reversion" arises by operation of law when one in whom an estate is vested conveys out of it a "particular" - a smaller-estate in the same land which carries seisin. ${ }^{49}$ There remains in the grantor of this particular estate, and his heirs, an estate which will confer possession upon the determination of the particular estate, and this estate is the reversion.

But a remainder arises by act of the parties, as when a particular estate is limited, and by the same instrument another estate is limited to come into possession after the determination of the particular estate. For example, if $A$, tenant in fee simple, conveys to B for life "and from and after the determination of $B$ 's estate to $C$ and the heirs of his body, " $\mathrm{C}$ is said to have an estate tail in remainder, expectant on the death of $B$.

'7 Pierson v. Lane, 60 Iowa $60 ; 14$ N. W. 90; Jewell v. Warner, $35 \mathrm{~N}$. H. 176; Rowland v. Warren, 10 Ore. 129; Burnett v. Burnett, 17 S. C. 545.

48 Williams 'Real Prop., 17th ed., part II, ch. 1; Leake Dig. Law Prop. in Land, p. 312.

${ }^{9}$ Co. Litt., 22 b. 
When a remainder is so created that from its commencement to its close the seisin could vest instantly in the remainder-man in case the particular estate be determined, it is a vested remainder. Thus, a limitation "to A for life, remainder to B and his heirs," confers a vested remainder on $B$, because his interest will come into possession the moment A's estate determines : should A survive $B, B$ 's interest will pass to his heir, devisee or alienee, without losing its characteristics.

When, however, a remainder is so created that the particular estate can be determined before the seisin of the remainder is able to vest in the remainder-man, it is a contingent remainder: this is the case when the remainder is limited to a person not in being, or to one not at present capable of taking the estate, or when it is made dependent on a future and uncertain event. Thus, in a limitation "to A for life, and after his decease to the eldest son of B, living at A's decease, and his heirs," the remainder is contingent: it may not come into possession, for B may not have sons, or, if he have sons, they may die in A's life, or none of them may be born till after A's death.

$\$ 145$. The rule in Shelley's Case.-Limitations in the form of remainders to the heirs or to the heirs of the body, which taken alone would create a contingent remainder in the persons designated, are affected by the rule of law known as the rule in Shelley's Case. ${ }^{50}$

The rule may be stated as follows:

Where an estate of freehold is limited to a person, and by the same instrument an estate is limited in the form of a remainder, whether immediately expectant on the former estate or after other estates interposed, to his

so 1 Rep. (Coke) 93 (1581). It is sometimes said that the rule is erroneously named because it was not applicable to Shelley's Case; but that the case was a decision in favor of the rule, see Challis Real Prop., pp. $125-132$. 
" heirs" in fee or tail, the word "heirs" is a word of limitation of an estate of inheritance in the ancestor, and is not a word of purchase. ${ }^{\text {b1 }}$ That is, in such a case the limitation to the "heirs" entitles the ancestor to the whole estate, and the heir must take his interest (if he should take any) by descent from his ancestor, for he is not made, by the words of the instrument, a "purchaser" of any separate estate for himself.

$\$ 146$. Not a rule of construction but one of lawWhen does not apply.-While the rule is sometimes said to be a rule of construction, ${ }^{52}$ and that therefore it should give way to an intention disclosed by the instrument that it should not operate, especially when the instrument is a will, ${ }^{63}$ it has generally been considered a fixed rule of law to be given effect regardless of the intention of the donor..$^{54}$

But the word "heirs" may be used in a context or with a further description, rendering it incapable of being regarded as a word of limitation, and it must then be taken as a word of purchase, giving a remainder to the person so designated-as, for example, if the expression were the "heir now living;" and the chief difficulty in regard to the application of the rule, in particular cases, consists in determining whether the remainder is to the heirs of the

61 See Williams Real Prop., 17th ed., p. 404; Leake Dig. L. Prop. in Land, p. 342. The rule is well discussed in "The Modern Law of Real Property" by Herbert T. Tiffany, and is there stated, page 308, in the following terms: "If, after a limitation to a person of an estate of freehold, there be limited, by the same instrument, an estate in the form of a remainder to his heirs, or the heirs of his body, he will, at common law, take an estate in remainder in fee or in tail, according to the class of heirs specified, and the freehold estate previously limited to him will merge therein, unless there be another estate interposed which will prevent merger."

6ee Wilmans v. Robinson, 1900, 67 Ark. 517; 65 S. W. 950.

bs De Vaughn v. Hutchinson, 1897, 165 U. 8. 566 ; Wescott v. Binford, 1898, 104 Iowa $645 ; 74$ N. W. 18 ; 65 Am. St. R. 530.

" Davis v. Sturgeon, 1902, 198 Ill. 520; 64 N. E. 1016; Shapley v. Diehl, 1902, 203 Pa. St. 566; 53 Atl. 374; Trumbull v. Trumball, 1889, 149 Mass. 200; 21 N. E. 366. 
person to whom the first estate is given, or is to his "children" or certain other persons, in which cases the "rule" would not apply. In deciding this question, which is one of construction, the principle that the rule in Shelley's case is one of law does not preclude a construction of the words used which will accomplish the donor's intention. ${ }^{55}$

\$147. The rule in the United States.-While it is probable that the origin of the rule-as to which there has been much speculation- "is to be found in the policy of feudalism," cause it facilitated alienation by "vesting the inheritance in the ancestor and making it alienable a generation sooner than it otherwise would be ;" ${ }^{57}$ and it has therefore been justified as a rule of property in harmony with the genius of our institutions, and "with the liberal and commercial spirit of the age." 58

It is still preserved as a rule of law applicable to both deeds and wills in several states-unless, that is, very recent statutes have altered the policy of these states. Such states are: Arkansas, Illinois, Indiana, North Carolina, Pennsylvania, and perhaps others. ${ }^{59}$

But in states where it is thus recognized it is affected by statutes, if any exist in them, regarding estates tail.

For example in Illinois, where by statute an estate

* Simonton v. White, 1899, 93 Texas 50; 53 S. W. 339; 77 Am. St. R. 824; Granger v. Granger, 1897, 147 Ind. 95 ; 44 N. E. 189; 46 N. E. 80 ; Daniel v. Whartenby, 17 Wall. 639; McCann v. McCann, 1901, $197 \mathrm{~Pa}$. St. $452 ; 47$ Atl. $743 ; 80$ Am. St. R. 846.

so Challis Real Prop., p. 135.

${ }^{67}$ Hileman v. Boüs'aūgh, $13 \mathrm{~Pa}$. St. 344 ; $53 \mathrm{Am}$. Dec. 474.

See last case cited and Polk v. Faris, 9 Yerg. (Tenn.) 209; 30 Am. Dec. 400 -it is now abolished in Tennessee.

* See, in addition to cases cited above from these states, Leathers $\mathrm{v}$. Gray, 1888, 101 N. C. 162 ; 7 S. E. 657 ; 9 Am. St. R. 30; Edgerton v. Aycock, 1898, 123 N. C. 134 ; 31 S E. 382; McIlhinny v. McIlhinny, 1894, 137 Ind. 411 ;24 L. R. A. 489; 45 Am. St. R. 186; Carpenter v. VanOlinder, 1889, 127 Ill. 42 ; 19 N. E. 868 ; 11 Am. St. R. 92.

12-Brews. CoN. 
tail is made a life estate only in the first taker, the rule in Shelley's Case, in so far as it would apply to estates tail, is abolished;60 while in Pennsylvania and North Carolina, where estates tail are made estates in fee simple, a remainder in tail creates a fee simple in the first taker and not an estate tail. 61

In most of the states, however, statutes have in effect abolished the rule by reversing it and providing that the "heirs" or "heirs of the body" of the life tenant shall take as purchasers by virtue of the remainder limited to them. ${ }^{62}$

But such statutes are inapplicable to wills and conveyances taking effect before their enactment, ${ }^{68}$ and, as many of these statutes are of recent date, the rule may still affect titles even in these states where it has been abolished.

In a few states-Kansas, New Hampshire, Ohio, Oregon-it is abolished by statute only so far as devises are concerned. ${ }^{64}$

${ }^{\infty}$ Griswold v. Hicks, 1890, 132 Ill. 494, 501; 24 N. E. 63 ; Butler v. Huestis, 68 Ill. 594.

${ }^{61}$ Sheeley $\nabla$. Neidhammer, 1897, 182 Pa. St. 163; 37 Atl. 939; Chamblee v. Broughton, 1897, 120 N. C. 170; 27 S. E. 111.

$*$ Ala. Co., 1896, § 1025; Cal. Civ. Co., 1901, § 779; Conn. G. 8., 1902, $\S 4028$; Ga. Co., 1895, $\S \S 3083,3084$, 3085; Idaho R. S., 1887, § 2855 ; Ky. St., 1899, § 2345; Maine R. S., 1883, ch. 73, § 6 ; Mass. R. L., 1902, ch. 134, § 4; Mich. C. L., 1897, § 8810; Minn. G. S., 1894, § 4389; Mis8. Ann. Co., 1892, § 2446 ; Mo. R. \$., 1899, § 4594; Mont. Civ. Co., 1895, $\S 1228$; New Mexico C. L., 1897, § 2045; N. Y. R. S. (Birdseye, 1901), p. 3021, §44; N. D. R. Co., 1899, § 3343; Okl. St., 1893, § 3716; R. I. G. L., 1896, ch. 201, § 6; S. D. Ann. St. 1901, § 3664 ; Tenn. Co. (Shannon), 1896, § 3674; Va. Co., 1887, § 2423; W. Va. Co., 1899, ch. 71, $\S 11$; Wis. St., 1898, § 2052.

6s Wilson v. Alston, 1898, 122 Ala. 630; 25 So. 225 ; Harris v. McCann, 1898, 75 Miss. 805; 23 So. 631 ; Hurst v. Wilson, 1890, 89 Tenn. 270; 14 S. W. 778; Spader v. Powers, 56 Hun (N. Y.) 153.

ot Kan. Gen. Stat. 1901, § 7990; Ohio R. S., § 5968; N. H. Pab. Stat. 1901 , ch. 186, § 8; Ore. Ann. St. 1892, § 3093. 


\section{CHAPTER XII.}

\section{CONCURRENT OWNERSHIP.}

148. Concurrent ownership in general.

149. Joint tenancy-Its characteristics.

150. Alienation by a joint tenant.

151. Joint tenancy not now favored-A merican statutes concerning it.

152. Statutes reversing the common law presumptionThe estate still created by apt words.

153. Exceptions to the modern rale favoring estates in common-TrasteesMortgagees.

154. Statutes abolishing survivorship-They do not destroy joint tenancy.

155. Joint tenancy expressly abolished.

156. Tenancy in common-Its characteristics-How created.
\$157. Alienation by tenant in common-Effect of conveyance of specific part.

158. Conveyance of the entire property by tenant in common-Ouster.

159. Coparcenary.

160. Partition-By deed.

161. Parol partition.

162. Tenancy by entireties.

163. Has been generally recognized as common law in the United States-Exceptions.

164. In what states now recognized-Effect of statutes as to joint tenancy and married women.

165. In what states not recognized because of statutes.

168. Conveyance of estates by entireties.

167. The community gystem.

\$148. Concurrent ownership in general.-Two or more persons may have concurrent interests in the same land. These concurrent interests may arise from an express limitation of the estate, or several persons may take the estate concurrently by descent. Not all persons interested in the same land are, however, co-owners; for one of them may be a tenant for years, another may have a re- 
mainder in fee or for life, another may have an easement in the land; or one may have an estate of one sort or another in the surface merely, while another may own the minerals beneath the surface. In such cases the right of each is several and distinct and may be connected with different portions of the land. ${ }^{1}$

Where co-ownership exists, however, each owner has no several right as to any distinct part of the land, but is interested in every part of the whole. While this quality is common to the several kinds of concurrent ownership each has peculiarities of its own.

Though there is now in this country practically absolute ownership of lands rather than a holding of and from some superior, the chief kinds of concurrent ownership are still known by their common-law names as tenancies. The kinds of concurrent ownership are not of equal practical importance and some of them are known to the law of but $f e w$ states. The several kinds are:

1. Joint tenancy;

2. Tenancy in common;

3. Coparcenary;

4. Tenancy by entireties;

5. Community ownership.

\$ 149. Joint tenancy-Its characteristics.-Joint tenancy can arise by "purchase" only, and not by descent. It may exist for any estate except an estate tail general. So if lands be given to two persons without further limitation they will, at common law, become joint tenants for life; after the death of either the survivor will be entitled to the whole during his life. If lands be given to them and the heirs of their bodies there will be created an estate tail special, if they are capable of marrying; but where they are not capable of marrying they

${ }^{2}$ Virginia Coal Co. v. Kelly, 1896, 93 Va. 332; 24 S. E. 1020; Ames v. Ames, 1896, 160 Ill. 599 ; 43 N. E. 592 ; Powell v. Lantzy, 1896, 173 Pa. 543 ; 34 Atl. 450. 
are joint tenants for life, and on the death of one the survivor takes the whole, but on his death the inheritance is divided between the heir of the body of the formerly deceased grantee and the heir of the body of the survivor, who become tenants in common. ${ }^{2}$ But a joint tenancy in fee simple is more usual than one for life or in tail. And, generally, at common law a grant to two or more persons (not being husband and wife) and their heirs, without further words, creates a joint tenancy in fee. The distinguishing feature of joint tenancy is the right by survivorship; on the death of one of several joint tenants the survivors hold the whole estate. For so far as tenure and survivorship are concerned the joint tenants together are regarded as one person.

Joint tenants are, by reason of their identity of interest and title, said to have four unities, namely: time, title, interest and possession. ${ }^{3}$

There must be "unity of title," that is, the estate of the joint tenants must arise under the same limitation; there is "unity of interest" because there is but one estate created, which can only last as long as the estates of all the joint tenants; there is "unity of possession" if the estate is in possession, but there may be a limitation of a remainder to two or more jointly; by the operation of the statute of uses the former necessity that the titles of all the joint tenants should begin at the same time is avoided, for joint tenants under this statute may take their shares at different times, that is, if the use is declared jointly to several persons, some of whom are not yet in being, they will be joint tenants when they come into being.4

$\$ 150$. Alienation by a joint tenant.-Though all the joint tenants are for some purposes regarded as composing one owner, each nevertheless has such a share that he

Williams Real Prop., 17th ed., p. 164.

See 2 Bl. Comm. 180.

•Challis Real Prop. 295; + Kent Comm. 358. 
may alienate it inter vivos. As, however, at the instant of the death of one joint tenant the right of survivorship attaches, alienation by will is prevented. ${ }^{5}$ A conveyance by one joint tenant of his entire interest to a stranger "severs" the joint tenancy and turns it to a tenancy in common, so far as his grantee is concerned. The interest of one joint tenant is also subject to levy and sale upon an execution against him. ${ }^{6}$ In conveying to a stranger a joint tenant conveys in the ordinary manner and with the usual words of limitation of a fee where necessary, but in conveying to a co-tenant he conveys by release, in which case no words of inheritance are required to pass a fee even where they are required in ordinary conveyances. $^{7}$

\$151. Joint tenancy not now favored-American statutes concerning it. - While by the earlier common law joint tenancy was, when contrasted with other forms of co-ownership, favored as being in accord with feudal principles in preventing the division of tenures, ${ }^{8}$ the reason for this preference ceased with the practical abolition of tenures, and the doctrine of survivorship came to be regarded as inequitable in making no provision for posterity.$^{9}$ In this country, irrespective of legislation on the subject, some courts early held that joint tenancy as at common law did not exist. ${ }^{10}$ In most states, however,

${ }^{6}$ Wilkins v. Young, 1895, 144 Ind. 1 ; 41 N. E. 68; 55 Am. St. R. 162.

- Midgley v. Walker, 1894, 101 Mich. 583 ; 60 N. W. 296.

' Co. Litt. 273b.

${ }^{8}$ Martin v. Smith, 5 Binn. (Pa.) 16; 6 Am. Dec. 395.

${ }^{\circ}$ Hawes v. Hawes, 1747, 1 Wils. 165 ; 3 Atk. 524 ; though in Cray v. Willis, 1729, 2 P. Wms. 529, the Master of the Rolls says there is nothing anreasonable in the law of joint tenancy, each tenant having an equal chance to survive, and as each is able to sever the joint tenancy if he wishes to do so, survivorship can be no hardship where it may be at pleasure prevented.

${ }^{10}$ Sergeant $\nabla$. Steinberger, 2 Ohio $305 ; 15$ Am. Dec. 553; Miles v. Fisher, 10 Ohio 1; in Connecticut the right of survivorship as a necessary incident of joint tenancy was never recognized. Whittlesey $\nabla$. Fuller, 11 Conn. 337, 340. 
statutes have been enacted materially changing the common law and lessening the practical importance of joint tenancy. American statutes on the subject are of three classes :

(a) Those reversing the common law rule that an estate granted or devised to two or more persons is presumed to create a joint tenancy rather than a tenancy in common ;

(b) Those destroying survivorship;

(c) Those expressly abolishing joint tenancy.

But hardly any two statutes on the subject, even of the same class, are identical in all respects.

$\$ 152$. Statutes reversing the common-law presumption -The estate still created by apt words.-As examples of those of the first class may be noted, the short statute of Iowa and the longer one of Massachusetts: "Conveyances to two or more in their own right create a tenancy in common, unless a contrary intent is expressed." "11

"A conveyance or devise of land to two or more persons or to husband and wife, except a mortgage, or a devise or conveyance in trust, shall create an estate in common and not in joint tenancy, unless it is expressed in such conveyance or devise that the grantees or devisees shall take jointly, or as joint tenants, or in joint tenancy, or to them and the survivor of them, or unless it manifestly appears from the tenor of the instrument that it was intended to create an estate in joint tenancy." 12

Statutes having the general effect of these exist in the majority of states where legislation has been had on the subject. ${ }^{18}$

"Iowa Ann. Co., 1897, § 2923.

12 Massachusetts, R. L. 1902, ch. 134, §6.

w Arkansas, Dig. Stat. 1894, §704; California, Civ. Co. $\$ \S 683,686$; Colorado, Stats. 1891, $\$ 429$; Idaho, Civ. Co. 1901, $\$ 2398$; Illinois, R. S., ch. 30, § 5 ; Indiana, Burns' R. S. 1901, § 3341 ; Iowa, Ann. Co. 1897. \$2923; Maine, R. S. 1883, ch. 73, §7; Maryland, G. L. 1888, art. 50, \$13; Massachusetts, R. L. 1902, ch. 134, §6; Michigan, C. L. 1897, 
Where statutes of this character are in force, estates in joint tenancy may still be created, though the terms most apt to create them will vary somewhat in the different states. The general rule, however, is that the precise terms of the statute need not be followed in order to create a joint tenancy rather than a tenancy in common; thus, under a statute providing that no estate in joint tenancy shall be held under a grant unless it shall "expressly be declared to pass not in tenancy in common, but in joint tenancy," a conveyance to two persons "and the survivor of them, in his or her own right," and reciting that it "is made in joint tenancy" creates an estate in joint tenancy, although it is not expressly declared that an estate in common is not granted; ${ }^{14}$ and where the statute provides that a conveyance to two or more shall be construed to create an estate in common, "unless it shall be expressed therein that the grantees shall hold the same in joint tenancy and to the survivor of them, or it shall manifestly appear, from the tenor of the instrument, that it was intended to create an estate in joint tenancy," by the use of the word "jointly" after the names of the grantees an estate in joint tenancy is created. ${ }^{15}$

\$153. Exceptions to the modern rule favoring estates in common-Trustees-Mortgagees.-It will be noticed that many of the statutes make important exceptions, in-

$\$ \S 8826,8827$; Minnesota, G. S. 1894, §4405; Missouri, R. S. 1899, $\S 4600$; Montana, Civ. Co. 1895, 1105 ; New Hampshire, Pub. St. 1901, ch. $137, \S 14$; New York, R. S. \& G. L. 1901, Birdseye, p. 3023, §56; North Dakota, R. Co. 1899, $\S 3283,3286$; Rhode Island, G. L. 1896, ch. 201, $\$ 1$; South Dakota, Ann. St. 1901, $\S \S 3604,3606$; Utah, R. S. 1898, $\S 1973$; Vermont, R. S. 1894, §2202; Wisconsin, St. 1898, §§ 2068, 2069.

"Slater v. Granger, 1897, 165 Ill. $329 ; 46$ N. E. 235.

${ }^{15}$ Case v. Owen, 1894,139 Ind. 22 ; 38 N. E. 395 ; 47 Am. St. R. 253, though not (in Indiana) if they are husband and wife; Simons v. Bollinger, 1900, 154 Ind. 33 ; 56 N. E. $23 ; 48$ L. R. A. 234. And see Morris v. McCarty, 1893, 158 Mass. 11; 32 N. E. 938; Purdy v. Hayt, 92 N. Y. 446, 453. 
dicating that the policy of the law is not opposed to the doctrine of survivorship in all cases. A very general exception is that made concerning estates granted or devised in trust. Joint tenancy is a convenient form of ownership in such cases as it is not desirable that the representatives of a deceased trustee should interfere with the management of the property; therefore, even where the statute makes no express exception, it seems that "slighter indications will suffice in a trust deed than in other deeds to amount to a 'manifest showing,' because the courts are inclined to hold that trustees are joint tenants;" 16 and where, in a statute changing joint tenancies to tenancies in common, or in one abolishing survivorship, an express exception is made of trust estates, if it is intended in a particular case that the rule of survivorship should not apply, this intent should appear in the instrument creating the trust estate. ${ }^{17}$

In several states, for example, Indiana, Maine, Massachusetts, Michigan and Wisconsin, the statutes except mortgages; but this does not prevent the making of a mortgage with covenants several as to each mortgagee so that there shall be no survivorship between the mortgagees. ${ }^{18}$

\$154. Statutes abolishing survivorship-They do not destroy joint tenancy.-Of the statutes abolishing survivorship, that of Alabama may be taken as an illustration: "When one joint tenant dies before the severance, his interest does not survive to the other joint tenants, but descends and vests as if his interest had been severed and ascertained." 19 Statutes of this character are found in

16 Franklin Institution v. Savings Bank, 14 R. I. 632 ; Parsons v. Boyd, 20 Ala. 112.

${ }^{17}$ Norris v. Hall, 1900, 124 Mich. 170; 82 N. W. 832; 7 Det. Leg. News 155; Boyer v. Sims, 1900, 61 Kan. 593; 60 Pac. 309.

${ }^{18}$ Cooley v. Kinney, 1896, 109 Mich. 34 ; 66 N. W. 674.

19 Ala. Code 1896, § 1033. 
some states that also have those of the kind discussed above; this is so in Colorado and Illinois. ${ }^{20}$ Other states having similar statutes are: Kansas, North Carolina, Pennsylvania, South Carolina, Tennessee, Virginia, Washington and West Virginia. ${ }^{21}$

But these acts abolishing survivorship as an incident to joint tenancy do not generally prohibit a grant or devise of an estate with survivorship. They do not, therefore, actually abolish joint tenancy. So, though the Pennsylvania statute provides that "if purtition be not made between joint tenants * the parts of those who die first shall not accrue to the survivors, but shall descend or pass by devise * * and be considered to every other intent and purpose in the same manner as if such deceased joint tenants had been tenants in common," a grant to four "as joint tenants, and not as tenants in common," preserves the right of survivorship, as it shows an intent on the grantor's part not to follow the statute, but to convey an estate subject to survivorshipthe distinguishing incident of joint tenancy. ${ }^{22}$ And where, as in Connecticut, the right of survivorship as an incident to joint tenancy has long been disregarded without legislation of this kind, it may, nevertheless, be expressly conferred by a grantor or testator. ${ }^{23}$

\$155. Joint tenancy expressly abolished.-Statutes expressly abolishing joint tenancy exist apparently in but two states, Georgia and Oregon. ${ }^{24}$ Under the Georgia

${ }^{\infty}$ Colo. Stats. 1891, § 2526 ; Ill. R. S., ch. 71, § 1. Soe ante, $\$ \S 152,153$.

${ }^{21}$ Kan. G. S. 1901, § 2534; Ky. G. S. 1899, § 2348; N. C. Co. 1883, $\S 1326$; Pa. Bright. Purd. Dig. 1894, p. 1089 ; S. C. R. S. 1893, § 1985; Tenn. Shannon Co. 1896, § 3677; Va. Co. 1887, § 2430; Wash. Ball. Co. 1897, § 4623; W. Va. Co. 1899, ch. 71, § 18.

* Redemptorist Fathers v. Lawler, 1903, 205 Pa. St. -; 54 Atl. 487. And see Lockhart v. Vandyke, 1899, 97 Va.356; 33 S. E. 613; Rowland v. Rowland, 1885, 93 N. C. 214; Bank of Greenbrier v. Effingham, 1902, 51 W. Va. 267 ; 41 S. E. 143.

2 Rockwell v.-Swift, 1890, 59 Conn. 289; 20 Atl. 200.

थ Ga. Co. 1895, §§ 3142, 3143; Ore. Hill's Ann. L. 1892, § 2991. 
provision that "Joint tenancy does not exist in this state, and all such estates, under the English law, will be held to be tenancies in common under this code," it seems that an estate in "joint tenancy" may not be created by express terms in a deed or will as it may be in most states, but that, nevertheless, survivorship may still be provided for. ${ }^{25}$ In states where by such statutes, or by decision (as in Ohio), joint tenancy does not exist, a grant to two or more jointly, their heirs, etc., and to the survivor of the grantees, his heirs, etc., might be construed, in order to carry out the intention of the parties without, perhaps, violating the law abolishing joint tenancies, as a joint estate for life with remainder to the survivor in fee..$^{26}$

\$156. Tenancy in; common-Its characteristics-How created.-Tenants in common hold severally, but by unity of possession, because none of them knows his own severalty. Unity of possession is the only unity required in a tenancy in common. The possession of the tenants may begin at different times, their titles may be diverse, and they may own different estates in the land, but so long as there is unity of possession there will be a tenancy in common. ${ }^{27}$ Without, however, this unity of possession-or an equal right to the possession of every part of the subjectmatter of the tenancy-several persons having interests in the same realty are not tenants in common. Where one has the exclusive right of possession in one part and others have such exclusive rights in other parts, this tenancy does not exist. ${ }^{28}$ Nor are tenants for life and remainder-men tenants in common, for the possession of the tenant for life is exclusive of possession by the remainder-men. ${ }^{29}$ The right of survivorship is not a legal characteristic of tenancy in common.

${ }^{26}$ Harrison v. Harrison, 1898, 105 Ga. 517, 521 ; 31 S. E. 455.

"Lewis v. Baldwin, 11 Ohio 352.

"Spencer v. Austin, 38 Vt. 258.

See ante, $\$ 148$.

' Chamberlain v. Gleason, 1900, 163 N. Y. 214, 218; 57 N. E. 487. 
At common law a tenancy in common originated only by purchase, and not by descent, for two or more heirs of the same person were coparceners. In the United States the estate may arise by descent as well as by deed or devise. At common law, as joint tenancies were favored, to create a tenancy in common there must have been a limitation to two or more expressly as tenants in common or in such a way as to imply a severance of interests, but now the terms of a deed or a will are of less importance than they were in former times, owing to the general rule that a conveyance or devise to two or more is presumed to create a tenancy in common. A tenancy in common will also be created by the "severance" of a joint tenancy by alienation.

Where one conveys an undivided interest in a tract of land in which he holds all interests not thus conveyed, he and his grantee become tenants in common; and the creation of this tenancy as between grantor and grantee, in many cases where a grantor conveys an undefined part of a larger tract, has been mentioned in the chapter on Description. ${ }^{30}$

$\$ 157$. Alienation by tenant in common-Effect of conveyance of specific part.-In consequence of the character of a tenancy in common, one tenant in common may convey his own undivided interest, and his grantee will become a tenant in common with the remaining tenants, ${ }^{31}$ or he may mortgage his undivided interest and if the mortgage be foreclosed the purchaser at the foreclosure sale becomes tenant in common with the former co-tenant of the mortgagor. ${ }^{32}$ But as one tenant in common cannot without his co-tenant's consent

${ }^{30}$ Ante, $\S 79$.

"Fleming v. Katahdin Pulp \&c. Co., 1899, 93 Me. 110; 44 Atl. 378; Banzer v. Banzer, 1898, 156 N. Y. 429; 51 N. E. 291 ; Tindell v. Tindell, 1896, 37 S. W. 1105.

${ }^{82}$ Moreland v. Strong, 1897, 115 Mich. 211; 73 N. W. 140; 4 Det. Leg. News 837. 
appropriate to himself any exclusive rights in a specific portion of the land held in common, so he cannot by grants or conveyances give to others any such rights; for example, he cannot grant an easement, so as to confer rights which can be enforced against his co-tenants. ${ }^{33}$ Nor may he grant the right to cut and remove timber from the land owned in common..$^{34}$ The vendee of the timber in such a case does not become a tenant in common of the timber with his vendor's co-tenants. ${ }^{36}$

The conveyance by one co-tenant of a portion of the common property by metes and bounds, though said to be "void" in some of the earlier decisions, will generally be held to be valid as against the grantor, though his grantee takes subject to the risk of loss if, on partition, the land should not be so divided as to give him the portion conveyed; for such a conveyance cannot be allowed to prejudice the rights of the co-tenants to a partition of the land as if it had not been made, and the grantee has no absolute right on partition to have the part attempted to be conveyed allotted to him..$^{36}$

That such a conveyance is not "void" is indicated by the fact that the other co-tenants may confirm it if they choose to do so $;^{37}$ and, according to many decisions, in making partition a court of equity will so far recognize

23 Palmer v. Palmer, 1896, 150 N. Y. 139, 149; 44 N. E. 966.

^ Sullivan $\nabla$. Sherry, 1901, 111 Wis. $476 ; 87$ N. W. 471; Nevels v. Kentucky Lumber Co., 1900, $108 \mathrm{Ky} .550$; 56 S. W. 969; 49 L. R. A. 416.

${ }^{26}$ Benedict v. Torrent, 1890, 83 Mich. $181 ; 47$ N. W. 129; 11 L. R. A. $278 ; 21$ Am. St. R. 589, though it was afterward held that, while the vendee of the timber was not entitled to partition of the timber, he might enforce a partition of the land and the timber as a whole, even though all the tenants in common had conveyed the land to a third person without reservation of the timber. Mee v. Benedict, 1893, 98 Mich. $260 ; 57$ N. W. 175 ; 22 L. R. A. $641 ; 39$ Am. St. R. 543.

${ }^{26}$ Gates $\nabla$. Salmon, 35 Cal. 576; 95 Am. Dec. 139; Markoe v. Wakeman, 107 Ill. 251; Warthen $\nabla$. Siefert, 1894, 139 Ind. 233 ; 38 N. E. 464.

st Gordon v. City of San Diego, 1894, 101 Cal. 522: 36 Pac. 18; 40 Am. St. R. 73; Goodwin v. Keney, 49 Conn. 563. 
the conveyance as to allot to the grantee the portion so attempted to be conveyed, if such allotment may be made without injuriously affecting the rights of the other cotenants. ${ }^{38}$

$\$ 158$. Conveyance of the entire property by tenant in common-0uster.-If one tenant in common attempts a conveyance by deed of the whole property, and his grantee enters and claims the whole title under his conveyance, this will generally be considered an "ouster" of the other tenants. The grantee's possession thus becomes adverse as to the co-tenants of his grantor, and his title may ultimately become good by this adverse possession. But to amount to "ouster," so that title by adverse possession may be acquired, the facts must have come to the notice, actually or constructively, of the co-tenant who is out of possession. ${ }^{40}$ Nor will possession by the grantee of one co-tenant amount to ouster if it is in recognition of the other co-tenants' rights and not adverse to them.1

\$159. Coparcenary.-An estate in coparcenary, or parcenary, arises by descent and not by purchase, thus differing from both joint tenancy and tenancy in common. It comes about when, either by virtue of the common law or special custom, an estate in fee or tail descends upon two or more as co-heirs of a deceased person. All the coparceners together form but one heir and

${ }^{38}$ Maverick v. Burney, 1895, 88 Texas 560; 32 S. W. 512; Young v. Edwards, 1890, 33 S. C. 404 ; 11 S. E. 1066; 26 Am. St. R. 689; Worthington v. Staunton, 16 W. Va. 209; Mee v. Benedict, 1893, 98 Mich. 260 ; 57 N. W. 175 ; 22 L. R. A. 641 ; 39 Am. St. R. 543.

${ }^{29}$ Sweetland v. Buell, 1900, 164 N. Y. $541 ; 58$ N. E. 663; Bennett v. Pierce, 1901, 50 W. Va. 604; 40 S. E. 395; Murray v. Quigley, 1902, Iowa -; 92 N. W. 869 ; Frost v. Courtis, 1899, 172 Mass. 401 ; 52 N. E. 515 ; Johnston v. Virginia Coal \&c. Co., 1898, 96 Va. 158 ; 31 S. E. 85.

${ }^{\star 0}$ Roberts v. Morgan, 30 Vt. 319; Warfield v. Lindell, 38 Mo. 581 ; 90 Am. Dec. 443.

11 Van Ormer v. Harley, 1897, 102 Iowa 150; 71 N. W. 241; Price v. Hall, 1895, 140 Ind. 314 ; 39 N. E. 941. 
have but a single freehold, ${ }^{42}$ and yet there is no right of survivorship among them.

In lands which descend by virtue of common law rules coparcenary among males is impossible, so that at common law the estate arose among females only, but in gavelkind lands coparceners may be males or females. ${ }^{43}$ As long as the descent is uninterrupted the parcenary continues, but one parcener may convey his share to another parcener or to a third person or may devise it."

If one parcener alien his or her entire estate in lands to a stranger this is a severance and the alienee is tenant in common with the other parcener or parceners. ${ }^{45}$

In this country parcenary is of little practical importance as distinguished from tenancy in common; for coheirs take generally as tenants in common, either under express statutory provisions which exist in some states, ${ }^{46}$ or without such statutes.

In a few states, however, statutes provide for descent "in parcenary" to the kindred of the intestate in the order designated in the statutes. ${ }^{47}$

\$160. Partition-By deed.-Partition is a division of the interests of co-owners into severalty.

There are two general methods of accomplishing this: (a) Voluntary partition, by the act of the parties; (b) compulsory partition, by judicial proceedings. ${ }^{48}$

Co. Litt. 164a.

Digby Hist. L. R. Prop., pp. 280, 281.

"Challis Real Prop., 301.

Co. Litt. 167b.

${ }^{46}$ For example, Ala. Co. 1896, \$1461; N. H. Pub. St. 1901, ch. 137, \$15: "Joint heirs shall be deemed tenants in common;" N. Y. Real Prop. L., \& 293, Birdseye 1901, p. 3081.

"For example, Colo. Ann. St. 1891, $\$ 1524$; Ky. Stats. 1899, 1393 ; Mo. R. S. 1899, § 2908; Ohio R. S., §4158; Va. Co. 1887, § 2548. American decisions discussing coparcenary are infrequent. See Stevenson v. Cofferin, 20 N. H. 150; Ward v. Ward, 1895, 40 W. Va. 611; 21 S. E. $746 ; 52$ Am. St. R. 911.

* By the common law only parceners were entitled to insist on partition, but by statutes in $1539-40$ joint tenants and tenants in com- 
Joint tenants, tenants in common and coparceners may, by mutual agreement, make partition among themselves, by conveying or releasing to one another so that each co-tenant receives from the others a certain part, designated specifically by metes and bounds, of the entire property.

The partition may be effected by one deed, executed by all the co-tenants, under which a share of the property in severalty is assigned to each, ${ }^{49}$ or by mutual deeds under which each co-tenant has transferred or released to him the interest of all the other co-tenants in the part assigned to him. Such deeds create no new title to the portions set off to the parties to be held in severalty, but merely designate each share by metes and bounds..$^{50}$

$\$ 161$. Parol partition.-In many states a partition by mutual agreement may be by parol, followed by possession by the several tenants respectively of the portions assigned to them, ${ }^{51}$ though the effect of such parol partition is not always to give the legal title to the tenant taking possession of his part under it, but merely an equitable title and the right to exclusive possession $;^{52}$ and in all cases the parol partition must be established by clear evidence that exclusive possession was taken of the part assigned..$^{53}$

In other states, however, it is held that a parol partition mon were given this right. In this country the matter of partition by judicial proceedings is regulated by statute. The subject is not within the scope of this volume.

49 Townsend v. Outten, 1898, 95 Va. 536; 28 S. E. 958. Soe Center v. Davis, 1896, 113 Cal. 307; 45 Pac. 468; 54 Am. St. R. 352.

so Whitsett v. Wamack, 1900, 159 Mo. 14 ; 59 S. W. $961 ; 81$ Am. St. R. 339; Carter v. Day, 1898, 59 Ohio St. 96 ; 51 N. E. 967 ; 69 Am. St. R. 757 .

${ }^{51}$ Byers v. Byers, 1898, 183 Pa. 509 ; 38 Atl. 1027 ; 39 L. R. A. 537 ; 63 Am. St. R. 765; Wood v. Fleet, 36 N. Y. 499 ; 93 Am. Dec. 528.

${ }^{52}$ Kash v. Coleman, 1898, 145 Mo. 645; 47 S. W. 503; Bruce v. Osgood, 113 Ind. $360 ; 14$ N. E. 563.

${ }^{63}$ Justice v. Lawson, 1899, 46 W. Va. 163; 33 S. E. 102; Sanger v. Merritt, 1892, 13 N. Y. $614 ; 30$ N. E. 100. 
is invalid, as the statute of frauds requires an agreement for such a division of lands to be in writing, ${ }^{54}$ though where this view is held, possession taken under a parol partition, if continued long enough, will give a legal title by virtue of the statute of limitations. 55

\$162. Tenancy by entireties.-At common law, "tenancy by entireties" -or "by the entirety" -occurs when a gift or conveyance, which, if made to two strangers, would create a joint tenancy, is made to a husband and wife during the coverture. The peculiarities of this estate arise out of the identity which the common law appears generally to have assumed to exist between husband and wife. At common law a husband and wife are tenants by entirety, unless the conveyance to them indicates an intention to create a different estate. "It constitutes the most intimate union of ownership known to the law." The most important characteristic of the estate by the entirety is the right of survivorship by which the survivor, whether husband or wife, becomes seized of the entirety. In this it resembles joint tenancy, but it differs from the latter in that this right of survivorship cannot be defeated by either spouse by a conveyance to a stranger. ${ }^{57}$

\$163. Has been generally recognized as common law in the United States-Exceptions.-This estate seems to have been very generally recognized as part of the common law of this country until affected by comparatively

4 Woodhull v. Longstreet, 18 N. J. L. 405; Berry จ. Seawall, 1895, 65 Fed. 742.

ss Slone v. Grider (1898 Ky.), 44 S. W. 384.

* Challis Real Prop., 304.

sr On divorce the estate is destroyed and husband and wife become tenants in common, as a general rule. Russell v. Russell, 1894, $122 \mathrm{Mo.}$ 235 ; 26 S. W. 677 ; 43 Am. St. R. 581 ; Stelz v. Shreck, 1891, 128 N. Y. 263 ; 28 N. E. $510 ; 26$ Am. St. R. 475; contra, Appeal of Lewis, 1891, 85 Mich. $340 ; 48$ N. W. 580; 24 Am. St. R. 94.

13-Brews. Con. 
recent statutes. But in two states-Connecticut and Ohio -irrespective of such statutes, it seems never to have existed, ${ }^{58}$ and in Nebraska, without reference to any special legislation, it is declared to be inapplicable to modern conditions and not the common law of that state, ${ }^{59}$ nor has it obtained in Oklahoma, ${ }^{60}$. nor, generally, in those states where the "community system" prevails. ${ }^{61}$

\$164. In what states now recognized-Effect of statutes as to joint tenancy and married women.-Tenancy by entireties seems still recognized with many of its common law attributes in about one-third of the states, among these being, Arkansas, Indiana, Michigan, Missouri, New York, North Carolina, Oregon, Pennsylvania, South Carolina, Tennessee and Vermont. ${ }^{6 r}$

In several of these states the acts changing estates in joint tenancy to estates in common, or abolishing joint tenancy do not apply to estates by the entirety, because husband and wife are expressly excepted from their operation $; 3$ and in the others they have been held inapplicable, because estates in entirety are not estates in joint tenancy.

So also the married women's property acts have been

${ }^{58}$ Whittlesey v. Fuller, 11 Conn. 337 ; Farmers' \&c. Bank v. Wallace, 45 Ohio St. 152, $165 ; 12$ N. E. 439.

${ }^{60}$ Kerner v. McDonald, 1900, 60 Neb. 663 ; 84 N.W. 92 ; 83 Am. St. R. 550 .

${ }^{60}$ Helvie v. Hoover, 1902, 12 Okl. -; 69 Pac. 958.

${ }^{61}$ Though see the commissioners' amendments to Cal. Civ. Co. 1901, $\$ 161,682,686$.

${ }^{62}$ Roulston v. Hall, 1899, 66 Ark. 305 ; 50 S. W. 690 ; 74 Am. St. R. 97 ; Simons v. Bollinger, 1900, 154 Ind. 83 ; 56 N. E. 23; 48 L. R. A. 234; Doane v. Feather's Est., 1899, 119 Mich. 691 ; 78 N. W. 884; 6 Det. Leg. News 25; Hume v. Hopkins, 1897, 140 Mo. 65; 41 S. W. 784; Hiles v. Fisher, 1895, 144 N. Y. 306; 39 N. E. 337 ; 30 L. R. A. 305; 43 Am. St. R. 762 ; Ray v. Long, 1903, 132 N. C. 891 ; 44 S. E. 652 ; Noblitt v. Beebe, 23 Ore. 4 ; Bramberry's Est., 1893, 156 Pa. St. 628; 36 Am. St. R. 64; 22 L. R. A. 594 ; McLeod v. Tarrant, 1893, 39 S. C. 271 ; 17 S. E. 773; 20 L. R. A. 846 .

${ }^{6 s}$ For example, Indiana, Michigan, Missouri and Vermont. 
held in many states not to have had the effect of abolishing tenancy by the entireties. ${ }^{64}$

$\$ 165$. In what states not recognized because of statutes.-On the other hand, statutes like that of Iowa, ${ }^{65}$ relating to joint tenancy, have been considered to apply to the estate by entireties, ${ }^{66}$ and in some states modern statutes enlarging the property rights of married women have been held to have had the effect of abolishing this estate by removing whatever reason there had once been for it at common law in the supposed identity of husband and wife. ${ }^{67}$

In addition to such statutes are those like that of Massachusetts quoted above, which expressly name estates granted to husband and wife as being estates in common; and statutes which, in abolishing survivorship in joint tenancy, expressly name estates in entirety, ${ }^{68}$ or expressly apply the rule abolishing survivorship to estates granted to husband and wife. ${ }^{69}$

As a general result of these different statutes, directly and indirectly affecting tenancy by entireties, it appears that in the majority of states the estate does not exist at present except in cases where it was created before such statutes took effect. But in jurisdictions where it has been recognized, but is not now, it is to be noted that its former recognition may still affect titles, and that, therefore, the doctrines regarding it cannot be ignored.

${ }^{64}$ See the cases cited above, in note 62, from Arkansas, Michigan, New York and Pennsylvania.

co Ante, $\$ 152$.

* Bader v. Dyer, 1898, 106 Iowa 715; 77 N. W. 469; 68 Am. St. R. 332 ; Wilson v. Wilson, 1890, 43 Minn. 398 ; 45 N. W.710.

${ }^{67}$ Mittel v. Karl, 1890, 133 Ill. 65; 24 N. E. 553; 8 L. R. A. 655; Robinson, Appellant, 1895, 88 Me. 17 ; 33 Atl. 652; 51 Am. St. R. 367; $30 \mathrm{~L}$. R. A. 331 ; Donegan v. Donegan, 1893, 103 Ala. 488; 15 So. 823; 49 Am. St. R. 53 ; Citizens' Loan \&c. Co. v. Witte, 1902, 116 Wis. 60.

Stewart v. Thomas, 1902, 64 Kan. 511; 68 Pac. 70.

McNeeley $\nabla$. South Pa. Oil Co., 1903, 52 W. Va. 616; 44 S. E. 508. See ante, $\S 154$. 
For example, in a recent action for flowing the plaintiff's land in a state where tenancy by entireties is not now created by a grant to husband and wife, ${ }^{70}$ the defendant claimed, under the husband's conveyance made while the title to the land stood in the names of husband and wife, but after conveyances to husband and wife had been declared by statute to create estates in common, and the plaintiff claimed title by a subsequent conveyance made by the surviving wife: it was held that, as the conveyance to the husband and wife was made before the statute changing the law took effect, the wife's right by survivorship became then vested, and a verdict for the plaintiff was proper.

$\$ 166$. Conveyance of estates by entireties.-A husband and wife may convey lands held in entirety by their joint conveyance, though in such a case the wife should not join in the conveyance "to release her dower," etc., but should be named in the granting part of the deed..$^{71}$ Neither tenant, however, can alone make a conveyance that will defeat or prejudice the right of survivorship in the other.

One of the husband's general marital rights at common law being the right to control and dispose of his wife's lands during their joint lives, he was entitled to the rents and profits of land held under this tenancy and could convey the land for his life, ${ }^{72}$ or incumber it subject to his wife's right of survivorship. ${ }^{73}$ This power of control by the husband of his wife's share is generally regarded as taken from him by the laws extending the property rights of married women.74 He may, however, in some states convey his own interest subject to his wife's right of sur-

${ }^{70}$ Pease v. Inhabitants of Whitman, 1903, 182 Mass. 363 ; 65 N. E. 795.

$n$ Wales v. Coffin, 13 Allen 213.

"2 Pray v. Stebbins, 141 Mass. 219; 4 N. E. 824 ; 55 Am. R. 462.

"Washburn v. Burns, 34 N. J. L. 18.

7" Hiles v. Fisher, 1895, 144 N. Y. 306; 39 N. E. 337; 43 Am. St. R. 762 ; 30 L. R. A. 305. 
vivorship, ${ }^{75}$ and the effect of statutes permitting the wife to convey either "as a feme sole," or "in the same manner as her husband," has been held to give her conveyance an equal force. ${ }^{76}$ On the other hand, in a few states (notably Indiana and Michigan) a conveyance, while both are living, by either spouse alone to a third person has no force, even though the one that conveyed survives the other. ${ }^{77}$ But in these states a husband may convey his interest in the tenancy by entireties directly to his wife, ${ }^{78}$ and in Michigan she may convey her interest in such an estate directly to him. ${ }^{79}$

$\$ 167$. The "community system."-The "community system" exists at present in Arizona, California, Idaho, Louisiana, Nevada, New Mexico, Texas and Washington, though it formerly prevailed in Missouri also. ${ }^{80}$

This system originated in the civil law, and was adopted by these states and territories from the French, Spanish or Mexican law.

Its general characteristic is that it reserves to the husband and the wife separately all property acquired by either before marriage, and what is acquired by gift, devise, or inheritance from others during marriage, but, in general, all other property acquired by either during the marriage is held as "community property." 81 There is,

${ }^{25}$ Hiles v. Fisher, 1895, 144 N. Y. 306 ; 39 N. E. 337 ; 43 Am. St. R. 762 ; 30 L. R. A. 305 ; Atkison V. Henry, 80 Mo. 151; Berrigan v. Fleming, 70 Tenn. 271.

${ }^{n}$ Howell v. Folsom, 1900, 38 Ore. 184; 63 Pac. 116; 84 Am. St. R. 785; Branch v. Polk, 1895, 61 Ark. 388; 33 S. W. 424 ; 54 Am. St. R. 266.

$\pi$ Naylor $\nabla$. Minock, 1893, 96 Mich. $182 ; 55$ N. W. 664 ; 35 Am. St. R. 595; Dyer $\nabla$. Eldridge, 1893, 136 Ind. 654, $662 ; 36$ N. E. 522.

7 Enyeart v. Kepler, 118 Ind. 34; 20 N. E. 539 ; 10 Am. St. R. 94.

7 Wilkinson v. Kneeland, 1900, 125 Mich. 261; 84 N. W. 142; 7 Det. Leg. News 499.

* Moreau v. Detchemendy, 18 Mo. 522.

a Meyer v. Kinzer, 12 Cal. 247; 73 Am. D. 538; De Blanc v. Lynch, 23 Texas 25. 
in general, a presumption that property acquired after marriage by either husband or wife is community property until it is shown to be separate property. ${ }^{82}$

But the system does not prevent either one of the married persons from having separate property which is distinct from the community property; though when the title is apparently in the community the evidence to establish its separate character must be such as to counterbalance the presumption that it is community property. ${ }^{83}$

A husband may convey community property to his wife, and when he does so the presumption is that its character is changed to her separate property. ${ }^{84}$

The wife, however, has such a slight interest in the community property that she alone can convey no title to it, unless she is abandoned by her husband..$^{85}$ On the other hand, the general rule is that the husband has the management of it and power to convey it or encumber it, except that he cannot convey it without consideration, unless with his wife's consent, nor can he convey it with intent to defraud her. ${ }^{86}$ Where this system prevails, courtesy and dower have either been abolished or have never existed; the rights of the survivor in the common property take the place of the one and the other ${ }^{87}$

${ }^{82}$ Morris v. Hastings, 70 Texas 26; 8 Am. St. R. 570; Hanna v. Reeves, 1900, 22 Wash. 6; 60 Pac. 62; Svetinich v. Sheean, 1899, 124 Cal. 216 ; 56 Pac. 1028; 71 Am. St. R. 50. But see Cal. Civ. Co., § 164, as amended, 1901.

8s Mattson v. Mattson, 1902, 29 Wash. 417; 69 Pac. 1087.

a Main v. Main (Ariz. 1900), 60 Pac. 888; Hamilton v. Hubbard, 1901, 134 Cal. 603, 606; 65 Pac. 321.

${ }^{80}$ Zimpelman v. Robb, 53 Texas 274.

${ }^{*}$ Spreckels v. Spreckels, 1897, 116 Cal. 339 ; 48 Pac. 228; 58 Am. St. R. 170; Wilson v. Wilson, 1899, 6 Idaho 597; 57 Pac. 708. In Washington, however, he cannot convey it or encumber it unless she joins with him in the deed, etc. Wash. Ball. Co. 1897, §4491.

${ }^{87}$ Local statutes and decisions have so far divergently modified the system as to make a further discussion of its doctrines impracticable. The leading treatise on the subject is Ballinger's Community Property, 1895. 


\section{CHAPTER XIII.}

\section{CONDITIONS.}

$\$ 168$. Conditions and limitations in general.

169. Implied conditions.

170. Express conditions - Conditions precedent.

171. Express conditions-Conditions subsequent.

172. Conditions precedent and subsequent compared.

173. Determinable or special limitations.

174. Determinable fees.

175. Conditional limitations.

176. Causes of difficulties in construing.

177. Words used in creating conditions.

178. The place for the condition.

179. The re-entry clause.

180. Particular classes of casesConvey ances for specified purposes.
$\S 181$. Effect in such cases of consideration and nature of purpose.

182. Particular classes-Building restrictions-Restrictions as to use.

183. Particular classes-Conditions and stipulations for support.

184. Conditions not created in such cases by inferenceRemedy in equity.

185. Void conditions - Requiring illegal acts-Restraining marriage.

186. Void conditions - Repugnant to estate granted or capricious.

187. General suggestions for drawing and construing conditions.

$\$ 168$. Conditions and limitations in general.-When an owner of land conveys it by deed to another and his heirs, or devises it by will, he does not always merely grant or devise it absolutely, but he often provides that something must happen or be done before the grantee's interest can begin or become complete, or he subjects the land to some restriction, or attempts to confine its enjoyment to some particular use, or he provides that the grantee's or devisee's estate shall come to an end on the happening of some contingency before the time at which it would otherwise terminate. 
A clause or recital in the instrument disposing of the estate by which such ends are sought to be accomplished may have the character of a condition imposed by the grantor, or of a covenant in the nature of a promise by the grantee, or of a stipulation amounting to a prohibition on the use of the land, or of a special limitation.

Such clauses in some particulars resemble one another in form, but their effects are quite different, according as they are really one or the other.

\$169. Implied conditions.-Conditions which qualify the existence of estates are primarily of two sorts: (1) implied conditions, or conditions in law, - such as the law itself annexes to estates; and (2) express conditions, or conditions in deed,-such as are expressly stated in the instrument by which the estate is created. ${ }^{1}$

An example of an implied condition at common law, a consequence of the system of tenure, was that a tenant for life should not convey, by feoffment or by fine or recovery, a greater estate than that which he had; for such conveyances, by which seisin was divested, worked a forfeiture. ${ }^{2}$ Implied conditions, of comparatively much less importance now than formerly, will not be discussed.

$\$ 170$. Express conditions-Conditions precedent.-Express conditions may be either conditions precedent or conditions subsequent.

A condition precedent is one which must be fulfilled before the estate dependent upon it can come into existence: prior to the fulfilment of the condition no estate passes from the grantor to the grantee, while after its ful-

${ }^{2} \mathrm{Bl}$. Comm. II, 152-154.

2 This doctrine did not apply to conveyances under the Statute of Uses, which conveyed only such an estate as the grantor had; nor does it apply at this time in this country. Quimby v. Dill, 40 Maine 528; McCorry v. King's Heirs, 3 Humph. (Tenn.) 267; 39 Am. Dec. 165. 
filment the grantee has an absolute and unconditional estate.

For example, a conveyance to a city of land for a park, provided that the city obtains authority from the legislature to remove bodies from the cemetery on the land conveyed within a certain time, is a grant on condition precedent, and the failure of the city to obtain this authority prevents its taking title. ${ }^{8}$ Or, a devise to one on condition that he, within a named time, shall come under the guardianship of a relative of the testator is a devise on condition precedent, and because of non-fulfilment of it the devisee takes no estate."

If a condition precedent be impossible or unlawful, the grantee can take nothing, as the condition cannot be fulfilled..$^{5}$

\$ 171. Express conditions-Conditions subsequent.A condition subsequent is one which affects an estate already vested, rendering it liable to be defeated. The characteristic of the condition subsequent is that it prescribes terms upon which the land granted shall revert to the grantor. If such a condition is impossible or unlawful, the estate already vested cannot be defeated. This is sometimes called a " condition of re-entry," or, at common law, a "condition" simply. It operates by reserving a right of re-entry to the grantor or his heirs : in a certain event named the estate may be defeated by this entry, but until entry (or some act equivalent to it) the estate continues. ${ }^{6}$

- Stockton v. Weber, 1893, 98 Cal. 433; 33 Pac. 332.

-Johnson v. Warren, 1889, 74 Mich. 491; 42 N. W. 74; Pearl v. Lockwood, 123 Mich. 142; 81 N. W. 1087; 6 Detroit Leg. New8 990.

${ }^{5}$ If, however, the condition becomes impossible through the act of him who has imposed it, it would seem to be no longer binding, but to be discharged. Jones v. C. \& O. R. R. Co., 14 W. Va. 514, 523. Though see, contra, II Bl. Comm. 156 ; Co. Litt. 218a.

- As to whether the right of re-entry should be expressed, see post, $\$ 179$. 
The grantor, having conveyed subject to a condition subsequent, thereafter holds no estate in the land conveyed. His interest, after such a conveyance and before the breach of the condition by the grantee, is a mere possibility of acquiring an estate in the land conveyed at some future time, and this possibility, not being an estate, was inalienable at common law; and after breach of the condition by the grantee the grantor's interest is a right of entry not assignable at common law.

Therefore, it is still the general rule, except where a statute has modified the doctrine, that advantage can be taken of a condition subsequent only by the grantor or his heirs.?

The condition may be of a positive or affirmative character, that is, that the grantee, after taking the estate in the land conveyed, shall do some specified thing-as that he shall within a certain time build on the land a factory of a certain capacity; ${ }^{8}$ or it may be of a negative character, that is, that the grantee shall not do some specified thing-as that he shall not make and sell intoxicating liquors on the land; ${ }^{9}$ or it may be not dependent on the act of the grantee, but on that of the grantor, as, in the case of the common-law mortgage, if land be conveyed upon the condition that if the grantor pay the grantee certain money at a certain day, then the grantor may reenter-the fulfilment of the condition gives the grantor the right of re-entry. ${ }^{10}$

$\$ 172$. Conditions precedent and subsequent compared. -While there is a marked difference in effect between a

'Upington v. Corrigan, 1896, 151 N. Y. 143 ; 45 N. E. 359 ; 37 L. R.A. 794; Ruch v. Rock Island, 97 U. S. 693; Bangor v. Warren, 34 Maine $324 ; 56 \mathrm{Am}$. D. 657. For statutes making such rights assignable see Cal. Civ. Co., § 1046; Idaho Civ. Co. 1901, § 2391; Connecticut Gen. Stat. 1902, § 4051.

- Langley v. Chapin, 134 Mass. 82.

${ }^{9}$ Cowell v. Colorado Springs Co., 100 U. S. 55.

${ }^{10}$ Litt., $\$ 332$. 
condition precedent and a condition subsequent, it is not always easy to determine whether a particular clause belongs to the one class or the other, for there are no technical words by which to distinguish between them. ${ }^{11}$ It is a matter of intention of the party imposing the condition to be gathered from the whole instrument and not merely from the terms of a part of it.

If it thus appears that the act on which the estate depends must be performed before the estate can vest, there is a condition precedent; if, however, the act does not necessarily precede the vesting of the estate, but may accompany or follow it, there is a condition subsequent. ${ }^{12}$

As the law favors the present vesting of estates-even though they may be subsequently divested-the courts are apt to construe a clause of doubtful import as a condition subsequent rather than a condition precedent, ${ }^{13}$ though where the clause imposes clearly a condition precedent there is no room for construction, as the manifest intention of the grantor or testator must be regarded. ${ }^{14}$

$\$ 173$. Determinable or special limitations. - An estate upon condition subsequent is to be distinguished from an estate upon "determinable limitation," or, as it is also - called, upon "special limitation," or "collateral limitation." 15

An estate on condition subsequent and one on determinable or special limitation resemble one another in that either may possibly end upon the happening of a contingency, before the time at which it would end had no such contingency been named.

"Nicoll v. N. Y. \& E. R. R. Co., 12 N. Y. 121.

18 Finlay v. King's Lessee, 3 Pet. 346, 374; Donnelly v. Eastes, 1896, 94 Wis. 390 ; 69 N. W. 157 ; Burdis v. Burdis, 1898, 96 Va. 81 ; 30 S. E. $462 ; 70$ Am. St. R. 825.

${ }^{13}$ Donnelly v. Eastes, 1896, 94 Wis. 390 ; 69 N. W. 157.

"Johnson v. Warren, 1889, 74 Mich. 491 ; 42 N. W. 74; Tilley v. King, 1891,109 N. C. $461 ; 13$ S. E. 936.

is See post, $\S 175$, note 22. 
But the contingency in a condition is a proviso cutting off the estate granted before what would otherwise be its natural termination by virtue of its original limitation, while the contingency in a determinable or special limitation defines or limits the quantum of the estate as part of its original limitation. For example, if land is granted to a woman "during widowhood," the words "during widowhood" define the time during which it is the intention of the grantor that the estate shall endure, and at the end of which time the estate shall end: they are words of limitation. The estate at the end of the period named terminates by virtue of its original limitation. No entry by any one nor act of any other person is necessary to divest the grantee of any interest, because her estate ceases at once upon the happening of the event by which it is limited.

If, however, the land is granted to a widow for and during her life, but in the event of her marriage her estate to cease and the land to revert to the grantor, the effect is different; for in this case an estate of a certain character is given, but by a separate provision, not a part of the original limitation, the estate is liable to be forfeited by the grantee's performance of an act which, but for this separate provision, might have been performed without affecting the duration of the estate as limited. This, therefore, is a condition, and the happening of the contingency named does not of itself terminate the grantee's estate, but renders it liable to be terminated by the entry of the grantor.

$\$ 174$. Determinable fees.-When an estate in fee simple is made subject to a special limitation it is known as a determinable or qualified fee. Such an estate is an estate limited to the grantee and his heirs until the happening of some future event, which must be of such a kind 
that it may by possibility never happen at all $;^{16}$ it is an estate whose continuance as a fee simple is made to depend upon the happening or not happening of some future event, but where the terms used in its creation are words of limitation, as distinguished from words of condition.

Old examples of determinable fees are limitations to one and his heirs "as long as the Church of St. Paul shall stand," or "until the grantee go to Rome"; 17 the most appropriate words to create a determinable fee being: during, so long as, till, until, whilst, etc.—such words fitly prefacing a limitation.

The difference between the interest of the grantor after the grant of a determinable fee and his interest after the grant of an estate upon condition is chiefly in this, that in the latter case a breach of the condition gives the grantor a right of entry, while in the former case, upon the happening of the event named as limiting the estate, the estate of the grantee terminates without entry and the right of possession reverts to the grantor.

It has been argued that as the grantor's "possibility of reverter" presupposed a tenure between grantor and grantee, which cannot exist since the statute Quia Emptores, ${ }^{18}$ and that the whole fee having been granted there is no reversionary interest left in the grantor by virtue of which he may claim possession, therefore no valid determinable fee can be created. ${ }^{19}$ But, nevertheless, determinable fees are expressly recognized by many decisions in this country.

For example, where the grant was to a religious society: "To have and to hold to the said [society] and their as-

16 Challis Real Prop., p. 197.

"Plowd. 557 ; 1 P. Wms. 75; Shep. Touchstone 125.

18 $1290,18 \mathrm{Edw}$. I, c. 1.

10 See Gray Rule Against Perpetuities, \$ 31-42; Pollock Land Laws, App., p. 221; papers by Prof. Gray and Mr. Challis in Law Quarterly Rev., Vol. 3, pp. 399, 403 (1887). 
signs, so long as said real estate shall by said society or its assigns be devoted to the uses, interests and support of those doctrines of the Christian religion," set forth in a certain formulary, it was held to create a determinable fee, terminating without entry and reverting to the grantor when the use specified ceased. ${ }^{20}$

$\$ 175$. Conditional limitations.-An estate upon conditional limitation partakes of the character of both an estate upon condition and one upon special limitation, but is identical with neither.

Where there is an estate upon condition with a limitation over to a third party in case of breach of the condition or in case of its non-fulfilment, there is a conditional limitation.

The limitation to the third party must be made at the time of the original grant, for if the grant be strictly upon condition subsequent the grantor has no estate which he can afterward alienate. ${ }^{21}$

Thus, if a grant be made to a widow for life, but in the event of her marriage her estate to cease and title to vest in a third person, the grant is not one upon condition merely, for the grantor has reserved (expressly or by implication) no entry; nor is the estate one upon special limitation merely, for there is a condition. The grant of an estate of this dual character is a grant upon conditional limitation. It resembles a condition subsequent but operates quite differently, for upon the breach of the condition involved in a conditional limitation no act of any one is necessary to terminate the estate, as it ceases,

${ }^{20}$ First Universalist Soc'y $\nabla$. Boland, 1892, 155 Mass. 171; 29 N. E. 524; 15 L. R. A. 231. See also Delhi School District v. Everett, 52 Mich. 314; $17 \mathrm{~N}$ W. 926; Friedman v. Steiner, 107 Ill. 125; Slegel v. Lauer, 1892, 148 Pa. St. 236; 23 Atl. 996 ; Hall v. Turner, 1892, 110 N. C. 292; 14 S. E. 791 ; Congregational Soc'y v. Stark, 34 Vt. 243.

${ }^{21}$ See supra, $\$ 171$. 
ipso facto, and the limitation over to the third person vests at once without entry. ${ }^{22}$

$\$ 176$. Causes of difficulties in construing.-It appears that the subject of conditional estates has always been considered one of some difficulty. On this matter it is said, in Preston's edition of Shepard's Touchstone, page 121, "Conditions annexed to estates are sometimes so placed and confounded amongst covenants; sometimes so ambiguously drawn, and at all times have in their drawing (when deeds, etc., are prepared by unskilful persons) so much affinity with limitations, that it is hard to discern and distinguish them." Time has not much lessened the difficulties mentioned in the Touchstone. ${ }^{23}$ Indeed, they seem to have somewhat increased during the two hundred and fifty years since the clause quoted from the Touchstone was written, and this is due to several causes. Increased and more varied business enterprises have led to a greater variety of uses to which land may be put, and at the same time to the imposition of a greater variety of

2z Proprietors Brattle Square Church v. Grant, 3 Gray 142; 63 Am. Dec. 725; Outland v. Bowen, 115 Ind. 150; 17 N. E. 281; 7 Am. St. R. 420. Some confusion has been caused by the use of the phrase" conditional limitation" to describe a special or collateral limitation. Challis (Real Prop., pp. 199, 200) styles the "special limitation" a "determinable limitation," and says that to describe it as a "conditional limitation" is "only to invite obscurity and confusion." The term conditional limitation is more properly used to describe "a proviso cutting short an estate previously created and substituting another in its stead": Gray Restraints on Alienation, $\$ 22$, note. The case of Atlanta Consolidated St. R. Co. v. Jackson, 1899, 108 Ga. 634; 34 S. E. 184, illustrates how differences of opinion may be entertained concerning conditional clauses: plaintiffs regarded the clause as a covenant and brought an action for damages, defendant contended that it was a condition subsequent, but the court, agreeing with neither party, refers to it as creating a "defeasible fee," and calls it also a "conditional limitation" and a "limitation."

${ }^{23}$ See, for example, Clapp v. Wilder, 1900, 176 Mass. 332 ; 57 N. E. $692 ; 50$ L. R. A. 120, in which case the court was about equally divided in opinion as to whether a clause in a deed was a conditional clause or a restriction merely. 
restraints on its free use. Besides, modern rules of construction have somewhat changed the effect of technical words; and while in construing conveyances the aim of the courts is to get at the intention of the parties from the whole instrument, read with regard to the circumstances in which it was made, they very often disregard forms of expression which once had more nearly a fixed meaning.

Moreover, the doctrine of conditional estates is not wholly in accord with American principles of ownership of land. When all lands were regarded as granted out by some superior lord and held on condition from him, reversionary interests and forfeitures, in certain cases, were natural legal incidents of estates. But the fundamental principles of allodial ownership are really inconsistent with the doctrine of reversionary rights still remaining with one who has parted with his title. Some American courts, therefore, incline further than do others toward avoiding if possible any forfeiture of an estate for breach of a condition. Others have been more influenced by the older rules. The result is that there is some conflict among the decisions, and in practice the questions raised are often perplexing.

The chief difficulty that seems to have arisen in connection with the subject has been that of ascertaining whether certain provisions annexed to grants of real property constitute conditions of such a character that a breach thereof confers a right of entry on the grantor or his heirs, or whether such provisions are covenants, restrictions, limitations, or trusts impressed on the property-affecting the estate in ways quite different from that in which a true condition affects it.

In view of the number and character of the decisions it is worth while to examine them in some detail with the view of distinguishing the condition subsequent from these other provisions. 
$\S 177$. Words used in creating conditions.-When an estate is granted on condition subsequent, a present estate passes, subject, however, to be defeated by the breach of the condition. The estate continues in the grantee until avoided. As, therefore, conditions subsequent tend to work a forfeiture of an estate already vested, it is well settled that they are strictly construed against the grantor, and if it is intended to create a condition subsequent it must be generally so expressed as to leave no room for construing it as something else.

No particular form of words is considered absolutely essential to create a condition; but it is essential that the intention to create it shall be clearly shown by some words. If the grantor, in attempting to create a condition subsequent, has so expressed himself that it is doubtful whether the clause is a covenant or a condition, it will be construed a covenant; or, if it is doubtful whether there is a condition or simply a trust, not resulting in a forfeiture on its breach, it will be construed as the latter. ${ }^{24}$

"Where, however, the terms are distinctly and plainly terms of condition, where the whole provision precisely satisfies the requirements of the definition, and where the transaction has nothing in its nature to create an incongruity, there is no room for refinement, and no ground for refusing to assign to the subject its predetermined legal character. In such a case the law attaches to the act, and - the parties cannot be heard to say that although they deliberately made a condition, and nothing but a condition, they yet meant that it should be exactly as a covenant." 25

« See post, $\$ 180$.

* Blanchard $\nabla$. Railroad, 31 Mich. 43, 51. In this case a conveyance was made upon the express condition that a railroad company should build and maintain a depot, and run trains, etc. The grantor seeks to specifically enforce this as a covenant; not, as is generally the case, to forfeit the estate as for the breach of a condition. But the court holds that equity will not enforce it as a covenant, for two reasons: flrst, be14-Brews. Con. 
While technical words are not essential to create a condition, and while they will not, when used, always be held to create one, it is well recognized that certain terms are more apt to create a condition than are others. The most appropriate words used for this purpose are such phrases as "on condition," "provided always," or similar expressions which indicate that in a certain event prescribed the estate becomes defeasible by entry of the grantor or his heirs (or an equivalent act), but that until entry the estate is to continue.

$\$ 178$. The place for the condition.-The appropriate place for the use of these words is just after the habendum, or as a part of it. In this place they qualify the grant, controlling, but not contradicting, the more general words used in the premises. If the words of condition are found in any other part of the deed, as, for example, among the covenants, or, as is often the case, in the premises, as a part of the statement of consideration, their unusual and inappropriate position may have an influence on the interpretation of the deed.

For example, where the words claimed to be a condition subsequent were placed after the usual covenants, and were to the effect that the grantees should not use the premises for any noxious or offensive business, nor use the said premises for any other purpose than as an ornamental park, the court decided that the clause was a promissory covenant, not for the benefit of the grantor and his heirs, but for the benefit of those to whom easements had previously been granted; and mentions the fact that the provision in question is not placed where conditions are usually found in deeds, but follows the covenants for title, saying: "While this is by no means

cause it is a condition subsequent, and, second, because equity cannot supervise the construction and maintenance of the depot and the operation of the railroad. See Ritchie v. Railroad, 1895, 55 Kan. 36; 39 Pac. 718; Mills v. Railroad, 1895, 10 Wash. 520; 39 Pac. 246. 
controlling, it has a significance not to be overlooked, as the instrument was evidently drawn by a skilful conveyancer, who was well acquainted with both forms and technical terms in common use by experienced draughtsmen of deeds. The absence of technical language appropriate, although not essential to create a condition, is also significant." 26

Where the short form statutory deed is used, in which there is no habendum clause, about the only place in the usual printed form for the insertion of a condition is just after the description, and this appears to be the place where the condition is inserted when this form of deed is used. ${ }^{27}$

$\$ 179$. The re-entry clause.-To make the condition clearer and more unmistakable, a clause providing for a re-entry by the grantor or his heirs, or for forfeiture of the estate on breach of the condition, should be added. The presence or absence of a clause of this kind has an important bearing upon the question whether the recital constitutes a condition or a covenant.

For example, in Post v. Weil, ${ }^{28}$ one having agreed to purchase land refused to complete the purchase and accept a deed, on the ground that by the provision of a former deed, through which the present vendor derived title, the property was subject to the operation of a condition subsequent. This action was brought to compel the specific performance of his contract to purchase the land. The clause in question was in the habendum clause, as follows: "Provided always, and these presents are upon this express condition, that the said premises shall not, nor shall any part thereof, or any building or buildings thereon erected or to be erected, be hereafter used or occupied as a tavern or public house of any kind." The court,

${ }^{26}$ Graves v. Deterling, 1890, 120 N. Y. $447 ; 24$ N. E. 655.

${ }^{27}$ Preston v. Bosworth, 1899, 153 Ind. 458; 55 N. E. 224.

21889,115 N. Y. 361 ; 22 N. E. 145 ; 12 Am. St. R. 809; 5 L. R. A. 422. 
in deciding that this was not a condition subsequent, notices that there is no clause in the deed giving the right to re-enter for condition broken, and says (p. 371): "While the presence of such a clause is not essential to the creation of a condition subsequent, by which an estate may be defeated at the exercise of an election by the grantor, or his heirs, to re-enter, yet its absence to that extent frees still more the case from the difficulty of giving a more benignant construction to the proviso clause. The presence of a re-entry clause might make certain that which, in its absence, is left open to construction." 29

And there are many other recent decisions in which the presence or absence of a provision for re-entry or for forfeiture has been considered important in determining whether the clause is or is not a true condition. ${ }^{30}$ But while such an express provision will generally be held to clearly make that a condition which might otherwise be regarded as a covenant, a condition may be created without such a provision; thus the following clause in the habendum is held a condition subsequent: "Subject, nevertheless, to the condition that no spirituous or other intoxicating drinks shall be sold on the premises." 31

* In the opinion of the majority of the supreme court of Massachusetts this case shows "considerable astuteness in the direction of modifying the severity of the language of conditions," but the minority opinion cites it with approval. Clapp v. Wilder, 1900, 176 Mass. 332, 335,$345 ; 57$ N. E. 692 ; 50 L. R. A. 120.

so Elyton Land Co. v. Railroad, 1893, 100 Ala. 396, 406; 14 So. 207 ; Scovill v. McMahon, 1892, 62 Conn. 378; 26 Atl. 479; 36 Am. St. R. 350 ; Brewery Co. v. Primas, 1896, 163 Ill. 652, 658; 45 N. E. 145 ; McAnaw v. Tiffin, 1897, 143 Mo. 667, 677; 45 S. W. 656; Bragdon v. Blaisdell, 1898, 91 Me. 326, 328; 39 Atl. 1036; Greene v. O'Connor, 1892, 18 R. I. 56, 59; 25 Atl. 692 ; 19 L. R. A. 262; Palmer v. Ryan, 1891, 63 Vt. 227 ; 22 Atl. 574; Mahoning Co. v. Young, 1893, 16 U. S. App. 253, 269; Hartung v. Witte, 59 Wis. 285, 293 ; 18 N. W. 275 ; King v. N. \& W. Ry. Co., 1901, 99 Va. 625 ; 39 S. E. 701.

"Lehigh Coal Co. v. Early, 1894, $162 \mathrm{~Pa}$. St. 338; 29 Atl. 736, and see Papst v. Hamilton, 1901, 133 Cal. 631 ; 66 Pac. 10; Langley v. Chapin, 134 Mass. 82; Clapp v. Wilder, 1900, 176 Mass. 332; 57 N. E. $692 ; 50$ L. R. A. 120. 
$\$ 180$. Particular classes of cases-Conveyances for specified purposes.-In conveyances there is frequently a clause reciting the use that is to be made by the grantee of the land conveyed, and the question has been often raised whether such conveyances create estates upon condition, conferring upon the grantor or his heirs a right of entry upon the grantee's ceasing to use the property for the purpose specified.

The grant may be without technical words importing a condition, as, for example, to a city of land-"To have and to hold to the city and its successors as and for a street and to be kept as a public highway," ${ }^{32}$ or the terms of the grant may more clearly import a condition, as where land was conveyed to a city, "On condition that it shall be forever kept open and used as a public highway, and for no other purpose," ${ }^{33}$ and yet be held-as it was held in each of these cases-not to create a condition subsequent working a forfeiture in case the use named is not maintained.

Technical words, therefore, do not absolutely control in such cases, and yet, as the aim of the courts is to give effect to the intention of the parties, and as one of the means of discovering this intention is the language used, there may be instances in this class of cases-as in others - where the intention is so clearly expressed that there is no doubt as to the creation of a condition subsequent and no need for applying rules of construction.

For example, the following language after the description in a conveyance to a city creates a condition subsequent: "Said land is to be used by said city for the purpose of building a city hall thereon, and this conveyance is made upon the express condition that in case the said plot of ground above described shall ever cease to be used

${ }^{32}$ Kilpatrick v. Baltimore, 1895, 81 Md. 179; 31 Atl. 805 ; 48 Am. St. R. 509.

33 Greene จ. O'Connor, 1892, 18 R. I. 56 ; 25 Atl. 692 ; 19 L. R. A. 262. 
by said city for a city hall, or other similar city buildings, then and in that case the said plot of land shall revert back to the parties hereto of the first part as if this conveyance had not been made." 3

In this class of cases, while the intention of the grantor may generally be clearly seen to be that the property should be used for the designated purpose only, nevertheless, unless he also clearly indicates his intention that the whole estate shall be forfeited and revert to him when such use ceases, the seeming condition will be likely to be construed rather as showing his intention to impose a trust in the grantee than as indicating his intention to create a condition. ${ }^{35}$

$\$ 181$. Effect in such cases of consideration and nature of purpose.- Yet the language alone in such cases will not always control, for this language must be read in connection with the circumstances of each case.

Among the circumstances very generally considered as of importance in the decision of cases of this character are the nature of the purpose or use named, and the fact whether the conveyance was made for a full and substantial consideration paid to the grantor, or was made for a nominal consideration, or none.

If one should purchase land, paying for it its full value, and the conveyance to him should recite that he was to use it for residence purposes, this alone would not indicate an intention that he should forfeit his estate by ceasing to use the land for the purposes recited. If, however, one owning much land in a new town should convey part of

4 Trustees of Union College v. New York, 1903, 173 N. Y. 38; 65 N. E. 853 .

${ }^{35}$ Rawson v. School Dist., 7 Allen $129 ; 83 \mathrm{Am}$. D. 670; Village of Ashland v. Greiner, 1898, 58 Ohio St. 67; 50 N. E. 99; Carroll Co. Academy v. Gallatin Academy Co., 1898, 104 Ky. 621 ; 47 S. W. 617; Mahoning County v. Young, 1893, 16 U.S. App. 253, 268, 269. . 
it without consideration to a railroad company for depot purposes, in the belief that the erection and maintenance of a depot would increase the value of his remaining land, it would be contrary to the intention of the grantor, as well as inequitable, if the grantee should dispose of the land or neglect to put it to the use specified; and, even if the language used in the conveyance did not technically express a condition subsequent, these circumstances might properly be considered in giving effect to it as such. ${ }^{36}$

Therefore, the presence or absence of a consideration is often regarded in determining the effect of such clauses, and if the grantor has received a substantial consideration for his land this fact will be taken into account in construing the alleged conditional clause, when he seeks to recover the land, and the clause will be more strictly construed against him than if the conveyance had been merely voluntary or on a nominal consideration. ${ }^{87}$

But the presence or absence of the consideration is, at the most, simply one of the facts to be regarded in arriving at the intention of the parties, and other facts may make this fact of little importance in particular cases.

Among these other facts is that of the nature or character of the purpose specified in the conveyance. If this purpose is in its nature general and public, and not such as will enure specially to the benefit of the grantor, the absence of a consideration seems of little importance in itself as indicating an intention to create a condition subsequent. ${ }^{38}$

* Horner v. C. M. \& St. P. Ry. Co., 38 Wis. 165 ; Indianapolis P. \&c. Ry. Co. v. Hood, 66 Ind. 580. But seo Gray v. C. M. \& St. P. Ry. Co., 1901,189 Ill. $400 ; 59$ N. E. 950 , holding that the consideration for such a conveyance may not be inquired into in an ejectment suit brought by the grantor.

" Ecroyd v. Coggeshall, 1898, 21 R. I. 1; 41 Atl. 260; 79 Am. St. R. 741; Faith v. Bowles, 1897, 86 Md. 13, 16; 37 Atl. 711; 63 Am. St. R. 489; Village of Ashland v. Greiner, 1898, 58 Ohio St. 67; 50 N. E. 99; Neely v. Hoskins, 1892, 84 Maine 386, 394 ; 24 Atl. 882.

" Rawson v. School District, 7 Allen 129; 83 Am. D. 670; Farnham 
\$182. Particular classes-Building restrictions-Restrictions as to use.-Stipulations regarding buildings to be erected may be expressed in the form of conditions and will have the effect of conditions; thus this clause: "Said party of second part hereby covenants with said party of the first part under penalty of forfeiture of the estate hereby conveyed, that previous to [dato] he shall erect on said lot a substantial dwelling house," was held a condition subsequent. ${ }^{29}$ But such stipulations and "building restrictions" in general, are more often regarded as covenants, especially when they are drawn, as most of them seem to be, without provision for forfeiture and re-entry.

So stipulations restricting to some extent the use of the land, or prohibiting its use for certain purposes, may, as many of the foregoing cases show, be drawn and construed as conditions ; to $^{\circ}$ but these also are, it seems, more frequently covenants, 11 and, with building restrictions, will be referred to later. ${ }^{2}$

\section{\$183. Particular classes-Conditions and stipulations} for support.-There is an important class of cases in-

v. Thompson, 34 Minn. 330; 26 N. W. 9; 57 Am. R. 59; Olcott $\nabla$. Gabert, 1893, 86 Texas 121 ; 23 S. W. 985 ; Newpoint Lodge $\nabla$. Newpoint, 1894, 138 Ind. 141; 37 N. E. 650. But in Papst v. Hamilton, 1901, 133 Cal. 631 ; 66 Pac. 10, where the purpose- "erecting and maintaining a collegiate school," etc.-seems not to have been for the grantor's special advantage, but rather public and general, importance appears to have been attached, in holding that there was a condition, to the fact that the purpose specified was the whole consideration for the conveyance.

${ }^{89}$ O'Brien v. Wagner, 94 Mo. 93 ; 7 S. W. 19; 4 Am. St. R. 362 . And see Langley v. Chapin, 134 Mass. 82 ; Clapp v. Wilder, 1900, 176 Mass. 332 ; 57 N. E. 692 ; 50 L. R. A. 120; Quatman v. McCray, 1900, 128 Cal. 285 ; 60 Pac. 855.

${ }^{10}$ See the recent case of Wakefleld v. Van Tassell, 1903, 202 Ill. 41; $66 \mathrm{~N}$. E. 830, in which a condition against using the granted premises for handling grain in elevators is sustained.

${ }^{41}$ Brewery Co. v. Primas, 1896, 163 Ill. 652; 45 N. E. 145.

2 See post, ch. 14. 
volving the consideration of conveyances made with the expectation on the grantor's part that the grantee will support and maintain him for life or for a definite time.

Where land is conveyed subject to a provision for support, the provision may be a condition subsequent, or it may be a covenant on the grantee's part, or it may create a lien on the land enforceable by the grantor; and whether it be one or the other will depend on the intention to be gathered from the language and the circumstances in which the conveyance is made.

In clear cases such a provision must be held a condition, as where a deed is made on the express condition that the grantee shall maintain and support the grantor, with a proper clause that the premises shall revert in case of failure. ${ }^{43}$

While in doubtful cases of this character the courts will usually follow the general rule and construe the clause as something else rather than a condition, still it is to be remembered that the circumstances surrounding conveyances of this kind are often such as to warrant a construction which will give the grantor a right of re-entry in case of the grantee's non-compliance with the terms of the conveyance.

The grantor in such cases is usually aged, the grantee is usually a relative, and often the anticipated support is the only consideration for the transfer; the kind of care and support necessary renders pecuniary damages inadequate, and the continuing nature of the contract would lead to continuous litigation if the grantee persisted in his neglect. The most practical and equitable redress in such cases is one that will place the parties in their original positions. Therefore, the general rule of construction -adverse to conditions-will not always be applied as strictly in these cases as in others."

w Delong v. Delong, 56 Wis. 514; 14 N. W. 591; Berryman v. Schumaker, 67 Texas $312 ; 3 \mathrm{~S}$. W. 46.

4 Glocke v. Glocke, 1902, 113 Wis. 303 ; 89 N. W. 118; Goldsmith v. 
$\$ 184$. Conditions not created in such cases by inference-Remedy in equity.-However, an intent to create a condition subsequent will not always be inferred merely from the circumstances under which such conveyances are made, in the absence of language susceptible of construction as a condition. So if a deed is made merely in consideration of support, or of the payment of certain sums by the grantee periodically, while the grantor may have other remedies, it will generally be held that there is not a condition subsequent. ${ }^{45}$

Such cases are recognized as forming a class by themselves and, though there may be strictly no condition subsequent, if there has been failure of consideration slight evidence of fraud and imposition should, it would seem, induce a court of equity to cancel the conveyance, ${ }^{46}$ and the death of the grantee has been held to afford ground for setting it aside; ${ }^{47}$ or where the deed will not be canceled, the court may decree a lien on the land for the value of such support. ${ }^{48}$

Goldsmith, 1899, 46 W. Va. 426; 33 S. E. 266; Hershman v. Hershman, 63 Ind. 451.

45 Anderson v. Gaines, 1900, 156 Mo. 664, 670; $57 \mathrm{~S} . \mathrm{W} .726$; Lowman v. Crawford, 1901, 99 Va. 688; 40 S. E. 17; Doescher v. Spratt, 1895, 61 Minn. $326 ; 63$ N. W. 736.

6 McClelland v. McClelland, 1898, 176 Ill. 83 ; 51 N. E. 559; Patterson v. Patterson, 1891, 81 Iowa 626; 47 N. W. 768.

4 Payette v. Ferrier, 1899, 20 Wash. 479; 55 Pac. 629.

60 Doescher v. Spratt, 1895, 61 Minn. 326; 63 N. W. 736; Childs v. Rue, 1901, 84 Minn. 323; 87 N. W. 918; Patton v. Nixon, 1898, 33 Ore. 159 ; 52 Pac. 1048 . In Knutson v. Bostrak, 1898,99 Wis. 469 ; 75 N. W. 156 , such a deed is said to be one on condition subsequent which equity will enforce by declaring a forfeiture (p. 483)-though in the later case of Glocke v. Glocke, 1902, 113 Wis. $303 ; 89$ N. W. 118, it is explained that this is not strictly accurate, and that a court of equity in such cases " does not lend its jurisdiction to effect a forfeiture," but that the forfeiture having been effected by re-entry of the grantor, or its equivalent, a court of equity will aid him in quieting his title. For equity will not generally enforce forfeitures: Pomeroy, Eq. Jur. I., $\$ \$ 459,460$. 
$\$ 185$. Void conditions-Requiring illegal acts-Restraining marriage. $-A$ condition which requires the performance of an act contrary to law or good morals is void. Hence a condition calling for the separation of husband and wife is invalid, ${ }^{49}$ as is one calling for the commission of a crime.

Upon the question as to how far conditions in restraint of marriage are invalid, there is much conflict.

A condition subsequent in absolute restraint of marriage will, by what seems to be the general rule, be held void; as will one thut unreasonably restrains the marriage of the grantee, as, for instance, by prohibiting marriage before an extreme age, or with a person of the same state as that of the grantee; but a reasonable restraint-as where marriage with a particular person is prohibited, or where the consent of a parent is required, or the marriage is forbidden before the attainment of a suitable age-is valid. ${ }^{50}$

Conditions in restraint of second marriages are not considered as within the same reason, and are therefore generally held valid. ${ }^{51}$

\$186. Void conditions-Repugnant to estate granted or capricious.-Conditions imposing restraints on the use of the land conveyed have been sometimes claimed in argument to be void as repugnant to the estate granted, ${ }^{62}$ but decisions are numerous, as. the foregoing citations

• Conrad v. Long, 33 Mich. 78; Hawke v. Euyart, 1890, 30 Nob. 149 ; $46 \mathrm{~N}$. W. 422.

${ }^{\circ}$ See Coppage v. Alexander's Heirs, 2 B. Mon. 313; 38 Am. Dec. 153, note; Randall v. Marble, $69 \mathrm{Me} .310$; $31 \mathrm{Am}$. R. 281. But a condition precedent restraining marriage may prevent the vesting of the estate. Phillips v. Ferguson, 85 Va. 509; 8 S. E. 241; 17 Am. St. R. 78.

w Herd v. Catron, 1896, 97 Tenn. 662; 37 S. W. 551; Knight v. Mahoney, 1890, 152 Mass. 523; 25 N. E. 971.

${ }^{52}$ See e. g. Cowell v. Colorado Springs Co., 100 U. S. 55. 
show, sustaining conditions reasonably restricting the use of property.

Where, however, after a grant or a devise in fee there is an attempt by condition to impose a general restraint on alienation, such a condition is void as repugnant to the estate limited. 33

So also are conditions which unreasonably restrict the use and enjoyment of the property, as, for instance, in the conveyance "of a house that there shall be no windows in it, or no passage in and out." 54 Conditions imposing restrictions which are of advantage to no one would seem to be void as contrary to public policy and wholly unreasonable; ${ }^{55}$ and this principle has been made statutory in a few states ${ }^{56}$ by enactments providing that when any conditions annexed to a grant are merely nominal and evince no intention of actual and substantial benefit to the party in whose favor they are to be performed, they may be disregarded, and a failure to perform the same shall not operate as a forfeiture of the lands conveyed subject thereto.

Where such statutes exist proof will often be necessary to establish the fact whether the expressed condition was or was not beneficial. ${ }^{57}$

$\$ 187$. General suggestions for drawing and construing conditions.- It appears, therefore, from the authorities that it is not difficult to draw a deed so that it will be a conveyance upon condition subsequent, so far, at least,

so Jones v. Port Huron Engine Co., 1898, 171 Ill. 502 ; 49 N. E. 700 ; Kaufman v. Burgert, 1900, 195 Pa. St. 274; 45 Atl. $725 ; 78$ Am. St. R. 813; Mandlebaum v. McDonnell, 29 Mich. 78.

ot Gray v. Blanchard, 8 Pick. 284, 290.

Bs Mitchell v. Leavitt, 30 Conn. 587.

s6 Michigan, C. L., 1897, § 8828; Minnesota, Gen. Stat., 1894, §4407; Wisconsin, Stat., 1898, §2070.

${ }^{37}$ Sioux City \&c. Ry. v. Singer, 1892, 49 Minn. 301; 51 N. W. 905; Smith v. Barrie, 56 Mich. 314 ; 22 N. W. 816. 
as form is concerned. The chief points to be observed are :

First. The recital should be in the general form of a condition.

Second. It should be in its appropriate place in the deed.

Third. There should be a clause of re-entry, or a declaration of forfeiture.

Fourth. The condition should not require the performance of an act contrary to law or good morals, should not be impossible, and should not be repugnant to the estate granted.

The first thing to do in construing such clauses, either for the purpose of ascertaining the remedy for an alleged breach, or in looking into the title to land, is to have before one either the original paper or an exact copy of it. An abstract of a conveyance containing conditional or restrictive clauses should quote these clauses fully, and should not merely state them according to what seems to the abstracter to be their legal effect.

And as the construction to be placed on the clause may depend on other parts of the instrument, a copy of the entire document should in such cases be examined.

Further, as we have seen, the use of certain words will not alone control the interpretation, but the attendant circumstances must be regarded, as, for instance, the state of the property, the situation of the parties, and the other provisions of the same instrument.

And, moreover, in estimating the force and effect of such conditional clauses, acts and events occurring since the making of the deed containing the clause may be considered, though not directly connected with the original transaction. For it may appear from these facts that the condition, though in proper legal form, is of no effect on the title, having been inserted in the deed for a dishon- 
est purpose and to obtain a monopoly, ${ }^{58}$ or it may so appear that the condition, though valid once, has been waived. ${ }^{59}$

${ }^{60}$ Chippewa Lamber Co. v. Tremper, 75 Mich. 36; 42 N. W. 532; Jenks v. Pawlowski, 1893, 98 Mich. 110; 56 N. W. 1105.

${ }^{59}$ Lehigh Coal Co. v. Early, 1894, 162 Pa. St. 338; 29 Atl. 736; Scovill v. McMahon, 1892, 62 Conn. 378; 26 Atl. 479; 36 Am. 8t. R. 350. 


\title{
CHAPTER XIV.
}

\author{
COVENANTS.
}

I. Covenants for Title.

$\$ 188$. Covenanto-Effect, in general, of the presence or absence of covenants for title.

189. Covenants for title in mortgages.

190. The usual covenants for title.

191. The form of covenants for title.

192. The designation of parties to be bound-The covenantor himself.

193. The covenantor's heirs, executors, etc.

194. Grantor's wife joining in her husband's deedHusband in wife's deed.

195. Married woman's covenants in conveyance of her separate property.

196. Designation of parties-The covenantee, his heirs, etc.

197. The covenantee's "heirs and assigns."

198. The covenants for seisin, and good right to convey.

199. The covenant against incumbrances-Form.

200. What are incumbrances?

201. Mortgages, building restrictions, d ower - Incumbrances.

202. Leasehold interests as incumbrances.
$\S 203$. Distinction between incumbrances visibly affecting the $\mathrm{ph}$ y $\mathrm{sical}$ condition and others.

204. If an incumbrance is to be excepted from the covenant, it should be so expressed.

205. The covenant for further assurance.

206. The covenants for quiet enjoyment and of warranty.

207. The covenant of warranty attaches only to the estate conveyed.

208. Effect of describing land as subject to an incumbrance.

209. Eviction necessary to a breach of covenant of warranty.

210. What is eviction-Constructive eviction.

211. Covenante implied-Common law-8tatutory deeds.

212. Effect of such statutes.

213. Whether lex situs or lex loci contractus controls.

214. The running of covenants for title with the land.

215. Conflicting views as to the running of some covenants.

216. The "English rule" as to the covenant of seisin running. 
$\$ 217$. The "American rule."

218. The rule as to the covenant against incumbrances.

219. Covenants for quiet enjoyment and warranty run with the land.

220. Subsequent grantees by quit claim deeds have the benefit of such covenants as run with the land.

221. "Personal" and "real" as used with reference to covenants for title.

II. Covenants Other than Covenants for Title.

222. General features of these covenants.

223. Form-No technical words essential.

224. Form-Effect of " heirs and assigns" or similar words in covenant.
\$225. The form of the deed in which covenants are-Effect of acceptance by grantee of deed poll containing covenants.

226. Distinction sometimes made between benefits and burdens.

227. Restrictive covenants and conditions, as to use of land, buildings, etc.

228. Building restrictions in pursuance of a "general plan."

229. The duration of such restrictions-Effect of laches, waiver, changes in neighborhood.

230. Provisions in effect restraining competition in trade.

231. Covenants in conveyances relating to party walls.

232. Agreements as to party walls without a conreyance.

I. Covenants for Title.

\$188. Covenants-Effect, in general, of the presence or absence of covenants for title.-A deed of conveyance is, of course, perfectly valid, and may convey title, without covenants of any kind, if otherwise conforming to law. The word "covenant" means, strictly, an agreement under seal for the performance or non-performance of certain acts, or that a given state of things does or shall exist, or does not or shall not exist. In its origin a covenant has no necessary connection with a conveyance. While a deed of conveyance, therefore, need contain no covenants, it may, on the other hand, contain covenants of various kinds, some intended to bind the grantor and some the grantee.

The covenants most often used in conveyances are some or all of the "covenants for title."

The general rule is well settled that a purchaser's right 
to relief against his vendor, in case he should suffer loss through a defective title when land has been conveyed to him, depends upon the covenants contained in the conveyance. If he has not taken the precaution to have covenants for title inserted in the conveyance, he cannot (generally speaking) either recover back the purchasemoney paid or keep back that which remains unpaid, should the title fail; neither in law nor equity can he have relief, unless the vendor was guilty of fraud, or the contract was founded in mistake as to some fact upon which the title depends. ${ }^{1}$ The grantee in such cases assumes the risk of the soundness of the title; he cannot show a parol agreement which will convert a deed without covenants into one with them; and his condition as to the recovery of the purchase-money on failure of title is similar to that of one who has voluntarily given away money. ${ }^{2}$ If, however, a purchaser who is entitled to a deed with covenants has accepted one without covenants, supposing that it contains them, the vendor may be compelled to execute a deed containing covenants. ${ }^{3}$

Whether a conveyance shall or shall not contain covenants for title is, therefore, a question of importance to the parties contracting for the sale and purchase of real estate, and the possibility that the title may be defective or incumbered generally has an effect on the purchase price: a purchaser assuming the risk may generally properly expect a reduction in price as an equivalent. A grantor who gives a deed with covenants for title may later prove pecuniarily irresponsible, so that some of the advantages of the covenants may be lost to the grantee, but the possibility of a recovery of damages for their

1 Peters v. Bowman, 98 U. S. 56; Whittemore v. Farrington, 76 N. Y. 452; Thorkildsen v. Carpenter, 1899, 120 Mich. 419; 79 N. W. 636; 6 Detroit Leg. News 196; Gibson v. Richart, 83 Ind. 313; Porter v. Cook, 1902, 114 Wis. $60 ; 89$ N. W. 823.

2 Gates จ. Winslow, 1 Mass. 65.

- Point Street Iron Works v. Simmons, 11 R. I. 496.

15-Brews. CoN. 
breach is not the only thing that makes covenants for title valuable to the purchaser. A conveyance containing a covenant of warranty will have the effect of transferring a title subsequently acquired by the grantor; though he may not have had the title when he made the conveyance -and sometimes the same effect is given to other covenants. 4 Whereas, when the conveyance merely purports to convey such an estate, title or interest as the grantor has, it cannot have this effect, ${ }^{5}$ and in some jurisdictions where, in a chain of title, there is a series of deeds with general covenants for title, the title is regarded as more sure than where the conveyances are "quit claim" deeds, or deeds with limited or special covenants only, the presence of which has been said to afford some ground for suspicion that there is some defect in the title. ${ }^{6}$

$\$ 189$. Covenants for title in mortgages.-It is not only in deeds intended to convey the legal title in fee that covenants for title may be important to the grantee, for they may be used in mortgages with practically the same effects; for example, a warranty of title contained in a mortgage will estop the mortgagor from questioning that, at the date of the mortgage he had title, and if he subsequently acquires the paramount title, it will enure to the benefit of the mortgagee and his legal representatives, ${ }^{\top}$

- Morris v. Jansen, 1894, 99 Mich. 436; 58 N. W. 365; Walton v. Follansbee, 1890, 131 Ill. 147; 23 N. E. 332 ; Broadwell v. Phillips, 30 Ohio St. 255.

6 Thompson v. Becker, 1902, 194 Ill. 119, 123; 62 N. E. 558; People v. Miller, 79 Mich. 93 ; 44 N. W. 172.

- Oliver v. Piatt, 3 How. 333, 410; Peters จ. Cartier, 1890, 80 Mich. 124,129 ; 45 N. W. 73 ; 20 Am. St. R. 508; Johnson v. Williams, 37 Kan. 179 ; 14 Pac. $537 ; 1$ Am. St. R. 243. Though, that there is nothing especially significant or suspicious in the use of quit claim deeds, see, Wilhelm v. Wilken, 1896, 149 N. Y. 447, 452; 44 N. E. 82.

7 Tefft v. Munson, 57 N. Y. 97 ; Thalls v. Smith, 1894, 139 Ind. 496; 39 N. E. 154; Caple v. Switzer, 1900, 122 Mich. 636 ; 81 N. W. 560; 6 Det. Leg. News 892. 
and the "covenant against incumbrances" in a mortgage binds the mortgagor. ${ }^{8}$

$\$ 190$. The usual covenants for title.-The usual covenants for title are six, namely: 1 , for seisin; 2, of good right to convey; 3 , against incumbrances; 4 , for quiet enjoyment; 5 , for further assurance; 6, of warranty; though some of these are more usual and important than others.

The covenants of seisin, against incumbrances and of warranty, are considered the most important, while the covenant for further assurance is, in the United States, the most unusual of the six.

A contract for the sale of land stipulating for a deed with "full covenants," would generally not be considered as complied with unless the deed contained all the six covenants, either expressed or implied. ${ }^{9}$ Where, however, the contract provides for a deed with the "usual covenants," it will not be construed with the same effect in all the states, for in some it is not usual to insert any other covenant than that of general warranty, ${ }^{10}$ while in others at least the three named above as the most important are customary.

So a contract stipulating for a "warranty deed" will bind the vendor in some states to execute a deed with a general warranty only, while in others such a contract requires a deed with full covenants. ${ }^{11}$

If the contract be silent as to the kinds of covenants for title which the grantor should give, the parties will generally be presumed to have contracted with reference to the known custom of the place where the land is situated,

Security Bank v. Holmes, 1896, 65 Minn. 531; 68 N. W. 113; 60 Am. St. R. 495; Bissell v. Hively, 1900, 123 Mich. 106; 81 N. W. 925; 6 Det. Leg. News 920; Butler v. Seward, 10 Allen 466; Lloyd v. Quimby, 5 Ohio St. 262.

9 Marphy $\nabla$. Lockwood, 21 Ill. 611, 618.

${ }^{10}$ Green $\nabla$. Irving, 54 Miss. 454.

11 Bethell v. Bethell, 92 Ind. 318. 
for, as the sufficiency of a deed is determined by the lex rei sitæ, the contract for a deed seems to be governed by the same principle, and the purchaser is entitled to such a deed as is usual by the custom of the place where the land is..$^{12}$

In making land contracts it is best to specify the covenants intended to be inserted in the conveyance, to save all question.

The covenants for title may be unlimited or general, that is, covenants against the acts of all persons claiming title; or they may be limited or special, that is, covenants against the acts of the covenanter or some other specially designated person or persons. Where they are thus limited they are not broken by the acts of any others than those designated.

\$191. The form of covenants for title.-No precise terms or particular forms of words are essential to create a covenant of any kind: all that is necessary is that it shall appear that the intent of the parties was to bind themselves. Therefore the words "covenant," "promise," etc., are not necessary ; and a clause which at first sight appears to be a "condition subsequent" may be construed to be a covenant. ${ }^{18}$

What is true in this respect of covenants generally is true of covenants for title. In Johnson $\nabla$. Hollensworth, ${ }^{14}$ Cooley, J., says : "There is no fixed and essential form for any covenant . . . Each covenant may constitute a separate sentence, but they may all be blended in a single sentence as well, and a single promise may embody the substance of several covenants, and thus constitute an undertaking to protect against existing claims or defects, and also to give assurance for the future."

The forms in use vary somewhat in the different states;

12 Gault v. Van Zile, 37 Mich. 22.

2s See supra, $\$ 176,177$.

1448 Mich. 140 ; 11 N. W. 843. 
and even in the same state there are generally several different printed blank forms used, expressing the covenants - for title in varied terms.

In the following form ${ }^{15}$ the words in parentheses, if used, will make the covenants special, and their omission will make the covenants general-A B being grantor, and X Y grantee :

The said A B doth hereby covenant for himself his heirs, executors, and administrators that (notwithstanding any act matter or thing by him done) he the said A B is now lawfully seised of the said premises and hath good right to convey the same that the same are free from all incumbrances (done, suffered, or committed by him). And that the said X Y his heirs and assigns shall and may at all times hereafter freely peaceably and quietly enjoy the same without molestation or eviction of him the said A B or any person or persons whomsoever (lawfully claiming or to claim the same by, from, or under him, them or any of them). And that he the said A B shall at all times hereafter at the request and expense of the said $X \mathrm{Y}$ his heirs and assigns make and execute such other assurances for the more effectual conveyance of the said premises as shall be by him reasonably required. And that he the said A B and his heirs all and singular the messuages and tenements \&c. hereby granted and mentioned or intended so to be with the appurtenances unto the said X Y his heirs and assigns against him the said $A B$ and his heirs and against all and every other person or persons lawfully claiming or to claim the same or any part thereof (by, from, or under him, them or any of them) shall and will by these presents warrant and forever defend.

The appropriate place for the covenants for title is at the end of the deed, just before the testimonium clause, though where they are expressed in a mortgage they often follow the habendum and immediately precede the condition.

"Sabotantially that given by Rawle Cov. Tit., p. 29. 
$\$ 192$. The designation of the parties to be boundThe covenantor himself.-The covenantor in this form covenants for "himself."

At this point in the ordinary printed blank form there is always a space left for the insertion of the words, "himself, his," "themselves, their," or "herself, her," as the circumstances of the case may require.

If, in the filling up of the blank form, the grantor is made to covenant "for his heirs," etc. (not for himself), the effect is, according to some decisions, that-unless the deed is reformed-no one is bound by the covenants during his lifetime, for the contract is plainly intended to make a charge on the covenantor's estate in the hands of his legal representative after his death. ${ }^{16}$ But in Hilmert v. Christian, ${ }^{17}$ the court, in a case where the covenant of seisin was expressed as "for his heirs, executors and administrators," say that they see no "force in the objection that the grantor did not covenant for himself but only for his heirs, etc. It is plain enough upon the face of the instrument that the defendant bound himself by the covenants." And in Smith v. Lloyd, ${ }^{18}$ it was considered in such a case, so far at least as the covenant of seisin and that against incumbrances are concerned, which "are broken, if ever broken at all, at the moment when made," that the grantor must be bound unless he could be held to be acting as the agent of his heirs, etc., which could not be pretended. ${ }^{19}$

${ }^{26}$ Traynor v. Palmer, 86 Ill. 477; Bowne v. Wolcott, 1891, 1 N. D. 497; $48 \mathrm{~N}$. W. 426.

${ }^{27} 29$ Wis. 104.

1829 Mich. 382, 385.

${ }^{19}$ See also, Judd $\nabla$. Randall, 36 Minn. $12 ; 29$ N. W. 589 . While it is true that all contracts should receive a fair, and perhaps even a liberal construction, it is also true that where contracts are clearly expressed in writing, in unambiguous terms, there is no room for "construction," and it is the duty of courts not to make contracts, but to enforce them according to the intent of the parties as shown by the language used. It therefore seems that, especially as to those covenants which relate to the future, the Illinois and North Dakota decisions are to be preferred. 
\$193. The covenantor's heirs, executors, etc.-The grantor usually covenants "for himself, his heirs, executors and administrators."

It was necessary at common law, in order to make an heir liable on the covenants of his ancestor: (1) that he be named in the covenant, and (2) that he should have assets by descent sufficient to meet the obligation.

At the present time the liability of the heir on his ancestor's covenants depends largely upon the statutes of the different states. These generally provide that the real estate of a deceased person shall be liable for the payment of his debts. Heirs, therefore, generally in the United States, take the land descended to them subject to all debts of their ancestors, but beyond assets received they are not personally liable, ${ }^{20}$ and naming them in the covenant will not make them liable to any greater extent. ${ }^{21}$

In most states it is probably not necessary for the covenantor to name his heirs, for they will be bound, to the extent to which they have received assets, whether or not they are named.22

Executors and administrators are bound as such, in general, without being named in the covenant.

"The executor doth more actually represent the person of the testator than the heir doth the person of the ancestor, for if a man bindeth himself his executors are bound though they be not named; but so it is not of the heir." ${ }^{23}$ The covenantor, by binding himself, binds his estate so far as it is represented by his executors and administra-

( Cutright v. Stanford, 81 Ill. 240, 244; Massie v. Hiatt, $82 \mathrm{Ky.} \mathrm{314,}$ 320; Bacon v. Thornton, 1897, 16 Utah 138; 51 Pac. 153.

21 See, Rinard v. West, 92 Ind. 359.

${ }^{n}$ Rohrbaugh v. Hamblin, 1896, $57 \mathrm{Kan} .393,396$; 46 Pac. 705. But in McDonald v. McElroy, 60 Cal. 484, 496, it was held that they were not liable for a breach of the covenant of warranty unlese the deceased covenantor covenanted that they should be bound.

Co Litt. 209a. 
tors, even though they be not named. ${ }^{24}$ If, however, the covenant is one which is to be personally performed by the covenantor, his executors and administrators are not bound. For example, if an author covenants to compose a work and dies before its completion his executors are not liable, for the covenant is personal in its nature, and by his death has become impossible of performance. ${ }^{25}$ Unless in such cases there has been a breach of the covenant before his death, his estate, represented by his executors, etc., is not bound. Covenants for title are not of this particularly personal character, and there is no distinction as to them between the liability of the executor upon such covenants broken after the testator's death and those broken before his death. ${ }^{26}$

\$194. Grantor's wife joining in her husband's deedHusband in wife's deed.-Where a wife joins in a conveyance of her husband's lands she is not ordinarily bound by the covenants in the deed even though she is named in them, as she generally is in practice. ${ }^{27}$ This is the general rule in the absence of a statute affecting her liability.

Such statutes, however, exist in several states, most of them being comparatively recent, and by virtue of them a wife, if named in the covenants in her husband's deed will be bound, though she need not have been named (in the covenants) to make the conveyance valid. ${ }^{28}$ And in some states she will be bound, when named in

24 McClure v. Gamble, $27 \mathrm{~Pa}$. St. 288.

${ }^{25}$ Marvel v. Phillips, 1894, 162 Mass. 401; 38 N. E. 1117.

${ }^{26}$ Hovey $\nabla$. Newton, 11 Pick. 421.

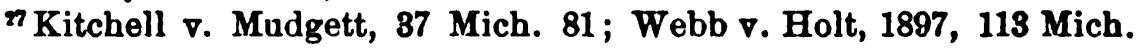
338, 341; 71 N. W. 637; 4 Detroit Leg. News 309; Sanford v. Kane, 1890, 133 Ill. 199; 24 N. E. 414; 23 Am. St. R. 602; Miller v. Miller, 1894, 140 Ind. 174, 178; 39 N. E. 547; Curry v. Mortgage Co., 1894, 107 Ala. 429; 18 So. 328 ; 54 Am. St. R. 105 ; Bennett v. Pierce, 1898, 45 W. Va. 654, 657; 31 S. E. 972 .

${ }^{28}$ Security Bank v. Holmes, 1897, 68 Minn. 538; 71 N. W. 699; Fisher v. Clark, 1898, 8 Kan. App. 483; 54 Pac. 511. 
the covenants, if it is also expressly stated that she is to be bound..$^{29}$

Where a husband joins in his wife's conveyance of her lands, simply to release his "dower," it has been held that he is not liable upon the covenants contained in the conveyance,,$^{80}$ but, as he is fully capable of contracting, he should, when he joins (in general terms and not merely to release his curtesy or "dower") in the covenants in his wife's deed, be liable to her immediate grantee, although he may not be so liable to a remote grantee, unless he has some title or interest to convey. ${ }^{81}$

$\$ 195$. Married woman's covenants in conveyance of her separate property. - Whether a married woman is bound by her covenants in a deed of her separate property is a matter so much controlled by statutes, which are constantly subject to change, that it is impracticable to attempt to state what the general rule of law is.

In the absence of a statute she is not liable in an action for damages at law for a breach of covenants for title. And statutes simply authorizing her to convey do not necessarily make her covenants binding on her.

But though she may not be liable in damages, she has been held in some cases estopped by her covenants from setting up a claim to an after-acquired title. ${ }^{32}$ Under the so called "married women's acts," of a general nature, which exist in many states, she is undoubtedly bound by her covenants or other contracts relating to her separate

20 Moore v. Graves, 1896, 97 Iowa 4, 8; 65 N. W. 1008. In Arthur v. Caverly, 1893, 98 Mich. 82 ; 56 N. W. 1102, a wife joining in the covenants was held liable jointly with her husband, because she had received the whole consideration, and must therefore be considered as having contracted with respect to her own separate estate. On a similar state of facts in Dean v. Shelly, 57 Pa. St. 426; 98 Am. D. 235, she was, however, held not liable.

* Center v. Elgin Banking Co., 1900, 185 Ill. 534; 57 N. E. 439.

is See Mygatt v. Coe, 1897, 152 N. Y. 457, 460, 466; 46 N. E. 949.

32 Hill v. West, 8 Ohio 222, 226; Beal v. Beal, 79 Ind. 280 . See, Knight $\nabla$. Thayer, 125 Mass. 25. 
property, and in some states statutes less general, and not relating to all contracts, provide that she shall be liable on her covenants for title. ${ }^{33}$

$\$ 196$. Designation of parties - The covenantee, his heirs, etc.-It is customary for the covenants for title to be expressed as made by the covenantor (the grantor), to and with the covenantee (the grantee), "his heirs and assigns," and in some forms as with "his heirs, executors, administrators and assigns," that is, the covenantor is made to bind himself (his heirs, etc.) not only to the grantee, but to the successors of the grantee. The question naturally occurs as to how far it is necessary to name these successors and what effect, if any, is had on their rights under the covenants if they are not named. There is a difference in the nature and purposes of the different covenants for title, and whether others than the original grantee, with whom the covenant was first made, may have the benefit of the covenant, will depend rather more upon its nature $e^{34}$ and certain other circumstances than upon its precise form, yet as certain words are almost invariably used as parts of the form, we should consider the reasons for their use, and to what extent they are necessary.

It appears to be unnecessary to name the covenantee's "executors and administrators" in the covenants for title. If the covenant is broken and the loss occurs during the covenantee's lifetime he should have his remedy against the covenantor, and if he has not had his remedy when the breach occurs, and dies without obtaining it, his executor or administrator may recover for the breach of covenant as for any debt due the deceased, ${ }^{35}$ and for this purpose the executor or administrator need not have been named in the covenant.

a See, e. g., Miller v. Miller, 1894, 140 Ind. 174, 178; 39 N. E. 547.

" See post, § 214.

* Wilson $\nabla$. Peelle, 78 Ind. 384. 
If the covenant is not broken during the life of the covenantee, and is such as passes with the land to his heir on his death, his executor or administrator has no concern with it and so can take no action on it, even if named.

\$197. The covenantee's "heirs and assigns."-The naming of the grantee's "heirs and assigns" in the covenants for title seems not necessary in order that they may take advantage of such of the covenants as are deemed capable of transmission or assignment-or, in other words, such of them as "run with the land."

But, as " heirs and assigns" are generally named, and as the naming of them (especially in some covenants other than those for title) has been considered important for some purposes, it is worth while to note why they have been and still are named.

The practice of naming the grantee's "heirs and assigns" arose from the necessity which existed under the early law (when deeds first came into use) of naming them, if they were to have the benefit of the ancient warranty.

This "warranty" was not' a covenant in the sense in which the term is now used; it was an incident of feudal tenure. The lord, having enfeoffed his tenant, must protect the title, or give the tenant other lands of equal value (not, generally, damages). And this warranty, thus arising from the ancient feudal relation of feoffor and feoffee, existed before deeds were used.

When deeds came to be used the warranty was either inserted expressly as a special clause (still distinct, however, from covenant), or was implied from the chief operative word of the charter of feoffment, "dedi," "I have given."

When thus implied, the warranty was implied for the benefit of the feoffee and his heirs only; that is, the implication did not include the feoffee's assigns. 
Express clauses of warranty became common in deeds as early as the thirteenth century, and when the transfer of land was so evidenced by a deed containing an express warranty, the feoffee's "heirs and assigns" could not avail themselves of the warranty (and call on the lord to defend the title or give other land), unless they were named in the deed of feoffment.

The warranty afterward disappeared and gave way to covenants for title. The old actions for land were replaced by actions for damages, but the principles on which the grantee's successors could have the benefit of these covenants for title were derived from those which had governed warranty. And in the covenants for title there continued to be used, often, the words "heirs" and "assigns," as the covenants were modeled after the warranty; and it seems to have been at first necessary to mention, at least, "assigns" in the covenants, as it had been in the clause of warranty.

Without, however, giving any clear reason for it, the "covenant is in many cases extended further than the warranty," 36 and it was held that the benefit of the covenants for title passed with the land to the grantee's heirs and assigns, though they were not named. ${ }^{37}$

$\S 198$. The covenants for seisin, and good right to convey.-Seisin signifies possession, and was at one time applied to the possession of chattels, as well as the possession of land..$^{38}$ Later it referred only to the possession of land, and signified the possession of land by one claiming

${ }^{36}$ Co. Litt., 384 b.

${ }^{37}$ See, Poll. \& Mait. Hist. Eng. L., I, p. 287 ; II, pp. 94, 224 ; Digby Hist. L. Real P., 5th ed., pp. 165, 171; Holmes The Common Law, pp. 374, 378, 401; Spencer's Case, 5 Coke 16; Rawle Cov. Tit., 5th ed., $\S \S 2,203,316$. The force and effect of the phrase "heirs and assigns" as an aid in determining when covenants "run with the land," will be considered after some of the characteristics of the different covenante for title have been taken up.

${ }^{88}$ Poll. \& Mait. Hist. Eng. L., II, pp. 29, 32. 
or having a freehold estate therein, either by himself or another on his behalf. Still later the word acquired a more extended meaning in England, and seems to have been regarded as synonymous with title. ${ }^{\circ 9}$ In this country a covenant that one is "lawfully seised" is given somewhat different effects in different states.

In several states a covenant that the grantor is "lawfully seised" is satisfied by an actual seisin, and he need not have an indefeasible estate in order that the covenant may be fulfilled. A seisin in fact under a claim of title, though tortious (that is, gained by disseisin), is sufficient to prevent the covenant from being broken. The grantor is regarded as covenanting that he is in possession of the land claiming such title as his deed purports to convey, and the covenant is not considered as broken if, as a fact, he has not the title he claims, though it is broken if another is in adverse possession of the land. ${ }^{*}$ But in other states the "covenant of seisin" is construed as a covenant for title; that is, a covenant by the grantor that he has the estate that he undertakes to convey, and in these states a covenant of "lawful seisin" in a conveyance of an estate in fee is satisfied only by the grantor's having an indefeasible estate in fee. ${ }^{11}$ Therefore, a grantor making this covenant is liable in an action on it if, by reason of a defect in an attempted conveyance to his grantor, the legal title is not conveyed, but is outstanding in some former owner, ${ }^{12}$ and such a grantor is liable on this covenant if, before he attempts to convey, part of the land has been sold for taxes."

These latter were cases where the grantor covenanted

- Rawle Cov. Tit., \$40.

${ }^{\circ}$ See Marston v. Hobbs, 2 Mass. 433, 439; 3 Am. Dec. 61; Wilson v. Widenham, 51 Maine 567; Watte v. Parker, 27 Ill. 228; Wetsell v. Richcreek, 53 Ohio 8t. 62, 70; 40 N. E. 1004.

" Mercantile Trust Co. v. South Park Co., 1893, 94 Ky. 271; 22 S. W. 314.

- Allen v. Allen, 1892, 48 Minn. 462; 51 N. W. 473.

usent v. Picken, 54 Iowa 535; 6 N. W. 750. 
in what appears to be the usual form; that is, "that he is lawfully seised of the said premises," but in the states where the doctrine of the former class of cases is followed this form of expression would not fully protect the grantee, and hence the covenant is often expressed more fully, as, "that he (grantor) is seised of an absolute perfect and indefeasible estate in fee simple." And in some states it is certainly prudent, if not necessary, for the grantee to require the latter form if he wishes to have the protection of the covenant.

The general object of inserting the covenant of seisin is to give the grantee relief where there has been a failure of title, but where there has been no assertion of title by any one else and no eviction of the grantee.

When the fuller form of the covenant is used ("is seised of an indefeasible estate, etc.") there can be no doubt as to what is intended, as this form is universally construed as meaning simply what is stated in it." ${ }^{4}$ The covenant for seisin is not generally considered as broken by the existence of liens or incumbrances on the land, nor by the fact that a third person may have a right of profit in it-for, while these may cause a breach of the covenant "against incumbrances," they do not affect the covenant for seisin. ${ }^{45}$

The covenant of good right to convey is sometimes said to amount to the same thing as the covenant for seisin, ${ }^{46}$ but while it is generally true that if one be seised in fee he has a good right to convey, it does not necessarily follow that because he may have the right to convey he is also seised in fee. ${ }^{47}$

\footnotetext{
"Frazer v. Supervisors, 74 Ill. 282; Adkins v. Tomlinson, 1894, 121 Mo. 487 ; 26 S. W. 573; Abbott v. Allen, 14 Johns. 248, 252.

${ }^{45}$ Douglass v. Thomas, 103 Ind. 187; 2 N. E. 562; Blondeau v. Sheridan, 81 Mo. 545; Fitzhugh v. Croghan, 2 J. J. Mar. 429; 19 Am. D. 139.

${ }^{4}$ Raymond $\nabla$. Raymond, 10 Cush. 140.

"Devoe v. Sunderland, 17 Ohio 52.
} 
One conveying under a power may have a right to convey without being seised in fee, and executors or administrators of ten covenant that they are executors or administrators and have a right to convey, under the order of a court or otherwise, without covenanting that they are seised.

$\$ 199$. The covenant against incumbrances-Form.The form of the covenant against incumbrances is usually "that the same are free from all incumbrances." But it was formerly expressed in connection with the covenant for quiet enjoyment, and as supplementary to that covenant; that is, that the vendee "shall peaceably and quietly enjoy the same, and that free from all incumbrances, etc." 48 . The latter form is occasionally seen still, and when used may properly have a different effect from the former, for the covenant for quiet enjoyment is clearly prospective in character, a covenant in futuro, and if the covenant against incumbrances is connected with it (as in the latter form given), it may properly be regarded as also prospective in character, or a covenant in futuro; that is, that the quiet enjoyment shall be free from incumbrances, whereas in the first form, that the premises are free from incumbrances, there is more reason for saying that it is a covenant in præsenti, merely.

The ordinary form of covenant against incumbrances may also be varied so as to make it a covenant looking to the future, without being thus supplemental to the covenant for quiet enjoyment. For example, in Post v. Campau, ${ }^{19}$ the covenant was substantially that the party of the first part covenants that " he has not heretofore done, committed, etc., any act, matter or thing whereby the premises granted are, or shall or may be charged, incumbered in title or estate or otherwise," and it was held that this covenant looked to the future, and promised inaemnity

4 Hall v. Dean, 13 Johnson 105.

99 42 Mich. 90, 99; 3 N. W. 272. 
for damages that might at any time in the future result from its breach, and that it was immaterial whether the ordinary covenant against incumbrances was or was not broken once for all at the delivery of the deed.

As there is some conflict upon the question as to whether the covenant against incumbrances is one of those covenants that run with the land, ${ }^{50}$ affording a remedy for a breach to subsequent holders, or whether it is simply a covenant in the present, broken, if at all, as soon as made, it will been seen that the form of the covenant may have some bearing upon this question in particular instances.

$\$ 200$. What are incumbrances ?-As this covenant is practically one of the most important, and as there is no technical definition of incumbrances that will fit all cases, it is well to note some of those things that may be incumbrances.

An incumbrance, within this covenant, is generally defined as : every right to, or interest in, the land which may subsist in third persons to the diminution of the value of the land, but consistent with the passing of the fee in it by deed..$^{11}$

The diminution of value which is one of the essentials of the above definition should not be understood as confined to cases where the thing granted is, by reason of some interest in a third person, of less pecuniary value, but must be considered as extending to cases where the grantee, by reason of such interest in some other person, does not acquire by the grant the complete dominion over the land granted, but is, or may be, deprived by the incumbrance of the use or possession of the thing granted, either wholly or partially.

It is of importance for those buying and selling land to

${ }^{\circ}$ Post, \$§ 215, 218.

22 Prescott v. Trueman, 4 Mass. 627; 3 Am. Dec. 246; Batley v. Foerderer, 1894, $162 \mathrm{~Pa}$. St. 460, 466; 29 Atl. 868; Huyck v. Andrews, 113 N. Y. 81 ; 20 N. E. 581 ; 10 Am. St. R. 452 ; 3 L. R. A. 789. 
consider what incumbrances exist on the property, and if it is understood that the purchaser is to take the land subject to incumbrances it should be so stated in the deed; or the incumbrance should be expressly excepted. The fact that the grantee knew of the incumbrance, it is generally held, will not relieve the grantor from liability for a breach of this covenant. ${ }^{52}$

\$201. Mortgages, building restrictions, etc.-Incumbrances.-Many interests which third persons have in the land are so clearly of such a nature as to diminish its value, and are so plainly incumbrances, that there is little occasion for difference of opinion about them. Of this sort are mortgages, money charges, or liens, private rights of way, a right to cut trees, or to mine; and it is generally considered that a right of dower, inchoate or consummate, is an incumbrance. ${ }^{63}$ And the same rule has been applied to the statutory substitute for dower. ${ }^{54}$

Building restrictions, which impair the free enjoyment of the land by the owner, are incumbrances, whether they are in the form of covenants or conditions. For example, where one bought land from another who owned on both sides of the street, and the grantor provided in the deed that only buildings of a certain class should be built on the lot sold (which was opposite the grantor's residence) with a "reversion to the grantor, his heirs," etc., in case of a breach of the condition, and this grantee then conveyed by a deed with covenants against incum-

${ }^{62}$ Demars v. Koehler, 1898, 62 N. J. L. 203; 41 Atl. 720; 72 Am. St. R. 642; Weisg v. Binnian, 178 Ill. 241; 52 N. E. 969; Edwards v. Clark, 1890, 83 Mich. 246; 47 N. W. 112.

McCord จ. Massie, 1895, 155 Ill. 123; 39 N. E. 592; Runnells v. Webber, 59 Maine 488. Though it was said by Judge Story that a possibility of dower is not an incumbrance, within the sense of this covenant, for that means a settled, fixed incumbrance. Powell v. MonBon, 8 Mason 355 ; Bostwick v. Williams, 36 Ill. 65.

" Crowley v. Lumber Co., 1896, 66 Minn. 400, 408; 69 N. W. 321.

16-Brews. CoN. 
brances and of general warranty, and without reference to these restrictions in the deed to him, and his grantee then conveyed to another by a similar deed; the last grantee could hold his grantor liable in an action for breach of the covenant against incumbrances, because the provision in the first deed mentioned, whether regarded as a condition or a restriction, created an incumbrance on the last grantee's land. ${ }^{.5}$

In Wetmore $v$. Bruce ${ }^{56}$ the defendant refused to complete a purchase of land, because the plaintiff had agreed to convey him a house and lot free of all incumbrances. Certain former owners of the land including the premises in question had, by mutual agreement, imposed restrictions upon the lands belonging to each of the owners of the block, for the purpose of securing uniformity in the position of the buildings, and imposing restrictions in perpetuity; it was held that these restrictions were incumbrances, and that the defendant was justified in declining to complete his purchase. In such cases, as has been said, "the "thestriction may not interfere with the use of the land for many purposes, but it is an absolute prohibition of its use for others for which the owner might otherwise lawfully use it."

$\$ 202$. Leasehold interests as incumbrances.-Some other interests in third persons are not, however, so clearly incumbrances. For example, a leasehold interest outstanding in a third person may be actually a benefit, rather than a detriment, to one buying the property leased. This would be the fact where the purchaser buys the land for the purpose of making an income producing investment, and the longer the term of the lease and the higher the rent, the greater the benefit would be to such a purchaser.

${ }^{65}$ Locke v. Hale, 1895, 165 Mass. 20; 42 N. E. 331.

681890,118 N. Y. 319 ; 23 N. E. 303.

${ }^{87}$ Foster v. Foster, 62 N. H. 46, 56. 
Nevertheless, on the ground that the purchaser does not obtain the full dominion and use of the property thus subject to a lease, the lease is held in many decisions to be an incumbrance within the covenant against incumbrances. The grantor, therefore, who conveys leased land by a deed containing this covenant may be held liable for its breach, unless he excepts the lease from its operation, and the grantee's knowledge of the lease will not affect his right to recover for the breach. ${ }^{58}$ Generally, in practice, when a conveyance is made of leased land the lease is not excepted from the covenant, because the tenancy is taken into account between the parties and the rent passes to the grantee, being allowed for or apportioned at the time the deed takes effect. And when the grantee recognizes the tenancy and receives rent from the tenant, though there may be technically a breach of the covenant, the amount of rent received by the grantee from the tenant should be deducted from the damages awarded the grantee for the breach of the covenant; but the mere fact that the conveyance of the leased premises gives the grantee a right to the rent will not relieve the grantor from his liability for a breach of the covenant against incumbrances. ${ }^{59}$ It has, however, been held in a few cases that, if the grantee of leased land knows of the tenancy, and there is a statute which has the effect of transferring possession without attornment by the tenant (i. e., without the tenant's express recognition of the grantee as his landlord), the existence of the lease cannot be a breach of the covenant. ${ }^{60}$

$\S 203$. Distinction between incumbrances visibly affecting the physical condition and others. $-A$ distinction

${ }^{58}$ Demars v. Koehler, 1898, 62 N. J. L. 203; 41 Atl. $720 ; 72$ Am. St. R. 642 ; Clark v. Fisher, 1894, 54 Kan. 403; 38 Pac. 493; Fritz v. Pusey, 31 Minn. 368; 18 N. W. 94; Porter v. Bradley, 7 R. I. 538; Crose v. Noble, $67 \mathrm{~Pa}$. St. 74, 77.

${ }^{69}$ Edwarde v. Clark, 1890, 83 Mich. 246 ; 47 N. W. 112.

$\infty$ See Kellum v. Berkshire L. Ins. Co., 101 Ind. 455. 
is sometimes made between the effect of such incumbrances as mortgages, or money charges, and such incumbrances as easements, especially where the latter are openly exercised and are visible to the grantee. And in this connection there is often quoted from Memmert $\nabla$. McKeen"1 this statement: "Incumbrances are of two kinds : first, such as affect the title; second, those which affect only the physical condition of the property. A mortgage or other lien is a fair illustration of the former; a public road, or a right of way, of the latter. Where incumbrances of the former class exist, it is of no importance that the grantee had notice of them. . . . Where, however, there is a servitude imposed upon the land which is visible to the eye, and which affects not the title but the physical condition of the property, a different rule prevails."

The argument is, that in cases where there is a physical burden of this sort, which is visible, there is a fair and reasonable presumption, in the absence of express agreement, that both parties act with reference to this plain, existing burden, and that the vendor on the one hand demands, and the vendee on the other hand pays, only the fair value of the land as visibly incumbered. Therefore, it is said, such burdens, by way of open and notorious easements, are not really incumbrances, within the meaning of this covenant, because the real subject-matter of the dealings between the grantor and grantee is the land, subject to the visible easements. ${ }^{62}$

This view appears to be approved by Rawle, in his work on covenants for title. ${ }^{68}$

112 Pa. St. 315, 320; 4 Atl. 542.

- Kutz v. McCune, 22 Wis. 628; 99 Am. D. 85; Judge Cooley's remark in Haldane v. Sweet, 55 Mich. 196, 200; 20 N. W. 902: "The alleys were open to observation at the time, and he must have known all about them, and bought with them in mind," is also quoted in this connection.

* See \$ 85. 
But it is criticised in Huyck v. Andrews, ${ }^{64}$ where the court (in speaking of the authorities that hold that where there is a visible burden imposed upon the land which affects the physical condition of the property, it is presumed that the grantee took the property in contemplation of such condition), says : "We do not yield assent to those authorities. They have no sanction in the cases decided in this state, and have no adequate foundation in principle or reason. They open to litigation upon parol evidence in every action for the breach of the covenant against incumbrances, caused by the existence of an easement, the question whether the grantee knew of its existence, and in every case the protection of written covenants can be absolutely taken away by disputed oral evidence. - . . If open, visible and notorious easements are to be excepted from the operation of the covenants, it should be the duty of the grantor to except them. . . The distinction which is attempted to be made between incumbrances which affect the title and those which affect merely the physical condition of the land conveyed, is quite illusory and unsatisfactory. Easements not only affect the physical condition of the land, but they affect and impair the title."

In many of the states, therefore, any right of way, public or private, is considered an incumbrance, without reference to the knowledge of the grantee as to its existence. This appears to be the law in the New England states, and in some others. ${ }^{65}$ Hence a right of way for a railroad is an incumbrance, though well known to both parties when the deed containing the covenant was delivered. ${ }^{67}$ While this is so, a public highway existing on the land

u 1889,113 N. Y. 81,$90 ; 20$ N. E. $581 ; 10$ Am. St. R. 432; 3 L. R. A. 789.

- Habbard v. Norton, 10 Conn. 423; Copeland v. McAdory, 1892, 100 Ala. 553 ; 13 So. 645.

7 Burk v. Hill, 48 Ind. 52; 17 Am. R. 731 ; Kellogg v. Malin, 50 Mo. 496; 11 Am. R. 426; Beach v. Miller, 51 Ill. 206; 2 Am. R. 290. 
has been regarded by some courts as not an incumbrance within this covenant, and this view has been taken in states which do not admit the same rule as applicable to open and visible private ways. The reason often given for this distinction in such states is that a public highway is not depreciative of the grantee's interest-is no burden -but rather is advantageous to him and enhances the value and utility of the land, and therefore cannot be an incumbrance. ${ }^{68}$

$\S 204$. If an incumbrance is to be excepted from the covenant, it should be so expressed. - The grantee's knowledge of an outstanding right or interest in a third person may, therefore, according to some authorities, be of importance in determining whether this right or interest is an incumbrance.

But when a third person's right or interest is really an incumbrance, the grantee's knowledge of it furnishes no defense to the grantor in an action against him on the covenant.

Therefore, for his own protection, the grantor should, when it is understood that the grantee is to take the land subject to the incumbrance, expressly except it from the covenant or otherwise make the conveyance subject to it. For, generally speaking, parol evidence will not be received in a court of law (when an action is brought on the covenant), to show that an incumbrance not excepted from the covenant was intended to be excepted. ${ }^{69}$ The

${ }^{68}$ Harrison v. Des Moines \&c. Ry. Co., 1894, 91 Iowa 114; 58 N. W. 1081 ; Huyck v. Andrews, 113 N. Y. 81 ; 20 N. E. 581 ; 10 Am. St. R. 452 ; 3 L. R. A. 789 . (See Ill. R. S., ch. 30 , § 10, which provides that no covenante of warranty shall be considered as broken by the existence of a highway upon the land conveyed, unless otherwise particularly specified in the deed. Under this statute a private right of way is not a highway, and the covenant is broken by its existence. Schmisseur v. Penn, 1892, 47 Ill. App. 278.)

${ }^{69}$ Edwards v. Clark, 1890, 83 Mich. 246; 47 N. W. 112; Flynn v. Bourneuf, 143 Mass. 277 ; 9 N. E. 650; 58 Am. R. 135; Long v. Moler, 5 Ohio St. 271; Van Wagner v. Van Nostrand, 19 Iowa 422. 
admission of such evidence would violate the rule that parol evidence is not admissible to vary the terms of a written contract; and so far as the grantee's mere knowledge of the incumbrance bears on the question, it may have been his chief reason for desiring the covenant that he knew of the incumbrance and wished to protect himself from it.

When, however, the grantee not only knows of the incumbrance but, where it is a money charge, agrees to discharge it himself, although this agreement does not appear in the conveyance, and although there is no exception made in expressing the covenant against incumbrances, parol evidence has been held admissible by some decisions to show this agreement, especially where in fixing the amount of the consideration allowance has been made for the incumbrance. In such cases the incumbrance, as between the parties to the deed containing the covenants, is regarded as paid, and the grantee cannot hold the grantor liable on the covenant. ${ }^{70}$ While such decisions are justified by the courts rendering them on the ground, chiefly, that the true consideration may be shown, the practical effect of the admission of parol evidence in such cases is to contradict and vary the writing of the grantor; and there would seem to be no hardship in requiring him, if it has been agreed that an incumbrance is to be excepted from the covenant, to insert the exception in his conveyance, or, if he does not do so, to suffer the consequences of his lack of caution. ${ }^{71}$

70 Wachendorf $\nabla$. Lancaster, 66 Iowa 458; $23 \mathrm{~N}$. W. 922; Johnston $\nabla$. Markle Paper Co., 1893, 153 Pa. 189, 195; 25 Atl. 560; Johnson v. Elmen, 1900, 94 Texas 168; 59 S. W. 253; 86 Am. St. R. 845; Hays v. Peck, 107 Ind. 389 ; 8 N. E. 274.

"In a few states statutes require that a grantor shall inform the grantee of incumbrances existing on the land conveyed: see, for example, R. L. Mass. 1902, ch. 134, §19; Minn. Stat. 1894, $\$ \$ 4194,4195$. And his neglect to inform the grantee of the incumbrance is a penal offense in Massachusetts. R. L. Mass. 1902, ch. 208, $\$ 66$. 
$\S 205$. The covenant for further assurance.-The covenant for further assurance, though less extensively used in this country than the other covenants, is one of importance to the purchaser. His remedy on the covenant is not restricted to an action for damages, but the performance of the covenant may be sought in equity to compel the vendor to execute the further assurance. The execution of the further assurance will operate to convey any interest which the grantor may have acquired since the execution of the original conveyance. "A vendor who has sold a bad title, will, under a covenant for further assurance, be compelled to convey any title which he may have acquired since the conveyance." 72

The case just cited indicates that this covenant may be advantageous to the vendor as well as to the vendee, for he may cure a bad title by a voluntary tender, under the covenant, of a further assurance, and thus bar the relief the vendee might otherwise have for a defective title.

The effect of this covenant will depend on the nature of the estate conveyed, and the other covenants in the deed; if these covenants are general and without limitation or restriction the vendee has a right, under the covenant for further assurance, to require the conveyance of a paramount title or the removal of an outstanding incumbrance, but if the covenants are limited he cannot require the conveyance to himself of a greater estate than he is entitled to by the deed, or the removal of incumbrances not created by the vendor. ${ }^{73}$ This covenant is not broken until the vendor refuses to execute such further conveyance as may be devised and tendered by the vendee, and such as he may reasonably require, or to do some act necessary to perfect the title which may be reasonably insisted on by the vendee. ${ }^{74}$ The covenant for further as-

7 Cochran v. Pascault, 54 Md. 1, 16.

7 Armstrong v. Darby, 26 Mo. 517.

7t Miller v. Parsons, 9 Johns. 336; Colby v. Osgood, 29 Barb. 349. 
surance is prospective, and passes with the land to subsequent grantees, that is, it "runs with the land." 75

\$206. The covenants for quiet enjoyment and of warranty.-In a lease, the covenant for quiet enjoyment, whether express or implied, is practically the one important covenant. It is a covenant that the lessee shall not be rightfully disturbed in his possession and enjoyment during the term.

In doeds purporting to convey an estate in fee, the covenant for quiet enjoyment is generally considered as practically identical with the covenant of warranty..$^{76}$

In some forms used these two covenants are combined, viz., "will forever warrant and defend the premises in the quiet and peaceable possession," etc.

In general the same circumstances are necessary to constitute a breach of either; they both run with the land, and the rules as to the measure of damages are the same in regard to both, and, though both are often used, they are for the most part so nearly the same that they are generally discussed in the cases together, or, rather, the covenant of warranty is discussed as including them both.

The modern covenant of warranty has taken the place of the ancient warranty. But the two are not the same. The ancient warranty was part of the system of feudal tenure. The remedy upon it was by a particular writ, by which the feoffor was called on to make good his warranty by giving his evicted feoffee other lands, and, only in rare cases, damages. The remedy on the covenant of

${ }^{75}$ Clarke v. Priest, 1897, 21 App. Div. (N. Y.) 174 ; Bennett v. Waller, 23 Ill. 97.

- Scott v. Kirkendall, 88 Ill. 465; 30 Am. Rep. 562; Fowler v. Poling, 2 Barb. 300. (Distinctions have sometimes been made between these covenants, as, for example, that a covenant of warranty is more "than one for quiet enjoyment. It is a covenant to defend not the possession merely, but the land and the estate in it." Williams $\nabla$. Wetherbee, 1 Aik. (Vt.) 233. And in technical pleading there may be a difference. Peck v. Houghtaling, 35 Mich. 127, 131.) 
warranty, on the other hand, is by a personal action sounding in damages. ${ }^{77}$

The word "warrant" (or rather its Latin equivalent) was indispensable to the ancient warranty when expressed in a deed of feoffment. ${ }^{78}$ But the same strictness does not now prevail. A covenant to "defend" the title against the claims of all, etc., has been held enough to make a covenant of warranty. ${ }^{79}$ It is not advisable, however, to depart from the usual form, for while in one case $e^{80}$ the following words in the habendum clause of a deed, "free and clear from me, my heirs, etc., and from all other persons," were considered to make a covenant for quiet enjoyment, in another" the words "to have and to hold the said premises unto said grantee, his heirs and assigns, forever, as a good and indefeasible estate in fee simple," were held not to constitute a covenant of warranty.

In some states the covenant of warranty is by statute, or as a result of decisions, made to include the other covenants for title..$^{82}$ But generally it is considered only as a covenant against eviction by one claiming under a better title. It is not a warranty that the title is good. In Tallmadge $\mathrm{v}$. Wallis, ${ }^{83}$ the court says: "It is a well known fact that land is frequently conveyed with general warranty, which is warranty against eviction only, when both parties to the sale perfectly understand that the title is doubtful or that there is some outstanding interest which may, perhaps, at a future period be the means of evicting the purchaser; and to protect the purchaser and

$\pi$ Other differences between the ancient warranty and the modern covenant are noted by Rawle, Cov. Tit., \$\$ 112-114.

${ }^{78}$ See the form in Appendix, Bl. Comm., Book II.

ro Kirkendall v. Mitchell, 3 McLean (U. S.) 144.

$\infty$ Midgett v. Brooks, 12 Ired. Law 145; 55 Am. Dec. 405.

" Wheeler v. Wayne County, 1890, 132 Ill. 599; 24 N. E. 625.

82 Van Wagner $\nabla$. Van Nostrand, 19 Iowa 422; Smith $\nabla$. Jones, 97 Ky. $670 ; 31$ 8. W. 475 ; Messer v. Oestreich, 52 Wis. 693; 10 N. W. 6.

$\approx 25$ Wend. 107, 115. 
enable him to recover against the vendor in case of eviction, the covenant of warranty is inserted in the deed."

Hence, as the covenant of warranty is intended as much for the protection of the vendee against known defects as against those which are unknown, the grantor cannot successfully defend an action on the covenant by showing that the vendee knew there was an adverse claim to the land.

$\S 207$. The covenant of warranty attaches only to the estate conveyed.-An important principle affecting in some cases the form of the conveyance is that the covenant of warranty attaches only to the estate purported to be granted, and does not enlarge that estate, even though the covenant be expressed in the most general terms. For example, if the conveyance is of a life estate, the covenant warrants nothing more. The object of the covenant is to defend the estate passed, not to enlarge or narrow it. ${ }^{84}$ And this is so when the covenants are implied from the statutory words with the same effect as if they had been expressed. ${ }^{85}$

Very often a conveyance purports to grant "the right, title and interest" of the grantor in certain premises, and such a granting clause is often followed by a covenant of warranty in general terms. On the principle just stated, the covenant applies to the estate granted, and not to the land described in the conveyance. ${ }^{96}$ Though the covenant of warranty be in such a case expressed in general and unrestricted terms, the deed practically amounts to no more than a quit-claim deed. ${ }^{87}$

* Adams v. Ross, 30 N. J. L. 505; 82 Am. Dec. 237.

* Lehndorf $\nabla$. Cope, 122 Ill. 319 ; 13 N. E. 505.

* Sweet v. Brown, 12 Met. 175; 45 Am. Dec. 243; Hull v. Hull, 1891, 35 W. Va. 155 ; 13 S. E. 49 ; 29 Am. St. Rep. 800 ; White v. Brocaw, 14 Ohio St. 339, 343.

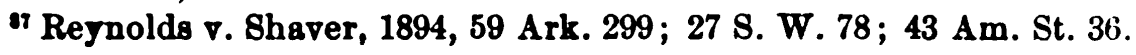


\$208. Effect of describing land as subject to an incumbrance.-The same principle is applied in cases where immediately following the description are words indicating that the land granted is subject to a mortgage described, or certain other incumbrances. The effect of such a statement is to qualify the covenants which follow, and they relate to the estate thus qualified; that is, the land conveyed, but subject to the incumbrance mentioned. For example, a deed, after the description of the property, contained the clause "subject to the following incumbrances," describing them, after which followed the covenant of freedom from incumbrances, containing no exceptions, and full covenants of warranty. It was held that the covenants applied only to the estate conveyed, which was not the land described, absolutely, but subject to incumbrances; and that the real covenant was that, otherwise than subject to the incumbrances named, the land was free from incumbrances, and that the grantor would warrant and defend the title. ${ }^{88}$

Generally, however, qualifying expressions apply to all the covenants only when they are part of the description of the property granted (as in these last instances), and therefore, a special exception or restriction annexed to one covenant alone will not have the effect of qualifying the other covenants.

As, for example, where there is a covenant against incumbrances, from which is excepted a certain mortgage, followed by a general warranty, without qualification or exception-the effect is not to except the mortgage from the covenant of warranty. ${ }^{89}$ There is, it is considered, no

is Drury v. Holden, $121 \mathrm{Ill} .130,137$; 13 N. E. 547. And see Crawford v. Nimmons, 1899, 180 Ill. 143, 149; 54 N. E. 200; Johnson $\nabla$. Nichole, 1898, 105 Iowa 122; 74 N. W. 750; Brown v. Bank, 148 Mass. 300 ; 19 N. E. 382 ; Freeman v. Foster, 55 Maine 508; Koch v. Hustis, 1902,113 Wis. 604 ; 89 N. W. 838.

Welbon v. Welbon, 1896, 109 Mich. 356; 67 N. W. 338; 3 Detroit Leg. News 112; Ayer v. Brick Co., 1892, 157 Mass. 57 ; 31 N. E. 717 ; 
inconsistency in the grantor's mentioning the incumbrance as an exception to the covenant against incumbrances, and at the same time warranting that there shall be no eviction by reason of the incumbrance..$^{90}$ So it is often stated as a general rule that a restricted covenant does not affect the operation of a covenant following it, when the latter covenant is not connected with the former nor of the same import.91

$\$ 209$. Eviction necessary to a breach of covenant of warranty.-The covenant of warranty is a covenant against eviction: it is not a covenant that the estate is indefeasible. In some states, as before stated, this covenant includes, or is in effect given the force of, a covenant of seisin as well as a covenant of warranty, but except in such states, a general warranty does not imply a covenant of seisin, and the covenant is therefore not broken by the existence of a better title in a third person. Nor does it include the covenant against incumbrances. Hence, the existence of a mortgage on the land when the grantee purchases is not a breach of the covenant of warranty, ${ }^{92}$ but an eviction of the grantee under a foreclosure and sale on the mortgage is a breach. ${ }^{93}$ While the existence of an incumbrance on the land conveyed will not always amount to a breach of the covenant of warranty, there may be outstanding rights in third persons which, though incumbrances, will also cause the covenant of warranty to be broken. Such are rights in third persons to an

Sumner v. Williame, 8 Mass. 162, 202, 214; 5 Am. Dec. 83; King v. Kilbride, 58 Conn. 109; 19 Atl. 519.

* Sand wich Mfg. Co. v. Zellmer, 48 Minn. 408; 51 N. W. 379.

$"$ But the rule as applied in the foregoing recent cases is not accepted universally, and as opposed to them is the case of Bricker v. Bricker, 11 Ohio St. 240, which holds that the exclusion of an incumbrance from the corenant against incumbrances, must be held to except it as well from the covenant of warranty, and all other covenants in the deed.

n Clark v. Lineberger, 44 Ind. 223.

- McLean v. Webster, 1891, 45 Kan. 644; 26 Pac. 10. 
easement in the land conveyed, interfering with the free use and possession of part of it and materially impairing its value : it is considered in such cases that there is an eviction. ${ }^{94}$

$\$ 210$. What is eviction-Constructive eviction.-Precisely what amounts to an eviction it is not always easy to say. But it appears that the rule stated in Kramer $v$. Carter" is, in general, accepted: "That any adverse assertion of a paramount right by which the covenantee is deprived of the enjoyment of the granted premises, or any part of them, or to which he yields, as by giving an equivalent for the paramount estate, will be such an eviction as will constitute a breach of the covenant of warranty."

The eviction which will constitute a breach of the covenant of warranty may be either an actual expulsion of the grantee by one who has a superior titlo-the expulsion being either a result of the peaceable entry by him who has the better title, or a result of judicial proceedings ; or it may be a constructive eviction, as where the premises when granted are in the adverse possession of one holding under a better title, or where the grantee buys in a better title to avoid expulsion. ${ }^{96}$ Where the grantee surrenders possession to one claiming to have a better title, in order to avoid an expulsion, or where he buys in such a title, the burden is on him, if he afterwards sues his grantor on the covenant, of showing that the title to which he yielded was superior, and that he would have been evicted had he not yielded. ${ }^{9 i}$ Neither

9 Harrington v. Bean, 1897, 89 Maine 470; 36 Atl. 986; Scriver v. Smith, 100 N. Y. 471, 477; 3 N. E. 675; 53 Am. R. 224; Copeland v. McAdory, 1892, 100 Ala. 553, 559; 13 So. 545; Engign v. Colt, 1802, 52 Atl. 829.

${ }^{95} 136$ Mass. 504, 509.

${ }^{96}$ Shattuck v. Lamb, 65 N. Y. 499; 22 Am. R. 656; Heyn v. Ohman, 1894, 42 Neb. $693 ; 60$ N. W. 952.

${ }^{97}$ McGrew v. Harmon, 1894, $164 \mathrm{~Pa} .115$; 30 Atl. 265, 268; Robinson v. Bierce, 1899, 102 Tenn. 428; 52 S. W. 992 ; 47 L. R. A. 275. 
the covenant of warranty nor that for quiet enjoyment is broken by a wrongful disturbance or eviction, by a third person other than the covenantor. ${ }^{98}$ But a tortious eviction or disturbance by the covenantor under a claim of title is a breach of the covenants. ${ }^{99}$

\$211. Covenants implied-Common law-Statutory deeds.-The short form statutory deeds have been referred to ${ }^{100}$ and the fact mentioned that certain covenants are in many of the states implied by the use of certain words. An ancient form of implied warranty is that arising from the use of the word "dedi." 1 There were important covenants implied at common law (as in exchange, partition, etc.), but few of these seem to be of practical importance at the present time. The covenants thus implied were called covenants in law. ${ }^{2}$ Among those thus implied which are of importance now are those implied in the case of a lease. These are, that the lessor has power to make the lease, and that the lessee shall have the quiet enjoyment of the premises.

Statutes exist in several of the states ${ }^{3}$ providing substantially " that no covenants shall be implied in a conveyance of real estate, whether the same contains express covenants or not," but these statutes have been consid-

* Andrus v. St. Louis Smelting Co., 130 U. S. 643, 647; Barry v. Guild, 126 Ill. 439, 446; 18 N. E. 759; Poley v. Lacert, 1899, 35 Ore. 166 ; 58 Pac. 37.

Akerly v. Vilas, 23 Wis. 207; 99 Am. Dec. 165; Sedgwick v. Hollenback, 7 Johns. 376.

100 See Ante, $\$ 30$.

1 See Ante, $\$ 197$.

2 "A covenant in law, properly speaking, is an agreement which the law infers or implies from the use of certain words having a known legal operation in the creation of an estate; so that after they have had their primary operation in creating the estate, the law gives them a secondary force, by implying an agreement on the part of the grantor to protect and preserve the estate so by those words already created." Tindal, C. J., in Williams v. Burrell, 1 C. B. 402, 429.

'E. g., New York, Michigan, Minnesota, Wisconsin and Oregon. 
ered as not applying to leases, because they are not conveyances of real estate within the meaning of the statute. Such statutes as those last mentioned must also be read in connection with other statutes which expressly allow covenants to be imported into conveyances by the use of certain words. The form given above, ${ }^{5}$ in which the chief words are "convey and warrant," is substantially like those in several other states, as there indicated.

There is another set of words, namely: "grant, bargain and sell," from the use of which in certain states covenants will be implied. These words, which are those used, for instance, in Alabama, Illinois, Pennsylvania and Missouri, were imported into this country by Pennsylvania from the English act. ${ }^{6}$

In some states both sets of words are to be found, as, for example, in Illinois, where the words " convey and warrant" may be used and will imply certain covenants, and the words "grant, bargain and sell" certain others."

And in some states, as in California and states influenced by its statutes, from the word "grant" alone certain covenants will be implied; such statutes appear to have been derived from the same Statute of Anne.

The point noticed before, ${ }^{8}$ that some of these words imply special covenants and some general, should not be overlooked, because, of course, the difference in effect is material. By the Statute of Anne (6 Anne, c. 35) the words "grant, bargain and sell" were to be considered as covenants that the bargainor, notwithstanding any act done by him, was at the time of the execution of such deed seized, etc., of an estate in fee simple, free from all incumbrances, and for quiet enjoyment thereof against

'See Boreel v. Lawton, 90 N. Y. 293; Mayor \&c. v. Mabie, 13 N. Y. 151 ; Shaft v. Carey, 1900, 107 Wis. 273, 277; 83 N. W. 288.

${ }^{5}$ See ante, $\$ 30$.

6 6 Anne, c. 35. See Douglase v. Lewis, 131 U. 8. 75, 82; Wheelcr จ. Wayne Co., 1890, 132 Ill. 599, 605; 24 N. E. 625.

'Illinois R S., ch. 30 , $\$ \$ 8,9$.

- See ante, § 30 . 
the bargainor and all claiming under him ; thus restricting the covenants to the acts of the grantor and those claiming under him, and the general features of this statute are preserved in the American statutes modeled upon it. ${ }^{9}$

And the word "grant" in several of the states, where used, has the effect of importing limited or special, rather than general, covenants into the deed..$^{10}$

\$212. Effect of such statutes.-When the statutory words are used, the effect is to import the covenants as effectively into the deed as if they were expressed at length."

But in order that this may be the effect, the statutory words must be used; as, for example, where the statute gives this effect to the words "grant, bargain and sell," the same effect will not be given to one of the words merely, "grant."12 The same general principles apply where statutory words may be used to imply covenants in mortgages. Such covenants work the same effect as if written at length in the mortgage. ${ }^{13}$

It appears that if the grantor, instead of using the statutory words alone, should insert an express covenant, this might have the effect of restricting the full force which would otherwise be given to the statutory words. For

- For example, see the statutes of Missouri, Illinois, Pennsylvania and Alabama; but note the changes in some cases in copying the act, as indicated in Douglass v. Lewis, 131 U. S. 75, 83-86.

${ }^{10}$ See, for example, Cal. Civ. Co., $\$ 1113$; Mon. Civ. Co., $\$ 1501$, 1519 ; N. Dak. Rev. Co. 1899, §3539; 8. Dak. Ann. Stat. 1901, §§ 4435, 4437.

"Van Wagner v. Van Nostrand, 19 Iowa 422; Meservey $\nabla$. Snell, 1895, 94 Iowa 223, 224; 62 N. W. 767; Foote v. Clark, 1890, 102 Mo. 394 ; 14 S. W. 981 ; Lehndorf v. Cope, 122 Ill. 317 ; 13 N. E. 505 ; Beasley $\nabla$. Phillips, 1899, 20 Ind. App. 185 ; 50 N. E. 488.

${ }^{12}$ Wheeler v. Wayne Co., 1890, 132 Ill. 599; 24 N. E. 625.

"Lagger v. Loan Asg'n, 1893, 146 Ill. 283, 300; 33 N. E. 946; Boyd v. Haseltine, 1892, 110 Mo. 203; 19 S. W. 822.

17-Brews. Con. 
example, "convey and warrant" in Washington imply a covenant against incumbrances: but where the grantor inserted an express covenant of warranty, it was held that the conveyance could not be considered as including the covenant against incumbrances. ${ }^{14}$ Where certain covenants only are implied and others are desired it seems better to express fully all the covenants desired than to attempt to combine the implied and expressed.

$\$ 213$. Whether lex situs or lex loci contractus controls.-As the words from which covenants are implied vary, therefore, in the different states, and as conveyances are not infrequently drawn in another state than that where the land lies, and are sometimes drawn according to the form of one state and sometimes according to the form of the other, it will be found not always easy to determine just what force shall be given to the lex situs.

These statutory conveyances have the dual capacity of transferring the title to the land, and importing covenants into the deed, some of which are clearly of a personal nature and not such as to run with the land-at least in all states. Hence, if an action is brought on the covenants imported into the deed by the operative words in them, and the action is brought in another state than that where the land conveyed is situated, the words may not be given the effect that they would have been given in the courts of the state where the land conveyed lies. For example, in Bethell v. Bethell, ${ }^{15}$ both parties to the action lived in Indiana. The defendant by deed conveyed to the plaintiff land in Missouri. The words of the deed were, "grant, bargain, sell and convey," but there were no express covenants. The defendant had never been in possession of the land and had no title to it, and it was held that if there was a covenant for seisin it was broken

14 Leddy v. Enos, 1893, 6 Wash. 247; 33 Pac. 508; 34 Pac. 665; Douglase v. Lewis, 131 U. S. 75.

${ }^{16} 54$ Ind. 428 ; s. c. 92 Ind. 319. 
as soon as made, and being therefore personal the action was governed by the lex loci contractus; but, moreover, as under that law (Indiana) no such covenant would be implied from the words used, the plaintiff had no cause of action.

While it is recognized by the court that the law of Missouri alone can be looked to in order to determine whether the deed in question was sufficient to pass title, "it does not, therefore, necessarily follow that the lex rei sitæ so far governs conveyances made elsewhere as to change their character as mere conveyances and invest them with the character of personal covenants not necessary to the transmission of the property."

In Jackson v. Green, ${ }^{16}$ the deed was one also executed in Indiana and conveyed land in Missouri, but was of the short form prescribed by the Indiana statute, the operative words being "convey and warrant." The breach alleged was that the grantors never had title to any part of the land, and could convey none, and that neither plaintiff nor defendant had ever been in possession. The court held that the laws of Indiana determined the question whether the deed contained the covenant of seisin, and that by force of the statute of Indiana "convey and warrant" did comprehend all the covenants as fully as if written at length: therefore the complaint in this case was good.

Where, however, the action is brought on covenants which run with the land, it seems that the law of the place where the land is situated should govern and not that of the place where the deed is executed. ${ }^{17}$

\$214. The running of covenants for title with the land.-Although in the covenants for title the covenantor

${ }^{16} 112$ Ind. $342 ; 14$ N. E. 89.

"Succession of Cassidy, 1888, 40 La. Ann. 827; 5 So. 292; Fisher v. Parry, 68 Ind. 465; Riley v. Burroughs, 1894, 41 Neb. 296; 59 N. W. 929. 
in form covenants generally with the grantee, his " heirs and assigns," the right of the successors of the original covenantee to recover against the original covenantor is not wholly fixed by the use of these words desiguating the grantee's successors. The use of the words "heirs and assigns" cannot cause the benefit of a covenant to pass with a transfer of the land to successive owners of it, if the covenant is of itself not of the nature to do so. ${ }^{18}$

So far as any of these covenants may be taken advantage of, not merely by the actual covenantee, but by subsequent holders of the interest comprised in the conveyance in which they are found, they form an exception to a leading principle of the law of contract, namely: that contracts can only be enforced by and against the original parties to them and their personal representatives.'

When the right of an heir or assign of a covenantee to recover against a remote grantor on a particular one of the usual covenants for title is being considered, it is generally said that the question is : does the particular covenant run with the land ${ }^{19}$

\$215. Conflicting views as to the running of some covenants.-Whether a grantee, heir or devisee of the original covenantee may have the benefit of any of the covenants for titlo-which covenants were not made with

${ }^{18}$ Mygatt v. Coe, 1895, 147 N. Y. 456, 467; 42 N. E. 17.

${ }^{19} \mathrm{It}$ seems likely that the application of this phrase, " running with the land," indiscriminately to both covenants for title and other covenants-those, for example, relating to the use of land-has helped to cause some confusion and to increase the difficulties connected with the subject of the "running of covenante" other than those for title "with the land." For the principles controlling, in this respect, other covenants than those for title are not identical with those controlling covenants for title. Covenants for title are more especially matters of contract, and when they pass to successors of the covenantee they do so because they " run with the estate," whereas rights arising from covenants concerning the use of the land become attached to the land-they "run with the land." See Norcross v. James, 140 Mass. 188; 2 N. E. 946; Holmes The Common Law, Ch. XI. 
him-will depend, then, on the nature of the covenant, or, rather, on the view taken by the particular court having the question before it as to its nature. And the fact that in this country different views have been taken as to the capacity of some of the covenants for title to run with the land has caused one of the conflicts in the American law of real property.

Covenants for title may be said to run with the land when, being either implied in a conveyance or expressed at length in it, they are of such a nature that they become incidents to the estate granted and pass with it through other transfers so that the owner for the time being is entitled to claim the benefit of them from the original covenantor; that is, generally, to recover damages for their breach.

Or, "A covenant may be said to run with the land when its purpose is to give future protection to the title which the deed containing the covenant undertook to convey, and it does not run with the land when its whole force is spent in giving assurance against something which immediately affects the title and causes present damage." 20

Succeeding as they did the ancient warranty ${ }^{21}$ it was probably never expected that the covenants for title would not each and all run with the land for the benefit of a subsequent owner of it. The terms in which they were originally expressed, and are still generally expressed, indicate that, taken as a whole, they make an engagement on the part of the covenanter to indemnify any one who suffers by the breach of them. That is, they together make a promise to save harmless against loss or damage which may happen in the future to the grantee, his heirs or assigns. The feoffee's heirs and assigns could take advantage of the old warranty under certain circum-

${ }^{20}$ Post v. Campau, 42 Mich. 90, 97; 3 N. W. 272.

"2upra, \$197. 
stances, and the substitution of covenants for title in the place of warranty seems to have been originally made, not for the purpose of lessening the security of titles, but rather for the purpose of getting rid of certain cumbersome features of the actions connected with warranty, and of affording surer and simpler remedies.

In theory all the covenants for title run with the land until they are broken. ${ }^{22}$

In England and in some of our states they all do, in fact, run with the land. But in many (it seems most) of the United States only the covenants for quiet enjoyment and warranty, and further assurance, practically do so, the others (for seisin and good right to convey, and of ten the covenant against incumbrances), being regarded as covenants in præsenti, that is, covenants for the present existence of certain facts, are considered broken as soon as made if these facts do not exist, and being thus broken instantaneously, they lose all capacity for running with the land. They have become at once choses in action, not assignable at common law, although the real substantial loss may not then occur, but may occur later when the land is owned by another than the original covenantee. ${ }^{28}$

\$216. The "English rule" as to the covenant of seisin running.-What is known as the English rule is substantially followed in many states. This rule was established in two cases, ${ }^{24}$ which are almost always cited in later discussions, and which may be briefly stated as follows :

2 Rawle Cov. Tit., p. 292.

${ }^{23}$ It has been suggested that the real question in such cases is, "At what time the right of substantial recovery accrues, whether at the moment of the delivery of the deed, or is it postponed under any circumstances until the actual damage is sustained?" Dickson v. Desire's Admr., 23 Mo. 151, 163 ; 66 Am. D. 661.

"s Kingdon $\nabla$. Nottle, 1 Maule \& Selwyn 355; Kingdon v. Nottle, 4 Maule \& Selwyn 53. 
In the first case, the plaintiff declared as executrix on a breach of covenant for seisin, entered into with her testator. But as it was shown that the only breach accruing in the lifetime of the testator was the mere non-existence of seisin in the covenantor, from which the estate had sustained no real injury before the testator's death, judgment was rendered for the defendant.

In the second case the plaintiff declared as devisee of the covenantee, and proved a substantial injury to the estate, caused by defect of title since the death of the covenantee. It was objected to this that there had been an instantaneous breach, and so a personal right of action in the covenantee, in his lifetime, which could not be assigned. But it was held that though according to the letter there was a breach in the testator's lifetime, yet according to the spirit the substantial breach "is in the time of the devisee. So long as the defendant has not good title there is a continuing breach as of a covenant to do a thing toties quoties [as often as] the exigencies of the case may require."

The view of the American courts holding substantially this doctrine is stated in Mecklem v. Blake, ${ }^{25}$ as follows :

"These courts hold that where the covenantor is in possession, claiming title, and delivers the possession to the covenantee, the covenant of seisin is not a mere present engagement, made for the sole benefit of a covenantee, but that it is a covenant of indemnity entered into in respect of the land conveyed, intended for the security of all subsequent grantees until the covenant is finally and completely broken; and they consequently hold that no such right of action accrues to the covenantee on the mere nominal breach, which always happens the moment the covenant is executed, as is sufficient to merge or arrest the covenant in the hands of the covenantee, or to deprive it of the capacity of running with the land for the

\$22 Wis. 495, 89 Amer. Dec. 68. 
benefit of the person holding under the deed when an eviction takes place, or other real injury is actually sustained."26

\$217. The "American Rule."-On the other hand, a different view was early taken by some of the courts of this country, and this view has been so generally followed in the United States as to warrant its being called, as it often is, the American rule on the subject. The rule is, that these covenants (for seisin and good right to convey, and, according to some courts, that against incumbrances) are strictly in præsenti; if they are broken, they are broken at once when the deed is executed and delivered, and cannot pass to the assigns of the covenantee. The chief reason for the establishment of this rule appears to have been the non-assignability of choses in action. But additional grounds are stated in some of the decisions which affirm the rule, among them, that if the covenantor is not seised, or has no right to convey, nothing passes as an estate in which the covenants may rest and be transmitted to later owners ; that by the terms of the covenants they are in presenti, and do not purport to be security against future injury; that the nonexistence of the facts covenanted for is a breach for which there can be but a single right of action, and that the first or immediate covenantee has that right, and hence an assign cannot have it.

This rule was established in New York in what is con-

${ }^{86}$ Other leading cases taking this view are Backus v. McCoy, 3 Ohio 211; 17 Am. Dec. 585 . See Betz v. Bryan, 39 Ohio St. 320; Schofield v. Homestead Co., 32 Iowa 317, 7 Am. Rep. 197. See also Boon v. McHenry, 55 Iowa 202 ; 7 N. W. 503 . But if covenantor have no title, and transfers to the grantee no possession, the covenant is broken when the deed is delivered. Zent v. Picken, 54 Iowa $535 ; 6 \mathrm{~N}$. W. 750. And as in such a case the right of action accrues then, the statute of limitations begins then to run. Mitchell v. Kepler, 75 Iowa 207; 39 N. W. 241 ; Martin $\nabla$. Baker, 5 Blackf. (Ind.) 232; Wright v. Nipple, 92 Ind. 310, 313; Wysong v. Nealis, 1895, 13 Ind. App. 165, 174 ; 41 N. E. 388. 
sidered the leading case of Greenby $v$. Wilcocks, ${ }^{27}$ and having been adopted also in early decisions in many other states, has since been followed, often without much discussion. ${ }^{23}$

\$218. The rule as to the covenant against incumbrances.-The so-called American doctrine has not been applied as universally to the covenant against incumbrances as it has been to the covenants for seisin and good right to convey. This is perhaps partly due to the fact that at first it was intimately connected with the covenant for quiet enjoyment, ${ }^{29}$ or otherwise made a covenant in futuro. This difference in form has been noticed in several cases other than those cited above..$^{30}$

And in addition to such cases, where the covenant has been expressly associated with the covenant for quiet enjoyment, have been others where the covenant against incumbrances, implied by statute from the use of the words " convey and warrant," is regarded as embracing a guaranty for future as well as present enjoyment."

But aside from the question. of form, the propriety of having the benefit of this covenant belong to the owner of the land for the time being has worked against the rule

272 Johns. 1,3 Am. Dec. 379, before the decisions in the English cases of Kingdon $\nabla$. Nottle, cited supra, $\$ 216$.

${ }^{28}$ Butler v. Barnes, 1891, 60 Conn. 170, 192; 21 Atl. 419; King v. Gilson, 32 Ill. 348; 83 Am. Dec. 269; Jones v. Warner, 81 Ill. 343; Smith v. Richards, 1891, 155 Mass. 79; 28 N. E. 1132; Matteson v. Vaughn, 38 Mich. 373; Sherwood v. Landon, 57 Mich. 219; 23 N. W. 778; Mygatt v..Coe, 1891, 124 N. Y. 212; 26 N. E. 611. (The doctrine that the covenant for seisin does not run with the land was based on reasons of a technical character, and the rule established does not appear to bring about as just results as would the rule which gives to the actual sufferer the benefit of the covenant. See 4 Kent's Comm. 472; Rawle Cov. T., §211).

See ante, § 199.

${ }^{30}$ Andrews v. Appel, 22 Hun 429; Nyce v. Obertz, 17 Ohio 71, 75; Carter v. Denman, 23 N. J. L. 260, 273.

« Worley $\nabla$. Hineman, 1892, 6 Ind. App. 240, 245; 33 N. E. 260; Dehority $\nabla$. Wright, 101 Ind. 382. 
which restricted the usefulness of the covenant for seisin; and especially in later cases, which have recognized the injustice of now allowing the old reason as to nonassignability of choses in action to control, this covenant is allowed to be taken advantage of by remote grantees; for example, in the recent case of Geiszler v. De Graaf, ${ }^{32}$ the court held that the reason for holding that this covenant does not run, no longer exists, and that the covenant "attaches to and runs with the land and passes to a remote grantee through the line of conveyances, whether there is a nominal breach or not when the deed is delivered." And this has been the tendency even in some states where the covenant for seisin is regarded as not running with the land. ${ }^{33}$

Nevertheless, it appears that in the greater number of states this covenant is classed as one of those that do not run with the land. ${ }^{34}$

$\S 219$. Covenants for quiet enjoyment and warranty run with the land.-The covenants for "quiet enjoyment" and "warranty" are, with substantial unanimity, held to be covenants in futuro, running with the land, for the protection of the owner in whose time the breach happens. They are not broken until there is an eviction, and hence they may be enforced by a later owner of the land claim-

${ }^{32} 1901,166$ N. Y. 339 ; 59 N. E. 993 ; 82 Am. St. 659.

s3 Richard v. Bent, 59 Ill. 38; 14 Am. R. 1; Security Bank v. Holmes, 1896, 65 Minn. $531 ; 68$ N. W. 113; 60 Am. St. R. 495. In Post v. Campau, 42 Mich. 90, 95; 3 N. W.272, Judge Cooley suggested that the covenant could have reasonable effect only when the fact that incumbrances are of different kinds is recognized: some are permanent in their nature, and it is reasonable to hold that the covenant against them is broken at once and finally, but as to those that are money charges, which cause no loss at once to the covenantee, but may later, a different rule should apply.

4 Guerin v. Smith, 62 Mich. 369; 28 N. W. 906; Ladd v. Noyes, 137 Mass. 151; McPike v. Heaton, 1900, 131 Cal. 109; 63 Pac. 179; 82 Am. St. 335; Sears v. Broady, 1902 (Neb.); 92 N. W. 214. See Notes, 47 Am. Dec. $569 ; 82$ Am. St. 664. 
ing under the covenantee, whether this owner is grantee, devisee or heir. ${ }^{35}$ But when once broken these covenants cease to run with the land. There is then a right of action that should be enforced by the person entitled to take advantage of the covenant at the time of its breach, or, if he be dead, by his personal representative. The subsequent grantee is not entitled to damages for the breach of the covenant occurring before his time. ${ }^{36}$

$\$ 220$. Subsequent grantees by quit claim deeds have the benefit of such covenants as run with the land.-The benefits of such covenants for title as run with the land will pass to a subsequent grantee by any conveyance that will transfer the title to the land to him; the immediate deed through which he claims need not be a deed with covenants; a quit-claim deed will have the same effect. ${ }^{37}$

§221. "Personal" and "real" as used with reference to covenants for title.-In decisions and discussions regarding covenants for title, the words "real" and "personal" are used in such a way as to cause some confusion unless certain distinctions are borne in mind. All the covenants for title are sometimes called personal, ${ }^{38}$ and, again, some or all of them are referred to as "real." 39 The explanation is that where they are spoken of in distinction from the ancient warranty which was "real," in

${ }^{25}$ Suydam v. Jones, 10 Wend. 180; 25 Am. D. 552; Baker v. Bradt, 1897, 168 Mass. 58; 46 N. E. 409; Tillotson v. Prichard, 60 Vt. 94 ; 14 Atl. $302 ; 6$ A m. St. R. 95.

* Ladd v. Noyes, 137 Mass. 151 ; Provident L. \& T. Co. v. Fiss, 1892, 147 Pa. St. 232 ; 23 Atl. 560; Clement v. Bank, 61 Vt. 298.

ת Jenks v. Quinn, 1893, 137 N. Y. 223; 33 N. E. 376; Thomas v. Bland, 1890, 91 Ky. 1; 14 S. W. 955; Johnson v. Johnson, 1902, 170 Mo. 34; 70 S. W. 241; Troxell v. Stevens, 1899, 57 Neb. 329, 337 ; 77 N. W. 781; Brady v. Spurck, 27 Ill. 478; Hunt v. Middlesworth, 44 Mich. $448 ; 7$ N. W. 57.

* For example, in 4 Kent Comm. 470, 471.

- Martin v. Baker, 5 Blackf. (Ind.) 232 ; Kingdon v. Nottle, 1 Maule \& Selwyn 355 . 
the sense that it bound the warrantor to yield (generally) lands rather than damages as compensation, they may be called personal, because of the remedy they afford; that is, an action for damages. ${ }^{40}$

On the other hand, a covenant which has for its object something annexed to, or connected with, or inherent in, real property is often defined as a "real covenant"; it generally runs with the land, and is the only kind that can do so. Hence when those covenants for title that are considered to run with the land are spoken of in contrast with any covenants that do not so run, they are often called "real," as distinguished from the others which are (as not running with the land) called "personal." 41

\section{Covenants, Other than Covenants for Title.}

$\$ 222$. General features of these covenants.-In conveyances there are often covenants other than covenants for title, and, as they may have for their subject-matter almost anything relating to land, they are of almost infinite variety. Among the more usual kinds of covenants not covenants for title are those providing for the erection and maintenance of fences, dams, etc.; those concerning the kind and cost of buildings, or the position of buildings; those relating to the uses of land, for example, that it shall not be used for business purposes, or for some particular business; those regarding the construction and use of party walls; those relating to ways or other easements.

40 "There is a diversity between a warranty which is a covenant real, which bindeth the party to yield lands in recompense, and a covenant annexed to the land which is to yield damages." Co. Litt., 384b.

${ }^{11}$ In the foregoing sketch of the covenants for title only the chief matters concerning them which relate directly to the form and effect of conveyances have been touched upon: many important topics connected with them, e. g., matters of pleading and proof, the measure of damages, etc., must necessarily be omitted. 
One of the features of these covenants, in which they differ from covenants for title, is that while the grantee of land has no occasion for making a covenant for title, either the grantor or the grantee may make one of these other covenants, and may in many cases bind himself and those who own his land after him to do something for the benefit of the land of the other party, or to refrain from doing something regarded as depreciative of that land. Thus the grantee may become the covenantor, and the grantor the covenantee.

Covenants relating to land may be made by landowners irrespective of a conveyance from one to the other, and some kinds of covenants (or agreements not under seal, and so not strictly covenants), are often so made, for example, agreements concerning party walls, but, for the most part, questions concerning covenants arise in connection with conveyances of some interest in land-either leases, conveyances of the fee or mortgages.

Some only of the more important features connected with covenants in conveyances of estates in fee can be here considered.

Questions in controversies between the original parties to such covenants usually present no special difficulties; but when the land of one or both of the parties has been transferred it is not in all cases easy to determine against whom and in favor of whom, as subsequent owners of the land, these covenants may be enforced, and, if enforceable, in what manner they may be enforced.

$\S 223$. Form-No technical words essential. - Cases often arise where there will be a difference of opinion as to whether a clause is or is not a covenant, and what is claimed by one interested party to be a "condition" may be held to be a covenant, for as no express technical words are essential to create a covenant, words appropriate to a condition may make a covenant when such is the 
intent. ${ }^{1}$ And as technical words of covenant or agreement are not essential to make a covenant, so words expressive of a covenant have sometimes been held to be a grant of an easement rather than a covenant.

For example, the plaintiff sues in tort for an interference by the defendant with an easement claimed by plaintiff by virtue of the following clause in a conveyance to plaintiff, inserted just after the description: "And said grantors agree that no building shall be erected on said lot next east of said granted premises nearer to the west line of said lot than four feet, being the east line of the premises hereby conveyed." The plaintiff's grantors in this deed owned the adjoining lot referred to in this clause, and after making the conveyance to the plaintiff containing the clause, conveyed this adjoining lot to the present defendant ; it was held that the word "agree" in the clause must be read as meaning "grant," and that therefore there was attached an easement in fee to the plaintiff's land-it was not merely a personal undertaking of the grantors-and that the burden of the easement granted by the grantors in their own land remained on the land when it passed to the defendant. ${ }^{2}$

$\S 224$. Form-Effect of "heirs and assigns" or similar words in covenant.-As the words "heirs and assigns" were necessary at one time to indicate that certain benefits were to extend beyond the first beneficiary to his successors in title, ${ }^{8}$ so now, in cases where a covenant is of such a character that it may or may not "run with the land," the presence or absence of the words "heirs and assigns" may have an important influence, among other circumstances, on the determination of the question

${ }^{1}$ Electric City Land \&c. Co. v. West Ridge Coal Co., 1898, $187 \mathrm{~Pa}$. 500,511 ; 41 Atl. 458. And see ante, $\S \S 176,177,182,183$.

${ }^{2}$ Hogan v. Barry, 143 Mass. 538; 10 N. E. 253. See also Wetmore v. Bruce, 1890, 118 N. Y. 319; 23 N. E. 303; Shannon v. Timm, 22 Colo. 167; 43 Pac. 1021; Brew v. Van Deman, 6 Heisk. (53 Tenn.) 433, 439.

'See ante, $\$ 197$. 
as to whether or not it does "run." For example, where the covenant related to the maintenance of a dam the court says: "We think that these covenants run with the land because they were in terms between the parties and their respective heirs and assigns, were connected with the subject of the grant, etc." 4 And again, where the covenant concerned the building of a fence, it is said: "The failure to include the word 'assigns' in the deed is not controlling, if it can reasonably be inferred from the language of the instrument that the parties intended that the covenant should run with the land; but the absence of such a word, or other words of like import, may be considered in connection with the context of the deed in arriving at the intent of the parties in this respect." 5

But this effect is given to such words only when the covenant is such that it may run with the land, and it is doubtful whether in the particular case it does so run.

This principle is stated in Mygatt v. Coe, ${ }^{6}$ as follows: "We do not think the fact that the covenant in question ran to the grantee, her 'heirs and assigns' is material. Whatever confusion may exist in the cases with reference to the use of these words * * it has never been held that a covenant which, in its nature or otherwise, is personal is made to run with the land by the mere employment of these words."

And as to the effect to be given to "words of like import" " substantially the same thing may be said; that is,

' Nye v. Hoyle, 1890, 120 N. Y. 195, 203; 24 N. E. 1; see Hart v. Lyon, 90 N. Y. 663.

Brown v. So. Pac. R. R. Co., 1899, 36 Ore. 128, 135 ; 47 L. R. A. 409 ; 58 Pac. 1104. And so in the recent case of Los Angeles \&c. Land Co. v. So. Pac. R. Co., 1902, 136 Cal. 36, 42-44; 68 Pac. 308, in deciding that a covenant restricting the use of land was not a covenant running with the land, the court attaches importance to the absence of "assigns" or similar words.

- 1895,147 N. Y. 456, 467 ; 42 N. E. 17.

' 36 Ore. 135. 
if a covenant is of such a character that it cannot run with the land it cannot be made to so run by any statement or agreement of the parties that it shall do so-as, for example, that it "shall run with the land." ${ }^{8}$ So, where a quarry company granted a railway company a right of way over its lands and covenanted that all products of the quarry should be transported over this railway, and by an express clause in the indenture, executed and acknowledged by both parties, it was agreed that "All and singular the grants and provisions herein set forth shall be binding and obligatory upon the respective parties hereto, their respective successors, lessees and assigns" it was nevertheless held that the successors in title to the quarry were not bound by this "traffic agreement," which was a personal covenant between the original parties. ${ }^{9}$

$\$ 225$. The form of the deed in which covenants areEffect of acceptance by grantee of deed poll containing covenants.-Technically, to bind the grantee the deed should be in the form of an indenture, signed and sealed by him as well as by the grantor. But as between the original parties the grantee himself may be bound by accepting a deed poll containing an agreement, for instance, to fence. And he will be considered so bound even though in the same jurisdiction it may be held that his successors in title to the land would not be bound. ${ }^{10}$ In many decisions nothing is said as to whether the deed is an indenture or a deed poll, it being held, in general terms, that not only the original grantee but his successor in title is bound by covenants-for example, in Kelly $v$. Nypano R. R. Co., ${ }^{11}$ the defendant railroad company was

B Glenn v. Canby, 24 Md. 127; Wilmurt v. McGrane, 1897, 16 App. Div. (N. Y.) 412, 417; Masury v. Southworth, 9 Ohio St. 340, 347, 348.

${ }^{9}$ Kettle River Ry. Co. $\nabla$. Eastern Ry. Co., 41 Minn. 461 ; 43 N. W. 469 ; 6 L. R. A. 111.

${ }^{20}$ Parish v. Whitney, 3 Gray 516; Kennedy v. Owen, 136 Mass. 199.

${ }^{11} 1901,200$ Pa. St. 229; 49 Atl. 779; 86 Am. St. R. 715. 
held liable on a covenant to "fence and keep such road fenced," which was contained in a conveyance of a right of way by the plaintiff to another railroad company whose property the present defendant had acquired by foreclosure proceedings; the original conveyance may have been an indenture (which form is largely used in Pennsylvania) or a deed poll, but this point is not mentioned or discussed as it is in the Massachusetts cases.

But in many cases it has been expressly held that the assigns of the grantee in a deed poll not signed by him, may be bound by the stipulations in the deed, for by the grantee's acceptance of the deed the obligation becomes binding upon him as owner of the land, and may pass to his successors in title. For example, in a deed to a railroad company of a right of way, a provision like that in the last case, though merely in a deed poll accepted by the grantee company, but not signed by it, has been held binding upon the successor of a railroad company, which obtains title through foreclosure of a mortgage of the railroad property. "The acceptance of the deed imposed a burden upon the land which was not only binding upon the original grantee, but runs with the title and is equally binding upon all who claim through the original grantee." 12

And in Hickey v. L. S. \&c. R. Co. ${ }^{18}$ the deed contained what was called a condition and agreement "that the grantee, his heirs and assigns, shall make and maintain fences * * which condition and obligation shall be perpetually binding on the owners of the land." The granteo afterward sold portions of the land. The fences not being maintained, the grantor constructed them, and in this action sought to recover from the original grantee the expense

${ }^{22}$ Lake Erie, etc., R. Co., v. Priest, 131 Ind. 413; 31 N. E. 77; Post v. Railroad Co., 50 Hun 301.

1894, 51 Ohio St. 40 ; 36 N. E. 672 ; 23 L. R. A. 396 ; 46 Am. St. R. 545.

18-Brews. Con. 
of such construction. The court held that the action was improperly brought against the first grantee, because the covenant was so connected with the estate as to run with the land and make the original grantee's assigns liable. "Nor," the court says : "is this principle to be restricted in its application to leases or deeds inter partes executed by both lessor and lessee, or grantor and grantee. Where a grantee accepts a deed and goes into possession of the premises under it he is bound as effectually as if he had signed and sealed the instrument. Although not executing the instrument, he should be deemed to have entered into an express undertaking to do what the deed says he is to do, and such undertaking or obligation imposed upon the grantee, if not technically a covenant running with the land, is nevertheless an agreement of the grantee, evidenced by his acceptance of the deed, which might bind him and his personal representatives, and, by express words, his heirs and assigns." And as in this case the obligation was to be binding on the "owners of the land," this provision is held to bind the original grantee to maintain the fences only during the time he is the owner of the land. ${ }^{14}$

$\S 226$. Distinction sometimes made between benefits and burdens.-The general rule is that the benefits of such covenants as concern or relate to the land will pass to subsequent owners who derive title from the covenantee. ${ }^{15}$ But the burdens imposed by a covenant will not as generally be held to pass with the land to the transferee of the covenantor, for some courts, following what seems to be the English doctrine, making a distinction between benefits and burdens, ${ }^{16}$ appear to be of opin-

14 The remark as to the liability in this case of the original grantee's assigns is "dictum."

${ }^{15}$ National Bank v. Segar, 39 N. J. L. 173, 184 et seq.; Graves $\nabla$. Deterling, 1890,120 N. Y. 447 ; 24 N. E. 655.

${ }^{16}$ Keppel v. Bailey, 2 Myl. \& K. 517; Austerberry v. Oldham, 29 Ch. D. 750. 
ion that the latter will not be enforceable against the subsequent owner of the covenantor's land. ${ }^{17}$ There are, however, many decisions in this country holding that the burdens imposed by covenants (as well as benefits given) will pass with the land. ${ }^{18}$

\$227. Restrictive covenants and conditions, as to use of land, buildings, etc.-In order to secure and maintain uniformity and harmony in the character of buildings erected in a particular locality, and to maintain the suitableness of the neighborhood for buildings and uses of a special character, or in order sometimes to secure to a landowner some special advantage in trade, agreements or conditions of one form or another are often inserted in conveyances. These provisions are generally restrictive in character. They appear sometimes in the form of conditions providing for a forfeiture on their breach, ${ }^{19}$ and sometimes they appear as reservations of easements. They may be created without an express mention in the deed of conveyance where a reference is made in it to a plat on which is designated, for example, a "building line" beyond which it is intended no building shall extend.0 And even an understanding not evidenced by any writing, but arising from the exhibition of a plan showing restrictions upon building, has been held to create easements as to the building line. ${ }^{21}$ Such restrictions appear, however, to be more usually drawn in the form of covenants, and are generally declared to be intended to run with the land. The effect of such provisions in creating

${ }^{17}$ See Tardy v. Creasy, 81 Va. 553; 59 Am. R. 676; Costigan v. Penn. R. R. Co., 1892, 54 N. J. L. 233, 242; 23 Atl. 810.

${ }^{18}$ See cases cited above in last section; Gilmer v. Mobile \&c. Ry. Co., 79 Ala. 569; Hottell v. Farmers' Association, 1898, 25 Colo. 67; 53 Pac. 327; 71 Am. St. R. 109 ; Bean v. Stoneman, 1894, 104 Cal. 49, 37 Pac. 777; 38 Pac. 39; Fitch v. Johnson, 104 Ill. 111.

${ }^{19}$ See instances above, $\$ 182$.

so Simpson v. Mikkelsen, 1902, 196 Ill. $575 ; 63$ N. E. 1036.

21 Maxwell v. East River Bank, 3 Bosw. (N. Y.) 124; Tallmadge v. East River Bank, 26 N. Y. 105. 
incumbrances within the meaning of the covenant against incumbrances has been noticed. ${ }^{22}$

The remedy usually applied for the practical enforcement of these restrictive provisions is an injunction restraining their violation. And if not unreasonable or contrary to public policy (as, for instance, in unduly restraining trade), ${ }^{23}$ they will be enforced not only between the original parties, but of ten between their successors.

$\$ 228$. Building restrictions in pursuance of a "general plan."-One of the most frequent uses of restrictive clauses in conveyances is where the owner of a tract of land divides it into lots, and conveys the lots to separate purchasers, subject to conditions or stipulations of a character to operate as inducements to the purchaser. In such cases where there is a general plan regarding building or use, etc., adopted by the owner, in consideration of which general scheme each purchaser has bought-the restrictive covenants being inserted in each deed, being intended for all the lands-each purchaser has the benefit of the restrictions, and-as owner of one of the lots-is subject to them.

He has attached to his own lot a right held to be, in many cases, in the nature of an easement in the lots of the other purchasers; and each purchaser may enforce this right against any other purchaser in a court of equity.

Therefore, a purchaser of lots may be held at the suit of the grantee of another lot, to conform to a restriction as to a building line. ${ }^{24}$ And it is not necessary in order to hold a purchaser to this line that the restriction should be mentioned in the immediate conveyance to him, if by plat and recorded deeds in his chain of title the line is designated. ${ }^{25}$ So restrictive provisions as to the use of

n See supra, §201.

${ }^{23}$ See post, $\S 230$.

"Hamlen v. Werner, 144 Mass. 396; 11 N. E. 684.

\$ Ewertsen v. Gerstenberg, 1900, 186 Ill. 344 ; 57 N. E. 1051 ; 51 L. R. A. 310; Towneend's A ppeal, 1896, 68 Conn. 358; 36 Atl. 815. 
the premises for residence purposes only, etc., may similarly be enforced by one grantee against another. ${ }^{26}$ Great weight is attached in many courts to the fact that there is a general plan; and the right of purchasers to enforce such restrictions against other purchasers is sometimes said to be dependent on the fact of a general scheme of improvement adopted by the owner of a larger tract. ${ }^{27}$

The fact that there is a general plan with regard to which each purchaser has bought, is considered as indicating that the restrictions were not merely personal to the grantor and for his benefit alone, but for the benefit of all the lands and each purchaser; and as each buys with knowledge of the general plan, he is regarded as assenting to the plan, and may be made to comply with it by an owner of any other lot without regard to which of the lots was first sold. ${ }^{28}$ And as such restrictions are not for the benefit of the original grantor alone, while he may waive his own right to enforce them, he cannot release or waive the rights of his grantees to do so. ${ }^{29}$ But restrictive clauses are often thus enforced without being part of a general plan, if it appears in some other way that they are not merely personal to the grantor. They are enforced because it would be inequitable as against the owners of adjoining estates not to enforce them, and be-

- cause it would be unjust to permit one taking an estate, with notice of a valid agreement respecting its use, to have his estate freed from its obligations. ${ }^{80}$

* Hills v. Metzenroth, 1899, 173 Mass. 423; 53 N. E. 890; Hopkins v. Smith, 1894, 162 Mass. 444; 38 N. E. 1122. See Frink v. Hughes, 1903 (Mich.) ; 94 N. W. 601; 10 Detroit Leg. News 106.

7 Summers v. Beeler, 1899, 90 Md. 474 ; 45 Atl. 19 ; 78 Am. St. R. 446.

- De Gray v. Monmouth Beach Co., 50 N. J. Eq. 329; 24 Atl. 388; Eq. Life Assur. Soc. v. Brennan, 1896, 148 N. Y. 661; 33 N. E. 173.

- Ivarson v. Mulvey, 1901, 179 Mass. 141; 60 N. E. 477.

- Whitney v. Union Ry., 11 Gray 359; 71 Am. Dec. 715; Frink v. Hughes, 1903 (Mich.); 94 N. W. 601 ; 10 Detroit Leg. News 106; Muzzarelli v. Hulshizer, 1894, $163 \mathrm{~Pa}$. St. 643; 30 Atl. 291; Post v. Weil, 115 N. Y. 361 ; 22 N. E. 145 ; 12 Am. St. 809 ; 5 L. R. A. 422-at end of opinion. 
Though they will not be enforced in equity in favor of an adjoining owner unless it appears from the deed, read in the light of the circumstances under which it was made, that the restrictions were inserted for the benefit of this adjoining owner. ${ }^{81}$

It will be noticed that in many cases where restrictive clauses are enforced between successors of the original parties they are referred to as covenants "running with the land," but it appears that they will be enforced in equity, generally, against those having actual or constructive notice of them, without regard to this particular quality, and even where there is no legal remedy concerning them as covenants running with the land at law, or where there is no legal privity of estate or contract between the person who seeks to enforce the restriction in equity and the person against whom he seeks to enforce it.

Indeed, the remedy by injunction, if sought in time, is so complete and satisfactory, that actions at law for damages for the breach of such restrictive covenants seem seldom to arise.

$\$ 229$. The duration of such restrictions - Effect of laches, waiver, changes in neighborhood.-A question in regard to such restrictions is: How long may they encumber the land and restrain its free use? Though in form unlimited as to time, will the courts perpetually compel their observance?

It appears that such restrictive covenants may lawfully endure perpetually, that is, they are not void because they are expressed to be unlimited as to time.

But circumstances may arise which would render their enforcement inequitable, so, practically, while in form perpetual, they actually are not so in perhaps the majority of cases.

The right to the benefit of them may be lost by laches

81 Hays v. St. Paul Church, 1902, 196 Ill. 633; 63 N. E. 1040. 
or may be waived, and if the party entitled to enforce them neglects to do so with reasonable promptness, when a violation occurs, his acquiescence in the violation and his delay in seeking a remedy, will prevent relief in a court of equity, not only for him but for his grantees. ${ }^{32}$

So if the character of a neighborhood has changed since the covenant was entered into, a court of equity will often decline to enforce it, because it would be inequitable to do so and would impose unjust burdens on the owner of the land, as the reason for the original making of the restrictive covenant has ceased to exist.

Especially will a court of equity decline to enforse such a restriction when the party seeking its enforcement and his predecessors in title have contributed to, or been responsible for, the change in the character of the neighborhood, ${ }^{33}$ for in such a case the person entitled to the benefit of the restrictive covenant may by his conduct have put himself in such an altered relation to the person bound by it as to make it manifestly unjust for him to ask a court to enforce the restriction by injunction. ${ }^{34}$ While a lot owner who has thus violated a general scheme of improvement cannot restrain another from doing what he himself has done, relief will nevertheless be given him if his own violation of the restrictions was not substantial and material. ${ }^{35}$

Where there has been a complete change in the neighborhood, as, for example, from residential to a business character, so as to defeat the purposes of the covenant as originally made, equity will not in all cases enforce the covenant, although the person seeking its enforcement is not responsible for the changed conditions.

Trout v. Lucas, 1896, 54 N. J. Eq. 361 ; 35 Atl. 153.

23 Bedford v. British Museum, 2 Myl. \& K. 552.

u Jenks v. Pawlowski, 1893, 98 Mich. 110; 56 N. W. 1105; 39 Am. St. R. 522 ; Sayers $\nabla$. Collyer, 28 Ch. D. 103, 108.

${ }^{36}$ Bacon v. Sandberg, 1901, 179 Mass. 396, 400 ; 60 N. E. 936; McGuire จ. Caskey, 1900, 62 Ohio St. 419 ; 57 N. E. 53. 
In such cases, though the defendant is violating the restriction, yet equity will not enforce it against him if the burden placed on him by so doing would be clearly disproportionate to the benefit conferred on the plaintiff, especially where damages will compensate the plaintiff, and the injunction, if granted against the defendant, could not, in any event, change the character of the neighborhood. ${ }^{36}$

The granting or refusing of relief in such cases rests in the discretion of the court and must depend on the circumstances of each case.

Even if, for example, there has been a change in the character of the neighborhood, or in the uses of adjacent land, this will not of itself deprive a lot owner of the right to restrain in equity the violation of a restrictive covenant made under former conditions, when it is still of substantial value and real benefit to him, especially if he is not responsible for the changed conditions. ${ }^{87}$

$\$ 230$. Provisions in effect restraining competition in trade.-The grantor's design may be to obtain an advantage by restricting competition, and stipulations having this effect have been sometimes upheld as not being unlawful restraints on trade, but as reasonable provisions for the benefit of the grantor as owner of the land retained by him. For example, in Star Brewery Co. v. Primas, the restrictive clause was: "The premises hereby conveyed are not to be used for saloon or dramshop purposes so long as the grantor owns" a certain house in the

^ Jackson v. Stevenson, 1892, 156 Mass. 496 ; 31 N. E. 691 ; 32 Am. St. R. 476; Amerman v. Deane, 1892, 132 N. Y. 355; 30 N. E. 741; 28 Am. St. R. 584.

" Rowland v. Miller, 1893, 139 N. Y. 93 ; 34 N. E. 765 ; 22 L. R. A. 182 ; Star Brewery Co. v. Primas, 1896, 163 Ill. 652 ; 45 N. E. 145 ; Landell v. Hamilton, 1896, $175 \mathrm{~Pa}$. St. 327 ; 34 Atl. 663 ; $177 \mathrm{~Pa}$. St. 23; 35 Atl. 242 ; 34 L. R. A. 227; Reilly v. Otto, 1886, 108 Mich. 330; 66 N. W. 228; 2 Detroit Leg. News 873.

87. 1896, 163 Ill. 652 ; 45 N. E. 145. 
neighborhood which was intended to be used for saloon purposes by the grantor; and the restriction was introduced into the deed for the purpose of preventing competition in the same business in the neighborhood. The court called this clause a "negative covenant," and at the suit of the grantor enjoined a subsequent grantee who had taken the premises with notice of the restriction from using them for the prohibited purpose. And a similar provision inserted in a deed for apparently a similar purpose, that is, to prevent competition, was enforced against a subsequent grantee in Sutton v. Head, ${ }^{88}$ and in Hodge v. Sloan, ${ }^{89}$ where the grantee agreed not to sell sand from the purchased lot in competition with the grantor's business, conducted on an adjoining lot, the agreement was enforced in equity on behalf of the grantor and against the grantee's vendee, though two judges dissented on the ground that the covenant was of a personal nature between the original grantor and grantee..$^{10}$

On the other hand, what seems to be the correct doctrine is held by some courts, that it is not enough to warrant a court of equity in enforcing such an agreement, against a subsequent owner of the land, that it indirectly benefits the land of the original covenantee by preventing competition in trade. To be so enforced the covenant

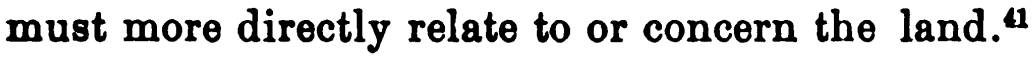

\$231. Covenants in conveyances relating to party walls.-For the purpose of reducing the expense of erecting buildings, agreements are frequently inserted in deeds conveying lands, or are entered into between adjoining landowners, concerning the construction and use of party

$086 \mathrm{Ky} .156$; 5 S. W. 410 ; 9 Am. St. R. 274 ; on the ground, it seems, in this case that the covenant ran with the land.

107 N. Y. 244 ; 17 N. E. 335 ; 1 Am. St. R. 816.

${ }^{\infty}$ And see Robbins v. Webb, 68 Ala. 393.

" Kettle River Co. v. Eastern \&c. Co., 41 Minn. 461; 43 N. W. 469; 6 L. R. A. 111; Norcross v. James, 140 Mass. 188; 2 N. E. 946; West Va. Trans. Co. v. Pipe Line Co., 22 W. Va. 600, 635. 
walls. Such agreements occur, generally, when the land is in a city or town where it is desirable to make the most of each lot. The party wall is generally a wall standing partly on the land of each adjoining owner, being a division wall between their buildings and used by both for the purposes of an exterior wall. Where there is no statute regulating the matter, the right to use the wall and the obligation to pay for its use arise usually from contract.

The right and obligation may originate in a covenant contained in a deed from an owner of several adjoining lots who conveys them to different grantees. For example, in Richardson $\nabla$. Tobey, ${ }^{42}$ the owner of several adjoining lots conveyed one of them by a deed, which was recorded, containing this provision: "It is understood and agreed that the partition wall of any building hereafter erected on the granted premises, or the adjacent lot on either side, may be placed one-half on the granted premises and one-half on the adjacent lot, and the owner of the lot adjacent to such building so erected shall, whenever he uses such wall, pay one-half the cost of the same, or so much thereof as he may use." The grantee erected a wall one-half on the land conveyed to him and one-half on one of the adjoining lots; this adjoining lot was then conveyed by the grantor of the first lot to another by a warranty deed, who conveyed it to still another, who built on the lot, using the wall erected by the first grantee; and it was held that this last grantee was liable for the use of the wall to the first grantee, who had built it. The court considered that this covenant could be regarded either as a covenant running with the land, creating mutual rights and obligations on the owners for the time being, or as giving the first grantee a right of property in the wall which had been built under the grant in the first deed; and the last grantee of the

(2 121 Mass. 457; 23 Am. R. 283. 
adjacent lot having used the wall, should pay for its use under either view.

But the fact that a stipulation regarding the use of and payment for a party wall is contained in a conveyance of land will not make the stipulation binding on subsequent grantees where it is a personal stipulation between grantor and grantee. As if one has already built a party wall between his two adjoining lots and, having conveyed one lot, afterward conveys the other (on which part of the wall stands) by a deed containing a clause providing that the grantee, by accepting this deed, agrees "for himself and his heirs and assigns" to pay the grantor the value, at the time of use, "of so much of said party wall standing on the premises as he or they may use;" the promise is personal to the grantor, and will not be binding on a grantee of the grantee. ${ }^{43}$

\$232. Agreements as to party walls without a conveyance.-Agreements concerning party walls appear to be more of ten made where there is no grant or conveyance of land. Two adjoining owners generally agree, by an instrument executed with the formalities of a deed, purporting to bind themselves, their heirs and assigns, that a wall about to be built on the division line may be built by one of them, half on each lot, and that the other shall pay half the cost of the wall when he makes use of it." Under the recording laws of many states these instruments may be recorded (if properly acknowledged, etc.), and in such cases their record will afford constructive notice of their provisions to subsequent purchasers of either lot; and where they are not merely personal covenants between the immediate parties they may affect subsequent owners of the adjoining lots. The questions

Lincoln v. Burrage, 177 Masg. 378; 59 N. E. 67.

" See forms of such agreements: Burr $\nabla$. Lamaster, 1890, $30 \mathrm{Neb}$. 688 ; 46 N. W. 1015 ; 27 Am. St. R. 428; King v. Wight, 1892, 155 Mass. 444 ; 29 N. E. 644. 
between the immediate parties relate generally simply to the construction to be put on the contract, the amount to be paid, etc.

Generally the most difficult questions connected with such agreements are those that arise as to the rights and liabilities of the assigns of the parties ; that is, for example, whether the assignee of the builder of the wall can recover on such a covenant for contribution, and whether the assign of the party who covenanted with the builder is liable on the covenant.

The decisions on these questions are not in harmony; and in the same court different conclusions are reached in cases where the facts vary but littlo-in one case the covenant being held to be personal, and in the other real.

- If it appears that the intention of the parties in making the agreement was to charge upon the land rather than upon the person the burden and expense of the party wall, and also to confer on the owner of each of the lots the right to construct the wall, on condition that any owner of the adjoining lands using the wall should pay for what he uses, and that the agreement relates not merely to the present, but to the future-the agreement may be regarded as a covenant real, running with the land; but if the agreement is a present one, and the person who is to build on the one hand and the person who is to pay on the other, are clearly designated, and the land is not charged with the obligation, the covenant is personal and does not affect the assigns of the parties. ${ }^{45}$

In Adams v. Noble ${ }^{46}$ the agreement is set out at length, and the court, recognizing the conflict among the authorities, divides them into two classes, "one class holding that the covenant for payment is personal and does not

4s Compare Mott v. Oppenheimer, 1892, 135 N. Y. 312; 31 N. E. 1097; 17 L. R. A. 409; with Sebald v. Mulholland, 1898, 155 N. Y. 455; 50 N.E. 260, where the material parts of the agreements are given, and the former case "distinguished" in the latter.

16 1899, 120 Mich. 545; 79 N. W. 810; 6 Detroit Leg. News 279. 
run with the land, when it is apparent from the contract that the payment should be made to the party building the wall, and there are no words indicating that the right to receive payment shall pass to his assigns ; the second class holding that the covenant runs with the land, and passes to the purchaser or assignee when the contract evinces such intention, and where the language used is between the parties and their assigns, and the contract declares the covenant shall be perpetual."

In many cases these agreements have been generally considered as not of the nature of covenants running with the land, and that therefore the grantees of the original parties cannot, because of their ownership of the adjacent lots, take advantage of the benefits of such covenants or be subjected to the burdens of paying for the wall, but that the right of recovery is personal to the builder, and the obligation of paying is on the original covenantor only. ${ }^{17}$

There seems, however, to be no good reason why party wall agreements should not run with the land if in particular cases they are evidently intended to do so. ${ }^{48}$

"Gibson v. Holden, 115 Ill. 199; 3 N. E. 282; 56 Am. R. 146, and note.

See Kimm v. Griffin, 1896, 67 Minn. 25; 69 N. W. 634; Burr v. Lamaster, 1890, 30 Neb. 688; 46 N. W. 1015; 27 Am. St. 428; Conduitt v. Ross, 102 Ind. 166; 28 N. E. 198; King v. Wight, 1892, 155 Mass. 444 ; 29 N. E. 644. 


\section{CHAPTER XV.}

SIGNING.

\$233. Signing not essential at common law.

234. Now generally necessary in the United States.

235. Place of signature.

236. Form of signature-Signing by mark.

237. Form of signature-Part of namo-Initials.
\$238. Signing by a nother for grantor.

239. Signing under power of attorney.

240. Execution of conveyance by corporation.

241. Conveyances by municipal, religious or literary corporations.

\$233. Signing not essential at common law.-The "execution" of a conveyance may include in its broad sense all the formalities of signing, sealing, attestation, acknowledgment and delivery; and in a few states all these are necessary to constitute the execution.

Sealing and delivery were the important elements in the execution of a deed at common law after the Norman Conquest, and signing was not required for its validity. ${ }^{1}$

It is often stated, as if it were a matter as to which no doubt has existed, that the statute of frauds ${ }^{2}$ required deeds to be signed, ${ }^{3}$ but the true view seems to be that the statute did not apply to instruments under seal, and that it is not because of that statute that deeds are signed in addition to the other formalities of execution."

${ }^{1}$ Shep. Touch., p. 56.

2 See 29 Car. II, c. 3 (1677).

3 See, for example, 2 Bl. Comm. 306.

4Aveline v. Whisson, 4 M. \& G. 801; 43 Eng. C. L. 414; Taunton v. Pepler, 6 Madd. 166; Challis R. Prop. 327; Shep. Touch. 56, note 24; Parks v. Hazlerigg, 7 Blackf. (Ind.) 536, 585; 43 Am. Dec. 106.

(286) 
$\S 234$. Now generally necessary in the United States. - However this may be, the laws of most of the states require expressly that all deeds conveying real estate shall be signed by the party making them, or by his agent duly constituted.

While there may still be some states in which sealing and delivery will be considered a sufficient execution without signing, ${ }^{5}$ it could not be generally so held; and under most of our statutes it would undoubtedly be held that an unsigned instrument, though delivered, is a nullity. For example: A mortgage attested, acknowledged, delivered and recorded, but not signed, is not merely defective but void, where the statute requires all conveyances to be "in writing, sealed by the grantor, and subscribed with his own hand * * or by his attorney," and a subsequent grantee of the premises, though he has assumed and agreed to pay the mortgage, is not estopped from claiming that the incumbrance has no existence in fact. ${ }^{6}$ And the naming of one as grantor in a deed will not make it his deed unless it is signed by him (and sealed where necessary). ${ }^{7}$

$\$ 235$. Place of signature.-While it is customary, and is the better practice, to sign the deed at its end, it seems that it is not essential (under statutes which provide simply for "signing") that the signature should be placed there if it appears in the body of the instrument, especially if the deed was written by the grantor himself who has inserted his name in it, ${ }^{8}$ or even if the deed was written by another, with the name so inserted at the

5 Sicard v. Davis, 6 Pet. 124.

- Goodman v. Randall, 44 Conn. 321. And see, Jones v. Gurlie, 61 Miss. 423; Boothroyd v. Engles, 23 Mich. 19; Miller v. Ruble, $107 \mathrm{~Pa}$. St. 395. But see, contra, Martin ₹. Nixon, 92 Mo. 26; 4 S. W. 503.

'Adams v. Medsker, 25 W. Va. 127 ; Thomas v. Caldwell, 50 Ill. 138.

- Saunders v. Hackney, 10 Lea (78 Tenn.) 194; Smith v. Howell, 11 N. J. Eq. 349, 354. 
grantor's direction, and acknowledged by him and delivered as his deed. ${ }^{9}$

The statutes of many states, however, require the instrument to be "subscribed," 10 and under such a provision the deed should be signed at its end or bottom, for, though the question has not often arisen as to deeds, it has been often held in cases where the question has been raised as to other instruments that there is a difference between "signing" and "subscribing." 11

\$236. Form of signature-Signing by mark.-By "signing" is generally understood the writing of one's name by himself, but there may be a valid signing without the grantor's name being written either by himself or another.

The primary meaning of the word sign is mark (signum ), and the statutory requirement as to signing is made for the purpose of securing some visible manifestation of the intention of the grantor to be bound.

The best way to signify this intention is that usually adopted by the grantor in himself writing his name in full, but he may adopt any " mark" as his signature, 12 and (in the absence of a statute providing otherwise) whether he can write his name or not. ${ }^{13}$

It is customary where a mark is used, to write near the device adopted, or made by the grantor, the words "his mark," but this is not necessary," nor is it necessary that a signing by mark should be specially attested by

- Newton v. Emereon, 66 Texas 142; 18 S. W. 348.

${ }^{10}$ And a few that it shall be signed at its foot: Winston $\nabla$. Hodges, 1893, 102 Ala. 304 ; 15 So. 528.

"Stone v. Marvel, 45 N. H. 481; Davis v. Shields, 26 Wend. 341; James v. Patten, 6 N. Y. 9. But see Cal. Canneries Co. v. Scatena, 1897, 117 Cal. 447 ; 49 Pac. 462.

${ }^{12}$ Devereux v. McMahon, 1891, 108 N. C. 134 ; 12 S. E. 902 ; 12 L. R. A. 205 ; Truman v. Lore, 14 Ohio St. 144.

"Mackay $\nabla$. Easton, 19 Wall. 619, 631.

14 Sellers v. Sellers, 98 N. C. 13; 3 S. E. 917. 
witnesses-unless witnesses to deeds otherwise signed are required..$^{15}$

Witnesses are required by the statutes of some states where the signing is by mark. Under such a statute it has been held that the signature by mark is not invalid, because not witnessed, but that it is not prima facie a signature unless witnessed, though it may be shown to be such. ${ }^{16}$

When not required by statute witnesses may be desirable where the signing is by an ordinary cross, which is not as easily identified as is the usual signature by name - the signature by mark may then be proved by the witness, and in practice it is usual to have witnesses for this reason, especially if the instrument is not acknowledged. Where, however, an instrument is properly acknowledged, the grantor must be regarded as having adopted the signature - whether mark or name-and as the acknowledgment is prima facie evidence of execution, ${ }^{17}$ witnesses are of little advantage in most cases. ${ }^{18}$

It is to be noted that the matter of signing by mark is regulated by statute in many states, and in some a signature by mark is allowable only when the signer is unable to write. ${ }^{19}$

\$237. Form of signature-Part of name-Initials.The signing of an instrument by the Christian name alone, where there is no doubt as to the identity of the person and of his intention to be bound, has been con-

\footnotetext{
${ }^{16}$ Meazles v. Martin, 1892, $93 \mathrm{Ky} .50$; 18 S. W. 1028; Finley v. Prescott, 1899,104 Wis. 614 ; 80 N. W. 930 ; 47 L. R. A. 695.

${ }^{16}$ Miller ex parte, 49 Ark. 18; 3 S. W. 883; Davis v. Semmes, 51 Ark. 48; 9 8. W. 434.

27 See post, \$259.

${ }^{20}$ Mackay v. Easton, 19 Wall. 619, 632; Meazles v. Martin, 1892, 93 Ky. $50 ; 18$ S. W. 1028.

19 See Re Guilfoyle, 1892, 96 Cal. 598; 31 Pac. 553; 22 L. R. A. 370. 19-Brews. Con.
} 
sidered a sufficient signing, ${ }^{20}$ as has been the signing by initials alone. ${ }^{21}$ And where the grantor's name appears in one and the same form in both the body of the deed and in the certificate of acknowledgment, but is signed in a different form, it has been held in many cases that such a variance does not invalidate the conveyance, ${ }^{22}$ but, on the other hand, there is authority for the view that a deed so executed appears to be signed and acknowledged by different persons, and that the record of such an instrument is not admissible without further proof of the identity of the person signing and acknowledging. ${ }^{23}$

In the preparation of conveyances such variations should be avoided; and where, in the examination of titles, they are found, as well as where the signatures are irregular or unusual (as by part of the name, etc.), they should, to avoid all question, be corrected by a new conveyance, if possible, or by obtaining proof that the substituted or irregular signing was intended by the signer to bind him.

\$238. Signing by another for grantor.-It is not generally necessary that the grantor should personally sign his deed, for if it be signed by another person for him, under his direction and in his presence, it is generally regarded as effective as if actually signed by him. ${ }^{2 t}$

In these cases the distinction between deeds so executed and those executed by an attorney-who must be authorized by an instrument equal in dignity to the instrument

${ }^{20}$ Zann v. Haller, 71 Ind. 136 ; 36 Am. R. 193; Knox's Estate, $131 \mathrm{~Pa}$. St. 220 ; 18 Atl. $1021 ; 6$ L. R. A. 353 ; an interesting case discussing signatures.

${ }^{21}$ Sanborn v. Flagler, 9 Allen 474; Salmon \&c. Mfg. Co. v. Goddard, 14 How. 446.

Hill v. Banks, 1891, 61 Conn. 25; 23 Atl. 712; Middleton v. Findla, 25 Cal. 76; Houx v. Batteen, 68 Mo. 84; Zann v. Haller, 71 Ind. 136.

23 Boothroyd v. Engles, 23 Mich. 19.

24 Gardner v. Gardner, 5 Cush. 483; 52 Am. Dec. 740; Middlebrook v. Barefoot, 121 Ala. 642; 25 So. 102 ; Lewis v. Watson, 1892, 98 Ala. 479; 13 So. 570 ; 39 Am. St. R. 82 ; 22 L. R. A. 297. 
to be executed-is recognized. If the disposing capacity is present, the mere fact that the grantor, for any reason, uses the hand of another instead of his own to perform the physical act of signing, makes the signing none the less his act. "To hold otherwise would be to decide that a person having a clear mind and full capacity, but through physical inability incapable of making a mark, could never make a conveyance or execute a deed, for the same incapacity to sign and seal the principal deed would prevent him from executing the letter of attorney under seal." 25

And even if the grantor is not present when his signature is affixed by another he may afterward adopt the signing by acknowledging the deed as his own, although no previous authority had been given the signer. ${ }^{26}$

$\S 239$. Signing under power of attorney. - A deed signed by another person than the grantor is, however, usually signed by him by virtue of a "power of attorney."

In such a case the deed, to follow the most generally approved form, should contain only the name of the principal till the testimonium clause is reached, being in fact of the same form as an ordinary deed to be signed by the principal. The testimonium clause may then be :

"In witness whereof the said A B has, by his attorney in fact, C D, hereunto set his hand (and seal, if noeded) this - day —, etc.
(Witnesses
A B.
[Seal]
if needed.) By C D, his attorney in fact."

* Gardner v. Gardner, 5 Cush. 483; 52 Am. Dec. 740. While this is the generally accepted view, the construction placed on particular statates in some cases will probably prevent it from being universally accepted : Wallace v. McCullough, 1 Rich. Eq. (B. C.) 426; Simpeon $\nabla$. Commonwealth, $89 \mathrm{Ky} .412$; $12 \mathrm{~S}$. W. 630.

${ }^{20}$ Blaisdell v. Leach, 1894, 101 Cal. 405; 35 Pac. 1019; 40 Am. St. R. 65; Bartlett v. Drake, 100 Mass. 174; 97 Am. Dec. 92; 1 Am. R. 101 ; O'Donnell v. Kelliher, 1895, 62 Ill. A pp. 641; Nye v. Lowry, 82 Ind. 316. 
It is the usage in many localities to insert in the deed a brief recital as to the power of attorney, its place of record, etc., which is convenient for purposes of reference. ${ }^{27}$

The deed should be in the name of the principal and be executed as his deed by the attorney, ${ }^{28}$ and not as the deed of the attorney. ${ }^{20}$ And where the deed is executed as the deed of the attorney parol evidence of an intention to bind the principal has been held inadmissible. ${ }^{30}$

To avoid all question as to the form of signing, the attorney should sign both the principal's name and his own, and not merely the principal's, ${ }^{31}$ though where the fact of the deeds being executed by the attorney is stated in the body of the deed, a signing by him of the principal's name alone has been held enough. ${ }^{32}$ And it should be noted also that the strictness of the older general rules, as to the form of the deed and the signature by an attorney, is modified by statute in several states-the general purport of such statutes being that it is enough if it appears from the deed as a whole, or from the signature, that the conveyance is that of the principal and not that of the attorney..$^{83}$

While there is thus a generally approved form of deed for one acting under a power of attorney, still, even in the absence of such statutes as those just referred to, it has been held that no precise order of words or form of expression is indispensable if it appears from the face of

n The testimonium clause will, of course, be varied to suit the form of deed used. See above, pp. 23 and 25.

${ }^{28}$ Elwell v. Shaw, 16 Mass. 42.

29 Williams v. Paine, 1897, 169 U. S. 55, 77; Clarke v. Courtney, 5 Pet. 319; Bassett v. Hawk, 114 Pa. St. 502; 8 Atl. 18.

${ }^{\infty}$ Hackney v. Butts, 41 Ark. 393. See Salem Bank v. White, 1895, 159 Ill. 136, 143; 42 N. E. 312; Townsend v. Hubbard, 4 Hill 351.

"Wood v. Goodridge, 6 Cush. 117.

Devinney v. Reynolds, 1 Watts \& S. 328.

* See Ohio R. S., \$\$ 4109, 4110; Penn. B. P. Dig., 12th ed., p. 152, \$8; Tenn. Shan. Code, $\S 3679-$ McCreary v. McCorkle, 1899, 54 S. W. 53 ; Va., §2416; W. Va., ch. 71, § 3 . 
the instrument who is intended to be bound, and if the mode of execution be such as to bind him, ${ }^{84}$ and a deed, for example, purporting at its beginning to be the deed of "A and B, of the first part," with covenants by the parties of the first part, concluding: "In witness whereof said parties of the first part have hereunto set their hands and seals.

(Signed.)

M N (Seal) and X Y (Seal), Attorneys in part for A and B," has been held to be the deed of $A$ and $B .{ }^{85}$

$\S 240$. Execution of conveyance by corporation.-As a corporation acts through agents, the general principles applicable to conveyances by an attorney apply to conveyances made on behalf of a corporation.

The corporation is mentioned as grantor, mortgagor or party of the first part, and the testimonium clause may be :

"In witness whereof, the said The $\mathrm{M} N$ Company has hereunto caused its corporate name to be signed and its corporate seal to be affixed, and the same to be attested by the signatures of $O P$, its president, and $X Y$, its secretary, thereunto duly authorized, on this - day of 18 - etc.

(Witnesses if needed.)

- (Corp. Seal.)

The M N Company, by $O \mathrm{P}$, its President, and $X Y$, its Secretary.

Or, the conveyance is often signed as follows:

"The M N Company, (Corp. Seal.) Attest, X Y, Secretary. ${ }^{86}$ by $\mathrm{O}$ P, its President.

" McClure v. Herring, 70 Mo. 18.

8 Martin v. Almond, 25 Mo. 313, and see Nobleboro v. Clark, 68 Maine 87, where a deed signed by the attorney in his own name alone was held to be the deed of the principal, as it appeared from the body of the deed to be the intention of the parties to bind the principal. See also Hunter v. Eastham, 1902 (Texas), 67 S. W. 1080.

* The testimonium clause, as in conveyances by individuals, being adapted to the form of deed used, whether indenture or deed poll. 
The conveyance should purport to be that of the corporation, and not merely that of its officers. ${ }^{37}$ The testimonium clause should recite the mode of execution and should give the name and title of the officer who is authorized to execute the conveyance on behalf of the corporation. The particular officers who should execute the conveyance of a corporation are in many states specified by statute, but in the absence of such a provision any officer may be authorized to do $80 .{ }^{88}$

As at common law the affixing of the corporate seal was the important element in the execution of a corporate deed it will still (it seems) be a sufficient execution-the proper officers signing their names-without the signing of the corporate name, unless the signing of its name is required by statute. ${ }^{89}$ Affixing the seal without signing the corporate name is not, however, enough when signing is required by statute as an element in the execution of conveyances in general; and signing the name may be of more importance than affixing the seal..$^{40}$

§ 241. Conveyances by municipal, religious, or literary corporations.-Particular modes are often prescribed by special or general laws for disposing of the property of certain classes of corporations, as, for example, municipal corporations, or private incorporated societies not organized for profit, but for religious, literary, and kindred purposes.

7 Norris v. Dains, 1894, 52 Ohio St. 215; 39 N. E. 660; Brown v. Farmers' Supply Co., 1893, 23 Ore. 541; 32 Pac. 548; if the instrument is clearly that of the corporation an execution by the proper officers in their own names may be enough, though not in the best form: Fond du Lac v. Otto's Est., 1902, 113 Wis. 39; 88 N. W. 917.

${ }^{28}$ Ellison v. Branstrator, 1899, 153 Ind. 146; 54 N. E. 433.

$\varpi$ Bason v. Mining Co., 90 N. C. 417 ; West Side Auction Co. v. Conn. M. L. Ins. Co., 1900, 186 Ill. 156 ; 57 N. E. 839.

“ Isham v. Iron Co., 19 Vt. 230; Hutchins v. Barre Water Co., 1901, 74 Vt. 36; 52 Atl. 70; Globe Ins. Co. v. Reid, 1897, 19 Ind. App. 203 ; I Wilgus Corp. Cases 1142 ; 47 N. E. 947; 49 N. E. 291. (As to the necessity or desirability of using the corporate seal, in view of statutes dispensing with seals in general, see post, $\$ 249$. ) 
The special mode prescribed for conveying property of a municipal corporation should be followed,"1 and if no special mode is prescribed, the conveyance should be under the corporate seal and in the corporate name. ${ }^{2}$

The legal title to the property held by religious or literary societies is often vested in trustees; conveyances by such corporations are generally made by the trustees. When the method of conveyance is prescribed by statute -and there are often requirements not found in other cases-that method is essential. ${ }^{48}$

Religious societies of ten have occasion to borrow money by mortgaging their property; the members may build a meetinghouse with borrowed money and use it as a place of worship, and yet raise technical objections to the validity of a mortgage securing the loan." So the lawyer's caution should not be laid aside in dealing with them.

4 Pimental v. San Francisco, 21 Cal. 351.

- Tiffin v. Shawhan, 43 Ohio St. 178; 1 N. E. 581.

"Lombard v. Chicago Sinai Cong., 64 Ill. 477, 487.

u Scott v. Trustees First Meth. Ch., 50 Mich. 528; 15 N. W. 891. 


\section{CHAPTER XVI.}

SEALING.

\$242. The seal-When necessary at common law.

243. Tendency to dispense with the seal-Effect of statutes.

244. Importance of the seal at common law.

245. Some effects of the sealLegal and equitable doctrines.
§246. What is a sufficient seal.

247. Recital in instrument as to seal-Necessity for, and effect of, recital.

248. Adoption of one seal by several persons - Timo and method of affixing the seal.

249. The corporate seal.

\$242. The seal-When necessary at common law.Since about the thirteenth century a seal has been essential to a deed at common law. From that time to this, when a deed has been mentioned a sealed instrument has been intended, unless some controlling statute has changed the word's meaning.

But a deed has not always been necessary for a conveyance of land. 1

The conveyance, however, of those interests in land that could not be transferred by feoffment, that is, incorporeal interests, required at common law a "grant," and a grant was always a deed, that is, an instrument under seal.

So the conveyance of an easement must be by deed unless some statute provides otherwise. ${ }^{2}$ Such interests

'See ante, §§ 11-15.

2 Wood v. Leadbitter, 13 Mees. \& W. 838; Huff v. McCauley, 53 Pa. St. 206; 91 Am. Dec. 203; Fuhr v. Dean, 26 Mo. 116; 69 Am. Dec. 484; Cagle v. Parker, 97 N. C. 271 ; 2 S. E. 76. 
were said at common law to "lie in grant" and "not in livery."

\$243. Tendency to dispense with the seal-Effect of statutes.-In the United States at the present time the state of the law as to whether conveyances must be under seal, and as to sealed instruments in general, is somewhat peculiar. On the one hand, the code of California ${ }^{3}$ provides that all distinctions between sealed and unsealed instruments are abolished, while by statutes in New Hampshire and Vermont" a "deed" of conveyance is expressly required to be signed and sealed; and in some of the older states there must be an actual seal, a "scroll," such as is permissible and usual in many states, not being sufficient. ${ }^{5}$

The matter is a little complicated on our statute books, from the fact that various acts have been passed at different times in many states relating to the subject, the later act very often not referring to the earlier, and frequently being found under a different division or part of the general laws from that containing the previous statute; thus, under the title "Conveyances" there may be one provision as to seals, under the title "Actions" another, under the title "Evidence" another, and it is not always easy to reconcile them. There will often be found a provision that conveyances of land may be by "deed," or "by deed, signed and sealed," and, in the same compilation, a provision dispensing with private seals.

Statutes doing away with seals do not always abolish the distinctions between sealed and unsealed instruments, as at first sight they seem to. For example, the statute of Texas, ${ }^{6}$ which is similar to those of many states, provides that "no private seal or scroll shall be neces-

- California Civ. Code, ; 1629.

`N. H. Pub. Stat. 1901, ch. 437, § 3; Vt. Stat. 1894, § 2213.

${ }^{6}$ See $§ 246$.

- Sayles, Ann. Civ. Stat., Art. 4862. 
sary to the validity of any contract, bond or conveyance * * except such as are made by corporations, nor shall the addition or omission of a seal or scroll in any way affect the force and effect of the same." In the case of Sanger v. Warren, ${ }^{7}$ the effect of this statute upon the older rules of law is considered. In this case an attempt was made to hold an undisclosed principal to an obligation assumed by his alleged agent, who had taken a conveyance in his own name, in which conveyance certain obligations were expressly assumed by the grantee. The rule that an undisclosed principal, when discovered, may be held in many cases is recognized, as are also several important exceptions to that rule, among other exceptions that regarding sealed instruments (in which case the undisclosed principal could not be held for the obligations of his agent assumed in the sealed instrument), and the court considers that this principle of law is not changed by the above statute, the effect of which is simply to dispense with seals for the validity of a conveyance, leaving the instrument still possessing the incidents it possessed as a sealed instrument at common law.

Under the statute of Michigan, ${ }^{8}$ providing that "no bond, deed of conveyance * * shall be deemed invalid for want of a seal or scroll," while a deed of conveyance may perhaps not require a seal, still the distinction between specialties and simple contracts is not done away with, and a "deed" or "bond," though unsealed, possesses qualities such as a sealed instrument possessed at common law-for example, an action of covenant may be brought on such an instrument if it is actually a "bond" or "deed," though assumpsit be barred by the statute of limitations. ${ }^{9}$ And it is considered that the

7 1898, 91 Texas 472, 483; 44 S. W. 477 ; 66 Am. St. 913.

- C. L. 1897, \$ 10417 .

' Rondot v. Rogers Tp., 1900, 99 Fed. 202 ; Jerome v. Ortman, 66 Mich. 668 ; 33 N. W. 759. 
question of a seal or no seal may become of importance in determining whether or not a particular instrument is a conveyance-as the absence of a seal, in spite of this statute, may be significant when the purpose of the instrument is not clear. ${ }^{10}$

In Jones v. Morris, ${ }^{11}$ the court says: "Though a seal may not now be necessary to a conveyance of a legal estate in lands, yet the instrument, the deed of conveyance, which it must still be termed, retains all the operation and effect of a deed sealed at common law.

The estoppel which at common law grew out of the covenants or the recitals of a sealed instrument, attaches now to an unsealed conveyance of the legal estate in lands."

While the tendency of modern law is to do away with the old distinctions, statutes dispensing with the necessity of sealing conveyances do not necessarily abrogate common law rules as to the effect of deeds as distinguished from unsealed instruments.

\$244. Importance of the seal at common law.-Much that is peculiar in the law as to the seal seems explained by its origin and early history. It is regarded as settled that the "charters" of the Anglo-Saxons before the Norman Conquest were generally signed, but not sealed. The illiterate signed by making a mark, usually the mark of the cross. Some of the Anglo-Saxons had seals, and used them before the Conquest, but they were not then regarded as indispensable, and it was not till about a century after the Conquest that seals came to be regarded as necessary to a deed. ${ }^{12}$ For the same reason that the Saxons signed with a cross, the Normans used a sealthat is, because they were generally too ignorant to write -and as the judges and lawyers after the Conquest were Normans, the seal was introduced into England by

${ }^{10}$ Spicer จ. Bonker, 45 Mich. 630, 635; 8 N. W. 518.

1161 Ala. 518, 522.

12 Palgrave Eng. Comm., p. CCXVI. 
them. ${ }^{18}$ Before the thirteenth century the necessity of sealing for a deed became fully established."

The importance attached to sealing soon after the Conquest is illustrated by a case decided by Henry II, in the twelfth century, the dispute being between a bishop and an abbot over land; Henry decided the dispute with what was then said to be the wisdom of Solomon, and held that the unsealed "land books" of the Anglo-Saxon kings were as good as sealed, since they were confirmed by a sealed charter of the Norman Henry I. ${ }^{15}$

So far as English law is concerned, therefore, the seal seems to have had its origin chiefly, though probably not wholly, in ignorance; and in view of this origin it is interesting to note such judicial observations as occur in many cases-for example, in Jackson $\nabla$. Wood, ${ }^{16}$ the matter is referred to thus: "This venerable custom of sealing is a relic of ancient wisdom."

However, most naturally the seal itself, being the chief distinguishing feature about a writing (especially to the unlearned, who were many), became an object of importance, and the act of sealing came to be regarded as a solemn and important act. The general consequence has been that the presence or absence of a seal has had for centuries most serious effects upon rights of property and of contract, the application of some of the rules of law producing most unjust results. ${ }^{17}$

18 Digby Hist. Law of Real Prop., p. 57, note.

"s Pollock The Land Laws, p. 73.

${ }^{15}$ See Poll. \& Mait. Hist. of Eng. Law, Vol. I, 136.

1612 Johns. 73, 76.

${ }^{17}$ The seal is undoubtedly of great antiquity. It is mentioned in ancient writings; among others frequently in the oldest books of the Bible. Its age, however, has not exempted it from abuse and ridicule. See, for example, an epitaphic annotation to the Mississippi Annotated Code, ch. 120, p. 899: "Beneath this lies all that remains of Locus Bigilli, a character of ancient date, etc." And note the contemptuous attack of Judge Lumpkin on this venerable character in Lowe v. Morris, 13 Ga. 147,150 , and the interesting defense of it in the same case, p. 159, by Judge Nisbet. The discussion between these judges, though relating 
$\S 245$. Some effects of the seal-Legal and equitable doctrines.-In view of the fact that seals, or substitutes for them, are still required for some purposes in many states, and were until recently required in many others, certain peculiar doctrines associated with the seal should be noted. The view taken often by courts of equity as to this formal matter of sealing, as distinguished from that taken by courts of law, should also be noted.

Some instances of these doctrines are:

1. An instrument imperfectly executed for want of a seal, or its statutory substitute, may be inoperative at law as a conveyance of real estate, ${ }^{18}$ and yet may be regarded in equity as an agreement to convey, and as creating an equitable lien upon or interest in real estate. ${ }^{19}$

And where the seal is omitted by mistake from any instrument a court of chancery will correct the instrument by affixing a seal, or accomplish the same end by restraining the setting up of the want of it to defeat a recovery at law. ${ }^{20}$

2. In contracts under seal a consideration was not essential at law to give validity to the promise. ${ }^{21}$ One object of the rule requiring a consideration in the case of a simple contract being to insure an intention on the part of the promisor that his promise should be binding, the same security was not required for contracts under seal, because a deliberate intention to make a binding promise is presumed to be sufficiently insured by the formalities required to be gone through with in the execution of a deed.

chiefly to the seal of a court, has furnished valuable ammunition to the friends and foes of the seal who have since been in conflict.

is Irwin v. Powell, 1900, 188 Ill. 107, 109; 58 N. E. 941.

20 Frost v. Wolf, 1890, 77 Texas 455 ; 14 S. W. 440; 19 Am. St. R. 761 ; Hyne v. Osborn, 62 Mich. 235, 244; 28 N. W. 821; Todd จ. Eighmie, 1896, 4 App. Div. (N. Y.) 9, 13; Beardsley v. Knight, 10 Vt. 185; 33 Am. Dec. 193.

* Bernard Township v. Stebbins, 109 U. S. 341, 349.

"21 See supra, \$54. 
That is, the common law required a consideration in order to render an agreement binding, but declared that a seal was evidence of consideration, and would not allow the seal's effect to be altered by evidence of no consideration. ${ }^{22}$

Equity also required a consideration, but allowed the absence of it to be shown notwithstanding the seal. So equity will not grant specific performance of a sealed instrument unless there be an actual consideration. ${ }^{23}$

3. The act of sealing being such a solemn act, it was not competent for one to give authority to another to execute a sealed instrument unless by an instrument of equal solemnity. Hence the authority to execute a sealed instrument must be under seal. ${ }^{24}$

4. So a sealed instrument could not at common law be set aside except by an instrument under seal. It was considered impossible to cancel such a solemn act by anything less solemn. Hence, a release of a sealed instrument must be under seal. ${ }^{25}$

Therefore, if a debtor on a sealed instrument had paid the debt, but had not obtained a release or a surrender of the sealed instrument, he was still liable at law for the debt. But equity here, as in other cases, not recognizing the force of the seal, would enjoin a second action. ${ }^{26}$

5. So a special form of action was set apart for sealed instruments, that of covenant. An action on a sealed contract when the damages were unliquidated had to be declared on in covenant; if it were merely a promise to

n Cosgrove v. Cummings, 1900, 195 Pa. St. 497 ; 46 Atl. 69.

${ }^{23}$ Burling v. King, 66 Barb. 633; Tatham v. Vernon, 29 Beav. 604, 615.

" Hibblewhite v. M'Morine, 6 M. \& W. 200, 215; Blood v. Goodrich, 9 Wend. 68; 24 Am. D. 121.

${ }^{25}$ Co. Litt. 222 B. See Pratt v. Morrow, 45 Mo. 404, 407.

8 This equitable doctrine has become generally the rule at law. SeeBlagborne v. Hunger, 1894, 101 Mich. 375 ; 59 N. W. 657. 
pay a definite sum of money, there might be an election between covenant and debt. ${ }^{27}$

6. Contracts under seal had a superiority over simple contracts in respect to the period of limitation for actions. A statute of James $I,{ }^{28}$ limiting the time within which actions could be brought, imposed no limitations on actions of covenant or debt on sealed instruments.

Generally the American statutes have allowed a longer period within which to bring an action on a contract under seal than on one not under seal.

\$246. What is a sufficient seal.-The seal having had these and other important effects, the question has often arisen as to what a seal is at common law.

It was formerly generally an impression on wax, but as the impression and not the substance on which it was made was its characteristic, it was later considered that it might be on a wafer or other tenacious material not necessarily of wax. And it appears now that annexing a piece of paper by any adhesive substance is enough to make it a private common law seal, though no impression is made, ${ }^{20}$ and an impression on the paper itself would now generally be regarded as a sufficient seal..$^{80}$

But there should generally, where the common law seal is needed, be some wafer annexed, or impression made, for it has been held lately that the letters "L. S." do not make a common law seal, though equity will recognize them as a seal if the intention is clear to make them

$n 1$ Chitty Pldg. 115.

${ }^{28} 1623,21$ Jac. I, c. 16.

20 McLaughlin v. Randall, $66 \mathrm{Me} 226$.

${ }^{\infty}$ Pierce v. Indseth, 106 U. S. 546; Town of Solon v. Bank, 114 N. Y. 122 ; 21 N. E. 168 . In Pease v. Lawson, 33 Mo. 35, 39, it was held that a good common law seal need make no impression that was visible, but that a small round piece of paper at the end of the signature was a common law seal, because when it was caused to adhere to the paper, it must from physical necessity have made an impression sufficient to comply with the law, though no impression was visible. 
such. ${ }^{81}$ And in Manning v. Perkins, ${ }^{32}$ which was an action for covenant broken, based upon an instrument in writing, it was held that the word "Seal" with a brace at each end, printed when the blank was printed, and following defendant's signature, was not a seal.

On the other hand, as showing remarkable liberality on the question as to what is a seal, see Hacker's Appeal. ${ }^{33}$ It appears that by usage, and without statute, in Pennsylvania a scroll is authorized. The question involved in this case was whether the donee of a power had executed the power properly, that is, under seal. The donee had made a testamentary instrument, and at the end of her signature placed a dash, between one-sixteenth and one-eighth of an inch long, and the dash was exactly like punctuation marks all through the instrument. There were no periods, commas or other marks of punctuation, except this small dash, like that following her name at the end. It was contended that there was no proper exercise of the power because the instrument was not under seal, but the court held that this dash was a seal, and in reply to the argument that the dash was simply like every other punctuation mark in the instrument, the court said: "If the donee used this sign indiscriminately for a comma, colon, or a period, why could she not have used it for a seal ?"

In many states a seal of some kind is essential to the execution of a conveyance; and while in many of these a common law seal is of ten used, it is provided by statute or adjudged by the courts that a scroll or, as it is sometimes called, a "scrawl," or other device, may be used..$^{34}$

31 Barnard v. Gantz, 1893, 140 N. Y. 249, 258; 35 N. E. 430

82 1894, 86 Maine 419; 29 Atl. 1114.

a 121 Pa. St. $192 ; 15$ Atl. 500.

"Among such states are: Florida, Georgia, Illinois, Maryland, Minnesota, North Carolina, Oregon, Penneylvania, Virginia, Wisconsin. 
In other states no seal or other device (where the grantor is a private individual) seems necessary, though one is often used, ${ }^{36}$ while in others a common law seal seems still necessary. ${ }^{86}$

\$247. Recital in instrument as to seal-Necessity for, and effect of, recital.-It was generally the practice at common law to recite at the conclusion of a deed that it was under seal: "In witness whereof the said party has hereunto set his seal." This practice is still preserved where under modern law, either statutory or by judicial decision, a symbolic seal, a "scroll," or "scrawl," is used, and the question arises as to whether such a recital is necessary to make a sealed instrument.

Some text writers lay down the proposition generally that an instrument is not sealed unless so recited to be, ${ }^{37}$ and this appears to be the law in some states, unless at least an actual seal is used. For example, in Breitling v. Marx, ${ }^{88}$ the action was on a writing, in the form of a promissory note, but with L.S. in brackets after the maker's name. It was objected that it could not be declared on as a promissory note because it was under seal. The court, agreeing with the proposition that a written promise under seal to pay money is not a promissory note, and cannot be declared on as such, holds that a writing is not under seal unless the purpose to seal it is expressed or indicated in its body, and the mere suffixing a scroll containing the word "seal" or letters "l. s." to the name of the subscriber does not make it a sealed writing. Hence in this case the instru-

2s Among such states are: Arkansas, California, Colorado, Indiana, Iowa, Kansas, Kentucky, Michigan, Missouri, Montana, Nebraska, North Dakota, Ohio, South Dakota, Tennessee, Texas, Utah, Washington.

* Maine, Maseachueette, New Hampshire, Vermont.

n Daniels Neg. Inst., §32: Tiedeman Com. Paper, \$82.

* 1899, 123 Ala., 222; 26 So 203.

20-Brews. CoN. 
ment was properly declared on as a note. And this appears to be the law in Virginia and Georgia. ${ }^{39}$

Such a recital was not necessary at common law. "And note the order of making a deed is first, to write it, then to seal it, and after to deliver it, and therefore it is not necessary that the sealing or delivery be mentioned in the writing, for as much as they are to be done after." so

And so now the recital appears, by the weight of authority, to be unnecessary, to make an instrument which is sealed, a sealed instrument. As where the recital was "in witness whereof we set our hands," but seals, consisting of wafers, were attached, it was held that these were the seals both of the individual and corporation, and that the corporation could adopt any seal ; $;^{41}$ and so, where without a recital, the word " seal " in brackets was on a note, the court held it was not a note, negotiable, etc., and observed that it is difficult to see how one could express that the device was a seal more clearly than by the word "seal" placed within the scroll or made part of it. ${ }^{42}$

On the other hand, the recital in an instrument that it

${ }^{39}$ Humphries $\nabla$. Nix, 77 Ga. 98. In Alt $\nabla$. Stoker, 1895, 127 Mo. 466; $30 \mathrm{~S}$. W. 132, the cases are collected. The former statute in Missouri, having made a scrawl sufficient for a seal, required also a recital on the face of the instrument that it was sealed. But the court says that where there is a real seal the requirement as to recital does not obtain. In such case the fact and not the assertion fixes the nature of the instrument.

"Goddard's Case, 2 Coke 5.

4 Foundry Co. v. Hovey, 21 Pick. 417.

12 Brown v. Jordhal, 32 Minn. 135; 19 N. W. 650. See also Osborne v. Kissler, 35 Ohio St. 99 ; Eames v. Preston, 20 Ill. 389. A distinction is recognized by some authorities between instruments, like conveyances, that are acknowledged and recorded-which, if having a seal, should be regarded as sealed, though there is no recital of sealing in the instrument-and other instruments, like promises to pay money, which should not be regarded as sealed unless the seal is recognized by a recital in the instrument. Cosner v. McCrum, 40 W. Va. 339, 345; 21 S. E. 739. 
is sealed will not generally be enough to make it a sealed instrument, when it is actually not sealed, or provided with a substitute for the seal, where such a substitute is allowable. ${ }^{43}$

\$248. Adoption of one seal by several persons-Time and method of affixing the seal.-Often one seal is adopted by several different persons executing the instrument, and this is a sufficient seal as to each, though the seal may be opposite the signature of but one of them. When the instrument purports by a recital to be sealed, the law presumes, prima facie, that each adopts the seal as his, though he may show that he did not do so:" The seal is not usually affixed at the time of signing, nor need it be, for the person executing the instrument may adopt the seal already placed on it. ${ }^{45}$

\$249. The corporate seal.-Statutes dispensing with private seals quite generally except the seals of corporations, and, though the corporate seal is not universally required to a conveyance by a corporation, it is used even where legislation on the general subject has been most radical, ${ }^{46}$ and it is, according to many authorities, essential to a corporate conveyance. ${ }^{17}$ In conveyances by corporations there is often a recital of the authority given by the stockholders for the conveyance, but the seal itself

Patterson v. Galliher, 1898, 122 N. C. 511 ; 29 S. E. 773; Vance v. Funk, 3 Ill. 263; Taylor v. Glaser, 2 8. \& R. 502.

"Davis v. Burton, 3 Scam. (Ill.) 41; 36 Am. Dec. 511; Lunsford v. LaMlotte Co., 54 Mo. 426 ; Northumberland v. Cobleigh, 59 N. H. 250;

Pickens v. Rymer, 90 N. C. 283 ; 47 Am. R. 521.

${ }^{45}$ Shep. Touch. 54, 57.

${ }^{6}$ Fudickar v. East Riverside \&c., 1895, 109 Cal. 29: 41 Pac. 1024; Blood v. Land Co., 1896, 113 Cal. 221 ; 41 Pac. 1017; 45 Pac. 252.

${ }^{47}$ Garrett v. Belmont Co., 1895, 94 Tenn. 459, 475; 29 S. W. 726; 1 Wilgus' C. C. 1138 ; Danville v. Mott, 1891, 136 Ill. 289; 28 N. E. 54 ; Shropshire v. Behrens, 1890, 77 Texas 275; $13 \mathrm{~S}$. W. 1043. See, however, as to the importance of signing, ante, $\$ 240$. 
has been held as prima facie evidence that it was affixed by the authority of the corporation. ${ }^{8}$

A purchaser from a corporation is not bound to know its by-laws, and when the proper officers affix the seal and sign the conveyance, the corporation is estopped as to purchasers without actual notice to deny the power of its officers. ${ }^{4 \theta}$ On the other hand, if there is no corporate seal affixed it will be necessary in some jurisdictions for the party relying on the deed to show that it was executed by authority of the corporation..$^{50}$ A corporation may adopt and use any seal which an individual might use..$^{51}$

As a corporation cannot have a characteristic handwriting, and as a public officer (as such) also has no distinctive and characteristic "hand," there is more reason for the continued use of corporate and official seals than for the use of the private seal.

"Gray v. Waldron, 1894, 101 Mich. 612; 60 N. W. 288; Sheehan v. Davis, 17 Ohio St. 571 ; Jinright $\nabla$. Nelson, 1894, 105 Ala. 399 ; 17 So. 91 ; Little Sawmill Co. v. Federal R. Co., 1899, 194 Pa. St. 144; 45 Atl. 66 ; 75 Am. St. R. 690; 1 Wilgue' C. O. 1147; Marvin v. Anderson, 1901, 111 Wis. $387 ; 87$ N. W. 226.

${ }^{\circ}$ Ins. Co. v. White, 106 Ill. 67; Kansas จ. R. R. Co., 77 Mo. 180.

${ }^{60}$ Barney v. Pforr, 1897, 117 Cal. 56 ; 48 Pac. 987; Duke v. Markham, 1890,105 N. C. 131 ; 10 S. E. 1017 ; 18 Am. St. R. 889.

BI G. V. B. Min. Co. v. Bank, 1899, 95 Fed. R. 23, 33; Thayer v. Nehalem Mill Co., 1897, 31 Ore. 437; 51 Pac. 202. But 800 Oaldwell v. Mfg. Co., 1897, 121 N. C. 339 ; 28 8. E. 475. 


\section{CHAPTER XVII.}

\section{ATTESTATION.}

$\S 250$. Witnesser to conveyances at common law.

251. Witnesses under statutes in the United States.
$\S 252$. The method of attesting.

253. Disqualification of witness by interest.

$\$ 250$. Witnesses to conveyances at common law.-No attestation of a deed was necessary at common law. ${ }^{1}$ There early arose a practice, however, of appending to the deed the names of many persons as witnesses, not always in early times the names of those only who were present, ${ }^{2}$ though undoubtedly later the names of witnesses were mainly the names of those present who heard the deed read. They appear to have been often numerous, and were written, not by the witnesses themselves, but by the person who prepared the deed. About the time of Henry VIII it became the practice for the witnesses to sign their own names either at the bottom of the deed or indorsed on it. ${ }^{\circ}$

Yet this later form of attestation was not a part of the

1 Co. Litt. 7a; Garrett v. Lister, 1 Lev. 25.

2 "* * people wrote down the names of abeent friends and got their consent afterwards. * * A witness to a deed, according to the popular conception, was not necessarily one who had seen it executed, but one who was willing to give it credit by his name. This may account for its turning out so often, when witnesses were questioned, that they knew nothing about the matter." Thayer Treatise on Evidence, pp. 97, 98; and the witnesses formed part of the jury to try the validity of the deed: Ib.; Fox $\nabla$. Reil, 3 Johns. 477.

- Burdett $\nabla$. Spilsbury, 6 M. \& G. (46 Eng. C. L. R.); C. J. Tindal, at pp. 456, 457. 
deed, necessary to its validity, but was merely a means of preserving the evidence of its due execution.

Where there were witnesses it was necessary, in order to prove the execution of the deed, to first call some of them, if possible, and other evidence could not be given of its execution until they were produced, or until it appeared that they could not be produced, or, if produced, that they denied its execution or were incompetent to testify.4

It is still the general rule (in the absence of a statute to the contrary) that at least one of the attesting witnesses to a written instrument must be called when the execution of the instrument is in dispute.

This common law rule has been changed, however, in some states, as in England, and statutes make it applicable to those written instruments only that are required by law to be attested, and unless the instrument is one of this character, it may be proved as if unattested, though it is actually attested. ${ }^{5}$

Moreover, it has been held, though it seems not in accord with the weight of authority, that, as one of the reasons for the rule requiring the attesting witness to be called was that at the time it arose the parties to an action were incompetent to testify (which is no longer so), the necessity for the rule no longer exists, and therefore, the execution of a deed may be proved by the grantor or the officer before whom it was acknowledged, as well as by the attesting witness. ${ }^{6}$

- Dundy v. Chambers, 23 Ill. 369; Brigham v. Palmer, 3 Allen 450.

5 For example: Mich. C. L. 1897, \$10199 provides: "That whenever, upon the trial of any action * * a written instrument is offered in evidence, to which there is a subscribing witness, it shall not be necessary to call such subscribing witness, but such instrument may be proved in the same manner as it might be proved if there were no subscribing witness thereto, except in the case of written instruments to the validity of which one or more subscribing witnesses are required by law." And see N. Y. Rev. Stat. 1901, p. 1283, § 107; R. I. Gen. L. 1896, ch. 244, §43; No. Dak. Rev. Co. 1899, §3888a; McManus v. Commow, 1901,10 N. D. $340 ; 87$ N. W. 8.

- Garrett v. Hanshue, 1895, 53 Ohio St. 482 ; 42 N. E. 256 ; 35 L. R. A. 
Attesting witnesses can result in little inconvenience, even when not necessary, especially where the common law rule as to the necessity for calling them is not in force, and they may under some circumstances be of value where proof of execution becomes necessary; deeds are, therefore, often witnessed in those states where they need not be.

$\$ 251$. Witnesses under statutes in the United States.Not being necessary at common law, attesting or subscribing witnesses are required to a conveyance in the United States only when some statute so provides.

In about one-half the states they are not required for any purpose to deeds, but in most of such states they may make proof before some officer, who certifies to this proof in a certificate on the deed similar to the certificate of acknowledgment and for the same purposes. ${ }^{7}$

In about an equal number of states statutes require them for some purposes and under some circumstances, and in these states in which they are required they are not always required for the same purposes.

For example, in some states it is necessary to the validity of the deed as a legal conveyance that there be subscribing witnesses, two witnesses being essential in Ohio $^{8}$ and in Connecticut. ${ }^{9}$

But, generally speaking, in those states where statutes provide that conveyances shall be attested by witnesses the requirement is not essential to the validity of the deed as between the parties, but, like the requirement as to acknowledgment, ${ }^{10}$ is a formality necessary under the statute to entitle the deed to be recorded, the title to the

321, with note as to necessity of calling subscribing witnesses. See Bowling v. Hax, 55 Mo. 446.

' See post, $\$ 205$.

- Langmede $\nabla$. Weaver, 1901, 65 Ohio St. 17; 60 N. E. 992 ; Richardson v. Bates, 8 Ohio St. 257, 261.

- Winsted Bank v. Spencer, 26 Conn. 195.

${ }^{20}$ Seo post, $\$ 281$, n. 19. 
land passing from the grantor to the grantee on the signing of the deed (and sealing it when necessary) and its delivery.

For example, although the statute of Michigan" provides that " deeds executed within this state " " shall be executed in the presence of two witnesses, who shall subscribe their names to the same as such * *," a deed with but one witness, or with no witness, is valid as a conveyance of the legal title, though it may not be recorded, ${ }^{12}$ and a statute in the same terms is construed in the same way in Wisconsin, ${ }^{13}$ and similar statutes in the same way in several other states. ${ }^{14}$

\$252. The method of attesting.-It will be noticed that statutes providing for witnesses to deeds generally require that they shall sign their names "as such" or " as witnesses," etc.

In order that it may appear on the instrument that they sign in this capacity, their signatures usually follow a brief attestation clause placed at the end of the instrument and to the left of the grantor's signature. This clause varies in form, the more usual forms being: "Signed, sealed and delivered in the presence of," "Sealed and delivered in the presence of," "In the presence of," or, in some states, simply one word, as "Attest," or "Witness" is used. .15 $^{\text {" }}$

While it is the better practice to have the witness sign directly under a clause in the form usual in the state

"C. L. 1897, §8962.

${ }^{12}$ Carpenter v. Carpenter, 1901, 126 Mich. 217; 85 N. W. 576; 17 Detroit Leg. New8 778; Fulton v. Priddy, 1900, 123 Mich. 298; 82 N. W. 65; 6 Detroit Leg. News 1053.

${ }^{18}$ Harrass v. Edwards, 1896, 94 Wis. 459 ; 69 N. W. 69.

14 Howard v. Russell, 1898, 104 Ga. 230; 30 S. E. 802; Kingsley v. Holbrook, 45 N. H. 313; 86 Am. Dec. 173; Conlan v. Grace, 36 Minn. 276 ; 30 N. W. 880 ; Pearson v. Davis, 1894, 41 Neb. 608 ; 69 N. W. 885 (and see Strough v. Wilder, 1890, 119 N. Y. 530, 535; 23 N. E. 1057).

${ }^{15}$ Though the word "delivered" often is used as above, in most cases the deed is not actually delivered in the presence of the witness. 
where the land lies, no particular place or form seems indispensable, provided it appears that the person signing signed as a witness. ${ }^{16}$

Where there are several grantors in the same deed their several executions may, of course, be attested by the same witnesses, but where the deed is executed by different grantors at different times and places, and before different witnesses (as is often the case in practice), there should be a statement near the name of the witness indicating which particular grantor's execution he attests. ${ }^{17}$ And in such cases the attestation as to each grantor should be complete, for a defective attestation as to one of several grantors is not made good by a proper attestation as to the other grantors in the same deed. ${ }^{18}$

It is not necessary that the witness should see the grantor sign, and it is quite customary for him to be called in to subscribe his name after the grantor has signed his; in such cases the grantor should acknowledge his signature to the witness, who should sign in the grantor's presence and at his request, ${ }^{19}$ and the witness should either see the grantor sign or hear him make such an admission of his signature.

\$253. Disqualification of witness by interest.-One having a direct interest in the conveyance as grantee or mortgagee should not be an attesting witness to it, ${ }^{20}$ nor

${ }^{16}$ Culbertson v. Witbeck Co., 127 U. S. 326; Link v. Connell, 1896, 48 Neb. $574 ; 67$ N. W. 475; Arrington v. Arrington, 1898, 122 Ala. 510; 26 So. 152. (Though as to "subscribing," which is the term sometimes used in the statute concerning witnesses, see supra, $\$ 235$.)

${ }^{27}$ See Culbertson v. Witbeck Co., 127 U. S. 326.

${ }^{18}$ Harrass v. Edwands, 1896, 94 Wis. 459 ; 69 N. W. 69; Hall v. Red8on, 10 Mich. 21.

10 Jackson v. Phillips, 9 Cow. 94, 113; Tate v. Lawrence, 11 Heisk. 503.

Amick v. Woodworth, 1898, 58 Ohio St. 86; 50 N. E. 437; Donovan v. St. Anthony \&c. Co., 1899, 8 N. Dak. 585; 80 N. W. 772; 73 Am. St. 
should one of several grantors witness the execution of the conveyance by another grantor; and it has been held that the wife of the grantor is not competent to witness her husband's deed. ${ }^{21}$

R. 779; Coleman v. State, 79 Ala. 49. See Child v. Baker, 24 Neb. 188, $201 ; 38$ N. W. 725.

"Corbett v. Norcross, 35 N. H. 99; Bank v. O'Brien, 1894, 94 Tenn. $38 ; 28$ S. W. 293. 


\section{CHAPTER XVIII.}

\section{ACKNOWLEDGMENT.}

$\S 254$. Terms ased.

255. What writing s may be acknowledged.

256. The subject regulated by statute-Form of acknowledging deeds generally the test.

257. General purposes of acknowledgment.

258. First, to entitle the instrument to be recorded.

259. Purpose of acknowledgment - Statutes relating to evidence.

260. Some points to notice as to such statutes.

261. When necessary to validity of conveyance.

262. Necessary to convey legal title in some states.

263. In many states acknowledgment necessary to validity of conveyance of homestead.

264. When necessary in conveyance by married woman.

265. The form of the certificate of acknowledgment.

286. Certiflcate 8 h ould show facts neceseary.

267. Substantial compli a n ce with statutes enoughClerical errors.

268. What is substantial compliance.

269. Substantial compliance Fact of acknowledgment.
\$270. When the word "acknowledged" should appear.

271. Substantial compliance Identity of party.

272. Identity of party - "Personally known."

273. Who may take the acknowledgment.

274. Authority to take wholly statutory.

275. Who may take-When acknowledgment is taken in the state where the land is.

276. Who may take-When acknowledgment is taken in another state - The commissioner of deeds.

277. When taken in another state - Questions as to what officers may take, ets.

278. Taken in another stateShowing as to official character, etc.

279. Taken in another state Certificate of conformity to foreign law.

280: Acknowledgments tak en out of the United States.

281. Competency of officer affected by interest-Party cannot take acknowledg. ment.

282. Practical effect of rule that party cannot take acknowledgment. 
\$283. Rule disqualifying party generally applies to acknowledgments of all instruments.

284. Effect of relationship on officer's competency.

285. Undisclosed interest as affecting competency of officer to take.

286. Undisclosed interest as affecting competency.

287. Officer of corporation not generally disqualified unless also a shareholder.

288. Agent or attorney of party to a conveyance may generally take acknowledgment.
$\$ 289$. The parts of the certificate

290. Date.

291. Signing by officer-His offlcial, not his personal signature.

292. Sealing.

293. Impeachment of the certificate-When it is conclusive.

294. Form of certificate to conveyance of corporation or by attorney.

295. Proof instead of acknowledgment.

$\$ 254$. Terms used.-Acknowledgment is the declaration, before a competent officer or court, by one who has executed an instrument that it is his act or deed.

The act of acknowledging the execution of an instrument is properly called "the acknowledgment."

The statement by the officer in the form of a certificate that the instrument was acknowledged before him is properly called "the certificate of acknowledgment." 1

The person acknowledging is said to make the acknowledgment. The officer before whom this acknowledgment is made takes the acknowledgment. ${ }^{2}$

$\S 255$. What writings may be acknowledged.-The instruments most commonly acknowledged, and regarding the acknowledgment of which there are statutory pro-

${ }^{1}$ But, "as the law knows no acknowledgment without a certificate," the term "acknowledgment" is often used as designating the certificate of the officer, as well as the act of the person acknowledging. Rogers v. Pell, 1898, 154 N. Y. 518, 529; 49 N. E. 75.

"Statutes on the subject often mention "prove" as practically equivalent to "acknowledge; e. g., the statement is quite common in statutes that, for certain purposes, a conveyance "must be acknowledged or proved." What is intended by "proved," as used in this connection, will be considered later. See post, $\$ 295$. 
visions in nearly all the states, are deeds, or other writings disposing of interests in real estate.

But provisions are quite general, either,

First, requiring certain other writings to be acknowledged before they are to be regarded as completely effective, or,

Second, authorizing or permitting certain other writings to be acknowledged.

Examples of statutes requiring the acknowledgment of writings other than deeds and instruments conveying interests in real estate are those requiring the acknowledgment of "articles of association," or similar instruments, by which persons associate themselves together to form a corporation; chattel mortgages in many of the states; deeds of adoption in several (Missouri, Iowa, Pennsylvania, Colorado); assignments for the benefit of creditors, etc.

Examples of statutes permitting or authorizing the acknowledgment of writings other than deeds or instruments affecting real estate, and providing the effect of such acknowledgment are those of Iowa and Michigan, viz.:

Iowa: "Every private writing, except a last will and testament, after being acknowledged or proved and certified in the manner prescribed for the proof or acknowledgment of conveyances of real estate, may be read in evidence without further proof."

Michigan:" "Every written instrument, except promissory notes and bills of exchange, and except the last wills of deceased persons, may be proved or acknowledged in the manner provided by law for taking the proof or acknowledgment of conveyances of real estate, and the certificate of the proper officer indorsed thereon shall entitle such instrument to be received in evidence on the trial of

- Iowa Code 1897, \$4621.

- Michigan compiled laws, § 10168. 
any action with the same effect and in the same manner as if such instrument were a conveyance of real estate." That is, the proper certificate is presumptive evidence of genuineness," "but the effect of such evidence may be rebutted by other competent testimony."

Statutes similar to these of Michigan and Iowa exist in other states, ${ }^{6}$ while in many there appear to be no such general statutes.?

Knowledge of such a statute in a particular state will often be of advantage, for under it various instruments, as, for example, chattel mortgages, bills of sale, etc., which may not require an acknowledgment, may nevertheless be acknowledged, the effect being to dispense generally with further or other proof on a trial than the certificate of acknowledgment.

$\$ 256$. The subject regulated by statute-Form of acknowledging deeds generally the test.-Many of these statutes relating to the acknowledgment of instruments of different kinds (and whether requiring or merely permitting it) refer to the manner and form of acknowledging conveyances of real estate as the test. Others simply speak of the instrument as being "acknowledged," without adding "as conveyances of real estate are." The usage in such cases is to follow, as far as the circumstances of the case allow, the law as to the acknowledgment of instruments conveying real estate. By following this usage one will generally get an acknowledgment that will withstand any criticism. At the same time it does not necessarily follow that all instruments for which an acknowledgment is desirable or necessary can be acknowledged only as real estate conveyances are: it has been

'Cameron v. Calkins, 44 Mich. 533; 7 N. W. 157; C. L. 1897, §8990.

- For example: Cal. Co. Civ. Proc., $\$ 1948$ (83 Cal. 270 ; Minn. G. Stat. 1894, § 5727; Neb. Stat. 1897, §5921; N. Y. Co. Civ. Pro., §937; Utah R. S. $1898, \S 3407$; Wis. Stat. $1898, \S 4185$.

'For example: Alabama (see Ala. R. Co., $\$ 3025$ ), Colorado, Illinois, Indiana, Kansas, Massachusetts, Missouri (see Mo. R. S., 5073), Ohio, West Virginia. 
recently held, for example, that a certificate of acknowledgment which might be defective if to a deed conveying real estate may be valid if to articles of incorporation $;^{8}$ and there are in some states special statutes regulating the acknowledgment of special instruments; for example, chattel mortgages in Illinois by a resident mortgagor cannot be acknowledged before a notary public as a deed may be. ${ }^{9}$

If one is fairly familiar with the questions that arise as to the acknowledgment of a conveyance of realty, he will find no difficulty in dealing with such special cases.

\$257. General purposes of acknowledgment.-While the subject is regulated by statute in each state, there are nevertheless certain general principles which may be considered before taking up any important details.

The purpose of the acknowledgment of an instrument is :

First, to entitle the instrument to be recorded, or,

Second, to entitle it to be read in evidence, or,

Third, in some cases, to give it validity. In some states (and in other states as to some instruments) all these purposes are within the purview of the statutes regulating the subject.

While the statutes vary in their details, there is a general tendency nowadays toward uniformity. ${ }^{10}$

Smith v. Sherman, 1901, 113 Iowa 601; 85 N. W. 747.

9 Long v. Cockern, 128 Ill. 29; 21 N. E. 201. See Gilbert v. Sprague, 1902, 196 Ill. 444, 451 ; 63 N. E. 993.

${ }^{10}$ It is sometimes said that the "acknowledgment" is entirely of American statutory origin, and was not known to the common law. It appears not to have been known to the early common law, but from references which occur in cases arising after the Statute of Enrollments, it appears that there was in England a custom of acknowledging deeds before they were enrolled. See, for instance, Taylor v. Jones, 1 Salk. 389, where the practice is spoken of as follows: "If a man lives in New England and would pass lands here in England, they join a mere nominal party with him in the deed, who acknowledges it, and it binds." And in Winscomb and Dunches Case, Godbolt 270, the bargainor is spoken of as having died before the enrollment of the deed, 
$\S 258$. First, to entitle the instrument to be recorded. -We have in this country a system under which instruments in writing affecting the title to real estate may be recorded in some public office. The record becomes notice, and persons dealing afterward with the property described in the recorded writing are charged with notice of the contents of the writing. Whether they actually knew of it or not, they are in general deemed in law to have notice of it. Furthermore, under this system properly recorded instruments are generally given preference over other instruments relating to the same property, actually made before the recorded instrument, but not recorded. These instruments are recorded by a public officer, known generally as the register of deeds or recorder.

The records, having these important effects upon titles, should not, it is considered, be encumbered with unauthenticated writings. So the statutes generally provide that only instruments duly authenticated are authorized to be recorded. This authentication usually consists of the certificate of some public officer, stating that the person named in the writing as transferring his interests in the property, acknowledged the execution of the writing. Upon this authentication the recording officer acts, and records the instrument. A writing actually acknowledged, but to which there is no certificate of that fact is not as a rule entitled to record; and if the recording officer should record it, its record is a nullity. It is not constructive notice, and has not the other effects which a proper record has.

So, also, a certificate of acknowledgment which is defective in substance does not authorize the instrument to be recorded. It is generally considered as no certificate. Therefore, if such an instrument is recorded it is not notice, and the grantee or mortgagee named in it acquires

and, "it not being acknowledged," the master of the rolls allowed it to be proved by witnesses. 
no interest in the property described in it, as against a subsequent purchaser in good faith and without actual notice of the previous conveyance.

In actual practice, the recording officer often records documents not properly authenticated, either because he does not scrutinize them, or because he does not know what the law requires, and if he sees any kind of a certificate of acknowledgment he does not stop generally to consider whether it is valid or not. But the fact that an instrument is actually written into the records, and appears at first sight to be regularly recorded, is not generally enough to warrant the subsequent introduction of the record in evidence, or to make it constructive notice, unless the instrument was entitled to record.

This may be stated as the general rule, as will be seen from the decisions cited later. ${ }^{11}$

11 But in this connection it should be noted that in some states statutes provide that deeds and other writings relating to real estate may be filed for record though not acknowledged or proved, and shall be deemed, from the time of filing, notice to subsequent purchasers and creditors, but they may not be read in evidence unless their execution be proved as required by the rules of evidence 80 as to supply the defects of such acknowledgment. See, for example, Illinois, ch. 30, par. 32, § 31; Colorado, §448; Alabama Code, §§991, 992. A statute of Michigan-C. L. 1897, $\S 9051$-provides substantially that no conveyance of land made in good faith and upon a valuable consideration shall be wholly void by reason of defects in statutory requirements as to execution or acknowledgment, but may be enforced as a contract, and when it has been recorded in the office of the register of deeds of the proper county such record shall operate as legal notice of all the rights secured by the instrument. Chicago Co. v. Powell, 1899, 120 Mich. $51 ; 78$ N. W. 1022 ; Lariverre v. Rains, 1897, 112 Mich. 276; 70 N. W. 583. "Curative" or "validating" acts have been passed in perhaps most of the states making valid, for one purpose or another, defective recordo-and they cure many defects in the acknowledgment and execution of deeds. Such statutes are practically important, but they vary so much in their terms that it is impracticable to refer to them in detail.

$$
\text { 21-Brews. Con. }
$$


$\S 259$. Purpose of acknowledgment-Statutes relating to evidence. - The second general purpose, as stated above, is to entitle the instrument to be read in evidence.

The statutes of most of the states provide that a conveyance properly acknowledged and certified by the official taking the acknowledgment may be read in evidence without further proof.

The effect of statutory provisions of this character is that the certificate of acknowledgment in proper form is prima facie evidence of the due execution of the instrument to which it is attached.

If it be claimed, for instance, that the instrument is a forgery, there is a presumption from the presence of the certificate that the alleged forgery is genuine, and this presumption can be overcome only by clear and convincing proof to the contrary. ${ }^{12}$

Or if the conveyance is attacked on other grounds, as, for example, that it was obtained by duress, the proper certificate is prima facie evidence of its due execution, and the burden of proof is on the person attacking it. ${ }^{18}$

The statutes generally provide also that the record of such instruments, which purport to be properly acknowledged and certified, ${ }^{14}$ and which are thus authorized to be recorded, may be received in evidence: that is, these copies are practically equal to the originals, as they may be offered and received in evidence as prima facie showing title.

Moreover, certified copies of the records (i. e., copies of copies) may be admitted in evidence in many states..$^{15}$

${ }^{12}$ Shelden v. Freeman, 1898, 116 Mich. 646; 74 N. W. 1004; Albsny Co. Bank v. McCarty, 1896, 149 N. Y. 71; 43 N. E. 427 ; Sassenburg v. Huseman, 1899, 182 Ill. 341 ; 55 N. E. 346.

13 Insurance Co. v. Nelson, 103 U. S. 544 ; Marston v. Brittenham, 76 Ill. 611; Springfield Engine Co. v. Donovan, 1898, 147 Mo. 622; 498. W. 500 . See $\S 293$, as to when the certificate may be impeached.

16 And, in many states, which are also properly attested; see supra, $\S 251$.

${ }^{25}$ Cal. Co. Civ. Proc. (ed. 1901), \$1951; Ind., Burns' R. \$., \$\$ 466, 3372, 
In other states the record may be introduced in evidence on a proper showing that the original deed is lost or beyond the reach of those claiming under it-or a certified transcript of the record may often be used under the same circumstances. ${ }^{16}$

\$260. Some points to notice as to such statutes.-The practical importance of a consideration of statutes of the character mentioned in the last section is obvious: it is important to know what is, and what is not, evidence of title.

Some matters worthy of attention in regard to such statutes are :

(1) That the acknowledgment of an instrument in writing does not dispense with proof of the execution of the instrument unless it is an instrument authorized to be acknowledged: for example, a certificate of acknowledgment attached to a promissory note or a will would not generally establish, even prima facie, the execution.

(2) That the acknowledgment being made primarily to entitle the instrument to record (in the case of conveyances at least), it does not necessarily follow that because the instrument is recordable it is also admissible in evidence.

(3) That in the absence of statutes so providing, neither the record of a conveyance nor copies of it are competent evidence.

(4) That neither records of conveyances nor copies of such records are admissible in evidence, unless the con.

3374 ; Mich. C. L. 1897, \$8990; Ore., Hill's Ann. L., \$3028-Serles v. Serles, 1899, 35 Ore. 289; 57 Pac. 634 ; Pa. Act 1715, May 28, § 5; P. \& L. Dig., p. 1570, § 88; P. \& L. Dig., p. 1891, \& 10; Cary v. Cary, 1899, 189 Pa. 65 ; 42 Atl. 19.

${ }^{2 s}$ Ala. Code, $\$$ 986, 992; Ill. R. S., ch. 30, $\$ 36$; Scott v. Bassett, 1898, 174 Ill. 390 ; 51 N. E. 577; Iowa Code, §4630; Kreuger $\nabla$. Walker, 1890, 80 Iowa 733; 45 N. W. 871; Oakland v. Hewitt, 1898, 105 lowa 668; 75 N. W. 497 ; Kan. Gen. Stat. 1901, § 1229; Mo. R. 8. 1899, $\$ 933$; Neb. Com. Stat. 1901, p. 939, § 13; Utah R. S., §3409. 
veyance recorded was entitled to record. For example, where an acknowledgment and certificate of acknowledgment are necessary for the recording, and an unacknowledged conveyance is recorded, ${ }^{17}$ or one is recorded with a substantially defective certificate, ${ }^{18}$ such records or copies of them cannot be used.

$\S 261$. When necessary to validity of conveyance.-In the third place, acknowledgment and a certificate of that fact are necessary in some cases to give validity to the conveyance.

It is well established, as a general rule, that a deed of conveyance is valid as between the parties to it without an acknowledgment. Therefore, if a deed is not acknowledged, or if it is so defectively acknowledged as not to be entitled to record, it nevertheless is a good conveyance of the legal title from the grantor to the grantee, generally speaking. ${ }^{19}$

But to this general rule there are exceptions, and among the most important of these exceptions are the following :

(1) Acknowledgment (or proof) and a proper certificate are essential to the validity of all deeds in some states ;

(2) They are essential to the validity, in many states, of conveyances of certain kinds of real property, especially the "homestead";

(3) They are essential to the validity, in many states, of conveyances by certain persons, e. g., sheriffs, and, especially, married women.

${ }^{17}$ Starnes v. Allen, 1898, 151 Ind. $108 ; 45$ N. E. $330 ; 51$ N. E. 78.

${ }^{18}$ Heintz v. Thayer, 1899, 92 Texas 658; 50 S. W. 929 ; 51 S. W. 640.

19 Taylor v. Youngs, 48 Mich. 268; 12 N. W. 208; Hayden v. Peirce, 1896, 165 Mass. 359; 43 N. E. 119; Fisk v. Osgood, 1899, 58 Neb. 486; $78 \mathrm{~N}$. W. 924; Kruger v. Walker, 1895, 94 Iowa 506, 511; $63 \mathrm{~N}$. W. 320 ; Grant v. Oliver, 1891, 91 Cal. 158; 27 Pac. 596, 861; Hannah v. Davis, 1892, 112 Mo. 599 ; 20 S. W. 686 ; Cable v. Cable, 1892, 146 Pa. St. 451 ; 23 Atl. 223. 
$\S 262$. Necessary to convey legal title in some states.The acknowledgment and a certificate of that fact are essential to the conveyance of the legal title in Ohio. ${ }^{20}$ And if the certificate is substantially defective, the effect is the same as if there were no certificate at all; for example, if the name of the grantor is omitted from the certificate. $^{21}$ The general effect of a conveyance not acknowledged, or defectively acknowledged, in states where this is the rule, is to make it a contract enforceable in equity, unless there is some "curative statute" making it valid.

\$263. In many states acknowledgment necessary to validity of conveyance of homestead.- Where the property involved in the transaction is a "homestead," an acknowledgment is absolutely essential in many states, at least where the owner is married, as is generally the case in practice.

In states where such statutes prevail, a conveyance of the "homestead" without the proper acknowledgment is not even an equitable conveyance; it is generally simply void-a nullity so far as the homestead is concerned. ${ }^{22}$

For example, in Illinois the statute provides that both husband and wife must subscribe and acknowledge the conveyance of a homestead (if the owner is married); therefore the conveyance of such property by the husband to the wife without her signing and acknowledging, is

\footnotetext{
${ }^{20}$ Hout $\nabla$. Hout, 20 Ohio St. 119; Hume v. Dickson, 37 Ohio St. 68; Kingman v. Loyer, 40 Ohio St. 109.

${ }^{21}$ Smith's Lessee v. Hunt, 13 Ohio 260; Anderson v. Logan, 99 N. C. 474 ; 6 S. E. 704 ; legal estate does not pass in North Carolina until the deed is proved and registered; Caperton v. Hull, 83 Ala. 171 ; 3 So. 234legal title not conveyed in Alabama unless deed attested or acknowledged.

"It is not intended at this point to consider what a "homestead" is, etc., or how it should generally be conveyed, but simply to call attention to this particular matter of acknowledgment.
} 
not good. ${ }^{22 a}$ And a chattel mortgage of a house used as a homestead on leased land has been held fatally defective, because the certificate of acknowledgment did not show that the mortgagor was " personally known," as is required by the Illinois statute. ${ }^{23}$

$\$ 264$. When necessary in conveyance by married women.-The general rule has been and is now, except where changed by recent statutes, that acknowledgment and a proper certificate of that fact are essential to the validity of a married woman's conveyance.

At common law the married woman could not make a valid deed of conveyance of her real property (except by special custom in some places; see post, section 360 ). Although for some time she has been quite generally free to hold and transfer real property, it must be remembered that her power to convey depends upon statute. She may convey in the mode, or by the method, prescribed by the statute alone; and, generally, any substantial departure from the course laid down by the statute renders her deed not merely defective, but void.

Quite generally her power to convey depends on its mode of execution. The power may be said to result from the mode, and when the mode prescribed is not followed there is a want of power, and her deed therefore is not merely incomplete but is void.24

Among the requirements as to the mode of making a married womar's deed, a very common one has been that her deed shall be c.uknowledged, and in nearly all the states there has been required for her something more than the ordinary acknowledgment. For it has been necessary

224 Kitterlin v. Ins. Co., 1890, 134 Ill. 64; 25 N. E. 772; Mueller $\nabla$. Conrad, 1899, 178 Ill. 276, 283; 52 N. E. 1031.

${ }^{23}$ Gage v. Wheeler, 129 Ill. 197 ; 21 N. E. $1075 . \quad$ See also the statutes of Alabama, Arkansas, California, Nebraska, Texas, Tennessee, Washington, Wyoming, North Dakota and Montana ; title "Homestead."

24 Sullivan v. Cummins, 13 Ohio 116, 119. 
in most of the states, until recently, that she should acknowledge the deed after a private examination apart from her husband.

Though the law as to this may have been altered many years ago, it still often becomes necessary, in the trials of actions relating to titles and in the examination of abstracts, to consider the former state of the law..$^{25}$

$\$ 265$. The form of the certificate of acknowledgment. - Having noticed, in this general way, the effects, on the one hand, of a proper acknowledgment and certificate of acknowledgment, and on the other hand, some of the effects of deficiencies, it will be necessary to consider what variations from the standard form, or from the essentials stated in the statute, will be regarded by the courts as fatal.

Forms are prescribed by the laws of some states for the certificate of acknowledgment; in others there is simply a general statement as to what is required to be done and what the certificate shall show.

The following general form is given to indicate the particulars that may be essential, though all these particulars are not necessary in all the states-while in some states, perhaps, some additional particulars are required, although they ought not to be :

State of $\longrightarrow$, County of $\longrightarrow$, ss :

I, (insert name and title of officer) hereby certify that on the - day of - in the year - before me personally appeared - and $\longrightarrow$, his wife, whose names are subscribed to the foregoing instrument as grantors (or mortgagors, lessors, etc.), to me personally known to be the same persons described in and who executed the said instrument, and acknowledged that they signed, sealed and delivered the same as their voluntary act and deed for the consideration, uses and purposes therein mentioned, (including the release and waiver of the right of homestead). And I further certify that the said -, wife of the said -, being of lawful age and being examined by

$\$$ Soo post, \$ 366. 
me separate and apart from her said husband, and the contents of said instrument being by me made known and fully explained to her, did declare and acknowledge that she did voluntarily and understandingly sign, seal and deliver the same, without any coercion or compulsion of her said husband, and that she is still satisfied therewith as her voluntary act and deed for the consideration, uses and purposes therein mentioned, and does not retract the same.

In testimony whereof I have hereunto subscribed my name and affixed my official seal this - day of — in the year -

(Seal.)

(Signature and title of officer.)

The form recommended by the American Bar Association, and substantially adopted in Iowa, Massachusetts, Minnesota, Michigan, and Missouri, is (for natural persons acting in their own right) as follows:

State of $\longrightarrow$, County of $\longrightarrow$, ss :

On this - day of,$- 19-$, before me personally appeared - (or - and - - ), to me known to be the person (or persons) described in and who executed the foregoing instrument and acknowledged that he (or they) executed the same as his (or their) free act and deed.

(Seal.) (Signature and title of officer.)

$\S 266$. Certificate should show facts necessary.- It may be stated in general that the certificate should show on its face that the statutory provisions have been substantially complied with. That is, it will not generally suffice for the officer to certify that the foregoing instrument was "duly acknowledged" or was "lawfully acknowledged." Such statements in the certificate simply certify the officer's conclusion. They are inferences which the officer is not, as a general rule, warranted in drawing. For example: "Signed, sealed and acknowledged in my presence the day and year aforesaid. J. J. $\mathrm{K}$., Notary Public", is not enough. The court says : 
"This falls short of such acknowledgment as has been sufficient to make legal evidence." 26

\$267. Substantial compliance with statute enoughClerical errors.-In considering the matter of defective certificates, there is generally applied a rule which will often relieve from the consequences of what seem to be serious defects. This rule is, that a substantial compliance with the statutory requirements is sufficient; exact and literal compliance is not necessary. It is the policy of the law to uphold certificates of acknowledgment, and to disregard technical defects and plain clerical errors. This principle is stated in most of the cases herein cited, and is applied, as will be seen from them, wherever it may be. ${ }^{27}$

So the instrument to which the certificate of acknowledgment is attached may be examined to supply defects in the certificate, or one part of the certificate may, in many cases, supply defects in another part. For example, if the mortgagor's name is entirely omitted from the certificate the omission will not make the certificate fatally defective, if the defect may be supplied by a reference to the body of the mortgage. ${ }^{28}$

In Fredrick v. Wilcox, ${ }^{29}$ the husband's name was

${ }^{26}$ Cooper v. Smith, 1889, 75 Mich. 247, 252; 42 N. W. 815. Statutes may make this general rule inapplicable. But such statutes seem unusual. For example, Kentucky: "Where the acknowledgment of a married woman shall be taken by an officer of this state, he shall simply certify that it was acknowledged before him, and when it was done, which shall be evidence that there was a separate examination: explanation of the contents, voluntary acknowledgment, and consent to record, are all presumed." Hence, a certificate in briefest form may be there sufficient, as, "Acknowledged by Willia C. Woods, this May 5, 1873," signed by the officer. Woods v. James, 87 Ky. 511 ; 9 S. W. 513.

" For example, King v. Merritt, 67 Mich. 194, 206; 34 N. W. 689; where the certificate read that the married woman acted "with fear," the court read it as "without."

23 Milner v. Nelson, 1892, 86 Iowa 452; 53 N. W. 405; 41 Am. St. R. 508; 19 L. R. A. 279.

1898, 119 Ala. 355 ; 24 So. 582 ; 72 Am. St. R. 925. 
omitted from the wife's acknowledgment, but there being two certificates, it was held that they could be read together, and in connection with the mortgage to which they were attached, to supply the defects in the certificate.

In Canal Co. v. Russell, ${ }^{30}$ J. F. and C., his wife, were stated as having personally appeared, being personally known, etc. And the certificate stated that said C. was examined separate and apart from her said husband, and the contents and meaning of the said husband were fully explained and made known to her, and she acknowledged that she executed the same and relinquished her dower in the premises described. It was claimed that the certificate was defective, because it stated that the contents and meaning of the husband were explained, instead of the contents and meaning of the deed. But the court says the certificate must be regarded in a common sense view, and filling the blank with the word "husband" renders the subsequent part of the certificate meaningless, but putting in the proper word, or leaving a blank, the vacancy is supplied by the subsequent tenor of the certificate.

$\$ 268$. What is substantial compliance.-What is a substantial compliance will of course vary somewhat in the different states, owing to differences in statutory detail. But there are some facts which, being obviously more important than others, are generally considered essential.

The prominently essential features are :

1. The fact of the acknowledgment of the instrument by the grantor.

2. The identity of the party making the acknowledgment with the party executing the instrument.

3. The showing in the certificate that the acknowledg.

$\$ 068$ Ill. $426,430,432$. 
ment was made before, and taken by, a competent, authorized officer, who certifies to these facts in the proper mode.

To state the matter more particularly, it may be said that the parts of the certificate requiring attention are (though all the parts are not of equal importance and value):

1. Venue, or statement of locality.

2. Body of certificate, stating :

Date when acknowledged, before whom, grantor's presence, grantor's name, officer's acquaintance with grantor, grantor's acknowledgment; when grantor is married woman some states require further: separate examination, explanation of instrument, separate acknowledgment of its execution, continued satisfaction with it; and when the property is a "homestead" a special clause releasing it is required in some states.

3. Officer's testimonium.

4. Officer's official signature and seal.

\$269. Substantial complianco-Fact of acknowledgment.-It is evident that many mistakes arise from the improper filling in of printed blank forms or from neglecting to fill the blank in any way.

1. The fact of the acknowledgment of the instrument should appear.

A certificate showing that the grantor appeared before the certifying officer, was known to him, etc., is not enough unless it also shows that he acknowledged: this omission will not be supplied by intendment or presumption. ${ }^{\text {B1 }}$

One would hardly suppose that so important a part of the certificate as the statement of this fact would be omitted; nevertheless, because of haste, carelessness, or

$n$ Short $\nabla$. Conlee, 28 Ill. 219; Bryan v. Ramirez, 8 Cal. 462; Stanton v. Button, 2 Conn. 527; Heintz v. Thayer, 1899, 92 Texas 658 ; $50 \mathrm{~S}$. W. 929 ; 51 S. W. 640. 
ignorance, this mistake occurs in practice not infrequently. For example, in Sarazin v. Railroad, ${ }^{82}$ an action was brought against the defendant railroad company to recover damages for the alleged negligent killing of a child; the child was granddaughter of plaintiffs and had been adopted by them; this action was begun by the adopting father and mother, but the father having died, it was continued by the mother. A necessary part of plaintiff's case was proof of adoption by deed which must be (in Missouri) acknowledged. A material part of certificate of acknowledgment was, "before me personally appeared S., and S., his wife, to me known to be the person described in and who executed the foregoing instrument, and acknowledged that he executed the same as his free act, etc." -i. e., the certificate shows that they personally appeared, but that he alone acknowledged; hence the deed, so far as the plaintiff is concerned, is void, as not acknowledged by her, and she cannot recover.

But in another recent case a mistake similar to that in the last case cited was held a clerical error; the court saying that to invalidate the certificate, for this "would be a strained and technical construction of the language used." 33

This slip (which may be, or may not be, a serious matter, according to the temper of the court) is very apt to occur in the use of printed blanks, where "-he-" is printed, to be made into "she," or "they," or left "he," as the circumstances require.

- $\$ 270$. When the word "acknowledged" should appear. -In certifying to the fact of acknowledgment, where the statute requires the instrument to be "acknowledged," the word "acknowledge" is clearly the best to use; but this word is not absolutely necessary if an equivalent word is used. There can be little gained in using what

821900,153 Mo. 479 ; 55 S. W. 92.

ss McCardia v. Billings, 1901, 10 N. Dak. 373; 87 N. W. 1008. 
seems to one an equivalent, however, for it may not seem so to another.

Where it was required that the certificate should show that a married woman "acknowledged," it was held ${ }^{34}$ that a certificate that she "stated," etc., was void: "stated" being held not equivalent to "acknowledged." On the other hand, "stated" may be proper where the statute provides that an acknowledgment shall be made by the grantor "stating that he executed the deed". ${ }^{35}$ The case of Bryant $v$. Richardson, ${ }^{36}$ where "acknowledged" was omitted, appears likely to mislead some into believing that, in the opinion of this court, this word or an equivalent is not essential.

But in this case the original instrument itself appears to have been offered in evidence, and the court holds that the instrument is not invalid by reason of the omission.

$\$ 271$. Substantial compliance-Identity of party.To show the identity of the party he should be named in the certificate. The name should correspond with the name in the deed and with that signed to it.

And the purchaser should avoid all question by seeing that there is this correspondence.

The difficulties caused by not doing so are illustrated by a case ${ }^{87}$ where the record of a deed signed Harmon S., and certified to, has been acknowledged by Hiram $\mathrm{S}$. (that being also the name inserted in the deed), was held inadmissible in evidence as the deed of Hiram S. because it appeared to have been "signed and acknowledged by different persons." ${ }^{38}$ So, although it seems that the Illinois

" Dewey v. Campau, 4 Mich. 565.

${ }^{25}$ E. g., Ark. Stat. 1894, p. 355.

$\approx 1890,126$ Ind. 145 ; 25 N. E. 807.

7 Boothroyd v. Engles, 23 Mich. 19.

${ }^{20}$ The omission of grantor's name in the certificate, or an error in it, will sometimes be cured by reference to other parts of the instrument acknowledged, on the principles stated above, $\$ 267$; but the prudent course for a proposing purchaser is not to leave such questions open. 
court will change the word "husband" to "deed" 39 it cannot fill a substantial blank that should have been filled before acknowledgment; as where the certificate stated that the grantors, naming them, personally appeared and acknowledged the deed, "and the said (blank), wife of said (blank), having been by me examined, etc., acknowledged that she freely executed, etc.," it was held that the deed could not be received in evidence. The certificate did not state who or whose wife was examined, etc. ${ }^{10}$

\$272. Identity of party-"Personally known."-To further assist in establishing the identity of the party acknowledging with the party executing, there is a very general statutory requirement that the officer shall not make a certificate of acknowledgment unless he personally knows of this identity.

If he does not know this fact he may generally require evidence of it, and if he certifies that he knows of this identity, when he does not, he and his sureties are liable for damages." And if the officer wilfully certifies falsely he is in some states guilty of a felony."

$\mathrm{He}$ is not expected to know, however, that the person acknowledging is the owner of the land described in the conveyance, and he is not obliged to certify to this fact. ${ }^{43}$

The law does not generally prescribe the extent of the officer's acquaintance : an ordinary introduction which satisfies his own conscience appears to be enough, though an introduction to a notary of one stranger by another is not enough to warrant his official certificate that he knows

${ }^{30}$ Canal Co. v. Russell, 68 Ill. 426 ; supra, $\$ 287$.

${ }^{\circ}$ Merritt v. Yates, 71 Ill. 636.

4 Bartels v. People, 1894, 152 Ill. 557; 38 N. E. 898; s. c. former appeal, 138 Ill. 322 ; Hatton v. Holmes, 1893, 97 Cal. 208; 31 Pac. 1131; Doran v. Butler, 74 Mich. 643; 42 N. W. 273; State v. Ryland, 1901, 163 Mo. 280 ; 63 S. W. 819.

12 N. Y. Pen. Co., $\$ 510$.

w State v. Thompson, 1899, 81 Mo. App. 549; Overacre v. Blake, 82 Cal. 77; 22 Pac. 979; Browne v. Dolan, 68 Iowa 646; 27 N. W. 795. 
the former." While the statutes very generally provide that the officer shall not take the acknowledgment unless he knows the person acknowledging to be the person executing, etc., it is not required in all states that this personal knowledge shall be certified to ; but where it is required, its omission from the certificate is a fatal defect.

For example, by New York statute the officer must know or have satisfactory evidence that the person acknowledging is the individual described in and who executed the conveyance, and it is held that the certificate should show this though the statute does not in terms require it to be shown. Therefore, a certificate: "Before me came $J$, to me personally known, and acknowledged the above to be his act and deed," is defective in not stating that the person who appeared was known to be the person described in and who executed, etc. ${ }^{45}$ And such a showing in the certificate would be more certainly necessary where the statute expressly requires it. ${ }^{46}$

\$273. Who may take the acknowledgment.-The acknowledgment must be made before, and taken by, a duly authorized and competent officer; who must certify to the necessary facts in the proper mode.

This statement involves, practically, much more than at first sight appears on its face.

If the writing acknowledged is a conveyance of interests. in real estate, the certificate should show that the certifying officer is one of those who, by the law of the place where the land is, is authorized to take the acknowledgment.

As the instrument may be, and often is, acknowledged either at the place where the land is or elsewhere, some

"Lindley v. Lindley, 1899, 92 Texas 446; 49 8. W. 593; Wood จ. Bach, 54 Barb. 134; Bidwell v. Sullivan, 1897, 17 N. Y. App. Div. 629.

6 Paolillo v. Taber, 56 A pp. Div. 241.

" Hart v. Randolph, 142 Inl. 521, 527; 32 N. E. 517. "Known" is equivalent to "personally known": Schley v. Car Co., 120 U. S. 575 
rules must be adopted to suit the different circumstances. There will be found, generally, statutory provisions in each state for three different sets of circumstances, viz.:

1. When the acknowledgment is made and taken where the land is,

2. When it is made and taken in one of the United States other than that where the land is,

3. When it is made and taken in a foreign country.

The officials who may act under these different circumstances are named in the statutes, and the modes in which they must respectively certify to the acknowledgment are prescribed.

If the certificate does not show on its face conformity to the law of the place where the land is it is no certificate, and the instrument is practically unacknowledged.

Many different officers are authorized to act in this matter; some of the statutory provisions are peculiar." The statutes are subject to amendment and are, as a fact, being constantly amended.

It is necessary, in each case, to look to the law at the time an acknowledgment is made.

For example, in Loree v. Abner, ${ }^{48}$ which was ejectment for thirty thousand acres, the deed in question was acknowledged in 1788-over one hundred years before the trial-before two justices of a court in Philadelphia : the land, though now in Kentucky, was then under the jurisdiction of Virginia, and it was held that two justices (of

"As illustrating the peculiarities of some of the statutes regarding the domestic officials who may, or may not, take acknowledgments, the following provisions may be cited: In Michigan, every senator and representative in the state legislature may, by Public Acts 1901, page 175 , take acknowledgments, - and a similar law exists in Minnesota,while in Rhode Island a state senator may do so: notaries public and justices of the peace may generally take acknowledgments, but a New Jersey notary may not, nor may a justice of the peace in Utah, while in Delaware two justices of the peace of the same county may. In about ten states mayors of cities may so act, while in Pennsylvania the mayors and aldermen of seven cities, only, may.

4 1893, 6 U. S. App. 649. 
this Philadelphia court) did not constitute "a court" within the meaning of Virginia's law : so the deed was not properly acknowledged, nor legally recorded, and a copy of it was not admissible in evidence. ${ }^{49}$

\$274. Anthority to take wholly statutory.-In all cases the general principle is applied that only those officers authorized by statute to take acknowledgments may do so; an acknowledgment taken by any other is ineffectual.

And where a statute providing for the acknowledgment of a particular kind of instrument specifies the officer or officers before whom it may be taken, an acknowledgment taken before any other officer (though he may be authorized to take acknowledgments of most instruments) is void.

For example: a chattel mortgage may not generally be acknowledged before a notary public in Illinois, ${ }^{50}$ nor a tax deed before a notary public in Missouri, ${ }^{51}$ nor a recognizance of special bail before a notary public in Michigan, ${ }^{52}$ nor (formerly) articles of incorporation before a notary public in Ohio. ${ }^{58}$

$\$ 275$. Who may take- When acknowledgment is taken in the state where the land is.-Among the domestic officers (i. e., officers of the state where the land lies) most commonly named in the statutes as qualified to take acknowledgments are notaries public and justices of the peace. Other officials are also designated in most of the statutes; e. g., judges of courts of record, in some states other judges, clerks of courts, registers or recorders of deeds, mayors, etc.; but in practice most acknowledg-

- See Trowbridge v. Addoms, 1897, 23 Colo. 518; 48 Pac. 535.

' Long v. Cockern, 128 Ill. 29 ; 21 N. E. 201.

61 Dunlap v. Henry, 76 Mo. 106.

Clink v. Russell, 58 Mich. 242; 25 N. W. 175.

- State v. Lee, 21 Ohio St. 662. 22-Brews. CoN. 
ments are taken by notaries public and justices of the peace.

In several jurisdictions if a justice of the peace takes an acknowledgment to a conveyance of lands which are in his state, but outside his county, there must be added to his certificate of acknowledgment a further certificate by the clerk of his county that he was at the time of taking the acknowledgment a justice of the peace in that county. ${ }^{54}$

$\S 276$. Who may take - When acknowledgment is taken in another state-The commissioner of deeds.Where the acknowledgment to a conveyance is taken in the United States, but in a state other than that in which the land conveyed is situated, it must be taken before some officer designated by the statutes of the state where the land lies. Otherwise, on the principles stated in Chapter I, the conveyance cannot be recorded in the state where the land lies, nor received in evidence in the courts of that state without further proof.

One of the most useful officers for this purpose is the "commissioner of deeds." The statutes of probably each state authorize the governor to appoint commissioners of deeds for his (the governor's) state resident in every other state; and there may be found in almost every city one or more commissioners of deeds for every state : usually the same person is commissioner for many of the states.

This official is recognized as an officer of the state from which he derives his appointment, ${ }^{65}$ and is authorized, generally, not only to take acknowledgments of conveyances of lands in that state, but to perform other acts; for example, to take depositions for use in that state. Generally speaking, his certificate of his official acts, under his hand and seal, is all that is needed for the authentication of such acts in the state from which he derives his ap-

64 This is so in Colorado, Illinois, North Carolina and Oklahoma.

os Fisk v. Hopping, 1897, 169 Ill. 105, 107; 48 N. E. 323. 
pointment: because he is an officer of that state and his official acts will be recognized there.$^{56}$

The statutes generally require the commissioner to affix his official seal to his certificate, and where this is required its omission is fatal to the validity of the certificate. ${ }^{.77}$ The seal should be one capable of making an impression on the paper, or on a wafer attached to the paper, for if it be wholly or partly written with pen and ink it may be held to be no seal, and the certificate, for this reason, ineffectual. . $^{58}$

$\$ 277$. When taken in another state-Questions as to what officers may take, etc.-Provision is made for the acknowledgment of conveyances in other states before officers other than the commissioner of deeds; and, as a commissioner is not always accessible, such provisions must often be resorted to in practice.

These other officers are not officials of the state where the land lies (as is the commissioner of deeds). Moreover, the forms or essentials of the acknowledgment may differ in the two states.

Hence the questions of practical importance to settle in each case of this kind are:

What are the statutory requirements of the state where the land lies :

(a) Regarding the officers in the other state who may take the acknowledgment?

(b) Regarding the showing, if any, necessary to estab-

68 In at least two states, however (New York and Nebraska), a further certificate from the secretary of state of the appointing state is needed before the commissioner's certificate is effective there: this requirement seems to be unusual. Nebraska Com. Stat. 1901, $\$ 4129$; Omaha Real Est. \&c. Co. v. Kragscow, 1896, 47 Neb. 592 ; 68 N. W. 658; New York Ch., 46 Gen. L., $\$ 260$ (Real Prop. Law); Williamson v. Branning, 1895, 86 Hun 203. See Evans v. Etheridge, 99 N. C. 43 ; 5 S. E. 386.

${ }^{67}$ Buell v. Irwin, 24 Mich. 145.

Oelbermann v. Ide, 1896, 93 Wis. 669; 57 Am. St. 947; 68 N. W. 393; Gage v. Railroad, 11 Iowa 310; 77 Am. Dec. 145. 
lish the official character of the officer taking the acknowledgment?

(c) Regarding the form of the certificate of acknowledgment?

There is much variance among the statutes of the several states on these points.

(a) The officers of the other state who may take the acknowledgment are generally specifically enumerated, and are of the same general character as the domestic officers who may act. But there is often added after their enumeration a general clause that any other officer may take the acknowledgment if he be authorized to take acknowledgments by the law of the state where the act is done, the result being in such cases that a foreign officer may, in some instances, take and certify to a valid acknowledgment when a domestic officer of the same quality could not do so.

$\$ 278$. Taken in another state-Showing as to official character, etc.-(b) Where the acknowledgment is taken in the foreign state it is quite usual to require, before it will be recognized in the state where the land is, another certificate (besides the certificate of acknowledgment) from the clerk of a court of record, or from some other official, duly authenticated by his official seal, stating that the of ficer taking the acknowledgment is the officer he purports to be, is authorized to act, and that his signature to the certificate of acknowledgment is genuine.

Where such requirements exist they must be strictly complied with or the conveyance is no more entitled to record than if not acknowledged. ${ }^{59}$ But it is held that "unless the statute requires evidence of official character to accompany the official act which it authorizes, none is necessary." 60

50 Dohm v. Haskin, 1891, 88 Mich. 144; 50 N. W. 108; Fleschner v. Sumpter, 12 Ore. 161, 167; 6 Pac. 506.

${ }^{60}$ Carpenter v. Dexter, 8 Wall. 513, 531 ; Knight $\nabla$. Leary, 54 Wis. 459,470 ; 11 N. W. 600 . 
This further certificate is generally required where the acknowledgment is taken in the foreign state by a justice of the peace, but it may be necessary in other cases.

The tendency now is to dispense with such a certificate of the official character of the person taking the acknowledgment where the foreign officer uses his regular official seal in certifying to the acknowledgment.

By many statutes, if the official acting is a notary public, who attests his acts with his seal, no other authentication is required. ${ }^{61}$

In such cases the proper practice is to use the form of certificate of acknowledgment used in the state where the land lies. ${ }^{62}$

\$279. Taken in another state-Certificate of conformity to foreign law.-(c) Where the acknowledgment is taken in a state other than that in which the land lies, it is permissible by some statutes to take it in accordance with the law of the place where it is taken. The law of the state, where the land is, adopts for this purpose the foreign law. ${ }^{62 \mathrm{a}}$

In such cases, however, a certificate of conformity to the foreign law is often required from some other official (county clerk, secretary of state, etc.), in addition to the certificate of official character mentioned above. The certificates as to these two matters are usually (and it seems should be) combined in one certificate; though a certificate as to one of these facts alone may be required. In each case it must be ascertained whether the certificate should be as to official character alone, or as to conformity to the foreign law alone, or as to both.

Where, however, the statute of the place where the

" This is so now in Alabama, Colorado, Iowa, Illinois, Indiana, Michigan, Ohio, Pennsylvania, Tennessee, West Virginia, and probably other states.

62 Glos v. Gerrity, 1901, 190 Ill. 545, 546; 60 N. E. 833; Goree v. Wadeworth, 1890, 91 Ala. 416; 8 So. 712.

mee ante, $\$ 9$. 
land lies permits the acknowledgment to be made in conformity with either the foreign law or its own law, the acknowledgment must conform wholly with one or the other, for if it conforms partly with one law and partly with the other it is ineffective. ${ }^{63}$

In all cases where a lawyer sends an instrument outside his state for acknowledgment it is proper and desirable for him to send explicit directions as to how the acknowledgment should be made and taken, and whether or not a further certificate is required, and, if so, its nature.

\$280. Acknowledgments taken out of the United States.-The same principles apply to acknowledgments taken out of the United States as to those taken in other states. The statutes designate the officers: consuls, commercial and diplomatic agents of the United States, notaries public, judges and mayors being usually named.

The officer must be one authorized by the statutes of the state where the land lies to take the acknowledgment in the foreign country. ${ }^{64}$

Importance is attached in such cases to the official seal, and most of the statutes require it. ${ }^{65}$

$\S 281$. Competency of officer affected by interest-Party cannot take acknowledgment.-Besides being competent in the sense that he is one of the officials who may, under the statute, take an acknowledgment, the particu-

Adams v. Bishop, 19 Ill. 395 ; Farrell Co. v. Dart, 26 Conn. 376; Carney v. Hopple, 17 Ohio St. 39. See Kruger v. Walker, 1895, 94 Iowa $506 ; 63$ N. W. 320 .

4t De Segond v. Culver, 10 Ohio 188; McMinn v. O'Connor, 27 Cal. 238; Sartor v. Bolinger, 59 Texas 411.

${ }^{65} \mathrm{It}$ is sometimes provided that the certificate may be in a foreign language, accompanied by a sworn translation; e. g., Mo. R. S. 1899, $\$ 909$, or that, if in a foreign language, the certificate must be accompanied by a further certificate of the United States consul, or other designated officer, stating the meaning of the certificate of acknowledgment; e. g., Ind., Burns' R. S. 1901, § 3357. 
lar officer must not be rendered incompetent to take the acknowledgment by his interest in the transaction.

It is well settled as a general rule that an officer cannot take the acknowledgment of the conveyance to which he is a party or in which he is directly interested.

In a case which is generally cited on this subject in later discussions, ${ }^{66}$ it is said that this rule is based on the fundamental principle that no one can properly be a judge in his own case or an executive officer in his own behalf; and, as it is always within the power of the parties to get a disinterested officer to take the acknowledgment, there is no reason why this fundamental principle should not apply, whether the act of the officer in taking the acknowledgment is regarded as ministerial in its nature, or as judicial, or "semi-judicial." 67

In other decisions the reason given for the rule is that it is contrary to public policy for one interested in the transaction to take an acknowledgment to an instrument to which he is a party. Hence an officer named as grantor cannot take his own acknowledgment so as to entitle the conveyance to record..$^{68}$

And the same principle applies to acknowledgments taken by grantees or mortgagees named in the conveyance. In Amick v. Woodworth ${ }^{69}$ it was contended that, there being nothing on the face of the mortgage other than identity of name to indicate that the mortgagee and notary taking the acknowledgment were the same persons,

es Wilson v. Traer, 20 Iowa 231.

"7 It may be noted that the court is not correct in saying it is always within the power of parties to get a disinterested officer: the only qualified officer may be a party to the instrument. Where this has happened it has been held that an acknowledgment was good though taken before a party, partly because he was the only officer who could take it. Stevenson v. Brasher, $1890,90 \mathrm{Ky} .23 ; 13 \mathrm{~S}$. W. 242. On the other hand, it has been held that the acknowledgment cannot be taken by a party, even though no one else can take it. Hammers v. Dole, 61 Ill. 307.

Leftwich v. Richmond, 1902, 100 Va. 164 ; 40 S. E. 651.

$\oplus 1898,58$ Ohio St. 86 ; 50 N. E. 437. 
the mortgage ought to be entitled to record and have the effect of notice, etc., but it was held that the general rule is that identity of name shows identity of person, and that it is contrary to public policy that a party to a conveyance should take an acknowledgment, even though it appear, as in this case, that he is merely a nominal mortgagee, having practically no substantial interest in the mortgage. ${ }^{70}$

Where, however, the grantor acknowledges a deed before one of several grantees, each one of whom takes under the deed a separate and defined interest, the deed may reasonably be regarded as if made separately to each grantee, and the acknowledgment being good as to all the grantees except the grantee taking it will enable the deed to be read in evidence. ${ }^{71}$

$\S 282$. Practical effect of rule that party cannot take acknowledgment. - The effect of the application of this rule will be that the instrument, so acknowledged before a party to it, will remain valid between the parties in all cases where it would be valid without any acknowledgment; but, as it cannot properly be recorded, its record is not noticed, nor should it be received in evidence without other proof than the certificate of acknowledgment.

When, however, the acknowledgment is essential to the validity of the conveyance, the effect of an acknowledgment before a party would be to render the conveyance invalid ; this seems to follow as a logical conclusion, because there is in such cases really no acknowledgment. Hence where the acknowledgment is necessary to the validity of a conveyance by a married woman, both acknowledgment and conveyance are void if the officer taking the acknowledgment is a party to the conveyance. ${ }^{72}$

7 See also Lee v. Murphy, 1897, 119 Cal. 364 ; 51 Pac. 549, 955; Hunton v. Wood (1903, Va.), 43 S. E. 186.

$n$ Murray v. Tulare Ir. Co., 1898, 120 Cal. 311 ; 49 Pac. 563; 52 Pac. 586.

${ }^{72}$ Rothschild v. Dougher, 1892, 85 Texas $332 ; 20$ S. W. $142 ; 34$ Am. St. R. 811; 16 L. R. A. 719; Tavenner v. Barrett, 21 W. Va. 656, 686 
And in a state where an acknowledgment is essential to the validity of a conveyance of a homestead, a mortgage of the homestead has lately been held absolutely void because the acknowledgment of the mortgagor was taken by the real party interested as mortgagee, though the nominal, ostensible mortgagee was this party's wife. ${ }^{78}$

\$283. Rule disqualifying party generally applies to acknowledgments of all instruments.-This rule that a party cannot take an acknowledgment applies not merely to deeds of real property and ordinary mortgages, but, in general, to all instruments requiring acknowledgment.

Illustrations: The acknowledgment of an assignment of a bond and mortgage by the holder thereof before one of the assignees is a nullity: the instrument though recorded is not legally entitled to record, and the record does not constitute notice of its existence, and one claiming under such assignee is not a bona fide purchaser as against a person to whom the holder had assigned the same bond and mortgage for value by a prior assignment. ${ }^{74} \mathrm{~A}$ chattel mortgage cannot be lawfully acknowledged before a mortgagee-even though he be the only officer who could take the acknowledgment. ${ }^{75} \mathrm{~A}$ trustee under a deed of trust cannot properly take the acknowledgment: the recording of the deed so acknowledged is improper and the record does not impart notice to subsequent purchasers. ${ }^{76}$ And the same result has been held to follow though the trustee taking the acknowledgment did not know at the time that he was named in the trust deed as a party, and refused to accept the trust as soon as he learned that ho was trustee. ${ }^{77}$

7 Hedbloom v. Pierson (Neb. 1902), 90 N. W. 218.

"A rmstrong v. Combs (1897, N. Y.), 15 App. Div. 246.

"Hammers v. Dole, 61 Ill. 307.

- German Am. Bank v. Carondelet, 1899, 150 Mo. 570; 51 8. W. 691.

n Iron Belt Bldg. \&c. Ass'n v. Groves, 1898, 96 Va. 138; 31 S. E. 23. 
$\$ 284$. Effect of relationship on officer's competency.It is his interest in the matter which disqualifies the officer from taking the acknowledgment, therefore, mere relationship, by blood or marriage, to one or both of the parties, is held, generally, not to render him incompetent to act officially. This is especially so wherever the act of taking the acknowledgment is regarded as a ministerial act rather than judicial.

Hence where the grantor was the officer's father, and the grantee the officer's wife, he was held not disqualified. ${ }^{78}$ And an acknowledgment of a mortgage before a brother of the mortgagor, including the privy examination of the mortgagor's wife by the same officer, is beld valid. ${ }^{79}$ But conveyances of married women acknowledged before the husband of the grantee have been held invalid: the reason for this view being, that the act of taking the acknowledgment in such cases, especially where the officer must ascertain whether the woman acts freely, without coercion, etc., is more judicial in its nature than ministerial, and such relationship as would disqualify a judge should disqualify the officer to perform this judicial or quasi-judicial act. ${ }^{80}$

$\$ 285$. Undisclosed interest as affecting competency af officer to take.-The rule that interest disqualifies the officer when it is direct and appears on the face of the instrument, is settled by the great weight of authority, but when the interest is not direct, and when it does not appear on the face of the papers, the questions arising are different, and there is disagreement on some points among the courts.

But inVa. Acts 1901-2, ch.127, after reciting the fact that numerous deeds of trust have been acknowledged before notaries and justices who were trustees in said deeds, validates all such acknowledgments.

${ }^{78}$ Remington Co. v. O'Dougherty, 81 N. Y. 474.

70 McAllister v. Purcell, 1899, 124 N. C. $262 ; 32$ S. E. 715.

${ }^{80}$ Silcock v. Baker, 1901, 25 Texas Civ. App. 508; 61 S. W. 939; Jones v. Porter, 59 Miss. 628. 
The question whether the certifying officer is disqualified frequently arises when he is agent or attorney for one of the parties, when he is a shareholder or officer of a corporation which is a party, or when a partnership, of which he is a member, is a party.

While his interest will vary according as he sustains one or the other of these relations to the parties, the question of general importance in most of such cases is, should an interest, often slight and remote, not disclosed in any way by the instrument or its record, avoid the acknowledgment and make the record no notice, and, in some cases, make void the conveyance?

Some courts hold that an actual interest disqualifies the officer, whether the interest is apparent or not.

Hence, under such a rule, the acknowledgment of a mortgage where a partnership is a party, before one of the partners, although his name does not appear in the firm name, is void ; the mortgage is not entitled to record, and its actual record does not afford constructive notice to a subsequent mortgagee; the latter's mortgage, therefore, taken without actual notice, takes priority over the mortgage so acknowledged and recorded. ${ }^{81}$

A shareholder has an interest in the business and assets of the corporation whose stock he holds, and therefore it has been held that the acknowledgment of an instrument before a shareholder of a corporation which is grantee, mortgagee, or beneficiary under the instrument, is void, and the record of such an instrument affords no notice, ${ }^{82}$ and if the instrument so acknowledged before a shareholder is one of those for whose validity an acknowledgment is essential, as, for example (in many states), the conveyance or incumbrance of a homestead, then the in-

a Bank v. Radtke, 1893, 87 Iowa $363 ; 54$ N. W. 435. Name of the frm in this case was: "City Bank of Boone"-that is, it did not contain the name of the officer taking the acknowledgment.

Smith v. Clark, 1897, 100 Iowa 605; 69 N. W. 1011; Kothe v. KragReynolds Co., 1898, 20 Ind. App. 293; 50 N. E. 594. 
strument acknowledged is invalid, though the interest which disqualifies the officer taking the acknowledgment nowhere appears on its face. ${ }^{83}$

In Ogden Bldg. Ass'n v. Mensch, ${ }^{84}$ a mortgage of a homestead acknowledged before a shareholder in the corporation mortgagee is held inoperative as to the homestead interest or estate, but valid and binding as to all over the homestead estate, when its execution is proved by evidence other than that afforded by the acknowledgment; the opinion further states (at its end) that, as the disqualifying interest of the acknowledging officer was not apparent, the registration and recording of the mortgage was effectual to charge subsequent mortgagees or purchasers with constructive notice. ${ }^{85}$

" Hayes v. Southern Home \&c. Ass'n, 1899, 124 Ala. 663; 26 So. 627; 82 Am. St. R. 216; Bexar Bldg. \&c. Ass'n v. Heady, 1899, 21 Texas C. App. 154 ; 50 S. W. 1079 ; 57 S. W. 583 ; Workman's Mut. Aid A8s'n v. Monroe, 1899 (Texas Ciy. App.) ; 53 S. W. 1029; Wilson v. Griess, 1902, $64 \mathrm{Neb} .792 ; 90 \mathrm{~N}$. W.866. In the last case the conveyance was a mortgage of the homestead, not given, however, directly to the corporation (a bank) whose stockholder was the officer before whom the mortgage was acknowledged, but to another bank. The debt secured was one in which both banks were interested, and that one whose stockholder took the mortgagor's acknowledgment was also owner of stock in the mortgagee. The court considered the stockholder's interest sufficient to diequalify him from taking the acknowledgment and held the mortgage void. since an acknowledgment is essential to the validity of a mortgage of the homestead in Nebraska. But as such a conveyance is not void on its face - the interest of the certifying officer not being apparent-it has been held valid for all purposes until it has been canceled in some direct proceeding brought for the express purpose of having the conveyance adjudged void; Monroe v. Arthur, 1899, 126 Ala. 362; 28 So. 476; $85 \mathrm{Am}$. St. R. 36, and its invalidity cannot be shown in an action of ejectment by the mortgagor against the corporation mortgagee after purchase by the latter at foreclosure sale under the mortgage. National Bldg. \& Loan Ass'n v. Cunningham, 1900, 130 Ala. 539; 30 So. 335.

84 1902, 196 Ill. 554; 63 N. E. 1049 ; 89 Am. St. K. 330. See post, $\S 287, \mathrm{n} .92$.

${ }^{85}$ Thus the acknowledgment in this case is both valid and invalid: which is not as unreasonable as it may perhaps seem, becanse an acknowledgment may exist for more than one purpose in the same state. 
$\$ 286$. Undisclosed interest as affecting competency.On the other hand, an acknowledging officer's interest in the transaction not disclosed on the face of the instrument acknowledged has been considered by other courts as not disqualifying him to take the acknowledgment. Hence a mortgage to one of two executors, acknowledged before the other executor and recorded on the strength of this acknowledgment, is held properly recorded so as to afford constructive notice to one afterward acquiring a lien on the property mortgaged, ${ }^{86}$ and a chattel mortgage to a corporation acknowledged before a notary public who was a shareholder in the corporation, has been held entitled to record so as to afford notice to a subsequent mortgagee. ${ }^{87}$ In neither of these cases was the acknowledgment necessary to the validity of the conveyance: the mortgage in each case was valid as between the parties without an acknowledgment; the question was as to the effect of the record as notice.

But in Cooper v. Hamilton \&c. Ass'n, ${ }^{88}$ a mortgage of a homestead acknowledged before a shareholder in the corporation mortgagee was held valid, though the acknowledgment seems to be, in Tennessee, essential to the validity of such a conveyance. The court regards it as not good practice to have an acknowledgment so taken, but holds that unless the officer's bad faith or improper conduct is shown the acknowledgment should not be held void. ${ }^{88}$

$\$ 287$. Officer of corporation not generally disqualified unless also a shareholder.-While a shareholder's interest has thus of ten been considered sufficient to render him incompetent to take the acknowledgment of a con-

${ }^{26}$ Morrow v. Cole, 1899, 58 N. J. Eq. 203; 42 Atl. 673.

7 Bank of Benson v. Hove, 1890, 45 Minn. 40; 47 N. W. 449.

๓ 1896, 97 Tenn. 285 ; 37 S. W. 12 ; 33 L. R. A. 338; 56 Am. St. R. 795.

${ }^{88 .}$ See Read v. Toledo Loan Co., 1903, 68 Ohio St. 280; 67 N. E. 729. 
veyance to which the corporation is a party, it is generally held that an officer of the corporation (who is not shown to be a shareholder) is not thus incompetent by reason of such connection with the corporation.

This would seem especially to be so where the nature of the officer's act is held to be ministerial rather than judicial, and where the rate of his compensation does not depend on the losses or gains of the corporation..$^{89}$ And even some interest in the particular transaction has been considered insufficient to disqualify him ; as, for example, where the cashier of a bank took the acknowledgment to a mortgage made by his debtor to the bank, the fact that part of the proceeds of the loan was used to pay off the cashier's debt did not give him such an interest in the matter as to invalidate his certificate of acknowledgment. ${ }^{90}$ In Horbach v. Tyrrell, ${ }^{91}$ which involved the question of the validity of a mortgage of a homestead, acknowledged before the secretary and treasurer of the corporation mortgagee, the majority of the court, in holding the mortgage valid, considered it important to determine that the act of the officer in taking the acknowledgment was ministerial merely ; in the dissenting opinion, however, no importance is attached to the determination of the character of the officer's act-whether ministerial or judicial-but it is considered of great importance that in performing an act which is essential to the validity of the conveyance of a homestead, the officer shall be entirely free from temptation to misstate the truth. ${ }^{92}$

Bank of Woodland v. Oberhaus, 1899, 125 Cal. 320; 57 Pac. 1070.

${ }^{90}$ Bardsley v. Bank, 1901, 113 Iowa 216; 84 N. W. 1041.

${ }^{91} 1896,48$ Neb. 514 ; 67 N. W. 485,489 ; 37 L. R. A. 434.

92 Legislation has been considered necessary on this matter in some States, and must be looked for in others, for example:

Illinois. Laws 1903, p. 120, acknowledgments taken by officers and stockholders legalized.

Indiana. Burns' R. S. 1901, $\$ 8041$. No one being an officer in any corporation, bank, or association possessing banking powers, can act as notary public in any business of such corporation, etc.

Pennsylvania. See P. \& L. Dig. 3239, $\$ 5$.

Ohio. R. S., $\$ 111$, am 190 O. L. 119 . Certain officers and agents 
\$288. Agent or attorney of party to a conveyance may generally take acknowledgment.-When the certifying officer is simply agent or attorney for a party interested in the instrument acknowledged, the general rule is that he is not disqualified unless it is shown that he has some beneficial interest in the conveyance, or that the amount of his compensation depends on the making of the conveyance. ${ }^{93}$

$\$ 289$. The parts of the certificate-Venue.-The competent, authorized officer must certify to the acknowledgment in the proper mode.

The purpose of the venue is to show where the official act is done, and that it is done within the territorial jurisdiction of the officer. ${ }^{94}$ For the sake of regularity, and to save all question, this should always appear. ${ }^{86}$ The jurisdiction of the officer taking the acknowledgment is of ten limited to the county (or other territorial district) for which he is appointed, and in such cases especially should the certificate show the county (or district).

A certificate, however, without a venue will not be fatally defective if the place where the acknowledgment was taken appears either from the body of the certificate or (as some cases hold) from the deed read in connection with the certificate. ${ }^{96}$

If the place of acknowledgment cannot be determined from the venue, the body of the certificate, or the instru-

of banks cannot act as notaries in any matter in which the bank is interested.

Minnesota. General Laws 1899, pp. 17, 60, 202. Acknowledgments by officers and stockholders validated and permitted in the future.

North Dakota. R. Co. 1899, $\$ 475 a$-validates acknowledgments taken by officers and stockholders-and see $\$ 3593$ a.

Havemeyer v. Dahn, 1896, 48 Neb. 536; 58 Am. St. 706; 33 L. R. A. 332 ; 67 N. W. 489; Penn v. Garvin, 1892, 56 Ark. 511; 20 S. W. 410.

9 Middlecoff $\nabla$. Hemstreet, 1901, 135 Cal. 173; 67 Pac. 768.

*In re Henschel, 1901, 109 Fed. 861.

* Carpenter v. Dexter, 8 Wall. 513, 528; Beckel v. Pettigrew, 6 Ohio St. 247. 
ment acknowledged, it will generally be considered as fatally defective. ${ }^{97}$ And under some decisions an absence of locality from the certificate will not be remedied by the name of a state and county at the beginning of the deed..$^{98}$

The acknowledgment should be actually taken within the officer's jurisdiction, and the venue should show this correctly, ${ }^{99}$ but if he may act in any part of the state, and no county is named in the venue, the certificate will not be fatally defective. ${ }^{100}$

\$290. Date.-The date should be stated, but while it is desirable that the certificate of acknowledgment should be dated, the omission of a date or the erroneous statement of it will not make the acknowledgment invalid (in the absence of a statute) if it is otherwise good. The true date may be shown as in the case of a deed. ${ }^{1}$

The true date of acknowledgment cannot, of course, be earlier than the true date of execution, but it may be later, and the time is generally immaterial if it be after the execution and before suit brought; and the acknowledgment may be made at different times (and places) by different grantors, in which case there should properly be different certificates.

The statutes of some states require the true date of acknowledgment to be stated, ${ }^{2}$ and in such cases the safe rule to adopt, in order to save all question, is to follow the statute.

A statement in the certificate that the acknowledgment was made on the date of the instrument acknowledged is

9 See Hardin v. Kirk, 49 Ill. 153; Hardin v. Osborne, 60 Ill. 93.

8 Emeric v. Alvarado, 1891, 90 Cal. 444, 462; 27 Pac. 356.

${ }^{*}$ Security Co. v. Payne, 1894, 107 Ala. 578; 18 So. 164.

100 Roussain v. Norton, 1893, 53 Minn. $560 ; 55$ N. W. 747.

' Durfee v. Grinnell, 69 Ill. 371.

2 For example, Mich. Com. L., \$8962; N. Y. R. S., ch. 547, L. 1896, $\S 256$; Pa. B. P. Dig., p. 632. 
enough, ${ }^{3}$ or the date may otherwise appear from the conveyance. 4

\$291. Signing by officer-His official, not his personal signature.-It is generally essential that the certificate be signed by the officer taking the acknowledgment. Irrespective of statutes requiring it, this should be done; and where the statute requires the certificate to be subscribed one not subscribed is ineffective, even if the officer's name appear in the body of the certificate, ${ }^{5}$ or even if it be attested by his official seal. ${ }^{6}$ But as to this particular a substantial compliance with the statute is sufficient.?

The officer's signature should not be merely his personal signature, but his official one, for he is acting, not in a personal capacity, but officially: therefore, he should sign: "A B, Notary Public," and further, if his locality has not already been stated, his signature should be: "A B, Notary Public, X County, Michigan."

It has, indeed, been held that the name of his county is a part of a notary's official signature, and that his certificate without it is not entitled to record, ${ }^{8}$ and the omission of the county is not cured by his seal which contains it, ${ }^{9}$ unless, at least, the body of the certificate sets out that he is a "Notary Public in and for X county," in which case it appears sufficient for him to sign: "A B, Notary Public" or "Notary Public, as aforesaid." 10

3 Abney v. DeLoach, 84 Ala. 393; 4 So. 757.

'Kelly v. Rosenstock, $46 \mathrm{Md} .389$; Dahlam's Est., 1896, $175 \mathrm{~Pa}$. St. $455 ; 34$ Atl. 807 . The relation of the date of the certificate to the date of delivery is referred to above, $\$ 34$.

5 Marston v. Brashaw, 18 Mich. 81; Hout v. Hout, 20 Ohio St. 119.

- Clark v. Wilson, 127 Ill. 449 ; 19 N. E. 860.

' Fisk v. Hopping, 1897, 169 Ill. 105, 107 ; 48 N. E. 323 ; Agan v. Shannon, 1890,103 Mo. 661 ; 15 S. W. 757.

- Greenwood v. Jenswald, 69 Iowa 53; 28 N. W. 433.

- Willard v. Cramer, 36 Iowa 22, 24.

${ }^{20}$ Colby v. McOmber, 71 Iowa 469; 32 N. W. 459. 23-BrEws. Con. 
Abbreviations of official titles, as J. P. and N. P., the meaning of which is well understood, may be used, ${ }^{\mathbf{}}$ but are not in the best form to designate the title.

Where the acting officer is a notary public the laws of several states ${ }^{12}$ provide that he shall add to his certificate a statement of the date upon which his commission as notary expires ("My commission as notary public expires - 190-"). For a neglect to make this statement he is, in some states (e. g., Indiana, Kansas), deemed guilty of a misdemeanor and may be fined: where no such penalty is provided, it would seem that his neglect might result in the loss of his commission. But the omission of this statement should not invalidate the certificate. ${ }^{18}$ Nor should the notary's neglect to state "his place of residence" (which is required in some states) invalidate the certificate: such omissions are not material defects. ${ }^{14}$

\$292. Sealing.-Many statutes require the officer to affi his official seal to his certificate, and where such statutes exist his certificate without such seal is fatally defective..$^{15}$ By such statutes his official seal is meant, not his private seal or "scrawl."16 But where a seal is not required by statute, the absence of one is not serious."

Generally the officers who take acknowledgments are

11 Final v. Backus, 18 Mich. 218; Rowley v. Berrian, 12 Ill. 198.

${ }^{12}$ For example: Colo. Ann. Stat., $\$ 3281$, no penalty; Ind., Acts 1899 , p. 79, Burns' R. S. 1901, $\$ 8039 a-b$, penalty $\$ 25$; Kan., Gen. Stat. 1901 , $\$ 4271-2$, penalty $\$ 100$; Mich., Pub. Acts 1903, No. 18, no penalty ; Mo., R. S. 1899 , § 8835; Pa. Laws 1901, p. 70, no penalty.I 451.

"Kansas City R. Co. v. Railway Co., 1895, 129 Mo. 62, 68; 31 S. W.

16 Griffin v. Catlin, 1901, 25 Wash. 474; 65 Pac. 755; 87 Am. 8t. R. 782.

${ }^{26}$ Grand Rapids v. Hastings, 36 Mich. 122; Pitts v. Seavey, 1893, 88 Iowa 336 ; $55 \mathrm{~N}$. W. 480; Thompson v. Scheid, 39 Minn. 102; 38 N. W. 801.

26 Mason v. Brock, 12 Ill. 273.

${ }^{17}$ Fisk v. Hopping, 1897, 169 Ill. 105 ; 48 N. E. 323. 
those required to have seals (except justices of the peace, who are not generally required to have them), and they should, as a rule, use them. The seal of the notary public is especially important, and judicial notice is generally taken of his seal.

\$293. Impeachment of the certificate-When it is conclusive.-As between the parties to a conveyance a certificate of acknowledgment may be impeached for duress or fraud in procuring it, when the grantee participated in the wrong or knew of it, ${ }^{18}$ and a subsequent grantee having knowledge of the fraud should be in no better position than his grantor. ${ }^{19}$ Moreover, irrespective of fraud on the part of the grantee, or of his knowledge of the fraud or mistake of the officer taking the acknowledgment, it may be shown, in contradiction to the statement contained in the certificate, that the grantor did not, in fact, appear before the officer for the purpose of making the acknowledgment. 20

The evidence, however, to show that the grantor did not appear before the officer and acknowledge the deed as certified must be clear and convincing. ${ }^{21}$

It is permissible, also, to show that a certificate of acknowledgment is a forgery or fabrication. ${ }^{2 n}$

When, however, a grantor has actually appeared before a competent officer to acknowledge the instrument, and the officer attempts to take the acknowledgment, and cer-

10 Fitzgerald v. Fitzgerald, 100 Ill. 385; McCandlese v. Engle, 51 Pa. St. 309.

${ }^{10}$ Ormsby v. Budd, 72 Iowa 80; 33 N. W. 457.

w Michener v. Cavender, $38 \mathrm{~Pa}$. St. 334 ; 80 Am. Dec. 486; Williamson v. Carskadden, 36 Ohio St. 664; Le Mesnager v. Hamilton, 1894, 101 Cal. 532 ; 35 Pac. 1054 ; 40 Am. St. R. 81; Wheelock v. Cavitt, 1898, 91 Texas 679; 45 S. W. 796; 66 Am. St. R. 920; Camp v. Carpenter, 52 Mich. $375 ; 18$ N. W. 113.

${ }^{21}$ Goulet v. Dubreuille, 1901, 84 Minn. 72; 86 N. W. 779; Spivey v. Rose, 1897,120 N. C. 163 ; 26 S. E. 701.

${ }^{22}$ Marden v. Dorthy, 1899, 160 N. Y. 39; 54 N. E. 726; 46 L. R. A. 694. 
tifies to it in regular form, the certificate is generally held conclusive as to those matters to which the officer is required to certify; and parol evidence cannot, therefore, be introduced to impeach the certificate in the absence of fraud known to those claiming under the conveyance. This rule applies, generally, not only to ordinary acknowledgments, but to those made by married women $;^{23}$ although, as in some states the certificate is prima facie evidence only, parol evidence has been held, in them, to be admissible to show, for example, that the deed of a married woman was not explained to her. ${ }^{24}$

$\$ 294$. Form of certificate to conveyance of corporation or by attorney.-The general forms given heretofore ${ }^{240}$ are appropriate to individuals acting in their own right, but where an instrument is acknowledged on behalf of a corporation, or by an attorney under a letter of attorney, the form of the certificate should be varied.

Forms to be used in both these cases are expressly provided in many states, either those known as the "American Bar Association Forms," or others.

Where not provided, the usual form for an individual may be varied to suit the case by remembering that the instrument should be acknowledged as the deed of the principal rather than as that of the agent who acts for him, or as the deed of the corporation rather than that of its officer, or it may better, perhaps, be acknowledged as the deed of both.

For example, in Illinois, no form for the acknowledgment by an attorney in fact being given, the statutory

2 Hitz $\nabla$. Jenks, 123 U. S. 297; Linton v. Nat'l L. Ins. Co., 1900, 104 Fed. R. 584 ; Mut. L. Ins. Co. v. Corey, 1892,135 N. Y. 326; 31 N. E. 1095 ; Am. Freehold \&c. Mort. Co. v. Thornton, 1895, 108 Ala. 258; 19 So. 529; 54 Am. St. R. 148; Council Bluffs Sav'gs Bank v. Smith, 1899, 59 Neb. $90 ; 80$ N. W. 270; 80 Am. St. R. 669.

${ }^{24}$ Mays v. Pryce, 1888, 95 Mo. 603; 8 S. W. 731; Barrett v. Davis, 1891, 104 Mo. 549; 16 S. W. 377; Dodge v. Hollinshead, 6 Minn. 25; 80 Am. Dec. 433 ; see Benedict v. Jones, 1901, 129 N. C. 470; 40 S. E. 221.

24s See supra, $\$ 265$. 
form for the individual may be changed so as to read as follows (and this plan may be adopted in other states where no form is prescribed):

State of - County, $\}$ ss:

I (name and title of officer) do hereby certify that who is personally known to me to be the same person whose name is subscribed to the foregoing instrument, as attorney in fact of the said - appeared before me this day in person, and acknowledged that he, as such attorney in fact, for and on behalf of his said principal, signed, sealed and delivered the said instrument, as the free and voluntary act of himself and of the said - his said principal, for the uses and purposes therein set forth (including the release and waiver of the right of homestead).

Given under my hand and - seal, this - day of - A. D. 19-. (Signature and title of officer.)

[Seal.]

Or for a corporation, the form for an individual may be changed to read:

$\left.\begin{array}{l}\text { State of }-, \\ \text { County of }-,\end{array}\right\}$ ss:

I (name and title of officer) do hereby certify that-, president, and - , secretary of the - company, who are personally known to me to be such officers and to be the same persons whose names are subscribed to the foregoing instrument, appeared before me this day in person, and severally acknowledged that as such president and secretary they signed and delivered the said instrument, and caused the corporate seal of said company to be affixed thereto pursuant to authority given by the board of - of said company, as their free and voluntary act and as the free and voluntary act of said company for the uses and purposes therein set forth.

Given under my hand and - seal this - day of - 19-.

[Seal.]

(Signature and title of officer.)

Or in Indiana, for example, where the acknowledgment for the individual is simpler than in some states 
the acknowledgment in these cases may be simpler. ${ }^{25}$ For a corporation there it may be much shorter than in many states; for example:

\section{(Caption.)}

Personally appeared before me (name and title of officer) this - day of,$- 19-$, A B, president of the (name of corporation), and S P, secretary of (name of corporation), and $A B$, as such president, and $S P$, as such secretary, and on behalf of said (corporation) acknowledged the execution of the annexed deed.

Witness my hand and seal of office this - day, etc. [Seal.]

(Signature and title of officer.)

In many states, however, the certificate in the case of acknowledgment by a corporation sets forth that the offcers of the corporation are sworn, etc. ${ }^{26}$

$\$ 295$. Proof instead of acknowledgment.-It is permitted in most of the states to prove deeds as well as to acknowledge them.

The general objects of the proof are the same as those of the acknowledgment.

Where proof is made one (or more) of the witnesses to the conveyance makes oath, before a duly authorized officer, that the grantor executed the instrument in the presence of affiant (and of the other witnesses generally), and the officer makes a certificate of this oath on the conveyance as a certificate of acknowledgment is made, and the conveyance, with the certificate, is recorded.

The same general principles apply to proof as to acknowledgment; no substantial departure from the statutory requirements is permissible. ${ }^{27}$ 203.

25 For acknowledgment by attorney, see Butterfield v. Beal, 3 Ind.

* For example, N. Y. R. S., ch. 547, L. 1896, § 258; also Am. Bar Ass'n forms used in Iowa, Massachusetts, Minnesota, Michigan, Missouri, to be found in the statutes; formerly so by usage in Pennsylvania, but see a simple form in Pennsylvania Laws 1901, p. 171.

${ }^{27}$ Irving v. Camphell, 1890, 121 N. Y. 353; 24 N. E. 821. 
It is better, generally, to have the conveyance acknowledged than proved; and in some states "proof" can be made only when the grantor has died, or cannot be found, or refuses to acknowledge, a statutory preference being thus shown for the acknowledgment. 


\title{
CHAPTER XIX.
}

\author{
DELIVERY
}

$\S 296$. Delivery essential to a deed and to the transfer of title.

297. Exception to rule that delivery is essential.

298. Elements of delivery-Surrender of control by the grantor.

299. Elements - The intent of the grantor.

300. Acceptance presumed until dissent is shown.

301. Acceptance by the grantee.

302. If acceptance is prevented there is generally no delivery.

303. Presumption of delivery from certain facts.
§304. Presumption of deliveryRecording.

305. Postponing complete delivery till death of grantor.

306. Effect of grantor's retention of possession and control of the deed.

307. Effect of grantor's depositing deed with a third person: reserving no control.

308. Effect of reserving control by grantor in such cases.

309. Delivery in escrow.

310. Effect of grantee's obtaining possession of escrow wrongfully.

311. Effect of surrender or destruction of a deed.

\$296. Delivery essential to a deed and to the transfer of title.-Always prominent in every definition or description-ancient or modern-of a deed is the idea of delivery. Assuming that the instrument is complete in substance, and that all formalities which may be regarded as representing sealing at common law are complied with, the instrument is not in a legal sense a deed, does not fulfill the meaning of its old name factum, a thing done, until it is delivered. The purpose of making the instrument has been to transfer title, and while popularly we may properly apply the term deed to the written instrument, and while in legal discussions we must often refer to this paper as a "deed," yet, strictly speaking, there is (360) 
no deed until the sealed writing is delivered. As on delivery of the conveyance the grantor is divested of title and the grantee is invested with it; as the former has, after delivery, no title in the property described in the deed which he may dispose of, or which may be taken by his creditors, or which will descend to his heirs; while the latter has title which cannot-generally speakingbe lost by a destruction or surrender of the deed, it is important in each case to determine whether there has been a delivery, and, further, at what time the delivery was complete,

That the subject is worthy of attention and is not free from difficulties, is demonstrated by the frequency of suits in which the chief, and often the only, question is as to delivery. The cause of difficulties in determining whether there has been a delivery is that it is not always accomplished by the simple manual transfer of the instrument from the grantor directly to the grantee, but may be accomplished in a great variety of ways-sometimes without a direct manual transfer between the parties, and sometimes without an actual transfer of the instrument at all. It is largely a matter of intention, which is to be ascertained from all the various circumstances of each case.

$\$ 297$. Exception to rule that delivery is essential.-To the general rule that delivery of the conveyance is necessary to a transfer of title there is an exception, which may be noted at the outset, namely: that conveyances by the government may transfer title without delivery of the patent or deed.

When a patent of government lands has been executed and recorded in the land office, it has become a solemn act of the government. Title to the land passes to the grantee by the record. The reason for the difference in this respect between public and private grants is indicated by the supreme court of the United States, in a 
case $^{1}$ where one contention was that a patent purporting to convey land of the United States was not effectual for that purpose for want of delivery, but the court distinguishes the public grant from the private grant, saying: "The importance attached to the delivery of the deed in modern conveyances arises largely from the fact that the deed has taken the place of the ancient livery of seisin in feudal times, when, in order to give effect to the enfeoffment of the new tenant the act of delivering possession in a public and notorious manner was the essential evidence of the investiture of the title to the land;" and then mentions the symbolical acts which took the place of the livery of seisin, followed later by the delivery of the deed, and shows that in transfers of title by matter of record, whether the record was a judgment or decree of a court, as a fine or a recovery, or the record made of the king's grant, neither livery of seisin was necessary, nor a delivery of the document sealed with the king's seal. ${ }^{2}$

\$298. Elements of delivery-Surrender of control by the grantor.-Delivery is, however, as essential to the deed of a private person as livery of seisin ever was under the older law to transfer title.

Delivery practically signifies, according to many modern authorities, not merely the act evidencing the intention of the grantor alone in liberating the instrument from his control. According to them there must be, to effect a complete delivery, an acceptance by the grantee of the instrument into his control; therefore, the conception of the term "delivery" embraces two distinct ideas : surrender by one, and acceptance by the other.

While it will appear ${ }^{3}$ that the authorities are not en-

1 United States v. Schurz, 102 U. S. 378, 398.

2 See also Gilmore v. Sapp, 100 Ill. 297; Leroy v. Jamison, 3 Sawyer 369, 390; Alvarado v. Nordholdt, 1892, 95 Cal. 116, 128; 30 Pac. 211.

'See $\$ \$ 300,301$, post. 
tirely in accord as to the necessity of acceptance as an element of delivery, all agree that the first essential of a valid delivery is that the grantor surrender control of the deed with intent that the grantee shall take title under it.

Surrender does not necessarily and always mean the actual, physical giving up of possession of the instrument; hence it is not always the case that a deed retained in the grantor's hands is invalid for want of delivery. There may be such attendant circumstances as, for example, relationship of grantor to grantee, or other acts of the grantor besides the mere signing and sealing of the deed, as to show that the title is beyond his control, though the deed is retained in his possession.

For example, in a case, the question was as to the ownership of real property which had been insured and had burned, and the settlement of this question depended upon whether there had been delivery of a deed from husband to wife. The husband, the grantor, did not give the deed to his wife, but after recording it kept it in his possession. It was decided that there was enough evidence to warrant the jury's finding of delivery; the court observing that " manual delivery is not always necessary."

This would especially be so in case of a conveyance from husband to wife, where the husband is the custodian of the wife's papers and manager of her property, either by arrangement between them in the particular case, or by the general policy of the law of the place. ${ }^{5}$ So, in the very common case of a parent's making a conveyance of land to his children and retaining possession of the deed, it is usually held that there has been a sufficient surrender of the deed by the parent, though there may have been no permanent transfer of possession of the deed. ${ }^{6}$

'Glaze v. Insurance Co., 1891, 87 Mich. 349; 49 N. W. 595.

6 Brown v. Brown, 61 Texas 56 ; Ruckman v. Ruckman, 32 N. J. Eq. $259,261$.

- Reed v. Douthit, 62 Ill. 348; Valter v. Blavka, 1902, 195 Ill. 610; 63 
Nor is relationship between the parties necessary in all cases for the application of this principle. In a Massachusetts case ${ }^{7}$ the deed purported to convey to a town a lot on condition that a library building be erected on it. The deed had been recorded, but appears to have been kept by the grantor, and after his death was found among his effects, and there was no evidence of its surrender to the town authorities : but the town had erected the building. It was held there was evidence of delivery which was not overcome by the facts that the deed was kept by the grantor and that the town authorities had no knowledge of its actual delivery. ${ }^{8}$

\$ 299. Elements-The intent of the grantor.-This surrender of control must be with the intent that the grantee is to take title. Hence the mere placing of the instrument in the hands of the person named as grantee is not necessarily such surrender as will constitute the first essential of delivery.

In Wisconsin ${ }^{9}$ it was argued that as the deed was handed by the grantor to the grantee there was a full and complete delivery, and that evidence was not admissible to show the actual condition then existing. The court says : "No doubt a great deal of discussion and unnecessary refinement may be found in the books bearing on this question; but the main principle must predominate, that, to constitute a valid delivery of the deed, the grantor must part with his dominion over it with intent to pass the title." And as here the deed was handed to the grantee for the purpose of examination and inspec-

N. F. 499; Colee v. Colee, 122 Ind. 109; 23 N. E. 687; 17 Am. St. R. :.1.); Reed v. Smith, 1899, 125 Cal. 491; 58 Pac. 139 ; Bunnell v. Bunnell, 1901, $23 \mathrm{Ky}$. Law R. 800; 64 S. W. 420.

' Snow v. Orleans, 126 Mass. 453.

'See also Wallace v. Berdell, 97 N. Y. 13; Scrugham v. Wood, 15 Wend. 545.

${ }^{9}$ Curry v. Colburn, 1898, 99 Wis. $319 ; 74$ N. W. $778 ; 67$ Am. St. Rep. 860. 
tion, and that he might take it to his counsel for such examination, there was no delivery. ${ }^{10}$

And the execution and recording of a deed by a husband to his wife may be shown by him to have been done without intent on his part to convey title, but simply to relieve his wife's insane anxiety and fear of destitution." As the intent of the grantor is of such importance, a transferring of the deed from the grantor's possession to that of the grantee, without the former's consent, conveys no title; such a deed has been said to be of no more effect than if it were a forgery. ${ }^{12}$ And if a stolen deed has been recorded, or is otherwise a cloud on the title of a grantor, it may be canceled upon his bringing suit for that purpose. ${ }^{13}$

This intent being of such vital importance, it is frequently said that the intention of the grantor is "the controlling element."14 But a mere intent on the part of the grantor not evidenced by some act which the law deems sufficient to show that he parted with control is not enough, because the first actual step in making delivery is lacking, that is, surrender or the relinquishment of control. This principle is applied chiefly in those numerous cases where a grantor evidently intends his conveyance to take effect as a deed after his death, yet does

${ }^{10}$ See S. P.-Chick v. Sisgon, 1893, 95 Mich. 412; 54 N. W. 895 ; Hollenbeck v. Hollenbeck, 1900, 185 Ill. 101, 103 ; 57 N. E. 36; Kenney v. Parks, 1902, 137 Cal. 527; 70 Pac. 556.

"McCartney v. McCartney, 1900, 93 Texas 359; 55 S. W. 310.

22 Felix v. Patrick, 1892, 145 U. S. 317, 329; Fitzgerald v. Goff, 99 Ind. 28, 40.

${ }^{13}$ Maratta v. Anderson, 1898, $172 \mathrm{Ill} .377 ; 50 \mathrm{~N}$. E. 103. In Meeks v. Stillwell, 1896, 54 Ohio St. $541 ; 44$ N. E. 267, husband and wife were in possession of a homestead the title to which was in the wife; they joined in a deed of gift, but with the intention of not delivering it until after the death of both. The wife, however, during the lifetime of her husband attempted to deliver the deed without his knowledge and consent, and it was held that his right in the homestead could not be affected by the deed.

${ }^{16}$ E. g., Leavitt v. Leavitt, 1899, 179 Ill. 87, 90; 53 N. E. 551. 
not in all cases completely surrender control of it: a matter to be discussed presently. ${ }^{15}$

$\$ 300$. Acceptance presumed until dissent is shown.The question as to whether or not there must be an acceptance by the grantee in order that there may be a transmission of title involves difficulties.

It seems true that "the law certainly is not so absurd as to force a man to take an estate against his will"; 16 he cannot, therefore, be compelled to accept a conveyance. On the other hand, experience has show'n that, as a rule, men do not decline to accept an ordinary conveyance which gives title to property.

If, then, a grantor executes a conveyance without the knowledge of the nominal grantee, and puts the conveyance out of his control, has the title to the property described passed from the grantor? May the grantee then decline to accept the conveyance, and if so, does the title pass back to the grantor? Who has the title in the meantimo-that is, after the grantor has surrendered all control of the conveyance and before the nominal grantee has declined to accept it? If during this interval third persons acquire apparent interests in the property-for example, creditors of either party to the deed-what becomes of these apparent interests?

It seems to have been established by English decisions that: (a) a conveyance of real property will be presumed to have been accepted by the person named as grantee, even though he was ignorant of the fact of the conveyance; but that (b) the nominal grantee may, on learning of the conveyance, decline to accept it. The grantee's dissent was called a " disclaimer;" and at one time a deed seems to have been necessary to make the disclaimer effectual, but by modern decisions there may be a valid

${ }^{15}$ See post, $\S 306,307$.

${ }^{16}$ Abbott, C. J., in Townson v. Tickell, 3 Barn. \& Ald. 31, 36. 
disclaimer by conduct alone. ${ }^{1 i}$ The matter was discussed in Butler and Baker's Case, ${ }^{18}$ where it is said: "If $\mathrm{A}$ make an obligation to $B$ and deliver it to $C$, to the use of $\mathrm{B}$, this is the deed of A presently. But if $\mathrm{C}$ offer it to $\mathrm{B}$, then $B$ may refuse it in pais, and thereby the obligation will lose its force." And see the later cases of Smith v. Wheeler ${ }^{19}$ and Thompson v. Leach. ${ }^{20}$ The argument of Justice Ventris in the latter case, which argument he says was adopted by the house of lords in finally deciding the case on appeal, ${ }^{21}$ appears to have been the chief authority for later decisions.

It has accordingly been held in many cases that when the grantor has parted with control of the deed the delivery is complete and no acceptance by the grantee need be shown, nor even his knowledge of the deed, for its acceptance by him will be conclusively presumed until his express dissent is shown. ${ }^{22}$

\$ 301. Acceptance by the grantee.-On the other hand, it is held that there must be acceptance by the grantee to complete "delivery."

In a Massachusetts case ${ }^{23}$ a charge that "If, after signing the deed, the grantor placed it upon the table, or placed it in M's hands with the intention that it should become effective and operative, then there was a good delivery of

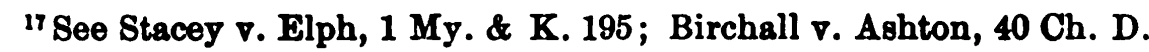
437, 439.

18 Butler and Baker's Case, 3 Co. Rep. 26 (1591).

19 Smith v. Wheeler, 1 Ventris, 128 (1671).

${ }^{20}$ Thompson v. Leach, 2 Ventris, 198 (1690).

$n$ Thompson v. Leach, 2 Ventris 208.

2 Robbins v. Rascoe, 1897, 120 N. C. 79 ; 26 S. E, 807 ; 58 Am. St. R. 774 ; Mitchell's Lessee v. Ryan, 3 Ohio St. 377; Jones v. Swayze, 42 N. J. L. 279; Guggenheimer v. Lockridge, 1894, 39 W. Va. 457, 461; 19 S. E. 874. The theory that title can pass from the nominal grantor without the knowledge or consent of the nominal grantee is assailed in an interesting and forcible opinion by Dixon, C. J., in Welch v. Sackett, 12 Wis. 270.

Meigs v. Dexter, 1898, 172 Mass. 217; 52 N. E. 75. 
the deed," was held to be erroneous, as M was merely the scrivener, not representing the grantee in any way, and he simply left the deed on the table. The court considers it settled that an acceptance is necessary, and that it must be either by the grantee or by some one representing him, or by some one assuming to represent him, whose act of acceptance is afterward ratified. ${ }^{24}$

Stronger evidence is required to show acceptance in some cases than in others, and it is essential in many cases to show an express acceptance.

Such would generally be the rule where, by the terms of the deed, some obligation or burden is imposed on the grantee, as, for example, the assumption of personal liability for a mortgage. ${ }^{25}$ In such cases an express acceptance may be by word, or by exercising acts of ownership in accordance with the deed, as by the grantee's selling the land conveyed. But it is evident that what might be acceptance in some other cases cannot amount to acceptance in such cases. A deed, for example, containing an assumption of a mortgage recorded by the agent of the grantor could not estop the grantee from disputing his acceptance of the deed as against a purchaser who had relied on the record. ${ }^{26}$

But if the grantee in such a deed has disposed of the land conveyed to him by the deed, or otherwise exercised acts of ownership over it, he cannot deny his acceptance when an obligation imposed upon him by the deed is sought to be enforced. ${ }^{27}$

On the other hand, the law often supplies the evidence of acceptance by a presumption, where the conveyance is clearly beneficial, or at least not prejudicial to the grantee,

* Dagley v. Black, 1902, 197 Ill. 53; 64 N. E. 275.

${ }^{25}$ Blass v. Terry, 1898, 156 N. Y. 122; 50 N. E. 953; Kellogg v. Cook, 1898, 18 Wash. 516; 52 Pac. 233.

${ }^{28}$ Hare v. Murphy, 60 Neb. $135 ; 82$ N. W. 312 . Same case, on a former appeal, 45 Neb. 809 ; 29 L. R. A. $851 ; 64$ N. W. 211.

${ }^{27}$ Beeson v. Green, 1897, 103 Iowa 406; 72 N. W. 555. 
and the grantee is not sui juris. In such cases a delivery to the parent or guardian of the grantee is generally considered a delivery. For example, a woman, in order to put her land beyond the reach of her former husband, signed and acknowledged a deed conveying it to her children, all of whom, with one exception, were infants, and retained the deed in her possession after recording it. ${ }^{28}$ The court says, substantially, that making a voluntary conveyance, absolute in form and beneficial in effect, by a parent to one who is not sui juris and placing it upon record, although possibly not effectual, without more, between adults, is deemed to evince an unmistakable intention to give to the deed effect, and pass title, and the assent of the grantee, if nothing further appears, is presumed from the beneficial character of the transaction. ${ }^{29}$

$\$ 302$. If acceptance is prevented there is generally no delivery.-While slight evidence only is needed to show acceptance in many cases, and while there will be a presumption of it in certain others, it cannot be found as a fact, even where the conveyance is clearly beneficial, when there has been a direct declination of the deed. For example, in Nicholl's Appeal, ${ }^{30}$ the proceeding was to restore

" Colee v. Colee, 122 Ind. 109; 23 N. E. 687 ; 17 Am. St. R. 345. There had been a divorce, though the report of this case does not show it.

${ }^{20}$ See Hall v. Cardell, 1900, 111 Iowa 206; 82 N. W. 503 . In this case the grantee was an infant but a few weeks old. Although, as the court saya, the deed may not have been actually beneficial to such a young child, yet, as it was not prejudicial, acceptance may be properly presumed. Rhea v. Bagley, 1897, 63 Ark. 374 ; 38 S. W. 1039; 36 L. R. A. 86; Arrington $\nabla$. Arrington, 1898, 122 Ala. 510; 26 So. 152; Winterbottom v. Patterson, 1894, 152 Ill. 334 ; 38 N. E. 1050; Hall v. Hall, 1891, 107 Mo. 101, 108; 17 S. W. 811; Compton v. Church, 1891, 86 Mich. 33; $48 \mathrm{~N}$. W. 635. But the mere making of a convey ance by a father for the benefit of his children, without recording it or mentioning it, has been considered as not evidence of delivery when taken in connection with his continued dominion over the property and possession of the deed. Cazassa v. Cazassa, 1893, 92 Tenn. 573; 22 8. W. 560; 36 Am. 8t. R. 112; 20 L. R. A. 178.

${ }^{\infty} 1899,190$ Pa. St. 308; 42 Atl. 692.

24-Brews. Con. 
what was called a "lost deed." A father had made and sealed a conveyance and handed it to his son, who declined it, simply saying to his father to keep it and all he had as long as he lived. The court remarks that as a result of this "filial suggestion" the case has to deal, not with a lost deed, but with an undelivered deed, which is no deed at all: it was undelivered and inoperative, because it was tendered and refused..$^{31}$ Hence also, in those states where acceptance is considered necessary to complete "delivery," if before acceptance something happens, other than express declination, to prevent it, there is no delivery. For example, if the grantee die before acceptance his heir cannot accept the deed so as to make the delivery complete. ${ }^{82}$ Or, if before acceptance of the conveyance by the grantee, the grantor recalls the deed, there is no delivery..$^{83}$ Nor is there if before acceptance the grantor conveys the land to some one else. ${ }^{\text {s }}$ So a lien placed upon the land before assent is given by the grantee will take precedence of the deed. The lien may be by an act of the grantor; for example, a mortgage given by him,, or by an act of a third party, as a creditor acquiring a lien by judgment. ${ }^{86}$

However, surrender and acceptance need not be concurrent aots, and, generally, where nothing happens to prevent acceptance, it may be made, it appears, at any time after the grantor's surrender. The grantee's acceptance will relate back to the grantor's surrender. The time between the two may be longer or shorter, and its length ap-

\footnotetext{
a See Spencer v. Spruell, 1902, 196 Ill. 119; 63 N. E. 621.

s2 Jackson v. Phipps, 12 Johns. 418, 422 ; McElroy v. Hiner, 1890, 133 Ill. $156 ; 24$ N. E. 435.

* O'Connor v. O’Connor, 1896, 100 Iowa 476; 69 N. W. 676.

น'Hawkes v. Pike, 105 Mass. 560.

${ }^{36}$ Parmelee v. Simpson, 5 Wall. 81.

36 Woodbury v. Fisher, 20 Ind. 387; 83 Am. D. 325; Cravens v. Ros өiter, 1893, 116 Mo. 338; 22 S. W. 736; 38 Am. St. R. 606.
} 
pears to be immaterial, so long as the rights of third parties have not intervened. ${ }^{37}$

$\S 303$. Presumption of delivery from certain factsPossession of deed.-If the essential elements of "delivery" exist, it is evident that they may be shown in almost innumerable ways. The discussion at length, therefore, of the question whether a particular fact constitutes delivery, would seem to be unprofitable, because the correct answer to such a question must depend upon what the other facts are that accompany the fact in question. There are, however, certain facts and circumstances which, if found in a particular case, give rise to presumptions of importance in settling the question of delivery.

For example, the possession of a regularly executed deed by the grantee named in it, or by one holding under him, is prima facie evidence of its delivery. ${ }^{88}$ And it has been said of such a circumstance " that only clear and convincing evidence can overcome the presumption, otherwise titles could be easily defeated, and no one could be regarded as being secure in the ownership of land." Plainly, however, it is not prudent to rely entirely on the nominal grantee's possession of the deed as evidence of his ownership: he may have possession when there has been no valid delivery, ${ }^{, 0}$ and a person dealing with him as owner in perfect good faith may be the loser-a principle well illustrated by a recent case..$^{11}$

"See Dettmer จ. Behrens, 1898, 106 Iowa 585; 76 N. W. 853.

* Butrick v. Tilton, 141 Mass. 93; 6 N. E. 563; Ward v. Dougherty, 75 Cal. 240; 17 Pac. 673 ; 7 Am. St. R. 151; Inman v. Swearingen, 1902, 198 Ill. 437; 64 N. E. 1112; McGee v. Allison, 1895, 94 Iowa 527; 63 N. W. 322 ; Hathaway v. Cass, 1901, 84 Minn. 192; 87 N. W. 610; Swank v. Swank, 1900, 37 Ore. 439; 61 Pac. 846.

* Tunisop v. Chamblin, 88 Ill. 379.

${ }^{\circ}$ Barron v. Mercure (Mich. 1903), 93 N. W. 1071; 9 Detroit Leg. News 671.

a Cameron v. Gray, $202 \mathrm{~Pa}$. St. 566. See also cases cited in $\$ \$ 306$ and 310. 
\$304. Presumption of delivery-Recording.-As to what effect is to be given to the recording of a deed, and to what extent it is evidence of delivery, there is some conflict of opinion.

The general rule, however, appears to be that the recording of a deed is prima facie evidence of delivery, but is not conclusive, and the presumption arising from recording may be rebutted, either by direct evidence or by the circumstances under which the recording was done. ${ }^{42}$

In states where acceptance by the grantee or knowledge by him of the deed need not be shown, the recording of the deed by direction of the grantor would place the title beyond his control so that he could not thereafter change his mind and defeat the title of the grantee by resuming possession of the deed, even though the grantee knew nothing of it till after the attempted recall by the grantor. ${ }^{33}$ On the other hand, where a deed has been recorded by the grantor, without the grantee's knowledge or assent, the recording has been considered simply as some evidence of delivery to be regarded with other evidence of accompanying facts or later circumstances, such as possession and control of the deed or the property. ${ }^{4}$ Though if the grantor, with the knowledge and consent of the grantee, records the deeds with intent to divest himself of title he will be concluded by the delivery thus shown. ${ }^{45}$

\footnotetext{
42 Jourdan v. Patterson, 1894, 102 Mich. 602; 61 N. W. 64 ; Holmes v. McDonald, 1899, 119 Mich. 563; 78 N.W.647; 5 Detroit Leg. News 914; Sullivan v. Eddy, 1894, 154 Ill. 199, 208; 40 N. E. 482; Bush v. Genther, 1896, 174 Pa. St. 154 ; 34 Atl. 520; Sweetland v. Buell, 1900, 164 N. Y. 541, 552; 58 N. E. 663 ; Koppelmann v. Koppelmann, 1900, 94 Texas 40; 57 8. W. 570; Smith v. Smith 1903, 116 Wis. 570; 93 N. W. 452.

Robbins v. Rascoe, 1897,120 N. C. 79 ; 26 S. E. 807 ; 58 Am. St. R. 774.

4 Cravens v. Rossiter, 1893, 116 Mo. 338; 22 S. W. 736 ; 38 Am. St. R. 606; O'Connor v. O'Connor, 1896, 100 Iowa 476;69 N. W. 676; Davis v. Davis, 1894, 92 Iowa 147 ; 60 N. W. 507; Weber v. Christen, 121 Ill. 91; 11 N. E. 893 ; 2 Am. St. R. 68.

${ }^{4}$ Brady v. Huber, 1900, 197 Ill. 291 ; 64 N. E. 264.
} 
The doctrine of some courts is that the mere recording of a deed by direction of the grantor without some other act or declaration manifesting his intent to deliver the deed, is not evidence of delivery, ${ }^{46}$ though the grantor actually intended, when he had the deed recorded, to pass the title to the land described in the deed to the grantee..$^{47}$

The general rule being that the record of a deed is but some evidence of delivery, often overcome by circumstances which are not matters of record, it is evident that the popular conception of the value of a "record title" is not well founded in law, and that the record really is of but slight assistance in establishing a fact relating to the title which is of vital importance: that is, delivery. This is one feature of our present system which is recognized as furnishing ground for some such reform as the socalled "Torrens System," under which it is claimed that the disadvantages resulting from the failure of our records to really show the title, in this and in other ways, will be lessened if not wholly removed.

$\S 305$. Postponing complete delivery till death of grantor.-Among the most difficult cases in which the question of delivery is involved are those where a grantor wishes to postpone till his death the complete effect of a deed. In such cases disappointed heirs of ten claim that

6 Egan v. Horrigan, 1901, 96 Maine 46; 51 Atl. 246.

47 Barnes v. Barnes, 1894, 161 Mass. 381 ; 37 N. E. 379. The court says in this case: "If the question were a new one there would perhaps be nothing difficult or impracticable in the conception that the act of leaving a deed with the register for record by the grantor, with the intent on his part thereby to vest the title in the grantee, should constitute the register the agent for delivery of the grantee, and that upon the assent of the grantee the transaction should take effect as a valid delivery. But we think the law is otherwise in this state." It is, however, now provided by statute in Massachusetts that the record of a deed duly acknowledged, etc., "shall be conclusive evidence of the delivery of such instrument, in favor of purchasers for value without notice, claiming thereunder." Mass. R. L. 1902, C. 127, §5. 
the deed is ineffectual for want of delivery, and while the purpose of the grantor may have been the avoidance of a contest over his will, had he made one, or the saving of the expense of administration, the result of ten is very different from what he intended, for the litigation and expense are increased, rather than diminished, by his conduct. Grantors in such cases might generally accomplish what they appear to desire by making conveyances reserving to themselves life estates in the property conveyed, and delivering the conveyance to the grantee, but, for one reason or another, this course is often not pursued.

Cases in which the grantor wishes and attempts to postpone the taking effect of his conveyance until his death may be grouped into two general classes:

1. Those in which the grantor himself retains possession of the deed, still with the intention that after his death it shall come into the grantee's possession.

2. Those in which the conveyance is deposited by the grantor with a person other than the grantee, to be finally delivered to the grantee after the grantor's death.

$\S 306$. Effect of grantor's retention of possession and control of the deed.-As to the first general class of cases, namely, those where the grantor signs, seals and acknowledges a deed, but retains possession and control of it, nevertheless plainly intending that it shall come into the grantee's control after the grantor's death, the general rule is that there has been no valid delivery, even though the grantor has left directions-written or otherwise-clearly showing his intention that the grantee is to have the deed.

The grantor in such a case has not taken the first step essential to delivery - that of surrendering control of the deed. When it is said that the grantor's intention is controlling, it must be meant not his intention merely that the grantee shall some time possess the land, but his in- 
tention that the deed shall be delivered in his lifetime, and that the grantee shall thereby finally possess the land. For, so far as the grantor is concerned, the delivery must be complete in his lifetime. He must therefore lose control of the deed.

Hence, the grantor's giving the grantee a key to his safety deposit box, with directions to get the grantor's will in case of his death, will not amount to the delivery of a deed found in the box with the will after the grantor's death; though the deed is in an envelope addressed to the grantee, which also contains written directions for the recording of the deed by the grantee on opening the envelope. ${ }^{18}$ Nor will a deposit by the grantor of a deed among the grantee's papers, of which the grantor has charge, the grantor intending the deed to come into the grantee's possession on his death, constitute a delivery..$^{49}$

The practical application of these principles will often result in loss to a person who has purchased land relying on the record title. For example, a deed was kept in the possession of the grantor, but with written directions for recording it and handing it to the grantee after the grantor's death: the grantee, having received the deed after the grantor's death and having had it recorded, afterward sold the land described in it to a bona fide purchaser : in this action by the heirs of the deceased grantor it was held that there had been no delivery of the deed and that therefore the deed was wholly void, and that the subsequent bona fide purchaser acquired no title as against the heirs of the grantor. ${ }^{50}$

In such cases the fact that the deed is found in the maker's possession is not enough of itself to settle the question of delivery; the mere fact that the grantor re-

48 Hawes v. Hawes, 1899, 177 Ill. 409; 53 N. E. 78. See also Taft v. Taft, 59 Mich. 185; 26 N. W. 426; 60 Am. R. 291; Parrott v. Avery, 1893, 159 Mass. 594 ; 35 N. E. 94 ; 38 Am. St. R. 465.

9 Van Dyke v. Grigsby, 1898. 11 S. Dak. 30; 75 N. W. 274.

${ }^{\infty}$ Stone v. French, 37 Kan. 145; 14 Pac. 530; 1 Am. St. R. 237. 
tains the deed in his own possession and under his control does not prevent its being enforced as a deed, if he has once effectually delivered it.

Even, however, in those cases where strong presumptions in favor of delivery are made (as where parents make deeds to children, but retain possession of the deeds), there must generally be something more-in order to constitute delivery-than the signing, sealing and acknowledging of the instrument, which is then retained by the grantor; and where delivery is found in such cases it will generally be because some other fact exists besides the mere making of the instrument-as, for example, recording with an expression of intention to make a present delivery. ${ }^{51}$

$\$ 307$. Effect of grantor's depositing deed with a third person: reserving no control.-The second class of cases mentioned $^{51}$ may include cases in which the grantor, though handing the deed to a third person, yet reserves control over it, as well as cases in which he reserves no control over the deed after parting with its possession.

Where the grantor deposits with a third person the deed as his present deed, directing the depositary to deliver it to the grantee at the grantor's death, and reserves no control over it, nor right to recall it, there is a valid delivery. There is a delivery, that is, so far as the grantor is concerned-he has surrendered control of the deed with intent that title shall pass to the grantee. The deed becomes operative when it finally is accepted by the grantee, on its being given to him by the depositary in accordance with the grantor's directions. In such cases generally the deed is regarded as delivered as of the time when the grantor surrenders control of it to the deposi-

B1 See Fain v. Smith, 14 Ore. 82; 12 Pac. 365 ; 58 Am. R. 281 ; Ireland v. Geraghty, 15 Fed. 35, and note; Cline v. Jones, 111 Ill. 563.

be See supra, $\$ 305$. 
tary: the delivery relates back to that time. ${ }^{52}$ So, for example, where a deed is delivered in this way to a custodian to give to the grantee on the grantor's death, title vests at the time of delivery to the custodian, and the deed will take precedence over a subsequent devise of the same property by the grantor..$^{53}$

Often in such cases there is a recital in the deed that it is not to become operative or be "delivered" until the death of the grantor. Such a recital, however, does not make the instrument testamentary in character, nor prevent its taking effect as a deed if the grantor has actually surrendered control of it to the depositary..$^{54}$

$\$ 308$. Effect of reserving control by grantor in such cases.-Such cases as those last cited are to be distinguished from those in which the grantor deposits the deed with a third person to be delivered to the grantee on the grantor's death, but retains dominion over it, or reserves to himself the power to recall it before his death. In these latter cases there is no delivery and no title passes to the grantee, and this is so, according to the weight of authority, even though the grantor does not recall the deed.

32 Cases in which the foregoing rule is applied are often before the courts. From the many decisions on the subject the following will suffice to show the general application of the rule: Ruiz v. Dow, 1896, 113 Cal. 490; 45 Pac. 867; Shea v. Murphy, 1897, 164 Ill. 614 ; 45 N. E. 1021 ; 56 Am. St. R. 215 ; Stout $\nabla$. Rayl, 1896, 146 Ind. 379 ; 45 N. E. 515 ; Dettmer v. Behrens, 1898, 106 Iowa 585; 76 N. W. 853; 68 Am. St. R. 326; Meech v. Wilder (1902, Mich.), 8 Detroit Leg. News 1141; $89 \mathrm{~N}$. W. 556; Fulton v. Priddy, 1900, 123 Mich. 298; 81 Am. St. R. 201; 82 N. W. 65; 6 Detroit Leg. News 103; Martin v. Flaharty, 1893, 13 Mon. 96; 32 Pac. 287; 40 Am. St. R. 415; 19 L. R. A. 242; Brown v. Westerfield, 1896, 47 Neb. 399 ; 53 Am. St. R. 532 ; 66 N. W. 439 ; Diefendorf v. Diefendorf, 1892, 132 N. Y. $100 ; 30$ N. E. 375 ; Ball v. Foreman, 37 Ohio St. 132.

ss Ranken v. Donovan, 1899, 46 App. Div. 225; affirmed, 166 N. Y. 626 ; 60 N. E. 1119.

u See ante $\$ 29$; in addition to the authorities last cited. 
Where the depositary is the servant or employe of the grantor, and is given charge of the deed in order to preserve it for the grantor and not absolutely for delivery to the grantee, the case is not difficult, for the possession of the servant in such a case is the possession of the grantor and his intent that the grantee shall ultimately have the deed is ineffectual, as it is not accompanied by an act by which the grantor parts with the possession of the deed for the benefit of the grantee,, 50 and even if the depositary is not the general servant of the grantor but holds the deed subject to his order as his bailee or agent, and in such a manner that the grantor may revoke the deed, there is no delivery. ${ }^{.66}$ Nor will the title of the grantee be good even though the depositary, holding the deed under such circumstances, delivers the deed to the grantee after the death of the grantor. ${ }^{67}$

The difficulty in many of these cases is in deciding whether or not the circumstances warrant the conclusion that there has been a reservation of control of the deed by the grantor. For example, in one case the deed was given to the grantor's housekeeper to keep and to give to the grantee (a son of grantor) at the death of the grantor: the housekeeper placed the deed in the grantor's trunk in his room and gave him the key of the trunk, and he carried the key in his pocket till his death. The deed seems therefore not to have left his possession and control, but the majority. of the court held that there

\footnotetext{
ssPorter v. Woodhouse, 1890, 59 Conn. 568; 22 Atl. 299; 21 Am. St. R. 131 ; 13 L. R. A. 64.

${ }^{56}$ Burk v. Sproat, 1893, 96 Mich. 404; 55 N. W. 985 ; Kenney v. Park, 1899, 125 Cal. 146; 57 Pac. 772 ; Tarlton v. Griggs, 1902, 131 N. C. 216 ; 42 S. E. 591.

${ }^{37}$ Osborne v. Eslinger, 1900, 155 Ind. 351; 58 N. E. 439; 80 Am. St. R. 240; Williams v. Schatz, 42 Ohio St. 47; Wilson v. Wilson, 1895, 158 Ill. 567 ; 41 N. E. 1007 ; 49 Am. St. R. 176; Baker v. Haskell, 47 N. H. 479 ; 93 Am. D. 455 ; Johnson v. Johnson (1903 R. I.), 54 Atl. 378.
} 
was sufficient evidence to warrant the finding by the jury of delivery. ${ }^{58}$

So in many cases the grantor, in giving the deed to the depositary, directs him to give the deed to the grantee if the grantor dies, but if the grantor recovers to return it to him.

In such cases where the grantor reserves no power to recall or revoke the deed, the question is whether it is beyond his control, and as he cannot control his death or recovery and has reserved no power to recall the deed before his recovery, there appears to have been a valid delivery, so far as he is concerned; yet it has been held in such cases that there has been no delivery, because the deed is under the control of the grantor up to the time of his death. ${ }^{69}$

\$309. Delivery in escrow.-In many of the decisions concerning the depositing of a deed with a third person to hold till the grantor's death, the transaction is spoken of as a delivery in escrow. Such cases, however, are not, strictly speaking, generally cases of delivery in escrow.

Whether when a deed is signed, etc., and not immediately delivered to the grantee, but is handed to a stranger to be delivered at a future time, it is to be considered as the deed of the grantor presently or as an escrow, is often a matter of some doubt; the answer to the question will generally depend rather on the words used and the purposes expressed, than upon the name which the parties give the instrument.

Where the future delivery is to depend on the payment of money or the performance of some other condition it will be deemed an escrow. Where it is merely to await the lapse of time or the happening of some contingency, and not the performance of any condition, it will be

\footnotetext{
${ }^{68}$ Monroe v. Bowles, 1900,187 Ill. 346 ; 58 N. E. 331.

${ }^{39}$ Williams v. Daubner, 1899, 103 Wis. $521 ; 79$ N. W. $748 ; 74$ Am. St. R. 902 ; Williams v. Schatz, 42 Ohio St. 47.
} 
deemed the grantor's deed presently-taking effect as a deed at the " second delivery," but by " relation from the first delivery." 60 The distinction is sometimes stated to be not important or material, but it may be so, because if there be a delivery in escrow no title passes till the " second" delivery or the fulfillment of the condition. While if the deed is one in praesenti the title passes upon the happening of the certain event designated or the lapse of time: it passes by relation, from the time the instrument was placed in the hands of the depositary.

An escrow is, therefore, a writing, having the form of a deed, but the effect of which depends upon the fulfillment of conditions upon which it is to be delivered to the grantee. ${ }^{61}$ The conditions upon which the escrow is to be delivered may be expressed in writing, or may be spoken, or may be partly in one form and partly in another. ${ }^{62}$ Thus the title is made to depend partly in parol, and it is said that some of the earlier authorities evidently contemplate that all escrows should be evidenced by writing, though such does not appear to be the modern rule. ${ }^{63}$ Escrows have therefore been called "deceptive instruments," not what they purport to be, and capable of being used to deceive innocent purchasers. ${ }^{64}$

Conditions, however, cannot, according to the weight of authority, be thus attached to a deed when it is delivered to the grantee, therefore there can be no delivery in escrow to the grantee; such a delivery must be to a "stranger" or a "third person," one not a party to the instrument nor identified with the parties in such a way as to prevent his being a depositary. ${ }^{65}$

' Foster v. Mansfield, 3 Met. 412. See Hathaway v. Payne, 34 N. Y. 92, 107.

${ }^{61}$ Prutsman v. Baker, 30 Wis. 644; 11 Am. R. 592.

${ }^{62}$ Gaston v. Portland, 16 Ore. 255 ; 16 Pac. 127.

${ }^{6 s}$ Taft v. Taft, 59 Mich. 185, 198; 26 N. W. 426.

${ }^{64}$ Hubbard v. Greeley, 1892, 84 Me. 340; 17 L. R. A. 511; 24 Atl. 799. And see Pawling v. U. S., 4 Cranch 219.

Es Darling v. Butler, 1891, 45 Fed. R. 332 ; 10 L. R. A. 469; Cincin- 
$\S 310$. Effect of grantee's obtaining possession of escrow wrongfully.-The obtaining by the grantee of a deed held in escrow, before the fulfillment of the condition, or otherwise wrongfully or fraudulently, can convey no title to him.

Whether an innocent purchaser from him acquires title, is a question upon which there is some conflict of opinion.

The evident hardship in such cases on the subsequent purchaser, who is warned by nothing on the face of the deed, has led many courts to protect a bona fide purchaser from a grantee who has obtained possession of an escrow, without performing the condition upon which the deed was delivered; ${ }^{66}$ and especially where the original grantor - who makes the escrow-has done some act by which he should be estopped from claiming title as against an innocent purchaser, as, for example, putting the person named as grantee (in the "escrow") in possession of the property. ${ }^{67}$ But the rule that appears to be supported by the weight of authority is, that in the absence of some act on the part of the grantor creating an estoppel, or amounting to a ratification of the conveyance by the grantee who has wrongfully obtained possession of the deed, no title passes to the subsequent purchaser. The reason for this view is that the original grantee, in such a case, acquires no title by the deed obtained from the depositary without performing the condition, and so can convey no title to his own grantee. ${ }^{68}$

nati \&c. Railroad Co. v. Iliff, 13 Ohio St. 235, 254 ; Dyer v. Skadan, 1901, 128 Mich. 348; 87 N. W. 277; 8 Detroit Leg. News 701.

${ }^{\circ 6}$ See Blight . Schenck, $10 \mathrm{~Pa}$. St. 285; 51 Am. Dec. 478; Hubbard v. Greeley, 1892, 84 Maine 340; 24 Atl. 799; 17 L. R. A. 511.

$\sigma$ Schurtz v. Colvin, 1896, 55 Ohio St. 274; 45 N. E. 527; Quick v. Milligan, 108 Ind. 419; 9 N. E. 392 ; 58 Am. R. 49. See Simson v. Bank, 43 Hun 156; affirmed, 120 N. Y. 623 ; 23 N. E. 1152.

Dixon v. Bristol Savings Bank, 1897, 102 Ga. 461; 31 S. E. 96 ; 66 Am. St. R. 193; Jackson v. Lynn, 1895, 94 Iowa 151; 62 N. W. $704 ; 58$ Am. St. 386; Burnap v. Sharpsteen, 1894, 149 Ill. 225; 36 N. E. 1008; 
$\S 311$. Effect of surrender or destruction of a deed.The effect of a properly delivered deed being to transfer the legal title to the grantee, this legal title cannot be reinvested in the grantor by a redelivery or surrender of the deed, or by its accidental or intentional destruction. For example, the cancellation of the grantor's name is not enough to revest the title in him; ${ }^{69}$ nor is the total de struction of the deed, whether done with or without the intention of reinvesting the grantor with the title. ${ }^{70}$ If, however, the grantee surrenders or redelivers an unrecorded deed with the intention that it be destroyed for the purpose of revesting the title in the grantor, though the legal title may not be reacquired by the grantor in this way, he may acquire an equitable title. ${ }^{71}$ And the intentional destruction by the grantee of an unrecorded deed for the purpose of revesting the title in the grantor may practically, according to many decisions, have the effect intended, for the grantee, having deliberately destroyed the best evidence of his title, may not produce secondary evidence to sustain it, and therefore he cannot establish it if he would. ${ }^{72}$

Everts v. Agnes, 4 Wis. 343; 65 Am. Dec. 314. In this case such a deed is likened to a forged or stolen deed, and distinguished from a deed which the grantor is fraudulently induced to execute: "In the latter case the legal title passes, and a subsequent purchaser is protected. In the former no title passes whatever, and a subsequent purchaser is not protected. In the one class of cases there is the voluntary assent of the grantor, in the other there is no assent at all."

- Turner v. Warren, 160 Pa. St. 336; 28 Atl. 781.

${ }^{70}$ Spangler v. Dukes, 39 Ohio St. 642; Albright v. Albright, 70 Wis. 528, 537 ; 36 N. W. 254 ; Hyne v. Osborn, 62 Mich. 235; 28 N. W. 821 ; Brown v. Hartman, 1899, 57 Neb. 341, oee note, p. 344, 77 N. W. 776.

"Fletcher v. Shepherd, 1898, 174 Ill. 262; 51 N. E. 212.

${ }^{12}$ See Potter v. Adams, 1894, 125 Mo. 118; 28 S. W. 490; 46 Am. St. R. 478; Farrar v. Farrar, 4 N. H. 191 ; 17 Am. Dec. 410. 


\section{CHAPTER XX.}

THE CONVEYANCE OF THE REAL Fstate OF INFANTS.

8312. Restrictions on alienation -Disabilities - "Void" and "voidable" conveyances.

313. Conveyances by minoreVoidable.

314. Former-distinctions between different kinds of conveyances-I I \& a $\mathrm{t}$ s' powers of attorney still sometimes held void.

315. When conveyance by an infant may be disaffirmed.

316. How soon after majority must infant disaffirmDoctrine that he has statntory period of limitation.

317. How soon after majority must disaffirm-"Within a reasonable time."

318. Former infant may disaffirm though his granteo has conveyed to another.

319. Infant's heirs may disaffirm - Others may not generally.
\$ 320. Effect of infant's misrepresentation as to age.

321. The restoration of the consideration on disaffirm. ance.

322. What constitutes disaffirmance.

323. Effect of conveyance to an infant.

324. How infants' real property may be conveyed.

325. The general principle controlling in such cases.

326. The application by proper party-Notice.

327. Such conveyances allowed for certain purposes.

328. Hearing on the application - Guardian's bond - Ap proval by court.

329. Statutes curing effect of irregularities.

330. Power of chancery court to order conveyance of minor's lands.

\section{\$12. Restrictions on alienation-Disabilities- "Void"} and "voidable" conveyances.-There are circumstances attending the ownership of real property under which the freedom of alienation is restrained, either wholly or partially. 
It is generally true that freedom of transfer of the title to the thing owned is one of the chief characteristics of ownership, and in considering conveyances so far this freedom has been generally assumed to exist, but restrictions on the owner's freedom and the effects of attempted alienation in violation of such restrictions must be considered.

One owning real property may be disqualified from conveying title to it by reason of personal disability arising either from lack of will power sufficient to direct the intelligent performance of the act attempted-as when he is of unsound mind; or the personal disability may be created by law-as is the case in many states when the owner is a married woman of sound mind. This personal disability may therefore be natural or, as having been imposed by law, may in some cases be designated legal; and it may be, as when the owner is a minor, either natural or legal or both, according to the circumstances of the case.

The owner may also be restrained from freely alienating real property to which he has the legal title because of the character or condition of the property-as when it is a "homestead," or is held by another adversely to him; and he may not be free to do as he wishes in a particular instance because the conveyance he attempts to make is in fraud of creditors or subsequent purchasers, or because it imposes conditions that are invalid, or because it violates the rule against perpetuities.

Attempts, however, to transfer title are often made by an owner who is thus under some restraint. His attempted conveyance will be in some cases void, in others voidable.

While these terms, "void" and "voidable," are sometimes used as synonyms, there is properly a distinction between them: the effect of a conveyance that is roid is quite different from the effect of one that is voidable. When a conveyance is void, it is a mere nullity ; it con. 
veys no title; it binds neither the grantor nor the grantee; it cannot be ratified by subsequent acts, and it may be disregarded by the parties to it and attacked by third persons. But when it is voidable, it is valid, not only as between the parties to it, but as to third persons, until it is avoided by the person who is entitled to avoid it; and it may be made completely valid by ratification.

Contracts and conveyances are more rarely void than voidable, and of ten, if somewhat defective, they may be spoken of, when regarded from one point of view and as to one person, as voidable; while if regarded from another point of view or as to another person they may be, not improperly, called void; ${ }^{1}$ and sometimes a conveyance is said to be void and yet to be capable of ratification, ${ }^{2}$ by which is intended that it is without validity until confirmed.$^{3}$

The different senses in which these words are actually often used should therefore be borne in mind in considering the consequences of a conveyance by one who is in some manner disqualified from making the particular conveyance.

There may be disabilities attending grantees as well as grantors, for certain persons are disqualified, either partially or wholly, from taking and holding title; as, for example, aliens under certain circumstances, and corporations to some extent. The general rule of law, however, as distinguishing disqualified or disabled grantors from disqualified grantees, is that the power to take and to hold real property is more widely extended than the power to convey.

§ 313. Conveyances by minors-Voidable.-It is now generally recognized as a settled rule of law that the con-

'See National Bank $\nabla$. Wheelock, 1895, 52 Ohio St. 534, 549, 550; Pearsoll v. Chapin, $44 \mathrm{~Pa}$. St. 9; Henry v. Root, 33 N. Y. 526, 537.

${ }^{2}$ Spafford v. Warren, 47 Iowa 47.

'Weeks v. Bridgman, 1895, 159 U. S. 541, 547. 25-Brews. Con. 
veyances by an infant of his real property are voidable, and not void."

Therefore, the general rule is, not that the conveyance of a minor is inoperative until ratified or affirmed, but that it is good until avoided. It transmits the title to the grantee, who may transfer it to others, and the title will thus continue and remain in the first grantee or subsequent grantees unless divested by the grantor, or, in proper cases, by his heirs. Being simply voidable, it is capable of ratification, but at the same time it does not need ratification, as it will stand good until impeached.

The title obtained by the infant's grantee is, however, practically of little actual value, since the infant grantor may, generally (in the absence of certain circumstances sometimes held to estop him in equity), entirely defeat it after attaining his majority. ${ }^{5}$

$\$ 314$. Former distinctions between different kinds of conveyances-Infants' powers of attorney still sometimes held void.-A distinction seems formerly to have been made between a feoffment with livery of seisin and cases where title was attempted to be conveyed by deed.

The older authorities held that where title usually passed at common law by delivery of the deed-as in the cases of grants, surrenders and releases-an infant was unable to convey, and his deed was void. But if the infant, himself, personally made livery of seisin, the title passed; and his feoffment was voidable merely, because it

- Dolph v. Hand, 1893, 156 Pa. St. 91; 27 Atl. 114; 36 Am. St. R. 25 ; Englebert v. Troxell, 1894, 40 Neb. $195 ; 58$ N. W. 852; 26 L. R. A. 177; 42 Am. St. R. 665; Keil v. Healey, 84 Ill. 104; 25 Am. R. 434; Green v. Wilding, 59 Iowa 679; 44 Am. R. 696. This principle applies to mortgages. Singer Mfg. Co. v. Lamb, 81 Mo. 221 ; Shrock v. Crowl, 83 Ind. 243; Walton v. Gaines, 1894, 94 Tenn. 420; 29 S.W. 458. There are decisions to the effect that a conveyance made by an infant without consideration is void, and not merely voidable, because it is clearly prejudicial to the infant. Robinson $\nabla$. Coulter, 1891, 80 Tenn. 705; 18 8. W. $250 ; 25$ Am. St. R. 708.

Soe post, $\$ 315$, et seq. 
should have a greater effect on account of its greater solemnity.

After the Statute of Uses, when livery of seisin fell into disuse, it was considered that an infant could not make even a voidable conveyance in the customary manner by a deed of bargain and sale, which was still regarded as void. And it was also held that even a feoffment where the infant did not personally make livery of seisin was void and not merely voidable. That is, if the infant made a deed of feoffment and gave a letter of attorney to another to make livery of seisin, the livery so made was void. ${ }^{6}$

While the distinction between the different sorts of conveyances has been lost sight of, the old rule as to the power of an infant to appoint an attorney has survived and has been applied in some modern decisions:-the infant's appointment of an attorney to convey being regarded as void-though in some cases where this rule is stated it appears not to have been necessary to the decision. ${ }^{7}$ So, a power of sale in a mortgage made by an infant has been held invalid, and a sale under it absolutely void; and though the infant has ratified the mortgage, he nevertheless may redeem from the sale. ${ }^{8}$

But this rule, that the appointment by a minor of an attorney to sell and convey land is void, is not recognized in all the later decisions, and the more reasonable modern doctrine appears to be that which applies the same rule to a power of attorney as to infants' contracts and acts generally, that is, that they are voidable rather than void.'

- See Shep. Touch. 232; Thompson v. Leach, 3 Mod. 301, 310; Zouch v. Parsons, 3 Burr. 1794 ; Tucker v. Moreland, 10 Pet. 58, 68.

'Philpot $\nabla$. Bingham, 55 Ala. 435; Trueblood $\nabla$. Trueblood, 8 Ind. 195 ; 65 Am. D. 756 ; Lawrence v. McArter, 10 Ohio 37.

- Rocks v. Cornell, 1900, 21 R. I. 532 ; 45 Atl. 552.

- Coursolle v. Weyerhauser, 1897, 69 Minn. 328; 72 N. W. 697. See Ferguson v. Houston \&c. R. Co., 73 Texas 344 ; 11 S. W. 347; Askey v. IVilliams, 74 Texas 294; 11 S. W. 1101 ; 5 L. R. A. 176. 
$\$ 315$. When conveyance by an infant may be disaffirmed-Not until majority.-While an infant's conveyance of land may thus be avoided or disaffirmed, the infant may not disaffirm it until his majority. ${ }^{10}$

This is an exception to the general rule regarding repudiation by infants of their ordinary contracts. Conveyances of personal property may be repudiated by an infant before his majority. So, for example, a chattel mortgage made by an infant may be avoided before he arrives at full age, or within a reasonable time thereafter. ${ }^{11}$ Various reasons are given for the difference in this regard between conveyances of real property and those of personal property. It is sometimes said to be due to the transitory nature of personal property, and therefore, " to withhold the right of disaffirmance from an infant (in such a case) until he became of age, would, in many cases, be to make it valueless, "-it being for his protection that such a disaffirmance is allowed..$^{12}$ Or, as is stated in some decisions, the same rule is held not to apply to conveyances of real property, because the infant is protected, while infancy lasts, by his right to enter the land conveyed and take the profits without conclusively avoiding the conveyance. ${ }^{13}$ And the reason for the rule is also said to be " that a disaffirmance works a reinvestiture of the estate in the infant, and he is presumed not to have sufficient discretion for that."14

This general rule that an infant may not disaffirm his

${ }^{10}$ Sims v. Everhardt, 102 U. S. 300, 309; Welch v. Bunce, 83 Ind. 382 ; Shipley v. Bunn, 1894, 125 Mo. 445; 28 S. W. 754; Bool v. Mix, 17 Wend. 119, 132; 31 Am. D. 285.

"Chapin v. Shafer, 49 N. Y. 407; Miller v. Smith, 26 Minn. 248. See Bloomingdale v. Chittenden, 74 Mich. 698; 42 N. W. 166.

12 Towle v. Dresser, 73 Maine 252, 256.

${ }^{13}$ Bool v. Mix, 17 Wend. 119, 132; 31 Am. D. 285. This right to enter, etc., is denied in some cases, however. Shipley v. Bunn, 1894, 125 Mo. 445 ; 28 S. W. 754.

16 Sims v. Everhardt, 102 U. S. 300, 309. 
conveyance of real property during his minority has been changed by statute in some states. ${ }^{15}$

$\S 316$. How soon after majority must infant disaffirm -Doctrine that he has statutory period of limitation.While he may not generally disaffirm his conveyance during his minority, he is not obliged to disaffirm it at once on attaining his majority. Upon the questions as to how much time he may have, after attaining his majority, in which to consider the matter, and as to how far mere silence on his part after majority amounts to affirmance or ratification of his former conveyance, there is some conflict among the decisions.

The doctrine of probably the greater number of courts is that mere silence continued after attaining majority for any period less than that fixed by the statute of limitations for the recovery of land will not prevent his di affirmanc

The reason generally given for this doctrine is that mere silence or acquiescence does not amount to either an affirmance or an estoppel, and that unless there has been an estoppel or affirmance the infant ought to have the whole period allowed by the statute of limitation in which to recover his land.

The effect of this doctrine is illustrated by a case ${ }^{16}$ in which two minors were, respectively, nineteen and twenty years of age when they conveyed land, for a nominal consideration, in order that their grantee might secure (by a mortgage on the land conveyed) the sureties on a bail bond of the minors' brother. The mortgage was given to the sureties, and was afterward foreclosed, and the land passed to others, against whom, eight years after the younger of the minors came of age, the former infants

${ }^{13}$ California Civ. Co., §35; Idaho Civ. Co., §1983; Montana Civ. Co., \$18; North Dakota Civ. Co. 1899, \$2703; South Dakota Civ. Co. 1901, $\$ 3415$.

${ }^{16}$ Donovan v. Ward, 1894, 100 Mich. 601; 59 N. W. 254. 
brought an action of ejectment. The court held that the action was seasonably brought, if within the period prescribed by the statute of limitations, remarking that there were no improvements made by the subsequent purchasers, nor had either plaintiff done anything indicating an affirmance or ratification of the deed.

A somewhat remarkable case, where there was no disaffirmance for nearly twenty-one years after the infant attained her majority, ${ }^{17}$ is frequently cited. The court considered that there were special reasons for the delay in this case, and that it was excusable, but the general rule is also stated as follows: "We think the preponderance of authority is, that in deeds executed by infants, mere inertness or silence continued for a period less than that prescribed by the statute of limitations, unless accompanied by affirmative acts manifesting an intention to assent to the conveyance, will not bar the infant's right to avoid the deed." 18

As the reason for this doctrine is that mere silence does not amount to affirmance or estoppel, it is held, where the doctrine is recognized, that the lapse of a shorter time, taken in connection with other circumstances, may amount to a ratification, or estop the infant grantor from avoiding the deed; as, for example, standing by and seeing improvements made upon the land by those who rely on the validity of the conveyance. In such cases the former infant should not be allowed the full time which might be permitted in others, and he must, within such a time as is reasonable under all the circumstances, give notice of his election to disaffirm. ${ }^{19}$ And the retention

${ }^{17}$ Sims v. Everhardt, 102 U. S. 300. See also Stull v. Harris, 51 Ark. 294 ; 11 S. W. 104 ; Cresinger v. Welch, 15 Ohio 156; Ship v. McKee, 1902, 80 Miss. 741 ; 32 So. 281; 92 Am. St. R. 616; Lacy v. Pixler, 1894, 120 Mo. 383; 25 S. W. 206; Ricbardson v. Pate, 93 Ind. 423.

${ }^{18}$ Sims v. Everhardt, supra, but especially p. 312.

${ }^{19}$ Irvine v. Irvine, 9 Wall. 617, 627; Davis v. Dudley, 70 Maine 236; 35. Am. R. 318. 
and use of the consideration after reaching his majority for a period much shorter than that prescribed by the statute of limitations would amount to a ratification..$^{20}$

\$317. How soon after majority must disaffirm"Within a reasonable time."-Other courts, however, hold that the former infant must disaffirm his conveyance within a reasonable time after attaining his majority or he will be bound by acquiescence, and by reasonable time is intended, under this view, not necessarily nor generally the full statutory period prescribed for the recovery of real property.

In a Minnesota case, ${ }^{21}$ the authorities are discussed, and the court says: "A reasonable time after majority within which to act is all that is essential to the infant's protection. That ten, fifteen or twenty years, or such other time as the law may give for bringing an action, is necessary as a matter of protection to him, is absurd. * * Reason, justice to others, public policy (which is not subserved by cherishing defective titles), and convenience, require the right of disaffirmance to be acted upon within a reasonable time. What is a reasonable time will depend upon the circumstances of each case, and may be either for the court or jury to determine. Where there is mere delay, with nothing to explain or excuse it, it will be for the court." In this case a delay of three and a half years was regarded as more than a reasonable time, and prima facie the conveyance was ratified. ${ }^{22}$

In a few states it is provided by statute that the infant must disaffirm within a reasonable time after attaining

${ }^{20}$ American Freehold Land Mort. Co. v. Dykes, 1895, 111 Ala. 178; 18 So. 292 ; 56 Am. St. R. 38.

${ }^{21}$ Goodnow v. Empire Lumber Co., 31 Minn. 468 ; 47 Am. R. 798.

${ }^{22}$ See also Bentley v. Greer, 1896, 100 Ga. 35; 27 S. E. 974 ; Englebert v. Troxell, 1894, 40 Neb. 195; 58 N. W. 852; 26 L. R. A. 177; 42 Am. St. R. 665 ; Thormaehlen v. Kaeppel, 1893, 86 Wis. 378; 56 N. W. 1089. 
his majority,,$^{23}$ and in at least two a definite short period is fixed by statute, ${ }^{24}$ while occasionally, though it seems rarely, the courts have established a definite period of time within which the former minor must disaffirm his conveyance, though there is no statute to this effect. For example, in Illinois three years after majority has been settled upon as the time, because when the first decision was made the time prescribed by the statute of limitations was that period, ${ }^{25}$ though of course the infant may, by acts amounting to a ratification, be estopped within this time. ${ }^{6}$

$\S 318$. Former infant may disaffirm, though his grantee has conveyed to another.-The former minor may not only avoid his conveyance when the property which he attempted to convey is in the hands of his immediate grantee, but may do so even though the land conveyed by him has been again conveyed by his grantee to a bona fide purchaser for value; for the infant's right to avoid his conveyance is an absolute right, superior to the equities of other persons. ${ }^{27}$ In the last case cited it was contended on behalf of a subsequent grantee, that when the grantee of a minor sells the land for value to such a purchaser, the right to disaffirm is lost; but the court says: "There is no authority to support such a proposition.

* California Civ. Co., § 35; Iowa Co. 1897, § 3189; Idaho Civ. Co. 1901, § 1983; Kansae Gen. Stat. 1901, \$4183; Utah R. 8. 1898, § 1542 ; Washington Ann. Co. \& Stat. 1897, § 4581.

"In North and in South Dakota he should dieaffirm within one year's time after his majority. No. Dak. Civ. Co. 1899, § 2703; So. Dak. Civ. Co. 1901, § 3415 .

${ }^{25}$ Keil $\cdot$ v. Healey, 84 Ill. 104; 25 Am. R. 434; Sayles v. Christie, 1900, 187 Ill. 420,437 ; 58 N. E. 480.

${ }^{26}$ In a valuable note on infants' contracts, $18 \mathrm{Am}$. St. R., at pagee 675 and 677 , many authorities on this subject are collected, showing the various circumstances which may affect the question of reasonable time.

${ }^{27}$ Lacy v. Pixler, 1894, 120 Mo. 383 ; 25 S. W. 206 ; Buchanan v. Hubbard, 96 Ind. 1; Searcy v. Hunter, 1891, 81 Texas 644; 17 S. W. 372; 26 Am. St. R. 837. 
Such a doctrine would enable the minor's grantee to make the deed valid by a mere sale to an innocent purchaser, and would practically destroy a rule established to protect minors against the consequences of their improvident conveyances."

\$ 319. Infant's heirs may disaffirm-0thers may not generally.-As the main ground for allowing the disaffirmance of the conveyance by the former infant on reaching his majority is that he may protect himself from the improvidence incident to youth, it is sometimes said that this right to disaffirm is a personal privilege and may not be taken advantage of by other persons. ${ }^{28}$ But what is intended by such expressions is that during his life this right to disaffirm is exercisable by the former infant alone and not by third persons for him, as it is not assignable. For example, the assignee of an insolvent debtor who gave a mortgage while an infant, cannot avail himself of the infant's privilege and relieve the estate from the mortgage ; ${ }^{20}$ nor may a creditor attach property conveyed by his debtor while a minor, and thus disaffirm the conveyance for the minor. ${ }^{80}$

If, however, the infant grantor has died without having himself either affirmed or disaffirmed his conveyance, or without being estopped to disaffirm it, his heirs may avail themselves of his infancy and repudiate $\mathrm{it}_{2}{ }^{31}$ and they have the same time in which to do so that the infant would have had if living. ${ }^{32}$

- Beardsley v. Hotchkiss, 96 N. Y. 201, 211.

- Mansfield v. Gordon, 144 Mass. 168; 10 N. E. 773.

* Kendall v. Lawrence, 22 Pick. 540.

" Gillenwaters v. Campbell, 1895, 142 Ind. 529; 41 N. E. 1041 ; Walton v. Gaines, 1895, 94 Tenn. 420; 29 S. W. 458; Searcy v. Hunter, 1891, 81 Texas 644 ; 17 S. W. 372 ; 26 Am. St. R. 837.

* Saylee v. Christie, 1900, 187 Ill. 420, 438; 58 N. E. 480; Eagan v. Scully, 1898, 29 App. Div. (N. Y.) 617; 51 N. Y. S. 680; affirmed 173 N. Y. $581 ; 65$ N. E. 1116; Bozeman v. Browning, 31 Ark. 364. 
\$320. Effect of infant's misrepresentation as to age.It sometimes happens that an infant makes misrepresentations in regard to his age at the time of making his conveyance. The question as to what effect such conduct shall have upon his right to disaffirm presents itself in a variety of ways; it may arise in a legal proceeding or in an equitable proceeding, and the representation may have been accompanied by other facts, so that it is difficult to state a general rule applicable, without qualification, to all cases.

By the weight of authority the rule appears to be that misrepresentations as to age made by an infant at the time of making his conveyance do not estop him at law from taking advantage of infancy after attaining his majority. For example, in an action of ejectment for the recovery of lands, the deed, executed by the plaintiff while a minor, ${ }^{83}$ recited that she was "unmarried and of age," and the court holds that by such a false recital in the deed she is not estopped from disaffirming it, on the general principle that the doctrine of estoppel is inapplicable to infants. ${ }^{34}$

But if the proceedings in which the former infant seeks to disaffirm his conveyance be in equity he has sometimes been held estopped by his fraudulent misrepresentations as to his age which have induced the grantee to accept his conveyance. ${ }^{35}$

While actual misrepresentation as to age, or any artifice which misleads, may thus be held in equity to estop the former infant, his mere failure to disclose his disability will not so estop him ; that is, if a minor of nearly full age, and appearing to be quite so, should (without

${ }^{23}$ Wieland v. Kobick, 110 Ill. 16 ; 51 Am. R. 676.

"And see Alt v. Graff, 1896, 65 Minn. 191, 195;68 N. W. 9; Buchanan v. Hubbard, 96 Ind. 1; 119 Ind. 187; 21 N. E. 538; Studwell v. Shapter, 54 N. Y. 249.

* Ryan v. Growney, 1894, 125 Mo. 474; 28 S. W. 189; Pemberton Bldg. \&c. Ass'n v. Adams, 1895, 53 N. J. Eq. 258; 31 Atl. 280. 
misrepresenting his age) convey to one who believed him to be of full age, he could, nevertheless, disaffirm the conveyance. ${ }^{36}$ And in spite of false representations, the infant will not be estopped, even in equity, unless the other party was actually deceived by such representations and relied upon them. Thus, if the representations as to age were made to some person other than the grantee and not communicated to him, or were made to the grantee by a boy ten years old-in such cases it would be impossible that the grantee could have relied on them, and the grantor would not be estopped to repudiate the conveyance. ${ }^{87}$

In Sims v. Everhardt, ${ }^{88}$ the case was in equity. The grantor had made a written statement that she was of age. But the court says, on the question as to whether she was estopped, that estoppel in pais is not applicable to infants, and a fraudulent representation of capacity cannot be an equivalent of actual capacity. A conveyance by an infant is an assertion of his right to convey. A contemporaneous declaration of his right or of his age adds nothing to what is implied in his deed. An assertion of an estoppel against him is but a claim that he has assented or contracted But he can no more do that effectively than he can make the contract alleged to be confirmed. ${ }^{39}$

To remove some of the uncertainty prevailing as to the effect of misrepresentations, and to apply to all cases the rule applied often in equity, statutes have been adopted

${ }^{26}$ Sewell v. Sewell, 1892, 92 Ky. 500; 18 S. W. 162; Baker v. Stone, 136 Mass. 405; Thormaehlen v. Kaeppel, 86 Wis. 378; 56 N. W. 1089.

87 Watson v. Billings, 38 Ark. 278; 42 Am. R. 1; Ex parte Jones, L. R. 18 Ch. Div. 109, 120; Charles v. Hastedt, 1893, 51 N. J. Eq. 171; 26 Atl. 564 ; Bradshaw v. Van Winkle, 1892, 133 Ind. 134 ; 32 N. E. 877.

${ }^{28}$ Sims v. Everhardt, 102 U. S. 300.

* This case was an exceptional one in many respects, and coercion on the part of the husband against his wife, the infant grantor, appears to have existed. 
in some states, ${ }^{, 0}$ providing that "No contract [of a minor] can be disaffirmed in cases where on account of the minor's own misrepresentations as to his majority, or from his having engaged in business as an adult, the other party has good reason to believe him capable of contracting." And in Indiana the statute provides that if the infant falsely represented himself to the purchaser to be over twenty-one, and the purchaser acted in good faith and relied upon the representation, the conveyance cannot be disaffirmed without restoring the consideration."

$\$ 321$. The restoration of the consideration on disaffirmance.-In the absence of a statute on the subject, shall the consideration received by the minor be restored upon his disaffirmance of his conveyance?

Some of the earlier authorities state the rule to be that on disaffirmance the former infant must restore the consideration. ${ }^{2}$ But the present doctrine cannot be stated so broadly, and the general rule now is, that so much of the consideration for the conveyance as remains in the infant's possession at his majority must be returned upon his disaffirmance; yet his disaffirmance will not be prevented by his inability to return what he has parted with during his minority.

In one form of expression or another, as applied to the particular circumstances of each case, the law says to the former infant who would disaffirm his conveyance that he cannot regain his land, and also retain after his majority what he received for it. ${ }^{43}$

${ }^{40}$ E. G., Iowa Co. 1897, § 3190; Kansas Gen. Stat. 1901, § 4184; Utah R. S. 1898, § 1543; Washington Ann. Co. \& Stat. 1897, §4582.

11 Ind. Burns' R. S. 1901, § 3365 .

"See Kent Comm. II, p. 240; Kilgore v. Jordan, 17 Texas 341 ; Farr v. Sumner, 12 Vt. 28; 36 Am. D. 327; Bartlett v. Cowles, 15 Gray 445. 4 MacGrael v. Taylor, 1897, 167 U. S. 688, 700; Ridgeway v. Herbert, 1899, 150 Mo. 606; 51 S. W. 1040; 73 Am. St. R. 464; Bullock v. Sprowls, 1899, 93 Texas 188; 54 S. W. 661 ; 47 L. R. A. 326; 77 Am. St. R. 849; Green v. Green, 69 N. Y. 553, 556; 25 Am. R. 233; Englebert 
This principle has boen made statutory in Iowa, Kansas, Utah and Washington, where the minor, on disaffirming, must restore "all money or property received by him by virtue of the contract, and remaining within his control at any time after his attaining his majority." "4 The force of such a statute is somewhat lessened by decisions that the former minor may disaffirm without restoring the consideration, unless he has the identical property, even the identical money, received by him,,$^{45}$ but statutes of similar character in a few states make it unnecessary to consider this question of identity, by requiring that if the minor was over eighteen years of age when the contract was made he may disaffirm upon restoring the consideration, or its equivalent. ${ }^{46}$

Where there are no such statutes the question of the identity of the consideration has sometimes been raised, and it has been held in some cases that, on disaffirmance, the former infant must return simply what he has, after majority, of the specific consideration received. For example, where an infant had conveyed, 17 and the money paid to the infant had been used by his father to purchase a piano for the infant, it was held that he might disaffirm the conveyance without surrendering or tender-

v. Troxell, 1894, 40 Neb. 195 ; 58 N. W. 852 ; 26 L. R. A. 177 ; 42 Am. St. R. 665 ; Ison v. Cornett, 1903 (Ky.); 75 S. W. 204.

* Iowa Co. 1897, § 3189; Kansas Gen. Stat. 1901, § 4183; Utab R. S. 1898, 1542 ; Washington Ann. Co. \& Stat. 1897, § 4581. See Montana Civ. Co., $\S 18$. See Indiana statute cited supra, note 41, as to restoration of consideration when misrepresentations are made; also the statate in the same state, Burns' R. S. 1901, $\$ 3364$, requiring its return when an infant feme covert conveys by a conveyance in which her husband, of full age, has joined, unless she avers that she has received none. Shroyer v. Pittenger, 1903, 31 Ind. App. 158; 67 N. E. 475.

${ }^{46}$ Hawes v. R. R. Co., 64 Iowa 315, 319; 20 N. W. 717 ; Leacox v. Griffith, 76 Iowa 89, 90; 40 N. W. 109.

* California Civ. Co., § 35; Idaho Civ. Co., § 1983; North Dakota Civ. Co., § 2703; South Dakota Civ. Co., § 3415.

" Englebert v. Troxell, 1894, 40 Neb. 195, 210; 58 N. W. 852 ; 26 L. R. A. $177 ; 42$ Am. St. R. 665. 
ing the piano. But in another case, ${ }^{48}$ where it was contended on behalf of a former infant that a trust deed given by her could be set aside without accounting for the money which had been raised by the deed and which had gone to improve the very property conveyed, the ground of the contention being that, as the money could not be specifically returned, it should not be accounted for, the court held that, as the improvements were in the hands of the former minor, she must account for them if the property could be sold for enough. The aim of the court was stated to be to put the former infant in the position occupied by her at the time the trust deed was given, so far as it could be done.

There would seem to be no hardship in requiring that, if the disaffirming party has not the specific consideration in his control, then whatever he has that can be identified as the direct proceeds of the consideration should be subject to the claims of the other party. ${ }^{49}$

Upon this matter of the return of consideration, a distinction has often been made between cases at law and in equity; the rule in proceedings at law being, that neither a return of the consideration, nor an offer to return, is a necessary condition precedent to the remedy sought by the action; while where the proceeding is in equity a return of the consideration which remains in the former infant's hands, or an offer to return, must be made as a condition to granting relief; for in equitable proceedings the courts will apply to this class of cases the maxim that "he who seeks equity must do equity," while in

48 MacGrael v. Taylor, 1897, 167 U. 8. 688, 700.

90 The former infant may not avoid a mortgage and at the same time retain the land benefited by the proceeds of the mortgage. Charles $\nabla$. Hastedt, 1893, 51 N. J. Eq. 171 ; 26 Atl. 564; U. S. Investment Co. v. Ulrickson, 1901, 84 Minn. 14; 86 N. W. 613; 87 Am. St. R. 326. Nor may he avoid a purchase-money mortgage and retain the land conveyed to him, in part payment for which he gave the mortgage. Young $\nabla$. McKee, 13 Mich. 552; Callis v. Day, 38 Wis. 643; Ready v. Pinkbam, 1902, 181 Mass. 351 ; 63 N. E. 887. 
legal proceedings conditions cannot be attached to the right to disaffirm. ${ }^{50}$

$\S 322$. What constitutes disaffirmance.-The disaffirmance may be accomplished in a variety of ways, as is seen from the foregoing cases.

The older authorities sometimes state the rule to be that an act of disaffirmance must be of solemnity and notoriety equal to that of the conveyance to be avoided, ${ }^{51}$ because at common law an infant's conveyance by livery of seisin could be avoided only by an act of equal notoriety-as an entry on the land.

But nowadays, generally speaking, any act which clearly shows an intention to disaffirm, and with which the continued validity of the former conveyance is inconsistent, is sufficient as a disaffirmance. As, for example, an absolute conveyance to another person after majority ; the bringing of an action in ejectment; the filing of a bill to cancel a former conveyance; in some cases, the filing with the recording officer of a notice of disaffirmance. ${ }^{52}$ The act after majority, however, must be inconsistent with the former conveyance to amount to a disaffirmance of it. And so a mortgage or quit claim deed made after majority will not necessarily amount to a disaffirmance of a mortgage given during minority. The two instruments are consistent with each other and may stand together..$^{53}$ And a conveyance made after majority may, by being made expressly subject to one made during minority, rather ratify the former, than disaffirm it; as, where a

so Chandler v. Simmons, 97 Mass. 508, 514; Eureka Co. v. Edwards, 71 Ala. 248, 256; 46 Am. R. 314 ; Stull v. Harris, 51 Ark. 294; 11 S. W. 104 ; Sewell v. Sewell, 1892, 92 Ky. 500; 18 S. W. 162.

s1 Bool v. Mix, 17 Wend. 119 ; 31 Am. D. 285. As to this, and the distinction between acts of avoidance and acts of affirmance, see Irvine v. Irvine, 9 Wall. 617, 627, 628.

${ }^{32}$ Tucker $\nabla$. Moreland, 10 Pet. 58; Haynes v. Bennett, 63 Mich. 15; 18 N. W. 539 : Shroyer v. Pittenger, 1903, 31 Ind. App. 158; 67 N. E. 475.

singer Mfg. Co. v. Lamb, 81 Mo. 221. 
mortgage made after majority recited a former mortgage, made during minority, it was held to give priority to the former..$^{54}$

$\S 323$. Effect of conveyance to an infant.-When an estate is conveyed to a minor the title vests in him, but subject to his right to repudiate the purchase on arriving at his majority, or within a reasonable time thereafter. If, therefore, he retains possession of real estate conveyed to him for an unreasonable time after majority he will be considered to have affirmed the conveyance to him, and it will then be impossible for him to repudiate the purchase and recover what he may have paid or given in exchange for the property. ${ }^{55}$ And affirmative acts of ownership after majority, as, for instance, selling the land conveyed to him, will the more clearly amount to a ratification and prevent a repudiation by him. ${ }^{.6}$

\$ 324. How infants' real property may be conveyed.While a minor's own conveyance is voidable, it is often desirable or necessary to convey or mortgage his real estate, and to do so in such a way that the purchaser or mortgagee may be secure in his title, and not hold it subject to the infant's right to repudiate it on majority.

The parent or other natural guardian has, as a rule, no authority to make a conveyance of the infant's land, and a court may not authorize a natural guardian, as such, to convey. ${ }^{5 i}$ Nor may the guardian of the estate of an infant generally convey the lands of his ward without special legal authority. ${ }^{58}$

st Ward จ. Anderson, 1892,111 N. C. $115 ; 15$ S. E. 933.

${ }^{55}$ Henry v. Root, 33 N. Y. 526 ; Scanlan v. Wright, 13 Pick. 523; 25 Am. D. 344; Baker v. Kennett, 54 Mo. 82; Ellis v. Alford, 64 Miss. 8.

${ }^{56}$ Langdon v. Clayson, 75 Mich. 204; Uecker v. Koehn, 21 Neb. 559 ; 59 Am. R. 849 ; and see note 49 , supra, $\$ 321$.

${ }^{67}$ Dengenhart v. Cracraft, 36 Ohio St. 549, 572 ; Shanks v. Seamonds, 24 Iowa 131; 92 Am. D. 465; Myers v. McGavock, 1894, 39 Neb. 843, $856 ; 58$ N. W. $522 ; 42$ Am. St. R. 627.

${ }^{58}$ Wolf v. Holton, 1895, 104 Mich. 107 ; 62 N. W. 174; State v. Com- 
There is some difference of opinion on the question whether courts of equity have inherently power to authorize the conveyance of infants' real property, ${ }^{59}$ and partly because of the doubts as to the existence of this power statutes have been enacted in nearly every state, empowering certain courts to order a conveyance of infants' real property, under certain circumstances.

Each state has power over the property of infants within its bounds, to the extent that it may provide for the disposition of their estates, the mode of appointing guardians, their qualifications and duties, ${ }^{, 0}$ and under this general power these statutes have been passed.

In most of the states the statutes give jurisdiction in such cases to the probate courts or orphans' courts; in some of the states the chancery courts, or courts of general jurisdiction, like circuit and district courts, are given authority in these matters, and in some states concurrent jurisdiction is given to probate and other courts.

$\S 325$. The general principle controlling in such cases. -The statutes vary in their details as to when and how a conveyance of an infant's lands may be made, but no matter what their particular requirements may be, it is a general rule that all the provisions of the statute must be complied with in order to transfer title from the minor and vest it in the purchaser.

"Statutory provisions in derogation of the common law by which the title of one is to be divested and transferred to another, must be strictly pursued, and every requisite thereof having the semblance of benefit to its owner must be complied with in order to divest his title." 61 The

missioners, 39 Ohio St. 58; Johns v. Tiers, 1886, 114 Pa. St. 611 ; 7 Atl. 923.

60 See post, $\S 330$.

${ }^{\infty}$ Hoyt v. Sprague, 103 U. 8. 613, 631.

allwood v. Northrup, 106 N. Y. 172, 185 ; 12 N. E. 590; Carder v. Culbertson, 100 Mo. 269; 13 S. W. 88; McMannis v. Rice, 48 Iowa 361. 26-Brews. Con. 
burden is on the party claiming title by such proceedings to show by affirmative evidence that he acquired title, and in the absence of proof there are no presumptions that the material requirements of the statute have been complied with, ${ }^{62}$ and the purchaser at such a sale is presumed to have knowledge of all the proceedings. ${ }^{63}$

$\S 326$. The application by proper party-Notice.-The first step in such cases is to apply to the court named in the statute for permission to convey; and the application must, of course, be made by the proper party. ${ }^{64}$ This party is generally the legally appointed guardian or curator of the minor, and the court has no jurisdiction to authorize a sale on the application of any one else when the legal guardian is designated by statute. Hence conveyances made on the application of a parent as natural guardian merely, or on the application of the infant by his next friend, have been held void. And where the application must be by the guardian, if the appointment of the guardian is void, a conveyance made on his application is void..$^{65}$

In a few states, however, the application may be made, and in some should be made, by the next friend of the infant. In such cases the petition is presented to the court by a natural guardian, or near relative, as next friend, who thus brings the matter before the court, which then appoints a responsible guardian, who gives security for the faithful performance of his duty, and is authorized to act on behalf of the infant. ${ }^{66}$

A very general provision of such statutes is that notice of the application shall be given either to the infant him-

62 Ellwood v. Northrup, 106 N. Y. 172, 186; 12 N. E. 590.

a Axtell's Case, 1893, 95 Mich. 244 ; 54 N. W. 889 ; Leuders v. Thomas, 1895, 35 Fla. 518; 17 So. 633 ; 48 Am. St. R. 255 ; Bachelor v. Korb, 1899, 58 Neb. 122, $130 ; 78$ N. W. $485 ; 76$ Am. St. R. 70.

a Grier's Appeal, $101 \mathrm{~Pa}$. St. 412.

6 State v. McLaughlin, 77 Ind. 335.

* Re Whitlock, 19 How. Proc. 380. 
self or to some one interested in his behalf. A sale made without notice of the application is, by some courts, held invalid, the proceedings being regarded as adversary to the ward $;^{67}$ on the other hand, they are by others regarded not as adversary to the infant or ward, but as proceedings in rem, and in such cases it is held that the jurisdiction of the court does not depend on the giving of notice, but that it is enough that the court has jurisdiction of the subject matter. ${ }^{68}$

$\$ 327$. Such conveyances allowed for certain purposes. -The statutes generally provide that such a conveyance may be ordered for certain purposes only. Therefore the application to the court must show that a sale is intended to be made for an authorized purpose, for a sale of an infant's lands for an unauthorized purpose is void. ${ }^{69}$ The most usual ground upon which such applications are authorized and are made, is that the sale is necessary for the infant's maintenance and education, but other purposes are authorized by some statutes-as, for example, sales for the purpose of investing the proceeds in income producing securities, or to discharge a debt on the land, or to prevent waste; and some statutes provide in general terms that a conveyance may be made if for any reason it may be deemed for the minor's interest.

$\$ 328$. Hearing on the application-Guardian's bondApproval by court.-The land is, of course, accurately described in the petition, and the petition is usually verified or accompanied by an affidavit of the truth of the facts set forth in it.

T Rankin v. Miller, 43 Iowa 11; Kennedy v. Gaines, 51 Miss. 625.

Myers v. McGavock, 1894, 39 Neb. 843, 862; 58 N. W. $522 ; 42$ Am. St. R. 627 ; Thaw v. Ritchie, 1890, 136 U. S. 519.

${ }^{\infty}$ Beal v. Harmon, 38 Mo. 435; Fowler v. Lewis, 36 W. Va. 112, 127 ; 14 S. E. 447; Lyman v. Conkey, 1 Met. 317, 324; Beezley v. Phillips, 1902, 117 Fed. R. 105; 54 C. C. A. 491 ; Liter v. Fishback, 1903 (Ky.); 75 S. W. 232. 
The court, after a hearing on the necessity or desirability of the sale, orders a contract of sale, and requires a bond from the guardian. If the guardian fails to give a proper bond the sale is invalid. ${ }^{70}$ Generally, the sale must be reported to and approved by the court; and where this is required the validity of the sale depends on its approval by the court. ${ }^{71}$ Such conveyances by guardians under the court's orders are judicial sales, and the guardian acts as the instrument of the court in carrying out its orders: hence, it has sometimes been held that an irregular sale when duly ratified and confirmed by the court is made valid, unless, at least, attacked in a direct proceeding; $;^{\text {i2 }}$ but for the court's confirmation to have this effect, the sale must have been simply irregular or voidable and not void. ${ }^{73}$

\$329. Statutes curing effects of irregularities. - To insure a fair degree of security to the purchaser in good faith at guardians' sales, the statutes of some states provide that such sales shall not be deemed invalid for irregularities if it appears that certain enumerated essentials have been complied with; among which essentials usually are: that a license to sell has been granted by the court having jurisdiction, that the guardian took the oath required, that he gave a bond, that he gave notice, that the

${ }^{70}$ Stewart v. Bailey, 28 Mich. 251; Ryder v. Flanders, 30 Mich. 336; Weld v. Johnson Mfg. Co., 1893, 84 Wis. 537; 54 N. W. 335; Barnett v. Bull, $81 \mathrm{Ky} .127$.

" Bone v. Tyrrell, 1892, 113 Mo. $175 ; 20 \mathrm{~S}$. W: 796. In this case former minors recover land over thirty years after a guardian's sale ordered by the court, but not approved. Dohms v. Mann, 76 Iowa 723; 39 N. W. 823; Titman v. Riker, 43 N. J. Eq. 122; 10 Atl. 397 ; Lumpkins v. Johnson, 1895, 61 Ark. 80; 32 S. W. 65; Hicks v. Blakeman, 1896, 74 Miss. 459, 477; 21 So. 7.

${ }^{72}$ Eliason $\nabla$. Bronnenberg, 1896, 147 Ind. 248; 46 N. E. 582 ; Hamiel v. Donnelly, 75 Iowa $93 ; 39$ N. W. 210.

73 Jenness v. Smith, 58 Mich. 280; 25 N. W. 191 ; Carder v. Culbertعon, 1890, 100 Mo. 269; 13 S. W. 88; McMannis v. Rice, 48 Iowa 361; Frazier v. Jeakins, 1902, 64 Kan. 615; 68 Pac. 24; 57 L. R. A. 575. 
premises were conveyed in accordance with the license, that the sale was confirmed by the court, and that the property is held by one who purchased in good faith. Statutes of this general character are to be found in Indiana, Michigan, Minnesota, Nebraska, Oregon, Wisconsin, and perhaps other states, though some require more to be shown on behalf of a purchaser than do others. ${ }^{74}$

$\$ 330$. Power of chancery court to order conveyance of minor's land.-In some states it is held that a court of chancery, acting under its general powers and without any statute authorizing it, may order the sale of an infant's real estate, where it is shown to be for his benefit..$^{75}$ It has, however, been held by the English courts that the court of chancery has not jurisdiction, by virtue of its inherent powers, to order the sale of an infant's real property, even for his advantage, and acts of parliament were considered necessary to enable guardians to convey for the infant. ${ }^{76}$ Some American courts have assigned as a reason for denying this jurisdiction in England that by changing the character of the minor's estate from real to personal the rights of those who would be entitled to the property, in case of the minor's death, would be affected, as real and personal property descends and is distributed, respectively, in different lines; and these courts have consequently considered that, as this reason does not obtain in this country, therefore the English rule should not be followed. ${ }^{77}$ Other American courts (and it seems

"Ind. Burng' R. 8. 1901, § 2698; Mich. C. L. 1897, §9129; Minn. G. L. 1894, $\$$ 4612, 4613; Neb. Com. Stat. 1901, $\$ 2579$; Ore. Hill's Ann. L. 1892, p. 1855, § 3; Wis. Stat. 1898, § 3919.

${ }^{75}$ Hale v. Hale, 1893, 146 Ill. 227, 249; 33 N. E. 858; 20 L. R. A. 247; Gorman v. Mullins, 1898, 172 Ill. 349; 50 N. E. 222; Thorington v. Thorington, 82 Ala. 489; 1 So. 716; Taylor v. Peabody \&c. Co., 65 Md. 388 ; 4 Atl. 886 ; Hurt v. Long, 1891, 90 Tenn. 445, 459; 16 S. W. 968.

Macpherson on Infants, p. 318.

$\pi$ See for discussion and review of authorities: Richards v. East Tenn. \&c. R. Co., 1899, 106 Ga. 614 ; 33 S. E. 193 ; 45 L. R. A. 712 ; Hale จ. Hale, 1893, 146 Ill. 227 ; 33 N. E. 858 ; 20 L. R. A. 247. 
the greater number) have, however, followed the view of the English courts, and have held that the power of the court of chancery extends only to the personal estate of infants and the income of real estate, and that the real estate cannot be conveyed except under statutes of the character mentioned..$^{78}$

${ }^{70}$ Losey v. Stanley, 1895,147 N. Y. 560, 569; 42 N. E. 8 ; Hoback v. Miller, 1898, 44 W. Va. 635, 638; 29 S. E. 1014; Faulkner v. Davis, 18 Grat. 651; 98 Am. D. 698, n. p. 735; Liter v. Fishback, 1903 (Ky.); $75 \mathrm{~S}$. W. 232 . It was generally considered necessary formerly, before the enactment of these general statutes, to apply to the legislature for a special act, authorizing the guardian to act in the particular case. But special legislation is now expressly prohibited by the constitutions of many states; and, besides, many courts have held that such laws, passed for the special purpose of allowing particular lands of a minor to be sold, are unconstitutional, because there is involved in the determination of such questions the exercise of judicial power by the legislature. Answer of court, etc., 4 N. H. 565, 572; Gannett v. Leonard, 47 Mo. 205, 208; Garth v. Arnold, 1902, 115 Fed. R. 468; Hoyt v. Sprague, 103 U. 8. 613, 634. See supra, § 324. 


\section{CHAPTER XXI.}

\section{TEE CONVEYANCE OF THE REAL Estate OF PERSONS OF UNSOUND MIND.}

§331. Insane persong' conveyances similar to infants' -Yet the two classes differ.

332. Conveyance of insane person, under guardianship, void.

333. While guardianship continues ward presumed incompetent-But not if merely adjudged insane or guardianship ended.

334. Effect of guardianship of spendthrifts and drunkards.

335. Conveyance of insane person not under guardianship generally voidable.

336. Such convey ancesometimes considered void-Powere of attorney.

337. Whether such a voidable deed conveys title without being affirmed.

338. The kinds and degrees of insanity.

339. The question as to insanity must relate to the time of the act.
\$340. Presumption of sanity-Not overcome by mere weakness of mind-Partial insanity.

341. Weakness of mind combined with inadequate consideration-Fiduciary relations.

342. The conveyance where regarded as voidable may be affirmed.

343. Deed of insane grantor may be disaffirmed by him when sane.

344. May be disaffirmed by his guardian.

345. Insane grantor's heirs may disaffirm-Creditors generally may not.

346. As to the return of consideration on disaffirmance.

347. Whether conveyance may be disaffirmed as against subsequent bona fide grantee.

348. Statutes providing for the disposal of insane persons' interests in lands.

§ 331. Insane persons' conveyances similar to infants' -Yet the two classes differ. - It is sometimes said that the same rules are applied in law to conveyances by persons of unsound mind as to conveyances by infants. But 
the statement is not quite accurate. While the two classes of cases strongly resemble each other at some points, the differences are so many that it is practically unwise to rely on the analogy between them. On many points regarding conveyances by those of unsound mind there is more conflict of opinion than there is on similar points regarding conveyances by infants; some of the conflict has undoubtedly been caused by an attempt in many instances to press the analogy between the two classes too far, and some by a failure to discriminate between acts that are voidable and those that are void. ${ }^{1}$

\$332. Conveyance of insane person, under guardianship, void.-There is one general rule upon which there is almost universal agreement, namely, the conveyance of a person who has been adjudicated to be of unsound mind, and who has been placed under guardianship is absolutely void.

Guardianship of this class of persons is provided for by statute in probably every state, though such guardians are known by different names in different states, as "Committee," "Conservator" or simply "Guardian." The general purpose of the guardianship is to protect the property of the incompetent; the guardianship takes from him the management of his estate, hence follows the general rule just stated. ${ }^{2}$

The conveyance in such a case being void, the guardian's assent to it will not make it valid, unless the assent is authorized by a court under statutory proceedings similar to those by which an infant's guardian conveys $;^{8}$ and so, for example, where a wife may relinquish her dower

1 See ante, $\$ 312$.

2 See Hughes v. Jones, 1889, 116 N. Y. 67, 73; 22 N. E. 446; 15 Am. St. R. 386 ; 5 L. R. A. 632 ; Wait $\nabla$. Marwell, 5 Pick. 217; 16 Am. D. 391 ; New Eng. Loan and Trust Co. v. Spitler, 1895, 54 Kan. 560; 38 Pac. 799; Imhoff v. Witmer's Admr., 31 Pa. St. 243.

See Ante, \$324. 
in the real estate of her husband only by a "joint deed" of herself and her husband, if an insane man, his wife and his guardian all join in a deed of the ward's land it is of no effect, and the ward's wife may claim her dower, because she has not barred it by executing a joint deed with her husband."

$\S 333$. While guardianship continues ward presumed incompetent-But not if merely adjudged insane or guardianship ended.-While the guardianship continues there is a conclusive presumption that the ward lacks capacity to make a conveyance, and evidence will not be received to rebut this presumption. 5 But to have this effect and to raise this presumption the guardianship must actually be in force at the time the conveyance is made. Hence, if the guardianship has ceased, either by removal of the guardian or by his abandonment of the guardianship, there is no such conclusive presumption. ${ }^{6}$

A mere adjudication of insanity without the appointment of a guardian does not establish this conclusive presumption. A distinction is to be noted between a proceeding to commit an insane person to an asylum for treatment and custody, and a proceeding having for its object the appointment of a guardian for him on the ground that he is not competent to manage his estate. A person may be so insane that he ought to be committed to an asylum and yet be sane enough to make a will or a deed. In many states a commitment to some retreat is not even prima facie evidence of the committed person's

\footnotetext{
- Rannells v. Gerner, 80 Mo. 474.

- Rannells v. Gerner, 80 Mo. 474 ; Loonard v. Leonard, 14 Pick. 280.

6 Willwerth v. Leonard, 1892, 156 Mass. 277; 31 N. E. 299; Thorpe v. Hanscom, 1896, 64 Minn. 201; 66 N. W. 1; Elston v. Jasper, 45 Tex. 409. This is the general rule where the matler has not been affected by statute; in some states the presumption exists by virtue of the statute, when idiocy or lunacy has once been found, even though the guardianship may have been abandoned. Ridden $\nabla$. Baker, 86 Ind. 191 ; Burnham v. Kidwell, 113 Ill. 425.
} 
incapacity to contract; and, even if prima facie evidence of such fact, evidence may, notwithstanding, be received to show that he was competent.?

\$334. Effect of guardianship of spendthrifts and drunkards.-There are other persons for whom guardians may be appointed under the statutes of some states, who are to some extent incompetent, and who yet are not insane, in the ordinary sense of the term: these are spendthrifts, drunkards and other persons who, by reason of certain qualities named in the statutes, are deemed unfit to have the management of their property. ${ }^{8}$

The statutes of several states provide that if a copy of the application for a commission or inquisition in regard to the competency of such a person be filed in the office of the register of deeds, or other public office designated in the statute, all contracts (except for necessaries), and gifts, sales and transfers of property shall thereafter be void, if, as a result of the application, a guardian is appointed for the alleged incompetent. ${ }^{9}$

\$ 335. Conveyance of insane person not under guardianship generally voidable.-There are, however, many persons who are of unsound mind, because of disease, old age, accident or intoxication, who have never been placed under guardianship, nor have been in any manner adjudged insane or otherwise incompetent. As to whether

${ }^{7}$ Dewey v. Allgire, 1893, 37 Neb. 6; 55 N. W. 276; 40 Am. St. R. 468; Leggate v. Clark, 111 Mass. 308; Topeka Water Supply Co. v. Root, 1895, 56 Kan. 187, 194; 42 Pac. 715; Miskey's Appeal, 107 Pa. St. 611, 627.

'Indiana, Burns' R. 8. 1901, §§5743, 5744; Iowa, Co. 1897, 3219 ; Missouri, R. S. $1899, \S 3701$.

9 Michigan, C. L. 1897, \$\$8712, 8714 ; Minnesota Gen. Stat. 1894, §4549; Nebraska, Com. Stat. 1901, $\S \S 3228,3230$; Oregon, Hill's Ann. L. 1892 , $\S 2893$; Wisconsin, Stat. $1898, \S 3979$. See for somewhat different type of statute, Connecticut, Gen. Stat. 1902, § 1833; Massachusetts R. L. 1902 , ch. $145, \S 8$. 
conveyances by such persons are void or merely voidable, there is some difference of opinion.

The general rule, as laid down by most of the American courts, is that the conveyance of a person of unsound mind, but not under guardianship, is voidable, merely, and not void. ${ }^{10}$

In states where this doctrine is announced in general terms, it appears that there might arise cases in which the conveyance would be held void-as, for example, where the grantor is so entirely devoid of mental power as to be wholly incapable of comprehending the nature of his act in making the conveyance, ${ }^{11}$ and especially where the grantee knew that this degree of mental unsoundness existed. ${ }^{12}$ On the other hand, it seems that there might arise cases in which the conveyance would be held not even voidable-as where the person dealing with the grantor was ignorant of his incapacity, and dealt with him in entire good faith and paid an adequate consideration. ${ }^{13}$

\$336. Such a conveyance sometimes considered voidPowers of attorney.- While the greater number of authorities hold that the conveyance by one of unsound mind, not under guardianship, is voidable, merely, good reasons have been given for holding it to be void, ${ }^{14}$ and there are recent decisions so holding. ${ }^{15}$

${ }^{10}$ Moran v. Moran, 1895, 106 Mich. 8; 63 N. W. 989; 58 Am. St. R. 462 ; Castro v. Geil, 1895, 110 Cal. 292 ; 42 Pac. 804 ; 52 Am. St. R. 84 ; Riley v. Carter, 1893, 76 Md. 581; 25 Atl. 667; 19 L. R. A. 489; French Lumbering Co. v. Theriault, 1900, 107 Wis. $627 ; 83 \mathrm{~N}$. W. 927; 81 Am. St. R. 856; 51 L. R. A. 910; McAnaw v. Tiffin, 1898, 143 Mo. 667, 678; 45 S. W. 656; Boyer v. Berryman, 1890, 123 Ind. 451; 24 N. E. 249.

"French Lumbering Co. v. Theriault, 1900, 107 Wis. 627; $83 \mathrm{~N}$. W. 927; 81 Am. St. R. 856; 51 L. R. A.910; Castro v. Geil, 1895, 110 Cal. 292 ; 42 Pac. 804 ; 52 Am. St. R. 84.

12 Thrash v. Starbuck, 1896, 145 Ind. 673, 680; 44 N. E. 543.

${ }^{18}$ Rhoades v. Fuller, 1897, 139 Mo. 179; 40 S. W. 760.

"Compare the court's opinions with the dissenting opinions in, Allen v. Berryhill, 27 Iowa 534, and Elder v. Schumacher, 1893, 18 Colo. 433.

${ }^{15}$ Boddie v. Bush, 1903, 136 Ala. 560; 33 So. 826; (ralloway v. Hen- 
That such a conveyance is void, is sometimes said ${ }^{16}$ to be the rule in the Federal Courts, "however conflicting the decisions of the state courts may be upon the question whether the deed of an insane person is void or voidable," and the case of Dexter v. Hall, ${ }^{17}$ is cited as fixing the law for these courts. In this case, however, it was merely decided that the power of attorney of an insane person is void, although much is said of deeds in general and reasons are given for holding them also void. But in spite of these reasons it appears that now the Supreme Court of the United States agrees with the majority of state courts in holding such a deed not void, but merely voidable. ${ }^{18}$.

This conflict of opinion as to whether the conveyance of one of unsound mind is void or voidable has arisen, probably, from the fact that it was formerly held in England that a feoffment with livery of seisin made by one insane was not void, but voidable merely, though his deed of bargain and sale was void-being similar to those of infants. ${ }^{19}$ The reasons for attaching greater importance to the feoffment than to the deed no longer exist, and the distinction between the different sorts of conveyances has gradually been lost sight of by many, and yet has been maintained by others. In this country a deed executed in proper form and duly recorded or registered is very generally regarded as equivalent to a feoffment, ${ }^{20}$ and therefore conveyances of all kinds by incompetents have of ten been held voidable merely, on the authority of the old English rule. ${ }^{21}$

don, 1901, 131 Ala. 280; 31 So. 603; German Savings \& L. Soc. v. DeLashmutt, 1895, 67 Fed. 399.

${ }^{16}$ Parker v. Marco, 1896, 76 Fed. 510, 512.

${ }^{17} 15$ Wall. 9.

${ }^{18}$ Luhrs v. Hancock, 1901, 181 U. 8. 567.

10 See ante, § 314.

${ }^{20}$ See ante, $\$ \S 53,58$.

"See Riley v. Carter, 1893, 76 Md. 581 ; 25 Atl. 667; 19 L. R. A. 489; Dexter v. Hall, 15 Wall. 9; Case of Sarah DeSilver, 5 Rawle 111. 
$\S 337$ CONVEYance OF INSANe PERSONs' LANDS. 413

For the same reasons that powers of attorney given by infants have been held void, ${ }^{22}$ those given by persons of unsound mind are often so considered, ${ }^{23}$ but the older rule which so holds is not always followed, for they have been held voidable merely. ${ }^{24}$

\$337. Whether such a voidable deed conveys title without being affirmed.-Whether an insane person's conveyance, in those states where it is held merely voidable, transmits the title as an infant's does, ${ }^{25}$ subject to its being divested, or whether the title is good only after confirmation or ratification, is a question, not, it seems, quite settled. It has been said ${ }^{26}$ that in such a case the legal title passes to the grantee, and therefore, that his title may not be attacked in an action of ejectment, but only by a bill in equity, when equitable defenses may be made by him. And that such a conveyance vests the title in the grantee which he holds until the conveyance is disaffirmed, appears to be the general doctrine. ${ }^{27}$

It is, however, sometimes said that the conveyance of a person of unsound mind is ineffectual to convey title to land unless it is confirmed by the grantor himself when of sound mind, or by his legally constituted guardian, or his heirs or devisees. ${ }^{28}$

22 See ante, § 314 .

2 Plaster v. Rigney, 1899, 97 Fed. 12; McClun v. McClun, 1898, 176 Ill. 376,$380 ; 52$ N. E. 928.

${ }^{24}$ Williams v. Sapieha, 1901, 94 Texas 430; 61 S. W. 115.

25 See ante, $\S 313$.

* Moran v. Moran, 1895, 106 Mich. 8, 13; 63 N. W. 809.

${ }^{27}$ French Lumbering Co. $\nabla$. Theriault, 1900, 107 Wis. 627; 83 N. W. 927; 81 Am. St. R. 856; 51 L. R. A. 910; McAnaw v. Tiffin,1898, 143 Mo., 667, 678; 45 S. W. 656 ; Castro v. Geil, 1895, 110 Cal. 292; 42 Pac. 804 ; 52 Am. St. R. 84; Woolley v. Gaines, 1901, 114 Ga. 122 ; 39 S. E. 892 ; 88 Am. St. R. 22 ; Downham v. Holloway, 1902, 158 Ind. 626; 64 N. E. $82 ; 92$ Am. St. R. 330.

* Brigham v. Fayerweather, 144 Mass. 48; Crawford v. Scovell, 94 Pa. St. 48, 51; 39 Am. R. 766. The distinction may be of some importance as bearing on the remedy ; if legal title has passed to the grantee, the remedy for the grantor, or those who represent him would be 
\$338. The kinds and degrees of insanity.-The mental unsoundness which will render a deed thus (generally) voidable may arise from one or more of several causes, and the different kinds of insanity will appear in a great variety of forms. Insanity may present itself as idiocy ( or " congenital insanity"), lunacy or mania, caused by grief, accident, disease, or continued intoxication, or it may appear as dementia arising from old age; it may be continuous and permanent, or intermittent, leaving the person "lucid intervals."

The proper inquiry in each case appears to be : whether the powers of the grantor's mind have been so far affected as to render him incapable of transacting this particular business; or, as expressed by some, was there an intelligent assent to this particular conveyance?

Only a small degree of mental capacity is required to make a valid conveyance, according to many authorities : "The question is not whether the grantor had ordinary capacity to do business, it is whether he had any, the smallest, capacity to understand what he was doing and to decide intelligently whether or not he would do it." 29 A higher test, however, appears to be demanded by some courts, and if the grantor is lacking in that degree of com-

in equity and not by ejectment, for, the legal title having passed, there would be simply an equitable title in the grantor which would not support an action of ejectment; and generally actions by a formerly insane person, or his representatives, to regain his land, are equitable proceedings to cancel the conveyance. The equitable proceeding is neceseary in most cases for the further reason that the grantee has, by the decisions of most courts, the right to a return of the consideration under certain circumstances, and this cannot be considered in an action of ejectment, being in the nature of an equitable defense. This distinction has been affected by the blending of legal and equitable forms of procedure in some jurisdictions, but still may affect the matter of pleading. Where the conveyance of one non compos mentis is held absolutely void, proceedings in equity have been held inappropriate as the remedy at law is complete and adequate. Boddie v. Bush, 1903, 136 Ala. 560 ; 33 So. 826.

${ }^{29}$ Mann v. Keene Co., 1898, 86 Fed. 51, 53. 
prehension which would make him capable of transacting ordinary business affairs in which his interest is involved " it may well be regarded he is incapable of understanding the nature and effect of the act of disposing of his land to another." 30

Generally a higher degree of mentality is needed to make a valid deed than to make a will, because in the bargaining which leads to the ordinary deed, mind is opposed to mind, and there is necessary a greater exercise of mental power than is required to make a valid will. ${ }^{31}$

The uncertain point at which the disposing mind disappears and insanity begins can be ascertained only by examining and weighing all the circumstances of each case. ${ }^{32}$

\$339. The question as to insanity must relate to the time of the act.-The inquiry as to the capacity of the grantor must relate to the very time of the act in question, ${ }^{33}$ and, as delivery must be the surrender of the deed with intent that the grantee shall take title under it, ${ }^{34}$ a deed signed and sealed by one while sane, but retained by him, and only delivered at his direction while he is insane, passes no title because there is no delivery. ${ }^{35}$

\$340. Presumption of sanity, not overcome by mere weakness of mind-Partial insanity.-In considering a case of this character one must start out with the legal presumption of sanity and ability, and, when lack of ability in the grantor is claimed, it must be shown by a

$\%$ Ring v. Lawless, 1901, 190 Ill. 520, 533; 60 N. E. 881.

"Converse v. Converse, 21 Vt. 168.

28 Dennett y. Dennett, 44 N. H. 531; 84 Am. D. 97; Conley v Nailor, 118 U. S. 127, 133; Bowdoin College v. Merritt, 1896, 75 Fed. 480, 487.

2s Carnagie v. Diven, 1897, 31 Ore. 366, 49 Pac. 891 ; Francis v. Wilkinson, 1893, 147 Ill. 370, 380; 35 N. E. 150.

" Ante, § 299.

${ }^{25}$ McClun v. McClun, 1898, 176 Ill. 376; 52 N. E. 928. 
preponderance of evidence. ${ }^{36}$ And showing some impairment of the mind, by extreme age or disease, is not enough to overcome this presumption. ${ }^{87}$

In practice a difficulty arises in this class of cases because of the opinion which prevails among jurors, and to some extent among medical men, who are often called as witnesses, that partial insanity or monomania, or even eccentricity on the part of the grantor, is enough to invalidate a conveyance. But the true view is stated as follows: "Though long doubted, it is now well settled both in England and the United States that the same person may be at the same moment both sane and insane, or, more accurately speaking, insane upon one or more subjects and sane upon all others, and in what he does with reference to the former will be treated both by the courts administering the criminal laws and by those administering the civil as insane, while in respect to the latter he will be held responsible in the criminal courts for crimes committed by him, and in civil courts his contracts and dispositions of property will be adjudged binding and valid." 88

Unless, therefore, the partial insanity or monomania relate to the particular subject out of which the conveyance grew, or be of such a character as to induce the conveyance, it should not render it even voidable. ${ }^{\circledR 9}$

${ }^{36}$ Argo v. Coffin, 1892, 142 Ill. 368; 32 N. E. 679; Jones v. Jones, 1893, 137 N. Y. 610 ; 33 N. E. 479; Brown v. Brown, 39 Mich. 792 ; Elcessor v. Elcessor, 1892, $146 \mathrm{~Pa}$. St. 359; 23 Atl. 230; Farnsworth v. Noffsinger, 1899, 46 W. Va. 410; 33 S. E. 246.

87 Shea v. Murphy, 1897, 164 Ill. 614, 619; 45 N. E. 1021; Cutts v. Young, 1899, 147 Mo. 587, 599; 49 S. W. 548; Buckey v. Buckey, 1893, 38 W. Va. $168 ; 18$ S. E. 383.

${ }^{38}$ Note on "Insane Delusions," 63 Am. St. R. 80.

${ }^{39}$ Meigs v. Dexter, 1898, 172 Mass. 217; 52 N. E. 75 ; Elwood v. O'Brien, 1898, 105 Iowa 239; 74 N. W. 740; Dennett v. Dennett, 44 N. H. 531; $84 \mathrm{Am}$. D. 97. This same principle is applied to wills in the following cases: Trich's Ex'r. v. Trich, 1895, $165 \mathrm{~Pa}$. St. R. 586; 30 Atl. 1053; Farmer v. Farmer, 1895, 129 Mo. 530; 31 S. W. 926; Blough จ. Parry, 1893, 144 Ind. 463, 475; 40 N. E. $70 ; 43$ N. E. 560. 
$\S 341$ CONVEYANCE OF INSANE PERSONS' LANDS. 417

\$341. Weakness of mind combined with inadequate consideration-Fiduciary relations.-While mere weakness of mind will not of itself warrant a court in setting aside a conveyance-unless it be of such a degree as to take from the grantor the power to intelligently assent to the conveyance-the weak mental condition of the grantor furnishes ground for suspicion, and if unfair advantage can be either shown or inferred from the circumstances, equity will set aside the conveyance.

For example, a deed will generally be set aside, if, in connection with weakness of mind, it is shown that the consideration is nominal or grossly inadequate-from such circumstances imposition will be inferred; $;^{40}$ or where there is weakness of mind in the grantor and the grantee sustains a fiduciary relation to him, or such a relation as enables him to influence the grantor, a presumption of undue influence is raised."11

The principle to be applied to such cases appears to be : Such other circumstances combined with weakness of mind do not constitute an absolute or necessary ground for equitable relief, but they throw the burden of proof on the grantee to show that the grantor acted freely, deliberately and intelligently. ${ }^{2}$

\$342. The conveyance where regarded as voidable may be affirmed.-The conveyance of an insane person (not under guardianship) being generally considered

${ }^{\infty}$ Allore v. Jewell, 94 U. S. 506 ; Griffith v. Godey, 113 U. S. 89, 95; Ashmead v. Reynolds, 1893, 134 Ind. 139; 33 N. E. 763 ; Hale v. Kobbert, 1899,109 Iowa $128 ; 80$ N. W. 308.

4 Disch v. Timm, 1898, 101 Wis. 179; 77 N. W. 196 ; Seeley v. Price, 14 Mich. 541; Duncombe v. Richards, 46 Mich. 166; 9 N. W. 149.

Smith v. Cuddy, 1893, 96 Mich. 562, 569; 56 N. W. 89; Thomas v. Whitney, 1800, 186 Ill. 225; 57 N. E. 808; Kellogg v. Peddicord, 1899, 181 Ill. 22 ; 54 N. E. 623; Carty v. Connolly, 1891, 91 Cal. 15; 27 Pac. 599 ; Fitch v. Reiser, 1890, 79 Iowa 34 ; 44 N. W. 214; Bruguier v. Peppin, 1898, 106 Iowa 432 : 76 N. W. 808; Paddock v. Pulsifer, 1890, 43

Kan. 718; 23 Pac. 1049. 27-Brews. CoN. 
voidable merely, and not void, may generally be affirmed or ratified by those in interest.

Hence the grantor himself may affirm it, either after complete restoration to sanity or during a lucid interval; but in either case the affirmation must be his intelligent act, with an understanding on his part of the nature of the instrument. ${ }^{43}$ He may confirm it in various ways; as, by receiving, while sane, the consideration; by a new conveyance or contract; or by failure, under some circumstances, to move in setting it aside. Any act which shows clearly a recognition of the conveyance as valid is competent evidence of ratification."4

But his guardian or committee cannot, generally, confirm an insane ward's conveyance, without the direction of a competent court; because, having no power to convey a ward's estate without the court's order, the guardian has no power to do such acts in ratification as are equivalent to a conveyance. ${ }^{45}$

\$ 343. Deed of insane grantor may be disaffirmed by him when sane.-Where a deed has been made by one who is mentally incompetent or insane, it may be disaffirmed by him on his restoration to sanity.

The old English rule was that he himself could not take steps to have such a conveyance set aside, because no one should be thus allowed to stultify himself and because he could not know, when he became sane, what he had done while he was insane. But this doctrine has been completely done away with: "it has been repudiated by every American court, and denounced as having no

4 Bond v. Bond, 7 Allen 1; Beasley v. Beasley, 1899, 180 Ill. 163; 54 N. E. 187.

4 This rule would not apply in those jurisdictions where the first conveyance is held void. In them the grantor could cure the infirmity in his former attempted conveyance only by executing another after his restoration to sanity-not strictly speaking a ratification.

«s Funk v. Rentchler, 1892, 134 Ind. 68; 33 N. E. 364, 898; New Eng. Co. v. Spitler, 1895, 54 Kan. 560; 38 Pac. 799. 
foundation in reason or justice, and as dishonoring the jurisprudence of a civilized people," 46

If, after his restoration to sanity, one conveys lands which he had attempted to convey while insane, the grantee in the second deed acquires by it the right which his grantor had, to avoid the deed made during his insanity. ${ }^{47}$

$\S 344$. May be disaffirmed by his guardian.-If the incompetent be not restored to reason his guardian may disaffirm his conveyance by proceedings to have the conveyance canceled.

There has been some question as to whether in such cases the insane person may bring suit by his "next friend," or whether it must be by his general guardian. The matter is somewhat governed by statute. The proper practice is said in some cases to be to bring the action on behalf of the incompetent by his guardian or conservator, and not by a next friend or guardian ad litem specially appointed for this purpose: the guardian has control of the incompetent's property and is responsible for proper conduct of the proceedings. The more general practice conforms to this view. 48

§ 345. Insane grantor's heirs may disaffirm-Creditors generally may not.-If the incompetent be dead his heirs may bring suit to cancel the deed, and this is common practice.

It was urged in one case that heirs, children of a deceased grantor, seeking to set aside his deed, were guilty of laches in not having had his competency tested while

* Turner $\nabla$. Rusk, 53 Md. 65, 68. See briefs for valuable collection of authorities.

${ }^{7}$ Clay v. Hammond, 1902, 199 Ill. $370 ; 65$ N. E. 352.

${ }^{*}$ Covington v. Neftzger, 1892, 140 Ill. 608; 30 N. E. 764; Row v. Row, 1895, 53 Ohio St. 249; 41 N. E. 239 ; Tiffany $\nabla$. Worthington, 1896, 96 Iowa $560 ; 65$ N. W. 817. But see, Plymton v. Hall, 1893, 55 Minn. 22 ; 56 N. W. 351 ; Wager v. Wagoner, 1898, 53 Neb. 511 ; 73 N. W. 937. 
he was living, but the court held this not such laches as should bar their remedy, and it was observed that children might well hesitate to drag an aged parent into court under such circumstances. ${ }^{49}$

While the grantor remains insane he has no power to disaffirm his conveyance, and during that time the statute of limitations will not run so as to bar an action by his heirs should he remain incompetent during his entire lifetime. ${ }^{.0}$

While the heirs of a grantor non compos mentis may thus have his conveyance set aside because of his incompetency, his creditors have not generally the same privilege, and a conveyance will not be set aside in their behalf, unless, besides the grantor's incompetency, other reasons exist for its cancelation. ${ }^{.1}$

$\$ 346$. As to the return of consideration on disaffirmance.-On the question as to whether there shall be a return of the consideration when the conveyance of an incompetent person is attempted to be set aside, there is less harmony among the decisions than there is on the similar question which arises concerning the infant's deed..$^{32}$

It appears that most courts in deciding this question will take into account the fairness of the transactionwhether it is free from fraud and undue influence-and also the knowledge of the grantee as to the grantor's incompetency. The general rule is: The conveyance of an insane person will not be set aside when the other party has acted in good faith and in ignorance of the grantor's unsoundness of mind, unless the consideration

${ }^{99}$ Hemphill v. Holford, 1891, 88 Mich. 293; 50 N. W. 300.

60 Downham v. Holloway, 1902, 158 Ind. 626; 64 N. E. 82; 92 Am. St. R. 330.

${ }^{61}$ See Rollet $\nabla$. Heiman, 1889, 120 Ind. $511 ; 22$ N. E. $666 ; 16$ Am. St. R. 340 ; Riley v. Carter, 1893, 76 Md. 581 ; 25 Atl. 667 ; 19 L. R. A. 489. See for similar rule as to infants, $\S 319$.

Ante, § 321 . 
can be restored-that is, the parties placed substantially in statu quo..$^{53}$ Or, where the grantee acted in good faith, and it is impossible to return the consideration paid by him to the incompetent grantor, the amount may be made a charge or lien on the land if the conveyance is set aside. Wh Where, however, the grantee knew of the grantor's unsoundness of mind, a return of the consideration received by the insane grantor does not seem to be a necessary prerequisite to an avoidance of the conveyance. ${ }^{.5}$

The doctrine that there must be a return of the consideration, where the grantee did not know of the grantor's insanity and acted in good faith, is not, however, universally approved, for it has been considered that the conveyance may be set aside without returning the consideration or placing the other party in statu quo; nor is it always considered material that in taking the deed the other acted in good faith and without knowledge of the grantor's insanity - because, it is said, he who deals with an insane person does so at his peril. ${ }^{.6}$

\$347. Whether conveyance may be disaffirmed as against subsequent bona fide grantee.-As to the title of subsequent purchasers in good faith, the same rule is frequently applied in these cases as controls in cases where the original grantor is an infant. ${ }^{57}$

This doctrine has been expressed as follows: "The insane man has not the power to convey an indefeasible

ss Eldredge v. Palmer, 1900, 185 Ill. 618; 57 N. E. 770; 76 Am. St. R. 59 ; Warfield v. Warfield, 1889, 76 Iowa 633; 41 N. W. 383; Boyer v. Berryman, 1890, 123 Ind. 451; 24 N. E. 249; Myers v. Knabe, 1893, 51 Kan. 720, 723; 33 Pac. 602; Schaps v. Lehner, 1893, 54 Minn. 208; 55 N. W. 911 ; Pearson v. Cox, 71 Texas 246; 9 S. W. 124 ; 10 Am. St. R. 740 ; McKenzie v. Donnell, 1899, 151 Mo. 431, 458; 52 S. W. 214.

4 Moran v. Moran, 1898, 106 Mich. 8, 11; 63 N. W. 989.

ss Thrash v. Starbuck, 1896, 145 Ind. 673; 44 N. E. 543; Crawford v. Scovell, 94 Pa. St. 48.

56 Brigham v. Fayerweather, 144 Mass. 48; 10 N. E. 735; Wager v. Wagoner, 1898, 53 Neb. 511 ; 73 N. W. 937.

"Ante, \&318. 
title. This incapacity inheres in all titles derived from him. The grantee whose title is thus derived must rely on the covenants of his deed. He risks the capacity to convey of all through whom his title has passed. The rights of infants and of insane alike to avoid their contracts is an absolute and paramount right, superior to all equities of other persons, and may be exercised against bona fide purchasers from the grantee." 58

But this rule has not been followed in cases of insane grantors with nearly so much uniformity as in cases of infant grantors. The presumption of law is in favor of sanity: "When, therefore, a purchaser sees a regular chain of title, formal in all particulars, upon the registration books, executed by grantors of full age and not feme coverts, he has a right to rely upon the presumption of sanity, and if without any notice, or matter to put him upon inquiry and for fair value, he takes a deed he should be protected. Any other doctrine would place all titles upon the hazard." 69

\$348. Statutes providing for the disposal of insane persons' interests in lands. - There are statutes relating to the conveyance or release of an insane person's interests in real property that should be noticed. There are two chief classes of such statutes.

First. Those which authorize the conveying or the mortgaging of the real property of such a person by his "committee," "conservator" or "guardian" under special direction of a court. Such statutes appear to exist in

${ }^{68}$ Hovey v. Hobson, 53 Me. 451, 458; 89 Am. D. 705. And see, Hull v. Louth, 109 Ind. 315 ; 10 N. E. 270 ; 58 Am. R. 405; Dewey v. Allgire, 1893, 37 Neb. 6; 55 N. W. 276; 40 Am. St. R. 468; Germ. Savings \& L. Soc'y $\nabla$. DeLashmutt, 1895, 67 Fed. 399. The uncertainty as to titles on this account is one reason advanced for the adoption of the "Torrens System" of registration.

${ }^{69}$ Odom v. Riddick, 1890, 104 N. C. 515,$520 ; 10$ S. E. $609 ; 17$ Am. St. R. 686; 7 L. R. A. 118; Ashcraft v. DeArmond, 44 Iowa 229, 235 ; Greenslade v. Dare, 20 Beav. 284. 
every state. In many states the statutes providing for the disposal of infants' lands $8^{60}$ also provide that the lands of those of unsound mind may be disposed of under the same circumstances; and where separate laws exist relating to the lands of the latter class, they are substantially similar to those concerning the lands of infants, and are governed by the same general principles.

Second. Statutes authorizing proceedings by virtue of which an insane wife's or husband's interests in real property belonging to the other spouse may be conveyed or released. An insane wife cannot release her dower in her husband's lands, as such a release must be her voluntary act, nor may her guardian do so for her without statutory authority. ${ }^{61}$

Therefore statutes have been passed in many states authorizing a judicial examination, after which a release of her dower (or its statutory substitute), and in some cases a release of her interest in the "homestead," may be directed by the court, on condition that the insane wife's share in the purchase money is paid to her guardian or secured to her use. ${ }^{62}$

In several states (e. g. Illinois, Indiana, Iowa and Massachusetts), the same or similar statutes provide for such proceedings when it becomes necessary to release an insane husband's interest in his wife's lands.

$\infty$ Ante $\$ 324$ et seq.

Eslava v. Lepretre, 21 Ala. 504, 529; Ex parte McElwain, 29 Ill. 442.

- Illinois R. S., ch. 68, § 17 ; Indiana, Burns' R. S. 1901, §3388a ; Iowa Co. 1897, §§ 3167-3169; Kentucky, Stat. 1899, § 2145 ; Massachusetts, R. L. 1902, ch. 153. §19; Michigan, C. L. 1897, $\$ 8947-8952$; Missouri, R. S. 1899, § 2985; Ohio, R. S., \$§ 5725, 6307 ; Virginia, Co., § 2625, am'd 1895, p. 260; Wisconsin, San. \& B. Stat. 1898, § 2225. 


\section{CHAPTER XXII.}

\section{CONVEYANCES IN WHICH MARRIED WOMEN ARE INTERESTED.}

§349. The married woman's different interests in real property.

350. The husband's rights in, and control over, his wife's property at common law.

351. The common law not wholly obsolete in this country.

352. The equitable separate estate-How created.

353. The intention to create the separate estate must generally be clearly expressed.

354. The "restraint on anticipation."

355. The wife's power over her separate estate in the absence of such restraint.

356. Manner of conveying separate estate.

357. Effect of statutes on the equitable separate estate.

358. Constitutional and statatory provisions creating a separate estate.

359. Statutes creating separate estate do not always remove the married woman's disability to convey.

360. Common law methods of alienation by married women - Deeds unusual -Fines.
361. The joinder of the husband at common law-The separate examination.

362. Early usages in the United States-The joint deedStatutes requiring joinder.

363. When the husband's joinder or assent is now necessary.

364. Whether husband and wife should join as grantors or merely execute the deed.

365. The married woman's acknowledgment-The separate examination.

366. How far the eeparate examination must now be regarded.

367. How far compliance with statutory provisions as to particulars is necessary.

368. Conveyances between huoband and wife.

369. Conveyances between husband and wife through $a$ third person.

370. Equitable view of conveyances between husband and wife.

371. Rule as to conveyances between husband and wife affected by statute.

372. Dower and its statutory substitate. 
$\S 349$ CONVEYANCES OF MARRIED WONEN'S INTERESTS. 425

373. Generally no act of the husband alone can defeat dower-Exceptions to this rule.

374. Inchoate right of dower not strictly property-Released not conveyed.
375. Wife cannot generally release dower to her husband.

376. Release of dower generally by deed of husband and wife.

377. Married women's powers of attorney to convey lands or release dower.

\$349. The married woman's different interests in real property.-The married woman appears as sustaining various relations to real property; and it will depend upon what relation she bears to the property in any particular case whether she can sever that relation-and if so, how -so that title may be conveyed freed from her interest, whatever it may be.

She may appear:

1. As having an interest in the "community property."

2. As having an interest in an "estate by entireties."

3. As holding realty as at common law-often called her "general estate" to distinguish it from those next mentioned.

4. As having a "separate estate"-either an "equitable" or a "statutory" separate estate.

5. As having a dower interest, or a statutory interest similar to dower, in her husband's property.

6. As having an interest in the "homestead."

Reference has already been made to "community property," " and to "tenancy by entireties.",

In this chapter the general principles concerning her other interests in realty, especially her separate estate and dower, will be considered, while the homestead will be discussed in the next chapter. ${ }^{3}$

1 Ante, $\$ 167$.

Ante, $\$ \$ 162-166$.

- Others than married persons may quite generally have a "homo- 
$\$ 350$. The husband's rights in, and control over, his wife's property at common law.-At common law a husband acquired, by virtue of the marriage, valuable rights in the property of his wife with which the exercise by her of powers of control and disposition were inconsistent. He had, for example, an estate in the lands in which his wife had a freehold estate which he could alienate without her concurrence, and he might take the entire rents and profits of her lands, while she could not, during the marriage, alienate them without his concurrence, and not then generally by deed."

While the death of either husband or wife put an end to this estate of the husband, yet if he survived her and there had been born to them a child capable of inheriting, the husband became vested with an estate for his life in all his deceased wife's lands-his curtesy estate.

These estates or interests of the husband in his wife's real property were subject to his debts; but no disposition could be made by him or his creditors of her freehold estate which would endure beyond his own interest.

$\$ 351$. The common law not wholly obsolete in this country.-In this country, by virtue of early statutes in some jurisdictions, a husband's rights in and over his wife's real estate (which was not her "separate estate") were even greater than they were at common law, and were equal to his rights at common law in her movable or personal property in possession, ${ }^{5}$ but such statutes seem unusual.

On the other hand, modern legislation has much modified the common law and has lessened, and in many stead," but it is mentioned in this connection, since husband and wife are usually especially concerned in matters relating to its transfer or release.

'Co. Litt. 351a ; Poll. \& Mait. Hist. Eng. Law, 2d ed., II, p. 404; Eaton v. Whitaker, 18 Conn. 222; 44 Am. D. 586; Hackett v. Moxley, 1895, 68 Vt. $210 ; 34$ Atl. 949.

${ }^{5}$ Hudgins v. Chupp, 1898, 103 Ga. 484 ; 30 S. E. 301. 
states substantially abolished, the husband's common law rights in his wife's property. Prior to such legislation courts of equity had permitted settlements of "separate estates" on married women.

In spite, however, of the influence of both equity and legislation common law doctrines, as to husband and wife, are not yet entirely obsolete in the United States, and in some states a husband's common law marital rights are still recognized in respect to such of his wife's real property as is not her " separate estate."

\$352. The equitable separate estate-How created.Courts of equity about the end of the seventeenth century allowed property to be settled on a married woman so that she should have the benefit of it to the exclusion of her husband's marital rights in it.

Such a "separate estate" may be constituted by a woman's reservation in her marriage settlement of a power to dispose of her estate, ${ }^{7}$ or by a transfer by her before marriage to a trustee.

It may also be created by the conveyance by her husband of property to a trustee for her use, ${ }^{8}$ and in many states by a conveyance from a husband directly to his wife, ${ }^{9}$ as well as by conveyance or devise of a third person to her sole and separate use, either before marriage or after it. ${ }^{10}$

A trustee may be provided for by the instrument creating the separate estate to hold and protect the estate for the wife, ${ }^{11}$ and such a provision was at one time considered necessary, but there now need be no trustee, and the conveyance or devise may be made directly to the mar-

6 Dietrich v. Hutchinson, 1901, 73 Vt. 134; 50 Atl. 810; 87 Am. St. R. 698 ; Brasfield v. Brasfield, 1896, 96 Tenn. 580; 36 S. W. 384.

7 Gore v. Knight, 1705, 2 Vern. 535.

- Ryland v. Banks, 1899, 151 Mo. 1; 51 S. W. 720.

- Barnum v. LeMaster, 1903 (Tenn.); 75 S. W. 1045.

${ }^{20}$ Fears v. Brooks, 12 Ga. 195 ; Hamaker v. Hamaker, 88 Ala. 431; 6 So. 754 .

11 Jones v. Jones, 1899, 96 Va. 749 ; 32 S. E. 463. 
ried woman. The "separate estate" being, however, dependent upon the equitable doctrine of trusts-with the legal and equitable titles separated-when a transfer is thus made directly to a married woman for her sole use, her husband, in the absence of an express trustee, is regarded in equity as taking the legal estate in trust for his wife for her separate use. ${ }^{12}$

$\$ 353$. The intention to create the separate estate must generally be clearly expressed.-In order to so create this equitable separate estate, the intention of the donor to give the married woman the complete use of the property free from her husband's control must clearly appear from the words used in the instrument creating the estate. ${ }^{18}$

And while the expression "sole and separate use" has been most often employed for this purpose, no special or technical form of words has been considered essential, if the intention to exclude the husband's marital rights is indicated.

Words which might be necessary, however, to show such an intention when the donor is a stranger are not always regarded as necessary in a conveyance by the husband to a trustee for the wife or in his conveyance directly to her, and in such cases conveyances in ordinary form without words evincing an intention to create a separate estate have been construed as operating to the wife's separate use, since otherwise they would be to a great extent inoperative; ${ }^{14}$ and it has also been held that real

12 Bennet v. Davis, 1725, 2 P. Wms. 316; Jones v. Clifton, 101 U. S. 225; Wood v. Wood, 83 N. Y. 575; Dezendorf v. Humphreys, 1898, 95 Va. 473 ; 28 S. E. 880.

13 Hackett v. Moxley, 1895, 68 Vt. 210; 34 Atl. 949; Lippincott v. Mitchell, 94 U. S. 767, 771; Holliday v. Hively, 1901, 198 Pa. St. 335 ; 47 Atl. 988; Richardson v. De Giverville, 1891, 107 Mo. 422; 17 S. W. 974; 28 Am. St. R. 426.

"Barnum v. LeMaster, 1903 (Tenn.); 75 S. W. 1045; Hamilton v. Hubbard, 1901, 134 Cal. 603, 606; 65 Pac. 321. 
\$ 354 CONVEYANCES OF MARRIED WOMEN'S INTERESTS. 429

property belonging to a married woman may be invested with the character of separate estate by the husband's long acquiescence in his wife's uninterrupted control of her property and his failure to contribute to her supportsuch facts being deemed equivalent to an express agreement on his part that her property should be held to her sole use. ${ }^{15}$

§354. The "restraint on anticipation."-In conveyances generally provisions in restraint of alienation are void, ${ }^{16}$ as are provisions that the property shall not be liable for the debts of its owner. ${ }^{17}$

An exception, however, to this general rule has long been recognized in the case of the separate estate of married women, and if in the instrument by which property is conveyed to a woman for her separate estate there is a clear expression of the donor's intention that she shall not be able to deprive herself of the enjoyment of the property she cannot alienate it.

This restriction, known as the "restraint on anticipation" (expressed in brief: "to the said [wife] so that the same shall be for her separate use without power of anticipation ")-is allowed as a protection to the wife, ${ }^{18}$ and is in effect a restraint on alienation. ${ }^{19}$

$\S 355$. The wife's power over her separate estate in the absence of such restraint. - In the absence of such a restriction the effect of the creation of a separate estate was finally considered by the English courts of equity, after doubts and denials in earlier cases, to be that the married woman had the same power over the property so settled that a feme sole had over her property-she might

\footnotetext{
${ }^{25}$ Curtis v. Simpson, 1900, 72 Vt. 232; 47 Atl. 829; but see Klenke v. Koeltze, 75 Mo. $239,243$.

${ }^{16}$ Ante, § 186, note 53; Potter v. Couch, 1890, 141 U. S. 296, 315.

${ }^{17}$ McCleary v. Ellis, 54 Iowa 311; 6 N. W. 571; 37 Am. R. 205.

${ }^{10}$ Fears v. Brooks, 12 Ga. 195 ; Tulett v. Armstrong, 1838, 1 Beav. 1 ; 1839, 4 Myl. \& Cr. 377, 390.

${ }^{19}$ In re Currey, 1886, 32 Ch. D. 361.
} 
dispose of it without her husband's concurrence and without the formality of acknowledgment which later English law generally required when she conveyed her realty. ${ }^{20}$

In the United States there has been a difference of opinion as to the wife's power of disposal over her separate estate. If there is in the instrument creating the estate no clause restraining alienation, she can, in most of the states, dispose of her separate property-the English doctrine being followed in a general way, but not followed exactly, it seems, in any state.

Some states adopt almost completely the English doctrine in recognizing her power to dispose of the property absolutely as any other owner may, ${ }^{21}$ at least, if statutory requirements as to acknowledgment are fulfilled. ${ }^{22}$

In some of the states where the English principle-that she has power of disposal of her separate estate unless restrained by the instrument creating it-has but partially prevailed, she may convey and charge simply her personal property and the income of her real property, but not, speaking generally, its corpus. ${ }^{23}$

In a few states a married woman is held to be restrained from alienating her separate estate, except so far as alienation is expressly permitted by the instrument creating the estate; if there is no provision in that as to the mode of disposition she cannot dispose of the property; if one method is provided for by that instrument she can convey the property in no other way-the mode of alienation prescribed is exclusive. This view has prevailed especially in Pennsylvania and South Carolina. ${ }^{24}$

${ }^{20}$ Taylor v. Meads, 4 De G. J. \& S. 597 (69 Eng. Ch. Rep.).

${ }^{21}$ Turner v. Shaw, 96 Mo. 22; 8 S. W. $897 ; 9$ Am. St. R. 319; Cadematori v. Gauger, 1901, 160 Mo. 352; 61 S. W. 195.

"2 Barnum v. LeMaster, 1903 (Tenn.); 75 S. W. 1045.

${ }^{23}$ Radford v. Carwile, 13 W. Va. 572; Price v. Planters' Bank, 1896, 92 Va. 468 ; 23 S. E. 887.

${ }^{24}$ Holliday v. Hively, 1901, $198 \mathrm{~Pa}$. St. 335; 47 Atl. 988; Ewing v. Smith, 3 Des. 417; 5 Am. D. 557; Porcher v. Daniel, 12 Rich. Eq. 
$\S 356$ CONVEYANCES OF MARRIED WOMEN'S INTERESTS. 431

It appears, therefore, that there are in the United States three rules as to the capacity of a married woman to convey her equitable separate property, namely:

1. That, unless the instrument creating the separate estate deprives her of this capacity, she has it ;

2. That, unless she is thus expressly deprived of capacity she may convey and charge merely her income from separate real property ;

3. That she has no capacity to deal with her separate estate except what is expressly given by the instrument creating it.

The lack of harmony on this subject is probably partly due to the fact that some American courts have been influenced by English decisions of one period and some by those of another, for the final English rule was gradually developed and was not recognized at all times. ${ }^{25}$

§356. Manner of conveying separate estate.-When a married woman has the capacity in a particular instance to convey her separate estate she may convey without specially referring to the instrument giving her the estate, ${ }^{26}$ nor need the trustee join to render the conveyance valid generally in equity, ${ }^{27}$ and, unless the instrument of settlement or some statute provides otherwise, she may execute the conveyance as if unmarried, for she is regarded as to such property as a feme sole. ${ }^{28}$

Statutes, however, making general provisions regarding conveyances by married women may apply to such equitable separate estates, and in such cases the formalities

349; and see Kirby v. Boyette, 1896, 118 N. C. 244 ; 24 S. E. 18; Ennor จ. Hodson, 1890, 134 Ill. 32 ; 25 N. E. 582.

2 See note 30 Am. D. 330.

* Porcher v, Daniel, 12 Rich. Eq. 349.

${ }^{27}$ Essex v. Atkins, 14 Ves. 542 ; Ryland v. Banks, 1899, 151 Mo. 1 ; 51 S. W. 720. See contra Kirby v. Boyette, 1896,118 N. C. $244 ; 24$ S. E. 18.

w Taylor v. Meads, 4 De G. J. \& S. 597 (69 Eng. Ch. Rep.); American Home Missionary Society จ. Wadhams, 10 Barb. 697, 602. See Breseler v. Kent, 61 Ill. 426. 
prescribed by statute as to a wife's privy examination or joinder of her husband should be complied with. ${ }^{29}$

To make a conveyance valid and effective both of the equitable and legal estates, the methods and forms of both law and equity should be combined; and if more be done than necessary, as if a husband should execute a conveyance with his wife when she has the power in the particular instance to make the conveyance alone, its validity would not be affected by thus joining a needless party. ${ }^{30}$

\$357. Effect of statutes on the equitable separate estates-The practical importance of the separate equitable estate has been much diminished by the married women's property statutes, which establish the "statutory separate estate." 81

For while these statutes do not necessarily take away the equitable separate estate or the jurisdiction of courts of equity over the property of married women, ${ }^{82}$ they do, by excluding to a greater or less extent the common law marital rights of the husband in his wife's property, remove the necessity, to the same extent, for the creation and existence of the equitable separate estate.

Moreover, the general statutes concerning trusts in several states ${ }^{33}$ prevent passive trusts for the separate use of married women; and a statute relating, not to trusts in general, but to those for married women alone may occasionally be found to the same effect; ${ }^{34}$ and under these

${ }^{29}$ Barnum v. LeMaster, 1903 (Tenn.); 75 S. W. 1045. Though the instrument settling the estate may make such compliance unnecessary. Dewey v. Goodman, 1901, 107 Tenn. 244; 64 S. W. 45.

${ }^{20}$ Sallee v. Chandler, 26 Mo. 124.

si See next section.

${ }^{32}$ Holliday v. Hively, 1901, 198 Pa. St. 335; 47 Atl. 988; Jones v. Jones, 1899, 96 Va. 749 ; 32 S. E. 463 ; Richardson v. Stodder, 100 Mass. 528; Devries v. Conklin, 22 Mich. 255, 260; Musson v. Trigg, 51 Miss. 172, 182. Though see Wood $\nabla$. Wood, 83 N. Y. 575, 579.

23 For example, New York, Michigan, Minnesota and Wisconsin.

" Simmons v. Richardson, 1894, 107 Als. 697; 18 So. 245. Where 
statutes where lands are given to a trustee upon an express trust for the benefit of a married woman she takes no estate and cannot convey or charge her interest. ${ }^{35}$

\$358. Constitutional and statutory provisions creating a separate estate.-The statutes of the different states providing for the bolding by married women of property to their own use and enjoyment, and destroying wholly or partially the husband's common law rights in his wife's property, differ greatly. What is a married woman's separate real property is defined by the statute; and property held by her under such a statute is called her "statutory separate estate" to distinguish it from her "equitable separate estate," which is not necessarily abolished by the statute. ${ }^{86}$ As the extent of her power over her "separate estate" and the extent to which it was freed from her husband's interests, before these statutes depended much upon the terms of the instrument settling the estate upon her, so now whether she has under these acts a legal separate estate, depends much upon how she acquires her title; for these modern statutes, making radical changes in the common law, in effect give a legal title to married women much like the former equitable title.

The general rule in all the states is that whatever land

property is conveyed or devised to a trustee for the separate use of a married woman his duty to protect it from the husband and his creditors is generally deemed so far active as to prevent the legal estate from vesting in the married woman by virtue of the statute of uses; if the statute operated in such cases the purpose of the donor would be defeated. Richardson v. Stodder, 100 Mass. 528; Dean v. Long, 122 Ill. 447; 14 N. E. 34 ; Bowen v. Chase, 94 U. S. 812. The Alabama statute expressly makes necessary an active trustee, otherwise the legal estate vests in the woman, and even without such a statute a like effect has been given in some cases to the married women's property laws. McLaughlin v. Ham, 1890, 84 Ga. 786 ; 11 S. E. 889; Georgia \&c. R. Co. v. Scott, 1892, 38 8. C. 34 ; 16 8. E. 185, 839.

* See Pomeroy Eq. Jur., $\$ \$ 1003-1005,1105$.

- See last section, note 32. 28-Brews. CoN. 
the wife owned before her marriage remains her separate property after marriage.

Whether what she acquires after marriage is her separate property will depend upon whether she acquires it in some way designated in the controlling statute.

In many states ${ }^{37}$ there are constitutional provisions as to the married woman's separate property, either defining what it is in some detail and what her power over it shall be, or merely directing the legislature to establish her rights in such property.

In most of these states statutes have been enacted to carry out in greater detail the general constitutional provisions, and in some cases the statutes enlarge the wife's power over her separate estate beyond that given by the constitution. ${ }^{88}$

$\$ 359$. Statutes creating separate estate do not always remove the married woman's disability to convey.But these constitutional and statutory provisions freeing real property of the wife from the control of her husband and from liability for his debts, and giving her on the other hand extensive powers in controlling it, have not conferred upon her by implication power to convey the property as if she were unmarried. While the courts have not always construed the acts by a uniform principle-some construing them more liberally than othersthe general rule has been that the married woman's common law disabilities still exist unless removed expressly by the statute or by necessary implication from its terms, nor do the acts abrogate the common law incidents of the

"For example, Alabama, Arkansas, California, Georgia, Kansas, Maryland, Michigan, North Carolina, Oregon, South Carolina, Texas, Utah and West Virginia.

${ }^{28}$ For example, in Michigan the constitution of 1850 gave her power of testamentary disposition, but the act of 1855 , now C. L. 1897 , $\$ \$ 8690$ 8694, gave her power to convey by instruments operating inter vivos. Ransom v. Ransom, 30 Mich. 328. 
$\S 360$ CONVEYANCES OF MARRIED WOMEN'S INTERESTS. 435

marriage relation which are not within their evident purpose.

For example, a provision making the wife's real property hers and not liable for the debts of her husband and giving her power to devise it " as if she were unmarried," does not enable her to convey it by her sole deed, ${ }^{89}$ nor may she so convey it under statutory power to "own, possess and enjoy it as if unmarried," 40 though she may thus lease it under such a statute for a term of years, ${ }^{11}$ and even if the statute gives her power to convey, but prescribes particular formalities in the mode of exercising the power, her deed must be executed with these formalities to be valid.

In spite of legislation, therefore, the position of a married woman with regard to contracts concerning, and conveyances of, real property is not in all the states free from difficulty, and, as in many of them legislation respecting the matter has been comparatively recent, it is necessary in investigating titles which depend upon alienations by married women to recur to common law rules as to their disabilities and to ascertain to what extent these rules have been changed.

$\S 360$. Common law methods of alienation by married women-Deeds unusual-Fines.-While it appears that by the earlier common law a married woman could, with the consent of her husband, convey her land by feoffment and execute a deed as evidence of her alienation, and that in London and other cities her deed concurred in by her husband ("she having been 'separately examined' by the mayor or some other officer") was authorized by custom, it gradually became law-settled during the thirteenth century-that the only proper conveyance for a married

* Ransom v. Ransom, 30 Mich. 328.

${ }^{10}$ Swift v. Luce, 27 Maine 285, 288; Moore v. Cornell, 68. Pa. St. 320, 322.

a Parent v. Callerand, 64 Ill. 97. 
woman, except where some such special custom as that of London was recognized, was a fine. ${ }^{42}$ Later the wife was made a party to a common recovery for the same purpose, though this proceeding was more usually resorted to in order to bar her dower. ${ }^{\text {B }}$

$\$ 361$. The joinder of the husband at common lawThe separate examination.-In order that the fine might be effectual as a conveyance of a wife's lands, her husband was required (except in certain unusual cases) to join with his wife in levying the fine." And since by common law she could perform no effectual act of alienation without the concurrence of her husband, the general rule has been in the United States that he must join in her conveyance, or assent to it, to make it valid, unless some statute, either in express terms or by necessary implication, renders such joinder or assent unnecessary..$^{\text {t5 }}$

But besides the husband's concurrence, it was, under the older law, generally essential that there should be proof of the wife's free action in alienating her land, and early instances are recorded of her acknowledging her gift of land in court. ${ }^{46}$ When, therefore, the fine was resorted to as a means of conveyance by the married woman, the court was supposed to ascertain by a private examination of the wife whether she acted voluntarily in the proceedings and not under her husband's compulsion. ${ }^{47}$ Therefore, another general result of these earlier customs has been that a married woman's acknowledg-

C2 See Pol. \& Mait. Hist. Eng. Law, 2d ed. II, pp. 410-413.

is Shep. Touchstone 41; Eare v. Snow, Plowd. 504, 515. The Fines and Recoveries Act abolished these proceedings in England in 1833, and authorized husband and wife to convey her lands by deed acknowledged as prescribed by the act.

4 Pol. \& Mait. Hist. Eng. Law II, p. 410; Clark v. Clark, 16 Ore. 224, 226; 18 Pac. 1.

is Post, §363.

« Pol. \& Mait. Hist. Eng. Law II, p. 410.

"Martin v. Dwelly, 6 Wend. 9; 21 Am. D. 245. 
$\S 362$ CONVEYANCES OF MARRIED WOMEN'S INTERESTS. 437

ment to a conveyance is a very different thing from that of others-both in form and effect. ${ }^{88}$

\$ 362. Early usages in the United States-The joint deed-Statutes requiring joinder.-In this country fines and recoveries, though recognized as legal and proper means of conveying the real property of married women, ${ }^{49}$ were seldom used for this purpose. Before the matter was regulated by statute the conveyance of the lands of a wife by a deed in which her husband joined was sustained by the courts as being in accordance with long established usage-local common law-which arose partly from the necessities of the colonists, courts not being always accessible, and partly, probably, under the influence of similar local customs prevailing in England. ${ }^{50}$

These early usages were recognized and confirmed by statutes, and in most of the states it has been expressly required at some period that a husband should join in his wife's conveyance of her real property. ${ }^{31}$

In many states where such joinder was formerly essential it is not now, but statutes dispensing with the husband's concurrence or joinder in his wife's deed cannot affect conveyances executed before their enactinent at a time when his concurrence or joinder was necessary.

$\S 363$. When the husband's joinder or assent is now necessary. - Whether a married woman's conveyance should be joined in or assented to by her husband depends upon statutes-often more than one in the same stato-and these are of such a character that the states may be grouped in three general classes: ${ }^{62}$

$\omega$ See post, $\$ 365$.

- Manchester v. Hough, 5 Mason 67; Lawrence v. Heister, 3 Har. \& J. 371.

$\omega$ Durant $\nabla$. Ritchie, 4 Mason 45; Lloyd v. Taylor, 1 Dall. 17 ; Fowler

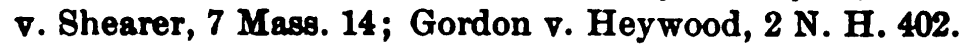

"In requiring the husband's concurrence to his wife's alienation such statutes are declaratory of the common law.

* In illustrating this point decisions are generally cited rather than statutes, as they refer to, discuss and construe the statates. 
1. In many states the married woman cannot convey the legal title to real estate unless her husband concurs in her conveyance : either, as is necessary in some of the states of this class, by "joining in". the conveyance, or, as in others, by "assenting" thereto.

To this general class belong, for example, Alabama, Florida, Idaho, Indiana, Kentucky, Minnesota, Nevada, North Carolina, Pennsylvania, Vermont and West Virginia. ${ }^{58}$

The necessity for this joinder or assent of the husband may, of course, exist irrespective of the requirement of a "separate examination" of the wife..$^{54}$ In several of these states where a husband's concurrence is ordinarily essential a married woman may convey alone under certain circumstances, as, if her husband is insane, has abandoned her or is imprisoned, ${ }^{55}$ but authority for her sole conveyance under such exceptional circumstances must be given by statute; ;6 unless, at least, there has been such complete abandonment of the wife by the husband as to be equivalent to his abjuration of the realm at common law, when perhaps she may convey alone. ${ }^{57}$

6s Adams v. Teague, 1898, 123 Ala. 591 ; 26 So. 221 ; 82 Am. St. R. 144 ; Walling v. Christian \&c. Co., 1899, 41 Fla. 479 ; 27 So. 46 ; 47 L. R. A. 608; Idaho, Code 1901, § 2403; Bartlett v. Williams, 1901, 27 Ind. App. 637; 60 N. E. 715; Werer v. Tanner, 1901 (Ky.); 64 S. W. 741; Lowe v. Lowe, 1901, 83 Minn. 206; 86 N. W. 11; Nevada C. L. 1900, $\S 2658$; Green v. Bennett, 1897, 120 N. C. 394; 27 S. E. 142; Adams Paper Co. v. Cassard, 1903 (Pa.) ; 55 Atl. 949 ; Dietrich v. Hutchinson, 1901, 73 Vt. 134; 50 Atl. 810; 87 Am. St. R. 698: See the statute referred to in this case, under which she may obtain a decree authorizing her to convey alone. Morgan v. Snodgrase, 1901, 49 W. Va. 387; 38 S. E. 695. The real husband should join in such cases, and not merely some one who is supposed by all parties to the conveyance to be the real husband. Soe Cook v. Walling, 117 Ind. 9; 10 Am. St. R. 17.

u Post, §365.

* Alabama Co. 1896, § 2528; Idaho Code 1901, § 2404; Indiana, Burns' R. 8. 1901, \$\$ 3387a, 3388a, 6983; Pennsylvania, P. \& L. Dig. 2904 ; Elsey v. McDaniel, 95 Pa. St. 472; Hall v. Walker, 1896, 118 N. C. 377 ; 24 S. E. 6 ; Bennett v. Pierce, 1898, 45 W. Va. 654 ; 31 S. E. 972.

o Pike v. Clark, 40 N. H. 9; 77 Am. D. 698; Richards v. McClelland, $29 \mathrm{~Pa}$. St. 385.

${ }^{57}$ Compare Rhea v. Rhenner, 1 Pet. 105, with Gallagher v. Delargy, 57 Mo. 29, 37. 
\$364 CONVEYANCES OF MARRIED WOMEN'S INTERESTS. 439

2. In other states a wife may convey the legal title to her land without her husband's joining in, or assenting to, her conveyance; but as he has an inchoate interest in her land, her deed without his joining will not release or convey his interest.

Such states are, for example, Illinois, Iowa, Kansas, Ohio and Oregon. ${ }^{58}$

3. In still other states a married woman may convey her land without the joinder or assent of her husband, and her grantee will take title free from any right or interest on the husband's part. The statutes of such states have given her power to convey alone and have excluded his rights to such an extent that he has an interest if he survives her in that part only of her real property which is left at her death undisposed of.

Among the states of this class are Arkansas, Colorado, Michigan and New York, besides other states (e. g. North and South Dakota and Utah) whose statutes have either limited curtesy to such realty as the wife has at her death or have expressly abolished it and have, at the same time, conferred upon a wife the power to convey her lands as if sole. ${ }^{69}$

$\$ 364$. Whether husband and wife should join as grantors or merely execute the deed.-Where the statute either expressly or by implication requires the husband to join in the deed of his wife's lands, they generally both appear as grantors in a single deed, the husband not

B8 Ill. R. S., ch. $41, \S 1$; ch. $68, \S 9$; Heisen v. Heisen, 1893, 145 Ill. 658; 34 N. E. 597; Center v. Elgin Banking Co., 1900, 185 Ill. 534 ; 57 N. E. 439; Iowa Code 1897, \$§ 2919, 3366 ; Kansas Stat. 1901, §§ 4020, 2529; Jenkins v. Dewey, 1892, 49 Kan. 49; 30 Pac. 114; Velten v. Carmack, 1892, 23 Ore. 282 ; 31 Pac. 658; 20 L. R. A. 101; Ohio R. S., $\$ \S 3114,4188$.

s0 Hampton ₹. Cook, 1897, 64 Ark. 353 ; 42 S, W. 535 ; Colorado Central R. Co. v. Allen, 13 Colo. 229 ; 22 Pac. 605; Michigan C. L. 1897, $\S 8690$; Hill $\nabla$. Chambers, 30 Mich. 422; Frickee v. Donner, 35 Mich. 151; Hatfield v. Sneden, 54 N. Y. 280; Mygatt จ. Coe, 1897, 152 N. Y. 457,460 ; 46 N. E. 949. 
merely signing his wife's conveyance in token of his assent. Under the statutes and decisions of some states this is the only proper method. ${ }^{60}$ There are, however, decisions holding that it is enough if he expresses his assent to her conveyance under his hand and seal, without joining in the granting clause, ${ }^{61}$ especially if the deed is acknowledged by both husband and wife. ${ }^{62}$

Whether the husband should actually join as grantor in the conveyance or should simply sign and seal it, will depend not only upon the extent of his interest in his wife's lands, ${ }^{68}$ but upon the terms of the statute requiring his concurrence, for a statute requiring his "assent" simply may well be construed differently from one requiring a "joint deed."

Even where the latter is required to convey the legal title, a conveyance by a married woman to which her husband has assented by executing it (though not by joining as grantor) may be valid as a contract to convey; ${ }^{\text {st }}$ and it may be that under some statutes the husband's assent may be shown without his even executing the conveyance, ${ }^{65}$ though generally parol evidence of his assent would not be admissible, as it must be shown by at least his signature to the deed. ${ }^{68}$

So, on the other hand, the wife should be named in the deed of conveyance as grantor, for merely signing,

" Warner v. Peck, 11 R. I. 431; Weber v. Tanner, 1901 (Ky.); 64 8. W. 741 ; Adams v. Teague, 1898, 123 Ala. 591; 26 So. 221 ; 82 Am. St. R. 144; Dietrich v. Hutchinson, 1901, 73 Vt. 134; 50 Atl. 810; 87 Am. St. R. 698. Soe Collins v. Cornwell, 1891, 131 Ind. 20; 30 N. E. 796.

- 12 Schley v. Pullman Co., 120 U. 8. 575; Clark v. Clark, 16 Ore. 224 ;

18 Pac. 1; Morgan v. Snodgrass, 1901, 49 W. Va. 387 ; 38 8. E. 695.

* Peter v. Byrne, 1903 (Mo.); 75 \&. W. 433.

Dietrich v. Hutchinson, 1901, 73 Vt. 194; 50 Atl. 810; 87 Am. St. R. 698.

*t Rushton v. Davis, 1900, 127 Ala. 279 ; 28 So. 476.

${ }^{65}$ See Lynch v. Moser, 1900, 72 Conn. 714 ; 46 Atl. 153.

* Buchanan v. Hazzard, 95 Pa. 8t. 240; Melley v. Casey, 90 Mass. 241; Green v. Bennett, 1897, 120 N. C. 394 ; 27 8. E. 142. 
$\S 365$ CONVEYANCES OF MARRIED WOMEN'S INTERESTS. 441

sealing and acknowledging the deed on her part, in which her husband is the only grantor named, will not convey her estate. ${ }^{67}$

$\S 365$. The married woman's acknowledgment-The separate examination.-The requirement as to the married woman's separate examination before she can make a proper acknowledgment to a deed, which has existed at some time in most of the states, ${ }^{68}$ and which still exists in several, was intended to answer the purposes of a fine under the older law. The object of requiring a deed acknowledged in this manner was to make more simple the conveyance of real property by the married woman, and at the same time to protect her from her husband's compulsion. ${ }^{69}$

As the acknowledgment of a married woman became, under statutes permitting her to convey by deed acknowledged, a necessary part of the execution of her conveyance, the effect of a failure to comply with the statute is very different from the effect of non-compliance with statutory forms and requirements concerning acknowledgments in other cases. The general rule as to the acknowledgment of others than married women is that it is not essential to the validity of the conveyance as between the parties, ${ }^{70}$ but the conveyance of a married woman without an actual acknowledgment, and without a proper certificate of that fact has repeatedly been held void wherever legislation has not enabled her to convey as others convey. ${ }^{\text {"1 }}$ And being thus void it has been held

67 Batchelor v. Brereton, 112 U. S. 396; Bradley v. Missouri Pac. R. Co., 91 Mo. 493 ; 4 S. W. 427. See ante, §37.

No separate examination seems to have been required in Maine, Massachusetts, New Hampshire and Vermont.

' Hitz v. Jenks, 123 U. 8. 297, 301; Harkins v. Forsyth, 11 Leigh (Va.) 294, 300.

o Ante, $\$ 261$.

"Mettler v. Miller, 129 Ill. 630; 22 N. E. 529; Evans v. Dickenson, 1902, 114 Fed. 284; Wilson v. Wilson, 1899, 6 Idaho 597 ; 57 Pac. 708; Krieger v. Crocker, 1893, 118 Mo. 531; 24 S. W. 170; Spencer v. Reese, 1895, 
that a married woman's deed not properly acknowledged and certified will not be enforced in equity as a contract to convey, ${ }^{72}$ nor reformed in equity by amending defects in the method of execution, because the power to convey, depending on the mode of its execution, "to amend the mode is to create the power." 78

And so where a bill was filed against husband and wife for the specific performance of a contract to exchange lands, the lands involved being the wife's, who had signed, but not acknowledged, the contract and refused to perform it, the court in dismissing the bill said: "The rights and powers of a married woman have been substantially revolutionized in recent years. But the mode of exercising them in the alienation of her land has remained without change for more than a century." 7

- In another case ${ }^{75}$ a married woman had made a conveyance, and afterwards again conveyed the property. There were defects in the certificate of acknowledgment to the first deed, and the court held that this deed, with the defective certificate of acknowledgment, was not merely voidable, but void $a b$ initio, and that the paper, though in form a deed, was no deed, and as to her passed no title whatever, legal or equitable; hence, the title remained in her, and she could, and did, convey by her subsequent deed. And even though her subsequent grantee had notice of the former seeming deed it did not alter the case, because his notice of that was in legal effect notice of nothing, as that deed was nothing in law. Nor did the second grantee hold as trustee for the former, nor could the married woman ratify, by admissions, pleadings, etc.,

165 Pa. St. 158; 30 Atl. 722; First National Bank v. Paul, 75 Va. 594 ; $40 \mathrm{Am}$. R. 740. See cases cited in the five notes following.

${ }^{2}$ Wambole v. Foote, 2 Dak. 1; Bagby v. Emberson, 79 Mo. 139.

7 Silliman v. Cummins, 13 Ohio 116.

"Bingler v. Bowman, 1899, 194 Pa. St. 210; 45 Atl. 80. See, however, Pa. L. 1901, p. 67, abolishing the "separate examination."

7 Central Land Co. v. Laidley, 32 W. Va. 134; 9 S. E. 61; 3 L. R. A. 826 ; 25 Am. St. R. 797. 
$\$ 366$ CONVEYANCES OF MARRIED WOMEN'S INTERESTS. 443

a deed so defective as the former deed was; and the only way the defect could be cured was by executing another deed properly acknowledged, or by reacknowledging the old deed. The conclusion was that the second purchaser's title was perfect, and the money paid by the first as a consideration was not a lien on the land.

In a very recent case ${ }^{76}$ the court, with evident reluctance because of the hardship inflicted on the defendants, held that a married woman who had permitted her grantee and subsequent grantees to take possession of land and make valuable improvements on it, could recover the land and improvements, because her deed, though executed according to the laws of the state where she lived, was void in the state where the land lay, as there had been no acknowledgment and privy examination of the grantor.

\$366. How far the separate examination must now be regarded.-The tendency of legislation is to do away with the privy examination of the married woman and to place her acknowledgment, so far at least as its form is concerned, on the same footing as that of any other person..$^{77}$

It is to be noted, however, that while a separate examination of the wife may not now be necessary in a particular state for her acknowledgment to conveyances in general, it may still be required in certain cases, as, for example, where she releases dower ${ }^{78}$ or homestead..$^{79}$

And though the separate examination is not now necessary in most states, nevertheless in the investigation of

Smith v. Ingram, 1903, 132 N. C. 959 ; 44 S. E. 643 ; 130 N. C. 100; 40 S. E. 984.

$\pi$ A separate or privy examination appears to be necessary now in the following states only, and is not necessary in all of these for ordinary conveyances (see the two notes following): Alabama, Arkansas, Delaware, Florida, Idaho, Kentucky, New Jersey, Nevada, North Carolina, South Carolina, Tennessee, Texas, Wyoming.

${ }^{78}$ Arkansas 8. \& H. Dig. 1894, $\S ~ 705,716$; McKenzie v. Sifford, 1897, 52 S. C. 104 ; 29 S. E. 388.

7 Alabama Code, § 2034; Burrows v. Pickens, 1901, 129 Ala. 648; 29 So. 694; Wyoming, R. S. 1899, §§ 2732, 2747, 2770, 2973. 
titles and in the trial of actions relating to titles one must remember that the former law was generally different from what it is now; and even though it was changed some years ago, it may be important for him at the present time to ascertain its details. It is obviously too much to expect that anyone can remember just what changes have been made and when, but he should remember that there have been in most states changes in this regard, and should look them up before passing upon a title or trying a case in which title is involved.

For example, in an action of ejectment decided in $1893,{ }^{80}$ the plaintiff claimed title through mesne conveyances from a deed executed in 1870 by M. E. and her husband. Title was in M. E. when she conveyed. The plaintiff offers the deed in evidence. The certificate is given in full in the report, and recites that the husband and wife appeared before the officer, were personally known to him, and that they acknowledged it, etc., and then proceeds: "And she, the said M. E., having been by me first made acquainted with the contents of said instrument of writing, acknowledged that she executed the same freely and without compulsion or undue influence of her said husband." The certificate failed to show that she was examined separate and apart from her husband, as the law then required. Defendant objected to the admission of the deed on this ground, and, while the plaintiff contended that this objection was purely technical, the court held the deed null and void, and that it transferred no title.

So, although the separate examination of a married woman was abolished in New York in 1879, it became necessary in 1893 to consider an acknowledgment made in 1846. ${ }^{81}$ The action in this case was to restrain defendant from building in front of his premises on a portion of

${ }^{\infty}$ Krieger v. Crocker, 1893, 118 Mo. 531; 24 S. W. 170.

aradley v. Walker, 1893, 138 N. Y. 291; 33 N. E. 1079. 
his lot, which it was claimed by the plaintiff was agreed in 1846 to be kept open, the agreement to that effect being recorded. But the then owner was a married woman, and by the agreement of 1846 a servitude was attempted to be imposed upon her separate property. The certificate to the agreement does not show a private examination, etc. Hence it was not, as against her, entitled to record. Nor was the record notice, nor could the transcript of the record be received in evidence, nor, it seems, could the original, if produced. The main question in this case was one of evidence, but the court substantially holds her agreement, so defectively acknowledged, void as to her.

\$367. How far compliance with statutory provisions as to particulars is necessary.-It is the general rule that the omission of any of the essential features of a married woman's acknowledgment which distinguish it from an ordinary acknowledgment-as, her examination apart from her husband, explanation of the instrument to her, her acknowledgment of its execution without fear, etc., etc.-renders the acknowledgment, and therefore the conveyance, fatally defective.

Not only in taking the acknowledgment, but in certifying to it, there has often been required a more nearly literal compliance with the statute than has been considered necessary in other cases. Therefore in drawing certificates of acknowledgment in the states where the separate or privy examination is still necessary the prudent course is to follow the statute literally.

There are, however, recent decisions holding certificates of acknowledgment valid which would formerly probably have been held invalid. ${ }^{82}$ But there always must be at least a substantial compliance with statutory requirements. ${ }^{83}$

* Geil v. Geil, 1903 (Va.); 9 Va. L. Reg. 530 ; 45 S. E. 325; Curtis v. Bunnell \&c. Co., 1898, 6 Idaho 298; 55 Pac. 659.

Wilson v. Wilson, 1899, 6 Idaho 597 ; 57 Pac. 708; Cox v. Holcomb, 
$\S 368$. Conveyances between husband and wife.-The doctrine of the common law that husband and wife cannot convey to each other has long been well settled. The authorities are not agreed, however, upon the reasons for this doctrine. Many hold that its reason is that the legal existence of the wife is suspended during marriage, or merged in that of the husband. This not entirely satisfactory explanation is given in perhaps most of the cases where the question is discussed. Others maintain that the explanation of the doctrine is that the wife, though legally existent, is under the dominion of the husband, and so presumably acts under his coercion. This, however, does not quite explain why a conveyance by a husband to his wife is not valid.

Judge Cooley, speaking of the common law rule that the husband could not directly convey to his wife, says : "Perhaps there was no sufficient reason why such a conveyance should not have been allowed at common law, but as it was not it is necessary to find when and how the common law was changed in this regard;" 84 and the matter is sometimes disposed of as follows: "It is not necessary for us to answer the inquiry which has been made, 'why a deed from a husband to his wife should not be a valid conveyance,' in any other manner than by observing that the law of the land declares such a deed to be a mere nullity." 85

The reason might, perhaps, be of little importance were it not that the construction of the recent statutes affecting property rights of husband and wife will be found to depend somewhat upon what the court construing the particular statute regards as the basis of the common law rule. ${ }^{852}$

87 Ala. 589; 6 So. 309 ; 13 Am. St. R. 79; Mettler v. Miller, 129 Il. 630;

22 N. E. 529 ; Spencer v. Reese, 1895, 165 Pa. St. 158; 30 Atl. 722.

${ }^{84}$ Ransom $\nabla$. Ransom, 30 Mich. 328.

es Martin v. Martin, 1 Maine 394.

8se See post, \$\$ 371, 375. 
\$368 CONVEYANCES OF MARRIED WOMEN'S INTERESTS. 447

In this connection it may be noted that Pollock \& Maitland ${ }^{86}$ express the view that the fundamental principle underlying the subject of the property relations of husband and wife is that the busband is the wife's guardian, and they observe that this explains a great deal "when we remember that guardianship is a profitable right." Further: "In particular we must be on our guard against the common belief that the ruling principle is that which sees a 'unity of person' between husband and wife. This is a principle which suggests itself from time to time; it has the warrant of holy writ; it will serve to round a paragraph, and may now and again lead us out of or into a difficulty, but a consistently operative principle it cannot be." 87

The common law rule has been affected practically by three different causes :

1. By the practice of having the conveyance between husband and wife made through some third person.

2. By the influence of courts of equity.

3. By statutes, which either expressly change the common law rule, or which have been construed by the courts to have had the effect of changing it.

It has resulted from these combined causes that the old rule of the common law appears at the present time to be most wholly done away with.

The subject is, however, affected by certain matters that should be considered in each particular case; as, for example, which is grantor, the husband or the wife? or, what is the nature of the estate or interest sought to be disposed of? Is it separate property or is it some interest or estate growing out of the marriage relation, like curtesy or dower? or is it a "homestead" right? or is a joint conveyance of husband and wife ordinarily, in the particular jurisdiction, required?

* Poll. and Mait. His. Eng. Law, II, p. 403.

${ }^{87}$ See Poll. and Mait. His. Eng. Law, I, p. 468. 
$\$ 369$. Conveyances between husband and wife through a third person.-It is now recognized that there is no legal impediment to this method, and it is very commonly resorted to. Where a husband must join in a deed of the wife's real property, the conveyance by both of them to a third person with the intention that the third person shall convey to the husband is valid. When the third person conveys to the husband in accordance with the understanding, the husband has good title. ${ }^{88}$ So, if the husband, for the purpose of preventing his real property from being taken by his creditors, voluntarily conveys it to his wife through a third person without fraud on her part, he himself cannot obtain a cancelation of the conveyance. ${ }^{89}$

Where it is the wife's property that is conveyed to the husband in this way, a court of equity will generally set aside the conveyance upon less evidence of coercion or undue influence than is required in other cases. It has been held that the conveyance of the wife's estate for the husband's use will be held void, unless it affirmatively appears from the attending circumstances or otherwise that the deed was her voluntary act and not induced by undue influence on the part of her husband; and that the court is disposed to impute a deed to a husband through a third person to influence rather than to love and affection, though this presumption may be overcome by showing that the transaction was fair. ${ }^{90}$

\$370. Equitable view of conveyances between husband and wife.-The rule of the common law that husband and wife could not directly convey to one another has been affected by the doctrine of courts of equity. This

es Leach v. Rains, 1897, 149 Ind. 152; 48 N. E. 858; Wicks v. Dean, 1898,103 Ky. 69 ; 44 S. W. 397.

${ }^{\circ}$ Fitzgerald v. Fitzgerald, 1897 ; 168 Mass. $488 ; 47$ N. E. 431.

'Darlington's Appeal, 86 Pa. St. 512 ; 27 Am. R. 726; Allen v. Drake, 1891, 109 Mo. 626, 641 ; 19 S. W. 41 ; Boyd v. De La Montague, 73 N. Y. 498, 602. 
$\$ 371$ CONVEYANCES OF MARRIED WOMEN'S INTERESTS. 449

equitable doctrine is, that whenever such a conveyance would have been good at law if made through the intervention of a trustee, it will be sustained in equity though made directly between the parties. This doctrine is especially applicable in cases of conveyances directly by the husband to the wife, and such conveyances, in spite of the common law rule, will be sustained in equity when the rights of creditors are not interfered with. ${ }^{91}$ In such cases, though the legal title may remain in the husband, he is in equity a trustee for his wife; equity exercises a jurisdiction not possessed by common law courts. Many of the decisions speak of conveyances from husband to wife as invalid in law, but valid in equity, though in some states this distinction may practically be more imaginary than real; "the distinction between actions at law and suits in equity is abolished. There is but one form of action. Why then shall we longer speak of the same instrument as void in law but valid in equity?"'92 Later decisions upholding conveyances made directly from husband to wife in such states do not discuss the distinction between law and equity. ${ }^{98}$

\$ 371. Rule as to conveyances between husband and wife affected by statute.-The so called married women's acts have modified the common law rule as to conveyances between husband and wife, but have not always been construed by the courts as might have been expected. That conflicting constructions have been placed upon similar statutes in different states has been due to the greater or less conservatism of particular judges, or to

${ }^{21}$ Moore v. Page, 111 U. 8. 117; Crooks v. Crooks, 34 Ohio St. 610; Sims v. Rickets, 35 Ind. 181; 9 Am. R. 679; Turner v. Shaw, 96 Mo. 22 ; 8 S. W. 897 ; 9 Am. St. R. 319; Ogden v. Ogden, 1894, 60 Ark. 70; 28 S. W. 796 ; 46 Am. St. R. 151 ; Barnum v. Le Master, 1903 (Tenn.); 75 S. W. 1045.

92 Thompson $\nabla$. Mills, 39 Ind. 528, 532.

* Building Ass'n v. Scanlan, 1895, 144 Ind. 11; 42 N. E. 1008. 29-Brews. Con. 
prejudices and local influences and differences in the course and history of legislation on the subject.

Upon one point there appears to be little conflict: where statutes allow married women to hold and convey real estate but also require that the husband shall join in the wife's conveyance, she cannot convey directly to him. The reason generally given for this rule is that the husband cannot be both grantor and grantee in the same deed, as he must be if the statutory requirement is fulfilled, while if it is not fulfilled his wife's deed is invalid in law. The only way, therefore, in such states for her to convey to him is through a third person, even though in the same states he may convey directly to her. ${ }^{94}$

Where, however, one statute provides that a married woman cannot alienate her lands without the assent and concurrence of her husband, to be manifested by his joining in the conveyance, but another provides "the husband and wife may contract with each other, but all contracts into which they enter are subject to the rules of law as to contracts by and between persons standing in confidential relations," it has been held that a sale and conveyance of land is a contract, that the two statutes must be construed together, and that the provisions of the former apply only to conveyances by a wife to a person other than her husband, therefore she may convey to him.95

The statutes of other states may be, first, those expressly permitting contracts and conveyances between husband and wife, or second, those simply referring to the wife's disabilities. Statutes of the former class declare in general terms that a conveyance executed by either husband or

M Johnson $\nabla$. Jouchert, 1890, 124 Ind. 105; 24 N. E. 580; 8 L. R. A. 795; Rico v. Brandenstein, 1893, 98 Cal. 465; 33 Pac. 480; 20 L. R. A. 702 ; 35 Am. St. R. 192; Bohannon v. Travis, 1893, 94 Ky. 59 ; 21 S. W. 354 ; Riley v. Wilson, 1893, 86 Texas 240; 24 S. W. 394; Worrell v. Drake, 1903 (Tenn.); 75 S. W. 1015.

\% Osborne v. Cooper, 1896, 113 Ala. 405; 21 80. 320; 69 Am. St. B. 117. 
$\S 371$ CONVEYANCES OF MARRIED WOMEN'S INTERESTS. 451

wife to the other shall be valid to the same extent as between other persons, or they provide that husband or wife may enter into any transaction with the other which either might if unmarried;96 though some of the statutes of this character have added to them the qualification that transactions between husband and wife are subject to the rules of law applicable to contracts between persons standing in confdential relations, ${ }^{97}$ or are qualified by other statutes excluding interests growing out of the marriage relation-dower, curtesy and analogous interests-from the classes of property as to which husband and wife may contract with each other..$^{98}$

Statutes of the second class just referred to are those enabling the married woman to hold and convey land "as if unmarried" or "in like manner as her husband or any other person."

Such statutes have been construed by many courts as doing away with the common law rule, although they do not specially refer to conveyances by a wife to her husband. By these courts the disability of the married woman is regarded as the basis of the rule, and as this disability is removed by such statutes, it is considered that either one may convey directly to the other without the intervention of a third party. ${ }^{99}$

On the other hand it has been considered that statutes

* For example, see N. H. Pub. Stat. 1901, ch. 176, §3; N. Y. R. 8. \& G. L. Birdseye's Ed. 1901, I, p. 1048, §26; N. Dak. Co. 1899, §2767; R. I. R. L. 1896 , ch. 194 , $\S \S 3$, 5 ; Utah R. S. 1898 , $\$ 1200$; Wis. R. $\$$. $1898, \S 2342$.

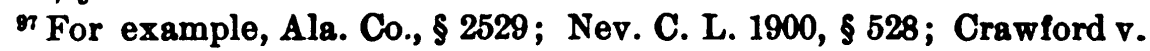
Crawford, 1899, 24 Nev. 410; 56 Pac. 94; Ohio R. S., § 3112; S. Dak. Civ. Co. $1901, \$ 3501$. As to the rules applicable when such relations exist, see Pomeroy Eq. Jur., $\S \S 956,1053$; Harraway $\nabla$. Harraway, 1903, 136 Ala. 499; 34 So. 836.

Newberry v. Newberry, 1901, 114 Iowa 704; 87 N. W. 658; Potter v. Potter, 1903 (Ore.); 72 Pac. 702.

* Despain v. Wagner, 1896, 163 Ill. 598 ; 45 N. E. 129; Welle v. Caywood, 3 Colo. 487 ; Burdeno v. Amperse, 14 Mich. 91; Ransom v. Ran60m, 30 Mich. 328; Savage v. Savage, 80 Maine 472; 15 Atl. 43. 
conferring upon the wife the capacity of a feme sole do not abrogate the common law rule, for no such question can arise as to a feme sole and that it is not the disability of the wife alone that renders such conveyances void, but' that the husband was at common law as much disabled to take from her as she was from him, and that this common law disability should be expressly removed by statute before conveyances can be made from one to the other. ${ }^{100}$ Hence, where this view is taken later statutes have been sometimes enacted, ${ }^{1}$ especially permitting conveyances between husband and wife.

\$ 372. Dower and its statutory substitute.-In the United States the matter of the rights of a surviving wife in the lands of her husband is so far regulated by statute that it is perhaps correct to say, speaking strictly, that the common law estate of dower hardly exists. In about half the states it exists in name, and in most of these the more important of its old characteristics are preserved. In many states dower has been expressly abolished, but in its place an interest or estate has, in some of these states, been created more valuable to the wife than dower, and which it is therefore even more important to the purchaser of the husband's title to have released or barred than it ever has been to have dower released or barred. Where it has been thus abolished and a statutory substitute supplied, the courts and the legal profession continue to use the term "dower" as applied to this substitute." And many of the principles applicable to the release of dower will be found to apply in those states where it has been abolished.

$\$ 373$. Generally no act of the husband alone can defeat dower-Exceptions to this rule.-It is a general rule

${ }^{100}$ Dean v. Metropolitan R. Co., 1890, 119 N. Y. 540; 23 N. E. 1054; White v. Wager, 25 N. Y. 328; Aultman v. Obermeyer, 6 Neb. 260.

1 For example, in New York, see supra, note 96.

2 For example, see Daugherty v. Daugherty, 69 Iowa 677; 29 N.W. 778. 
$\$ 373$ CONVEYANCES OF MARRIED WOMEN'S INTERESTS. 453

that no act or conveyance of a husband without the concurrence of his wife can defeat her right of dower. ${ }^{3}$ This is generally true also of the statutory substitute for dower in those states where dower has been abolished or substantially modified."

But a purchase money mortgage made by the husband alone, that is, a mortgage given by him to his vendor to secure the payment of the purchase price of land bought by him, is superior to his wife's interest, though given without her consent, ${ }^{5}$ as is also a vendor's lien for the price where this is recognized. ${ }^{6}$

Moreover, where a dedication of land has been made by the husband alone to public uses, as for markets, streets or parks, the wife is not dowable in the land, ${ }^{7}$ and this rule has been held to apply where the conveyance has been made for purposes not in the fullest sense public, for example for railroad purposes. ${ }^{8}$

It is therefore generally important for a purchaser in most states that a wife should join in her husband's conveyance of lands.

In a few states, however, though provision is made for a wife if she survive her husband, he may transfer his

'House v. Jackson, 50 N. Y. 161 ; Grady v. McCorkle, 57 Mo. 172 ; 17 Am. R. 676.

'Indiana, Burng' R. S. 1901, § 2652; Iowa Code, §3366; Kansas Gen. Stat. 1901, § 2510; Minnesota Gen. Stat. 1894, §4471; Utah R. S. 1898, $\S 2826$.

${ }^{5}$ Denton v. Arnold, 1898, 151 Ind. 188; 51 N. E. 240; Hurst จ. Dulaney, 1891, 87 Va. 444; 12 S. E. 800 ; Frederick v. Emig, 1900, 186 Ill. $319 ; 57$ N. E. 883 . By statute in Illinois and Indiana as in other states. For example, Michigan C. L. 1897, §8921; Nebraska Com. Stat. 1901, $\S 2517$; New York Real Prop. L.,Art. V, § 173; Wisconsin Stat. 1898, $\S 2163$.

${ }^{6}$ Elliott v. Plattor, 43 Ohio St. 198; 1 N. E. 222 ; Noyes v. Kramer, 54 Iowa 22 ; Cocke v. Bailey, 42 Miss. 81.

'Duncan v. Terre Haute, 85 Ind. 104; Gwynne v. Cincinnati, 3 Ohio $24 ; 17$ Am. D. 576.

Venable v. Wabash Ry. Co., 1892, 112 Mo. 103; 20 S. W. 493; $18 \mathrm{~L}$. R. A. 68; Baker v. Atchison \&c. R. Co., 1894, 122 Mo. 396; 30 8. W. 301. But see contra, Nye v. Taunton Ry. Co., 113 Mass. 277. 
land during his life without her concurrence and is relieved from all claims by her, provided the transaction is not merely colorable and a fraud on her. ${ }^{9}$ And as in a few other states, for example Michigan, Nebraska and Wisconsin, a non-resident wife is entitled to dower only in the lands of which her husband dies seised, she need not join in his conveyance. ${ }^{10}$

In a few states ${ }^{11}$ while a resident married man whose wife is not, and never has been, a resident of the state may convey his lands without her concurrence, it is important for her to join in his conveyance if she has been at any time a resident of the state. ${ }^{12}$

$\$ 374$. Inchoate right of dower not strictly propertyReleased not conveyed.-While this inchoate interest of the wife is necessarily considered in conveyancing, we do not properly speak of a conveyance of "dower." This interest of the wife while for some purposes considered an interest in lands, is not generally regarded as property in the ordinary sense, but as a right incident to another thing: namely, the estate of her husband in the land..$^{13}$ During the life of the husband and up to the time of its

9 Phillips v. Phillips, 1903, 30 Colo. 516; 71 Pac. 363; Smith v. Smith, 1896, 22 Colo. 480 ; 46 Pac. 128; 34 L. R. A. 49; 55 Am. St. R. 142; Flowers v. Flowers, 1892, 89 Ga. 632; 15 S. E. 834; 18 L. R. A. 75; Thayer v. Thayer, 14 Vt. 107; 39 Am. D. 211 . See Connecticut Gen. Stat. 1902, §§ 386, 391; Tennessee Co. 1896, \$§ 4139, 4140, 4149.

${ }^{10}$ Michigan C. L. 1897, § 8938; Ligare v. Semple, 32 Mich. 438; Nebraska Com. Stat. 1901, §2533; Atkins v. Atkins, 18 Neb. 474; 25 N.W. 724; Wisconsin Stat. 1898, §2160. See Bennett $\nabla$. Harms, 51 Wis. 251, holding that the non-residence intended is at the time of death; it would seem, therefore, better that a non-resident wife should join, as she might be resident at the time of her husband's death, though she was not at the time of his conveyance.

${ }^{11}$ Kansas Gen. Stat. 1901, § 2510; Montana Civ. Co. 1895, § 233; Utah R. S. $1898, \S 2826$.

${ }^{12}$ Kennedy v. Haskell, 1903 (Kan.); 73 Pac. 913.

${ }^{18}$ See Hoy v. Varner, 1902, 100 Va. 600; 42 S. E. 690 ; 8 Va. L. Reg. 666 ; Haggerty v. Wagner, 1897, 148 Ind. 625; 48 N. E. 366; Flynn v. Flynn, 1898, 171 Mass. 312 ; 50 N. E. 650; Penfold v. Warner, 1893, 96 Mich. $179 ; 55$ N. W. 680 . 
"assignment" to the widow, dower is an interest which cannot be bargained, sold and conveyed in the ordinary sense, but may be released, relinquished or barred.

Hence where the conveyance by the husband of his lands, in which his wife joins, is set aside as fraudulent against creditors, ${ }^{14}$ or because of his incapacity, ${ }^{15}$ her interest is revived or re-established.

On the same principle, there must be a conveyance of the husband's lands; for if husband and wife join in a deed for the purpose of conveying her inchoate interest alone, while the fee remains in him, the deed is a nullity. ${ }^{16}$ She cannot, therefore, release her dower to one who does not in some way hold under her husband; her release cannot be to a mere stranger. ${ }^{17}$

So, generally, after the death of her husband, unassigned dower is not the subject of sale and transfer in law, but of release to one who has the fee. ${ }^{18}$

\$375. Wife cannot generally release dower to her husband.-In the absence of a statute permitting her to do so, a wife cannot bar her dower by a release to her husband during coverture, ${ }^{19}$ and the married women's acts removing the wife's disabilities and giving her power to contract with reference to her property have more generally been considered not to have affected this common

"Hinchliffe v. Shea, 103 N. Y. 153; Frederick v. Emig, 1900, 186 Ill. 319, 322 ; 57 N. E. 883 ; Wells v. Estes, 1900, 154 Mo. 291, 297 ; 55 S.W. 255.

${ }^{15}$ Brothers v. Bank, 1893, 84 Wis. 381, 396; 54 N. W. 786.

${ }^{16}$ Davenport v. Gwilliams, 1892, 133 Ind. 142 ; 31 N. E. 790.

${ }^{17}$ Reiff v. Horst, 55 Md. 42; Hart จ. Burch, 130 Ill. 426; 22 N. E. 831 ; 6 L. R. A. 371; French จ. Lord, 69 Maine 537; Mason v. Mason, 140 Mass. 63; 3 N. E. 19.

${ }^{28}$ Fletcher $\nabla$. Shepherd, 1898, 174 Ill. 262 ; 51 N. E. 212; Grubbs v. Leyendecker, 1899, 153 Ind. 348; 53 N. E. 940. Though by virtue of statute anassigned dower may be transferred by the widow in some states. For example, Missouri R. S. 1899, $\$ 2934$; and it may be transferred in equity. Mut. Life Ins. Co. v. Shipman, 1890, 119 N. Y. 324, 330.

${ }^{29}$ Wilber $\nabla$. Wilber, 52 Wis. 298; 9 N. W. 163; Pillow จ. Wade, 31 Ark. 678; Rowe v. Hamilton. 3 Maine 63. 
law rule; ${ }^{20}$ though in Michigan it is settled that, because of the statutes enlarging in general a wife's powers, she may release her dower directly to her husband, provided there is a fair consideration for her release..$^{21}$

A wife may, however, in some states contract with her husband to release or extinguish her inchoate interest in his lands in consideration of receiving its equivalent in value; ${ }^{22}$ while, on the other hand, the policy of the common law inhibiting such contracts is in some states preserved by express statutes, though the married woman's general disabilities are to a great extent removed in the same states. ${ }^{23}$

Agreements between husband and wife under which they are to live separate and by the terms of which each one gives up all interest in the estate of the other, have been held, in some cases, not to bar the wife's dower, ${ }^{24}$ while in others their validity has been sustained and her dower held to have been barred. ${ }^{25}$

\$376. Release of dower generally by deed of husband and wife.-While, therefore, dower is not property, strictly speaking, it has nevertheless generally been considered such an interest in lands as to require under the statute of frauds some instrument in writing for its re-

${ }^{20}$ Pinkham v. Pinkham, 1901, 95 Maine 71; 49 Atl. 48; 85 Am. St. R. 392 ; Land v. Shipp, 1900, 98 Va. 284 ; 36 S. E. 391 ; 50 L. R. A. 560.

${ }^{21}$ Rhoades v. Davis, 51 Mich. 306; 16 N. W. 659 ; Dakin v. Dakin, 97 Mich. 284; 56 N. W. 562; in the Virginia case, Land v. Shipp, supra, decided under statutes similar to those of Michigan, this doctrine is criticised.

${ }^{22}$ Higgins v. Ormsby, 1901, 156 Ind. 82, 85 ; 59 N. E. 321 ; McBreen จ. McBreen, 1900, 154 Mo. 323; 55 S. W. 463; 77 Am. St. R. 758. See Luttrell v. Boggg, 1897, 168 Ill. 361 ; 48 N. E. 171.

${ }^{23}$ Newberry $\nabla$. Newberry, 1901, 114 Iowa 704; 87 N. W. 658; Potter v. Potter, 1903 (Ore.); 72 Pac. 702.

${ }^{24}$ Land v. Shipp, 1900, 98 Va. 284 ; 36 S. E. 391 ; 50 L. R. A. 560; Stephenson $\nabla$. Osborne, 41 Miss. 119; 90 Am. D. 358; Whitney $\nabla$. Closson, 138 Mass. 49.

25 Hitner's Appeal, 54 Pa. St. 110; Scott's Estate, 1892, 147 Pa. St. 102. See cases cited in note 22 to $\$ 375$ supra. 


\section{$\S 376$ CONVEYANCES ÓF MARRIED WOMEN's INTERESTS. 457}

lease ; a wife cannot bar her dower by parol. ${ }^{26}$ And, generally speaking, if the writing is anything short of a deed properly executed it will not amount to a release.

Statutes usually make provision for the release by the wife during coverture of her interest, and the statutory provisions must be strictly complied with.

Where a statute requires an acknowledgment, a conveyance of the husband joined in by the wife but not properly acknowledged will not bar her dower, ${ }^{27}$ nor will one where there is no separate examination of the wife in states where the separate examination is required, ${ }^{28}$ and in general the same rules are applied concerning the acknowledgment of the wife's release of dower as are applied to her acknowledgment of other deeds.

The general rule is that the wife must join in her husband's conveyance of his lands in order to release her interest in them $;^{29}$ and there have been decisions that she should expressly state in the conveyance that she executes it for the purpose of releasing dower. ${ }^{30}$ But it has also been held that a joint deed of husband and wife will bar her dower though it contains no express relinquishment. ${ }^{31}$

It seems that the common and proper practice in the greater number of states is for the wife to join with her husband in the granting clause of the conveyance. There are exceptional cases where the wife's merely signing her husband's deed has been considered enough, though she is not mentioned in the deed, either as a grantor or as re-

${ }^{9}$ Davis $\nabla$. Davis, 61 Maine 395; Worthington v. Middleton, 6 Dana 300; Wright v. DeGroff, 14 Mich. 164; Carnall v. Wilson, 21 Ark. 62 ; Davis v. McDonald, 42 Ga. 205.

"Maynard v. Davis, 1901, 127 Mich. 571; 86 N. W. 1051; Grove v. Todd, 41 Md. 633 ; 20 Am. R. 76.

${ }^{28}$ Stidham v. Matthews, 29 Ark. 650; Hand v. Weidner, 1892, $151 \mathrm{~Pa}$. St. $362 ; 25$ Atl. 38.

29 As to the release of an insane wife's dower, see ante, p. 423.

${ }^{\infty}$ Lathrop v. Foster, 51 Maine 367; Carter v. Goodin, 3 Ohio St. 75, 78; Leavitt $\nabla$. Lamprey, 13 Pick. 382; 23 Am. Dec. 685.

u Jones v. Des Moines, 43 Iowa 209; Learned v. Cutler, 18 Pick. 9. 
leasing her interest, ${ }^{32}$ but this is clearly not the best practice.

A wife's sole or separate deed (made after a deed by her husband) will not generally release her rights in his lands, unless such a deed is expressly authorized by statute. It is therefore so authorized in a few states, among them Alabama, Maine, Massachusetts and Michigan. ${ }^{83}$

$\$ 377$. Married women's powers of attorney to convey lands or release dower.-A married woman not having capacity at common law to convey real property by attorney, the same rule prevails in those states where it has not been changed by statute. ${ }^{84}$

Statutes, however, empowering her to convey her land without expressly authorizing her to convey by attorney have been construed as authorizing her to do so, on the general ground that the power to convey directly includes the power to appoint an attorney to do the same thing. ${ }^{35}$

On the other hand there have been decisions holding that where she may convey by deed acknowledged after a "separate examination," she may not convey by attorney, since she cannot delegate to another the power given to her by statute to convey in this particular way, ${ }^{36}$

To remove all doubt statutes have been enacted in many states expressly authorizing a married woman to convey

a Lancaster v. Roberts, 144 Ill. 213, 222.

is Ala. Co., $\$ \S 1509,1510$; Maine R. S., ch. 103, $\$ 6$; Mass. R. L. 1902, ch. $132, \S 5$; Mich. C. L. $1897, \S 8930$; but the Michigan statute provides that the intent to bar dower must be expressed in the deed, and the deed must be to one who then holds the husband's title, and she may do this though under twenty-one years of age, if over eighteen. Michigan Pub. Acts 1899, p. 284.

s4 Drury v. Foster, 2 Wall. 24; McCreary $\nabla$. McCorkle, 1899 (Tenn.); 54 S. W. 53; Bank of Louisville v. Gray, 84 Ky. 565 ; 2 S. W. 168.

${ }^{23}$ Williams v. Paine, 1897, 169 U. S. 55; Morris v. Linton, 1901, 61 Neb. $537 ; 85 \mathrm{~N}$. W. 565 . Such would seem to be the effect of general statutes removing a wife's disabilities. For example, Ohio R. S., $\S \S 3112,3114,4108$.

${ }^{26}$ Mott v. Smith, 16 Cal. 533; Sumner v. Conant, 10 Vt. 9; Dawson v. Shirley, 6 Blackf. 531. 
by attorney. Many of these statutes require that her husband shall join in her "power of attorney," while some expressly authorize her to constitute her husband her attorney. ${ }^{87}$

Under the statutes of some states she may release her dower by attorney, ${ }^{38}$ and may appoint her husband her attorney for this purpose ; $^{39}$ though, as powers of attorney are generally strictly construed, a general power of attorney by a wife to her husband to convey her lands has been held not to authorize him to release her dower, ${ }^{\circ 0}$ nor does her power of attorney to him to "sign deeds and mortgages" in general terms, but not referring to the homestead nor describing any real estate, authorize him to mortgage the homestead where the "joint consent" of husband and wife is neccessary to create a valid encumbrance on it. ${ }^{11}$

"Arkansas Pab. Acts 1895, p. 58; California Civ. Co., \$1094; Indiana, Burns' R. S. 1901, §3369; Iowa Co. 1897, \$§ 2919, 3150, 3161 ; Missouri R. S. 1899, §902; Rhode Island Gen. L. 1896, ch. 194, §§ 3, 6, 12 ; Utah R. S. 1898, § 1205; Virginia Co. 1900, § 2502; West Virginia Co. 1899, ch. 66, § 3; Wisconsin Stat. 1898, § 2223.

${ }^{20}$ Bertschy v. Bank, 1895, 89 Wis. 473; 61 N. W. 1115 ; Hull v. Glover, 126 Ill. 123 ; 18 N. E. 198 ; Penfold v. Warner, 96 Mich. 179 ; 55 N. W. 680; Alabama Co. 1896, § 1509.

W Wronkow v. Oakley, 1892, 133 N. Y. 505 ; 31 N. E. 521 ; 16 L. R. A. 209 ; 28 Am. St. R. 661; Wilkinson v. Elliott, 1890, 43 Kan. 590; 23 Pac. 614; 19 Am. St. R. 158.

${ }^{\omega}$ Security Savings Bank v. Smith, 1900, 38 Ore. 72; 62 Pac. 794 ; 84 Am. St. R. 756, see note to this case.

1 Wallace v. Ins. Co., 1894, 54 Kan. 442; 38 Pac. 489 ; 45 Am. St. R. 288. 


\section{CHAPTER XXIII.}

\section{THE HOMESTEAD IN CONVEYANCING.}

\$378. The homestead in general.

379. Who may have a homestead-Not necessarily a married person only.

380. But restraints on its alienation apply usually to married persons only.

381. Restraints on alienation apply usually to residents only.

382. Occupancy generally eseential- "Constractive occupancy."

383. Occupancy-Abandonment - "Temporary absence."

384. Occupancy as a home-Use for business parposes.

385. The selection of the homestead - By record - By occupancy.

386. The limits of the homestead.

387. May be a homestead in an estate less than fee simple-Joint estates.

388. Owner of a homestead may alienate it unless rostrained - Partial rostraints.

389. Some restriction on voluntary alienation usual.
\$390. Usually husband and wife must concur in the transfer.

391. Effect of non-compliance with statute.

392. Effect of non-compliance with statute-The alienation void in many states.

393. Effect of wife's insanity.

394. Subsequent abandonment will not make the conveyance valid-Nor death or divorce-Transfer by wife alone.

395. To what extent husband may leaso-Sell timberGrant rights of way.

396. The defective conveyance valid as to the excess over homestead.

397. Non-compliance with statute does not make alienation void in some states.

398. The mode of manifesting consent to the alienation of the homestead.

399. The acknowledgment to the conveyance of the homestead.

400. Conveyance of the homestead between husband and wife.

$\S 378$. The homestead in general.-Certain real property may become, under the laws of most states, a "home- 
stead," and, as such, may have legal characteristics distinguishing it from other real property.

Provisions concerning the homestead exist in the constitutions of about one-third of the states, and in most of these statutes also have been enacted for carrying the con-stitutional provisions into effect; in the other states the subject is regulated by statute alone. ${ }^{1}$

The general object of these laws is to protect the family in the possession and enjoyment of a home, secure, not only from the claims of creditors, but from the improvidence of the head of the family.

For the attainment of this object the laws generally provide :

1. That the homestead shall be exempt from sale on execution to pay the debts (with certain exceptions) of its owner;

2. That the owner may not convey or incumber it as freely as he may convey or incumber his other real property;

Less generally it is held:

3. That the owner may not dispose of it by will, this inhibition being usually implied from the statute rather than expressly provided for. ${ }^{2}$

1 The states which seem to have no homestead in the technical sense of the term are Delaware, Indiana, Maryland, Pennsylvania and Rhode Island.

In these states certain real property, as well as personal, may be exempt by law from sale for the payment of debts, but the laws allowing this exemption are not, properly speaking, "homestead laws."

The homestead provided for by state laws is to be distinguished from that provided for by the federal laws, under which land is donated by the United States to settlers on certain conditions.

2 The homestead being considered as a provision for the family, it has been held often that surviving wife and children cannot be deprived of it by the will of the husband and father. Bell v. Bell, 84 Ala. 64; 4 So. 189; Kleimann v. Geiselmann, 114 Mo. 437; 21 S. W. 796; 35 Am. St. R. 761 ; McCrae v. McCrae, 103 Tenn. 719; 54 S. W. 979; Hall v. Fields, 81 Tex. 553 ; $17 \mathrm{~S}$. W. 82; Hatch's Estate, 62 Vt. 300 ; 18 Atl. 814; Sulzberger v. Sulzberger, 50 Cal. 385; Pratt v. Pratt, 161 Mass. $276 ; 37$ N. E. 431. 
While the general design of the homestead laws is the same there is great variance in the constitutional and statutory provisions, the variance existing not only as to matters of detail but often as to matters of fundamental importance affecting the nature of the homestead.

The courts, moreover, have often placed different constructions upon these laws, even where they are similar in terms.

For these reasons, and because the statutes have been frequently amended, only the leading principles can be here stated, with a reference to such exceptional statutes or decisions as are important in themselves or serve to make more distinct the general rules. In practice it is necessary to refer to the details of the controlling law and to the latest decisions in the jurisdiction where the land lies.

In conveyancing it becomes necessary, because of these laws, to consider something more than the mere title and possession of real property attempted to be conveyed, for if the property is a homestead a special release or waiver will sometimes be required, or, at least, there will be found special restraints on alienation not applying to other real property.

Homestead laws have generally been liberally construed in order that their purpose may be made effectual; that is, they have been construed liberally as to the owner and his family, but strictly as to the owner's creditors and purchasers from him. They are not considered as in derogation of the common law, because at common law real property was not liable to be taken on execution for the payment of debts. ${ }^{8}$

In determining whether real property is a technical homestead and to what extent the general rules of conveyancing ure affected by this fact, the chief points in the controlling law to notice are: (a) who may have a home-

' 3 Bl. Comm. 418, 419; Poll. \& Mait. Hist. Eng. L., II, p. 696. 
stead, (b) in what property and to what extent may it exexist, (c) how may it be selected, (d) what restraints, if any, are placed on the alienation of the homestead.

In considering some of these matters those points relating to alienation only will be generally discussed, and many points which relate to the homestead in its character as exempt property alone will not be referred to.

$\S 379$. Who may have a homestead-Not necessarily a married person only.-The chief object of the homestead laws being to protect the family home, the person entitled to the homestead must be, in the majority of the states, the head of a family or a householder having a family. Such a person is generally a husband or father; but one may be married without being the head of a family, or one may be the head of a family without being married.

So far as restraints on alienation are concerned, they affect, generally, those only who are married. But the homestead is not necessarily dependent on marriage, and some statutes provide for certain formalities in conveying land impressed with the character of a homestead without regard to whether the owner is at the time married or single.

For example, in Illinois every householder having a family is entitled to an "estate" of homestead to the extent in value of one thousand dollars in land owned and occupied as a residence, 4 wich can be aliened only in the mode prescribed by statute. Among the statutory formalities required are a releasing clause in the body of the conveyance and a similar clause in the certificate of acknowledgment. ${ }^{5}$

If the property, therefore, does not exceed in value the amount named in the statute, the estate embraces the entire title and interest of the householder therein, leaving

- Illinois R. S., ch. 52, §1.

- Illinois R. S., ch. $30, \S \S 12,28$. A like statute requiring this special release exists in Wyoming, R. S. 1899, §2770. 
no interest in him which he can alien by a deed not conforming to these requirements; ${ }^{6}$ and while there is a statute of the state requiring additional formalities where the owner is married, the requirements mentioned above are applicable to those having a homestead who are not at the time married, and conveyances by such persons not conforming to these statutory requirements are nullities so far as the homestead is concerned. ${ }^{7}$

$\$ 380$. But restraints on its alienation apply usually to married persons only.-In many other states an unmarried person may be entitled to a homestead, which is exempt from a forced sale for the payment of most of its owner's debts: for example, in Alabama, Michigan, Minnesota, North Carolina, Wisconsin and probably other states, the exemption is expressly allowed to "any resident of this state," 8 and under such laws the benefits of the exemption are not restricted to married persons or to heads of families. ${ }^{9}$

The exemption may be allowed, as in Missouri and Vermont, to a "housekeeper or head of a family," 10 or, as in Arkansas, to "a resident of this state who is married or the head of a family," 11 and under such laws one may be entitled to the exemption whether married or single, and it would seem whether man or woman. ${ }^{12}$

In all these cases, while an unmarried person may have a homestead, as in Illinois, he is not required as he is

- Unless the property is abandoned to the grantee in pursuance of such conveyance.

'Davis v. McCullouch, 1901, 192 Ill. 277; 61 N. E. 377.

- Ala. Const., art. 10, §2; Civ. Co., §2033; Mich. Const., art. 16, §2; Com. L. 1897, § 10362 ; Minn. Stat. 1894, §5521 ; N. C. Const., art. $\times$, $\S 2$; Wis. Stat. 1898, § 2983.

${ }^{9}$ Myers v. Ford, 22 Wis. 139 ; Gardner v. Batts, 114 N. C. 496 ; 19 S. E. 794 ; Beard v. Johnson, 87 Ala. 729; 6 So. 383.

${ }^{10}$ Mo. R. S. 1899 , §3616; Vt. R. L. 1894, \$2179.

"Ark. Const. art. 9, § 3 ; S. \& H. Dig. Stat. 1894, §3710.

12 Hyser v. Mansfield, 1899, 72 Vt. 71; 47 Atl. 105; Broyles v. Cox, 1899, 153 Mo. 242; 54 S. W. 488; 77 Am. St. R. 714. 
there to execute a conveyance with any special formalities unless he is married; and this is generally so, the Illinois requirements being, it seems, exceptional.

\$381. Restraints on alienation apply usually to residents only. - Generally to entitle one to a homestead in a particular state he must be a resident of that state, so that when one owns real property in a state other than that of his residence it is not generally necessary when he conveys it to consider the homestead laws of the state where his property lies. While this is true, generally, he may, nevertheless, according to some decisions, acquire a residence (not a "homestead") in one state and yet his former home in another state may still retain its homestead character, if it is occupied as a home by his family; his conveyance, therefore, of this property would seem to be governed by the homestead law of the state where it lies-the state of his former, though not his present, residence. ${ }^{18}$

\$382. Occupancy generally essential- "Constructive occupancy."-To constitute a homestead it is, either by express provision of the constitution or statute or by judicial decision where such provision is wanting, generally necessary that the premises in question be occupied and used as a home by the owner. ${ }^{14}$ Some courts have been more strict than others in this regard and have held that actual occupancy is essential to the creation and continued existence of the homestead..$^{15}$

But, owing to the liberal construction placed upon the

1s Savings Bank v. Kennedy, 58 Iowa 454; 12 N. W. 479.

26 Exempt realty though not occupied by its owner is in some states called " homestead," especially if used in connection with the home. Folsom v. Asper, 1902, 25 Utah 299; 71 Pac. 315; Howell v. Jones, 1892, 91 Tenn. 402 ; 19 S. W. 751 ; Vance v. Hill, 26 S. C. 227 ; 1 S. E. 897.

${ }^{15}$ Turner v. Turner, 1894, 107 Ala. 465; 18 So. 210; 54 Am. St. R. 110; First National Bank v. Hollingsworth, 78 Iowa 575; 43 N. W. 536; 6 L. R. A. 92 ; Currier v. Woodward, 62 N. H. 63; Quehl v. Peterson, 47 Minn. 13; 49 N. W. 390; Boreham v. Byrne, 83 Cal. 23; 23 Pac. 212. 30-Brews. Con. 
homestead laws by many other courts, in order to effect the law's "humane purpose" of preserving a home for the family, it is by no means universally necessary that there shall be actual occupancy and use of premises as a home, to constitute them a homestead. A legal homestead may in many states be created provided land is held with the intention of making a home thereon within a reasonable time, such intention being manifested by some acts of home preparation on the land-though such acts are of ten only slightly indicative of this intention.

For example, though in Michigan and Wisconsin the laws give the homestead character to certain lands "owned and occupied by a resident of the state" it has been held in Michigan that a vacant lot situated on the main business street of a village, purchased by husband and wife who erect on it a store building, part of which they intend to occupy as a dwelling, becomes a homestead, so that it cannot be made subject to a mechanic's lien for the building so erected under a contract executed by the husband alone, though made with the wife's knowledge and consent; ${ }^{16}$ and in Wisconsin, that vacant, uncleared land may become a homestead from the date of its purchase, if obtained with the intention on the purchaser's part of making it such, and partially prepared for occupancy, though not occupied by the owner or his family for three years, during a year of which period, it is occupied by a tenant. ${ }^{17}$

Many other decisions to the same general effect have been rendered under homestead laws similar in terms as to the requirement of occupancy to those of Michigan and Wisconsin; " constructive occupancy," as it is sometimes called, being regarded as sufficient, actual occupancy as a home not being deemed essential. ${ }^{18}$

16 Jossman v. Rice, 1899, 121 Mich. 270; 80 N. W. 25.

${ }^{17}$ Shaw v. Kirby, 1896, 93 Wis. 379; 67 N. W. 700 ; 57 Am. St. R. 927. ${ }^{10}$ Gill v. Gill, 1901, 69 Ark. 596 ; 65 S. W. 112 ; 86 Am. St. R. 213 ; 55 L. R. A. 191; Upton v. Coxen, 1898, 60 Kan. 1; 65 Pac. 284 ; 72 Am. St. R. 341. 
The reason given for such decisions is that "the acquisition of a completed homestead is seldom instantaneous. Generally it requires years of industry and economic living. The purpose necessarily precedes the inception of the work, and that is followed by successive steps until completion is attained. * * These successive steps in the acquisition of a completed homestead, made in good faith, come within the spirit of the statute and are each entitled to the protection afforded by it." 19

\$ 383. Occupancy - Abandonment - "Temporary absence."-As actual occupancy is not in all cases required for the creation of a homestead, so when the homestead character has once been fixed it is not always dependent upon an actual, continued and continuous personal residence or occupation as a home by its owner.

The homestead may be abandoned, and the property then ceases to be exempt as a homestead, and any restraints as to its alienation under homestead laws no longer apply to it. ${ }^{20}$

But a temporary absence of the owner from it with an intention on his part of returning to it as a homestead is not such an abandonment, ${ }^{21}$ and under this rule it has been held that an owner's absence from his homestead for two years, ${ }^{22}$ three years, ${ }^{23}$ or even six years, ${ }^{24}$ will not

29 Scofield v. Hopkins, 61 Wis. 370; 21 N. W. 259. But mere intention to make the premises, at some futare time, a homestead with no preparatory acts, will not be sufficient "occupancy." Feurt v. Caster, 1903, 174 Mo. 289; 73 S. W. 576; Davis v. Kelly, 1901, 62 Neb. 642; 87 N. W. 347; Ball v. Houston, 1901, 11 Okla. 233; 66 Pac. 358; Brokken v. Baumann, 1901,10 N. D. $453 ; 88$ N. W. 84.

${ }^{\infty}$ Smith v. Kneer, 1903, 203 Ill. 264 ; 67 N. E. 780.

${ }^{21}$ Rand Lumber Co. v. Atkins, 1902, 116 Iowa 242; 89 N. W. 1104; Blumer v. Albright, 1902, 64 Neb. 249; 89 N. W. 809; Kelly v. Duffy, 31 Ohio St. 437.

${ }^{22}$ Gardner $\nabla$. Gardner, 1900, 123 Mich. 673; 82 N. W. 522.

2 Minnesota Stoneware Co. v. McCrossen, 1901, 110 Wis. 316; $85 \mathrm{~N}$. W. $1019 ; 84$ Am. St. R. 927.

a Kaeding v. Joachimsthal, 1893, 98 Mich. 78; 56 N. W. 1101. 
amount to an abandonment if during such absence he had a continuing intent to return and occupy it as a homestead.

The practical importance of such liberal doctrines as to occupancy will be realized when it is remembered that in many of the states where they prevail no other notice of the homestead character of real property is given to persons who may deal with it as creditors of, or purchasers from, its owner than that furnished by occupancy; that is, no record is required or made of the fact that the owner claims the property as a homestead..$^{25}$

\$384. Occupancy as a home-Use for business parposes.-The occupancy (actual or "constructive") must be as a home, and, generally speaking, occupation of premises for business purposes will not give them the character of a homestead..$^{26}$

But where part of the premises occupied as the owner's home is used for business purposes, the general rule is that they may still be his homestead in spite of such partial use for business. For example, the use of about onehalf a house by a tinner as a tinshop and the use of the other half both for ordinary living purposes and for the millinery business of the tinner's wife, do not destroy the homestead character of the premises in whole or in part. ${ }^{27}$

In Michigan, even if the premises are primarily used by the owner in his business as hotel proprietor, they may still be his homestead if also used as the sole home of himself and his family, ${ }^{28}$ and in other states nearly the

* See post, $\$ 385$, n. 35.

* Unless the constitution or statute authorizes a business homestead, as in Texas.

"Ogburn's Estate, 1894, 105 Cal. 95; 38 Pac. 498. See, also, Berry v. Meir, 1902, 70 Ark. 129; 66 S. W. 439; Marx v. Threet, 1901, 131 Ala. 340; 30 So. 831; Groneweg v. Beck, 1895, 95 Iowa 717; 62 N. W. 31; Sever v. Lyons, 1897, 170 Ill. $395 ; 48$ N. E. 926.

${ }^{28}$ Lamont v. Le Fevre, 1893, 96 Mich. 175; 55 N. W. 687; King v. Welborn, 1890, 83 Mich. 195; 47 N. W. 106; 9 L. R. A. 803. 
same rule has been adopted. ${ }^{29}$ Sometimes a distinction has been made, however, between the use of a residence for hotel purposes and the use of a hotel for residence purposes ; and in determining whether or not the premises are a homestead, consideration has been given to the primary and principal use, and if the premises are thus used primarily in the owner's business of keeping an hotel they have been held not to be his homestead, though he and his family may dwell on them. ${ }^{30}$

$\S 385$. The selection of the homestead-By record-By occupancy.-Mere occupation and use of certain property as a home do not in all the states having homestead laws constitute the property so occupied and used a technical homestead.

To render it such there must be, in about one-third of the states, some sort of recorded claim or notice or declaration by the owner (or in some cases by his wife), that the property described in the notice or declaration is a homestead within the meaning of the statutes making it exempt from certain debts of its owner. ${ }^{31}$ Occupancy and use as a home are very generally necessary to impress the property with the homestead character, ${ }^{32}$ but where this method of making some record of the selection is made necessary by statute, mere residence and use as a home are not of themselves enough without the statutory declaration, ${ }^{30}$ and where this record or declaration is essential to establish the

${ }^{20}$ Cass Co. Bank v. Weber, 1891, 83 Iowa 63 ; 48 N. W. 1067; 32 Am. St. R. 288; 12 L. R. A. 477; Harriman v. Queen Ins. Co., 49 Wis. 71, 84 ; 5 N. W. 12; Kiesel v. Clemens, 1899, 6 Idaho 444; 56 .Pac. 84.

${ }^{80}$ McDowell v. Creditors, 1894, 103 Cal. 264; 35 Pac. 1031; 42 Am. St. R. 114; Beronio v. Ventura \&c. Co., 1900, 129 Cal. 232; 61 Pac. 958. But see King $\nabla$. Welborn, 1890, 83 Mich. 195 ; 47 N. W. 106; 9 L. R. A. 803.

"Among 8uch states are: California, Colorado, Connecticut, Georgia, Idaho, Louisiana, Maine, Massachusetts, Montana, Nevada, New York, Utah, Virginia, Washington, West Virginia.

"Ante, \$\$ 382, 384.

23 Bank of Woodland v. Oberhaus, 1899, 125 Cal. 320; 57 Pac. 1070. 
homestead and has not been made, restraints which apply to the alienation of the legal homestead do not apply to the alienation of property merely because it is a home. ${ }^{34}$

But in the majority of states having homestead statutes no special record or written declaration of any kind need be made in order to select and establish a homestead, for, unless the constitution or statute requires some special form of dedication or selection, occupancy alone of a piece of land as a home constitutes it a homestead and is notice to every one of its selection as such. ${ }^{85}$

$\$ 386$. The limits of the homestead.-The extent of the homestead is generally limited by statute. The methods, however, of fixing its limits are so varied that it is impracticable to attempt to set them out in any detail. Its extent may be fixed in one state by its value, or in another by its area, or in another by its value and area.

Where its limits are measured by its pecuniary value this may be as high as $\$ 5,000$ (as in California, Idaho, Nevada and the Dakotas), or as low as $\$ 500$ (as in Maine, New Hampshire and Vermont).

Where its extent is limited by its territorial area, or the number of acres, a greater area is generally allowed where the property is rural or farm property than where it is urban property: 40,80 or 160 acres being common limits in the former case, while in the latter the quantity is often restricted to one lot of certain dimensions.

In a few states no monetary limitation is fixed, provided the property is of the quality or area designated by statute-as in Kansas, Minnesota and Texas (under certain . circumstances)..$^{36}$

"Lowenthal v. Coonan, 1902, 135 Cal. 381; 67 Pac. 324; Child v. Singleton, 15 Nev. 461.

${ }^{25}$ Evans $\nabla$. The Grand Rapids \&c. R. Co., 68 Mich. 602; 36 N. W. 687; Barton v. Drake, 21 Minn. 299; Feas's Estate, 190230 Wash. 51; 70 Pac. 270.

${ }^{28}$ Improvements may be of any value, e. g. $\$ 60,000$. Chase v. Swayne, 88 Texas $218 ; 30 \mathrm{~S}$. W. 1049 . Until 1901 there was no limit in Wisconsin (Wis. L. 1901, ch. 269). 
\$387. May be a homestead in an estate less than fee simple-Joint estates. - While the statutes usually require that the real property claimed as a homestead shall be "owned" by the claimant, it is not generally necessary that he have title in fee, for the character of his estate is not designated in the statutes.

There may be a homestead in a life estate, ${ }^{87}$ and, as a lessee may have a homestead in lands leased and occupied by him, an assignment of the lease without his wife's concurrence (which is usually necessary for any alienation of the homestead) is invalid; ${ }^{88}$ as is also an assignment of a contract under which land is held and occupied as a homestead. ${ }^{39}$

Where land is held by husband and wife in common or jointly, ${ }^{40}$ or as tenants by the entirety, ${ }^{41}$ it may be a homestead, and according to some decisions an occupying tenant in common may in any case have a homestead, 12 though this doctrine is denied by others. ${ }^{43}$

A partner, it is generally considered, has no such individual and separate interest in partnership property as to enable him to acquire a homestead in it."

" Kendall v. Powers, 96 Mo. 142; 8 S. W. 793; 9 Am. St. R. 326; Tyler v. Jewett, 82 Ala. 93 ; 2 So. 905.

so Maatta v. Kippola, 1894, 102 Mich. 116; 60 N. W. 300.

- Rawles v. Reichenbach, 1902 (Neb.); 90 N. W. 943; Anderson v. Cosman, 1897, 103 Iowa 266; 72 N. W. 523; 64 Am. St. R. 177. A chattel mortgage may not be made on a house owned and occupied as a homestead standing on leased land, without compliance with statutory requirements as to the alienation of a homestead. Gage $\nabla$. Wheeler, 129 Ill. 197 ; 21 N. E. 1075; Hogan v. Mannerg, 23 Kan. 551.

${ }^{\infty}$ Lozo $\nabla$. Sutherland, 38 Mich. 168.

"Cole v. Cole, 1901, 126 Mich. 569; 85 N. W. 1098.

${ }^{42}$ Thompson v. King, 54 Ark. 9 ; 14 S. W. 925; Giles v. Miller, 1893, 36 Neb. 346 ; 54 N. W. 551 ; 38 Am. St. R. 730.

4 Howes v. Burt, 130 Mass. 368; Case Threshing Machine Co. v. Joyce, 89 Tenn. 337 ; 16 S. W. 147.

4 Michigan Trust Co. v. Chapin, 1895, 106 Mich. 384; 64 N. W. 334 ; 58 Am. St. R. 490; Hoyt v. Hoyt, 69 Iowa 174 ; Trowbridge v. Cross, 117 Ill. 109; but see Hunnicutt v. Summey, 63 Ga. 586; Clemente v. Lacy, 51 Texas 150. 
\$388. Owner of a homestead may alienate it unless restrained-Partial restraints.-The mere exemption of a homestead from a forced sale does not of itself restrict the power of alienation by the owner, and in the absence of constitutional or statutory provisions restraining him from freely conveying the homestead, he has as full a right to convey it as to convey any other property. So, for example, under the former laws of Missouri, Nebraska and Utah, which provided for the exemption of the homestead from forced sale, but placed no restraint on its alienation, ${ }^{45}$ a husband could freely convey lands owned by him and occupied as a homestead without the consent of his wife, though subject to her dower or analogous rights. ${ }^{46}$

So also there may be merely restrictions against certain kinds of conveyances but none as to others, as in ${ }^{465}$ Kentucky a married man owning a homestead may sell and convey it absolutely without consulting his wife, but he may not mortgage it without her joinder, ${ }^{47}$ and in rare instances mortgages of the homestead of $a$ married man are prohibited entirely except for the purchase price of the premises. ${ }^{48}$

Special restraints as to mortgaging lands impressed with the homestead character are probably due to the fact

4s Except, in Missouri, where the wife had filed a claim of homestead under R. S. 1889 , $\$ 5435$.

c Cook v. Higley, 1894, 10 Utah 228; 37 Pac. 336; Greer v. Major, 1893, 114 Mo. 145; 21 S. W. 481; Rector v. Rotton, 3 Neb. 171. See Moran v. Clark, 30 .W. Va. 358; 4 S. E. 303; 8 Am. St. R. 66. The present statutes in Missouri, Nebraska and Utah require the wife's consent: Mo. R. S. 1899, § 3616; Gladney v. Sydnor, 1903, 172 Mo. 318; 72 S. W. 554; 60 L. R. A. 880 ; Neb. Com. Stat. 1901, § 3259; Utah R. S. $1898, \S 1155$.

46. This was also true in Colorado but has been changed by a very recent statute. Colo. L. 1903, pp. 153, 247. Now a husband and his wife must join in any conveyance.

${ }^{47}$ Wright v. Whittock, 1892, 18 Colo. 54 ; $31 \cdot$ Pac. 490 ; Gullett r. Arnett, 1898, 19 Ky. Law 1892; 44 S. W. 957; Carr v. Winlock, 1900, 109 Ky. 488 ; 59 S. W. 747 . Such restrictions as exist in New York and Ohio relate simply to mortgages: N. Y. Civ. Co., \$ 1404 ; Ohio R. S., § 5442.

${ }^{48}$ See Parrish v. Hawes, 1902, 95 Texas 185; 66 S. W. 209; Maxwell v. Roach, 1901, 106 La. $123 ; 30$ So. 251 . An unmarried man may mortgage his homestead in Texas: Davis v. Converse, $46 \mathrm{~S}$. W. 910. 
that property is generally mortgaged for much less than its full value, and may thus be lost to its owner and his family without adequate return, whereas an absolute conveyance is generally made for nearly the full value of the property conveyed.

\section{$\$ 389$. Some restriction on voluntary alienation usual.} -But while restraint on alienation is not necessarily incident to the exemption of the homestead from sale on execution, the purpose of the homestead laws is generally considered to be promoted by the imposition of some restraint on the owner's right of transfer.

In those states where some sort of recorded declaration by the owner is necessary to secure to him the exemption of certain property as a homestead, he voluntarily accepts such restraints as the statute imposes on his freedom of transfer by declaring and recording his homestead; $;^{49}$ and in those states where he obtains the exemption by occupancy without such a record the restraint is accepted by him when he places himself, by becoming a householder, in the class entitled to the exemption on the one hand and subject to the restraint on the other.

$\S 390$. Usually husband and wife must concur in the transfer.-The most usual constitutional or statutory provision which amounts to a restraint on the freedom of alienation of the homestead is the requirement that husband and wife (if the owner be married) shall unite in the conveyance.

This requirement appears in some form in most of the states having homestead laws, though the terms in which the requirement is expressed vary greatly. The provision may be that husband and wife "must execute and acknowledge" the same instrument, or that they must "concur in and sign the same joint instrument," or that

49irginia and Tenn. Coal Co. v. Mrclelland, 1900, 98 Va. 424; $36 \mathrm{~S}$. E. 479 . 
there must be "joint consent" of husband and wife, or that the husband's conveyance shall not be valid "without the signature of the wife." 50

The husband or wife who joins in the instrument conveying or incumbering the homestead by the other spouse who has the legal title, usually conveys nothing by this joinder, for having, strictly speaking, no estate in the homestead, the joinder in the conveyance is not for the purpose of transferring an interest in land but is simply a means of manifesting that consent to the transfer which the statute requires. ${ }^{51}$

The wife's joining in her husband's homestead conveyance is not analogous to her release of dower, because he may convey a valid title to his own lands subject to her dower interest, while he may not convey any title (in many states) to the homestead without her consent. ${ }^{62}$

§ 391. Effect of non-compliance with statute.-The effect of the alienation of the homestead when the instrument of alienation is not executed in accordance with the statutory requirement as to the joinder of hus- ' band and wife is not the same in all the states, even where the statutory provisions are expressed in similar terms.

The restriction on alienation by the husband alone is considered in many of the states having homestead stat-

\footnotetext{
${ }^{\infty} \mathrm{By}$ such provisions it is intended that the real wife shall concur; a purchaser or mortgagee takes the risk of the pretended wife's being the actual wife of the grantor: Security Loan Co. v. Kaufiman, 1895, 108 Cal. 214; 41 Pac. 467; Sherrid v. Southwick, 43 Mich. 515. But see as to a non-resident deserted wife: Stanton $\nabla$. Hitchcock, 64 Mich. 316; Black v. Singley, 91 Mich. 50.

${ }^{31}$ Hamilton v. Detroit, 1901, 85 Minn. 83; 88 N. W. 419; Pounds v. Clarke, 1892, 70 Miss. 263; 14 So. 22; Creath v. Creath, 86 Tenn. 659; 8 S. W. 847; Godfrey v. Thornton, 46 Wis. 677.

${ }^{32}$ Although it has been sometimes said that a wife has a right or interest in the homestead, title to which is in her husband, which she may protect and which she may refuse to "release." Rogers v. McFarland, 1893, 89 Iowa 286; 56 N. W. 504; California Fruit Trans. Co. v. Anderson, 1897, 79 Fed. R. 404.
} 
utes as applying to the land constituting the homesteada certain amount of realty exempt from execution for the payment of debts-which its owner is incapacitated from transferring as he may transfer other property, his disability being established for the protection of the family, and, according to the views of some, for his own protection as well. ${ }^{.3}$

In other states, however, the restraint on alienation is regarded as applying only to whatever right or interest in the homestead premises is necessary for family protection; and it is considered that it is not the alienation of the land itself that is prohibited or restrained, but the privilege of occupancy and the right of exemption. . $^{\text {th }}$

\$392. Effect of non-compliance with statute-The alienation void in many states.-It follows from these constitutional and statutory restraints on alienation that the transfer or incumbrance (except it be a purchase money mortgage) of land impressed with the character of a homestead made by the husband alone when the legal title is in him is, in many states, an absolute nullity, so far as that land is concerned. It is not merely void as to the wife, but as to the husband also, and the grantee or mortgagee acquires no title. ${ }^{55}$ When the law makes his sole alienation thus void he is not estopped ${ }^{56}$ by his deed or mortgage, to which his wife has not assented in statutory form, to dispute its validity, for the general doctrine of estoppel cannot apply to acts that are nullities, and his grantee or mortgagee is presumed to know that the hus-

se See post, §392.

4 Post, § 397.

BS Goodwin v. Goodwin, 1901, 113 Iowa 319; 85 N. W. 31; Pritchett v. Davis, 1897, 101 Ga. 236; 28 S. E. 666; 65 Am. St. R. 298; Webster v. Warner, 1899, 119 Mich. 461; 78 N. W. 552; Hubbard v. Sage Land \&c. Co., 1902, 81 Miss. 616; 33 So. 413; Virginia-Tennessee Coal Co. v. McClelland, 1900,98 Va. 424 ; 36 S. E. 479.

see post, $\$ 394$, note 68 , as to estoppel when the conveyance is not made void, and see Marler v. Handy, 1895, 88 Texas 421; 31 S. W. 636. 
band cannot thus convey or mortgage the homestead premises, ${ }^{57}$ and the fact that his conveyance contains covenants for title is held immaterial where the doctrine that the instrument of transfer thus made is void prevails. ${ }^{58}$

Whether the restraint be regarded as imposed for the benefit of his wife and children, ${ }^{59}$ or as imposed, not merely for their benefit and protection, but for his own protection as well, ${ }^{60} \mathrm{he}$ is, as to this land, under a disability to convey as he may convey his other property.

\$393. Effect of wife's insanity.-The fact that his wife is insane and residing in another state will not enable a married man to mortgage his homestead without her joinder when the statute requires that the mortgage shall be signed and acknowledged by both husband and wife, ${ }^{61}$ nor on the other hand will the insane wife's joining with him in his alienation render it valid when the statute provides that husband and wife must "concur" in and sign the same joint instrument, ${ }^{62}$ or that it shall not be valid without her "voluntary signature and assent," ${ }^{63}$ nor may an insane wife's guardian act for her in such cases in the absence of a statute authorizing him to do so. ${ }^{64}$

s7 Cowan v. Southern R. Co., 1898, 118 Ala. 544; 23 So. 754; Garner v. Black, 1901, 95 Texas 125; 65 S. W. 876; Whitlock v. Goseon, 1892, 35 Neb. 829 ; 53 N. W. 980.

${ }^{68}$ Stickel v. Crane, 1901, 189 Ill. 211; 59 N. E. 595; Rogers v. Day, 1898, 115 Mich. 664 ; 74 N. W. 190; Alt v. Banholzer, 39 Minn. 511 ; 40 N. W. $830 ; 12$ Am. St. R. 681.

${ }^{60}$ Gadsby v. Monroe, 1897, 115 Mich. 282; 73 N. W. 367.

${ }^{60}$ Martin v. Harrington, 1901, 73 Vt. 193; 50 Atl. 1074; 87 Am. St. R. 704.

a Whitlock v. Gosson, 1892, 35 Neb. 829; 53 N. W. 980; Anderson v. Stadlemann, 1898, 17 Wash. 433 ; 49 Pac. 1070.

"Alexander $\nabla$. Vennan, 61 Iowa $160 ; 16 \mathrm{~N}$. W. 80.

whompeon v. New Eng. Mort. Co., 1895, 110 Ala. 400; 18 So. 315; 55 Am. St. R. 29.

" Flege v. Garvey, 47 Cal. 371; as to such statutes see ante, p. 423. 
\$394. Subsequent abandonment will not make the conveyance valid-Nor death or divorce-Transfer by wife alone.-The result is that the subsequent abandonment of the premises as a homestead will not render valid a conveyance that was invalid when made; ${ }^{65}$ nor will the wife's subsequent death ${ }^{66}$ or divorce ${ }^{67}$ make it valid. ${ }^{68}$

And in those states where husband and wife must both execute the conveyance, irrespective of which of them has the legal title, the same consequences in general will result from a conveyance by the wife alone when the title is in her, ${ }^{69}$ though in other states where there is no such requirement as to execution by both of them in all cases, but simply one as to the wife's execution or consent to her husband's alienation, it seems that she may convey the homestead without her husband's joining with her if in those states she has capacity to so convey other real property..$^{70}$

co Gleason v. Spray, 81 Cal. 217 ; 22 Pac. 551 ; 15 Am. St. R. 47 ; Bruner v. Bateman, 66 Iowa 488; 24 N. W. 9; American Savings \& Loan Ass'n v. Burghardt, 1897, 19 Mon. 323 ; 48 Pac. 391 ; 61 Am. St. R. 507. Though, on acquiring a new homestead, the husband may be estopped by his sole deed previously made of his former homestead; Marler $\nabla$. Handy, 1895, 88 Texas 421; 31 S. W. 636.

${ }^{c 6}$ Shoemaker v. Collins, 49 Mich. 595; 14 N. W. 559; Martin v. Harrington, 1901, 73 Vt. 193; 50 Atl. 1074; 87 Am. St. R. 704.

or Alt v. Banholzer, 39 Minn. $511 ; 40$ N. W. $830 ; 12$ Am. St. R. 681; Lange v. Geiser, 1903, 138 Cal. 682; 72 Pac. 343.

- In the recent case of Adams v. Gilbert, 1903 (Kan.), 72 Pac. 769, it is held that, while the husband's deed without his wife's consent is ineffectual while the property remains a homestead, he may be estopped by it, or may confirm it by silence after his wife's death. It is to be noted that the Kansas constitution and statute provide simply that the homestead "shall not he alienated without the joint consent of husband and wife when that relation exists," and though alienations not so consented to have been called void (Schermerhorn v. Mahaffie, 34 Kan. 108) they would seem to be voidable merely.

Lange v. Geiser, 1903, 138 Cal. 682 ; 72 Pac. 343; France v. Bell, 52 Neb. $57 ; 71$ N. W. 984 ; Low $\nabla$. Anderson, 41 Iowa 476.

${ }^{0}$ Morley Bros. v. National Loan \&c. Co., 1899, 120 Mich. 171; 78 N. W. 1078; Price v. Osborn, 34 Wis. 34. 
$\S 395$. To what extent husband may lease-Sell timber-Grant rights of way.-The statutes of most states are broad enough in their terms to restrain the husband from transferring any interest in the homestead premises without his wife's concurrence in the form prescribed by statute.

He may not generally, for example, lease the premises without her properly expressed consent; at least this would seem to be the general rule when, by the terms of the lease, the lessee's occupation would interfere with the use of the premises as a homestead, or when the lease gives the lessee the right to remove substantial portions of the realty - as minerals and timber-and creates encumbrances on the premises by giving him extensive rights of ingress and egress. ${ }^{71}$ Nor may the husband alone convey the minerals or timber in and upon the premises, at least when the conveyance is in general terms and is in reality an alienation of a substantial part of the property ${ }^{72}$ though it has been held that a license by the husband alone to remove ore from a part of homestead lands is not invalid when their possession for the uses of the homestead is not interfered with, especially when the wife has knowledge of the expenses incurred by the licensee under the license and makes no objection. ${ }^{73}$

It appears also that under most of the homestead statutes a husband may not grant by his sole deed a right of way across the homestead premises, ${ }^{74}$ nor may he alone

${ }^{7}$ Pritchett v. Davis, 1897, 101 Ga. 236 ; 28 8. E. 666; 65 Am. St. R. 298; Wea Gas, Coal, etc., Co. v. Franklin Land Co., 1895, 54 Kan. 533 ; 38 Pac. 790 ; 45 Am. St. R. 297; Barrett v. Cox, 1897, 112 Mich. 220 : 70 N. W. 446.

${ }^{72}$ Virginia-Tennessee Coal Co. v. McClelland, 1900, 98 Va. 424; $36 \mathrm{~S}$. E. 479; McKenzie v. Shows, 1892, 70 Mise. 388; 12 So. 336; 35 Am. St. R. 654 .

$n$ Harkness $\nabla$. Burton, 39 Iowa 101.

"Cowan v. Southern R. Co., 1897, 118 Ala. 354; 23 So. 754; Erans v. Grand Rapids \&c. R. Co., 68 Mich. 602; 36 N. W. 687; Pilcher v. Atchison \&c. R. Co., 38 Kan. 516; 16 Pac. 945; 5 Am. St. R. 770; Gulf \& Ship Iød. R. Co. v. Singleterry, 1901, 78 Miss. 772; 29 So. 754. 
dedicate a portion of them to the public as a street; ${ }^{75}$ though it has been held that where the grant of an easement, or of a right of way to a railroad, does not interfere with the actual use and occupancy of the homestead it may be made by the husband alone. ${ }^{76}$

\$396. The defective conveyance valid as to the excess over homestead.-Nevertheless, while the conveyance is thus often said to be "void," it is not void for all purposes, but simply as an alienation of the homestead; for, even in the states where the courts have been most emphatic in declaring it void, when there is included in it other lands besides the homestead it may be a valid conveyance as to these other lands, though invalid as to the homestead. ${ }^{77}$ If, however, severance of the parcels is impracticable, the conveyance will be wholly invalid, at least where the measure of the homestead is territorial and does not depend upon its value entirely; ${ }^{78}$ while, where value (rather than territorial extent) regulates or measures the homestead, the excess over the statutory value may be conveyed by the husband's sole deed, ${ }^{79}$ and the grantor and grantee become co-owners and may have partition..$^{80}$

$\$ 397$. Non-compliance with statute does not make alienation void in some states.-If the restraints as to the

"San Francisco v. Grote, 1898, 120 Cal. 59 ; 52 Pac. 127 ; 41 L. R. A. 335 ; 65 Am. St. R. 155.

${ }^{16}$ Stokes V. Max8on, 1901, 113 Iowa 122 ; 84 N. W. 949 ; 86 Am. St. R. 367; Chicago \&c. R. Co. v. Titterington, 1882, 84 Texas 218; 19 S.W. 472; 31 Am. St. R. 39.

$\pi$ Engle v. White, 1895, 104 Mich. 15; 62 N. W. 154; Weitzner v. Thingstad, 1893, 55 Minn. 244; 56 N. W. 817; Pryne v. Pryne, 1902, 116 Iowa 82; 89 N. W. 108; Townsend v. Blanchard, 1902, 117 Iowa 36; Thorp v. Thorp, 70 Vt. 46; 39 Atl. 245.

7 Sammon v. Wood, 1895, 107 Mich. 506; 65 N. W. 529.

Donahue v. Cricket Club, 1898, 177 Ill. 351 ; 52 N. E. 351.

0 Anderson v. Smith, 1895, 159 Ill. 93; 42 N. E. 206; Gray v. Schofleld, 1898, 175 Ill. 36; 51 N. E. 684. 
alienation of the homestead are considered as applying to the right of exemption or privilege of occupancy rather than to the exempt land, an effect is given to the husband's sole conveyance different from that given to it when they are regarded as applying to the land itself.

In Wisconsin the homestead is provided for by a statute ${ }^{81}$ in terms similar to those of many states. "A homestead, - consisting, when not included within any city or village, of any quantity of land, not exceeding forty acres, used for agricultural purposes, and when included in any city or village, of any quantity of land not exceeding one-fourth of an acre, and the dwelling house thereon * * owned and occupied by any resident of this state shall be exempt from sale on execution," etc., and another statute ${ }^{82}$ provides that "no mortgage or other alienation by a married man of his homestead, exempt by law from execution, shall be valid or of any effect as to such homestead without the signature of his wife." Under statutes almost identical with these, it has been held by many courts, as the cases cited in the preceding sections show, that a conveyance by the husband alone is void. But in a recent decision in this state ${ }^{83}$ it is held, following the settled rule there, that the prohibition against the husband's conveying, without his wife's signature, applies only to the homestead as a right or interest in the land, and that a warranty deed by a married man, which his wife refused to sign, will convey an equitable interest to the grantee, which will entitle him to the legal title when the homestead right ceases by the death of both husband and wife or otherwise, and that the deed may be enforced against the grantor's child who takes the legal title to the homestead upon his death. ${ }^{84}$

${ }^{81}$ Wis. R. S. 1898, $§ 2983$ (amended by laws 1901, ch. 269, limiting the exemption to the amount of $\$ 5,000)$.

${ }^{82}$ Wisconsin R. S. 1898, §2203.

Jerdee v. Furbush, 1902, 115 Wis. 277; 91 N. W. 661.

(Some decisions in other states which influenced the Wisconsin

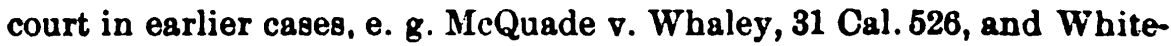


In North Carolina the constitution ${ }^{85}$ provides that " every homestead and the dwellings and buildings used therewith, not exceeding in value $\$ 1,000$, to be selected ${ }^{86}$ by the owner thereof," or at his option a city lot, "owned and occupied by any resident * " shall be exempt" from sale on execution; and that ${ }^{87}$ he may dispose of "the same" by deed, "but no deed made by the owner of a homestead shall be valid without the voluntary signature and assent of his wife, signified on her private examination according to law."

These clauses were recently the subject of an interesting series of opinions by the justices of the supreme court of that state, ${ }^{88}$ and while one member of the court on the first hearing" considered that the "homestead" of the constitution is the land and that any conveyance of it by a husband alone is void, and the other justices then composing the court did not agree as to its legal character, the doctrine finally established on rehearing is that the constitutional restraint on alienation applies only to a conveyance of the owner's homestead right of exemption and that a deed of trust by the husband alone, reserving the homestead of the grantor, conveys the entire land subject only to the "determinable exemption" in one thousand dollars worth of it from the payment of the grantor's debts during his life, which exemption ceases on his death.

Such a conveyance by the husband alone, reserving the

man v. Field, $53 \mathrm{Vt}$. 554, would not now be followed in these states. See Powell v. Patison, 1893, 100 Cal. 236; 34 Pac. 677; Martin v. Harrington, 1901, 73 Vt. 193; 50 Atl. 1074; 87 Am. St. R. 704.

${ }^{*}$ Art. X, § 2.

* There is no provision as to the method of selection, and occupancy seems sufficient.

87 Const., Art. X, \$8.

Joyner $\nabla$. Sugg, 1902-1903, 131 N. C. 324 ; 42 S. E. 828; on rehearing 132 N. C. $580 ; 44$ S. E. 122.

${ }^{*}$ Furches, C. J., in 131 N. C. 332. 31-Brews. CoN. 
use and occupancy during the lives of himself and his wife, or reserving the "homestead right," would probably be held valid by other courts, ${ }^{90}$ though under the view generally taken of the character of the homestead and the purpose of restraints on its alienation, such a reservation would not make his sole deed effective in most states. ${ }^{91}$

$\S 398$. The mode of manifesting consent to the alienstion of the homestead.-The proper forms and methods of expressing the consent of husband or wife to an alienation of the homestead by the other vary somewhat in the different states.

A constitutional provision as to the mode will, of course, control a statutory provision conflicting with it; so, for example, where the constitution provides for the "joint consent" of husband and wife, a statute purporting to authorize an alienation of the homestead by the joinder of a guardian of an insane husband or wife with the other spouse in the instrument of transfer is unconstitutional, as the guardian cannot give the consent required by the constitution..$^{22}$

As a general rule the concurrence or consent of husband and wife to the alienation should be expressed by their joint act, and not separately. This is clear from the terms of many of the statutes, but even where not expressly so provided the laws have been construed so as to render ineffective separate releases and consents. ${ }^{93}$

'0 See Allbright $\nabla$. Hannah, 1897, 103 Iowa 98; 72 N. W. 421-not deciding the matter; Adams v. Gilbert, 1903 (Kan.); 72 Pac. 769. See ante, \$394, note 68; Gunnison v. Twitchel, 38 N. H. 62, the N. H. statute (Pub. Btat. 1901, ch. 138, \$ 4) now provides that "no deed shall convey or incumber the homestead right" unlese executed by both husband and wife, a very different provision from those of most states.

" Gadsby v. Monroe, 1897, 115 Mich. 282; 73 N. W. 367.

Locke v. Redmond, 1897, 6 Kan. App. 76 ; 49 Pac. 670 ; affirmed, 59 Kan. 773 ; 52 Pac. 97.

Donahoe v. Chicago Cricket Club, 1898, $177 \mathrm{Il} .351$; 62 N. E. 351 ; Hart v. Church, 1899, 126 Cal. 471; 58 Pac. 910; 77 Am. St. R. 195; Hubbard ₹. Sage Land \&c. Co., 1802, 81 Miss. 616; 33 So. 418. 
It results necessarily from the terms of most of the laws that the consent required must be manifested by at least some writing, but where the constitution provides that the homestead cannot be alienated "without the joint consent of husband and wife," and nothing further is required by any statute, it is held that the consent need not be written. ${ }^{\text {st }}$

Usually the joinder of the husband and wife in a conveyance in ordinary form is a sufficient release, conveyance or consent, without special reference being made to the homestead, though in two states-Illinois and Wyoming - a special releasing clause is required.

Even though the consenting husband or wife may, strictly speaking, have nothing to convey, ${ }^{90}$ it seems generally the more prudent practice for both of them to appear as grantors in the instrument of conveyance, and this has been considered essential under a statute providing that they shall "concur in and sign the same joint instrument;" 96 though under the statutes of some states which require simply the "signature" of the wife she need not be named as grantor in her husband's conveyance of the homestead. ${ }^{\text {n }}$

In any case a wife joining in her husband's conveyance should not restrict its effect as to her, if it is intended to convey or release the homestead, by declaring that she joins to " release her dower."

* Sullivan v. Wichita, 1902, 64 Kan. 539; 68 Pac. 55; Matney v. Linn, 1898, 59 Kan. 613 ; 54 Pac. 668.

* Ante, \$ 390, n. 51 .

* Seiffert \&c. Lumber Co. v. Hartwell, 1895, 94 Iowa 576; 63 N. W. 333; 58 Am. St. R. 413.

${ }^{9}$ Shelton $\nabla$. Aultman \&c. Co., 82 Ala. 315; 8 So. 232; Barrett $\nabla$. Cox, 1897, 112 Mich. 220; 70 N. W. 446; Lawyer v. Slingerland, 11 Minn. 447; Godfrey v. Thornton, 46 Wis. 677; 1 N. W. 362 . See Davis v. Jenkins, 1892, 93 Ky. 353; 20 S. W. 283; 40 Am. St. R. 197.

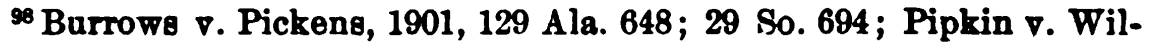
liams, 1893, 57 Ark. 242; 21 S. W. 433; 38 Am. St. R. 241; Sharp v. Bailey, 14 Iowa 387 ; 81 Am. D. 489. 
$\S 399$. The acknowledgment to the conveyance of the homestead. - It is required in many states that the instrument by which the homestead is conveyed shall be acknowledged. ${ }^{99}$ Such a requirement must be fulfilled in order that the alienation may be effectual; therefore, if the instrument has not actually been acknowledged, or if it has been acknowledged before some one not authorized to take the acknowledgment, as an officer disqualified by reason of interest; ${ }^{100}$ the conveyance is generally considered invalid as to the homestead.

So, if the certificate of acknowledgment is substantially defective the conveyance to which it is attached is of no more effect than if not acknowledged. ${ }^{1}$ And if the wife's "separate examination" 2 is required to be certified to in such cases this is also essential to its validity $;^{3}$ and so, for instance, a conveyance not conforming to this requirement, being a nullity, cannot be made valid by the wife's acknowledgment after her husband's death."

Unless, however, the homestead laws of the state expressly require an acknowledgment to a conveyance of the homestead, or unless some other law makes an acknowledgment essential to conveyances generally, there is no reason why the absence of an acknowledgment should have any other effect upon the alienation of the homestead than upon that of other property. ${ }^{6}$

${ }^{99}$ See ante, $\$ 263$.

100 Watkins v. Youll, 1903 (Neb.) ; 96 N. W. 1042. See ante, $\$ \S 281,282$, 285-287 and cases cited.

${ }^{1}$ Penny v. British \&c. Mortgage Co., 1901, 132 Ala. 357; 31 So. 96 ; A merican Savings \& Loan Ass'n v. Burghardt, 1897, 19 Mon. 323; 48 Pac. $391 ; 61$ Am. St. R. 507.

${ }^{2}$ Ante, $\$ 365$.

3 Marx v. Threet, 1901, 131 Ala. 340; 30 So. 831; Garner v. Black, 1901, 95 Texas 125 ; 65 S. W. 876.

'Richardson v. Woodstock Iron Co., 1890, 90 Ala. 266 ; 8 So. 7.

- For example, the statute relating to married women. Fisher $\nabla$. Meister, 24 Mich. 447, 452.

${ }^{6}$ Barrett v. Cox, 1897, 112 Mich. 220; 70 N. W. 446; Lawyer v. Slingerland, 11 Minn. 447; Karcher v. Gans, 1900, 13 S. D. 383 ; 83 N. W. 431 ; 79 Am. St. R. 893; Godfrey v. Thornton, 46 Wis. 677; 1 N. W. 362. 
$\S 400$. Conveyance of the homestead between husband and wife.-Owing to the requirement that husband and wife must execute and acknowledge the conveyance of the homestead, or that the wife must execute her husband's conveyance, some question has arisen as to conveyances of the homestead between husband and wife.

Its transfer by the husband to the wife has often been held valid when the instrument of transfer has not been executed by her, although her signature, or joinder, or acknowledgment, after a separate examination, are essential in the same jurisdictions in conveying it to other persons. ${ }^{7}$

The reason usually given for sustaining conveyances in this form from husband to wife is that as the restraint on alienation is imposed for the benefit of the family there is no violation of the spirit of the law in the making of such a conveyance by the husband to the wife. And sometimes it is also said that such a conveyance is not within the statute, because to require her signature or joinder under such circumstances would be to make her both grantor and grantee in the same conveyanco- "a vain and senseless thing." 8

But this latter reason is based on the view that she has in such cases some estate to convey, which is not universally recognized as the correct view of the nature of her interest. ${ }^{9}$ And in Illinois the fact that the wife appears in such cases (where she joins in her husband's transfer to her) to be both grantor and grantee is considered to be no obstacle to such a transfer, for a direct conveyance of the homestead from him to her without her joinder is invalid as to the homestead property, ${ }^{10}$ though it conveys

'Thompson v. McConnell, 1901, 107 Fed. 33; Burkett จ. Burkett, 78 Cal. 310; 20 Pac. 715; 12 Am. St. R. 58; 3 L. R. A. 781; Turner v. Bernheimer, 1892, 95 Ala. 241 ; 10 So. 750.

'Lynch v. Doran, 1893, 95 Mich. 395; 54 N. W. 882; Furrow v. Athey, 21 Neb. 671; 59 Am. R. 867; Harsh v. Griffin, 72 Iowa 608 ; 34 N. W. 441 ; Hall v. Powell, 1899, 8 Okla. 276; 57 Pac. 168.

-Ante, 390, n. 51.

20 Shields v. Bush, 1901, 189 Ill. 534 ; 59 N. E. $962 ; 82$ Am. St. R. 474. 
title to the excess in value over $\$ 1,000,11$ but nothing if the homestead attempted to be so conveyed is worth less than that sum ; ${ }^{12}$ and the same principles apply to a conveyance from the wife to the husband of the homestead to which she has the legal title. ${ }^{\text {n }}$

In the foregoing cases from various states where conveyances of the homestead between husband and wife have been sustained, the homestead character of the property has been preserved, though the legal title to the realty has passed from one to the other, and it has been therefore considered that the spirit of the statutes has not been violated. But where the transfer between husband and wife would tend to destroy the homestead a more strict construction has been placed upon the statute requiring joint execution and acknowledgment, and it has been held that a mortgage of homestead community property executed by the wife alone to the husband, to secure a debt from him to her, is void in the hands of his assignee. ${ }^{14}$

u Stickel v, Crane, 1901, 189 III. 211; 59 N. E. 595.

12 Anderson v. Smith, 1895, 159 Ill. 93; 42 N. E. 306.

13 Despain v. Wagner, 1896, 163 Ill. 598; 45 N. E. 129. It does not seem to have been decided in Illinois that a conveyance executed and acknowledged by both would be valid in such cases, but that it would be may be inferred from the foregoing decisions.

"Freiermuth v. Steigleman, 1900, $130 \mathrm{Cal}$. 392; 62 Pac. 615; $80 \mathrm{Am}$. St. R. 138. The question as to when conveyances of the homestead between husband and wife may be considered fraudulent as to creditors is one not within the scope of this work. See Kettleschlager v. Ferrick, 1900, 12 S. Dak. 455; 76 Am. St. R. 623; White Sewing Machine Co. v. Wooster, 1899, 66 Ark. 382 ; 74 Am. St. R. 100. 


\section{CHAPTER XXIV.}

CAPACITY OF CORPORATIONS TO PURCHASE AND CONVEY REAL PROPERTY.

\$401. Oapacity of corporation to take title at common law -Statutes of mortmain.

402. Capacity to take title-May take in fee though its duration is limited.

403. Effect of corporation's dissolution on title.

404. May purchase and hold only lands appropriate to corporate purposes-Prosumption that land is so held.
$\S 405$. When its power is exceeded the state only may complain - Conveyance to corporation in such case voidable, not void.

406. Capacity of private corporation to alienate real property.

407. Capacity of public and quasi-public corporations to alienate real property.

\$401. Capacity of corporation to take title at common law-Statutes of mortmain.-At common law a corporation has capacity to purchase and hold such lands as are reasonably required for the purposes of its creation without any special authority. ${ }^{1}$

By a series of "statutes of mortmain," 2 designed primarily to prevent the accumulation of lands by ecclesiastical foundations-bodies having some of the attributes of the later "corporation" B-this power was, in England, taken from corporations, both ecclesiastical and lay," which were prohibited from purchasing lands with-

' Lathrop v. Commercial Bank, 8 Dana 114; 33 Am. D. 481; First Parish in Sutton v. Cole 3 Pick. 232, 239; Page v. Heineberg, 40 Vt. 81 ; 94 Am. Dec. 378.

2 Beginning with Magna Carta (1225), 9 Hen. III, c. 36.

- See Poll. \& Mait. Hist. Eng. L., 2d ed. I, pp. 494 et seq.

(1391) 15 Rich. II, c. 5. 
out a license from the crown (and originally also from the lord, if any, from whom the land was held); the violation of the prohibition being a cause for forfeiture.

Though these statutes of mortmain have not been recognized as being in force in this country, ${ }^{5}$ except in Pennsylvania, ${ }^{6}$ their policy has been adopted where restrictions have existed on the power of corporations to acquire real estate by devise, ${ }^{7}$ or on their power to acquire more than a specified amount of land, a restriction frequently imposed by statute on religious and charitable corporations especially.

$\$ 402$. Capacity to take title-May take in fee though its duration is limited.-The capacity of corporations in this country being unaffected by the English statutes of mortmain, they may take, hold and convey such lands as are reasonably necessary for carrying out the business for which they were created unless some restriction is imposed by their charters or by statute. ${ }^{8} \mathrm{~A}$ corporation, moreover, though its duration is limited, ${ }^{9}$ may take an estate in fee, so that it may convey title in fee; its grantee's title being unaffected by its own subsequent dissolution. ${ }^{10}$

403. Effect of corporation's dissolution on title.-It has been said that at common law, on the dissolution of

- See decisions note 1, supra, and Perrin v. Carey, 24 How. (U. S.) 465, 498; Mallett จ. Simpson, 94 N. C. 37 ; 55 Am. R. 594; Fayette Land Co. v. Louigville \&c. R. Co., 1896, 93 Va. 274; 24 S. E. 1016.

- Methodist Church v. Remington, 1 Watts 218; 26 Am. D. 61. A corporation is not prevented from acquiring lande, but from holding those which it has acquired without a license. Leazure v. Hillegas, 7 Serg. \& R. 313; 1 Wilgus Corp. Cas. 1008.

${ }^{7}$ Downing v. Marshall, 23 N. Y. 366; 80 Am. D. 290; In re McGraw's Estate, 111 N. Y. 66, 137; 19 N. E. 233; 2 L. R. A. 387; 1 Wilgus Corp. Cas. 1034.

Thompson v. Waters, 25 Mich. 214; 12 Am. R. 243.

9 Nicoll v. N. Y. \& E. R. Co., 12 N. Y. 121 ; Bailey v. Platte \&c. Canal Co., 12 Colo. 230.

${ }^{10}$ Wilson v. Leary, 1897, 120 N. C. 90 ; 26 S. E. 630 ; 58 Am. St. R. 778; 1 Wilgus Corp. Cas. 903. As to the use of the word successors in creating a foe, see ante, $\$ 137$. 
a corporation its real estate reverted to the original grantor or his heirs, "1 but whether this is a correct statement of the common law or not, ${ }^{12}$ the modern doctrine is that on the dissolution of a private business corporation, lands held by it are disposed of as part of its assets, and do not revert to the grantor. ${ }^{13}$

On the dissolution, however, of a charitable corporation, not organized for the purposes of private gain or profit, the rule that its real estate reverts to the donor is sometimes applied, ${ }^{14}$ though in such a case the property is said to be still subject to the charitable use-at least where no private donor is entitled to it, - - if this use is contrary to public policy it is subject to a legitimate charitable use conforming as nearly as practicable to that to which the property was originally dedicated. ${ }^{15}$

$\$ 404$. May purchase and hold only lands appropriate to corporate purpose-Presumption that land is so held. - Statutory provisions are general in the United States declaring that private business corporations may acquire, hold and convey such real property as may be necessary for the transaction of their business, and limitations are at the same time often placed upon the power thus conferred. But without regard to such statutes it is a settled general principle that corporations have the right to purchase and hold such real property, and such only, as is necessary or reasonably convenient for carrying out their

"State Bank $\nabla$. The State, 1 Blackf. 267; 12 Am. D. 234; 1 Wilgus Corp. Cas. 891 ; Bingham v. Weiderwax, 1 N. Y. 509.

12 See Gray Perpetuities, $\$ \$ 44,50,51$.

"2 People v. O'Brien, 111 N. Y. 1; 18 N. E. 692 ; 7 Am. St. R. 684 ; 2 L. R. A. 255; 2 Wilgus Corp. Cas. 1426.

${ }^{14}$ See Danville Seminary v. Mott, 1891, 136 Ill. 289 ; 28 N. E. 54, there having been generally in such cases a gift without consideration for a particular purpose, such a reverter resembles that which may occur on the breach of an express condition subsequent. Mott v. Danville Seminary, 129 Ill. 403, 415; 21 N. E. 927.

${ }^{15}$ Mormon Church v. United States, 1890, 136 U. S. 1; 1 Wilgus Corp. Cas. 906. 
legitimate corporate purposes; ${ }^{16}$ when, however, a purchase of lands has been made by a corporation there is, in general, a presumption, in the absence of evidence to the contrary, that the purchase was made for a legitimate purpose, and the contrary must be shown by one alleging it. ${ }^{17}$

$\$ 405$. Where its power is exceeded the state only may complain-Conveyance to corporation in such case voidable, not void.-Moreover, the question whether a corporation which has acquired title to real estate has exceeded its powers in so doing is one that can be raised, generally speaking, only in a proceeding instituted in behalf of the state (or the national government in proper cases), ${ }^{18}$ and even if the corporation has exceeded its powers, a forfeiture of the lands so acquired does not follow as a consequence unless this is made by statute the penalty for the corporation's act. ${ }^{19}$

Therefore, though the law of a state provided that no foreign or domestic corporation maintained for pecuniary profit should purchase or hold real estate in the state except as provided for in the act, and a foreign corporation, without attempting to comply with the provisions of the act relating to foreign corporations, purchased lands in the state and afterward conveyed them, it was held that the conveyance to the corporation was not void, but void-

${ }^{26}$ Case v. Kelly, 1890, 133 U. S. 21; 1 Wilgus Corp. Cas. 1012; South and North Alabama R. Co. v. Highland Ave. R. Co., 1898, 119 Ala. 105 ; 24 So. 114 ; People v. Pullman's Palace Car Co., 175 Ill. 125; 51 N. E. 664 ; 1 Wilgus Corp. Cas. 926.

${ }^{17}$ Stockton Savings Bank v. Staples, 1893, 98 Cal. 189; 32 Pac. 936 ; 1 Wilgus Corp. Cas. 1007; Regents of University v. Detroit Y. M. Soc'y, 12 Mich. 138; Conn. Mut. L. Ins. Co. v. Smith, 1883, 117 Mo. 261; 22 S. W. 623 ; 38 Am. St. R. 656.

${ }^{18}$ National Bank v. Mattbews, 98 U. 8. 621.

19 People v. Stockton Savings \& Loan Soc'y, 1901, 133 Cal. 611; 65 Pac. 1078; 85 Am. St. R. 225; Commonwealth v. N. Y. \&c. R. Co., 1890, 132 Pa. St. 591 ; 19 Atl. 291 ; 1 Wilgus Corp. Cas. 1014 ; Favette Land Co. v. Louisville \&c. R. Co., 1896, 93 Va. 274 ; 24 S. E. 1016. See "Consequences of illegal or ultra vires acquisition of real estate by a corporation," A. M. Alger, 8 Harv. L. R. 15. 
able at the instance of the state, and that title passed to the corporation which then could convey good title not subject to be defeated by one holding from the grantor of the corporation. ${ }^{20}$

Where the corporation has power to acquire title to land at all, its power in a particular instance to hold land already conveyed to it cannot be questioned by the grantor himself, ${ }^{21}$ or by his heirs, ${ }^{22}$ or by his subsequent grantee, ${ }^{23}$ or by his creditors. ${ }^{24}$ And, on the other hand, the corporation is itself estopped, and cannot, for example, defeat the foreclosure of a mortgage executed by it on the ground that it was not authorized by law to acquire title to the land mortgaged..$^{25}$

As the corporation may in such cases convey good title, one that has contracted to purchase lands from it may be compelled by a court of equity to perform his contract, and cannot successfully defend a suit brought by the corporation for specific performance, on the ground that the corporation could not acquire title to the lands; $; 6$ nor may the grantee of a corporation, when it is sought to enforce the conditions of the conveyance under which he has taken title, deny the validity of the title conveyed to him, alleging the incapacity of the corporation to hold the land. ${ }^{27}$

${ }^{\infty}$ Fritts v. Palmer, 132 U. S. 282.

"L Long v. Georgia Pacific R. Co., 1890, 91 Ala. 519; 8 So. 706.

* Shelby v. Chicago \&c. R. Co., 1892, 143 Ill. 385 ; 32 N. E. 438; Mallett v. Simpson, 94 N. C. 37; 55 Am. R. 594. That the heirs of devisor may not complain in such a case, see Farrington v. Putnam, 1897, 90 Maine 405; 37 Atl. 652; 1 Wilgus Corp. Cas. 1029; 38 L. R. A. 339. Contra, that they may complain, see In re McGraw's Estate, 111 N. Y. 66; 19 N. E. 233; 2 L. R. A. 387; 1 Wilgus Corp. Cas. 1034.

${ }^{23}$ Hafner v. St. Louis, 1901, 161 Mo. 34 ; 61 S. W. 632.

24 Gilbert v. Berlin, 1900, 70 N. H. 396; 48 Atl. 279.

๓ Butterworth \& Lowe v. Kritzer Milling Co., 1897, 115 Mich. 1; 72 N. W. 990 . See Hagerstown Mfg. \&c. Co. v. Keedy, 1900, 91 Md. 430; 46 Atl. 965.

3 Banks v. Poitiaux, 3 Rand. 136 ; 15 Am. D. 706.

$n$ Cowell v. Springs Co., 100 U'. S. 55 ; and that a lessee of corporation may not deny its title on such grounds when sued for rent or posses- 
A distinction, however, is made in the application of this general rule, that the state only may complain when a corporation exceeds its power in taking real estate, between contracts or conveyances that are incomplete or executory and those that are completed. While the courts will not generally interfere, except at the instance of the state, to deprive a corporation of land already acquired by it, they will not aid it to acquire land which it has not authority to hold.28

\section{$\$ 406$. Capacity of private corporation to alienate real} property.-A corporation having general capacity to take title to real property has as an incident to its ownership authority and capacity in general to alienate such property. ${ }^{29}$ Moreover, although a corporation may not in a particular instance have the power to retain land which it has acquired, as against the state, yet, until the state complains, it may, as the decisions previously cited indicate, convey good title to its own grantee; and it may grant to another corporation rights to use land for a purpose within the powers of the grantee corporation, though it could not itself use the land for the same purpose..$^{30}$

But whether a corporation has the same power to alienate its real property that an individual has will depend upon the character of the corporation and the nature of its duties to the public, for some corporations are under greater disabilities in this regard than others are..$^{31}$

sion, see Rector v. Hartford Deposit Co., 1901, 190 Ill. 380; 60 N. E. 528; First Eng. Evangelical Church v. Arkle, 1901, 49 W. Va. $92 ; 38$ S. E. 486 .

${ }^{28}$ Case v. Kelly, 133 U. S. 21; 1 Wilgus Corp. Cas. 1012; Pacific R. Co. v. Seely, 45 Mo. 212; 100 Am.D. 369.

${ }^{29}$ The case of Sutton's Hospital, 10 Coke 30a. Some matters of form have already been referred to: execution of conveyance by corporation, ante, $\S 5240,241$; the corporate seal, $\$ 249$; acknowledgment, $\S 294$.

${ }^{80}$ Benton v. Elizabeth, 1898, 61 N. J. L. 411, 693; 39 Atl. 683, 906; 40 Atl. 1132.

s1 See next section. 
A private corporation, having no peculiar public duties to perform, has full power to dispose of its property, unless specially restrained, if such disposition is assented to by its stockholders and does not injuriously affect creditors $;^{82}$ and it has been held that it may dispose of its entire property by direction of a majority of its stockholders who, in the exercise of a sound discretion, deem it expedient to do so and thus close its business to prevent a loss. ${ }^{83}$

But a distinction as to the power of a majority of the stockholders to direct an alienation of its property has been made between such cases as these and those where such an alienation would have the effect of putting an end to a corporation which was doing a fairly prosperous business for which it was organized, and which it might have continued but for the alienation of its property. It has been held that under such circumstances the transfer will not be sustained as against dissenting stockholders, ${ }^{34}$ and that not only minority stockholders but the state may properly complain of the action of the majority stockholders. ${ }^{85}$

$\S 407$. Capacity of public and quasi-public corporations to alienate real property. - Much of the real property of a municipal corporation is held by it in trust for the public, and the duties imposed by this trust can be properly discharged only when it continues in the man-

${ }^{32}$ Aurora Agricultural \&c. Society v. Paddock, 80 Ill. 263; 1 Wilgus Corp. Cas. 1065; Holmes \&c. Mfg. Co. v. Holmes \&c. Metal Co., 1891, 127 N. Y. 252; 27 N. E. 831; 24 Am. St. R. 448; Spokane v. Amsterdam Sch. Trustees, 1900, 22 Wash. 172; 60 Pac. 141.

${ }^{23}$ Treadwell v. Salisbury Mfg. Co., 7 Gray 393; 66 Am. D. 490; 2 Wilgas Corp. Cas. 1787; Phillips v. Providence Steam Engine Co., 1899, 21 R. I. $302 ; 43$ Atl. $598 ; 45$ L. R. A. 560.

24 Harding $\nabla$. American Glucose Co., 1899, 182 Ill. 551 ; 55 N. E. 577 ; 74 Am. St. R. 189; Forrester v. Boston \& Montana Copper Co., 1898, 21 Mon. 544, 565 ; 55 Pac. 229, 353.

${ }^{25}$ People v. Ballard, 1892, 134 N. Y. 269; 32 N. E. 54 ; 17 L. R. A. 737; 1 Wilgus Corp. Cas. 1066. 
agement and control of such property. It cannot relinquish its management and control by an alienation of such of its lands as the public has an interest in. Therefore, streets and parks which have been dedicated or set apart for public purposes, and property of similar character, may not generally be conveyed by the municipal authorities..$^{38}$

But a municipal corporation may have title to real property which has not been dedicated to a public use, and which is held much as an individual holds his property. As an incident to its ownership of such property the corporation has power to alienate it unless restrained by its charter or a statute. ${ }^{37}$

Quasi-public corporations that have obtained franchises in consideration of the discharge of duties in which the public is interested cannot deprive themselves, without special authority, of such property as is necessary to the proper discharge of these duties. Railroad companies are the most familiar bodies of this class, and the rule has been frequently applied to them when, under various forms of alienation, attempts have been made to transfer all or the chief part of their real property, ${ }^{88}$ though they may convey such of their real property as is not needed for railway purposes. ${ }^{*}$ Among other kinds of quasipublic corporations to which the rule has been applied are plank-road and turnpike companies, gas and electric

* San Francisco v. Itsell, 80 Cal. 57; 22 Pac. 74; Methodist Church v. Hoboken, 33 N. J. L. 13; 97 Am. D. 696; Brooklyn Park Com'rs v. Armstrong, 45 N. Y. 234; Southport v. Stanley, 1899, 125 N. C. 464 ; 34 S. E. 641.

"Ames v. San Diego, 1894, 101 Cal. 390; 35 Pac. 1005; Chicago v. Middlebrooke, 1892, 143 Ill. 265, 269 ; 32 N. E. 457; Fort Wayne v. Lake Shore \&c. R. Co., 1892, 132 Ind. 558; 32 N. E. 215 ; 32 Am. St. R. 277.

${ }^{28}$ Oregon Railway v. Oregonian Railway, 130 U. 8. 1; Memphis \&c. R. Co. v. Grayson, 88 Ala. 572; 7 So. 122 ; 16 Am. St. R. 69; Middlesex R. Co. v. Boston \&c. R. Co., 115 Mass. 347; Coe v. Columbus \&c. R. Co., 10 Ohio St. 372 ; 75 Am. D. 518.

* Branch v. Jesup, 106 U. S. 468, 478; Yatee v. Van De Bogert, $56 \mathrm{~N}$. Y. 526; Walsh v. Barton, 24 Ohio St. 28. 
lighting companies and canal companies and other corporations charged with the performance of public duties. ${ }^{10}$

$\omega$ Snell v. Chicago, 1893, 152 U. 8. 191; Ammant v. New Alezandria Turnpike Co., 13 Serg. \& R. 210; 15 Am. D. 593; Visalia Gas \&c. Co. v. Sims, 1894, 104 Cal. 326 ; 37 Pac. 1042 ; 43 Am. St. R. 105 ; Brunswick Gas Light Co. v. United Gas Co., 1893, 85 Maine 532; 27 Atl. 525 ; 35 Am. St. R. 385. See Central Trans. Co. v. Pullman's Palace Car Co., 139 U. 8. 24. 


\section{CHAPTER XXV.}

\section{CAPACITY OF ALIENS TO PURCHASE AND CONVEY REAL PROPERTY.}

\$408. At common law aliens could acquire title by purchase, not by descent.

409. Nature of the title thus acquired-Office found.
\$410. Alien may convey before office found.

411. Common law as modified by statute.

412. Power of the states to remove disabilities.

\$408. At common law aliens could acquire title by purchase, not by descent.-At common law an alien could acquire a defeasible title to real property by purchase, ${ }^{1}$ but could not inherit from either an alien ancestor or a citizen. ${ }^{2}$

Real property acquired by devise is generally considered as acquired by purchase within this rule, as "purchase" includes devise not only at common law, ${ }^{3}$ but under statutes which relate to the acquisition of real property by aliens."

$\$ 409$. Nature of the title thus acquired-0fice found. -The title to real property thus acquired by an alien was defeasible by the sovereign. The alien could hold the property until "office found"-a proceeding by a public

1 Manuel v. Wulff, 1894, 152 U. S. 505.

${ }^{2}$ Wunderle $\nabla$. Wunderle, 1893, 144 Ill. 40 ; 33 N. E. 195 ; 19 L. R. A. 84 ; Crane v. Reeder, 21 Mich. 24 ; 4 Am. R. 430; Glynn v. Glynn, 1901, 62 Neb. 872; 87 N. W. 1052.

- Fairfax v. Hunter, 7 Cranch. 603; Jones v. Minogue, 29 Ark. 637; Guyer v. Smith, 22 Md. 239; 85 A m. Dec. 650.

' Doehrel v. Hillmer, 1897, 102 Iowa 169; 71 N. W. 204; Stamm $\nabla$. Bostwick, 1890,122 N. Y. 48 ; 25 N. E. 233 ; 9 L. R. A. 597. 
officer upon an inquest by which the fact of alienage was established and made a matter of record. ${ }^{5}$

A conveyance, therefore, to an alien is not void, but voidable merely, and until the state or sovereign power procures an escheat or forfeiture upon proceedings in the nature of office found the alien has complete dominion over the property; ${ }^{6}$ and to divest his estate during his lifetime an office found, or some proceeding equivalent to it, on the part of the state is necessary. ${ }^{7}$

Nor may the alien's title be assailed because of alienage by any person except the state. ${ }^{8}$

\$410. Alien may convey before office found.-Having, therefore, a title subject to be divested by the state alone, the alien may, before office found, convey real property, acquired by him by purchase, to any one capable of taking and holding title; and the title of his grantee, according to the weight of authority, will not thereafter be subject to be defeated on account of the grantor's alienage.'

It has, however, been sometimes said that the grantee of the alien takes a title liable to be defeated by the state; ${ }^{10}$ but as the real reason for the disability of aliens is that it is against public policy to allow those owing no allegiance to the government to own lands within its jurisdiction and protection, it would seem unreasonable and unjust that the state, after refraining from enforcing a forfeiture

\footnotetext{
s Phillips v. Moore, 100 U. S. 208.

- McKinley Creek Mining Co. v. Alaska Mining Co., 1802, 183 U. 8. 563.

'Jackson v. Adams, 7 Wend. 367; Elmondorff v. Carmichael, 3 Litt. 472 ; 14 Am. D. 86.

- Governeur's Heirs v. Robertson, 11 Wheat. 332 ; Justice Mining Co. v. Lee, 1895, 21 Colo. 260; 40 Pac. 444 ; 52 Am. St. R. 216.

- Halstead v. Board Comm'rs, 56 Ind. 363; Goodrich v. Russell, 42 N. Y. 177 ; Oregon Mortgage Co. v. Carstens, 1896, 16 Wash. 165 ; 47 Pac. 421 ; 35 L. R. A. 841 ; Strickley v. Hill, 1900, 22 Utah 257; 62 Pac. 893; 83 Am. St. R. 786.

10 Harley $\nabla$. State, 40 Ala. 689; Scanlan v. Wright, 13 Pick. 523; 25 Am. D. 344 ; Purczell v. Smidt, 21 Iowa 540.
}

32 Brews Con. 
while the land is held by an alien, should have the right to divest the title of one-especially if he be a citizensimply because the land had been conveyed to him by an alien.

When, however, an alien that holds title to land by purchase, dies without having conveyed the land and without having had his title divested in proceedings taken by the state, the state at once becomes entitled thereto, although he may have left those who might have inherited his land had he been a citizen. Nor is any proceeding in the nature of office found necessary to vest title in the state in such a case. ${ }^{11}$

\$ 411. Common law as modified by statute.-The common law principles as to the property rights of aliens are still generally recognized in the United States except in so far as they have been expressly modified by statute.

Both in England and in most of the United States, however, there have been extensive modifications of the common law in this respect, and in some of the states almost all distinctions between citizens and aliens regarding property rights have been removed, ${ }^{12}$ while in about one-half the states special privileges are conferred only upon aliens resident in the state (or in some cases in the United States), non-resident aliens being prohibited in some cases from holding more than a certain amount of land, or from inheriting at all, or from inheriting unless

1 Slater v. Nason, 15 Pick. 345; Crane v. Reeder, 21 Mich. 24; 4 Am. R. 430; Colgan v. McKeon, 24 N. J. L. 566; Sande v. Lynham, 27 Gratt. 291 ; 21 Am. R. 348. See, for the application of this principle, where a statute has enabled alien heirs to inherit under certain circumstances, State v. Stevenson, 1898, 6 Idaho 367; 55 Pac. 886.

22 In the following states the disabilities of aliens are substantially removed, though in some (Maryland, Virginia, West Virginia) their removal is expressly restricted to "alien friends": Alabama, Arkansas, Colorado, Florida, Maine, Maryland, Massachusetts, Michigan, Nevada (except Chinese), New Jersey, North Carolina, North Dakota, Ohio, Oregon, Rhode Island, South Dakota, Tenneseee, Utah, Virginia, West Virginia. 
within a certain time they claim the land, and either become citizens or sell it. ${ }^{13}$

In other states the policy has been to impose by constitution or statute somewhat greater restrictions on the right of aliens to take and hold real property than were imposed by common law. ${ }^{14}$

\$ 412. Power of the states to remove disabilities.-The removal of all an alien's common law disabilities or the addition of other disabilities is a matter within the control of each state, subject to the treaty-making power of the United States, under which the disabilities of aliens may be removed irrespective of the policy of any state; ${ }^{15}$ though, plainly, in the absence of any treaty the power of the state to legislate upon the subject is absolute. ${ }^{16}$

As constitutional provisions regarding land-holding by aliens exist in many states, the legislatures of such states have not complete control of the subject. Yet constitutional provisions in a particular state enlarging the rights of aliens do not of themselves prevent the legislature of that state from still further removing their disabilities. So, for example, where a state constitution gives certain special privileges to "resident aliens," while the legislature may not deprive this class of the privileges thus conferred, it may, nevertheless, extend to other aliens equal

18 No brief abstract of the laws would be of value, and they cannot here be set out at length. Some conditions as to residence appear in those of the following states: California, Connecticut, Delaware, Idaho, Illinois, Iowa, Indiana, Kansas, Kentucky, Minnesota, Mississippi, Montana, Nebraska, New Hampshire, New York, Pennsylvania, Texas, Wisconsin, Wyoming.

"For example: By the constitution of Washington conveyances to an alien, except under certain circumstances, are void; and a lease for forty-nine years to a corporation, the majority of whose stock is beld by aliens, is void. State $\nabla$. Hudson Land Co., 1898, 19 Wash. 85; 52 Pac. 574 ; 40 L. R. A. 430.

16 See ante, $\$ 4$.

16 Blythe v. Hinckley, 1901, 180 U. S. 333; Blythe v. Hinckley, 1900, 127 Cal. 431 ; 59 Pac. 787. 
privileges, unless some other clause of the constitution prohibits such action. ${ }^{17}$

17 Nicrosi v. Phillipi, 1890, 91 Als. 299; 8 80. 561 ; State v. Smith, 70 Cal. 153; 12 Pac. 121; Blythe v. Hinckley, 1900, 127 Cal. 481; 59 Pac. 787; Thompen v. Waters, 25 Mich. 214, 227. 


\section{CHAPTER XXVI. \\ CAPACITY OF CONVICTS TO TAKE AND CONVEY REAL PROPERTY.}

§413. Attainder at common lawStatutory changes in England.
\$ 414. Effect of sentence for crime in this country-Statutes.

\$ 413. Attainder at common law-Statntory changes in England.-At common law among the consequences of attainder for treason or felony was the forfeiture of the lands of the attainted person to the crown as part of the punishment for the crime, the forfeiture being enforced by office found. Moreover, the blood of the attainted person was corrupted so that it was no longer inheritable, and consequently his lands escheated to the lord, as if the tenant had died without heirs, though this escheat was subject to the paramount right of the crown to forfeiture. ${ }^{1}$ There followed also as a consequence of attainder such a destruction or suspension of the rights of the attainted person, that he was accounted in law "civilly dead."

One attainted of treason or felony could, however, both take and alienate lands, subject to the crown's right to enforce a forfeiture. ${ }^{8}$

In England statutory modifications were made in the

${ }^{3}$ Bl. Comm. II, 251, 252, 254 ; IV, 381-387 ; Digby Hist. L. Real Prop. 91, $132,426$.

- Civil death arose in other cases as where one entered a monastery, or abjured the realm as a consequence of claiming sanctuary. Bl. Comm. I, 132; IV, 332.

Shep. Touchstone 232; Doe d. Griffith v. Pritchard, 5 Barn. \& Ad. 765 ; 27 Eng. C. L. 179. 
law of attainder, until in $1870^{4}$ the crown's claim of forfeiture and escheat (except in the rare case of forfeiture following outlawry) was abolished, as well as corruption of blood. Under the act (somewhat similar to some American statutes) an administrator may be appointed by the crown to have the custody and management of the convict's property with power to alienate it, or a curator may be appointed whose duties are merely to preserve the property. The convict is not deprived of his lands, but if adjudged guilty of treason or felony and sentenced either to death or penal servitude, he is rendered legally incapable of alienating them during the continuance of the sentence. Upon the completion of his sentence, or his pardon or death, such of his property as has not been disposed of reverts to him or his representatives.

\$414. Lffect of sentence for crime in this conntryStatutes.-In this country forfeiture of estates in fee and corruption of blood are generally impossible under our constitutions, nor is civil death generally recognized. Therefore as a rule, the disabilities consequent upon conviction and sentence for crime are such only as are im. posed by statute. ${ }^{5}$

Legislation, however, in several states has placed one sentenced to imprisonment under some disability in regard to taking and transferring property, though the extent of the disabilities varies among the states having statutes on the subject.

For example, in Rhode Island no person sentenced to

- By the Forfeiture Act, 33 \& 34 Vict., c. 23.

'Donnelly's Estate, 1899, 125 Cal. 417; 58 Pac. 61 ; 73 Am. St. R. 62; Willingham v. King, 23 Fla. 478; 2 So. 851; Smith v. Becker, 1901, 62 Kan. 541; 64 Pac. 70; 53 L. R. A. 141; Rankin's Heirs v. Rankin's Exrs., 6 T. B. Mon. (Ky.) 531 ; 17 Am. Dec. 161; Avery v. Everett, 1881,110 N. Y. 317 ; 18 N. E. 148; 6 Am. St. R. 368; 1 L. R. A. 264: Commonwealth v. Clemmer, 1899, 190 Pa. St. 202, 210; 42 Atl. 6i5; Davis v. Laning, 1892, 85 Texas 39; 19 S. W. 846; 34 Am. St. R. 784; 18 L. R. A. 82 ; Baltimore v. Chester, 53 Vt. 315 ; 38 Am. R. 677. 
imprisonment in the state prison may, during his imprisonment, make any will or conveyance of his property $;^{6}$ and while this does not deprive him of his property nor of his capacity to enforce his rights in it, ${ }^{7}$ he is unable to convey it, and there may be an administrator appointed to take charge of it.

While there appear to be few American statutes directly prohibiting, as does this statute, any alienation by the convict, those of Kansas, Missouri, Oregon and South Dakota may have that effect in providing that a sentence of imprisonment for any time less than for life suspends all the civil rights of the person so sentenced,${ }^{8}$ for it has been held that such a statute deprives the convict of the power of alienating or incumbering his property during the term of his imprisonment, and that a mortgage given by him during this period is void. ${ }^{9}$ This would seem to be the effect of similar statutory provisions in California, Idaho, Montana, North Dakota and Utah ${ }^{10}$ were it not for provisos in those states that the statutes shall not be construed to render the convict incompetent to convey his property.

In most of the states already mentioned and in some others-as Maine, Minnesota and New York ${ }^{11}$-one sentenced to imprisonment for life is deemed civilly dead, and such a statute has been held to prevent the convict from inheriting. ${ }^{12}$ Under some statutes his estate may be "administered and disposed of" as if he were naturally

- R. I. Gen. L. 1896, ch. $285, \S 53$.

' Kenyon v. Saunders, 1894, 18 R. I. 590; 30 Atl. 470; 26 L. R. A. 232.

- Kansas Gen. Stat. 1901, §2301 ; Missouri R. 8. 1899, § 2382 ; Oregon, Hill's Stat., § 2021 ; S. Dak. Ann. Stat. 1901, §8237.

'Williams v. Shackleford, 97 Mo. 322; 11 8. W. 222; but see La Chapelle v. Burpee, 69 Hun 436.

${ }^{20}$ California Penal Co., $\$ \$ 673,674$; Idaho Penal Co. 1901, $\$$ 5124, 5125; Montana Penal Co., \$§ 1239, 1240; North Dakota R. Co. 1899, $\$ \S 7706,7707$; Utah R. S. 1898, $\$ 4501$.

11 Maine R. S. 1883, ch. 64, §18; Minnesota Stat. 1894, §6836; New York Penal Co., \$ 708.

12 Donnelly's Estate, 1899, 125 Cal. 417; 58 Pac. 61 ; 73 Am. St. R. 62. 
dead, and though it has been held that such a provision does not necessarily produce the effects of natural death in regard to the descent of his property, ${ }^{13}$ there appear to have been no decisions as to the effect of slightly different statutes providing that upon imprisonment for life the convict's property shall be "divided among his heirs at law and distributed as though he were dead." 14

In a few states-for example, Kentucky, Missouri, New York and Virginia ${ }^{15}$ - there may be appointed a committee, curator or trustee of the convict's estate, and upon such appointment being made the convict's power to alienate any of his property would seem to be suspended during the continuance of the curatorship on principles analogous to those applied when a guardian has been appointed to care for the property of one of unsound mind. ${ }^{16}$

13 Smith v. Becker, 1901, 62 Kan. 541; 64 Pac. 70; 53 L. R. A. 141. See Avery v. Everett, 110 N. Y. 317; 18 N. E. 148; 6 Am. St. R. 368; 1 L. R. A. 264.

14 R. I. Gen. L. 1896, ch. 285, §56. See Maine R. S. 1883, ch. 64, 18.

${ }^{15}$ Kentucky Stat. 1903, $\$ 1383-1385$; Missouri R. 8. 1899, 8930; New York L. 1889, ch. 401, Birdseye's 3d ed. Gen. L., II, p. 1814 ; Virginis Code, $\$$ 4115-4121.

${ }^{26}$ Soo ante, $\$ \$ 392,383$. 


\section{CHAPTER XXVII.}

\section{THE DISABILITY OF A GRANTOR ARISING FROM ADVERSE POSSESSION.}

$\S 415$. Disability of disseisee at common law-Statinte 32 Henry VIII.

416. Statutes in this country adopting the principles of this statute.

417. Disseisee's conveyance not void for all purposes.
$\$$ 418. The principle recognized in some states without legislation.

419. To what transfers the rule does not apply.

420. Character of possession rendering the transfer void.

421. The old rule generally abrogated in the United States.

\$415. Disability of disseisee at common law-Statute 32 Henry VIII.-At common law a right of entry was not assignable, though it might be released to the person in actual seisin or possession of the freehold; ${ }^{1}$ and, as by the earlier common law such importance was attached to the possession of land and to the real, actual transfer of this possession when a freehold was conveyed, ${ }^{2}$ there could be no conveyance of land held in adverse possession; therefore in this sense it may be said that it was a rule of the common law that the conveyance of land in the adverse possession of another was void. ${ }^{3}$

After the statute of uses and when it was possible to transfer the legal title to land without this actual change

${ }^{1}$ Co. Litt. 214a; Digby Hist. L. Real Prop. 149n; 2 Poll. \& Mait. Hist. Eng. L. 91.

22 Poll. \& Mait. Hist. Eng. L. 42, 81, 84.

'Bernstein v. Humes, 60 Ala. 528; 31 Am. R. 52 ; Brackner's Lessee v. Lawrence, 1 Doug. (Mich.) 19, 38.

(1535) 27 Hen. VIII, c. 10. 
of possession there was enacted a statute ${ }^{5}$ which prohibited the buying or selling of any pretended rights or titles to any lands, tenements or hereditaments, unless the seller or his ancester, or those by whom he claimed, had been in possession of the same, or of the reversion or remainder thereof, or had taken the rents or profits thereof, for a year next before the sale; this statute also confirmed all previous statutes against champerty and maintenance, but permitted the purchase of a pretended title by one in the lawful possession of the rents and profits of lands. The object of the statute was to prevent the transfer of titles for the purpose of maintaining or assisting a suit and to leave to the land-claimant the conduct of his own suit unaided by the means of others who might expect to share in the property recovered. ${ }^{6}$

\$416. Statutes in this country adopting the principles of this statute.-The statute of Henry VIII has been followed more or less closely in statutes in some of the United States; the chief reason given for its adoption being that, in accordance with a wise policy, it prevents the purchase of doubtful claims by strungers to them for the purpose of litigation. ${ }^{7}$

In several states, therefore, conveyances of lands which at the time of the conveyance are in the adverse possession of another are declared by statute to be void; ${ }^{8}$ and in some states the buying or selling of such pietended titles is declared to be a misdemeanor. ${ }^{9}$

${ }^{5}$ The bill of bracery and buying of titles, usually called "The Pretended Title Act," 32 Hen. VIII, c. 9 (1540).

"Baker $\nabla$. Whiting, 3 Sumn. 475.

${ }^{7}$ Russell v. Doyle, 84 Ky. 386, 389; 1 S. W. 604; McMahan v. Bowe, 114 Mass. 140 ; 19 Am. R. 321.

${ }^{8}$ Connecticut Gen. Stat. 1902, §4042; Kentucky Stat. 1903, §210; New York Real Prop. L., § 225; N. Y. R. S. Birdseye's 3d ed. III, p. 3057; Tennessee Code 1896, $\$ \S 3171,3172,3175$.

${ }^{9}$ New York Penal Co., $\$ 130 ;$ N. Y. R. S. Birdseye's 3d ed. I, p. 407; North Dakota Co. 1899. $\$ 7002$; a similar provision in South Dakota Penal Code, $\$ 7648$, though found in the statutes of 1901 , appears to 
$\S 417$ GRANTOR'S DISABILITY-ADVERSE POSSESSION. 507

\$ 417. Disseisee's conveyance not void for all purposes.-Nevertheless a conveyance made under such circumstances where these statutes exist (as also in those states where the same doctrine is recognized without legislation) are not generally regarded as absolutely void for all purposes.

As against the party in possession, holding the land mentioned in the conveyance adversely to the grantor, the conveyance passes no title and is thus often said to be void,,$^{10}$ or voidable ${ }^{11}$ as to him, and it gives the grantee, generally, no right to maintain an action in his own name against the adverse claimant.

Yet such a conveyance is usually regarded as valid between the parties to it and as transferring to the grantee the right to maintain an action of ejectment against the adverse possessor in the name of his grantor. ${ }^{12}$

The grantee in such cases uses his grantor's title, which still remains in the grantor in spite of his deed, for the purpose of getting possession of the land; and, therefore, if the grantor, before the grantee brings an action against the adverse possessor, releases his legal title to the adverse possessor, the latter has then the legal title and possession under it, and neither the grantor nor the grantee in the former deed can recover the land..$^{13}$

$\$ 418$. The principle recognized in some states without legislation.-In a few other states the principle of the statute of Henry VIII has been recently recognized irrespective of express statutes adopting it.

have been repealed in 1899, see Civ. Co., $\$ 4492$; Campbell v. Equitable Loan \&c. Co., 1903 (S. Dak.), 94 N. W. 401.

${ }^{10}$ Mead v. Fitzpatrick, 1902, 74 Conn. 521 ; 51 Atl. 515 ; Green v. Cumberland \&c. Co., 1903 (Tenn.), 72 S. W. 459; Farmerg' Bank's Assignee v. Pryse, 1903 (Ky.), 76 S. W. 358.

"11 Fort Jefferson Improvement Co. $\nabla$. Dupoyster, 1899, 108 Ky. 792 ; 51 S. W. $810 ; 48$ L. R. A. 537.

12 Farnum v. Peterson, 111 Mass. 148; Galbraith v. Paine, 1903 (N. Dak.), 96 N. W. 258; Key v. Snow, 90 Tenn. 663; 18 S. W. 251. But see contra Crowley v. Vaughan, 11 Bush (Ky.), 517.

13 Dever v. Hagerty, 1902, 169 N. Y. 481; 62 N. E. 586. 
In Alabama, for example, a conveyance of lands which at the time of the execution of the conveyance are in the adverse possession of a third person, while good as between the parties to it, is void for champerty as to the adverse possessor; ${ }^{14}$ and in Florida the same doctrine prevails. ${ }^{15}$

In Indiana, at an early period, the general rule that a conveyance of land in the adverse possession of another is void as against the adverse possessor, was adopted as part of the common law ; ${ }^{16}$ but the grantee could maintain an action in the name of his grantor; for, as the deed was valid between the parties to it, the grantor could not deny the use of his name for this purpose, and if the land was recovered by the grantee in the name of the grantor, the recovery inured to the benefit of the grantee. ${ }^{17}$

As the present statute, ${ }^{18}$ while not directly authorizing the conveyance of lands held adversely to the grantor (as do statutes in half the states), provides that any person having the right to recover the possession of real estate, or to quiet the title thereto in the name of any other person, shall have a right to recover possession or quiet title in his own name, the older doctrine seems to be practically abolished. ${ }^{19}$

\$ 419. To what transfers the rule does not apply.The rule that conveyances of lands by one disseised are invalid as against the disseisor, does not apply to certain conveyances, even though the lands are adversely pos-

"Berry v. Tennessee \&c. R. Co., 1902, 134 Ala. 618; 33 So. 8; Pear8on v. Adams, 1901, 129 Ala. 157 ; 29 So. 977 ; Chevalier v. Carter, 1899, 124 Ala. 520; 26 So. 901.

is Reyes v. Middleton, 1895, 36 Fla. 99 ; 17 So. 937 ; 29 L. R. A. 66.

${ }^{16}$ Patterson $\nabla$. Nixon, 79 Ind. 251, 255.

${ }^{17}$ Steeple v. Downing, 60 Ind. 478, 484.

${ }^{18}$ Burns' R. S. 1901, \$ 1086.

${ }^{10}$ See Peck v. Sims, 120 Ind. 345 ; 22 N. E. 313; Chapman v. Jonee, 1897, 149 Ind. 434 ; 47 N. E. 1065; Winstandley v. Stipp, 1892, 132 Ind. 548 ; 32 N. E. 302. 
sessed when the conveyances are executed. For instance, such a conveyance is not invalid if made in pursuance of a valid contract entered into while the land was not held adversely. ${ }^{20}$ Nor is the doctrine that the conveyance of a disseisee is void, applicable to a patent or deed of land from the state, because the state cannot be disseised; ;1 nor does the rule apply to judicial sales. ${ }^{22}$ It has also been held that one in possession under a conveyance from a minor does not hold adversely within the meaning of these statutes so that his possession will render void a conveyance by the former infant to another after his majority in disaffirmance of his former voidable conveyance. ${ }^{23} \mathrm{~A}$ release made to one in possession by the disseisee seems to have been always allowable. ${ }^{24}$

\$420. Character of possession rendering the transfer void.-While the possession of a third person which will render void a conveyance of the land must be adverse to the grantor, and such as, if continued long enough, will give the possessor title, ${ }^{25}$ it need not generally be under color of title or claim of some specific title, unless the statute provides that the possession shall be by one "claiming under a title adverse to that of the grantor," in which case it has been construed to require a claim under some specific title $;^{26}$ not every invasion, however, of a grantor's rights as landowner, even though of a character which if continued would ultimately ripen into a per-

${ }^{\infty}$ Harral v. Leverty, 50 Conn. 46; 47 Am. R. 608; Greer v. Winteremith, 85 Ky. 516; 4 S. W. 232; 7 Am. St. R. 613.

21 Candee v. Hayward, 37 N. Y. 653; Cassedy v. Jackson, 45 Miss. $397,407$.

22 Ward v. Edge, 1897, $100 \mathrm{Ky} .757$; 39 S. W. 440; Coleman v. Manhattan Beach Co., 94 N. Y. 229.

Moore v. Baker, 1892, 92 Ky. 518; 18 8. W. 363.

* Adams v. Buford, 6 Dana 406, 413.

* Merwin v. Morris, 1899, 71 Conn. 555; 42 Atl. 855; Murray v. Hoyle, 1890, 92 Ala. 559; 9 So. 368.

${ }^{26}$ A rents $\nabla$. Long Island R. Co., 1898, 156 N. Y. 1; 50 N. E. 422; Kreuger v. Schultz, 1896, 6 N. Dak. 310; 70 N. W. 269. 
petual easement, will amount to such adverse possession, or ouster of possession, as will render the grantor's conveyance invalid; so, for example, the possession and occupancy of a structure projecting over, but not touching, the grantor's land is not such ouster. ${ }^{27}$

While the possession of the adverse holder must generally be actual as distinguished from construction, ${ }^{28}$ it is enough to make his possession adverse within the policy of these statutes that he is in actual possession of a part of the land claiming the whole tract under an assurance of title in which the boundaries of the whole are specified and defined. ${ }^{29}$

$\$ 421$. The old rule generally abrogated in the United States.-In a few states the principle of the statute of Henry VIII has never been recognized by either the courts or legislatures. The reasons for the statute have been considered inapplicable to this country, and it has been deemed the better policy to render the transfer of land as free as possible and to disregard the question as to whether the grantor is in or out of possession..$^{30}$

And in accordance with the same policy statutes have been enacted in more than half the states, and in many where until recently the statute of Henry VIII had been recognized, abrogating entirely the old doctrine. These statutes either declare that no grant or conveyance of lands shall be void for the reason that the lands are in the adverse possession of another than the grantor when the conveyance is executed, or they provide that one may convey his interest in lands in the adverse possession of

${ }^{27}$ Norwalk Heating \&c. Co. v. Vernam, 1903, 75 Conn. 662 ; 55 Atl. 168.

${ }^{2}$ Dawley $\nabla$. Brown, 79 N. Y. 390.

${ }^{20}$ Green v. Cumberland \&c. Co., 1903 (Tenn.); 72 8. W. 459.

${ }^{30}$ Hall's Lessee v. Ashby, 9 Ohio 96; 34 Am. D. 424; Borland's Lee see v. Marshall, 2 Ohio St. 308, 314; Stoever v. Whitman, 6 Binn. (Pa.) 416, 420; Overfleld v. Christie, 7 Serg. \& Rawle (Pa.) 173; Campbell v. Everts, 47 Texas 102. 
$\S 421$ GRANTOR's DISABILITY-ADVERSE POSSESSION. 511

another with the same effect as if they were not so held. ${ }^{31}$

The abolition, however, of the rule making void conveyances of land in adverse possession will not render valid contracts and conveyances which are essentially champertous in their nature and thus void. ${ }^{82}$

" Ark. Dig. Stat. 1894, §701; Cal. Civ. Co., § 1047; Colo. Mill's Co., $\S 431$; Ga. Code 1895, §3605; Idaho Civ. Co. 1901, §2393; Ill. R. S., ch. 30, § 4 ; Iowa Ann. Co. 1897, § 2916; Kan. Gen. Stat. 1901, §1208; Maine R. S. 1883, ch. 73, §1; Mass. Rev. L. 1902, ch. 127, §6; Mich. C. L. 1897, §8961; Minn. Gen. Stat. 1894, §4165; Miss. Co. 1892, § 2433; Mo. R. 8. 1899, §905; Montana Co. 1895, § 1443; Neb. Com. Stat. 1901, $\S 4123$; Nev. Com. L. 1900, §2673; Ore. Hill's L. 1892, §3009; R. I. Gen. L. 1896, ch. 201, § 23; So. Dak. Civ. Co. 1901, §4492 (though, see Penal Co., §7648); Utah R. S. 1898, §1980; Vermont Stat. 1894, §2240; Wis. Stat. 1898, §2205; Wyoming R. S. 1899, §2735.

" Johnson v. Hilton, 1895, 96 Ga. 577; 23 S. E. 841; Illinois Land \&c. Co. v. Speyer, 1891, 138 Ill. 137; 27 N. E. 931; Burton v. Perry, 1893, 146 Ill. 71; 84 N. E. 60; Stewart v. Welch, 41 Ohio St. 483. 


\section{. CHAPTER XXVIII.}

the examination OF the title to REAL PROPERTY.

\$422. General characteristics of $\$ 427$. Defects not shown by recthe recording system.

423. Imperfections in title.

424. Defects shown by original instruments in the chain of title, and by records of them.

425. Defects shown by other records-The abetract of title.

426. Defects not shown by recorde-Forged inetruments. ords-Identity of person -Delivery-In I an cyHomestead.

428. Defects not shown by records-Questions on death of landowner.

429. Purchaser's risk in relying on the records alone.

490. Possession, not shown by records, always easily investigated.

431. Possession by grantor, after conveyance, as notice.

$\$ 422$. General characteristics of the recording system.-Certain prominent characteristics of our prevailing system of recording conveyances will be noticed with the purpose of considering the principal matters to be regarded in the investigation of title to real property, and with the further purpose of introducing in the following chapter a brief consideration of that means of reform popularly known as the "Torrens System."

The chief characteristic of our system of conveyancing is that, generally speaking, title to land passes on the delivery by the grantor to the grantee of a deed of convey. ance properly signed (and, in many states, sealed, etc.) by the grantor.

Registration of instruments affecting the title to real property is provided for in each state and this registration 
$\$ 422$ EXamination OF title to ReAL PROPERTy. 513

is held to impart notice of the contents of instruments lawfully recorded.

In order, however, to be recorded, each instrument must be properly executed by the grantor and then properly authenticated by some public officer. It is then recorded by another public officer in books provided at public expense. It is the duty of these public recording officers to record only those instruments that are executed and authenticated with all the formalities prescribed by law. As a means of securing prompt recording by the grantee, statutes provide in general that his unrecorded conveyance, while good as between him and his grantor, is invalid as against any subsequent deed which a bona fide grantee may receive from the grantor; in some states (about one-third of them) this preference to the subsequent conveyance over the prior unrecorded one is given only when the later is first recorded.

This general system is distinctively American. At common law there was no obligation to record conveyances, though it is probable that the statute of enrolments (1535) which related to deeds of bargain and sale, ${ }^{1}$ suggested to the colonists the idea of recording deeds. Statutes of Queen Anne's time ${ }^{2}$ provided for record in certain English counties; but for half a century before this in several American colonies laws had provided for such records.

The American design was to place a record of titles to real estate in a public office within the reach of anyone, on which record anyone might rely in buying the land or accepting an incumbrance, and the theory of this system is that the records will show the condition of the title: which is generally true in practice, but with important exceptions which the lawyer must have in mind.

It is thus the policy of the law that, so far as title de-

'Ante, \$12; 27 Hen. VIII, c. 16.

' (1703) 2 \& 3 Anne, c. 4; (1708) 7 Anne, c. 20.

33-BRETs. CoN. 
pends on the fact of alienation from one person to another, it shall be evidenced by some solemn written instrument, and that there shall be some evidence preserved of most of these written instruments by record, and, further, that the record of an instrument entitled to be recorded shall be notice to all who may deal with the property.

There may, however, be a good title to land in one who has never had written evidence of his title; and this either by descent or by a voluntary, though parol, transfer, with lapse of time, ${ }^{8}$ or by adverse possession for a sufficient time. And, on the other hand, there may be what seems to be evidence, from writings and records, of good title in one who really has no title.

$\$ 423$. Imperfections in title.-Lord Hardwicke once said:" "It is impossible in the nature of things there should be a mathematical certainty of a good title," and while this is true, it is yet possible to establish, with reasonable certainty, the true condition of every title, although in many instances it costs much pains to do so.

Imperfections in the title may proceed from various causes. Thus particular defects may arise:

1. From matters apparent on the face of the instruments themselves through which title is claimed.

2. From matters appearing in the record of these instruments, and in the record of other instruments affecting the title.

3. From matters appearing neither on the face of the instruments under which title is claimed, nor in the records.

Many of the defects that will appear from an inspection of the original instruments through which title is claimed will be shown also from the records of those instruments, provided the records are true copies of the originals. But there are matters that may affect the title

- See ante, $\$ 17$.

- In Lyddal v. Weston, 2 Atk. 20 (1739). 
$\S 424$ examination of title to Real PROPerty. 515

which can be discovered only by an examination of the original instruments themselves, as, for example, a fraudulent alteration by interlineation or erasure. It is probably true that in most cases persons intending to purchase land rely rather on the records (or copies, or abstracts of them) than on the original instruments, but it is not entirely prudent to do so, and wherever it is possible all original instruments in the chain of a vendor's title should be read by the proposing purchaser.

$\S 424$. Defects shown by original instruments in the chain of title, and by records of them.-Among defects shown by the records, if they are true copies, as well as by the originals, may be noted the following, most of which have been discussed in the preceding pages. There may be insufficient operative words, or words of conveyance; ${ }^{5}$ or an insufficient description which may be so defective as to make the conveyance void, ${ }^{6}$ or so defective as to make the record ineffectual as notice. ${ }^{7}$ The title may be incomplete or incumbered by reason of covenants running with the land, or restrictions of various kinds by way of condition, or covenant, or reservation appearing in instruments directly in the chain of title; ${ }^{8}$ there may be recitals affecting the title, or there may be insufficient recitals when full recitals are required by statute, ${ }^{9}$ and there may be insufficient signing, sealing, attestation or acknowledgment.

These defects will appear in the records as well as in the originals, if the records are correct copies of the originals, but in order that they may be seen to be defects one must have some knowledge of forms and the substantive law of real property in conveyancing. The examination of rec-

- Ante, $\$ 71$.

- Ante, $\$ \$ 76,77,80$.

'Ante, \$74.

- Ante, \$\$227-232.

- Ante, $\$ \$ 40,50$. 
ords, whether in the original or abstracted, by those really unfamiliar with the law of the subject, is practically of little value, though it is the method often resorted to.

$\$ 425$. Defects shown by other records-The abstract of title.-A title may be defective because of what appears in the public records relating to the land concerned, but not necessarily involved in a consideration of the instruments through which the present owner claims. The "public records" which may contain matter affecting the title are not merely the registers in which deeds and mortgages are recorded, but books and documents of various sorts which are open to the inspection of the public, such as court records, original papers in suits, and records kept in other books than those which contain the copies of deeds and mortgages.

When one intends to buy land or accept a mortgage as security, he practically seldom sees many of the-original documents relating to the land, nor does he even examine the records, by himself or his attorney. He usually examines, or has examined for him, an abstract of title. The American abstract of title is generally an examination of the title to a particular piece of land; the English abstract of title is an abstract of the title of a particular person to certain land. The American abstract of title is an abbreviated history of a particular piece of land, and states usually at its beginning that it is an "abstract of title to lot No. - ." As its name indicates, it is an abstract, a summary or condensed history of the title, containing statements of the material parts of all conveyances of every kind which affect the land, as shown by the records. When it is considered that there is such great variety of matters of record that may affect land titles, it is clear that it requires a person of special skill and training to properly prepare an abstract. He must determine not only what instruments are to be summarized, but what 
parts of them are to be noted. An abstract should show not merely patents, deeds and mortgages, but wills; judicial proceedings relating to the land,-for example, partition suits, proceedings to quiet title, etc.; notice of liens, such as taxes, assessments, lis pendens, mechanics' liens, execution sales, etc. "An abstract in a legal sense is a summary or an epitome of the facts relied on as evidence of title * * and must contain a note of all conveyances, transfers or other facts relied on as evidences of the title, together with all such facts, appearing of record, as may impair it." 10 Abstracts are not generally prepared by practicing lawyers, but by men who make a specialty of that line of work, and who are in a greater or less degree fitted for it; they are required in some states to give bonds, and, generally, for a failure to use due care they are liable in damages to the person em. ploying them, directly or through an agent ${ }^{11}$, and by some decisions to any one else who relies in good faith on the correctness of the abstract. ${ }^{12}$

\$ 426. Defects not shown by records-Forged instraments.-Assuming that the abstract is skillfully prepared, it is important to remember that, inasmuch as it is taken from the records, it cannot show more than the records show, and that there are many things which may affect the legal title that the records cannot show. A proposing purchaser is not bound to inquire as to whether any equities may possibly exist in favor of third persons, unless there are facts known to him that should lead him to inquire as to rights of third persons : if this were not so there would be practically no limit to his inquiries outside

${ }^{10}$ Heinsen v. Lamb, 117 Ill. 549, 556; 7 N. E. 75.

"Young v. Lohr, 1902, 118 Iowa 624; 92 N. W. 684; Kenyon v. Charlevoix Imp. Co. (Mich.), 1903, 97 N. W. 407; 10 Det. Leg. News 713.

"See Brown v. Sims, 1899, 22 Ind. App. 317; 53 N. E. 779; 72 Am. St. R. 308, note; Gate City Abst. Co. v. Post, 1898, 55 Neb. 742 ; 76 N. W. 471 ; Dickle v. Abst. Co., 1890, 89 Tenn. 431; 14 S. W. 896; 24 Am. St. R. 616. 
the records. But this rule applies only where the vendor has the legal title to the land, while others may hold equities therein. Where the vendor has no complete legal title to convey, the rule caveat emptor applies.

For example, the record affords no means of verifying the genuineness of the signature of a grantor. If an instrument purporting to affect the title to land is forged it cannot affect the title. Therefore the registration of a forged instrument has no effect on the title, and even an innocent purchaser takes the risk of forgery. ${ }^{\text {1s }}$ This principle applies not merely, of course, to deeds, but to other instruments which may be recorded as affecting title, as, for example, a mortgage, ${ }^{14}$ and so where a release of a mortgage is a forgery, an innocent purchaser buys subject to the mortgage. ${ }^{15}$ Nor can the genuineness of the signature of the official taking the grantor's acknowledgment be verified from the records.

It is to be remembered also that forgery may be accomplished in other ways than by signing some other person's name as grantor. The grantee's name may be changed by a slight erasure, so that some other person's name will appear as grantee, and the latter by then giving a deed or a mortgage, though he signs his own name, cannot convey a good title, for he is not the grantee; and the fact that such a deed is recorded will not help the innocent purchaser. ${ }^{16}$

Or the alteration of a date, by giving an apparent prior-

${ }^{13}$ Austin v. Dean, 40 Mich. 386 ; Haight v. Vallet, 1891, 89 Cal. 245; 26 Pac. 897 ; 23 Am. St. R. 465 ; Gray v. Jones, 14 Fed. 83.

14 Lee v. Kellogg, 1896, 108 Mich. 535; 66 N. W. 380.

${ }^{15} \mathrm{D}^{\prime}$ Wolf $\nabla$. Hayden, 24 Ill. 525.

${ }^{16}$ Pry v. Pry, 109 Ill. 466. In this case the deed was made to John W. Pry and Hamilton Pry, and placed in the hands of John Pry, a relative, for them, they being infants. The depositary changed the deed by erasing "Hamilton Pry" and the initial "W," and recorded the deed, which then appeared to convey title to him, and afterward conveyed parts of this land to innocent purchasers. On a bill filed by John W. Pry, it was held that all these deeds should be set aside. 
ity to a deed over a judgment and making the record title seem clear, may cause loss to an innocent purchaser. ${ }^{17}$

Even though the grantor's signature and that of the acknowledging officer both be genuine, they yet may be considered in law as forgeries, because obtained by a trick, and an innocent purchaser or mortgagee may in such a case be the loser by relying on the records alone. This is forciby illustrated by a case ${ }^{18}$ where one obtained the signature of his mother-in-law to a deed which she did not intend to execute or deliver, and also by a trick obtained the notary's signature to the certificate of acknowledgment, and then mortgaged the land for $\$ 5,000$ to one person and for $\$ 1,300$ to another. Both of these mortgagees relied on the record, but it was held that their mortgages should be canceled, as well, of course, as the original recorded deed-as in effect it was a forgery, though the signature was genuine.

In a similar case ${ }^{19}$ a lawyer obtained a deed from an old man who supposed he was signing the duplicate of a lease he had just executed. The deed thus obtained was put on record, and a mortgage given on the land to secure $\$ 6,000$. The mortgagee examined the record, and found the title clear. On a bill filed by the owner to set aside the deed and the mortgage, it was held that the deed was a forgery, and the deed and mortgage must be canceled..$^{20}$

${ }^{17}$ Reck v. Clapp, $98 \mathrm{~Pa}$. St. 581.

2 Marden v. Dorthy, 1899, 160 N. Y. 39; 54 N. E. 726 ; 46 L. R. A. 694.

20 McGinn v. Tobey, 62 Mich. 252; 28 N. W. 818; 4 Am. St. R. 848.

${ }^{20}$ In Marden $\nabla$. Dorthy, $160 \mathrm{~N}$. Y., at p. 50, it is noticed that such cases as these are to be distinguished, as far as innocent purchasers are concerned, from those where a deed is obtained by fraud: a fraudulent grantee may create a valid incumbrance on the property in favor of innocent parties, since as to such parties he has the title and has been clothed with power to deal with the property: the deed obtained by fraud is voidable, but until set aside it transfers the title, but a forged deed is no deed and conveys no title. See Cornell v. Maltby, 1901, 165 N. Y. 657, reported as Carr v. Maltby, 59 N. E. 291. 
\$427. Defects not shown by records-Identity of person-Delivery-Infancy-Homestead.-Theidentity of the grantor with the owner of the land is not shown by the records, and if the signature of the person taking the acknowledgment be genuine, there may be a question whether he was at the time the official he is represented to be, and the records cannot show this. For example, in some states no officer of a bank can be a notary public, and his acceptance of any such office vacates his appointment as notary; and in some, no person holding any official relation to any bank, banker or broker can act as notary in any matter in which the bank, banker or broker is interested. ${ }^{21}$

The records do not conclusively show delivery, though it should be said that where there has been a record standing for some years it is practically sufficient evidence of delivery to warrant one ordinarily in relying upon it. ${ }^{23}$

Infancy or unsoundness of mind are not disclosed by the records, and the effect of conveyances by persons so incapacitated has been discussed. 220

While in some states there will be some record showing whether the land conveyed is or is not a "homestead," this is by no means universally true, and there is often nothing on the record to show the character of the land in this respect; and yet conveyances of a homestead in which the special formalities required are neglected, are often void..$^{23}$

$\$ 428$. Defects not shown by records-Questions on death of landowner.-When a landowner dies, his land passes either by the law of descent or by his will. Subsequent purchasers from his devisees or his heirs claim

"See ante, $\$ 287$, n. 92 . As to the effect of the offeer's undisclosed interest see $\$ \S 285-288$.

See ante, $\$ 304$.

2m Chapters XX and XXI.

Ante, \$\$ 392-395. 
$\S 429$ EXAMination OF title to ReAL PROPERTy. 521

title to the land through his will or through descent. Suppose, for example, that one of the links in a chain of title is a devise, and a purchaser has taken his title from the devisee. The will containing the devise is of record, in one office or another, and the devisee may be identified. It would seem at first sight that the devisee has a valid title, and may give one to his grantee, and that the chain of title is complete and may be relied on. But facts, shown by no records, may render the title imperfect. For example, ${ }^{24}$ there was a will executed in 1849 , by which the testator devised his real estate to his widow. Five years afterwards he died (1854), and his will was duly probated. Sixteen years after his death (1870) his widow, as devisee under the duly probated will, conveyed the land to the present holder. Between the time of making the will and the testator's death (1849-1854) a child was born to the testator. It was held that the birth of a child to the testator before his death, but after the execution of his will, operated as a revocation of the will. The child now (twenty-three years after the testator's death) claims the title as heir, and regains the land from the purchaser from the widow, who was the original devisee. ${ }^{25}$

The question of implied revocation of a will by such a change in the domestic circumstances of a testator, as well as the effect of the omission of a child's name from a will, is generally regulated by statute, and these statutes vary greatly. By marriage and the birth of a child after the making of a will, the will is by many statutes either partially or wholly revoked, ${ }^{26}$ so that a person

24 Fallon v. Chidester, 46 Iowa 588.

${ }^{25}$ See also Salem Nat'l Bank v. White, 1895, 159 Ill. 136; 42 N. E. 312, explained in Hawhe v. Chicago \&c. R. Co., 1897, 165 Ill. 561; 46 N. E. 240.

${ }^{26}$ In some states adoption will produce this effect: Hilpire v. Claude, 1899, 109 Iowa 159; 80 N. W. 332 ; 46 L. R. A. 171 ; 77 Am. St. R. 524; Glascott v. Bragg, 1901, 111 Wis. $605 ; 87$ N. W. 853. 
taking as purchaser from a devisee named in the will, or from an executor with power of sale, cannot from that fact alone be sure of his title. ${ }^{2 i}$

If, however, the devise is regular, but a later will is discovered, making a different disposition of the same property, the effect may be serious as to those who have derived title from the devisees named in the first will; for a will may be admitted to probate at any time after the testator's death, in the absence of statutory limitations to the contrary. ${ }^{28}$

It may be that there seems to be no will, and one having possession as heir of the deceased landowner may convey or mortgage real property, and on the subsequent discovery of a will the devisees under it may deprive the heir's grantee of the land. ${ }^{29}$

In case there is actually no will the land passes to the intestate's heirs; title to it depends subsequently upon the question of heirship. Administration may be or may not be taken out upon the deceased's personal estate, but even if it be, decrees, recitals and records as to who are his next of kin for purposes of a distribution of personal property, are not necessarily conclusive concerning the heirs' title to real estate. A subsequent holder must, at his peril, ascertain whether those claiming as heirs are really such, and, if so, whether they are all the heirs. As time goes on this becomes more difficult to ascertain, and in fact in the case of persons of foreign birth, leaving no issue, it is often practically impossible to learn whether

${ }^{27}$ Robeno v. Marlatt, 1890, 136 Pa. St. 35 ; 20 Atl. 512; Smith v. Olmstead, 1891, 88 Cal. 582; 26 Pac. 521 ; 22 Am. St. R. 336; 12 L. R. A. 46. See "Subsequent birth of children as a revocation of a will," by M. H. Altizer, Va. L. Reg., IX, pp. 473, 579.

${ }^{24}$ In Haddock v. Railroad, 146 Mass. 155, 15 N. E. 495, a will was admitted to probate sixty-three years after death of testator, and in Rebhan v. Mueller, 114 Ill. 343; 2 N. E. 75, thirteen years. The matter is regulated by statute in many states, but the length of time varies from a "reasonable time" to several years.

20 Reid's Admr. v. Benge, 1902 (Ky.), 66 S. W. 997. 
$\S 429$ EXAMINATION OF TItLE TO REAL PROPERTY. 523

those who claim as heirs are such, or are all the heirs. The statutes of limitation may in time remove some diffculties arising from this cause, but owing to the many exceptions made in them a defect arising from uncertainty as to heirs may not be settled for a long time. ${ }^{30}$

\$429. Purchaser's risk in relying on the records alone. -There may be other interests than those yet named, the existence of which can be ascertained only by investigation outside the records, as: rights of dower or curtesy, or analogous statutory rights; questions of fact as to the happening or not happening of various conditions on which the title depends; the existence of incumbrances of a physical nature, such as a right of way, etc.

The purchaser, therefore, that relies upon the records alone takes the risk that the actual state of the title shall correspond with the title that appears of record, and this is as a fact often done, not merely to save expense, but because of ignorance as to the desirability of doing anything else. Or he may pursue inquiries outside the record. In many cases this latter course is feasible, and involves but little trouble and expense. In some cases, however, it is expensive and troublesome, and very often purchasers, though advised of the necessity and importance of investigating beyond the records, prefer to take the risk than to go to the expense and trouble of investigation. When, however, a lawyer is consulted as to the title, he should, in justice to his client and to himself, advise the client that there is much beyond the abstract of title and the records to be examined. While it is not strictly his duty to look up equities not apparent or fairly to be inferred from the abstract, nor to consider the matter of unrecorded evidence, nevertheless, as he is

\footnotetext{
- Statutes in some states exist for determining who are the heirs of a deceased person. But by the terms of some such statutes the result is only prima facie evidence : see, for example, Michigan C. L. '97, $\$ 9471$; Lorimer v. Judge, 1898, 116 Mich. 682; 75 N. W. 133.
} 
consulted about the title to the land, both his client's interests and his own require that he should at least direct attention to those matters not shown by the records which may affect the title.

$\$ 430$. Possession, not shown by records, always easily investigated.-One matter which the records do not show is of ten overlooked, though easily investigated; this is the matter of possession, which, as it affects the title most seriously should not be ignored. The general rule is that the possession of land is notice of the possessor's rights.

If, therefore, for example, one is asked to lend money on a mortgage security on land the record title to which is in the proposing mortgagor, but there is an unrecorded land contract given by the mortgagor by which he has agreed to sell the same land to another, and this other is in possession of the land when the mortgagee takes his mortgage, relying on the records, the mortgagee will take what title he gets subordinate to the prior equity of the vendee under the land contract, because the possession by the vendee under his unrecorded contract is notice of the contract and of his equity in the land; until actual notice of the mortgage the vendee in possession may continue to pay his purchase money to his vendor, and if he makes full payment to his vendor before actual notice, he may get a deed cutting out the mortgage. ${ }^{31}$

So the possession of land by the grantee named in an unrecorded deed is in most states notice of his title to a subsequent purchaser from the same grantor; an unrecorded deed is valid as between the parties and as against subsequent purchasers having notice of it, and possession is notice. ${ }^{82}$ And the principle applies to the actual pos-

s1 Jaeger v. Hardy, 1891, 48 Ohio 8t. 335 ; 27 N. E. 863; Williams v. Spitzer, 1903, 203 Ill. 505; 68 N. E. 49; Van Baalen v. Cotney, 1897, 113 Mich. 202; 71 N. W. 491; Corey v. Smalley, 1895, 106 Mich. 257; 64 N. W. 13; 58 Am. St. R. 474; Chapman v. Chapman, 1895, 91 Va. 397; 21 S. E. $813 ; 50$ Am. St. R. 846.

${ }^{32}$ Beattie v. Crewdson, 1899, 124 Cal. 57; 57 Pac. 463; Roberte v. 
session of an easement, though there is no record of any instrument creating it. ${ }^{83}$

Where this doctrine is recognized it is generally held that a tenant's possession gives notice of his landlord's title as well as of his own; his possession imposes upon a purchaser the obligation of inquiring by what right the tenant holds the land. ${ }^{34}$

As a title good on the records may amount to nothing after a lapse of time by reason of adverse possession, the importance of looking into the possession cannot be overestimated where there is an interval of several years between the conveyances as recorded; and as contracts and deeds are often drawn in one state for land in another, a matter to be noted in this connection is that the statutes of limitation vary much in the different states.

It should, however, be noticed in this connection, that if one is in possession of land and the records show some conveyance under which he is entitled to possession, his possession will generally be referred to this record title, and a subsequent purchaser will not be charged with notice, by his possession alone, of any other title or equity which the occupant may have; for, as his possession is consistent with the record title, it will be presumed to be under that title. ${ }^{35}$

Decker, 1903 (Wis.), 97 N. W. 519. See Miner v. Wilson, 1895, 107 Mich. $57 ; 64$ N. W. 874, for the combined effect of misdescription and possession. Where a statute requires actual notice of the former deed by a subsequent purchaser in order to dispense with recording the occupant's conveyance, possession has been held not to amount to notice of an unrecorded deed. Lamb v. Pierce, 113 Mass. 72.

* Ashelford v. Willis, 1902, 194 Ill. 492; 62 N. E. 817; Robinson v. Thrailkill, 110 Ind. $117 ; 10$ N. E. 649.

${ }^{34}$ Haworth $\nabla$. Taylor, 108 Ill. 275; O'Neill v. Wilcox, 1901, 115 Iowa $15 ; 87$ N. W. 742 ; Wilkins v. Bevier, 43 Minn. 213; 45 N. W. 157; 19 Am. St. R. 238; United States v. Sliney, 21 Fed. 894.

26 Schumacher v. Truman, 1901, 134 Cal. 930; 66 Pac. 591; Mullins v. Butte Hardware Co., 1901, 25 Montana 525; 65 Pac. 1004; 87 Am. St. R. 430. 
$\$ 431$. Possession by grantor, after conveyance, as notice.-It is sometimes stated as a general rule, that possession by a grantor after a conveyance from him is recorded, is no notice to subsequent purchasers of any rights reserved to the grantor. ${ }^{36}$ On the other hand, there are many later decisions holding that the grantor's continued possession is notice; because, as the law allows possession to have the effect of notice, there is no good reason for making a distinction between possession by a stranger to the record title and possession by the grantor after delivery of his deed. ${ }^{37}$

"Bloomer v. Henderson, 8 Mich. 395, 404; 77 Am. D. 453; Van Keuren v. Railroad, 38 N. J. L. 165; May v. Sturdivant, 75 Iowa 116; 39 N. W. 221; 9 Am. St. R. 463; Love v. Breedlove, 1890, 75 Texas 649; $13 \mathrm{~S}$. W. 222. Bloomer v. Henderson, 8 Mich. 395-though often citedhas been somewhat modified by later decisions: it has been held that the continued possession of a grantor for a long time after the recording of his deed to another may raisc a presumption that he has either retained, or since acquired, some right to the land; Bennett $\nabla$. Robinson, 27 Mich. 26; Stevens $\nabla$. Hulin, 53 Mich. 98.

${ }^{37}$ Groff v. Bank, 50 Minn. 234; E2 N. W. 651 ; 36 Am. St. R. 640; Ronan $\nabla$. Bluhm, 173 Ill. 277, 288; 50 N. E. 694; Turman v. Bell, 54 Ark 273 ; 15 S. W. 886 ; 26 Am. 8t. R. 35. 


\section{CHAPTER XXIX. \\ Registration OF title to ReAL PROPERTy.}

\$432. Defects in present system suggest desirability of reform in registration laws.

433. The "Torrens System"Briefly historical.

434. General principles of the title registration acts.

435. Proceedings to determine and register title are judicial-The applicationThe court.

436. Notice to adverse claimants -Process-Constitutional objections.

437. The investigation of titleFunctions of the examiner.
§438. Appearance of interested parties - The conclusive effect of decree.

439. Subsequent dealings with the land appear on the registry.

440. No title can be acquired to registered land by adverse possession.

441. Transmission of title on death of owner of registered land.

442. The assurance or indemnity fund.

443. Voluntary, or compulsory, registration.

$\S 432$. Defects in present system suggest desirability of reform in registration laws.-Such defects in our present system as are indicated in the preceding chapter, and the uncertainties as to land titles now quite generally existing, have induced the consideration of measures of reform. It is because of defects in this system that title guaranty companies have been formed for the purpose of investigating titles and taking risks that an individual may not feel warranted in taking for himself. And it has been urged that our system now furnishes ample security to any owner or purchaser, especially as he may generally get his title insured. ${ }^{1}$ The policies of these guaranty

1 See "The Torrens System; Its Cost and Complexity," by Wm. C. Niblack, 1903. The author of this work admits that his judgment may be affected by the fact that he is a stockholder in, and attorney for, the Chicago Title and Trust Co. 
companies, however, usually contain important exceptions, and, while they offer protection against pecuniary loss to the extent of the policy, they cannot, of course, make the title indefeasible, nor can they protect the insured in the possession of the land, which is what he desires, especially where expensive improvements have been made.

At its best the present system is simply the putting on record at length of great numbers of documents that do not, after all, show what the title to the land concerned really is. The accumulation of these copies as time goes on is one of the objections made to the present method, for the records must be safely kept in buildings provided at public expense. Each time the land, or a part of it, is dealt with, these records must be examined, that is, the abstract must be "brought down to date," for, while records cannot absolutely show the title, they cannot be ignored. So that repeated examinations of title are required by each purchaser or mortgagee, with repeated expense and delay. And one of the incidents of such a method is the liability to error in transcribing and indexing so many documents.

\$ 433. The "Torrens System"-Briefly Historical.Among the reforms considered within recent years the "Torrens System" of registering title to real property and of dealing with the title after registration, has been most discussed and is the most radical. ${ }^{2}$ This system takes its name from Robert Torrens. He was born in Cork; emigrated to South Australia in 1841; was collector of customs and thus, though not a lawyer, became familiar with the shipping laws. It is said that the starting point of

2 The American statutes providing for registration of land titles differ materially in important particulars from the Australian, and are not appropriately designated "Torrens laws." As Torrens was, however, the first to direct the attention of English speaking people to registration of title, any scheme of title registration at all like the Australian will probably be called by his name. 
his system was the application of the principles which regulate the transfer of vessels by means of registration, to the transfer of land.

In parts of Europe the same general plan has been in use for centuries, and there is nothing new about the fundamental principles involved, ${ }^{8}$ but it does not appear that Torrens had studied these continental methods or was, at first, even aware of them.

He suggested the reform in 1850 , but met with much opposition. The chief justice of South Australia told him the proposed system was "both unwise and impracticable," but in 1858 it was adopted in that colony and has since been adopted throughout Australia, where it has become so popular that about eighty per cent. of all the land of Australia has been brought under the law. New Zealand and several Canadian provinces then adopted the system, and after years of discussion England has followed the colonies."

By its adoption in Illinois (1895 and 1897), California (1897), Massachusetts (1898), Oregon (1901), Minnesota (1901), Colorado (1903), ${ }^{5}$ and its discussion in many other states, it has become to such an extent American that the Australian, Canadian and English acts and decisions need not be consulted by one who wishes to get a

" Land Transfer by Registration of Title in Germany and AustriaHungary." (Am. Law Rev., vol. 31, p. 827.)

438 and 39 Vict., c. 87 (1875); 60 and 61 Vict., c. 65 (1897).

- The acts to which references are made in this chapter are: California, Stat. 1897, ch. CX. ; Colorado, L. 1903, in effect July 12, 1903; Illinois, L. 1897, p. 139, Hurd's R. S. 1899, ch. 30, \$§ 44-154, Starr \& Curt. Supp., vol. 4, pp. 259-282 ; Massachusetts, Stat. 1898, ch. 562, to be found as amended (in 1899 aud 1900) in Mass. R. L. 1902, ch. 128-in the revision, $\S 1$ of the original act is omitted, and the section numbers, therefore, are not the same as in the original act; Minnesota, Lawe 1901, ch. 237; amended, Laws 1903, ch. 234; Ohio, 92 O. L. 220 (1896), this act was declared invalid in 1897 and repealed in 1898, 93 O. L. 8; Oregon, Gen. L. 1901, p. 438.

34-Brews. Con. 
general view. Indeed, under our constitutions a too close following of the foreign models is detrimental. ${ }^{6}$

$\$ 434$. General principles of the title registration acts. - The details of the American statutes vary, and at some points the differences extend beyond details; nevertheless, the underlying principles of the several acts are the same.

The features of the system of registration of title to land as distinguishing it from the present system are that it provides fur the registration of title, not merely for the registration or recording of deeds, or instruments affecting the title; under it title to land passes only by the entry of the transfer upon the official register, not by the execution and delivery of the deed; it is intended that this register shall show the condition of the title to real property upon a single page, and all dealings with the land must be entered on this page.

In this system two main objects are sought to be attained:

First, certainty and facility in proof of title.

Second, simplicity in dealings with land after the title is thus proved.

The chief means by which the first result is secured is the issuance of a document called a certificate of title, which authoritatively declares that the person named in it owns a specified estate in a specified piece of land.

The first and important step, then, is to secure the registration of title, the "initial registration," as it is called.

$\S 435$. Proceedings to determine and register title are judicial-The application-The court.-In order that general constitutional provisions may be complied with, the "initial registration" of title, upon which the certifi-

- The Ohio law, 1896, was declared unconstitutional in 1897. State $\mathbf{}$. Guilbert, 56 0. St. $575 ; 47$ N. E. 551 ; 38 L. R. A. 519 ; 60 Am. St. R. 756. And the first Illinois law, 1895, was also: People v. Chase, 165 IIl. 527; 46 N. E. $454 ; 36$ L. R. A. 105 ; in each case because the Australian model was followed too closely. 
cate of title is issued, must be the result of judicial proceedings to establish title; there must be notice to all having interests adverse to those of the applicant for registration; and only judicial officers may exercise judicial functions, whether as to the initial registration or as to subsequent dealings with the registered title.

The first proceeding under the registration acts is the application by the person claiming to own the land in fee simple, or, under the Massachusetts and the proposed Virginia acts, the person having the power of appointing or disposing of an estate in fee simple in the land, for the registration of his title.

The application is in writing, signed and sworn to by the applicant, describing the land, and naming the occupants and adjoining owners. The owner begins, by this application, a proceeding in court to have ascertained and confirmed his title. In Illinois the application is addressed to the judges of the circuit court for the county in chancery. In Massachusetts it is addressed to the judge of the "court of land registration," a court specially constituted by the registration act, and having exclusive original jurisdiction of all applications made under the act, with power to hear and determine all questions arising upon such application. In Colorado and Minnesota it is made to the district court of the county in which the land is situated.

The Massachusetts provision, for the creation of a special court to administer the law, is thought by many to have advantages over the Illinois plan of having the proceedings before the circuit court, or the Minnesota plan, which is similar. The courts named in the laws of these latter states, being chiefly occupied with other matters, will not be able to give the necessary attention to the important and often intricate questions arising in registration cases, while under the Massachusetts plan there is always at hand a judge, supposed to be well versed in real 
property law, who may be consulted at all times by the recorder or his assistants, or by any applicant or owner, in regard to questions that may arise. Under the Massachusetts plan the recorder of the court of land registration is its clerk, and acts under its direction. The registers of deeds throughout the state are assistant recorders, and in executing the provisions of the act are subject to the general direction of the recorder, and act "in accordance with the rules and instructions of the court." If an assistant recorder is in doubt upon any question, or if any question is raised by a party interested in subsequent dealings with registered land, the question is referred to the court, which determines the matter after notice to all parties and a hearing. ${ }^{7}$

\$ 436. Notice to adverse claimants-Process-Constitutional objections.- On the filing of this application provision is made for giving notice to all who may have interests in the land adverse to those of the applicant. At this point difficulties occur, and objections have been raised on constitutional grounds to every method suggested.

Under our constitutional provisions that no man shall be deprived of his property without due process of law, it has been maintained by many that each American statute is unconstitutional in that there is no sufficient notice required to be given to, and no sufficient process against, persons having claims adverse to the applicant. It appears to be further claimed by some that no scheme can be devised which will fully meet this constitutional objection. This was one of the chief objections to the Ohio law, and was one of the grounds of the court's decision

'Before the Massachusetts plan can be adopted in some states their constitutions need amendment. The Virginia constitution of 1902 provides: "The legislature shall have power to establish such court or courts of land registration as it may deem proper for the administration of any law it may adopt for the settlement, registration, transfer or assurance of titles to lands in the commonwealth, or any part thereof." 
against it. ${ }^{8}$ But the provisions as to the issuance and service of summons, and giving of notice, were materially different in the Ohio law from the provisions as to these matters in the Illinois and Minnesota laws and the later acts of Colorado and Oregon.

The last Illinois act, which was held constitutional, ${ }^{9}$ and the Minnesota act, which has been declared so, in spite of this objection, ${ }^{10}$ are certainly less objectionable in this regard than the Ohio law. These acts practically require all adverse claimants who reside within the jurisdiction of the court to be made parties defendant, and to be served with process. All other persons are to be made parties defendant under the name and designation of "all whom it may concern," and notice is to be published, and mailed to defendants substantially as in other chancery cases.

The original Massachusetts act provides at this point for mailing notices and for publication by the recorder, and for the posting of notice on the land. The supreme court of that state holds the act constitutional-two justices dissenting. ${ }^{.1}$

The Massachusetts act thus disregards what appears to have been the general practice, under statutes involving the determination of land titles, of bringing resident defendents into court by summons served, in requiring simply mailing of notices, publication, and posting on the land. Justice Holmes says in this connection that, with the rest of the court, he thinks the act should be amended in the direction of still further precaution to secure actual notice before a decree is entered; and that if

- State v. Gailbert, 56 Ohio St. 575, 617; 47 N. E. 551 ; 38 L. R. A. $519 ; 60$ Am. St. R. 756.

- People v. Simon, 1898, 176 Ill. 165; 52 N. E. 910; 44 L. R. A. 801; 68 Am. St. R. 175.

${ }^{10}$ State $\nabla$. Westfall, 1902, 85 Minn. 437 ; 89 N. W. 175 ; 89 Am. St. R. 571 ; 57 L. R. A. 297.

${ }^{11}$ Tyler $\nabla$. The Judges, \&c., 1900, 175 Mass. 71 ; 55 N. E. 812 ; 51 L. R A. 433. 
it is not amended the judges of the court ought to do all that is in their power to satisfy themselves that there has been no failure in this regard before they admit a title to registration. In accordance with this suggestion the act has been amended so that the land registration court is required to, "so far as it considers it possible, require proof of actual notice to all adjoining owners and to all persons who appear to have any interest in or claim to the land included in the application. Notice to such person by mail shall be by registered letter." 12

437. The investigation of title-Functions of the examiner.-After the application and notice, the question of the applicant's title is investigated by official " examiners of title," who report to the court. The court, if satisfied with the applicant's title, then makes a decree, ordering the title to be registered, and that a duplicate certificate of title issue to the applicant. In this way it is hoped to attain the first general object of the system,- to make the decree conclusive as to showing title. These questions, it will be noticed, are determined by a court, not by the recorder or examiner of titles.

Under the system adopted in the Australian colonies the application to have land placed on the register of titles was submitted, together with deeds, abstracts of title and plans of the land, to a barrister and a conveyancer, styled "examiners of titles," for their examination. These "examiners" then reported to the "recorder" or "registrar" their conclusions upon the applicant's title.

\footnotetext{
${ }^{12}$ Mass. R. L. 1902, ch. $128, \S 31$. The Supreme Court of the United States has not yet passed directly on the constitutional questions involved in these laws. In Tyler v. Judges, \&c., 1900, 179 U. S. 40.5, the court held-four justices dissenting - that it had no jurisdiction to pass on the questions involved, as it did not appear that the plaintiff was personally interested in the litigation, or had been, or was likely to be, deprived of his property without due process of law. The writ of error which had been sued out for the purpose of testing the constitutionality of the Massachusetts act was therefore dismissed.
} 
They made such recommendations regarding the serving of notices as the nature of the case and the domicile of parties likely to be interested in the land seemed to require. It was not essential, however, that there should be in all cases, as a basis for the registration of the applicant's title, any other proceeding than this.

The adoption in the Illinois law of 1895 of this scheme of giving the registrar authority to determine the applicant's title on the advice of two competent attorneys acting as examiners, rendered that law unconstitutional, as conferring judicial power on the registrar in violation of the constitutional restriction against the legislative grant of such powers to non-judicial officers. ${ }^{18}$

Under the later statutes in the several states which provide for constitutional judicial proceedings it would be possible for the court, which must ultimately determine whether or not the applicant's title is good, to undertake the investigation of the title, upon evidence submitted by the parties interested and without independent investigation. Each American act, however, provides for the appointment of an examiner of titles to aid the court in this investigation. The application is referred to him immediately after its filing, and his duty is to investigate the facts stated therein and to see that all persons having claims to the land are before the court. When the examiner suggests that a person named by him be made a defendant, his recommendation cannot be ignored by the applicant without rendering the decree of registration of the applicant's title void as against this person and as against all persons in privity with him and who are not defendants. ${ }^{14}$

The examiner has extensive powers and responsibilities.

18 People v. Chase, 1897, 165 Ill. 527; 46 N. E. 454; 36 L. R. A. 105. This was also one of the grounds of the decision in the Obio case adverse to the constitutionality of the law. State v. Guilbert, 1897, 56 Ohio St. 575 ; 47 N. E. 551 ; 38 L. R. A. 519 ; 60 Am. St. R. 756.

${ }^{14}$ Dewey v. Kimball (Minn.), 1903, 95 N. W. 317, 895; 96 N. W. 704. 
Though he may hear the parties and their evidence, he also investigates the title independently of proofs offered. By some of the acts it is his especial duty to ascertain if the land is occupied, and if so, the nature of the occupation, and even where there is no such express requirement this would be a part of his duty, as the application must state the facts in regard to occupation, and the examiner must report on all matters stated in the application. He looks into all matters affecting the title, whether they are of record or in pais. His report is similar to that of a master in chancery where that officer is recognized, ${ }^{25}$ or to that of a referee. ${ }^{16}$ As the effect of a decree of registration is far reaching, it is evident that the examination of title should be thoroughly conducted by one well qualified for such work. This is especially true where there is no separate land registration court established and where, therefore, the court to be aided by the examiner is one of general jurisdiction. In statutes strictly following the Illinois act additional importance attaches to the office of examiner of titles because of the power given him in regard to dealing with registered land when an equitable interest has been created in it by a declaration of trust. Most of the acts provide that no instrument dealing with land so held shall be registered without an order of court approving it as being in accordance with the trust. But under the Illinois act this may be done either "pursuant to the order of some court, or upon the written opinion of two examiners" that such instrument is in accordance with the true intent of the trust, and when the registrar is satisfied with this opinion the validity of this later transfer is conclusively established. ${ }^{17}$

\footnotetext{
25 Gage v. Consumers' El. Lt. Co., 1901, 194 Ill. 30; 64 N. E. 653.

${ }^{16}$ Minnesota Act, § 24. Minn. Laws 1901, ch. 237.

17 Illinois Act, $\$ \$ 68,69$, Ills. Hurd's R. 8. 1899, ch. 30 ; the Oregon Act, $\$ \oint 67,68$, Oregon Gen. L. 1901, p. 438, makes the later deating dependent upon the order of some court "or the filing of an affidavit of the person applying for registration" of the instrument, that it is in accordance with the meaning of the trust. To peculiar provi-
} 
$\S 438$. Appearance of interested parties-The conclusive effect of the decree.-The decree mentioned in the last section is not made until every party interested has had an opportunity to appear and answer, stating objections to the application; but if there is no appearance default may be entered, ${ }^{18}$ and the report of the examiner of titles is considered by the court, with such other proof as the court may require; for example, as to boundaries, etc. If interested parties appear and answer there is a hearing before the decree is made and entered. Evidence establishing title good as against the world is essential to warrant a decree awarding initial registration of title. ${ }^{19}$ It is held in the case last cited that the proceeding to register title is not a bill in equity to remove a cloud, and that the applicant must establish that the true title is in him before he can have relief or require those whom he has brought in as defendants to bring their titles before the court for adjudication; the defendant, therefore, may be heard to urge that the applicant has not shown a title proper to be registered, and if this be true the application should be dismissed, without regard to the question whether the title or claims of the defendant are but mere clouds; if, however, the applicant shows a title proper to be registered, he may not only have a decree to that effect, but may also have the claims of defendants decreed to be invalid or but clouds on his title..$^{20}$

The Massachusetts law makes the decree conclusive from its entry against all persons if no appeal is taken sions in the California law regarding the investigation of the applicant's title is undoubtedly largely due the fact that the act is practically inoperative. The examiner's compensation is made a part of the costs of the proceeding, to be paid by the applicant (\$18), and an abstract of title is required to be filed by him, but the abstract can be furnished by those only who have given bonds in the sum of not less than ten thousand dollars, which sum "may be increased from time to time by order of the court." (\$6.) California Act, Cal. Stat. 1897, ch. CX.

18 Reed v. Carlson, 1903 (Minn.), 95 N. W. 303.

${ }^{19}$ Glos v. Kingman \& Co., 1904 (Ill.), 69 N. E. 632.

${ }^{0}$ See Lancy $\nabla$. Snow, 1902, 180 Mass. 411; 62 N. E. 735. 
within thirty days, except that one deprived of an interest in land by a decree of registration obtained by fraud may file a petition for review within a year, provided no innocent purchaser for value has acquired an interest.

In Illinois persons residing within the state if not parties to the decree may assert such rights as they may have within two years-the act providing this short period of limitations; otherwise, and as to parties to the decree, the decree is conclusive, subject to the right of appeal as in other chancery cases.

No exception as to the conclusiveness of the decree is made in the acts, as a rule, as to infants or persons otherwise under disability. ${ }^{21}$

The provision of the Massachysetts law for the conclusiteness of the decree practically at once, is regarded by many as preferable to that of the Illinois law.

It has been adopted in Minnesota, though with a modification-sixty days being there allowed, from the entry of the decree, in which persons not bound by it, because of irregularity, etc., may bring action, provided no innocent purchaser for value has acquired an interest.

The supreme court of Minnesota holds this provision valid as a statute of limitations, saying: "The time limit seems to us to be a short one, but, in view of the complete and far-reaching provisions of the act for notice to all parties, and the fact that the right of appeal as in civil actions is given, we cannot hold that the legislature arbitrarily exercised its discretion in fixing the limit," and further holds that the provision forbidding the commencement, in opposition to the decree, of any action to recover the land after sixty days cannot apply to an adverse claimant in actual possession upon whom no summons is served. ${ }^{22}$

"11 The constitution of the United States gives to minors no special rights beyond others, and it is within the legislative competency of a state to make or not to make exceptions in favor of infants, or persons under disability. Vance $\nabla$. Vance, 103 U. S. 514, 521.

${ }^{22}$ State v. Westfall, 85 Minn. 437; 89 N. W. 175; 89 Am. St. R. 571; 
\$439. Subsequent dealings with the land appear on the registry.-The acts uniformly provide that the obtaining of a decree of registration and the entry of a certificate of title shall be regarded as an agreement running with the land, and binding upon the applicant and all his successors in title, that the land shall be and always remain registered land, and subject to the provisions of the act and all amendments thereof. An owner of registered land may convey or mortgage or lease it as if it were not registered, and he may use for these purposes the same forms of instruments that he would use had his land not been registered; but none of these instruments (except a lease for a short term) shall take effect as conveyances, but shall operate only as a contract between the parties and as evidence of authority to the recorder to make registration, when accompanied by the owner's certificate of title. This certificate, on a conveyance of an estate in fee, is surrendered and canceled, though not necessarily always so when a lesser estate is conveyed.

The act of registration is the operative act to convey or affect the title, not the delivery of a deed as is now the case.

These features are of importance and are essential to the proper working of the system. The subsequent dealing with the land in this way is one of the fundamental principles upon which registration of title is based.

The reform was much delayed in England by the unworkable character of Lord Westbury's Act of 1862,

57 L. R. A. 297. The Massachusetts provision in regard to the conclusiveness of the decree against all persons not named in the proceedings-except by the general designation "to all whom it may concern"-even though residing within the state, is regarded by the dissenting justices of the court of that state as rendering the act unconstitutional; Tyler v. Judges, 175 Mass., at p. 91. But as the court holds it constitutional, the certificate of title based on the decree is conclusive, and purchasers may so regard it, and thus one of the chief objects of the law is at once attained. 
which provided that " registered land may be conveyed, charged, etc., * * by any deed * * or instrument by which such land, if not registered, might now according to law, be charged, etc.; " the use of deeds, thus sanctioned, involving a combination of two incompatible principles, "registration of deeds" and "registration of titles." 23 The principle is similar to that applied in the transfer of stock in a corporation; the stock is generally transferable only on the books of the company; the "certificate of stock" is the certificate of title to the stock-it is the evidence of title; and when a transfer is made the certificate is surrendered and canceled, and entries are made on the books by the proper officer of the company authorized by the owner. And the owner when he takes the stock practically agrees that the title to it shall be transferred in this way only.

Provision is made in the acts for notification to the recorder by the owner of loss or theft of his certificate, and for the issuance to him of a certificate, in place of one lost, on proper proof.

\$ 440. No title can be acquired to registered land by adverse possession.- In adherence to this principle that title shall be acquired to registered land only through a transfer on the books, is the provision of each act relating to adverse possession: that no title to registered land in derogation of that of the registered owner shall be acquired by prescription or adverse possession.

Mere possession, therefore, becomes no notice of rights, and all rights appear as entered on the original certificate of title. No adverse possession can ever ripen into title.

This feature is considered by the advocates of the system as one of its most admirable features-for, they say, the more wrongful the "squatter's" acts are in gaining and keeping possession, the more sure he is to acquire

23 Torrens, "Essay on Transfer of Land by Registration"-Cobden Club, 1881. 
the title in fee simple under our present system. Its opponents, on the other hand, argue that title by limitation of time is a most reasonable and proper basis of ownership, and that a law which abolishes it is opposed to the best interests of society.

It will be noticed that the provisions of these acts will work a radical change in law in this respect, and if all land should be registered the owners might remain out of possession and leave land unimproved for any length of time, without the possibility of any one's acquiring the title.

Statutes of limitation have been said to rest on the policy of compelling those who have a right of entry to take actual possession of the land and settle the country, at the peril of being ousted by those who will settle the land and improve the country. ${ }^{24}$ This provision of these acts, therefore, not only makes a radical change in our present law, but opens up an important question of public policy.

$\S 441$. Transmission of title on death of owner of registered land.-Under our present system certain diffculties arise ${ }^{24 s}$ when title to real property is transmitted on the death of the owner in fee. Uncertainty and doubt must exist in many cases because of the difficulties of ascertaining who are the successors to the title. Many difficulties would be removed by letting the property pass at the owner's death to his executor or administrator, to be dealt with in the manner in which personal estate is dealt with under such circumstances.

The Illinois Torrens law, section 70 , provides that in such case the estate in registered lands shall "go to the personal representatives of the deceased owner in like manner as personal estate, whether the owner dies testate or intestate, and shall be subject to the same rules of administration, as if the same were personalty, except as other-

« Kinney $\nabla$. Vinson, 32 Texas 126, 128.

sto See ante, $\S 428$. 
wise provided in this act, and except that the rule of division shall be the same as in the descent of real property, or as shall be provided by will ;" and the law also, in section 76, provides for filing in the registration office proof of heirship before the distribution of undevised registered land, which shall be conclusive evidence in favor of all persons subsequently dealing with the land that certain persons named as the only heirs at law of the deceased owner are such heirs. That is, the executor or administrator will be registered on production of evidence of his authority (his "letters" testamentary or of administration), and the rights of those beneficially interested will be ascertained and enforced, and it may be settled definitely and without great delay what persons are the successors to the title. Questions concerning heirship, dower, homestead, creditors' rights, may be conclusively settled once and for all, and cannot arise some time afterwards, as possible defects of title, needing investigation at each later transfer.

It seems that a reform of this nature could be made without adopting the whole plan of registering titles, and it further seems desirable, whether or not the general plan is adopted. If, however, the general scheme of registering titles is adopted this part of it appears almost essential to the proper working of the system.

The Massachusetts law, section 91, and the Minnesota law, section 74 , provide for more direct transmission to the heirs or devisees, who themselves may make application for the entry of a new certificate; upon which application the court issues notice to the executor or administrator and others interested, and, after hearing, directs the entry of a new certificate, or certificates, to the persons entitled as heirs or devisees.

These latter acts do not, it seems, expressly provide for conclusively establishing the matter of heirship,-but the provisions as to transmission on death are such that they will probably be construed to have that effect. 
$\S 442$. The assurance or indemnity fund.-The acts generally provide for the accumulation of a fund for making good any loss one may suffer through mistake, negligence or wrong in the practical operation of the law. This provision is made in recognition of the fact that no system of transferring title has yet been devised in which there is not liability to loss. But the provision is not an essential feature of this system of land title registration and transfer. There is no "assurance fund" provided for by the California act, and the Illinois Supreme Court gives this part of the Illinois law no consideration, saying: "The law can, as we think, stand and accomplish its purpose without it." 25 Each of the acts, however, except that of California, makes provision for such a fund by requiring the payment, when lands are brought under the act, of a small sum-one-tenth of one per cent. of the value of the land, the value being, generally, ascertained by reference to its appraisement for taxation. The payment is to be made to the public treasurer. The methods by which recovery may be had from it by those entitled to compensation are prescribed in detail. Wherever the system has been in operation, however, the demands upon the fund have been extremely rare.

The Supreme Court of Ohio especially criticises this part of the act, stating that the fund is to be raised to indemnify those whose lands have been "wrongfully wrested "from them, and that the "penitential scheme" is both inadequate and forbidden by the constitution, as taking private property for public use without compensation; ${ }^{26}$ but in the Massachusetts case ${ }^{27}$ the provision is not referred to-as it must have been had there been grounds for regarding it as so clearly unconstitutional.

${ }^{25}$ People v. Simon, 176 Ill. 165, 177; 52 N. E. 910; 44 L. R. A. 801 ; 68 Am. St. R. 175.

${ }^{26}$ State v. Guilbert, 56 Ohio St. 575, 623, 625; 47 N. E. 651 ; 38 L. R. A. $519 ; 60$ Am. St. R. 756.

"Tyler v. Judges, 175 Mass. 71 ; 55 N. E. 812 ; 51 L. R. A. 433. 
There appears to be nothing in the state constitutions prohibiting the legislature from incorporating provisions practically guaranteeing titles or furnishing indemnity, in case it is considered best to do so.

$\$ 443$. Voluntary, or compulsory, registration.-The American laws so far enacted provide that registration of title shall be entirely optional: as they now stand, no land in any state where the system exists need be registered.

It is the opinion of those who have closely followed the practical working of the system that provision should be made for compulsory registration to some extent. It has been suggested that this could be brought about, without hardship or inconvenience, by requiring administrators or executors to register title, before heirs or devisees can legally acquire title to the lands of a deceased owner. Under this method all land would gradually come under the new system.

The later English act ${ }^{28}$ provides that by Order in Council registration of title to land may be made compulsory on sale of the land in any county named in the order, and orders have been made by which registration is compulsory in certain parts of the county of London : a purchaser does not, therefore, where the order applies, acquire the legal estate until he is registered as proprietor of the land.

The Illinois act has been amended-subject to adoption by the people of any county where the act is operativeso that upon the death of one owning real estate in any county where the "Torrens law" is in force his administrator or executor must, within six months after his appointment as such, apply to the circuit court for the

${ }^{28}$ Land Transfer Act, 1897, 60 and 61 Vict. c. 65, s. 20. 
registration of the title to the land-unless the probate court shall excuse him from so applying. ${ }^{20}$

${ }^{29}$ Laws Ills. 1903, p. 121.

Most of the literature on the subject of registration of title is in the form of addresses, papers in legal periodicals, etc.

In Theo. Sheldon's "Land Registration in Illinois," 1901, a full list of treatises and papers relating to the subject will be found. Among the papers published since Mr. Sheldon's list was prepared are :

Land Title Registration in the United States, by Leonard A. Jones, 36 Am. Law Rev. 321.

Virginia and the Torrens System, by Eugene C. Massie, $35 \mathrm{Am}$. Law Rev. 727, 14 Reports Va. State Bar Association.

The Torrens System of Land Registration; by Alex. H. Robbins, 54 Cent. L. J. 282.

Practical Operation of the Torrens System in Massachusetts, by Clarence C. Smith, 54 Cent. L. J. 285.

A report of the case of State v. Westfall, with note, 54 Cent. L. J. $290,293$.

Address by Edward T. Taylor, Reports Colorado State Bar Association for 1902.

Discussion on The Recording of Land Titles and Transfers by Jadicial Procese, by Chas. Wetherill and Paul H. Gaither, 9th Ann. Rep. Pa. Bar Aseociation (1903).

"The Torrens Acts," Some Comparisons, J.H. Brewster, Mich. Law Rev., Vol. 1, p. 444 ; The Court of Land Registration, by Chas. T. Davie, Yale Law Jour., February, 1904.

The proposed Virginia act, most carefully drafted, may be found in 16 Va. Bar As8'n Reports (1903). 


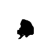




\section{INDEX.}

\section{[References are to Sections.]}

\section{ABANDONMENT,}

of guardianship of insane, effect of, 333 .

of homestead, 383.

will not generally make valid conveyance of homestead that was invalid when made, 394 .

of wife by husband, she may convey, 363 .

\section{ABBREVIATION,} of official title in acknowledgment, 291.

"ABOUT,"

effect of in naming quantity, 92 .

\section{ABSENCE,}

signing in grantor's, 238.

ABSTRACT OF TITLE, 425.

should show conditional clauses, 187.

\section{ACCEPTANCE,}

as an element of delivery, 298, 300-302.

assuming control of property shows, 301 .

express, acceptance of deed, when necessary, 301.

presumed until dissent shown, 300 .

when parent conveys to child, 301 .

prevented, title does not pass, 302 .

surrender and acceptance need not be concurrent acts, 302 .

\section{ACCESS,}

to navigable water, private property, 106.

to water cannot be cut off, 117 .

\section{ACCRETIONS,}

on half street, 91.

to riparian owner's land, 117. 
[References are to sections.]

ACKNOWLEDGMENT,

"acknowledge," whether necessary, 270.

by corporation, 294.

by married women, $264,361,365,367$.

certificate of, clerical errors do not vitiate, 267 .

date, 34, 290.

date differing from that in deed, effect of, 34 .

conclusive, when, 293.

fact of acknowledgment must appear in, 269.

forgery may be shown, 293.

form of, 265, 294,

impeachment, 293.

in foreign language, $280, \mathbf{n}$.

parts of, 289.

"personally known," 272.

prima facie evidence of, due execution of deed, 259.

Beal of officer, 292.

signing by officer, 291 .

defined, 254.

grantor or grantee cannot take, 281.

identity of person acknowledging with grantor, $271,272$.

jurisdiction of officer to take, 289.

of grantor to witness, 252.

of writing not authorized, effect, 260.

one of several grantees may take, 281.

partner of party cannot take, 285.

party cannot take, 281.

purposes of, 257-264.

record of deed with defective acknowledgment, 258, 260, 366.

stockholder cannot take, when, 285.

substantial compliance with statute necessary, 267-272, 367, 399.

taken in state other than that where land is, 276-279.

to conveyance of homestead, 399.

trustee in deed cannot take, 283.

venue, 289.

what instruments may have, 255.

when necessary to validity, $261,262,365,399$.

when required for release of dower, 376 .

who may take, 274-277.

\section{ACQUIESCENCE,}

by former infant in deed made during minority, 316,317 .

of husband in wife's control of property, effect of, 353 .

ACRES,

statement of number, effect, 92. 
ACTION,

\section{[References are to sections.]}

on covenants ranning with the land governed by lex situs, 213.

\section{ADDITIONS,}

to name by way of recital,44.

ADJOINING LOT, as monument, 87.

ADMINISTRATOR, covenantee's need not be named,196.

deed of, recitals in, 50 .

naming of, in covenants for title, 193.

when not bound by deceased's covenants, 193.

ADOPTION,

of child, effect on will, 428, $n$.

of one seal by several grantors, 248.

of signature by grantor, 238.

\section{ADVERSE POSSESSION,}

character of, to render deed void or voidable, 420 .

conveyance of land held in, 415-421.

generally valid now, 421 .

valid between the parties, 417,418 .

disability from, 415-421.

title not acquired by, under "Torrens System," 440.

\section{AFFIRMANCE,}

of deed made during infancy, not needed, 313.

what is, 316.

of voidable conveyance of insane person, 342 .

AFFIRMATIVE CONDITIONS, 171.

AFTER ACQUIRED TITLE, enures to grantee in warranty deed, 188.

to mortgagee, when, 189.

married woman estopped to claim, when, 195.

AGE,

extreme age does not show grantor's incapacity, 340 .

misrepresentation by infant as to, 320 .

AGENT. See Attorney.

\section{AGREEMENT,}

of grantee to pay mortgage, how shown, 65 .

to convey, distinguished from deed, 28. 
ALIEN,

\section{[References are to Sections.]}

capacity to purchase and convey real property, 408-412.

may convey before office found, 410 .

may not acquire title by descent at common law, 408 .

property rights affected by treaty, 4,412 .

states may add to or remove common law disabilities, 412 .

treaty may remove disabilities of, 412 .

\section{ALIENATION,}

by joint tenant, 150 .

by owner in fee, 1, 139.

by tenant in common, 157 .

by tenant in entirety, 166 .

by tenant in tail, 140 .

general restraint on, void, 186.

restraint on, valid in creating "separate estate," 354.

restrictions on, 312 .

ALLEYS. See StreEts.

ALTERATION, forgery by, 426.

of date, 426.

of grantee's name, 426 .

\section{AMBIGUOUS,}

clause, of condition, 172.

construed as a covenant, 177.

of exception and reservation, 121 .

description of property, 76-80.

AMERICAN ACTS FOR REGISTRATION OF TITLE, inappropriately called "Torrens Acts," 433, $n$.

AMERICAN BAR ASSOCIATION FORMS, form of acknowledgment recommended by, 265, 294.

AMERICAN RULE, as to covenants running with the land, 217.

ANCIENT DEEDS, recitals in, evidence, 44.

APPLICATION, to register title, 435.

to sell infants' lands, 326.

APPROVAL,

by court, of sale of infant's land, 328 . 
[References are to sections.]

\section{APPURTENANCES,} what are, 118.

APPURTENANT, easement, reservation of, 125 .

land not appurtenant to land, 99, 118.

ARTIFICIAL POND, boundary on, 111.

ASSENT, of husband to wife's deed, 363 .

ASSIGNMENT, indorsed on deed, 70.

"ASSIGNS,"

covenantee's, naming of, 197 .

covenants broken do not pass to, 217.

effect of, in covenant, 224.

not needed to create a fee, 138 .

of grantee in deed poll bound by covenants, 225 .

ASSUMED NAME,

deed by one under, valid, 43.

deed to one under, valid, 43.

ASSURANCE, further, covenant for, 205.

ASSURANCE FUND, under "Torrens System," 442.

ASYLUM, commitment to, effect of, 333 .

ATTAINDER, forfeiture on, 413.

ATTESTATION, at common law not necessary, 250 .

by one interested in the conveyance invaljd, 253. clause of, not essential, 252.

generally, 250-253.

in United States, 251.

method of, 252.

of signature by mark, 236 .

proof by witness attesting, 295. 


\section{ATTORNEY,}

\section{[Reforences are to Bections.]}

acknowledgment by, 294.

married woman's power of, 377.

of party may generally take acknowledgment, 288 .

power of, by infant, when void, 314 .

by insane person, 336 .

signing under power of, 239.

\section{ATTORNMENT,}

effect of statute dispensing with, 202.

"BANK,"

effect of, in description, 100.

BARGAIN AND SALE, after statute of uses, 20,56 . consideration in, 55 .

deed of, 12.

deeds in United States usually based on, 56.

operative words in deed of, $57,69$.

BENEFITS AND BURDENS,

distinction between in covenants, 226 .

\section{BLANKS,}

authority to fill, 39.

filling in, certificate of acknowledgment, 267, 269, 271.

BOND, forms of covenants for title, 192.

guardian's, on sale of infant's lands, 328.

BOUNDARY. See Description. at water's edge, 117.

lake as, 111.

meander line as, 103.

street as, 89.

uncertain starting point, 80 .

water as, 98-117.

BREACH OF COVENANT, against incumbrances, what constitutes, 200-203.

for further assurance, 205.

for good right to convey, 198.

for quiet enjoyment, 206.

for seisin, 198.

of warranty, 206, 209, 210.

\section{BUILDING LINE,}

on plat referred to in deed, 227.

purchaser may be held to, by another lot owner, 228 . 
[References are to sections.]

BUILDING RESTRICTION, as a condition, 182.

incumbrance, 201, 227, 228.

in pursuance of a general plan, 228.

BUILDINGS, as monuments, 88.

BULK, sale in, 92.

BURDEN8, of covenants, when pass with the land, 226.

BUSINESS, occupancy of homestead for, 384 .

CANCELATION, of grantor's name does not revest title in him, 311 .

\section{CAPACITY,}

mental, degree required in grantor, 338.

of alien to convey, 410-412.

of convict, 413,414 .

of corporation, 406, 407.

of disseisee, $415-421$.

of infant, 313, 314 .

of insane person, 332-337.

of married woman, 340-372.

of tenant in tail, 143.

\section{CAPACITY TO TAKE TITLE,} of alien, 408, 409.

of convict, 413,414 .

of corporation, 401-405.

of infant, 323.

CAPRICIOUS CONDITIONS, 186.

CENTER, of monument boundary, 88,89 .

"CENTER RULE,"

what expressions prevent operation of, when way is boundary, 90 .

CERTAINTY, in description, 75.

CERTIFICATE OF ACKNOWLEDGMENT. Sae ACkNowledgmant. date of, 34, 290.

defective, to deed of married woman, 366 
CERTIFICATE OF ACKNOWLEDGMENT-Continued.

form of, $26.5,291$.

form, when taken in another state, 278 .

how far evidence, 259 .

impeachment of, 293.

parts oi, 289.

what should show, 266, 268.

CERTIFICATE OF CONFORMITY, 279.

CERTIFICATE OF OFFICIAL CHARACTER, of officer taking acknowledgment, 275, 277, 278.

CHAMPERTOUS, conveyances invalid, 421.

CHAMPERTY, statutes against, 415 .

CHANCERY, power of court of, to authorize conveyance of infants' lands, 330 .

CHANGE, in character of neighborhood, as affecting right to enforce restrictione, 229.

CHILD, unborn, cannot be grantee of immediate eetate, 43 . may be grantee in remainder, $43, \mathrm{n}$.

"CHILDREN,"

"heirs" construed as, 40.

CHRISTIAN NAME, signing by, 237.

CHURCH SOCIETY, deed by, 241.

CIRCUMSTANCES, considered in construing conveyances, $181,183,187$.

“CIVIL DEATH," 413, 414.

CLERICAL ERRORS, in certificate of acknowledgment, 267 .

COKE'S, definition of deed, 19.

COLLATERAL LIMITATION, 173.

COMMISSIONER OF DEEDS, 276. 


\section{[References are to Sections.]}

COMmitTeE. See Guardian.

COMMON RECOVERY, 18.

by married women, 360 .

COMMON,

tenancy in, 156-158.

exceptions to rule favoring, 153.

tenant in, conveyance by, 157.

homestead of, 387 .

COMMON LAW DEEDS, 20.

“COMMUNITY SYSTEM," 167.

COMPETENCY,

of officer to take acknowledgment affected by interest, 281-288.

COMPETENT,

grantor may be shown to be, though in asylum, 333 .

COMPETITION, provisions restraining, 230.

CONCLUSION, of deed, 31 .

CONCLUSIVE, certificate of acknowledgment, when, 293.

CONCURRENT OWNERSHIP, 148-167.

CONDITIONAL FEE, 139.

CONDITIONAL LIMITATION, 175.

\section{CONDITIONS,}

capricious, may be disregarded, 186.

conveyances for specified purposes, not always on condition, 180 .

difficulties in construing, 176.

drawing and construing, 187.

express, 170.

forfeiture provided for, 179.

for commission of crime, void, 185.

for separation of husband and wife, void, 185 .

implied, 169.

imposing a general restraint on alienation, void, 186.

in short statutory deeds, follow the description, 178.

nominal, of no benefit, void, 186 .

place for, $31,178$.

precedent and subsequent compared, 172. 


\section{[References are to sections.]}

\section{CONDITIONS-Continued.}

precedent defined, 170.

impossible, grantee takes nothing, 170 .

through act of person imposing it, discharged, 170, $\mathrm{n}$.

unlawful, grantee takes nothing, 170.

repugnant to estate granted, void, 186.

restraining marriage, how far void, 185 .

subsequent, affirmative in character, 171 .

advantage can be taken of, only by grantor or his heirs, 171 .

characteristics of, 171.

construed strictly against grantor, 177 .

distinguished from estates on conditional limitation, 175.

upon deteruninable limitation, 173, 174.

expressed ambiguously construed as covenants, 177 .

grantor conveying subject to, has no estate, 171 .

impossible cannot defeat estate, 171.

negative in character, 171.

place for, 178.

preferred to precedent, 172.

re-entry clause in, 179.

technical words not necessary to create, 177.

until entry, the estate continues, 171.

unreasonably restricting use, void, 186.

void, when, 185, 186.

waiver of, 187.

words appropriate to, may make covenants, 223.

CONFIRMATION,

by court of sale of infant's lands, 328 .

CONFLICTING PARTS OF DESCRIPTION, 83, 84.

rules for construing, 84 .

CONFORMITY, certificate of, when acknowledgment in another state, 279.

CONSENT, parol, to alienatiou of homestead sufficient, when, 398.

CONSERVATOR. See Guardian.

CONSIDERATION, additional, evidence as to, 59. agreement to support as, 184.

assumption of mortgage as, 64 . contractual statement of, 63 .

effect of, in construing conveyances for special purposes, 181. equitable doctrine as to, 55 . 
[References are to sections.]

CONSIDERATION-Continued.

evidence of, different than that named, 60-61.

feoffment did not require, 53.

"good" and "valuable," 55.

inadequate, combined with weakness of mind, 341 .

necessity for, 52 .

not essential to sealed contract at common law, 245 .

parol evidence as to, 59 .

return of, on disaffirmance of infant's deed, 321.

on disaffirmance of insane person's deed, 346 .

"seal importing," 54.

third parties not bound by statement of, 67 .

true, may be shown, 61,64 .

may not be shown to defeat conveyance, 66 .

CONSTITUTIONAL OBJECTIONS,

to "Torrens System," 433, 436, 437, 438, 442.

CONSTITUTIONAL PROVISIONS,

as to separate estate of wife, 358 .

CONSTRUCTION, lex situs controls, 8 .

of deed as a whole, 132.

rule in Shelley's case not a rule of construction, 146 .

CONSTRUCTIVE EVICTION, 210.

"CONSTRUCTIVE OCCUPANCY,"

of homestead, 382.

CONSTRUCTIVE POSSESSION, 420.

CONSTRUING, conditions, 187.

difficulties in, 176.

CONSUL,

United States, certificate of, to acknowledgment in foreign language, 280, $\mathrm{n}$.

CONTINGENT REMAINDER, 144.

CONTRACT, courts do not make, 192.

deed of wife's lands in which husband not properly joined construed as, 364 .

married woman's unacknowledged deed not, 365.

reference to, for description, 97 . 
CONTRADICTION,

[References are to sections.]

between premises and habendum, 129.

CONTROL,

by grantor of deed in third person's hands, 308.

CONUSEE, 18.

CONUSOR, 18.

CONVERSION, equitable, question of, settled by lex situs, 8 .

"CONVEY,"

as operative word, 69 .

"CONVEY AND WARRANT,"

efiect of, 30, 211, 212, 213.

later words restricting, 130 .

CONVEYANCE,

between husband and wife, 368-371.

by alien, $410-412$.

by corporation, $240,406,407$.

by joint tenant, 150 .

by married woman, 355-372.

by parcener, 159 .

by tenant in common, 157 .

for specified use, when conditional, 180.

of community property, 167.

of estate by entireties, 166.

of infants' real property, 312-330.

of land held in adverse possession, 415-421.

party wall agreement in, 231.

CONVEYANCING,

includes what, 2.

CONVICTS,

capacity to take and convey real property, 413, 414.

COPARCENARY,

tenancy in, 159.

COPIES OF RECORDS,

as evidence, 259, 260.

CORPORATION,

acknowledgment, form, 294.

as party, 46.

capacity to alienate real property, 406, 407.

purchase and convey real property, i:01-407. 


\section{[References are to Sections.]}

\section{CORPORATION-Continued.}

effect of dissolution, 403.

execution of conveyance by, 240 .

may convey good title to land held in excess of power to hold, 405.

may take a fee though its duration is limited, 402.

officer of, may take acknowledgment when, 287 .

presumption that it holds only lands appropriate to corporate purposes, 404.

seal of, 249.

stockholder can not take acknowledgment of conveyance to, 285 .

what lands may hold, 404, 405.

CO-TENANT, conveyance by, $157,158$.

\section{COUNTERPARTS,} of indentures, 21.

\section{COUNTY,}

name of, part of notary's signature, 291.

named in description, 82.

COURSES AND DISTANCES, control description by monuments, when, 87 . statements of quantity, 84, 92 .

controlled generally by monuments, 84,87 .

COURT OF LAND REGISTRATION, 435.

COURTS,

what, have jurisdiction over guardian's conveyances, 324 .

\section{COVENANT,}

action of, 245.

an agreement under seal, 188.

deed may be without, 188.

grantee liable in action of, on assuming mortgage, 24 .

heir's liability on, 193.

"negative," 230.

not essential in a covenant, 191.

restraining competition, 230 .

to stand seised, 55 .

when conditional clause construed as, 177 .

COVENANTEE,

administrators of need not be named, 196 .

assigns, naming of in covenant, 197, 224, 232.

designation of, 196.

executors of need not be named, 196 .

heirs of, naming in covenant, $197,224$. 


\section{[References are to Bections.]}

COVENANTOR designation of, 192.

wife of, when not bound by covenant, 194 .

COVENANTS, 188-232.

as to party walls, whether run with the land, 232.

bind grantee in deed poll, 225.

broken do not run with the land, 219.

condition placed among, 178.

in law, 211.

in praesenti do not run with the land, 215, 217.

other than for title, 222-232.

form of such covenants, 223.

relating to party walls, 231.

pattern, 30.

personal, 221.

place for, 31 .

real, 221.

restrictive, 227.

running with the land, 214, 224, 232.

special, 190.

effect of, 188.

implied from "grant," 211.

COVENANTS FOR TITLE, 188-221.

designation of parties, 196.

executors and administrators named in, 193.

form of, 191.

husband joining in wife's conveyance, how far liable on, 194.

implied, 30, 211.

in mortgages, 189.

ineffective in void conveyance of homestead, 392.

place for, 191.

running with the land, 214-221.

pass by quitclaim deed, 220 .

special, 191.

succeeded the ancient warranty, 197.

usual covenants, 190.

against incumbrances, 199.

breach of, 200-203.

form of, 191, 199.

in a mortgage, 189.

runs with the land, when, 218.

when a covenant in futuro, 199.

for further assurance, 205.

breach of, 205.

rung with the land, 205. 


\section{[References are to sections.]}

\section{COVENANTS FOR TITLE-Continued}

usual covenants for quiet enjoyment, 206.

breach of, 206.

runs with the land, 219.

for seisin, 198.

breach of, 198.

runs with the land in some states, 216.

of good right to convey, 198.

of warranty, 206.

breach of, 206, 209, 210.

attaches only to estate granted, 207.

runs with the land, 219.

for title, wife of grantor not generally bound by, 194 .

\section{CREDITOR,}

of infant may not disaffirm deed, 319 .

of insane grantor may not disaffirm deed, 345 .

of grantor not bound by statement of consideration, 67 .

CRIME,

conviction and sentence for, effect, 414 .

CROSS,

as signature, 236.

"CURATIVE" ACTS, 258, n.

CURTESY,

at common law, 350.

none under community system, 167 .

\section{CUSTOM,}

authorized deed by married woman, where, 360 .

effect of, on contract for conveyance, 190.

\section{DAMAGES,}

for negligently preparing abstract, 425 .

not generally recoverable under the ancient warranty, 197, 206.

measure of, in action on covenant against incumbrances affected

by rent received by grantee, 202.

on breach of covenant for further assurance not sole remedy, 205. possibility of recovery of, not the sole advantage of covenants for title, 188

seldom sought for breach of restrictive covénants, 228 .

\section{DATE,}

deed valid without, 32 .

delivery presumed at, 33 .

figures or words for, 32 .

36-Brews. CoN. 
DATE-Continued.

\section{[References are to sections.]}

in certificate of acknowledgment, 34, 290.

in deed and certificate of acknowledgment, 34. generally controls date of acknowledgment, 34 . place for, 32.

recording within limited time after, 35 . true, may be shown, 35 .

DEATH,

delivery at grantor's, 305, 307.

of grantee in conveyance conditioned for support, 184.

of landowner, effect of under "Torrens System," 441, 443. questions on, 428.

wife's, effect on invalid conveyance of homestead, 394 .

\section{DECLINATION,}

of deed, effect of, 302 .

"DEDI,"

warranty implied from, 197, 211.

\section{DEDICATION,}

by husband alone, wife not dowable, 373 .

of streets and parks, 95 .

DE DONIS,

statute, 140.

in United States, 143.

DEED,

acceptance of, presumed when, 300,301 .

assignment indorsed, 70.

bargain and sale, 12, 56, 57.

conditions in, 168-187.

consideration in, 52-66.

construed in its entirety, 132.

conveys a present interest, $27,29$.

covenants in, 188-232.

date of, 32-35.

definitions of, 19.

delivery essential, 19, 296.

does not transfer title under "Torrens System," 434, 439.

description of property in, 73-118.

destruction of, effect, 311.

disaffirmance of, by infant, 315-318.

distinguished from contract to convey, 28.

from will, 29.

effect given to if possible, $25,58,69,79$. 
[References are to sections.]

DEED-Continued.

execution of, what, 233.

in consideration of support, 184.

insane person's, when void, 332 .

instrument in form of, may be inoperative, 29 .

Kent's form, 25.

kinds of, 20, 21.

married woman's, unusual at common law, 360 .

may be delivered though in grantor's possession, 298.

of corporation, 46, 240, 241, 406, 407.

operative words in, 15, 68-72.

appropriate to a will, 29.

parties to, 36-46.

parts of, 31 .

passing no present interest may operate as a will, 29.

possession of as evidence of delivery, 303 .

preserved a record of early transfers, 15.

recitals in, 47-51.

reference in one to another for description, 97.

seal essential, 19, 242.

short statutory form, 30 .

stolen, effect of, 299.

superfluous operative words, 15 .

tendency to shorten, 25.

to take effect at death, $29,305-308$.

under title registration acts, $434,439$.

warranty deed probated as will, 29.

without covenants for title, effect, 188.

DEED POLL, 21.

containing covenants by grantee, acceptance by grantee, 225.

effect, 24.

form, 22, 23.

DEFECTIVE,

certificate of acknowledgment, effect, 258, 260, 262.

DELIVERY, 296-311.

acceptance, as an element of, $298,300,301$.

if prevented, no delivery, 302 .

accomplished in many ways, 296.

at death of grantor, 305,307 .

blanks in deed filled after, 19, 39.

by insane grantor, 339 .

cancelation of grantor's name after, 311 .

date, may be shown, 35 .

presumption of, at date of deed, 33 .

deed should be completely written before, 19 . 


\section{[References are to Bections.]}

\section{DELIVERY-Continued.}

destruction of deed after, does not revest title, 311.

deposit among grantee's papers not, 306 .

elements of, 298.

essential to deed, 19, 296.

grantee's possession of deed does not show, 299, 303, 310.

grantor's intention as an element of, 299.

possession of deed after delivery, 306 .

retaining possession till death, generally no delivery, 30 ti.

in escrow, 309.

may not be to grantee, 309 .

manual, not necessary, 298.

name of grantee inserted after, 39.

not necessary, when, 297 .

not conclusively shown by records, 304,427 .

of conveyance from parent to child, 298.

patent of public lands needs no delivery, 297.

presumed from certain facts, 303, 304 .

recording, 304.

surrender and acceptance need not be concurrent acts, 302 .

takes the place of livery of seisin, 297 .

title passes on, 296.

title does not pass on, under Registration of Title Acts, $434,439$.

to third person, for grantee, 307 .

grantor reserving control of the deed, not delivery, 308.

\section{DEMANDANT, 18.}

DEMENTIA, 338.

\section{DEMISE,}

operative word, 72 .

\section{DEPOSIT,}

by grantor, of deed among grantee's papers not delivery, 306 .

with third person, 307 .

\section{DERIVATIVE DEEDS, 20.}

\section{DESCENT,}

alien could not acquire title by, at common law, 408 .

in parcenary, 159.

\section{DESCRIPTION,}

addition to sufficient description to be avoided, 83 .

certainty necessary, 75 .

conflicting parts of, 83.

controversies regarding, arise in a variety of ways, 73 .

course and distance control quantity, 92. 
[References are to Sections.]

DESCRIPTION-Continued.

construed liberally, 73.

essential, 73.

exception must be described, $78, \mathrm{n}$.

false, rejected, 85 .

general, allowable, 81 .

in contract, incorporated into deed by reference, 97 .

intention, when plain prevails, 86 .

maps referred to, 93, 96, 100.

monuments control courses, distances and quantity, 84 .

incorrect maps, 96 .

"more or less" in, 92.

notice to subsequent purchasers, 74 .

of land on water, 98-117.

of the property, 73-118.

parol evidence, can not supply, 76.

to apply, 75.

part of larger tract, 78.

particular, controls general, 86. place for, 73.

quantity in, 92.

rules for construing, 84 .

specific usually, 82 .

streets and ways in, 89.

uncertain, starting point, 80 .

void, 76, 77, 80, 81 .

uncertainty avoided, when, 78 .

DESTRUCTION,

of deed after delivery, effect, 311 .

DETERMINABLE FEE, 174.

DETERMINABLE LIMITATION, 173.

DEVISEE,

purchaser from, 428.

DIAGRAM,

of land described, 82

DISABILITY,

grantor's, arising from adveree possession, 415-421.

from alienage, 408-412.

from conviction for crime, 413-414.

from infancy, 313-323.

from insanity, 331-348.

legal and natural, 312

married woman's to convey, 359 . 


\section{[References are to sections.]}

DISA BILITY-Continued.

of corporations, $401-407$.

of disseisee, $415-421$.

of drunkard, 334, 338.

of tenant in tail, $140,143$.

DISAFFIRMANCE,

of deed by an infant, 315-318.

by infant, what constitutes, 322 .

by infant's heirs, 319 .

of insane person on restoration to sanity, 343 .

of insane person's deed against subsequent grantee, 347 .

restoration of consideration on, 321,346 .

DISCLAIMER,

by grantee, 300 .

DISQUALIFICATION, of witness, 253.

to take acknowledgment arising from interest, 281-28s.

DISSEISEE, conveyance of land by, $415-421$.

invalid at common law, 415.

by statute, 416 .

now generally valid, 421.

DISSOLUTION,

of corporation, effect of, 403.

DIVORCE,

effect on invalid conveyance of homestead, 394 .

on estate by entireties, $162, \mathrm{n}$.

\section{DOWER,}

barred by common recovery, 360 .

husband's sole act cannot generally defeat, 373 .

incumbrance, 201.

insane wife cannot release, 348 .

released under statutes, 348 .

none under community system, 167 .

not released generally to husband, 375 .

to a stranger, 374.

not shown by records, 429 .

release of, by attorney, 377 .

requires separate examination, when, 366 .

released generally by deed of both husband and wife, 376 .

not conveyed, 374.

wife joining in insane husband's deed doss not release, when, 332. 
DRUNKARD,

\section{[References are to Sections.]}

conveyance by, when void, 334 .

guardianship of, effect of, 334 .

DURATION, of restrictions as to use, 229.

\section{EASEMENT,} as appurtenance, 118.

grant of, in form of covenant, 223.

incumbrance, when, 203.

in fee appurtenant to other land, 125.

possession of, notice, 430.

reservation of, 119, 121, 125.

right of flowing passes as appurtenance, 118.

transferred by deed, 242.

EDUCATION, conveyance of infant's lands to provide for, 327.

\section{ELEMENTS,} of delivery, 298.

\section{ENGLISH RULE,} as to covenants running with the land, 215, 216.

\section{ENROLMENTS,} statute of, 12.

suggested recording to colonists, 422 .

\section{ENTIRETIES, .}

estate by, conveyance of, 166.

homestead in, 387.

husband may convey to wife, where, 166 .

not now general, 165.

tenancy by, 162-166.

effect of divorce, $162, \mathrm{n}$.

married woman's property acts as affecting, 164, 165.

in United States, 163, 164.

statutes regarding joint tenancy, as affecting, 164, 165 .

wife may convey to husband, where, 166 .

\section{ENTRY,} none necessary to terminate conditional limitation, 175 . to defeat estate on condition, 177. 
EQUITABLE,

[References are to sections.]

doctrines as to seal, 245.

interest in homestead transferred by defective conveyance, 397.

separate estate of married woman, 352, 355 .

not abolished by statutes creating separate estate, 358 .

title, corporation not organized has, as grantee, 46 . passes by instrument without seal, 245 .

EQUITY,

cancelation in, of conveyance in consideration of support, 184.

covenant for further assurance enforced in, 205.

doctrine of, as to consideration, 55 .

as to conveyances between husband and wife, 370 .

effect in, of infant's misrepresentation as to age, 320 .

forfeiture not enforced in, 184, $n$.

instrument without seal enforced in, 245.

no relief generally for grantee in deed without covenants for title, 188.

power of courts of, to authorize conveyance of infant's property, $324,330$.

wife's power in, over separate estate, 355 .

will enforce contract to purchase land of corporation acquired in exceas of power, 405.

will not aid corporation to acquire land in excess of power, 405.

will not enforce restrictions, when, 229, 230.

ERASURE,

forgery by, 426.

\section{ERRONEOUS DESCRIPTION,} rejected, 85.

\section{ESCHEAT,} on attainder, 413.

ESCROW, delivery in, 309.

grantee's wrongful possession, effect, 309.

ESTATE,

husband or wife joining in alienation of homestead has none, 390 . in which homestead may exist, 38i.

limited in habendum, 128.

\section{ESTATES TAIL,}

in United States, 142, 143.

kinds of, 140, 141. 
ESTOPPEL,

\section{[References are to Sections.]}

by misrepresentation as to age, 320 .

grantor not estopped to contradict recital of receipt of consideration, 59.

married woman estopped by covenents, when, 195 .

not applicable to transfers of homestead not complying with statute, 392.

of mortgagor by covenants in mortgage, 189.

silence on former infant's part not, 316 .

EUROPEAN SYSTEMS, of registering title, 433.

EVICTION, constructive, 210 , covenant of warranty a covenant against, 206. necessary to breach of covenant of warranty, 209. of grantee by grantor, when a breach of covenant, 210 . what is, 210.

EVIDENCE, acknowledgment as, 259.

of additional consideration, 60 .

of grantor's intention when street is boundary, 89 . parol, as to consideration, 59.

inadmissible to except incumbrance, 204.

to apply description, 75 . to identify grantee, 40.

records as, 259, 260.

to prove attested deed, 250 .

\section{EXAMINATION OF TITLE, 422-431.}

\section{EXCEPTION,}

and reservation, difference in effect of, 120.

annexed to one covenant, inapplicable to others, 208.

description of, $78, n$.

"excepting," "reserving," used synonymously, 123.

of incumbrance from covenant, 204.

of minerals, 124.

of part of property granted, 119-127.

of riparian rights, 100.

of timber, 124.

place for clause of, 122.

relates to thing in esse, 119.

repugnant to estate granted void, 126.

to rule that delivery is essential, 297 . 
EXCHANGE,

\section{[References are to Sections.]}

covenants implied in, 211.

primary deed, 20.

EXECUTE,

authority to execute sealed instrument, 245.

EXECUTION,

by corporation, 240 .

by one not named as party, 37 .

certificate of acknowledgment evidence of, 259.

includes what, 233.

of deed by attorney, 239 .

proved by grantor, when, 250 .

real property not taken on, at common law, 378 .

\section{EXECUTOR,}

covenantee's need not be named, 196.

deed of, recital in, 51 .

naming of, in covenants for title, 193.

when not bound by testator's covenant, 193.

EXEMPTION,

restraints on conveyance of homestead apply to right of, where, 97.

EXPIRATION OF COMMISSION, date of, to be stated by notary, 291.

EXPRESS, and implied covenants combined, effect o:, 212.

conditions, 170, 171.

warranty distinct from covenant, 197.

FALSA DEMONSTRATIO, 85.

FALSE DESCRIPTION REJECTED, 85.

FEE,

alienable generally, 1 .

arising by implication restricted in habendum 130 .

conditional, 139.

corporation may take though its duration is limited, 402 .'

determinable, 174.

"heirs" essential to creation of, 135.

when not necessary, 125, 136, 137.

qualified, 174.

reservation in, 119, 125.

statutes as to creation of, without "heirs," 136. 
FEE SIMPLE,

[References are to Sections.]

conditional, 139.

subject to special limitation, 174 .

FEE TAIL, 140.

a fee simple, where, 143.

FENCE,

covenant to, binds assigns, 225.

FEOFFMENT,

by insane person voidable, 336 .

by married woman at common law, 360 .

consideration not essential to, 53 .

consists simply and solely in livery of seisin, 11 .

conveyances equivalent to, when, $53,58,336$.

deed required for, when, 14 .

form, 14, 15.

in United States, 16.

recorded deed given effect as, 58 .

warranty implied, 197.

FICTITIOUS, name, deed valid to one in fictitious name, 43. person, deed to, invalid, 43.

FIDUCIARY RELATION, effect of, 341.

FILING,

for record without acknowledgment, effect, $258, \mathrm{n}$.

FILLING BLANKS, authority for, 39.

in certificate of acknowledgment, 267, 269, 271.

in forms for covenants of title, 192 .

FINE, 18.

advantage of, 18.

conveyance of married women by, 360,361 .

not usual in United States, 362.

FIRM NAME, conveyance in, 45.

FISHING, right of riparian owner, 107.

FOREIGN LAW, certificate of conformity to, 279 .

FOREIGN LANGUAGE, certificate of acknowledgment in, 280, $n$. 
FORFEITURE,

\section{[References are to Sections.]}

enforced against one attainted, 413.

by state against alien, 409 .

none, of land held by corporation in excess of power, 405 .

not enforced in equity, $184, n$.

\section{FORGERY,}

certificate of acknowledgment may be shown to be, 293 .

effect of, on title, 426 .

presumption against, from acknowledgment, 259.

records do not show, 426.

undelivered deed in grantee's possession as ineffective as if forged, 299.

what is, 426.

"FOR HIS HEIRS,"

covenant so expressed, effect, 192.

FORM,

of certificate of acknowledgment, 265 .

by corporation, 294 .

of covenants for title, 191 .

of deed poll, 22, 23.

of feoffment, 14.

of indenture, 22, 23.

of signature by attorney, 239.

FRAUD,

Coke's advice as to, 26.

effect of, in conveyance in consideration of support, 184.

in absence of, grantee assumes risk as to quantity, 92.

in public survey, 103.

inferred, when, 341 .

FRAUDS, see also Statute of FraUds.

statute of, required writing for feoffment, 14.

for release of dower, 376 .

title by voluntary transfer without writing, passes, how, 17 .

whether required deed to be signed, 233.

FRAODULENT CONVEYANCE, of homestead, $400, \mathrm{n}$.

FREEHOLD, transferred by feoffment, 11 .

"FULL COVENANTS," contract for deed with, 190.

FURTHER ASSURANCE, covenant for, 205. 


\section{[References are to sections.]}

FUTURE DELIVERY, dependent on performance of condition is in escrow, 309 .

\section{GAS COMPANY,} capacity to alienate real property, 407 .

\section{GENERAL DESCRIPTION,} allowable, 81.

controlled by particular, 86 .

GENERAL PLAN, restrictions in pursuance of, 228.

GIFT, parol, 17. primary deed, 20.

"GIVE, DEVISE AND BEQUEATH," as operative words, 29.

"GIVE, GRANT, BARGAIN AND SELL," as operative words, 72 .

GOOD FAITH, of grantee from insane person, effect of, 335,346 .

GOOD RIGHT TO CONVEY, covenant of, 198.

(iRANT, as operative word, 69,72 . "bargain and sell," effect of, 211. effect of, in statutory deeds, 211. instrument under seal, 242.

GRANT OF LAND ON STREET, grantee takes to center, 89.

GRANTEE, acceptance of deed by, presumed when, 300 . accepting deed without covenants for title, position of, 188. assuming mortgage, 24 .

assumption of mortgage by, must be shown by express acceptance of deed, 301 . incumbrance by, 204 .

blank as to, 38,39 . corporation as, 46. covenantor when, 222. death of, effect on conveyance conditioned for support, 184. deed uncertain as to, 40 . void for lack of, 38 . 


\section{[iieferences are to sections.]}

GRANTEE-Continued.

designation of, 38 .

erroneous designation of, 40.

identified by parol, 40.

in deed poll bound by covenants, 225 .

infant as, 19, 301, 323.

in warranty deed, his knowledge of defects immaterial, 208.

knowledge of incumbrance when material, 204.

may recover excess over true consideration, 64 .

must be in esse, 43.

name erroneous, deed valid, 40.

named in habendum, 133.

in premises usually, 38.

no delivery in escrow to, 309 .

of land on street takes to center of street, 89.

when takes entire way, 91.

partnership as, 45.

possession by, of undelivered deed, $299,303,310$.

rights of in street shown on map, 94.

should not be witness, 253.

subsequent, effect on, of insanity of prior grantor, 347 .

surrender of deed by, after delivery, effect, 311 .

surrendering to superior title, 210.

taking acknowledgment, 281, 282.

when must show that grantor acted freely, 341 .

\section{GRANTOR,}

corporation as, 46, 406, 407.

cannot take acknowledgment, 281.

covenanting "for his heirs," 192.

designation of, 37 .

estopped to deny existence of streets, 94 .

identity of, with person acknowledging, 271, 272.

intent to deliver deed, 299.

may use assumed name, 43.

mental capacity required in, 338 .

name same as that of previous grantee shows identity of person,

41.

named in deed not signing, 234.

not estopped by statement of consideration, 59 .

one, should not attest deed of others, 253.

possession of land by, after his conveyance, 431.

of deed by, after delivery, 306 .

signing by another, 238.

by mark, 236 ,

surrender of control of deed by, necessary to delivery, 298. 
GRANTORS,

\section{[References are to sections.]}

adoption of one seal by several, 248 .

whether husband and wife should both be, in conveyance of her land, 364 .

"GREAT LAKES," public grants on, 101.

title to bed, 112.

GUARDIAN, application by, to convey ward's lands, 326 .

assent of, to insane ward's conveyance ineffective, when, 332 .

bond of, on sale of infant's land, 326, 328 .

conveyance by, of infant's land, 324-ís0.

insane person's may convey how, 348 .

wife's, may not release homestead, 393 .

may not release dower, 348 .

may disaffirm insane ward's deed, 344 .

not convey ward's lands without authority, 324.

natural, may not convey ward's real property, 324 .

of insane person may not confirm deed, when, 342 .

GUARDIANSHIP,

insane person under, conveyance void, 332.

of drunkards, spendthrifts and others, 334.

of insane, while continues, ward presumed incompetent, 333 .

HABENDUM, 31, 128-147.

condition in or after, 178.

contradiction between habendum and premises, 129 .

enlarges estate granted in premises, when, 130, 131.

estate arising by implication from the premises may be abridged

by, 130.

limited in, 128.

grantee named in, 133.

not essential to a deed, 128.

one named in, but not in premises may take in remainder, 133.

reconciled with premises if possible, 132.

repugnant as to estate in premises, void, 129.

trusts declared in, 134.

HEAD OF FAMILY, entitled to homestead, 380 .

HEARING, on application to convey infant's lands, 328.

to register title, 438.

"HEIR OF," as describing party, 44 . 
HEIRS,

conveyance by, discovery of will, 428 .

covenantee's, naming of, 196, 197 .

deed to heirs of a living person when void, 40 .

grantor covenanting for, 192.

infant grantor's, may disaffirm his deed, 319.

insane grantor's, may disafirm bis deed, 345 .

lex situs determines who are, 7 .

liability of, on ancestor's covenants, 193.

uncertainty as to, 428 .

"HEIRS,"

"construed as children," 40.

necessary to create a fee, 135 .

estate tail, 141.

statutes as to use of, 136.

when a word of purchase, 146 .

when necessary in reservation, 119 .

when not needed to create a fee, 125, 136, 137.

"HEIRS AND ASSIGNS,"

efiect of, in covenants, 214, 2:4.

"HEIRS OF BODY,"

effect of, 139, 140.

HIGH WATER MARK, in rivers, 109.

shore below not private, 104 .

\section{HIGHWAY,}

as boundary, 89, 90, 91 .

grantee, generally takes to center, 89 . takes entire when, 91.

not always an incumbrance, 203.

"HIS MARK,"

when used, 236.

HOME,

occupancy as, essential to homestead, 384 .

HONESTEAD, 3i8-400.

abandonment of, 383 .

after invalid conveyance, 394 .

arknowledgment to converance of, 263,399 .

alienation of, void when, 392 .

constitutional provisions as to, 378 .

"constmetive occupancy," 382. 


\section{[References are to sections.]}

\section{HOMESTEAD-Continued.}

conveyance of, between husband and wife, 400 .

defective, valid as to excess, 396 .

not void where, 397 .

of reserving "homestead right," 397.

or release of, separate examination neeled when, 366 .

extent of, 386.

federal, $378, \mathbf{n}$.

grant of right of way over homestead premises, 395 .

hotel as, 384 .

insane wife's release of, 348 .

in estates less than fee, 387 .

laws providing for, liberally construed, 378 .

lease of, 395 .

mode of conveying, 398 .

not generally shown by records, 427 .

occupancy essential to, $382,383,384$.

as a home, 384 .

partial restraints on alienation of, 388 .

restraints on alienation of, $388,389,390$.

selection of, 385 .

by record, 385 .

by occupancy, 385 .

who may have, 379 .

HOTEL,

as homestead, 384 .

HOUSEHOLDER, entitled to homestead, 379.

\section{HCSBAND,}

as custodian of wife's deed, 298.

assent of, to wife's conveyance, how shown, 37 .

cannot generally defeat dower by his sole act, 373 .

conveyance to wife creates separate estate, 352.

executing wife's conveyance, 37 .

insane, statutes for release of his interests in wife's land, 348.

joinder of in wife's fine, 361 .

in wife's conveyance, $362,363$.

joining in wife's deed when liable on covenants, 194.

power over community property, 167 .

right to convey estate by entireties, 166.

rights of, in wife's property at common law, 350 .

wife cannot generally release dower to, 375 .

3i-Brews. Con. 


\section{[References are to Bections.]}

HCSBAND AND WIFE, conveyance between, 166, 368-371. of homestead between, 400 .

grant to, creates estate by entireties, 162.

joint act necessary in alienation of homestead, 398.

must generally concur in alienation of homestead, 390 .

separation agreemente, 375 .

ICE,

in navigable rivers, ownership of, 107.

IDEM SONANS, 42.

IDENTITY, of name shows identity of person, $41,281$.

of party acknowledging with grantor, 271, 272.

IDIOCY, 338.

ILLEGAL ACTS, condition requiring void, 185 .

ILLEGAL CONSIDERATION, may not be shown by grantor to defeat deed, 66 .

IMPEACHMENT, of certificate of acknowledgment, 293.

IMPLIED CONDITIONS, 160.

IMPLIED COVENANTS, 30, 211. words necessary for, 212.

IMPRISONMENT, effect on capacity to take and convey title, 414.

IMPROVEMENTS, after gift, 17.

INADEQUATE CONSIDERATION, effect of, 341 .

INCHOATE RIGHT OF DOWER, not property, 374.

INCORPOREAL INTERESTS, tranferred by grant, 242

\section{INCOMBRANCES,} certain incumbrance not shown by records, 429 . covenant against, 199. land "subject to," 208. not breach of covenant of warranty, 209. what are, 200-203. whether covenant against, runs with the land, 218. 
[Réferences are to sections.]

INDEFEASIBLE ESTATE IN FEE, when needed to satisfy covenant for seisin, 198.

\section{INDEMNITY,} covenants for title intended to indemnify, 215, 216.

INDENTURE, 21.

effect, 24.

form, $22,23$.

more usual than deeds poll, 23.

technically appropriate when covenants are to bind grantee, 225 .

IN ESSE,

grantee must be, 43,46 .

INFANCY, not shown by records, 427.

INFANT,

as grantee, 323.

conveyance by, in general, 312-330. voidable, 313 .

deed of infant and of insane person similar, 331 .

disaffirmance of conveyance by, 315-318.

how soon after majority must be, 316,317 .

not during minority, 315 .

of deed by, what constitutes, 322 .

though land held by subsequent purchaser, 318 .

guardian can not convey land of, without special authority, 324 .

heirs of, may disaffirm deed, 319.

land of, conveyed for certain purposes, 327 .

may repudiate purchase at majority, 323 .

misrepresentation of age by, 320 .

one in possession under deed of, does not hold adversely, 419.

parent can not convey land of, 324 .

power of attorney of, void, when, 314 .

real estate of, conveyed, how, 324 .

restoration of consideration on disaffirmance by, 321 .

right of former, to disaffirm deed is personal, 319.

statute authorizing conveyance of lands of, must be strictly followed, 325.

statutes affecting right to disaffirm, 320, 321 .

unborn, can not be grantee of immediate estate, 43. may be grantee of estate in remainder, $43, n$.

INFERENCE,

condition not created by, 184 .

INFLUENCE, undue, presumed when, 341 . 


\section{INHERITANCE,}

\section{[References are to sections.]}

words of, not needed in exception, 120.

IXITIALS, signing by, 237 .

IN REM, proceeding to sell infant's lands, 326 .

INSANE HUSBAND, wife may by statute convey without joinder of, 363 .

INSANE PERSON, conveyance of lands of, 331-348.

deed of, may be aftirmed by him while sane, 342 . disaffirmed by him while sane, 343 . generally voidable, 335 . whether transwits title, 337. disaffirmance, restoration of consideration, 346 . lands of, statutes authorizing conveyance of, $3+8$. under guardianship, conreyance void, 332, 333.

INSANITY, adjudication of, without appointment of guardian, effect of, 333 . kinds and degrees of, 338 . not shown by records, 427 . partial, effect of, 340 . question as to, must relate to time of act, 338,339 weakness of mind not, 340 . wife's, does not make valid busband's sole deed of homestead, 393 .

\section{INSTRUMENT,}

recital in, as to sealing, effect of, 247 .

INSLRANCE, of title, 432 .

\section{INTENT,} essential element of delivery, 299. grantor's, to deliver must be evidenced by acts, 299, 306. of parties given effect if possible, 25, 58, 19, $132,190$. to create condition should be expresed. 150. exception or reservation shnulil be made clear, 121 . separate estate must be expressed, 353 .

INTEREST, disqualifies witness, 253.

of officer taking acknowledgment, 281-283.

undisclosed as affecting competency to take acknowledgment, 285,286 


\section{[References are to Sections.]}

INTERPRETATION,

rule that grantee takes to center of way, a principle of interpretation, 89.

INTOXICATING LIQUORS, condition not to sell valid, $171,179$.

parol agreement not to sell, may be shown as part of consideration, 61.

restriction against selling, 230 .

INTOXICATION, insanity caused by, 338 .

IRREGULARITIES, in sale of infant's land, cured by statute, 329 .

ISLANDS, in navigable rivers, 107 .

JOINT ACT, of husband and wife, generally necessary in alienation of homestead, 398.

JOINT DEED, of husband and wife of wife's lands, $362,363,364$.

in alienation of homestead, $390,398$.

wife joining with insane husband as grantor does not make, 332.

JOINT ESTATE, homestead in, 387.

JOINT TENANCY, 149-155.

abolished, where, 155 .

alienation of estate, 150 .

created, how, 152.

exceptions to rule that it is not favorel, 153.

not favored, 151.

statutes as to, apply to estate by entireties, 165 .

JOINT TENANTS, partition among, 160.

JUSTICE OF THE PEACE, certificate of clerk when necessary to acknowledgment before, 275.

may abbreviate official title to J. P., 291.

not generally required to have a seal, 292 .

KNOWLEDGE,

grantee's as to incumbrance, effect of. 203, 204.

as to grantor's insanity, effect of. 3\%. 346. 
"KNOWN,"

\section{[References are to Sections.]}

in certificate of acknowledgment, 272.

\section{LACHES,}

effect of, on right to enforce restrictions, 229 .

LAKES,

beds of, privately owned, 116.

boundries on, 111.

common law as to ownership of bed, 113.

conflicting views as to private ownership of bed, 114.

effect of Massachusetts' colonial ordinances as to "great ponds,"

$111, \mathbf{n}$.

meandered, public in some states, 112, n., 117.

ownership of bed, 113.

sectional line rule, 115 .

state owns beds of great lakes, 112

all in some states, 117 .

LAND,

not appurtenant to land, 99, 118.

LAND REGISTRATION, court of, 435 .

LANDMARKS, control courses and distances, 84.

“LAWFULLY SEISED," effect of, 198.

LEASE, implied covenants in, 211. incumbrance when, 202. of homestead, 395 .

LEASE AND RELEASE, 13.

LEGAL SEPARATE ESTATE, of married women, 358.

LEX LOCI CONTRACTUS, effect of, when covenants implied, 213.

LEX SITUS, 2-10.

contract for deed controlled by, 190.

controlling, reason for doctrine, 5 .

effect of, when covenants implied, 213.

limitations on doctrine, 10.

married woman's deed governed by, 365 . 
"LIE IN GRANT,"

\section{[References are to Bections.]}

incorporeal interests, 242.

LIEN,

declared in conveyance conditioned for support, 184 .

LIFE ESTATE, created in absence of "heirs," 135.

homestead in, 387 .

\section{LIMITATION,} collateral, 173.

conditional, 175.

determinable, 173.

infant has statutory period of limitation in which to disaffirm, 316.

special, 173.

\section{LIMITS OF HOMESTEAD, 386.}

\section{LITERARY CORPORATION,} deed by, 241.

\section{LIVERY OF SEISIN,} abolished, 16, 53.

by infant, effect, 314 .

deed delivered equivalent to, 297.

feoffiment consiste of, 11, 14 .

in United States, 16.

"L. 8.,"

not a seal, when, 246.

LUCID INTERVAL, grantor may affirm voidable deed during, 342.

LUNACY, 338.

MAINTENANCE, statutes against, 415 .

MAJORITY, how soon after, infant must disaffirm deed, 316, 317. infant may not disaffirm deed before, 315 .

MANUAL DELIVERY OF DEED, not always essential, 298.

MAP, incorrect controlled by monuments, 96 . may aid description though not referred to, $\mathbf{9 5}$. referred to incorporated in description, $93,100$. streets shown on, grantee's rights in, 94 


\section{MARK,}

\section{[References are to sections.]}

signing by, 236.

MARRIAGE,

not essential to acquisition of homestead, 379,380 .

property acquired by wife after, whether separate estate, 358 . restraint of, by condition, 185.

settlement, form, 36 .

valuable consideration, 55 .

MaRRIEd WOMan. See, also, Husband and Wife.

ack nowledgment by, $261,264,365,367$.

alienation by at common law, 360 .

covenants in deed of, 195.

deed of husband's joinder in, 362,363 .

disabilities, exist unless removed by statute, 359 .

generally, 349-377.

equitable separate estate of, 352-357.

intention to create separate estate of, must be expressed, 353 .

legal separate estate of, 358.

not liable on covenants, when, 194, 195.

power over separate estate, 355 .

of, to convey statutory separate estate, 359 .

of attorney by, 377 .

restraint on anticipation, 354 .

separate examination of in acknowledging, 360, 365-367.

sole deed when authorized, 363 .

statutory separate estate of, 358 .

MARRIED WOMEN'S ACTS,

effect of, on conveyances between husband and wife, 371 . estate by entireties, 164, 165 .

MEANDER LINE,

not generally a boundary, 102 .

when a boundary, 103.

MEANDERED LAKES,

public where, 117.

MENTAL CAPACITY, degree required, 338.

MILL,

right of flowage appurtenant to, 118.

MINERALS,

exception of, 124.

ownerships of, may be distinet from that of surface, 148.

reservation of right to remove, 124 .

transfer of, in homestead premises. $\$ 95$. 
[References are to Sections.]

MINORS. See Infant.

MISREPRESENTATION, by infant, of his age, effect, 320 .

MISTAKE, in public survey, 103.

MONOMANIA, grantor's, does not make deed void, 340.

MONUMENT, controls course and distance, 84,87 . incorrect map, 96.

part of, taken as boundary, 88. usually named in description, 82. what may be, 87 .

"MORE OR LESS," effect of, 92 .

MORTGAGE, assumption of by grantee must be shown by acceptance, 301 . in deed poll, 24. may be shown by parol, 65 .

covenants for title in, 189.

excepted from covenant against incumbrances not from covenant of warranty, 208.

implied covenants in, 212. incumbrance, 201. not allowed of homestead when, 388 .

not breach of covenant of warranty, 209. purchase-money, superior to dower, 373. short form, 30.

MORTGAGOR, estopped by covenants, 189 .

MORTMAIN, statutes of, 401.

MUNICIPAL CORPORATION, capacity to alienate real property, 407. deed by, 241.

NAME, additions to, by recital, 44 . correct name desirable, 41. deed need not be signed by, 236. execution of deed with grantee's, blank, 39. 
NAME-Continued.

fictitious, 43 .

firm name, describing grantee by, 45.

grantee may be designated otherwise than by name, 38 .

idem sonans, 42.

identity of, shows identity of person, 41, 281.

initials of, in signing, 237.

mark as grantor's, 236.

middle name, 42.

one name at common law, 42.

parol evidence to show grantee when name erroneous, 40.

part of, in signing, 237.

NATURAL MONUMENT, preferred to artificial, 84.

NAVIGABILITY, how far the test of public ownership at common law, 105, 108. test of, un reliable, 108.

NAVIGABLE,

river, bed privately owned, where, 105, 106. public grant on, 101.

when rivers are, 110.

NAVIGATION, private ownership subject to public right of, 106 .

NEGATIVE CONDITIONS, 171.

NEGATIVE COVENANT, 230.

NEGATIVE EASEMENT, shown by parol, 61.

NEXT FRIEND, action by, to disaffirm insane person's deed, 344 . application by, to convey infant's lands, 326.

NOMINAL CONDITIONS, 186.

nON COMPOS Mentis. See Insanity, Insane Prosons.

NON-NAVIGABLE RIVERS, 110.

NON-RESIDENT, alien, may not always hold lands, 411 . restraints as to alienation of homestead inapplicable to, 381 .

NON-TIDAL, NON-NAVIGABLE RIVERS, riparian owner's rights, 110. 
[References are to Sections.]

NON-TIDAL WATERS,

public grants on, 101.

NOTARY PUBLIC,

date of expiration of commission to be stated, 291 .

interested should not take acknowledgment, 281-283, 285.

may not always take acknowledgments, 273 , n., 274 .

name of his county part of his official signature, 291.

residence, statement of when required, 291.

seal of, effect, 278.

signature official, not personal, 291.

NOTICE,

from possession, 430.

by grantor after conveyance, 431 .

from recitals, 49.

from records, 74, 422.

improperly recorded instrument not, 2.5s, 366 .

of application for conveyance of infant's lands, 326.

to register title, 436.

of grantor's insanity, effect of, 335,346 .

of incumbrance by grantee, effect of, 203, 204.

purchaser with notice of restriction bound, 228 .

tenant's possession, notice of landlord's title, 430 .

to one co-tenant of adverse possession of another, 158 .

NUMBER,

sale of lot by, 95 .

OCCUPANCY,

of homestead, 382, 383 .

selection of homestead by, 385 .

OCCUPATION, party's, as means of identification, 44.

OFFICE FOUND, alien may convey before, 410 . hold until, 409.

not necessary to vest title in state on alien's death, 410 .

OFFICER, of corporation, whether may take acknowledgment, 287 .

OFFICIAL CHARACTER,

of officer of another state, taking acknowledgment, how shown, 278.

OFFICIAL SEAL, what intended, 292. 


\section{[References are to sections.]}

\section{OFFICIAL SIGNATCRE,}

to certificate of acknowledgment, 291.

OLD AGE, dementia from, 338 .

impairment of mind by, does not always overcome presumption of sanity, 340 .

OPERATIVE WORDS, 63-72. essential, 71 .

"assign" as, 70 .

"convey" as, 69.

"exchange" as, 68.

"give, devise and bequeath" as, 29.

"give, grant, bargain and sell" as, 72 .

"grant" as, 69, 72, 211.

"grant, bargain and sell" as, 211.

"remise, release and quitcluim," as, 57.

"waive and renounce," not, 71 .

"warrant and defend," not, 71 .

superfluous, 69.

ORDER OF PARTS, of deed, 31 .

ORIGINAL DEEDS, 20.

OUSTER, of co-tenant, 158.

of possession, invasion of rights are not always, 420 .

OWNERSHIP, concurrent, 148-167.

\section{PARCENARY,} estate in, 159.

\section{PARENT,}

as custodian of child's deed, 298, 301 .

may not convey child's real property, 324,326 .

PAROL,

assent, of husband to wife's deed not enough, 364 . authority to fill blank, 39 .

wife may not bar dower by, 376 .

\section{PAROL EVIDENCE,}

admissible to show real grantee, erroneously named, 40 . can not supply description, 75 .

inadmissible to except incumbrance from covenant, 204. of additional consideration, 60 . of negative easement, 61 . rule, 59-62. 
[References are to Sections.]

PARTICULAR DESCRIPTION, controls general, 84, 86.

PARTICULARS,

to regard in description, 82 .

PARTIES, 36-46.

conveying, should be grantors, 37 .

designation of, 36 .

in covenants for title, 192.

essential to deed, 36 .

order of, 36.

partnerships as, 45.

PARTITION,

deed of, 160.

parol, 161.

PARTNER, cannot take acknowledgment, when, 28.5.

may not generally have homestead in partnership property, 387.

PARTNERSHIP,

as party, 45 .

PART,

of larger tract designated, 78.

PARTS,

of certificate of acknowledgment, 268, 289.

of deed, all reconciled if possible, 132.

the several, of the deed, 31 .

PARTY,

cannot take acknowledgment, 281.

PARTY WALL,

agreements as to, not always in a conveyance, $222,232$.

may be personal, 232.

run with the land, 232.

covenants as to, 231.

PATENT,

by government, recorded, need not be delivered, 297 .

not invalid because of adverse possession, 41 ?.

"PERSONAL COVENANTS," 221.

action on, effect of lex loci contractus, 213.

law of place not controlling, 10.

PERSONAL PROPERTY,

not appurtenant to land granted, 118. 


\section{[References are to sections.]}

"PERSONALLY KNOWN,"

in certificate of acknowledgment, 272.

Persons of Unsound Mind. See Insane Person, Insanity. conveyance of real property of, 331-348.

PHYSICAL INCUMBRANCES, 203.

PLACE,

for clauses of exception and reservation, 122.

for condition, 178.

for covenants for title, 191.

for signature of grantor, 235.

witness, 252.

of taking acknowledgment, how determined, 289.

PLANK ROAD COMPANY, capacity to alienate real property, 407 .

PLAT,

reference to in description, 93.

showing building line, effect of, 227.

statutory, 95.

streets shown on, grantee's rights in, 94 .

POND,

boundary on, 111 .

ownership of bed, 113 .

POSSESSION,

adverse by one co-tenant, 158.

conveyance of land held in, 415-421.

notice of possessor's title, 430 .

of deed by grantee as evidence of delivery, 303 .

of delivered deed by grantor, 298.

of land by grantor after conveyance, 431 .

referred to record title, 430.

seisin signifies, 198.

title not acquired by, under "Torrens System," 440.

unity of, in tenancy in common, 156.

POSTPONING DELIVERY, till grantor's death, 305.

POWER OF ATTORNEY, acknowledgment of conveyance under, 294.

by infant, when void, 314 .

form of deed poll, 23.

of insane person, 336

of married woman, 377 .

signing under, 239. 
[References are to Sections.]

PRECEDENT CONDITIONS, 170.

PREMISES, habendum repugnant to, void, 129.

limitation of estate in, 128.

of deed, includes what, 31 .

\section{PRESUMPTION,}

from identity of name, $41,281$.

of delivery from recording deed, 304 .

PRESUMPTION, of sanity, 340 .

of undue influence, 341 .

that grantor of land on highway reserves no part of it, 89, 90 .

that land held by corporation is held for corporate purpose, 404 .

that possession is under record'title, when, 430.

when grantor conveys land on water, 99.

PRETENDED TITLES, transfer of, 415.

PRIMARY DEEDS, 20.

PRINCIPAL, name of, signed by attorney, 239 .

PRIVATE CORPORATION, capacity to alienate real property, 406.

PRIVATE OWNERSHIP, of beds of great lakes, 112.

PRIVY EXAMINATION, of married woman, 360, 365-367.

PROOF, acknowledgment dispenses with, 255. instead of acknowledgment, 295.

PUBLIC CORPORATION, capacity to alienate real property, 407 .

PUBLIC GRANTS, meander line, 102. on waters, 101.

PUBLIC OWNERSHIP, of beds of great lakes, 112.

PUBLIC SURVEYS, 102. 
PIRCHASE,

alien could acquire title by, at common law, 408 .

PURCHASE-MONEY MORTGAGE, superior to dower, 373.

PURCHASER, how far takes the risk of sanity of prior grantors, 347 .

of infant's lands under statute presumed to have knowledge of all proceedings, 325 .

right to relief if title defective, depends on covenants, 188.

PURPOSE,

of acknowledgment, 257 .

of deed shown by recital, 48 .

PLRPOSES, conveyances for special, $180,181$.

QLALIFIED FEE, 174.

QLANTITY, statement of, when important, 92.

QUIA EMPTORES, statute, 31,174 .

QUIET ENJOYMENT, covenant against incumbrances connected with covenant for, 199. coveuant for, 206.

not broken by wrongful eviction, 210 . runs with the land, 219.

\section{QUITCLAIM DEED,} effect of, on title, 188.

grant of "right, title and interest" equivalent to, 207.

grantee in, has benefit of covenants that run with the land, 220.

RAILROAD COMPANY, capacity to alienate real property, 407 .

RAILROAD, right of way, incumbrance, 203.

RATIFICATION, by infant of conveyance to him, 323 . during lucid interval, 342 .

infaut's conveyance passes title without, 313 .

"REAL" COVFXANTS, 221.

party wall agreement may be, 232. 
[References are to Sections.]

REASONABLE TIME,

infant must disaffirm within, after majority, 317.

RECALL, grantor reserving right to, no delivery, 308.

RECALLING DEED, before acceptance, 302 .

RECEIPT, of consideration may be contradicted, 59,63 .

RECITAL, as to seal, effect of, 247 . containing history of title, 47. ignorance of, no excuse, 49.

in ancient deeds, evidence, 44. in deed as to delivery on grantor's death, 307. in deed poll, 22.

notice from, 49.

of power of attorney, 239. prima facie evidence, 51 . required when, 50 . useful though not required, 51 .

\section{RECORD,}

acknowledgment necessary to, 258.

copies of, as evidence, $259,260$.

defects in title not shown by, 426-431.

liability to err in indexing, 432.

notice from, when description adequate, 74 .

of defectively acknowledged instrument, not effective, 258, 260, 366.

of homestead, 385 .

of properly acknowledged deed admitted in evidence, 259, 260.

title by, not always reliable, 304,306 .

witnesses sometimes necessary to record deed, 251.

RECORDABLE INSTRUMENT, not always admissible in evidence without proof, 260.

\section{RECORDED,} deed, equivalent to feoffment, 336.

\section{RECORDING,} as evidence of delivery, 304 .

\section{RECORDING SYSTEM,} characteristics of, 422 .

38-Brews. Con. 


\section{[References are to Bections.]}

PECOVERY, 18.

REDDENDUM, 31.

RE-ENTRY CLAUSE, 179.

REFERENCE,

in deed to description in other instrument, 97.

to maps, 93, 100.

REGISTRATION OF TITLE, 432-443,

adverse possession after, cannot give title, 440 .

appearance of parties defendant, 438.

application to register, 435.

assurance or indemnity fund, 442.

certificate of title, $437,439$.

compulsory, or voluntary, 443.

constitutional objections to, 433, 436, 437, 442.

dealings with registered land, 439.

decree, effect of, 438.

effect of death of owner of registered land, 441, 443.

examiner's functions, $43 \%$.

general principles, 434.

initial registration, $434,435,438$.

in what states acts provide for, 433 .

notice to adverse claimants, 436 .

parties to the proceedings, $435,436,437$.

proceedings are judicial, 435.

process, 436.

RELATIONSHIP,

to parties as affecting competency to take acknowledgment, 284.

\section{RELEASE,}

by disseisee, to one in adverse possession, valid, 419.

consideration clause in form of, 59.

of sealed instrument must be sealed at common law, 245 .

RELIGIOUS CORPORATION, deed by, 241.

REMAINDER, 144.

one first named in habendum may take, 133.

REMEDY,

for breach of covenant for further assurance, 205.

of warranty, 206.

in equity, for violation of condition to eupport, 184 .

restrictive covenants, 227. 


\section{[References are to Sections.]}

RENT,

reeervation of, in reddendum, 31 .

vendee's right to, does not relieve grantor from liability on covenant, 202.

\section{REPUGNANT,} condition, void, 186.

exceptions and reservations void, 126.

habendum, void, 129.

\section{RESERVATION,}

creates new interest, 119.

exception, difference in effect of, 120 .

grantor's, of rights to water, 100.

in general, 119-127.

of an easement, 121, 122.

appurtenant to other land of grantor, 125.

of right to take minerals, timber \&c., 124.

repugnant to estate granted, void, 126.

"road" reserved, an easement, 121.

to third party, 127.

words of inheritance necessary, when, 119. unnecessary, when, 119, 125.

RESIDENT, entitled to homestead, 380.

RESIDENT ALIENS, privileges accorded, 411, 412.

RESTORATION OF CONSIDERATION, on disaffirmance of infant's deed, 321. insane person's deed, 346.

\section{RESTRAINT,}

on alienation in general, void, 186.

\section{RESTRAINT OF MARRIAGE,} by condition, 185 .

RESTRAINT ON ANTICIPATION, 354.

RESTRAINTS ON ALIENATION OF HOMESTEAD, apply generally to married persons, 379,380 .

\section{RESTRICTED COVENANT,} when does not affect other covenants, 208.

\section{RESTRICTION,} building, 182, 227, 228.

enforced how, 227, 228.

notice of, from recital, 49 . 
RESTRICTION-Continued.

on alienation, 312.

on use not void, 186.

right to enforce, how lost, 229.

RESULTING USE, 55.

REVERSION, 144.

\section{RIGHT OF WAY,}

grant of, over homstead premises, 395 .

incumbrance, 203.

reservation of, $120,121$.

"RIGHT, TITLE AND INTEREST,"

effect of these words, 207.

\section{RIPARIAN RIGHTS,}

controlled by state laws, 104, 112.

on lakes, 117.

reserved, 100.

\section{RIVERS,}

as monuments, 87

"bank," effect of in description, 100.

bed of navigable, privately owned, when, 105, 106 .

islands in, owned by shore owner when, 107 .

meander line not a boundary, 102.

navigable, when, $105,110$.

non-tidal and non-navigable, private, 110.

ownership of ice on navigable, 107.

private title to bed in some states, 106.

of navigable, not recognized where, 108.

"shore," effect of, in description, 100.

tidal, public, 105.

three rules as to ownership of bed, 109 .

ROYAL CHARTERS, rights under passed to states, 104.

RULE IN SHELLEY'S CASE, 145-147.

RULES, for construing description, 84 . flexible, 84, 86, 87.

\section{RUN WITH THE LAND,}

covenants for further assurance run, 205.

covenants may when, 224 .

whether covenants against incumbrances do, 199.

depends on their nature, $215,224$. 


\section{SANITY,}

\section{[References are to Sections.]}

deed made on restoration to, effect, 343. presumption of, 340 .

"SCRA WL,"

a seal in some states, 246 .

SCROLL,

a seal in some states, 246.

"SEAL,"

not a seal in some states, 246.

SEAL,

adoption of that on instrument, 248.

corporate, 240, 249.

effect of statute abolishing use of, 243 .

effects of, 245.

essential at common law, 19, 242, 244.

"importing consideration," 54, 245.

in general, 242-249.

notary's, effect of, 278.

of commissioner of deeds, 276 .

of officer taking acknowledgment, 278, 280, 292.

still required in some states, 246.

what is sufficient, 246.

SEALED INSTRUMENT, limitation of actions on, 245.

SECURITY,

by guardian on sale of infant's lands, 326 .

\section{SEISIN,}

covenant for, 198.

livery of, 11.

abolished, 16.

signifies possession, 198 .

whether covenant of, runs with the land, 216.

SELECTION,

of homestead, 385.

SEPARATE ESTATE, intention to create must be expressed, 353 .

of married woman, 352.

effect of statutes on, 357 .

her power over, 355 .

method of conveying, 356 . 


\section{[References are to Sections.]}

SEPARATE EXAMINATION, of married woman, $360,361,365,366$.

of wife in conveyance of homestead, 399.

\section{SEPARATION AGREEMENTS,} between husband and wife, 375 .

\section{SHAREHOLDER,} cannot take acknowledgment, when, 285.

SHELLEY'S CASE, rule in, 145-147.

SHERIFF, abolished, 147.

deed of, recitals in, 50 .

"SHORE," effect of, in description, 100 .

private title not beyond, when, 117 .

SHORE OWNER, on great lakes, extent of title, 112.

\section{SHORT FORM,} deeds usually dated, 32 . not always useful, 26.

\section{SHOOTING,}

rights of, on navigable rivers, 107.

SIDE, of way as boundary, 90 .

\section{SIGNATURE,}

form of, 236, 237.

genuinenese of, not shown by records, 426 .

name not necessary to, 236.

notary's official, county part of, 291.

to deed, place for, 235.

\section{SIGNING,}

by another, 238.

by assumed name, 43.

by corporation, $240,241$.

by mark, 236.

by officer taking acknowledgment, 291.

deed by one not named as party, 37 .

in general, 233-241.

name not necessary, 236.

not essential to deed at common law, 233.

now generally necessary, 234 .

under power of attorney, 239. 
SILENCE,

\section{[References are to Bections.]}

after majority, not affirmance of infant's deed, 316.

SOCIETY,

literary or religious, deed by, 241.

"SOLE AND SEPARATE USE,"

in creating separate estate, 353.

SOLE DEED, of wife, when authorized, 363 .

wife's, will not bar dower unless authorized by statute, 376 .

SPECIAL COVENANTS, implied, 211.

SPECIAL LEGISLATION, authorizing conveyance of infant's land, $330, \mathbf{n}$.

SPECIAL LIMITATION, 173.

SPENDTHRIFT, conveyance of, when void, 334.

guardianship of, effect of, 334 .

STARTING POINT, uncertain in description, 80.

STATE,

cannot be disseised, 419 .

each has power to regulate conveyance of infants' lands, 324.

grant from, on water, 101.

named usually in description, 82.

only, may complain of alien's holding real property, 409.

of corporation's holding land in excess of power, 405.

power of, to remove alien's disabilities, 412.

to regulate transfere, 3.

"BTATED,"

for "acknowledge," 270.

STATUTE, curing effect of irregularities in sale of infants' land, 329.

STATUTE DE DONIS, 140.

STATUTE OF ENROLMENTS, 12.

STATUTE OF FRAUDS,

bargain and sale in writing after, 13.

feoffment after, 14.

parol gift valid, when, 17 .

requires writing for release of dower, 376 .

whether required signing of deerls, 233. 
STATUTE OF USES,

applied to the lease and release, 13.

deed under, 20. sustained as a conveyance under, when, 58 .

effect of, in transferring legal estate, 56 .

on feoffment, 56.

STATUTE QUIA EMPTORES, 31, 174.

STATUTES,

affecting infant's right to disaffirm, 320, 321.

against conveying lands held in adverse possession, 416 .

as to execution, adoption of in another state, 9 .

authorizing conveyance of infants' lands, 324-329.

insane person's lands, 348 .

concerning aliens, 411.

concerning estates tail, 143.

estates tail, affect, rule in Shelley's case, 147.

implied corenants, 30, 211.

joint tenancy, 151-155.

nominal conditions, 186.

use of "heirs," 136.

effect of, on rule preventing conveyances between husband and wife, 371 .

English recording acts, 422.

wife liable on covenants, under, 194.

STATUTES OF MORTMAIN, 401.

STATUTORY DEEDS, 30, 211, conditions in, 178 .

dual capacity of, 213.

no habendum in, 128.

STATUTORY SEPARATE ESTATE, of married woman, 358 .

what is, 358.

STATUTORY SUBSTITUTE FOR DOWER, 372.

STOCKHOLDER, cannot take acknowledgment, when, 285.

STOLEN DEED, recording of, effect, 299.

STRANGER, reservation to, 127. 


\section{[References are to sections.]}

STREAM. See Rivers.

as boundary, 100 .

grantor owning both sides does not grant to center, 98.

STREET,

as boundary, 89, 90, 91 .

as monument, 87 .

grantee takes title to center, when, 89.

rights in street shown on map, 94.

laid out on edge of grantor's land, 91.

named in description, 82.

"SUBJECT TO INCUMBRANCE," effect of, 208.

"SUBSCRIBE," signing at end, 235.

SUBSEQUENT, conditions, 171.

SUBSEQUENT GRANTEE, former infant may disaffirm conveyance against, 318 .

SUBSTANTIAL COMPLIANCE, what is as to acknowledgment, $268,269$.

with statute concerning acknowledgment necessary, 266, 267, 367.

SUPPORT, condition for, 183.

SORNAME, baptismal name, once more important than, 42. firm name composed of, 45.

SURRENDER, acceptance and, need not be concurrent act, 302 . by grantor of control of deed necessary to delivery, 298, 306 . derivative deed, 20.

grantee's, of deed after delivery, effect, 311 .

SURVEY, named in description, 82.

on ground controls conflicting map, 96.

SURVIVORSHIP, in estate by entireties, 162.

in joint tenancy, 149.

not defeated by conveyance of tenant by entireties, 166 . statutes abolishing, 154 . 


\section{TAIL,}

\section{[References are to sections.]}

estate, barred by recovery, 18.

in United States, 142, 143.

tenant in, 140.

TEMPORARY ABSENCE,

from homestead, not abandonment, 383.

TENanCY. See Entiretizs; Estate by, Etc.

by entireties, 162-166.

joint, 149-155.

TENANCY IN COMMON, 156-158.

alienation by one tenant, 157.

exceptions to rule favoring, 153.

TENANT, possession by, notice of landlord's title, $\mathbf{4 3 0}$.

TENANTS IN COMMON, partition among, 160.

TENENDUM, 31.

TESTIMONIUM CLAOSE, 22-31.

THIRD PERSON, conveyances between husband and wife through, 369 . reservation to, 127.

TIDAL, rivers, public, 105. test of public ownership, 105. waters, land bounded by, 104.

TIMBER, exception of, 124.

reservation of right to cut, 124 . transfer of, on homestead, 395.

TITLE. See, also, Regibtration of Tithe and "Torrens System." abstract of, 425.

after acquired, inures to grantee in deed, when, 188. covenant of warranty not a covenant that title is good, 206. covenants for, 188-221.

in mortgage, 189.

running with the land, 214.

defects in, not shown, by records, 426 .

shown by original instruments, 424.

records, when, $424,425$. 


\section{[References are to Sections.]}

TITLE-Continued.

delivery necessary to transfer, 296.

effect of death of landowner on, 428.

forgery on, 426.

of insane person's deed, 337 .

form of covenants for, 191.

grantee's wrongful possession of, escrow, does not convey, 310 .

how far does it extend to land under water, 104, 105.

imperfections in, 423.

insurance of, 432.

one may have without any writing, 422 .

possession, notice of, 430 .

records do not show, 304, 306.

registration of, $432-443$.

"TO HAVE,"

as operative words, 69.

"TORRENS SYSTEM." See Registration of Title. constitutional objections to, $433,436,437,438,442$. registration of title, 18, 304, 437-443.

\section{TRACT OF LAND,} as monument, 87.

TRADE, competition in, provisions restraining, 230 .

TRANSCRIPT, of records, evidence, $259,260$.

TRANSLATION, of certificate of acknowledgment in foreign language, $280, \mathbf{n}$.

TREATY, effect of, on state law, 4 . may remove alien's disabilities, 412 .

TRUE DATE, of acknowledgment may be shown, 290 . of deed may be shown, 35 .

TRUST, declared in habenbum, 134.

imposed by grantor as to use, 180. notice of, from recital, 49.

\section{TRUSTEE,} cannot take acknowledgment, 283. deed of, recital in, 51 . for separate estate, 352 . 


\section{[References are to Sections.]}

TRLSTEE-Continued.

husband is, of wife's equitable separate estate, 352 .

joint tenants, when, 153.

title held by, for literary or religious society, 241 .

\section{UNBORN CHILD,}

as grantee, 43.

\section{UNCERTAIN,} description, void, 76 .

general description not always, 81 .

\section{UNCERTAINTY,} deed void for, 40,76 .

in description, arises, how, 77,80 .

UNDEFINED PART, of larger tract, 77.

UNDISCLOSED INTEREST, as affecting competency to take acknowledgment, 285, 286.

UNDIVIDED INTEREST, conveyance of, creates tenancy in common, 79,156 .

UNDUE INFLUENCE, presumed, when, 341 .

UNITED STATES, acknowledgment taken out of, 280 . courts of, follow state laws, 4. devise to, 7 .

"UNMARRIED," addition of, to name, 44.

UNRECORDED, deed, effect of grantee's destruction of, 311 . possession under, effect of, 430 .

map or plat, referred to, 93 .

UNSOUND MIND. See Insane Person; Issanity. conveyance of real property of those of, 331-348.

USE,

restrictions as to, how enforced, 228 . when condition, 182 .

resulting to grantor, 55 .

USES,

deeds under, 20.

statute of, 56 . 
[References are to Sections.]

USUAL COVENANTS, for title, 31, 190.

VALIDITY, of deed, acknowledgment when necessary to, 261 . witnesses not generally necessary to, 251 .

VALUE, of homestead, 386 .

VARIANCE, in name, in parts of conveyance, 237 . of one signing and acknowledging, 271.

VENDOR, possession by, after his conveyance, 431 . when may be compelled to execute deed with covenants, 188 .

VEYUE, in certificate of acknowledgment, 289.

VESTED REMAINDER, 144.

"VOID" AND "VOIDABLE," compared, 312.

VOID,

condition, 185, 186. repugnant, 186.

conveyance by drunkard, when, 334 . by spendthrift, 334 . of homestead, when, 392 .

of land held in adverse possession, how far roid, 416,417 . description of person or property inherently uncertain render deed void, 40, 76 .

exception or reservation when void, 126.

insane person, conveyance so held often, 335-336. under guardianship, conveyance void, 332 .

married woman's deed not properly acknowledged, 365 . restraint on alienation generally, 354 .

VOIDABLE, conveyance by infant, generally, 313 .

insane person not under guardianship, generally, 335 . of homestead by husband alone, when, $394, \mathrm{n}$. of land held in adverse possession, 417.

to alien, 409.

to corporation, when, 405 . 
"WAIVE AND RENOUNCE," as operative words, 71.

WAIVER, of conditions, 187 .

of right to enforce restriction, 229 .

WALLS, party covenants as to, 231 .

Ward. See Guardian; Infant; Insane Prrson.

"WARRANT AND DEFEND," as operative words, 71 .

“WARRANT," not essential to covenant of warranty, 206.

\section{WARRANTY,} ancient not same as covenant of warranty, 206. covenant of, 206. runs with the land, 219. incident of feudal tenure, 197.

“WARRANTY DEED," contract for, 190. grantee in, takes after acquired title, 188. short form, 30, 211.

WATER. See Rivers, LAKEs. as a boundary, 98-117. land under, title to, 104, 105, 106, 110, 116. non-tidal, public grants on, 101. tidal, public grants on, 101.

WAX, not essential to seal, 246.

WAY, right of, as incumbrance, 203. passes with land, 118.

WEAKNESS OF MIND, combined with inadequate consideration, 341. not insanity, 340.

WIDOW, grant to, for life or during widowhood, 173. 


\section{WIFE,}

\section{[References are to sections.]}

as witness to husband's conveyance, 253.

could not alienate at common law without husband's consent, 350.

insane, guardian of may release dower \&c., when, 348 .

joining in husband's deed, when not bound by covenants, 194 .

may convey homestead alone, when, 394 .

may not convey directly to husband, when, 371 .

non-resident, whether entitled to dower, 373.

power over separate estate, 355 .

signing husband's deed not generally enough to bar dower, 376 .

statutory separate estate of, 358 .

\section{WILL,}

deed distinguished from, 29.

disposition of homestead by, 378.

less capacity required in testator than in grantor, 338 .

probated, when, 428, n. 28.

revocation of, by changed domestic circumstances, 428 .

WINDOWS,

condition that there shall be no, unreasonable, 186 .

WITNESSES. See Atrestation.

disqualified by interest, 253 .

how they sign, 252.

in general, 250-253.

necessary for what purpose, 251.

not needed at common law, 250.

proof by, 295.

to signature by mark, 236.

WORDS,

appropriate to create condition, 177.

determinable fee, 174 .

of conveyance, 63-72.

\section{WRITING,}

deeds superior to other writings, 54 .

generally necessary in alienation of homestead, 398.

other than deeds, acknowledged how, 256.

title may pass without, 17.

what may be acknowledged, 255 .

when not necessary to transfer land, 11 .

WRONGFUL EVICTION,

no breach of covenant of warranty, 210 .

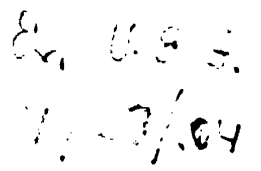




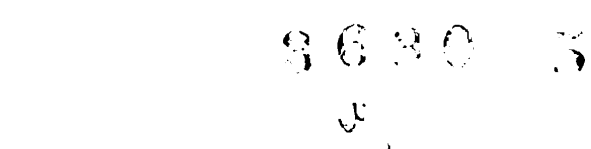

Digitized by GOOgle

Original from

HARVARD UNIVERSITY 


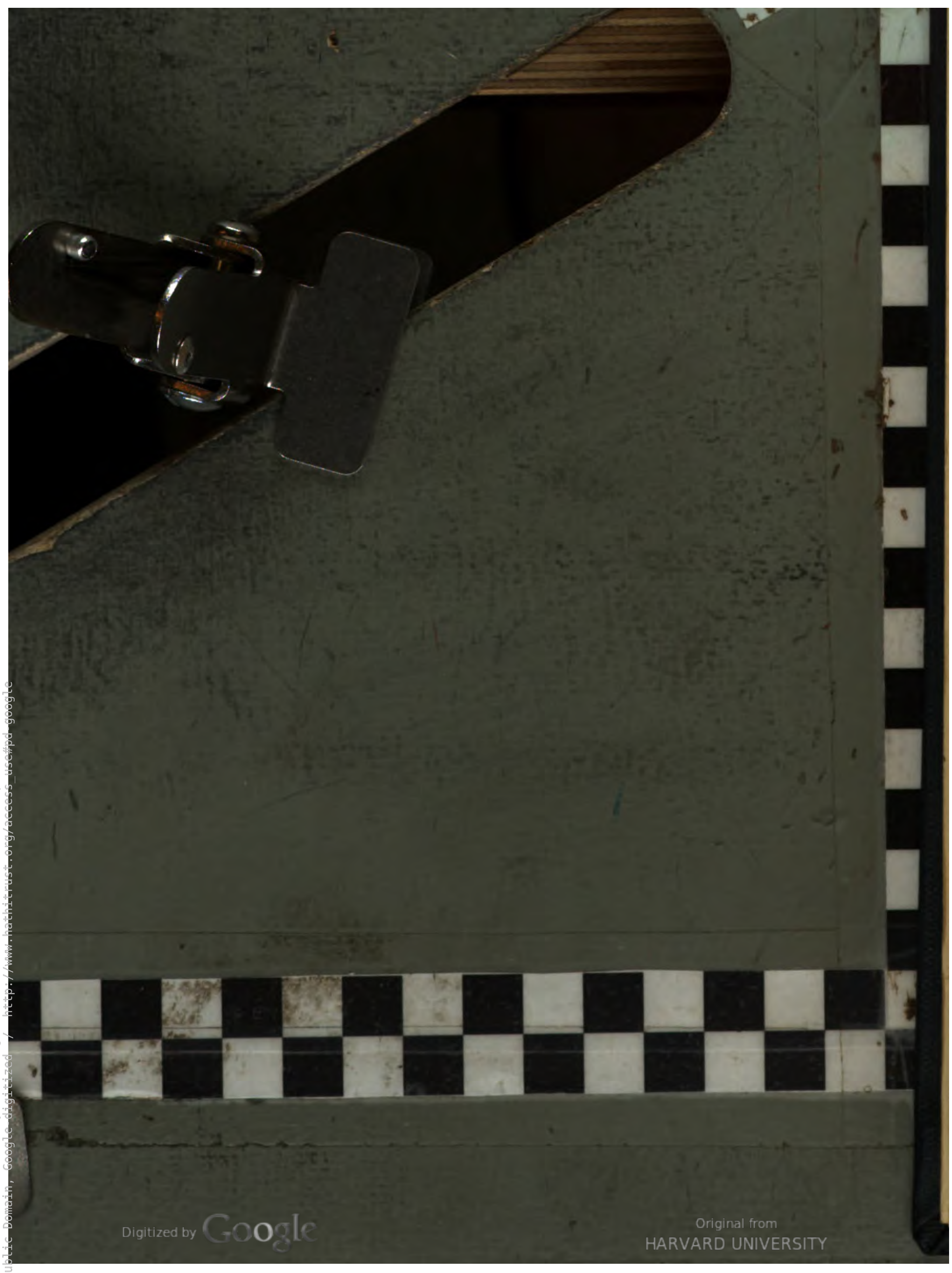

